UNIVERSIDADE DE SÃO PAULO

FACULDADE DE FILOSOFIA, LETRAS E CIÊNCIAS HUMANAS

DEPARTAMENTO DE SOCIOLOGIA

PROGRAMA DE PÓS-GRADUAÇÃO EM SOCIOLOGIA

\title{
Cotia: imigração, política e cultura
}

(Versão corrigida) 
UNIVERSIDADE DE SÃO PAULO

FACULDADE DE FILOSOFIA, LETRAS E CIÊNCIAS HUMANAS

DEPARTAMENTO DE SOCIOLOGIA

PROGRAMA DE PÓS-GRADUAÇÃO EM SOCIOLOGIA

\title{
Cotia: imigração, política e cultura
}

(Versão corrigida)

\author{
GUSTAVO TAKESHY TANIGUTI
}

Tese apresentada à Faculdade de Filosofia, Letras e Ciências Humanas da Universidade de São Paulo, para obtenção do título de Doutor em Sociologia.

Área de Concentração: Sociologia

Orientadora: Prof $^{\mathrm{a}} \mathrm{Dr}^{\mathrm{a}}$ Nadya Araújo Guimarães

De acordo:

São Paulo 
Para Mitiyo, Shizue e Flávio 


\section{AGRADECIMENTOS}

Ao longo da minha trajetória acadêmica, iniciada no curso de graduação, tive a felicidade de conhecer professores que sempre manifestaram o seu apoio e incentivo aos meus interesses de pesquisa. Considero-os verdadeiros mestres, e a minha admiração por eles se construiu em um agradável e constante ambiente de convivência e aprendizado. Sou extremamente grato aos professores Nadya Araújo Guimarães, Sedi Hirano, Iram Jácome Rodrigues e Jacob Carlos Lima. Também sou grato àqueles professores com quem ao longo do período de realização desta tese tive a oportunidade de aprender e dialogar, sendo sempre recebido com respeito e simpatia: Mônica Raíssa Schpun e Oswaldo Mário Serra Truzzi. Não poderia deixar de agradecer aos professores que colaboraram com esta pesquisa: Akihiro Ikeda, Álvaro Comin, Ana Cristina Braga Martes, Ana Lúcia Pastore Schritzmeyer, Ângela Alonso, Antônio Delfim Netto, Antônio Sérgio Alfredo Guimarães, Bruno Carvalho, Edward Telles, Geny Wakisaka, Helena Hirata, Jeffrey Lesser, João Biehl, José Guilherme Cantor Magnani, Koichi Mori, Laura Moutinho, Márcia Lima, Maria da Glória Bonelli, Mário Antônio Eufrásio, Michael Burawoy, Paul DiMaggio, Paulo Fontes, Paulo Sérgio Neves, Sérgio Miceli, Shozo Motoyama, Paulo Yokota, Paulo Menezes, Pedro Meira Monteiro, Ruy Gomes Braga Neto, Takashi Maeyama, Valter Silvério, Vera da Silva Telles, Viviana Zelizer, Yumi Garcia Dos Santos. Agradeço às pessoas que colaboraram de forma importante para a realização deste estudo: Lidia Yamashita, Guilherme Arduini, Thelma Carvalho, Angela Ju, Ana Luisa Nakamoto, Bianca Vyunas, Samara Konno, Álvaro Kanashiro, Thiago Haruo Santos, Carolina Cruz Gonzalez, Jéssica Zanovello, Karina Satomi, Bianca Hsiao, Luzia Miyuki Teruya, Júlia Maria França, Priscila Vasconcelos, Sussumu Miyao e Isidoro Yamanaka. Sou muito grato aos colegas da OSET: Ana Carolina Andrada, Ian Prates, Jaime Santos Júnior, Jonas Tomazi Bicev, Laura Chartain, Lucas Rodrigues Azambuja, Marcel Maia, Monise Picanço, Murillo Marschner Alves de Brito, Rogério Barbosa, Priscila Pereira Faria Vieira. Gostaria de agradecer às seguintes 
pessoas pela amizade sincera e pelo convívio: meu grande amigo e parceiro intelectual Matheus Gato de Jesus, Edilza Sotero, Flávia Mateus Rios, Marcelo da Silveira Campos, Luis Carlos Sabino, Renan Oliveira, Haroldo Beraldo, Leonardo Carniato Rodrigues, Saulo Santil, Daniel Osterreicher Laporta, Marcos Castro Carvalho, Rogério da Palma, José Alexandre Theóphilo, Marco Maia, Victor Hugo Fischer, Plínio Stocco Muniz, Talita Pimentel, Bruna Alonso, Juliana Tonche, Augusto Salvador, Bira Abreu, Angelo Martins Júnior, Henrique Mendes Motta, Ricardo Bernis, Larissa Santos, Yuki Shiraito, Katsunori Wakisaka, Mayumi Shimizu, Maria Alice Silva Araújo; aos princetonianos: Fernanda Rosa, Justin Robert Milliet, Ticiana Marini, Gustavo Rossi, Marcio Zamboni, Marilia Giesbrecht, Mauricio Acuña, Juliana Mara, Benjamin L. Fogarty, Liziane Gonçalves, Magalie Myoupo, René Flores, Kyla Thomas, Cary Beckwith, Danielle Santiago. Também sou grato a Maria Angela Ferraro, Gustavo Barbosa Mascarenhas, Raphael Motta. Por fim, gostaria de agradecer a toda a minha família pelo suporte, carinho e amizade. 


\section{RESUMO}

Esta tese é um estudo sobre mediações de natureza política e cultural que facultam o ambiente de funcionamento do universo empresarial. Almejo atingir pontos de entrecruzamento entre as atividades econômicas, a política e a cultura no percurso de uma parcela de imigrantes japoneses de São Paulo. Examino o repertório de motivações dos agentes que, em períodos distintos, ocuparam os principais cargos de comando em uma empresa: a Cooperativa Agrícola de Cotia. Avalio se, e sob quais condições, certos fundamentos sociais condicionaram as ações desses agentes. São analisadas as suas percepções sobre acontecimentos e momentos históricos específicos, bem como as respostas por eles formuladas ao sistema de alocação de direitos e oportunidades oferecidos aos estrangeiros na sociedade brasileira ao longo do século XX. Argumento que processos sociais inseparáveis da experiência migratória dos japoneses no Brasil como a busca pelo reconhecimento de suas diferenças e a formulação de estratégias de incorporação social - reverberam, em muitos casos, no repertório de motivações desses gestores.

Palavras-chave: Cooperativa Agrícola de Cotia - Imigrantes - Imigração japonesa Sociologia econômica - Estudos migratórios. 


\begin{abstract}
This thesis is a study on the cultural and political mediations that affect the operating environment of the business world. I seek to reach points of intersection between economic activities, politics and culture of a small fraction of São Paulo's Japanese immigrants. I examine the repertoire of motivations of agents that, at different period of times, were at the top leadership in a firm: the Cooperativa Agrícola de Cotia. I examine whether and under what conditions certain social foundations conditioned the actions of these agents. I analyze their perceptions of events and specific historical moments, as well as the responses made by them to the allocation system rights and opportunities offered to the foreigners in Brazilian society throughout the twentieth century. I argue that inseparable social processes of the migratory experience of the Japanese in Brazil such as the search for recognition of their differences and the formulation of social incorporation strategies - reverberated on the repertoire of motivation from the firm's top managers.
\end{abstract}

Keywords: Cooperativa Agrícola de Cotia - Immigrants - Japanese Immigration Economic Sociology. 


\section{LISTA DE FIGURAS E QUADROS}

Figura 1. Concentração da população japonesa no estado de São Paulo, 1934 .............70

Figura 2. Rede de comercialização da produção da Cooperativa Agrícola de Cotia, 1970

Figura 3. Organograma da Cooperativa Agrícola de Cotia, 1988

Quadro 1. Cooperativas ligadas à coletividade de origem japonesa - final

da década de 1930 . .68

Quadro 2. Tipos ideais de dois períodos institucionais da Cooperativa

Agrícola de Cotia. .79

Quadro 3. Relação da Diretoria da Cooperativa Agrícola de Cotia, 1941 a 1945.

Quadro 4. Lista de lideranças a serem assassinadas pela Shindo-Renmei 151 


\section{LISTA DE TABELAS E GRÁFICOS}

Tabela 1. Pessoas empregadas com 10 anos de idade ou mais por grupo ocupacional e porcentagem de mulheres, 1958

Tabela 2. Evolução do quociente Imobilizações/Patrimônio Líquido da CAC (1967-1989)

Gráfico 1. Evolução do número de cooperados da CAC, 1942-1957 


\section{LISTA DE FOTOGRAFIAS}

Sede da Cooperativa Agrícola de Cotia no bairro de Pinheiros, São Paulo, década de 1930 .64

Takeo Goto, diretor da matriz das Casas Fujisaki ....................................................... 101

Kenkiti Simomoto em Moinho Velho, década de 1920 .................................................114

Ata da Assembleia de Constituição da Cooperativa...................................................... 117

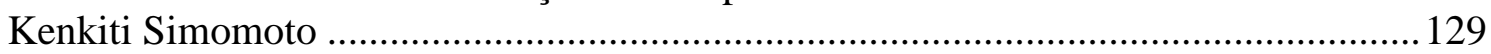

Nota Geral escrita pelo Cônsul-Geral Hara Kaoru, 1942 ............................................ 132

Cooperativa Agrícola de Cotia na lista de embargo comercial do governo

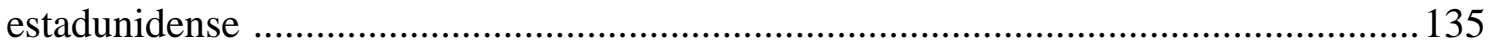

Festejos comemorativos do $25^{\circ}$ aniversário da Cooperativa Agrícola de Cotia, 1952

Texto escrito por Kenkiti Simomoto em edição do informativo Shūhō, julho de 1946

Festejos comemorativos do $25^{\circ}$ aniversário da Cooperativa Agrícola de

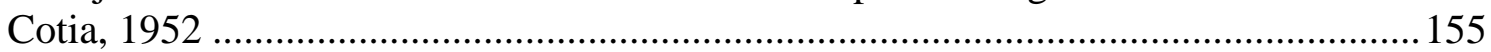

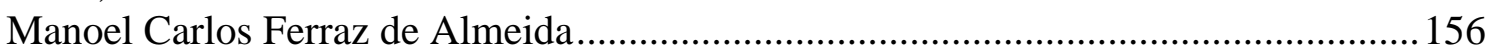

A primeira edição do jornal Gakusei ......................................................................... 162

Reunião de membros da Liga Estudantina Nipo-Brasileira, agosto de 1936 ................. 165

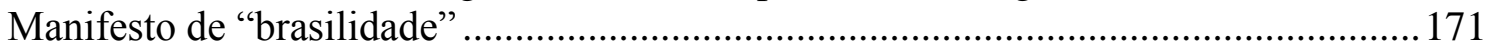

Emílio Garrastazu Médici e seus Ministros durante cerimônia de posse

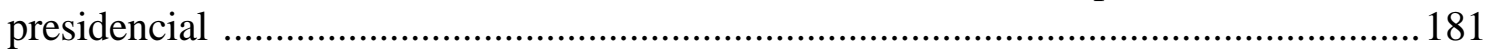

General Macedo de Soares (à direita) transfere o cargo de ministro da

Indústria e Comércio para Fábio Ryodi Yassuda ........................................................ 182

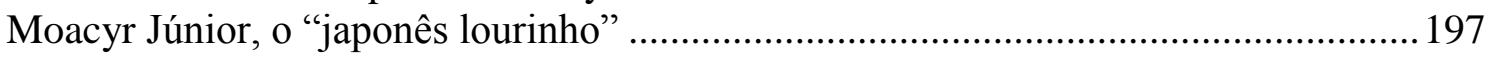

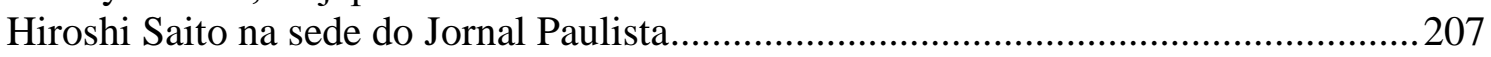

Assembleia de fundação da Cooperativa Central Agrícola e de Colonização

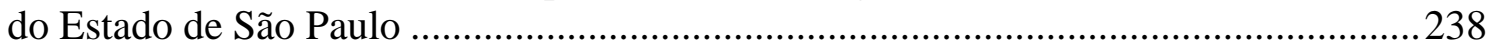

O Príncipe Takahito Mikasa e sua esposa Yuriko Mikasa em discurso nas

instalações da Cooperativa Agrícola de Cotia ...........................................................242

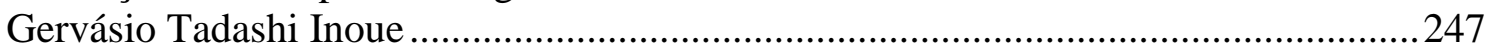

Ocasião da comemoração do cinquentenário de fundação da Cooperativa

Agrícola de Cotia no Palácio de Convenções do Anhembi..........................................2276

Reunião do Conselho Administrativo da Cooperativa Agrícola de Cotia, 1977 ...........286 


\section{LISTA DE SIGLAS E ABREVIATURAS}

Aliança Brasileira de Cooperativismo (ABCOOP)

Aliança Cooperativa Internacional (ACI)

Aliança Renovadora Nacional (ARENA)

Assembleia Legislativa do Estado de São Paulo (ALESP)

Associação Nacional de Pesquisas Econômicas e Sociais Aplicadas (ANPES)

Banco Nacional de Crédito Cooperativo (BNCC)

Banco Nacional de Desenvolvimento Econômico e Social (BNDES)

Caixa de Crédito Cooperativo (CCC)

Carteira de Crédito Agrícola e Industrial do Banco do Brasil (CREAI)

Comissão Nacional de Política Agrária (CNPA)

Conselho Nacional de Desenvolvimento Científico e Tecnológico (CNPq)

Consórcios Profissionais Cooperativos (PCPC)

Cooperativa Agrícola de Cotia - Cooperativa Central (CAC-CC)

Cooperativa Agrícola de Cotia (CAC)

Coordenação de Aperfeiçoamento de Pessoal de Nível Superior (CAPES)

Departamento de Assistência ao Cooperativismo do Estado de São Paulo (DAC)

Departamento de Ordem Política e Social (DEOPS)

Diretoria de Organização e Defesa Da Produção (DODP)

Empréstimo do Governo Federal (EGF)

Escola Livre de Sociologia e Política (ELSP)

Faculdade de Economia e Administração da Universidade de São Paulo (FEA)

Faculdade de Filosofia, Ciências e Letras (FFCL)

Federação das Associações Rurais do Estado de São Paulo (FARESP)

Federação das Indústrias do Estado de São Paulo (FIESP)

I Plano Nacional de Desenvolvimento (I PND)

II Plano Nacional de Desenvolvimento (II PND)

Imposto sobre Circulação de Mercadorias (ICM)

Instituto de Estudos Brasileiros da Universidade de São Paulo (IEB) 
Instituto Nacional de Imigração (INIC)

International Sociological Association (ISA)

Liga Estudantina Nipo-Brasileira (LENB)

Office of the Coordinator of Inter-American Affairs (OCIAA)

Organização das Cooperativas do Estado de São Paulo (OCESP)

Organização das cooperativas Brasileiras (OCB)

Organização das Cooperativas da América (OCA)

Overseas Economic and Finance Corporation (OECF)

Partido Comunista Brasileiro (PCB)

Partido Democrata Cristão (PDC)

Partido Democrático Trabalhista (PDT)

Partido Republicano (PR)

Partido Republicano Democrático (PRD)

Partido Social Democrático (PSD)

Partido Social Progressista (PSP)

Partido Social Trabalhista (PST)

Partido Socialista Brasileiro (PSB)

Partido Trabalhista Brasileiro (PTB)

Partido Trabalhista Nacional (PTN)

Política de Garantia de Preços Mínimos (PGPM)

Programa de Assentamento Dirigido do Alto Paranaíba (PADAP)

Programa de Assentamento Dirigido do Sul de Minas (PADSUL)

Programa de Desenvolvimento do Vale do Rio São Francisco (PROVALE)

Programa de Desenvolvimento dos Cerrados (POLOCENTRO)

Programa de Doutorado Sanduíche no Exterior (PDSE)

Serviço de Economia Rural (SER)

Serviço Nacional de Aprendizagem do Cooperativismo (Sescoop)

Tribunal Superior Eleitoral (TSE)

União das Cooperativas do Estado de São Paulo (UCESP)

União Democrática Nacional (UDN)

Visiting Student Research Collaborator (VSRC) 


\section{SUMÁRIO}

Na trilha do objeto. Uma introdução.

Cotia como objeto: imigração, negócios e incorporação

Pontos de partida e desafios: novas fontes primárias e antigas interpretações.

Capítulo 1 - Gestão, agentes e relações: entre as oportunidades e os limites da incorporação .56

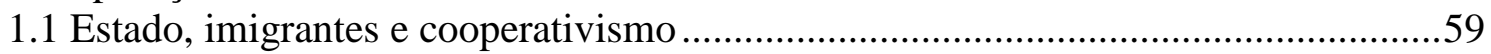

1.2 Modelos de gestão empresarial e clivagens geracionais ........................................73

1.3 Lógicas de diferenciação interna e formação de lideranças .....................................90

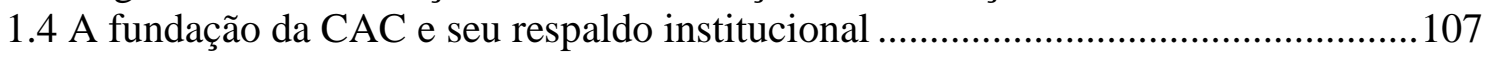

1.5 Gestores de primeira geração em meio a conflitos ................................................130

1.6 Uma segunda geração em busca de reconhecimento............................................157

Capítulo 2 - Pela consagração de uma jornada ascendente ..........................................173

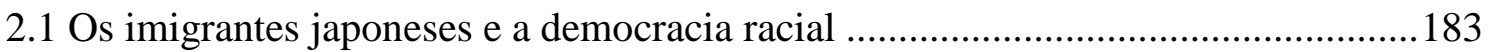

2.2 O Jornal Paulista e os primeiros políticos de origem japonesa ...............................201

2.3 Incorporação em debate: gerações de lideranças se encontram .............................217

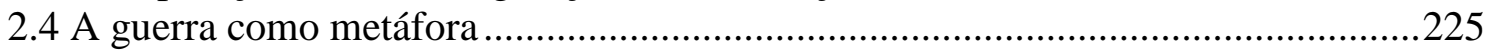

2.5 Gestores de segunda geração e o seu protagonismo..................................................230

2.6 Por dentro da estrutura de poder e decisão política ................................................251

2.7 Agricultura em evidência e personificação exemplar..............................................265

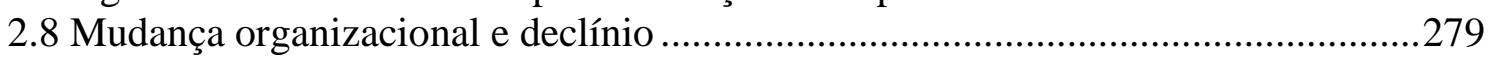

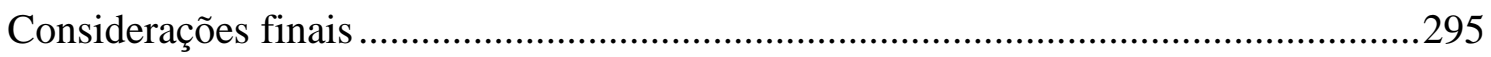

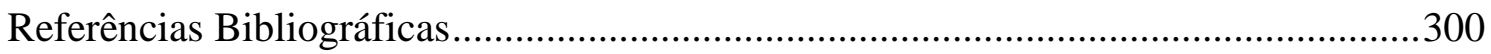

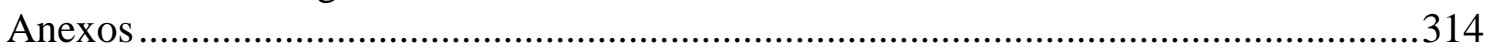




\section{Na trilha do objeto. Uma introdução \\ Cotia como objeto: imigração, negócios e incorporação}

Esta tese é um estudo sobre mediações de natureza política e cultural que facultam o ambiente de funcionamento do universo empresarial. Emprego uma abordagem que visa examinar o universo de motivações dos agentes que ocuparam os principais cargos de comando em uma empresa: a Cooperativa Agrícola de Cotia (CAC).

Essa empresa foi fundada em 1927 no município de Cotia, no estado de São Paulo, por lavradores japoneses egressos do sistema de colonato. Inicialmente voltada à distribuição da produção agrícola de um núcleo de imigrantes para o mercado consumidor da capital paulista, no período mais próspero de sua atuação essa Cooperativa era referida por muitos como um dos mais bem-sucedidos empreendimentos da coletividade japonesa em todo o Brasil. Mais ainda, entre meados da década de 1960 e o início da década de 1990 (quando entrou em processo judicial de liquidação) o seu reconhecimento no mundo dos negócios - a exemplo da chancela pública que a identificava como a maior cooperativa agrícola da América Latina - podia ser facilmente constatado nos principais veículos de comunicação impressos ${ }^{1}$, em periódicos do setor agrícola, ou mesmo no imaginário popular.

Do ponto de vista nativo, não é exagero afirmar que a CAC esteve no epicentro de um processo simbólico de legitimação que lhe chancelou com o título de um dos

\footnotetext{
${ }^{1}$ Um exemplo de seu reconhecimento público pode ser encontrado, por exemplo, em caderno especial do jornal $O$ Estado de S. Paulo que circulou no ano de 1987: "Presente em 14 estados brasileiros, a Cooperativa Agrícola de Cotia é formada por dez cooperativas agrícolas regionais ligadas à Cooperativa Central, mais uma Cooperativa de Crédito Rural e várias empresas coligadas. Este complexo, que congrega cerca de 15 mil associados e 11 mil funcionários, ocupa a $19^{a}$ posição entre as maiores empresas do país, segundo a edição "Maiores e Melhores 87", da Revista Exame" ( O Estado de S. Paulo, 25 de novembro de 1987, p.22). Ou ainda, nas palavras do economista Jacques Marcovitch: "A Cotia tornou-se uma das mais expressivas cooperativas agropecuárias do mundo. Em 1987, era uma das 20 maiores empresas brasileiras. Presente em 15 estados, com 10 Cooperativas Singulares e Associadas e 90 Depósitos Regionais. Mais de 15.000 cooperados e 8.800 funcionários comercializavam 250 produtos e faturavam, anualmente, US\$ 760 milhões. Da monocultura à plena diversificação, constituiu-se em uma das mais complexas organizações agropecuárias" (MARCOVITCH, 1996, p.3).
} 
"três baluartes" da "colônia" japonesa ${ }^{2}$. No imaginário coletivo dos japoneses que viviam no Brasil, tanto quanto no imaginário brasileiro a eles referido, essa Cooperativa representava uma referência constante e que se expressava em múltiplas dimensões. Em São Paulo, em especial, onde a população japonesa se concentrou, a notoriedade do empreendimento era frequentemente associada a uma narrativa de êxito, que celebrava a experiência migratória do grupo.

Sua proeminência no mundo dos negócios fez dela objeto de investigação por estudiosos de diferentes áreas do conhecimento, como a sociologia, a geografia econômica, a economia e a ciência política. Interpretações sobre a sua trajetória recobriram um amplo espectro de temas, tais como: a existência de uma "transplantação cultural" das formas de associativismo agrícola japonês enquanto algo constitutivo da experiência de imigrantes japoneses no Brasil (SAITO, 1964); as características da sua estrutura de funcionamento e de suas operações no mercado de abastecimento agrícola (SEABRA, 1971, 1977); a análise do seu desempenho financeiro no mercado (VEGRO, 1992; GONÇALVES; VEGRO, 1994; MARCOVITCH, 1996); os processos de inovação tecnológica conduzidos pelo empreendimento (HIRATA, 2001).

Ainda que esse conjunto de estudos ofereça inegáveis contribuições, pouca atenção foi devotada a um espaço central de relações sociais, no qual o comportamento organizacional é produzido, adquire validade, se dissemina enquanto conduta estabelecida e é também modificado: o ambiente gestionário. A isso se dedica este trabalho, a entender tal espaço social, caracterizando suas propriedades específicas; um ambiente em que as condutas dos agentes em posições de comando se realizam, informadas por um amplo repertório de motivações.

\footnotetext{
${ }^{2}$ A CAC, a Cooperativa Agrícola Sul-Brasil e o Banco América do Sul são considerados os três grandes empreendimentos de imigrantes japoneses no Brasil, segundo a Sociedade Brasileira de Cultura Japonesa e de Assistência Social (Bunkyo), principal órgão nipo-brasileiro, localizado no bairro da Liberdade. No texto Imagens e Breve Cronologia da Imigração Japonesa no Brasil, podemos encontrar a seguinte menção: "As cooperativas agrícolas de Cotia e Sul-Brasil, juntamente com o Banco América do Sul criado como uma facilidade de crédito para os imigrantes japoneses -, foram acompanhando o ritmo acelerado de crescimento do pós-guerra e se tornaram os principais empreendimentos nipo-brasileiros". Disponível em: $<$ http://www.bunkyo.bunkyonet.org.br/index.php?option=com content\&view=article\&id=64:imagens-ebreve-cronologia-da-imigracao-japonesa-no-brasil\&Itemid=1\&lang=br>. Acesso em: jun. 2013.
} 
Embora abordagens institucionais procurem compreender de que formas agentes em posições de comando nas firmas interpretam os ambientes internos e externos à organização para atuar política e estrategicamente, acredito que elas satisfazem apenas parcialmente uma análise criteriosa do universo de relações sociais em que esses agentes estão imersos. Isso porque suas ações dependem também de arranjos situacionais envolvendo percursos coletivos, em que é possível identificar operações de mercado que extrapolam a condição de agentes concorrendo em um ambiente sob condições ideais de fluidez, transparência e cuja métrica de cálculo é avaliada de maneira unicamente instrumental. Acredito que a compreensão de decisões tomadas em âmbito gestionário pode ser complementada, se bem situada em seus respectivos contextos histórico-sociais - e, principalmente, se assumirmos que elas estão permanentemente mediadas por fatores de ordem cultural e por constrições políticas, a depender do grau de regulação estatal exercido sobre as atividades econômicas.

Por isso mesmo, esta tese se situa na interface de dois campos de produção científica: a sociologia histórica das migrações e a sociologia econômica. Ao transitar entre esses dois campos, a análise aqui conduzida procura validar o argumento de que as relações entre as atividades econômicas, a política e a cultura são locais interdependentes e privilegiados de manifestação da realidade social, de sorte que a sua investigação possibilita compreender as formas pelas quais as diversas nuances de seu entrelaçamento se conformam no mercado e, ao fazê-lo, conformam o mercado, ele próprio. Considerando que este último é resultado de uma composição de natureza heterogênea, busco averiguar se, e até que ponto, além de uma trajetória empresarial, a CAC resguardou um espaço de atuação relevante para a direção da ação de indivíduos e grupos de origem japonesa que buscavam paulatinamente construir estratégias de incorporação à sociedade paulista. Almejo, portanto, atingir pontos de entrecruzamento de atividades econômicas, da política e da cultura no percurso de uma parcela de imigrantes japoneses em São Paulo.

As contribuições advindas do presente estudo, que considera a relevância dos fundamentos sociais que condicionam as ações em situações de mercado, se alinha com aqueles que questionam a exclusividade explicativa da dimensão econômica dos fenômenos mercantis. Os resultados aqui apresentados se concentram, por isso mesmo, 
nas percepções que os principais gestores da CAC possuíram sobre acontecimentos e momentos históricos específicos, bem como nas respostas por eles formuladas ao sistema de alocação de direitos e oportunidades oferecidos aos estrangeiros na sociedade brasileira ao longo do século XX. Sobretudo, busco demonstrar que processos sociais inseparáveis da experiência migratória dos japoneses no Brasil - como a busca pelo reconhecimento de suas diferenças e a formulação de estratégias de incorporação reverberam, em muitos casos, no repertório de motivações desses gestores.

Inspirado em Spitzer (2001), este estudo conduz sua aproximação analítica do objeto empírico considerando aspectos biográficos e relacionais, bem como condicionantes estruturais de natureza política. $\mathrm{O}$ ambiente gestionário da $\mathrm{CAC}$ não é concebido, portanto, dissociado de um contexto de relações em que se produziram projetos variados de incorporação da população japonesa à sociedade paulista.

Um dos objetivos iniciais da pesquisa foi o de investigar se os significados de suas ações possuem correspondência com determinados contextos de maior ou menor incidência de barreiras à aceitação da população japonesa na sociedade local. Ao longo da tese, procuro demonstrar que as ações desses gestores podem ser melhor compreendidas quando situadas em meio a processos dinâmicos de modificação bilateral dos marcadores de diferença, que relacionaram a população estrangeira e a sociedade local em conjunturas políticas variadas, como o Estado Novo (1937-45), o período de intervalo democrático (1945-64) e o regime militar (1964-85). Esses processos adquiriram formas específicas, a depender das condições de realização ofertadas pelos diferentes regimes políticos. Embora condicionantes político-estruturais se apresentassem aos grupos estrangeiros como um forte vetor de influência em processos de negociação dos marcadores de diferença, isso configurou cenários mais gerais em que a experiência migratória dos japoneses se realizou. Acredito haver espaços relacionais em que projetos de incorporação adquiriram significados próprios e qualitativamente diferenciados, e um desses espaços foi a sede da CAC.

Ao nos debruçarmos sobre a posição social de seus gestores, deparamo-nos com evidências empíricas indicativas de que, ao menos desde a década de 1930, eles foram ativos partícipes de um restrito grupo de lideranças de origem japonesa em São Paulo: 
um núcleo de sociabilidade cujos membros foram capazes de produzir e disseminar ideias sobre a condição social do grupo na sociedade local, e para quem interessava conceber projetos que pudessem resultar de maneira geral em benesses pelas vias da incorporação social. Sobretudo, o que deve ser ressaltado é a existência de um ativo grupo que convergia expoentes empresariais e intelectuais de origem japonesa, evidência essa que contribui para atestar os argumentos aqui apresentados.

Circunscrever o ambiente de relações dos gestores desse empreendimento permite compreender como determinadas decisões empresariais foram tomadas, informadas por certos componentes sociais indissociáveis da experiência migratória. A escolha por analisar um ambiente específico de relações sociais não significa que outros agentes protagonistas em processos transformadores de barreiras sociais são desconsiderados, e sim que busco averiguar o caso de gestores de uma empresa em particular, por meio do exame dos significados de suas ações. Essa aproximação em relação ao objeto reconhece a capacidade de agência de indivíduos. Em certa medida, realizo uma abordagem prosopográfica ${ }^{3}$, sob viés sociológico, dos principais gestores do empreendimento com o intuito de identificar singularidades no âmbito individual, enquanto o seu contexto de relações permite a formulação de tipologias que se aproximam dos fatos, ou seja, a elaboração de categorias classificatórias voltadas à generalização de padrões de comportamento.

Em termos gerais, é possível afirmar que este estudo está centrado no exame de um circuito bastante singular de relações dos indivíduos de origem japonesa em São Paulo. Alguns leitores poderão interpretá-lo como uma espécie de grupo de "elite", por se tratar de agentes situados em posições de elevado prestígio da hierarquia social, cuja distinção se fazia valer pela posse de determinados bens, principalmente de capital econômico, político ou cultural. Entretanto, de forma alternativa, optei pela utilização

\footnotetext{
${ }^{3}$ Uma definição sucinta do termo é apresentada por Heinz, para quem: "A prosopografia, ou método das biografias coletivas, pode ser considerada um método que utiliza um enfoque de tipo sociológico em pesquisa histórica, buscando revelar as características comuns (permanentes ou transitórias) de um determinado grupo social em dado período histórico. As biografias coletivas ajudam a elaborar perfis sociais de determinados grupos sociais, categorias profissionais ou coletividades históricas, dando destaque aos mecanismos coletivos - de recrutamento, de seleção e de reprodução social - que caracterizam as trajetórias sociais (e estratégias de carreira) de indivíduos" (HEINZ, 2006, p.9).
} 
do termo "lideranças" em vez de "elites", por alguns motivos que esclareço nos parágrafos a seguir.

A literatura sobre o tema das elites nas ciências sociais é ampla e possui uma longa tradição, que remonta a autores como Joseph Schumpeter, Raymond Aron, Karl Mannheim, Harold Lasswell, C. Wright Mills, Robert Dahl, Giovanni Sartori e, principalmente, às obras pioneiras de Vilfredo Pareto, Gaetano Mosca e Robert Michels entre as décadas de 1910 e 1930 (GRYNSZPAN, 1999, 1996; PERISSINOTTO; CODATO, 2008). No Brasil, ao menos desde a década de 1960 podemos encontrar estudos voltados ao tema, como: elites empresariais (CARDOSO, 1964; BRESSERPEREIRA, 1974; DINIZ, 1978; BOSCHI, 1979), elites políticas (FAORO, 2007; SCHWARTZMAN, 1975; REIS, 1982; LIMA; CHEIBUB, 1996; CARVALHO, 1996; BOSCHI; DINIZ; SANTOS, 2000), a relação entre intelectuais e classes dirigentes (MICELI, 1979), e o patronato artístico das elites paulistas (MICELI, 2003). Mais recentemente, na avaliação de Grynszpan e Grill (2011), os estudos sobre elites se diversificaram no plano internacional e nacional, o que contribuiu para ampliar o escopo dos grupos estudados (a exemplo de elites culturais, científicas, religiosas e profissionais), bem como tem se fortalecido um diálogo teórico e metodológico entre diferentes tradições disciplinares ${ }^{4}$.

Conforme já foi anteriormente mencionado, a tese procura se situar de maneira mais explícita na interface dos campos da sociologia histórica das migrações e da sociologia econômica, ainda que diálogos sejam estabelecidos com outras áreas do conhecimento. Disso decorre que não possuo enquanto objetivo principal realizar uma discussão sobre grupos de elite me reportando a categorias conceituais próprias a um campo já estabelecido, bem como não estabeleço um diálogo exaustivo com autores da área, embora eu me valha de subsídios metodológicos de recentes agendas de pesquisa sobre o tema (HEINZ, 2006). Talvez mediante uma aproximação com o campo da

\footnotetext{
${ }^{4} \mathrm{O}$ interesse pelo tema, que se mantém recente, na produção acadêmica brasileira pode ser percebido pelas edições de novos conjuntos de trabalhos, recentemente veiculadas em coletâneas tais como: REVISTA TOMO. Dossiê: Sociologia do poder e das elites. São Cristovão-SE, NPPCS/UFS, v.10, n.13, 2008; REVISTA DE SOCIOLOGIA E POLÍTICA. Dossiê: Elites e instituições políticas. Departamento de Ciências Sociais/Universidade Federal do Paraná. Curitiba-PR, v. 16, n.30, 2008; e REVISTA DE SOCIOLOGIA E POLÍTICA. Dossiê: Elites em diferentes escalas: teoria e metodologia no estudo dos grupos dirigentes. v. 22 n. 52, 2014.
} 
história social, este estudo possa oferecer uma modesta tentativa de contribuição para o diálogo interdisciplinar sobre elites que envolve as áreas da história, da ciência política e da sociologia, identificado por Heinz (2011).

A minha escolha por analisar o ambiente gestionário da CAC em diferentes contextos está fundamentada em uma discussão teórica própria ao campo da sociologia econômica contemporânea. Em linhas gerais, ela se inspira em uma proposta mais abrangente, dedicada a demonstrar as diversas formas de comportamento social para se explicar a articulação entre atores e mercado (GRANOVETTER, 1985; STEINER, 2006; SWEDBERG, 2005, 2008). Ainda que a própria racionalidade do ator, enquanto disposição instrumental, seja alvo de discussões e discordância entre autores da "nova" sociologia econômica, há consenso na ideia de que, metodologicamente, o indivíduo não pode ser analisado de forma isolada e atomizada e, dessa forma, fatores extramercantis ganham validade explicativa (BECKERT, 1996). Assim, considero que as atividades econômicas dos agentes aqui examinados são socialmente orientadas, ou seja, que normas sociais, valores e estruturas de relações moldam não somente as intenções dos indivíduos, mas também as estratégias e os recursos empregados para a realização dessas atividades (GRANOVETTER, 1985).

No campo da sociologia econômica contemporânea, os estudos históricos representam ainda uma minoritária, porém significativa, parcela. Podemos mencionar, por exemplo, Dobbin (1994, 1999), que demonstra a existência de concepções culturalmente determinadas que influenciaram as políticas ferroviárias nos Estados Unidos e na França no século XIX. Já Fligstein (1996) demonstra a emergência de concepções de controle organizacional em executivos de grandes empresas norteamericanas nas décadas de 1950 e 1960, voltadas para a garantia de crescimento estável e lucrativo. Tais concepções, segundo o autor, teriam surgido da interação entre os campos político e legal norte-americano. Levy (2006) analisa o surgimento dos mercados de futuros e das práticas de especulação no fim do século XIX nos Estados Unidos. Zelizer (2010) investiga, entre outros, a gradual aceitação dos seguros de vida nos Estados Unidos no fim do século XIX; os critérios sentimentais presentes na atribuição de valor às crianças, processo de valoração que teria resultado na sacralização das crianças, justificando os dispositivos legais de indenização por sua morte. Além 
desses estudos, é possível mencionar avanços conceituais no interior do debate acadêmico (ORLÉAN, 1994; FLIGSTEIN, 1996, 2001, 2008). O que neles se sublinha é, sobretudo, o intuito de compreender o que confere legitimidade a certos arranjos institucionais do que a outros, promovendo-se um debate sobre a influência da vida social na atividade econômica.

Neste estudo optei por avaliar situações específicas de interação entre agentes, de modo a ressaltar o protagonismo destes últimos na constituição paulatina e dinâmica do domínio supostamente autônomo da economia. A singularidade do caso por mim analisado é que os agentes em questão, bem como o empreendimento que fundaram, possuem origem estrangeira. Condição essa que torna imperioso estabelecer um diálogo com o campo dos estudos migratórios, situando a experiência dos imigrantes japoneses no Brasil.

As situações aqui analisadas foram informadas, em partes, por conjunturas históricas que caracterizaram a experiência de estrangeiros na sociedade paulista e, vale dizer, esta nem sempre foi um ambiente favorável à aceitação desses indivíduos: no caso dos japoneses, uma série de restrições lhes foi imposta pelo Estado brasileiro no período entre as décadas de 1930 e 1950, bem como as diferenças culturais e linguísticas alimentaram intolerâncias. Mas, sobretudo, a influência de agentes e grupos sociais se revela central para a interpretação de fenômenos circunscritos a experiências migratórias que, à primeira vista, poderiam ser atribuídos a fatores estritamente econômicos.

Se na sociedade brasileira houve resistências à incorporação de imigrantes, moldadas por parâmetros reguladores, componentes políticos e simbólicos, elas foram tensionadas por processos bilaterais de constante redefinição, abrindo caminhos para mudanças de fronteiras entre grupos já estabelecidos e os recém-chegados. Sobre esse assunto, estudos recentes têm avançado na discussão a respeito dos processos de aceitação e integração política de imigrantes e seus descendentes no estado de São Paulo na primeira metade do século XX (TRUZZI; KERBAUY; BARBOSA, 2012). Esse tipo de abordagem dos fenômenos migratórios permite compreender como certos grupos, antes estigmatizados e privados de alguns direitos ou mesmo de fazer parte de 
determinados circuitos sociais, mobilizaram recursos de forma a ganhar aceitação e a ocupar posições de prestígio na sociedade receptora.

Segundo Truzzi (2012), há atualmente no Brasil uma agenda de pesquisa que a sociologia dedicada aos estudos migratórios pode proficuamente desenvolver. Ela diz respeito, basicamente, à discussão sobre modelos de incorporação de imigrantes à sociedade de destino, em uma perspectiva intergeracional. Não por acaso, o autor encontra na obra de Alba e Nee (2003) uma referência para tal tarefa. Nessa obra, o conceito de "assimilação" é reavaliado, deslocado do plano de significação que lhe atribuía conotações espúrias, em prol de um novo modelo de análise de incorporação dos imigrantes na sociedade estadunidense. Para Alba e Nee, compreender trajetórias de incorporação demanda analisar a interação entre a ação intencional de imigrantes e seus descendentes e os contextos, ou seja, estruturas institucionais, crenças culturais e redes sociais que lhes conformam (ALBA; NEE, 2003, p.14). Os autores especificam "mecanismos" de assimilação que atuam em âmbito individual, grupal ou institucional, como capitais sociais, culturais, econômicos, bem como políticas de regulação estatal na economia, na educação e no âmbito dos direitos.

Essa nova agenda de pesquisa delineada por Truzzi, sugere aos pesquisadores investigar:

como cada grupo ou segmento de grupo [...] transitou de um regime onde o crivo étnico pautava as agendas culturais, de inserção econômica [...] e de sociabilidade [...] para outro regime [...] no qual aquele pouco interferia no cotidiano concreto dos indivíduos, a não ser pela remota alusão a uma origem comum. (TRUZZI, 2012, p.544)

Por "regimes", compreende-se aqui, de forma abrangente, modos de regulação das estruturas política e econômica de uma sociedade em que a experiência migratória de um grupo social ocorre.

$\mathrm{Na}$ tentativa de contribuir com essa agenda, esta pesquisa propõe trazer à discussão a experiência de uma fração dos imigrantes japoneses que teve a sua trajetória fortemente associada ao cooperativismo agrícola no estado de São Paulo. Inicialmente, esse grupo construiu as suas oportunidades de inserção social e econômica no setor 
agrícola, e especialmente os empreendimentos de produção associativa constituíram um dos vários núcleos sociais com potencial de agregar recursos para a transformação de barreiras que impediam a sua aceitação e inserção na sociedade local. Aqui, o tema do cooperativismo de imigrantes japoneses possui centralidade, mas de forma distinta dos estudos precursores (SAITO, 1954, 1955a, 1955b, 1955c, 1955d, 1964), em que a ênfase nos elementos culturais por vezes ofuscava o potencial explicativo desse fenômeno. Esta pesquisa atenta, sobretudo, aos processos sociais que possuem lugar no mercado, evitando adotar, por um lado, os seus resultados como ponto de partida para explicações fundamentadas apenas na gerência mercantil e, por outro lado, uma essencialização dos aspectos culturais.

Esse interesse investigativo se apoia no argumento inicial de que, a despeito das restrições estruturais e culturais enfrentadas pelos imigrantes japoneses nos primeiros cinquenta anos de sua chegada ao Brasil, a agricultura constituiu um domínio central em que se operou a inserção social e econômica de uma parcela considerável desse grupo. Concentrados de forma relativamente homogênea no setor de atividade agrícola, os japoneses experimentaram rapidamente a transição ocupacional do colonato à produção própria em pequenas propriedades (SAITO, 1961; SUZUKI, 1969). Especialmente no estado de São Paulo, a emergência da forma associativa de produção complementou as necessidades de organização de uma estrutura comercial mais adequada às demandas de abastecimento dos centros urbanos em expansão.

Como apresentarei ao longo desta tese, especialmente nos anos posteriores à Segunda Guerra Mundial, certas conjunturas, sob influência das políticas de Estado, possibilitaram a expansão das cooperativas agrícolas paulistas. Dentre aquelas que se beneficiaram de tais políticas, a CAC obteve destaque e por meio dela, especialmente nas décadas de 1950 a 1980, uma segunda geração de imigrantes japoneses construiu caminhos de inserção não apenas econômica mas também política, e passou a participar da gestão pública da economia. Investigar como tais caminhos foram construídos, tendo como referência a atuação dessa cooperativa no mercado representa um dos objetivos mais gerais desta pesquisa. 
A partir da década de 1950 ocorreu um crescente movimento inter-regional dos imigrantes japoneses em direção à capital do estado, mas isso não se traduziu em uma ruptura imediata de sua experiência no setor agrícola. Em outras palavras, mesmo que esse grupo progressivamente passasse a realizar a migração rural-urbana, muitas vezes acompanhada da mudança ocupacional para atividades não agrícolas, pode ser enganoso induzir o abandono da experiência rural em razão da ocorrência desse movimento. Com essa afirmação, avento que a experiência migratória desse grupo em São Paulo tenha ocorrido acompanhada de um processo de redefinição de seus elementos de representação e pertencimento: a agricultura, além de representar um meio para a ascensão na estrutura ocupacional, foi transformada em um produto imagético compartilhado, referente a valores positivos associados aos japoneses e ressignificada em um contexto urbano. As mudanças de fronteiras desse grupo em particular estiveram associadas, portanto, ao universo agrícola.

Ao criar estruturas adequadas para a organização de um segmento do mercado, os empreendimentos cooperativos criados por imigrantes japoneses no estado de São Paulo emergiram no plano simbólico como uma referência e também atuaram como dispositivos facilitadores de coordenação das atividades econômicas. Principalmente a CAC se tornou responsável por desenvolver e legitimar instrumentos técnico-científicos para a coordenação do mercado. Amparada pela sua ingerência, especialmente no estado de São Paulo, uma elite de segunda geração de imigrantes japoneses se beneficiou de estruturas que lhes permitiram ascender socialmente e participar da gestão pública dos interesses econômicos.

Mas, as intersecções entre a política e os negócios estiveram presentes de forma bastante desigual ao longo da história dos empreendimentos de origem rural fundados por imigrantes japoneses; elas foram sendo construídas ao longo do tempo e de forma processual, adquirindo contornos mais definidos notadamente a partir da década de 1950. Os seus desdobramentos tiveram implicações para o próprio destino dessas cooperativas: em 1967, após reformas na legislação cooperativista brasileira, a CAC se tornou Cooperativa Central, de forma que a sua atuação se expandiu para todo o país e, ao final da década de 1980, ela era reconhecida como uma das 20 maiores empresas brasileiras pela imprensa especializada em negócios. Naquela década, essa Cooperativa 
era composta por dezenas de milhares de associados e funcionários, possuía um complexo sistema de produção agroindustrial e de distribuição, tendo participado de projetos de modernização da agricultura durante o governo militar, realizado inúmeros projetos de pesquisa e desenvolvimento agrário em parceria com instituições nacionais e internacionais, além de ter atuado no mercado externo.

A forma adquirida pelo cooperativismo agrícola no Brasil após a Segunda Guerra - que, enfatizo, a CAC foi o seu maior expoente - representou uma entre tantas outras possibilidades de conformação desse mercado. Isso significa que não necessariamente as formas economicamente mais eficientes de organização foram alcançadas, e que por isso se legitimaram, mas sim que determinadas condições histórico-sociais de realização e a interferência de agentes específicos conduziram os caminhos pelos quais esse mercado se estruturou. Ao longo deste trabalho, procurarei mostrar algumas formas pelas quais a trajetória da CAC pode ser interpretada a partir de sua atuação no mercado. Essa trajetória esteve intimamente relacionada à experiência de uma fração dos imigrantes japoneses na sociedade brasileira. Entretanto, embora possuísse a maior estrutura de funcionamento que uma empresa desse tipo pudesse dispor à época, e por mais que controlasse uma parcela significativa da distribuição dos produtos agrícolas, isso não lhe garantiu uma posição estável no mercado. Em setembro de 1994, enfrentando dificuldades financeiras, ela encerrou as suas atividades e entrou em processo judicial de liquidação.

Argumento, portanto, que a modalidade de ascensão econômica e política alcançada por essa fração de imigrantes japoneses, acompanhada da reconfiguração de componentes simbólicos de sua representação, ocorreram de maneira processual e resultaram, em grande medida, da atuação da CAC. Dessa forma, certas condições estruturais de suporte aos imigrados e seus descendentes foram estabelecidas, atuando como fontes de recursos para a incorporação desse grupo na sociedade local. Esse processo dependeu das formas pelas quais a CAC operou no mercado, ao criar estruturas adequadas para a sua coordenação.

Sobretudo, argumento que essa Cooperativa constituiu, ao longo do tempo, um importante espaço de relações sociais em que projetos de incorporação de imigrantes 
japoneses adquiriram significados próprios e qualitativamente diferenciados. A sua compreensão é dependente de um exame mais detalhado do ambiente em que as principais decisões empresariais eram tomadas: o ambiente gestionário.

Os dados utilizados neste estudo são, em sua maioria, de natureza documental e qualitativa, e possuem origens diversas. O leitor encontrará em seguida uma descrição detalhada do material documental que foi produzido durante o período de realização da pesquisa. Talvez seja pertinente e de interesse explicativo para o leitor que sejam explicitados certos aspectos de minha relação com o objeto estudado.

Em primeiro lugar, devo assumir que a minha interpretação dos fatos não pode ser divorciada da minha posição, situada em época e lugar que se relacionam aos personagens examinados. Disso decorre que certos acontecimentos aqui apresentados são também o resultado de um processo de reconstituição por mim empreendido. Ele é realizado de maneira parcial, pois é dependente de interesses próprios, da forma como enxergo o objeto e da disponibilidade de dados. Embora essa condição seja constitutiva da pesquisa, acredito que ela não se apresenta como um impedimento incontornável para a tarefa de estruturar uma análise que busque se aproximar do ponto de vista dos agentes aqui analisados.

A forma como o objeto é por mim percebido também demanda maiores esclarecimentos, pois a CAC esteve presente em uma parte da minha biografia. Especificamente, ela se apresentava para mim sob a forma de um universo de sociabilidade - algo característico de filhos de seus funcionários e cooperados. Isso porque o empreendimento dispunha de um amplo circuito de entidades (a ele vinculadas administrativamente) voltadas à reprodução de vida: assistência médico-hospitalar, rede de supermercados, clube poliesportivo, colônia de férias, previdência privada, colégio técnico, entre outros. Considerando a presença ativa da empresa nos modos de vida de seus funcionários - que, vale ressaltar, eram em sua maioria filhos de imigrantes japoneses -, era recorrente que desses espaços resultassem matrimônios, como é o caso de meus pais, ex-funcionários dessa Cooperativa.

Há vários desdobramentos e leituras possíveis sobre a existência de certo grau de endogenia no recrutamento do seu quadro administrativo e associativo. A forma como o interpreto é bastante particular, baseada em experiências familiares próprias, ainda que 
possivelmente haja semelhanças com outras trajetórias. As memórias que me foram contadas por vezes retratavam a Cooperativa como uma espécie de entidade facilitadora do ingresso de filhos de imigrantes japoneses no mercado de trabalho da capital paulista em meados da década de 1970. No início da década de 1990, pude assistir ao desmoronamento dessa gigantesca estrutura empresarial, e observar de perto os seus efeitos sobre carreiras profissionais que eram consideradas supostamente estáveis. A súbita interrupção de projetos profissionais, somada a decisões tomadas no plano individual e familiar baseadas em motivações diversas, faziam da experiência de trabalho no Japão uma opção viável para muitos filhos de imigrantes que então buscavam, por vezes sem ter as suas expectativas atendidas, uma reinserção profissional no mercado de trabalho local.

Em casos como o meu e o dos membros da minha família, trabalhar no Japão despertava um interesse adicional pois, entre outros, possibilitou confrontar uma referência ancestral imaginada com a realidade cotidiana de intensas jornadas de trabalho nas fábricas, ou até mesmo com hábitos, costumes e formas de interação que se mostraram incomuns para nós. É assim que, acredito, fenômenos migratórios não deixaram de exercer sobre mim um certo fascínio enquanto formas de manifestação da realidade: a imigração é algo constitutivo da minha própria biografia, e uma constante na definição de minha posição social.

Possuir uma biografia em certo grau vinculada à CAC certamente possui implicações sobre a minha condição de pesquisador no trabalho de campo. O meu acesso a entrevistados pode ter sido diferenciado, não apenas por possuir redes de relações que tornavam o percurso a fontes primárias menos custoso, mas também ao contar com certa empatia daqueles que me viam, possivelmente, como semelhante em uma trajetória comum. $\mathrm{O}$ reconhecimento tácito foi em alguns casos potencializado em situações em que meus contatos reconheciam positivamente o meu intuito de pesquisar o empreendimento e a possibilidade de produzir conhecimento a partir de suas histórias de vida. Mas a minha biografia também pode gerar limitações na realização da pesquisa, principalmente por meio de vieses. Nesse aspecto, é válido registrar o meu esforço constante em minimizar o seu potencial de acarretar prejuízos à análise. Baseado nas considerações de Roberto Cardoso de Oliveira, considero que a experiência vivida pelo 
pesquisador não elimina do exercício da compreensão a sua capacidade geradora de hipóteses e conjecturas, ou seja, de desenvolver analiticamente a explicação: "a validação das observações construídas no interior das experiências vividas pelo pesquisador - tipicamente no exercício da pesquisa de campo - não tiram seu caráter eminentemente interpretativo-compreensivo" (OLIVEIRA, 2006, p.91).

A escolha por investigar o ambiente de gestão da Cooperativa e oferecer uma interpretação sobre a atuação de seus principais membros foi estimulada por contatos iniciais em trabalho de campo. Nos discursos produzidos pelos entrevistados nesta pesquisa - em sua maioria ex-funcionários e ex-diretores da Cooperativa - dois assuntos se mostraram recorrentes: o processo falimentar do empreendimento e a reprodução de uma narrativa exitosa da imigração japonesa. Esses assuntos emergiam aleatoriamente nas entrevistas, mas geralmente obedecendo a um tipo de estrutura discursiva que intercalava momentos em que relatos individuais se associavam a uma narrativa exitosa da imigração, e outros em que considerações gerais sobre a trajetória da empresa se associavam ao processo falimentar. Nas entrelinhas desses discursos, pude constatar menções aos principais gestores da Cooperativa, como Kenkiti Simomoto, Gervásio Inoue e Fábio Yassuda. Pessoalmente, isso não representava algo inédito pois, ao que posso recordar, esses personagens eram frequentemente enaltecidos e possuíam status de autoridades - principalmente nos espaços de sociabilidade ligados à Cooperativa.

Um dado relevante a ser destacado é que a imagem desses personagens parecia subsistir no imaginário coletivo, a despeito da forma diacrônica de organização dos fatos históricos que pudessem levá-los ao esquecimento. No caso de Kenkiti Simomoto e Fábio Yassuda, o sentimento de admiração manifestado pelos entrevistados era recorrente, enquanto no caso de Gervásio Inoue parecia haver mais ressalvas. Apesar dessa diferenciação, se um certo tipo de memória desses gestores podia ser observado no discurso nativo, os meus interesses de pesquisa me conduziram à investigação detida dos motivos que nutriam a preservação dessas biografias, além da óbvia constatação de que se trata de personagens que ocuparam os cargos máximos de comando da Cooperativa.

Envolvi-me, então, numa longa pesquisa, realizada entre os anos de 2011 e 2014. A análise do material empírico, tal como apresentada nesta tese, se divide em duas 
grandes partes. De forma sintética, o Capítulo 1, intitulado "Gestão, agentes e relações: entre as oportunidades e os limites da incorporação" discorre sobre acontecimentos envolvendo os gestores de primeira geração da CAC e o universo dos imigrantes japoneses residentes em São Paulo entre as décadas de 1930 e 1950, enquanto o Capítulo 2, intitulado "Pela consagração de uma jornada ascendente", aborda os gestores de segunda geração entre as décadas de 1950 e 1980.

No Capítulo 1, inicialmente descrevo dois modelos de gestão empresarial que foram predominantes no núcleo gestionário da $\mathrm{CAC}$, considerando-os enquanto um conjunto de práticas organizacionais institucionalizadas, recorrentes e passíveis de classificação. Ao longo do capítulo apresento evidências de que as suas particularidades encontram correspondência nas diferentes respostas dos gestores a conjunturas que ofertavam possibilidades historicamente situadas de atuação empresarial e de incorporação. Ao assumir que o comportamento dos gestores representa um dado relevante para compreender os caminhos percorridos pelo empreendimento, busco identificar quais relações sociais e fatores subjacentes às ações desses gestores adquirem qualidade explicativa. O capítulo se organiza em seis seções.

No tópico 1.1, "Estado, imigrantes e cooperativismo", são abordados dois assuntos distintos e inter-relacionados: a emergência do cooperativismo e a dinâmica da imigração japonesa no Brasil. A sua breve análise procura situar o início das atividades da Cooperativa em uma conjuntura política possuidora de características singulares. Exponho que a regulação da atividade cooperativista teve início nos primeiros 15 anos do governo de Getulio Vargas, em uma conjuntura em que a modernização e a diversificação agrícola foram estimuladas, bem como o Estado passou a adquirir uma centralidade, talvez inédita, no período da história republicana do país: em âmbito político, a regulação estatal se expressou por meio de um controle mais amplo e sistemático sobre as condições de vida da população, e no plano cultural buscou-se a construção de valores e ideias que sintetizassem um ideal de "nação" brasileira. Argumento que nesse contexto o cooperativismo emergiu como oportunidade institucionalizada, apresentando uma dualidade quando observada a partir da realidade vivenciada pelos imigrantes japoneses: ao longo da década de 1930 a repressão política estatal dirigida aos grupos estrangeiros residentes no país se intensificou, enquanto o 
cooperativismo passou a ser estimulado por meio de políticas que ofertaram uma estrutura financeira e legal de suporte a esse tipo de atividade. Foi nesse referido contexto que a CAC foi fundada por iniciativa de imigrantes japoneses egressos do sistema de colonato.

No tópico 1.2, "Modelos de gestão empresarial e clivagens geracionais", apresento as características mais manifestas dos dois modelos de gestão empresarial da Cooperativa por mim identificados. Elas indicam que esses modelos constituíram formas organizacionais formuladas no seio gestionário do empreendimento, foram predominantes em épocas distintas e representaram respostas situacionais a diferentes conjunturas. É argumentado que esses modelos de gestão podem ser examinados sob uma abordagem sociológica, que por um lado complexifique o seu entendimento e, por outro, ofereça uma alternativa à literatura já existente a respeito dessa Cooperativa. A forma aqui adotada para a realização dessa tarefa foi examinar as relações de tais modelos de gestão com processos sociais indissociáveis da experiência migratória vivenciada por uma fração dos imigrantes japoneses residentes em São Paulo - um restrito grupo de indivíduos que alcançou posições de liderança entre a população de origem japonesa e que, por vezes, formulou respostas às barreiras de aceitação e de incorporação na sociedade local. Em diferentes conjunturas históricas e durante duas gerações sucessivas de comando da empresa, os principais gestores da Cooperativa compuseram esse grupo de lideranças, bem como ofereceram diferentes respostas às barreiras de aceitação e de incorporação à sociedade local. Partindo dessa formulação inicial, proponho um exame da inter-relação entre esses dois espaços sociais (o de lideranças da coletividade japonesa e o de gestão da Cooperativa) em períodos de predominância dos modelos de gestão identificados.

Nos tópicos 1.3, "Lógicas de diferenciação interna e formação de lideranças", e 1.4, “A fundação da Cooperativa Agrícola de Cotia e seu respaldo institucional”, busco situar a posição social dos gestores da Cooperativa no universo dos imigrantes japoneses residentes em São Paulo entre o início da década de 1930 até o ano de 1942. Nesse período, os principais cargos de comando do empreendimento eram ocupados por indivíduos de primeira geração, fato diretamente associado à predominância de um tipo de gestão na condução dos negócios. Busco demonstrar que esses gestores tiveram 
participação em um espaço social específico de lideranças da coletividade japonesa, à época fortemente influenciado pelo Consulado Geral do Japão em São Paulo. Por esse motivo, no tópico 3, reconstituo alguns aspectos da presença da população japonesa no bairro da Liberdade, localizado na região central da cidade, destacando certas iniciativas de organização social que se concretizaram sob tutela do órgão consular. Argumento que a forte presença do Consulado e de órgãos encarregados de administrar a vinda dos japoneses para o país no cotidiano desses imigrantes particularizou as formas de organização local do grupo, ao impulsionar um processo de diferenciação social interno que criou condições para a formação de um grupo de liderança.

Inicio o tópico 1.4 reconstituindo as iniciativas que resultaram na criação da Cooperativa Agrícola no município de Cotia por imigrantes japoneses, em sua maioria egressos do sistema de colonato. Argumento que a sua fundação dependeu de incentivos oferecidos pelo Consulado, fato que possibilitou aos gestores da Cooperativa integrar o restrito circuito social encabeçado pelo órgão. A estreita relação da Cooperativa com o Consulado representou uma espécie de vínculo institucional que informava o escopo de atuação dos gestores do empreendimento: as suas ações obedeciam a uma relativa dependência jurídica e administrativa de órgãos oficiais, principalmente do referido Consulado e do Departamento de Assistência ao Cooperativismo do Estado de São Paulo. Dois eventos que permitem atestar esses argumentos são reconstituídos e analisados neste tópico.

O tópico 1.5, "Gestores de primeira geração em meio a conflitos", é dedicado a investigar como os gestores de primeira geração da CAC vivenciaram certos acontecimentos localizados no contexto da Segunda Guerra Mundial, considerando-se os efeitos da repressão política conduzida pelo Estado para a população de origem japonesa residente no Brasil. Especial atenção é conferida a uma transformação significativa no núcleo gestionário da Cooperativa ocorrida em 1942: a substituição de japoneses dos principais cargos de comando por brasileiros natos, sem descendência japonesa. Busco complexificar a compreensão de acontecimentos como esse, considerando a relevância explicativa de fatores extramercantis diretamente relacionados ao percurso de lideranças na experiência migratória dos imigrantes japoneses em São Paulo. Argumento que a abdicação do cargo máximo de comando do 
empreendimento por seu presidente, Kenkiti Simomoto, é um dado indicativo de que condicionantes políticos e culturais também conformaram o ambiente de decisões empresariais da Cooperativa. Nesse tópico também são reconstituídos outros acontecimentos que, acredito, revelam a atuação dos gestores em iniciativas formuladas enquanto respostas às barreiras de aceitação e de incorporação da população japonesa.

O tópico 1.6, "Uma segunda geração em busca de reconhecimento", encerra o capítulo, e é dedicado a examinar a formação de um restrito grupo de jovens estudantes - em sua maioria de segunda geração - residentes na capital paulista, e que a partir da década de 1930 passou a adquirir reconhecimento social por meio da criação de uma liga estudantil. Algumas características dessa liga revelam o seu pertencimento ao circuito de lideranças da coletividade japonesa da época: iniciativas como a publicação de periódicos próprios - o jornal Gakusei e a revista Transição -, foram em muitas ocasiões subvencionadas pelo Consulado Geral do Japão e pela CAC. Ademais, os seus membros eram seletos filhos de japoneses que passavam a ingressar no ensino superior, como Gervásio Inoue (que viria a ser presidente da Cooperativa em 1957) e Yukishigue Tamura (o primeiro filho de japoneses a ingressar na política ao assumir o cargo de vereador em 1947). É argumentado que, a despeito de possuir estreitos laços com as lideranças de primeira geração de imigrantes japoneses, esse grupo de estudantes formulou respostas distintas na tentativa de confrontar resistências à sua aceitação e incorporação, e aqui o processo de negociação identitária em bases étnico-raciais obteve centralidade.

A interpretação das atividades desse grupo é apresentada em uma análise que considera a dinâmica de sua organização coletiva no espaço de sociabilidade das lideranças de origem japonesa, concentradas no bairro da Liberdade. Procuro complexificar a constatação mais imediata que relaciona a existência desse grupo de estudantes com processos de negociação identitária, mediante a interpretação dos seus significados mais latentes. Se, inicialmente, os seus anseios de incorporação enxergavam na escolaridade a forma mais adequada de uma ascensão social, demonstro que em um contexto de repressão contra estrangeiros, a política se revelou uma dimensão central para as aspirações desses indivíduos de segunda geração. Por fim, é argumentado que as diferentes respostas às barreiras de aceitação na sociedade local 
formuladas por indivíduos de primeira e segunda geração de japoneses - pertencentes a um restrito circuito de lideranças - se realizaram em um intercâmbio com o universo de gestão da CAC.

Inicio o Capítulo 2 abordando um evento específico capaz de ilustrar, de maneira mais imediata, três aspectos da trajetória da Cooperativa que interessam diretamente a este estudo: a inserção de seus gestores no núcleo de poder governamental de um regime político dotado de características singulares na história da sociedade brasileira: o governo militar (1964-1985); a condução e a predominância de um modelo de gestão empresarial da Cooperativa por indivíduos de segunda geração de imigrantes japoneses; a ocorrência desses eventos em uma conjuntura em que as formas de organização social das diferenças e oportunidades conformaram um ambiente de maior aceitação da população japonesa, quando comparado às três décadas anteriores.

O evento em questão é a posse do cargo de ministro da Indústria e Comércio no Governo de Emílio Garrastazu Médici (1969-1974) por um personagem que há ao menos duas décadas havia feito parte do corpo diretivo da CAC: Fábio Yassuda. A sua posse ministerial se mostrou envolta por uma simbologia que, em minha interpretação, foi representativa em expressar processos sociais mais amplos observáveis na experiência migratória dos japoneses no Brasil. O evento analisado é, portanto, adotado como um ponto de partida para o objetivo de examinar processos que possibilitaram uma maior aceitação da população japonesa em São Paulo, situando agentes que, em maior ou menor grau, tornaram a CAC um espaço relevante para a construção de relações de poder e de estratégias de incorporação. Essa problematização relaciona mercado e cultura sob o entendimento que processos que culminaram em um ambiente maior aceitação social dos japoneses se desenvolveram em confluência com o sucesso econômico de seus maiores empreendimentos agrícolas.

O tópico 2.1, "Os imigrantes japoneses e a democracia racial", é dedicado a analisar o constructo - recorrente no cotidiano da cidade de São Paulo à época da posse de Fábio Yassuda - de que a origem japonesa estaria associada a valores positivos e desejáveis. Isso demandou observar, nos anos do pós-guerra, de que formas a sociedade local e os grupos estrangeiros mobilizaram categorias centrais para a conformação de 
um novo contexto de oportunidades e diversidade social, como "nação", democracia", "desenvolvimento" e "raça". É argumentado que o período de intervalo democrático (1945-1964) possui centralidade para compreender a conformação de um ambiente mais favorável e inclusivo para a população de origem japonesa no Brasil. Nele vigorou um pacto político e de classes que sustentou as bases do mito da democracia racial, oferecendo certas condições para que a aceitação das diferenças da população japonesa fosse concebida. Em âmbito relacional, estratos privilegiados da coletividade japonesa se valeram de recursos ao seu alcance para experimentar a sua inserção no meio profissional, intelectual e em núcleos de poder em âmbito político e econômico. Individualmente, certos personagens - especialmente os de segunda geração - foram proeminentes na tarefa de disseminar e validar uma narrativa de sucesso da trajetória migratória, ou mesmo publicizar uma imagem positiva de si próprios enquanto retrato do sucesso por muitos vislumbrado.

O tópico 2.2, "O Jornal Paulista e os primeiros políticos de origem japonesa", apresenta evidências empíricas que permitem sustentar a relação entre uma conjuntura na qual vigorou um pacto de classes que sustentou o mito da democracia racial e a conformação de um ambiente mais favorável e inclusivo para a população de origem japonesa no Brasil. São analisados os casos do Jornal Paulista, fundado em 1947, e o ingresso do filho de japoneses Yukishigue Tamura na vida política, ocorrido naquele mesmo ano. Demonstro que tanto a criação do periódico quanto a candidatura de Yukishigue Tamura se realizaram dentro do escopo de influência da Cooperativa nos acontecimentos mais notáveis e prementes das lideranças da coletividade japonesa da época. Argumento que mais do que uma empresa cujo espaço de atuação se limitaria ao mercado, a Cooperativa se apresentava como uma organização coletiva de notável capacidade de controle e disseminação de ideias. O que se sobressai dessa característica é o seu comprometimento com um projeto coletivo de incorporação à sociedade brasileira formulado pela liderança intelectual do grupo, em um contexto político de redemocratização.

No tópico 2.3, "Incorporação em debate: gerações de lideranças se encontram”, são abordadas duas reuniões realizadas na sede da CAC que congregaram a denominada intelectualidade japonesa de São Paulo - entre eles, membros do Jornal Paulista e 
Yukishigue Tamura - com a finalidade de debater a questão geracional. Os relatos a respeito das reuniões permitem identificar a existência de uma heterogeneidade de interesses e de pontos de vista a respeito de uma proposta coletiva de incorporação elaborada pelo grupo e, principalmente, a respeito das formas de equacionar uma complexa ordem cultural de constituição de diferenças visando à aceitação social, objetivo demarcado pela nacionalidade e pela geração. Argumento que os gestores da CAC de primeira e segunda geração vivenciaram o contexto de repressão política do Estado Novo de formas qualitativamente distintas, fato que contribuiu para que suas respostas às constrições se expressassem de maneira diferenciada.

No tópico 2.4, "A guerra como metáfora", problematizo dois aspectos da nomeação de Fábio Yassuda ao cargo de ministro da Indústria e Comércio em 1969: o seu discurso de posse ministerial e a sua ascensão política enquanto filho de imigrantes japoneses, expoente do universo empresarial. Argumento que a compreensão dos significados presentes em seu discurso de posse pode ser complexificada mediante o exame de processos que possibilitaram que grupos minoritários passassem a ser paulatinamente reconhecidos e incorporados nos planos político, econômico e cultural. A sua ascensão no núcleo de poder governamental enquanto filho de imigrantes deve ser interpretada considerando-se: processos bilaterais de redefinição dos parâmetros reguladores e dos componentes políticos e simbólicos que distanciavam a população japonesa de sua aceitação; e a sua visibilidade enquanto gestor construída ao longo de duas décadas com o respaldo da CAC, característica que correspondia aos critérios de recrutamento do quadro governamental durante o regime autoritário.

O tópico 2.5, "Gestores de segunda geração e o seu protagonismo", é dedicado ao exame de certas ações dos principais gestores da CAC, Fábio Yassuda e Gervásio Inoue, entre as décadas de 1950 e 1960. No período considerado, esses personagens de segunda geração foram centrais nos caminhos percorridos pelo empreendimento ao consolidar um tipo de gestão distinto daquele predominante até a década de 1940. Analiso algumas das respostas desses gestores a conjunturas que ofertavam possibilidades historicamente situadas de atuação empresarial e de reconhecimento social. São apresentados dados que indicam a mobilização de recursos visando a melhores resultados por meio de relações políticas - como a presença desses gestores 
em órgãos classistas setoriais -, bem como a participação desses dois gestores em iniciativas do restrito grupo de lideranças da coletividade japonesa visando à produção de narrativas a respeito da experiência migratória do grupo - a exemplo de sua presença em comissões de celebração dos 56 anos da imigração japonesa no Brasil. Argumento que as ações dos gestores desse empreendimento, em fins da década de 1960, possuíam uma origem e foram tributárias de fatores que se localizam além da mera instrumentalização de recursos disponíveis visando unicamente ao alcance de interesses racionais. Elas também foram informadas por processos relacionados à experiência migratória dos japoneses no Brasil, em que uma segunda geração passava a viver a sua inserção em dimensões importantes da vida social.

No tópico 2.6, "Por dentro da estrutura de poder e decisão política", interpreto a participação e a posição ocupada por Fábio Yassuda no governo Médici a partir da caracterização da estrutura estatal vigente naquele regime. Dois aspectos dessa estrutura são destacados: a relação entre o Estado e o capital privado e a emergência da tecnocracia e sua lógica de operação. Além disso, ressalto a centralidade do Estado como agente repressivo, cooptativo e propulsor ativo das decisões político-econômicas a partir do funcionamento de um núcleo decisório restrito em que o Ministro da Fazenda concentrava grande poder. Argumento, portanto, que a posição ocupada por Fábio Yassuda no quadro governamental deve ser compreendida em relação à estrutura de poder e de planejamento econômico do regime político autoritário. Pois, ao final da década de 1960, a Cooperativa operava em todo o país e possuía controle sobre grande parte do fornecimento e do preço de determinados produtos agrícolas nos principais entrepostos de alimentos de São Paulo, da região metropolitana e de outros estados, como o Rio de Janeiro. Mas os desdobramentos da mudança de regime político se apresentaram para as lideranças de origem japonesa em São Paulo como um novo desafio de adequação, tanto do ponto de vista da estrutura burocrática, quanto em relação às benesses que a incorporação em núcleos de poder e de representação de interesses pudessem oferecer. O que o caso da ascensão de Fábio Yassuda ao poder parece indicar é que a CAC elaborou formas de se adequar a essa nova conjuntura de desenvolvimento econômico ao alcançar uma posição capaz de operar a articulação entre os interesses empresariais e os núcleos de poder decisório estatal. 
No tópico 2.7, "Agricultura em evidência e personificação exemplar", apresento de maneira breve as políticas econômicas em curso em fins da década de 1960 e início da década de 1970 na tentativa de demonstrar como os gestores da CAC formularam estratégias para se adaptar a esse novo contexto. É ressaltado que, sob a retórica de um modelo agrícola-exportador, o governo federal ofereceu grandes estímulos à agricultura especialmente sob a forma de crédito, a legislação cooperativista sofreu alterações e programas de parceria público-privada foram criados. A CAC passou a adotar uma estratégia de investimentos centrada no endividamento a longo prazo para o autofinanciamento de suas imobilizações e, diferente de qualquer outro empreendimento cooperativo do setor agrícola, apresentava sinais evidentes de ter alcançado uma posição estratégica no mercado de abastecimento nacional, a ponto de ser partícipe dos planos de desenvolvimento agrícola do governo militar. Acompanhando esse novo tipo de conduta, as ações dos gestores da Cooperativa, nessa conjuntura, se apoiavam em uma retórica singular, produzindo discursos em sintonia com um tipo de pensamento técnicocientífico vigente. À frente do empreendimento, seu presidente, Gervásio Inoue, também gozava de prestígio em meio à opinião pública, a ponto de ser considerado um expoente das lideranças da coletividade de origem japonesa no Brasil e uma autoridade em temas relacionados à agricultura. A sua imagem enquanto um expoente do mundo dos negócios era frequentemente associada a uma narrativa exitosa da imigração em jornais e revistas de ampla circulação: uma espécie de personificação exemplar, cujo sucesso profissional e econômico oferecia indícios que pudessem atestar a "integração" dos japoneses na sociedade brasileira.

No tópico 2.8, "Mudança organizacional e declínio", abordo o processo de crise financeira e de mudança institucional da Cooperativa entre as décadas de 1980 e início da década de 1990. Nesse período, o seu principal gestor, o presidente Gervásio Inoue, assistiu ao declínio do seu prestígio, ao passo que nos principais meio de comunicação a narrativa que associava a Cooperativa a uma trajetória exitosa da imigração japonesa dava lugar ao acompanhamento do seu quadro de crise financeira. Demonstro que condicionantes de natureza política, em curso a partir da década de 1960, tiveram efeitos sobre a sua estrutura organizacional, a exemplo de mudanças na posição ocupada pela base cooperada e pelo núcleo decisório nessa estrutura. Partindo do diagnóstico mais 
geral de endividamento financeiro da Cooperativa - em evidência a partir da década de 1970 e intensificado na década seguinte -, busco demonstrar que esse fenômeno não esteve dissociado do universo de relações sociais que organizavam as práticas adotadas no ambiente gestionário. Um enfoque especial é conferido a um aspecto dessas mudanças que, de forma inédita, passou a caracterizar aquele ambiente: a predominância de relações de poder, expressas por disputas por recursos e cargos de comando.

Este percurso interpretativo foi feito sob a orientação da $\operatorname{Prof}^{a} \operatorname{Dr}^{a}$ Nadya Araújo Guimarães e co-orientação do Prof. Dr. Sedi Hirano. Fui contemplado com uma bolsa de doutorado do Conselho Nacional de Desenvolvimento Científico e Tecnológico (CNPq), a quem sou grato. Ao longo desse período também pude participar de outras importantes atividades para a minha formação acadêmica, desenvolvidas no âmbito do Programa de Pós-Graduação em Sociologia da Universidade de São Paulo: a Oficina de Sociologia Econômica e do Trabalho (OSET), coordenada pela Prof ${ }^{a}$ Nadya Guimarães; a revista Plural, do Programa de Pós-Graduação em Sociologia; a Newsletter Global Dialogue, editada pela International Sociological Association (ISA).

Entre os meses de fevereiro e junho de 2014 realizei um estágio doutoral na Universidade de Princeton, Estados Unidos, sob a condição de Visiting Student Research Collaborator (VSRC), sendo recebido pela Professora Viviana Zelizer, do Departamento de Sociologia daquela instituição. O estágio doutoral foi realizado com o suporte do convênio firmado entre a Universidade de São Paulo e a Universidade de Princeton, denominado Rede de Pesquisa: Raça e Cidadania na América (Global Collaborative Network: Race and Citizenship in the America). Fui contemplado por uma bolsa do Programa de Doutorado Sanduíche no Exterior (PDSE) fornecida pela Coordenação de Aperfeiçoamento de Pessoal de Nível Superior (CAPES), a quem sou grato. 


\section{Pontos de partida e desafios: novas fontes primárias e antigas interpretações}

O desenvolvimento do argumento acima apresentado se fez sob o impulso do desafio de construir uma análise do tema que pudesse inovar não somente por, como dito até aqui, embeber a reflexão sobre o caso de Cotia nos debates teóricos contemporâneos, mas que revisitasse antigas interpretações contruídas tendo em mente também novas fontes primárias às quais foi possível ter acesso durante o processo de pesquisa. Situar melhor esse desafio é, por isso mesmo, um último preliminar de natureza introdutória que valeria estabelecer. Comecemos pelas novas fontes.

Durante o período de realização desta pesquisa tive acesso a duas fontes de dados documentais que se revelaram centrais: o acervo pessoal do sociólogo Hiroshi Saito, disponibilizado por sua família em julho de 2011; e documentos do Centro de Documentação do Instituto de Assistência ao Cooperativismo da Secretaria da Agricultura do Estado de São Paulo, coletados entre maio de 2013 e janeiro de $2014^{5}$.

O acervo pessoal do sociólogo Hiroshi Saito foi inicialmente recebido pela Casa de Cultura Japonesa da Universidade de São Paulo. Ele foi disponibilizado em cerca de 35 caixas contendo a sua biblioteca, manuscritos, transcrições de entrevistas, cadernos de campo (em língua portuguesa e japonesa) e correspondências pessoais. Os documentos recobrem o período de maior atividade de pesquisa de Hiroshi Saito, entre fins da década de 1940 e o início da década de 1980. O seu acervo pessoal representou uma valiosa fonte de dados, por alguns motivos.

Hiroshi Saito foi o primeiro sociólogo a dedicar inteiramente uma pesquisa acadêmica (no caso, a sua dissertação de mestrado, iniciada em 1953 sob orientação de Donald Pierson) à CAC. Hiroshi Saito chegou ao Brasil na década de 1930 como imigrante, e posteriormente abandonou as lavouras de algodão para residir definitivamente na capital paulista. Ao longo desta tese demonstrarei que já em meados

\footnotetext{
${ }^{5}$ Sou especialmente grato a Koichi Mori, Hugo Saito, Thelma Carvalho e Diogenes Kassaoka, pessoas que contribuíram de várias formas para o meu acesso a essas fontes. Também não posso deixar de registrar meus agradecimentos aos professores Sedi Hirano, Nadya Guimarães, Mário Eufrásio, Bianca Vyunas, Samara Konno, Álvaro Kanashiro, Thiago Haruo Santos, Carolina Cruz Gonzalez, Jéssica Zanovello, Bianca Hsiao, Júlia Maria França e Priscila Vasconcelos pela ajuda no trabalho de organização e de digitalização dos documentos.
} 
da década de 1940, quando se dedicava ao jornalismo, Saito foi um importante membro do núcleo de lideranças da coletividade japonesa em São Paulo. Essa condição privilegiada possibiltou que o sociólogo realizasse entrevistas com alguns dos principais gestores da CAC, como Kenkiti Simomoto, Kumaki Nakao e Kameiti Yamashita. Trechos dessas entrevistas foram transcritas em fichas e compõem o seu acervo. Essas entrevistas constituem-se num rico - e novo - acervo de dados sobre a CAC produzidos pelo pesquisador na década de 1950 e até aqui desconhecidos, que pude acessar com exclusividade. Pude digitalizar as suas fichas, nas quais se continham transcrições de entrevistas e seus diários de campo ${ }^{6}$.

No primeiro semestre de 2013, tive acesso a documentos da Cooperativa na Secretaria da Agricultura do Estado de São Paulo. Em seus depósitos pude encontrar uma grande quantidade de documentos originais da Cooperativa que recobrem o período entre as décadas de 1930 e 1990. Com exceção de alguns exemplares dos Relatórios de Serviços Sociais da Cooperativa, grande parte desses documentos não estava organizada, mas apenas armazenada em caixas. O material ali encontrado foi produzido ao longo de décadas de contato entre a Cooperativa e a Secretaria da Agricultura. Dei início então a um trabalho de digitalização desses documentos, que pude classificar basicamente como: relatórios de atividade comercial, balanços financeiros, estatutos, pedidos de assistência enviados ao Departamento de Assistência ao Cooperativismo, listas de cooperados, pedidos de financiamento e isenção de impostos, registros em junta comercial, atas de assembleias da diretoria. Ao total, foram digitalizadas cerca de sete mil páginas de documentos ${ }^{7}$.

Tudo leva a crer que esta foi a primeira vez em que esses dois acervos foram utilizados para fins de pesquisa, e estou seguro de que os dados ali disponibilizados

\footnotetext{
${ }^{6}$ No segundo semestre de 2013, após um incidente que quase resultou na destruição desse acervo, entrei em contato com a família Saito e propus a doação do acervo ao Instituto de Estudos Brasileiros da Universidade de São Paulo (IEB), instituição que poderia abrigá-lo em uma infraestrutura mais adequada. Até o momento de finalização desta tese, o pedido de doação ao IEB encontra-se em trâmite, e não há certezas sobre qual será o destino do acervo.

7 O fato de eles ainda não terem sido classificados e organizados por qualquer instituição os torna momentaneamente indisponíveis para consulta. Todavia, tenho reunido esforços para que esse material possa futuramente ser disponibilizado para o acesso público.
} 
iluminam e podem reorientar muitas das interpretações produzidas anteriormente sobre o caso da CAC.

Com efeito, convém finalizar estas notas introdutórias localizando as contribuições e as limitações de estudos anteriores, resultantes do processo de constituição de um campo de estudos. Elas nos permitem reconstruir a realidade pesquisada, situando-a em um lugar teórico-metodológico particular. Parafraseando Guimarães (2004), parte-se também aqui do pressuposto de que a descrição e a análise empírica são procedimentos que informam intenções, e as ferramentas conceituais e metodológicas utilizadas dependem da forma como o campo é compreendido.

Chama a atenção, por ser considerável, o número de estudos sobre a experiência de imigrantes japoneses no Brasil. Mesmo se restringíssemos a produção existente sobre o tema à área das ciências sociais, seria uma tarefa infindável apresentar uma revisão que abordasse esses estudos em suas diversas temáticas. Por esse motivo, apresento aqui unicamente a produção acadêmico-científica de destaque que tratou especificamente da CAC. Procurarei informar ao leitor sobre as principais características dessa produção e sugerir os novos caminhos de pesquisa que se abriam a partir delas, sustentando, assim, a relevância de um estudo atual sobre o tema.

Uma revisão das pesquisas existentes sobre a CAC permite localizar estudos em ao menos três áreas de conhecimento: sociologia, geografia e economia agrária. Além dessa literatura, é possível afirmar que as publicações da própria instituição também são provedoras de narrativas internas sobre a sua história.

Apesar de a imigração japonesa no Brasil ter iniciado oficialmente em 1908, foi somente na metade da década de 1930 que as instituições científicas na área das ciências humanas se institucionalizaram em São Paulo, tornando possível então a realização de estudos específicos sobre esses imigrantes. É possível ressaltar que os estudos sobre japoneses no Brasil tiveram início no seio do projeto acadêmico de desenvolvimento das ciências sociais paulista e, nas duas décadas seguintes, se desdobraram em numerosas pesquisas. Contudo, foi no início da década de 1950 - e, portanto, após o término da Segunda Guerra Mundial - que estudos específicos sobre agricultores japoneses em Cotia se realizaram. Nas duas décadas seguintes, houve uma reorientação das questões 
que motivaram esses estudos precursores e, por fim, na década de 1990, o caso dessa cooperativa foi estudado com o objetivo de explicar as circunstâncias do seu fracasso.

Inicialmente, o caso dos agricultores de Cotia despertou o interesse de geógrafos que acompanhavam o processo de desenvolvimento da agricultura no estado de São Paulo, por vários motivos: do ponto de vista regulatório, durante o Governo Provisório de Getulio Vargas foi criada a primeira legislação cooperativista brasileira em 1932. No ano seguinte, era criado o Departamento de Assistência ao Cooperativismo (DAC), subordinado à Secretaria da Agricultura, Indústria e Comércio do Estado de São Paulo, por meio do Decreto n. 5.966. As condições institucionais agora estimulavam a criação de cooperativas, resultando em um aumento considerável de novas organizações desse tipo. No caso da população japonesa isso teve impactos bastante representativos: ao final da década de 1930 havia 23 cooperativas agrícolas de imigrantes japoneses e 4.938 cooperados associados a elas.

O crescimento urbano e populacional do município de São Paulo passou a constituir um tema de estudos nas recém-criadas faculdades de ciências humanas, pois além da reconfiguração intensa dos centros urbanos, havia grande demanda pela expansão das áreas cultiváveis que se voltassem para a produção de alimentos. Foi nesse contexto que a agricultura diversificada em pequenas propriedades se desenvolveu nos subúrbios da cidade, a exemplo de Itaquera, Suzano, São Roque, Vargem Grande, Itapecerica da Serra, Ibiúna e Cotia ${ }^{8}$. Para os imigrantes japoneses, a "agricultura suburbana" representou também oportunidades de inclusão em melhores posições na estrutura ocupacional, especialmente para os agricultores que haviam chegado ao Brasil sob a condição de colonos, como era o caso da maioria dos japoneses. Por meio do arrendamento de terras ${ }^{9}$, muitas famílias de imigrantes japoneses passaram a se dedicar

\footnotetext{
${ }^{8}$ Segundo Penteado: "A função agrícola é também muito importante e constitui, sob certos aspectos, uma tradição dos subúrbios de São Paulo. Nos últimos 25 anos, criou-se em tôrno da cidade uma verdadeira zona hortense, com a multiplicação das culturas de legumes e também de flôres; as chácaras, que já aparecem no próprio perímetro urbano, multiplicam-se através da região da Cantareira e nas vizinhanças da Penha e estendem-se mesmo muito além da zona Central. Ao mesmo tempo, na região de Cotia e Itapecerica da Serra, culturas maiores (batatinha, milho, feijão, mandioca, arroz frutas) apresentam muita importância" (PENTEADO, 1958, p.7).

${ }^{9} \mathrm{O}$ "arrendamento" é uma modalidade de contrato em que o proprietário da terra cede por tempo determinado o uso de uma propriedade rural para exploração, observado pelos limites da lei. No caso, era comum o uso do Código Civil de 1916, especialmente os artigos 678, 689 e 724. O arrendatário, por sua
} 
a esse tipo de produção, abandonando o cultivo do café e o tipo de relação contratual anteriormente estabelecida com grandes fazendeiros.

Antes da entrada do Brasil na Segunda Guerra, a população japonesa no país ultrapassava 140.000 indivíduos para o ano de 1940, sendo que 91,5\% residiam no estado de São Paulo ${ }^{10}$ e um percentual expressivo exercia atividades ligadas à agricultura. Se a parte majoritária dos imigrantes iniciou as suas atividades em colônias espalhadas pelo estado e subsidiados pelo governo estadual e pelo governo japonês, na referida década o perfil da população japonesa já apresentava sinais de mudança. Observa-se uma tendência crescente à condição de arrendatários, locatários ou proprietários de terras ${ }^{11}$.

Esse conjunto de transformações demográficas, econômicas e sociais expõe o contexto mais geral em que "Propriedades de japoneses na região de Cotia" foi escrito. De autoria de Emília da Costa Nogueira e Francisca M. Nunes, o artigo foi publicado no número 9 da revista Geografia Agrária, em outubro de 1951. As informações ali contidas expõem em detalhes as características geomorfológicas da região, bem como as condições climáticas e técnicas voltadas para o plantio. Entretanto, trata-se de um estudo sobre as propriedades de lavradores japoneses - sendo eles cooperados da CAC - e não de um estudo propriamente sobre essa cooperativa.

O interesse das autoras, licenciadas em Geografia pela Faculdade de Filosofia, Ciências e Letras da Universidade de São Paulo, se voltou para a análise de duas propriedades de japoneses, em virtude de sua presença marcante nas atividades agrícolas do município:

Os japoneses predominam, sem dúvida alguma, no bairro do Moinho Velho. Estabeleceram-se na área dominada por Cotia há cêrca de 30 anos, em terras outrora pertencentes a grandes fazendas, que se viram partilhadas. Muitos

\footnotetext{
vez, se responsabiliza pelos riscos e custos da atividade agrícola e se obriga a pagar uma quantia líquida para o arrendador. Para mais detalhes, ver: SALGADO, G.M.. Discussões legislativas do Código Civil de 1916: Uma revisão historiográfica. Âmbito Jurídico, Rio Grande, v. XV, n. 96, jan. 2012.

${ }^{10}$ Para mais detalhes, ver: [IBGE] INSTITUTO BRASILEIRO DE GEOGRAFIA E ESTATÍsTICA. Resistência e integração: 100 anos de imigração japonesa no Brasil. Brasília: IBGE, 2008.

${ }^{11}$ Ver SUZUKI, T. The Japanese Immigrant in Brazil. v. 2, p. 241, 1969, tabela 255.
} 
deles não se fixaram, partindo em busca de outras zonas mais próximas (Ibiúna, Piedade, Vargem Grande) ou bem mais afastadas (Lins); outros, porém, permaneceram e continuam a marcar fortemente a paisagem com sua presença. (NOGUEIRA; NUNES, 1951, p.39)

As propriedades, consideradas típicas, eram de dois tipos de ocupação: em uma delas o lavrador era o proprietário da terra cultivada, de área de um alqueire e dez tarefas; na outra, o lavrador era arrendatário de uma área de quatro alqueires. A diferença na ocupação da terra, segundo as autoras, trazia consigo também diferenças nas técnicas de cultivo empregadas e na maneira de aproveitamento do solo.

$\mathrm{Na}$ descrição do primeiro caso analisado pelas autoras, Nogueira e Nunes escrevem que a atividade principal da propriedade, localizada a 1.800 metros da estrada que liga São Paulo a Cotia, é dedicada predominantemente à horticultura associada à criação de galinhas, sendo a maior parte do solo ocupada pela plantação de tomates. Nesse caso, possui destaque o uso estratégico da terra, inclusive adotando-se técnicas apropriadas de irrigação:

Em pequena área de um alqueire e 10 tarefas, tôda terra precisa ser intensamente aproveitada para poder compensar a exploração. Ali o fato se tornou possível por ser o agricultor bom conhecedor do labor agrícola. As delicadas técnicas, que emprega, dão à cultura o aspecto de verdadeira jardinagem e permitem o total aproveitamento do solo. (NOGUEIRA; NUNES, 1951, p.42).

Em seguida à descrição inicial da propriedade, as autoras mencionam o fato de o lavrador ser cooperado da Cooperativa. O proprietário entregava metade de sua produção à cooperativa e esta fornecia adubo, sementes e folhetos mensais para orientação do plantio. A criação de galinhas do tipo Leghorn e a produção de ovos também eram realizadas em parceria com a Cooperativa, pois esta fornecia os filhotes e ração especial. Segundo as autoras: “A safra (de ovos) é entregue à cooperativa de dois em dois dias, embalada em caixas especiais. A CAC fica com $12 \%$ do preço obtido, $4 \%$ sendo consignado como quota no nome do proprietário e os $8 \%$ restantes como lucro da cooperativa” (NOGUEIRA; NUNES, 1951, p.47). 
$\mathrm{Na}$ segunda propriedade estudada, que era arrendada, uma área relativamente menor estava cultivada e os principais produtos eram couve-flor, batata e milho. As técnicas de plantio seguem um padrão semelhante à primeira propriedade, ou seja, há o emprego de técnicas agrícolas apropriadas. A orientação para a lavoura, o fornecimento dos insumos e a comercialização dos produtos também era feita pela por meio da cooperativa japonesa: "A venda do produto é feita através da CAC, a qual se encarrega também do transporte da mesma desde a propriedade até o centro de comércio" (NOGUEIRA; NUNES, 1951, p. 52).

O principal objetivo do artigo era apresentar em detalhes o cultivo, as técnicas empregadas e o uso do solo em relação às formas de ocupação da terra. O argumento mais geral é de que na condição de proprietário, o lavrador realizaria um esforço constante para melhorar o desempenho da agricultura, resultando num melhor aproveitamento do solo. No caso do arrendatário, isso não era observado. Como conclusões, as autoras afirmam:

\begin{abstract}
Se há diferenças entre as propriedades, existe um traço comum a ambas: as culturas são resultantes da adaptação de técnicas agrícolas orientais ao novo quadro geográfico. Também o homem apresenta características comuns: num e noutro caso, a posição de agricultor é transitória, os filhos já frequentam a escola e os pais não desejam que eles continuem na lavoura; além disso, caracterizam-se por um forte sentimento de cooperação, o que, aliás, é comum aos núcleos de colonização japonêsa, fato perfeitamente explicável pela necessidade de mútuo apoio que sentem os imigrantes. (NOGUEIRA; NUNES, 1951, p. 59)
\end{abstract}

Esse artigo guarda possivelmente as primeiras menções à CAC na literatura produzida por pesquisadores stricto sensu das ciências humanas. Como já foi dito anteriormente, os primeiros estudos sobre imigrantes japoneses nas ciências sociais foram realizadas anos antes, no início da década de 1940. Entretanto, por parte dos pesquisadores, até a década de 1950 pouca ou nenhuma atenção havia sido conferida às atividades econômicas desses imigrantes e a sua trajetória na estrutura ocupacional e, dessa forma, o cooperativismo agrícola japonês poucas vezes havia sido objeto de análise. 
Isso pode ter explicações no próprio desenvolvimento desse campo de estudos, pois o que se verifica é que grande parte da discussão se dedicava à explicação das formas de "assimilação" e "integração" da população japonesa à sociedade de destino. Os estudos sobre a imigração japonesa no Brasil no âmbito acadêmico das ciências sociais procuravam apresentar, implicitamente ou explicitamente, contra-argumentos à intolerância que afirmava a impossibilidade de convivência social desse grupo na sociedade brasileira, intensificados no período da Segunda Guerra ${ }^{12}$. Considerando esses aspectos, o texto de Nogueira e Nunes possui certo ineditismo.

Sob a direção do geógrafo Aroldo Edgard de Azevedo, um dos primeiros professores de Geografia da Universidade de São Paulo, é que a autora do texto anterior, agora sob o nome Emília Viotti da Costa, publicou o capítulo "Cotia e Itapecerica da Serra, subúrbios agrícolas" no volume IV (Os subúrbios urbanos) do livro A cidade de São Paulo - estudos de geografia urbana, de 1958. No texto, dois tópicos despertam especial interesse para os objetivos da presente pesquisa: "O elemento japonês e a paisagem regional" e "As cooperativas agrícolas".

No primeiro tópico, inicialmente é destacado no texto a presença japonesa em pequenas propriedades agrícolas dedicadas à agricultura mista, ao plantio de batatas e aves e uso de técnicas avançadas:

Onde quer que se localizem, imprimem os japonêses sinais iniludíveis de sua presença. São as culturas intensivas. É o cuidadoso arranjo de suas propriedades, caracterizadas pelas linhas geométricas dos canteiros, pelo terraceamento das encostas, pelas canaletas abertas nas várzeas, para a drenagem ou para a irrigação. As técnicas que empregam, que muito têm de jardinagem, constrastam de maneira evidente com as dos agricultores nacionais, sobretudo os caipiras, que não sabem compor suas propriedades, tudo fazem de maneira empírica e só utilizam processos atrasados e deficitários.

São as pequenas propriedades que predominam: em 1951, para um total de 1.557 propriedades localizadas no município de Cotia, nada menos de 1.383 tinham áreas inferiores a 20 alquerires e 134 entre 20 e 50 alqueires; os casos mais freqüentes possuem de 1 a 10-15 alqueires. [...]

O sistema de arrendamento é bastante comum na região, particularmente no caso de propriedades exploradas por japonêses. Enganam-se, porém os que supõem seja

\footnotetext{
${ }^{12}$ Entre os autores das ciências sociais brasileira que produziram obras nesse sentido, podemos mencionar Emílio Willems, Herbert Baldus, Hiroshi Saito, Seiichi Izumi. Para mais detalhes ver: TANIGUTI, G.T.; JESUS, M.G. Sociologie de l'immigrant: Hiroshi Saito et l’institutionalisation des études sur les Japonais du Brésil (1940-1960). Brésil(s), v. 2, p.201-224, 2012.
} 
êste o único existente, nem o mais preferido; com freqüência, o arrendatário japonês transforma-se em proprietário, bastando para isso que disponha de meios próprios para consegui-lo. (COSTA, 1958, p.116)

A essas considerações iniciais seguem descrições detalhadas sobre os tipos de produtos cultivados pelos japoneses e aspectos sociais de sua "adaptação" e "assimilação" à sociedade brasileira sob a perspectiva de uma geografia humana. A religião, os costumes, o idioma e o convívio com os brasileiros foram analisados. Por fim, são feitas considerações sobre a organização dos japoneses em cooperativas agrícolas:

Tôda sua produção se destina à cidade de São Paulo, onde é vendida no Mercado de Pinheiros, no Mercado Central e nas feiras-livres e nas quitandas. Para isso, recebem substancial auxílio da "Cooperativa Agrícola de Cotia", a que muitos pertencem, sobretudo quando se trata de pequenos proprietários e de arrendatários; cabe àquela entidade transportar o produto dos centros de produção e encaminhálos aos de consumo.

Cumpre acentuar que muitos proprietários agrícolas, não japoneses, também são sócios da "Cooperativa" e tomam como modelo a técnica nipônica. Daí a semelhança que apresentam suas propriedades com as dos japonêses, como acontece com uma situada próximo ao Moinho Velho, pertencente a um agricultor de nacionalidade húngara. (COSTA, 1958, p. 122).

No tópico seguinte a autora descreve a criação da CAC e a estrutura de desenvolvimento técnico-científico prestada aos associados, ressaltando o fornecimento de insumos, transporte, orientações para o plantio e setores de experimentação. Sumariamente, esse capítulo se dedica a apresentar informações sob a perspectiva de uma geografia urbana sobre os dois municípios em questão.

Os dois textos até agora apresentados informam que o cooperativismo agrícola passava agora a se tornar uma realidade dificilmente despercebida, especialmente nos arredores da capital paulista. Por se tratar de estudos inseridos numa proposta mais descritiva e informativa e, portanto, pouco analítica, não é possível encontrar neles maiores considerações sobre a Cooperativa no que se refere, por exemplo, à relação do 
cooperativismo com a experiência migratória dos japoneses, a trajetória desses imigrantes no mercado de trabalho e com o contexto político mais amplo.

Os estudos acadêmicos sobre os imigrantes japoneses no Brasil tiveram início no seio do projeto acadêmico de desenvolvimento das ciências sociais paulista, especialmente na Escola Livre de Sociologia e Política (ELSP), fundada no ano de 1933. O pioneirismo pode ser atribuído às pesquisas iniciadas em 1940 pelo antropólogo alemão Emílio Willems e pelo etnólogo filho de alemães Herbert Baldus, ambos professores daquela instituição (BALDUS; WILLIEMS, 1941; WILLEMS, 1945 , 1948). Em um primeiro momento, essas pesquisas apresentavam dados bastante descritivos e, posteriormente à entrada do Brasil na Segunda Guerra, observa-se nos escritos de Willems um empenho cada vez maior em combater o preconceito antinipônico, este que era reforçado na opinião pública pelo recrudescimento da relação entre os imigrantes e o Estado brasileiro durante a guerra por meio de prisões arbitrárias, proibição de falar a língua japonesa em lugares públicos, confisco de rádios e jornais escritos em língua japonesa, fechamento de suas escolas autônomas, vigilância e controle. De fato, isso impeliu aos núcleos coloniais japoneses um clima de insegurança e isolamento reforçado pela diferença linguística e cultural.

A necessidade de remontar aos estudos precursores justifica-se: é por meio de uma análise crítica que podemos compreender o seu lugar teórico-metodológico e, dessa forma, tornar procedente a afirmação de que os objetivos centrais desses estudos precursores eram, de forma geral, analisar o que compreendiam como processo de "assimilação" e "integração" desses imigrantes na sociedade brasileira. Estudos específicos que articulassem economia e sociedade, como a mobilidade social dos japoneses, suas atividades econômicas e a sua experiência no mercado de trabalho só viriam a lume nas décadas de 1960 e 1970, principalmente a partir de novas orientações de pesquisas sobre o tema, tendo destaque as publicações do sociólogo Hiroshi Saito, da antropóloga Ruth Corrêa Leite Cardoso, da historiadora Arlinda Rocha Nogueira e de Teiiti Suzuki, este último um dos primeiros imigrantes japoneses a ingressar no curso de Ciências Sociais da Universidade de São Paulo. 
Foi também na ELSP, enquanto um primeiro desdobramento desses estudos precursores, que a principal pesquisa sociológica inteiramente dedicada à CAC até o presente momento passava a ser publicada na mais prestigiada revista especializada em ciências humanas do país. $\mathrm{O}$ artigo "O cooperativismo e a comunidade: estudo sobre a Cooperativa Agrícola de Cotia (I)”, de autoria de Hiroshi Saito, foi publicado na revista Sociologia em agosto de 1954. Trata-se de uma primeira apresentação de sua dissertação de mestrado em sociologia defendida na ELSP em 1956 sob orientação de Donald Pierson $^{13}$, levada ao público em uma série de cinco artigos entre 1954 e 1955 e, posteriormente sob formato de livro em 1964. Trata-se de um estudo fundamentado por uma metodologia de investigação explicitamente influenciada pelas orientações teóricas de Donald Pierson e de Emílio Willems.

Essa obra será analisada aqui em seu conjunto, havendo algumas diferenças substantivas entre o conteúdo dos artigos e a sua versão final em livro. Apresentarei os principais argumentos do autor, bem como as contribuições desse estudo e as suas limitações que, em seu conjunto, contribuem para a justificativa de uma atual pesquisa dedicada à CAC.

Em junho de 1953, na ELSP, Donald Pierson passou a coordenar um conjunto de pesquisas sobre a "acomodação" e "assimilação" de japoneses no Brasil, contando com a participação de Saito como assistente e orientando, como relata Pierson no trecho a seguir de 1954, em introdução ao primeiro dos cinco artigos de Saito:

No Brasil, um dos grupos de imigrantes de maior importância foi o dos japoneses, especialmente no Estado de São Paulo; grupo esse que, já no passado, começou a receber a atenção de alguns estudiosos, especialmente a dos Professôres Emílio Willems e Seiichi Izumi, e de Hiroshi Saito. Em junho de 1953, Hiroshi Saito, que é atualmente meu Assistente de Pesquisas, iniciou, junto comigo, três estudos de acomodações e de assimilação do grupo em aprêço. A primeira destas pesquisas lidava com a transplantação do complexo cultural do cooperativismo, do Japão,

\footnotetext{
${ }^{13}$ Donald Pierson foi um sociólogo norte-americano. Defendeu a sua tese de doutorado pela Universidade de Chicago em 1939 intitulada "Negroes in Brazil: a study of race contact at Bahia", sob orientação de Robert Ezra Park. Pierson foi contratado pela ELSP para o cargo de professor de sociologia em 1939 e criou a Divisão de Estudos Pós-Graduados. Pierson deixou a instituição em 1954, retornando aos Estados Unidos, onde faleceu em 1995. Para mais informações ver: CORRÊA, M. (Org.). História da antropologia no Brasil (1930-1960). Testemunhos: Emílio Willems e Donald Pierson. Campinas: Editora da Unicamp/Vértice, 1987.
} 
para o Brasil, e as modificações havidas neste processo, levando-se em consideração especialmente a Cooperativa de Cotia. (PIERSON, 1954, p.248)

O interesse de Saito em tornar essa cooperativa um objeto de estudo sociológico de seu mestrado revela a convergência entre sua trajetória pessoal de imigrante japonês e a tentativa de sistematizar uma interpretação sociológica a respeito de uma das organizações agrícolas mais difundidas até então entre os japoneses em São Paulo. O seu estudo também revela o desdobramento do projeto de pesquisa inicial de Willems: Saito dava início ao desenvolvimento de um tema que oferecia alternativas às interpretações que afirmavam a "inassimilabilidade" dos japoneses no Brasil. O instrumental utilizado para lidar com a questão é tributário em grande medida das noções de "peneiramento" de traços culturais, como proposto por Willems e de “ecologia humana", proposta por Pierson. A respeito deste último, a sua influência na obra de Saito teve implicações em alguns aspectos importantes da obra de Saito e, por esse motivo, tratarei da discussão de forma mais detalhada no final do tópico 3, "Um mercado sob medida: a Cooperativa Agrícola de Cotia e os fundamentos sociais de domesticação de um mercado". Por ora, reproduzo as palavras de Pierson no prefácio da obra de Saito:

O estudo da assimilação é tanto de valor prático, para o país em questão, como de proveito para o desenvolvimento da teoria sociológica. Quanto a esta, o estudo da assimilação (e da migração e acomodação que lhe são associadas) nos oferece meios de compreender melhor a integração e desintegração grupal, ocasionadas pela migração de indivíduos que, desligando-se dos seus grupos originais, vêm a incorporar-se a grupos novos no país adotivo. (PIERSON, 1954, p.248)

Na edição de 1964, o prefácio de Pierson reforça os argumentos que sustentam a hipótese da "transplantação" de um complexo cultural (manifestado pelo cooperativismo agrícola japonês) para outra localidade, e os elementos que permitiram e facilitaram a "incorporação" do grupo social japonês na sociedade brasileira. O interesse do trabalho residia, portanto, na análise do contato entre grupos portadores de traços e costumes distintos: 
É pesquisa em que o autor - na minha opinião um dos mais dedicados pesquisadores do País -, descreve a maneira em que certo "complexo cultural" foi transplantado de uma cultura para outra; em outras palavras, como certa organização agrícola atravessou os mares, na "bagagem cultural de imigrantes japonêses e se enraizou no Brasil. [...]

Descrevendo e analisando êste "caso" da fundação e subseqüente funcionamento de uma cooperativa nacional, o autor primeiro traça, com certos pormenores, a natureza da cooperativa no Japão, antes de "sair" para a América do Sul. [...]

Acompanhando, depois, a "viagem" dêste complexo cultural até o Brasil, o autor descreve e analisa as circunstâncias do contacto, em aprêço, dos "portadores" da cultura japonêsa com os moradores nacionais, sob as condições físicas do habitat; as várias etapas na formação da atual comunidade, dedicando-se alguma atenção às modificações que se processaram nos costumes tradicionais japonêses; as primeiras tentativas de se fundar a nova cooperativa e as razões dos malogros; as circunstâncias da fundação definitiva, e o papel desempenhado pelos acontecimentos e pelas experiências de que eram portadores os imigrantes; e, então as modificações verificadas na cooperativa, após a sua fundação. (PIERSON, 1964, p.12-13)

Os dois objetivos centrais do estudo foram expressos da seguinte forma, segundo o próprio Saito: i) a melhor compreensão da realidade rural " [...] estudando os tipos de reações que poderiam ser provocados pelo impacto de novos padrões culturais nas sociedades de folk e o processo de acomodação que se segue a esse impacto no contexto da estrutura social” (SAITO, 1954, p.249); ii) e, além disso,

[...] estudar o problema da transplantação de um complexo cultural pelos grupos de imigrantes: o 'peneiramento' de traços e padrões culturais que se processam quando os imigrantes entram em contacto com a sociedade 'nativa', os ajustamentos ecológicos ao novo habitat e o aparecimento de novos padrões como resultado de acomodação e assimilação. (SAITO, 1954, p.249)

No formato de livro, a obra é divida em duas partes. Sumariamente, na primeira delas, denominada "O Cooperativismo na Região de Cotia", está contida a série de artigos publicados na revista Sociologia. Aqui, o autor discutiu as seguintes questões: a) o surgimento e o desenvolvimento do cooperativismo no Japão em relação às formas de 
organização rural daquela sociedade; b) a imigração japonesa e a estrutura da família rural; as características geográficas do município de Cotia; c) a "reorganização" dos japoneses em Cotia no que se refere aos seus costumes mais gerais (alimentação, habitação, vestimentas, idioma, educação), suas instituições sociais (associações, escolas); d) a fundação da Cooperativa e as suas características mais gerais de funcionamento e organização da produção agrícola; e) aspectos mais gerais do seu desenvolvimento até os dias atuais, estabelecendo-se uma divisão em três fases históricas;

Sobre os argumentos mais centrais dos capítulos, é possível apresentá-los sumariamente da seguinte forma: o autor afirma que o contato entre japoneses e brasileiros não apresentava maiores indícios de conflito cultural:

Nos primeiros anos, o contacto manteve-se em níveis de caráter secundário, baseado mais em necessidades de subsistência e dêsse contacto surgiu uma relação simbiótica dos dois grupos [...] Não se verificaram choques, nem conflitos, ocasionados pela diversidade de padrões culturais em contacto. (SAITO, 1955a, p.68-69)

E, por fim, o autor argumenta em favor de elementos culturais japoneses que foram essenciais para o desenvolvimento da Cooperativa. Tais elementos teriam origem nas formas historicamente concebidas de organização rural da sociedade japonesa e seriam, dessa forma, componentes do "complexo" cultural trazido pelos imigrantes em questão. Na sociedade de destino, o contato entre os imigrantes japoneses e os brasileiros "nativos" representaria o locus privilegiado para se compreender as relações sociais entre grupos culturalmente distintos. Sob essa perspectiva, o caso dessa cooperativa seria ilustrativo:

O presente estudo demonstra, pelo menos no caso da Cooperativa Agrícola de Cotia, que a proteção oficial ou uma legislação eficiente nem sempre constitui condições necessárias, ainda que úteis e favoráveis, na implantação efetiva do cooperativismo; essenciais eram aquelas condições proporcionadas pela própria 
organização da comunidade rural, com alto grau de integração social e a eficiência de sanções. (SAITO, 1964, p.146)

Por representar um caso de sucesso no setor agrícola, o empreendimento de Cotia fornecia a Saito dados empíricos que podiam sustentar argumentos favoráveis à assimilação do grupo estrangeiro. Essa afirmação se torna mais evidente na segunda parte do livro. Denominada “A Cooperativa e a Comunidade", ela contém considerações posteriores ao término de sua dissertação, escritas entre 1961 e 1962 e que foram incorporadas ao livro. Vale lembrar que foi também em 1961 que Saito publicou a sua tese de doutorado "O japonês no Brasil - estudo de mobilidade e fixação", defendido na Universidade de Kobe em 1959. Na publicação sobre a Cooperativa, o autor analisa: a) os casos de seis regiões em que essa cooperativa atuava; b) a ampliação da atuação da cooperativa e o surgimento de mudanças relacionadas ao crescimento da cooperativa; c) as formas de "integração" e "desintegração" dos cooperados com a organização comunitária local a partir da criação de uma tipologia.

O autor coletou dados em seis regiões representativas de atuação da Cooperativa (Nova Esperança e Joaquim Távora, no estado do Paraná, e Santo Anastácio, Biguá, Campinas e Ibiúna, no estado de São Paulo), bem como realizou um survey. O principal interesse do autor foi investigar as transformações pelas quais o empreendimento estaria passando, agravadas pela ampliação de suas atividades e pelo seu crescimento. Tratarse-ia de mudanças no "sistema de comportamento" dos cooperados, especialmente os filhos de imigrantes, que não mais reproduziam padrões culturais do país de origem de seus pais, deixando de contribuir, portanto, para as funções da "comunidade étnica". Tais funções, a exemplo do "controle social interno" e da "coesão grupal", controlariam as relações internas do grupo e regulariam a sua relação com o "mundo de fora", ou seja, externo à comunidade. $\mathrm{O}$ conjunto dessas transformações teria afetado também a forma de associação cooperativa, o que teria motivado a realização de uma segunda investigação:

O crescimento trouxe uma série de problemas, não só pela complexidade proveniente do aumento de serviços, como também pelo surto de novos problemas antes desconhecidos. Entre estes, sobressai o da possível deterioração das relações entre a Cooperativa e seus cooperados precisamente porque o crescimento 
desmedido, mesmo desordenado, provocaria um certo descompasso funcional nos diferentes níveis e setores da organização.

A diretoria da CAC mostrou-se naturalmente interessada em saber se as relações entre a Cooperativa e seus associados achavam-se, realmente, em deterioração e, se confirmada, quais as subseqüentes repercussões nos sistemas internos de contrôle, de decisão e de comunicação. Sabedores dêsse interesse, propusemo-nos a realização de um "survey" destinado ao levantamento e formulação de problemas. (SAITO, 1964, p.152)

Por pressupor que do contato entre grupos culturalmente distintos decorreria um processo de "aculturação", Saito entendia que as formas sociais internas de organização dos japoneses - e cuja característica associativa teria destaque - possuíam funções específicas, mas que progressivamente estariam desvanecendo. Em sua interpretação, as mudanças experimentadas pela Cooperativa seriam, portanto, indícios de que a população japonesa estava progressivamente se "integrando" à sociedade brasileira:

Em primeiro lugar, deve-se citar o processo de transformação que está atingindo as comunidades japonesas da zona rural. Nesta pesquisa foi-nos possível constatar alguns dos aspectos dessa transformação em suas múltiplas manifestações. Ao que tudo indica essa transformação tem como molêjo principal, contràriamente aos que manifestam pouca confiança à geração nova, o crescimento dos nisei, filhos nascidos no Brasil, cuja habilitação está neutralizando ou, pelo menos, está atenuando o "handicap" dos imigrados no manêjo da língua e na familiaridade de usos e costumes do país. Em suma, a coletividade de origem japonesa em seu processo de aproximação e integração à sociedade dominante, depende cada vez menos das razões que anteriormente determinaram a ação coletiva e a vida em comum dos elementos da mesma etnia. É claro que à medida que diminui essa dependência, o poder coercitivo da comunidade sôbre seus indivíduos enfraquece. [...]

Assim, os imigrantes deixaram, ou estão deixando, de ser "imigrantes" à medida que vão se emancipando do seu status anterior. Nessa altura, a função social da comunidade étnica de origem japonesa não poderia deixar de sofrer uma grande modificação, pois não mais existem as condições que exigiam a coesão grupal para a concretização de relações econômicas com o "mundo de fora". (SAITO, 1964, p.167-168)

A existência de um duplo aspecto social na experiência da CAC, referente ao sucesso da Organização Cooperativista Japonesa em São Paulo e aos problemas trazidos 
pela mudança geracional da população japonesa enquanto indícios de "aculturação", fez desse empreendimento um caso imperdível de estudo para o sociólogo interessado em compreender a realidade social dos imigrantes em questão. Isso porque os referenciais teóricos e as ferramentas de análise de Saito, tributárias em grande medida de autores da Escola de Chicago, permitiam-no formular a tese de um processo de "ajustamento" e, portanto, argumentar cientificamente em favor da possibilidade de convivência social desses imigrantes a despeito do preconceito existente à época.

Afora as motivações de pesquisa intimamente condicionadas pelas experiências e pelos impasses vivenciados por Saito enquanto imigrante japonês na primeira metade do século XX, a publicação de uma pesquisa sociológica sobre essa cooperativa revelanos três aspectos relativos à construção de um campo acadêmico de estudos: a institucionalização de um tema de pesquisas sobre japoneses no Brasil nas ciências sociais brasileiras; a existência de uma narrativa sobre a imigração japonesa no Brasil em que a CAC foi protagonista central; uma orientação de pesquisa que argumentou em favor da relevância de fatores culturais para a compreensão da realidade social dos imigrantes japoneses.

Após o seu doutoramento, realizado na área de ciências econômicas da Universidade de Kobe, Saito confere outra direção aos seus textos ${ }^{14}$, também incluindo a questão da mobilidade social e econômica em seus objetivos de investigação. Em sua tese de doutorado "O japonês no Brasil - estudo de mobilidade e fixação", Saito procurou apresentar outros elementos de explicação além daqueles estritamente culturais para a questão da imigração japonesa:

A nossa preocupação está em descrever, analisar e interpretar a vida dos imigrados como um todo orgânico e, principalmente, o papel desempenhado per esta figura central no decurso dos processos migratórios. Sem dúvida, êsse propósito nosso se acha estritamente ligado ao estudo sócio-psicológico e antropológico da migração e de seus aspectos correlatos. Contudo, isso não significa que vamos dispersar a nossa atenção com os amplos e complexos processos de assimilação e aculturação. A amplitude do problema obriga-nos a restringir a atenção apenas ao campo da mobilidade e fixação. $\mathrm{Na}$ análise, aqui proposta, procuraremos enfatizar o fator

\footnotetext{
${ }^{14}$ Ver também SAITO, H. Mobilidade de ocupação e de status de um grupo de imigrantes. Sociologia: revista dedicada à teoria e pesquisa nas Ciências Sociais. Escola de Sociologia e Política de São Paulo, v. 22, n. 3, p. 241-253, set. 1960.
} 
econômico, utilizando certos conceitos dêsse campo, que não são comuns aos estudos especificamente sociológicos. (SAITO, 1961, p.14-15)

Essa obra se apresenta de maneira um tanto diferente do estudo anterior sobre a CAC. O autor associa o surgimento do cooperativismo agrícola de japoneses ao desenvolvimento de um novo tipo de agricultura praticado nas áreas próximas à capital, à mudança de status ocupacional dos imigrantes ao longo do tempo e à sua mobilidade geográfica. No decorrer de poucos anos desde a sua chegada ao Brasil, Saito argumenta que os japoneses ultrapassavam a condição de colonos e cada vez mais se encontravam na condição de arrendatários, proprietários de terras ou locatários. Ademais, as cooperativas teriam sido um instrumento de reajustamento das relações de mercado:

[...] do ponto de vista objetivo, os imigrados conseguiram, em geral, ascender socialmente através da mobilidade ocupacional e de status dentro do quadro hierarquizado da estrutura sócio-econômica. Ainda mais, os deslocamentos no espaço acompanharam, inevitavalmente, a mobilidade de status e de ocupação. [...] Por outras palavras, essa mudança adveio como resultado da introdução de novos padrões econômicos em substituição aos tradicionais [...] e por fim a organização Cooperativa permitiu ao arrendatário japonês o reajustamento de relações de mercado, bem como se desvinculassem da economia pré-moderna e participassem diretamente da economia moderna, capitalista e metropolitana. (SAITO, 1961, p. 192-193)

Percebe-se a partir da leitura da tese de doutorado de Saito que o surgimento do cooperativismo agrícola dos japoneses agora ganhava outras explicações de natureza econômica. Isso ocorreu por alguns motivos particulares: no âmbito acadêmico, o período entre as décadas de 1950 e 1970 foi aquele em que os estudos sobre japoneses no Brasil consolidaram-se e institucionalizaram-se, tendo como expoentes, principalmente, o próprio Hiroshi Saito, Zenpati Ando, Seiichi Izumi, Ruth Cardoso, Francisca Isabel Schurig Vieira, Arlinda Rocha Nogueira e Teiiti Suzuki. O trecho a seguir, extraído de A sociologia no Brasil de Antonio Candido revela o reconhecimento dos pares obtido por Saito: 
Os estudos de aculturação vêm sendo também levados a efeito, embora em menor escala, sem todavia terem aparecido em livro pesquisas neste campo, cuja atração sobre os sociólogos pode ser comprovada por numerosos artigos de revista e pesquisas em andamento, como a de Florestan Fernandes sobre os sírios, as de Vicente Unzer de Almeida e Hiroshi Saito sobre os japoneses. (CANDIDO, 2006, p.299)

Entretanto, a consolidação do tema de pesquisas não esteve imune a críticas e disputas. As transformações internas no campo da sociologia, a ascensão social dos imigrantes japoneses e, consequentemente, o surgimento de problemas sociais muito diferentes daqueles que marcaram os anos de antiniponismo do pós-guerra, tornaram os argumentos das suas investigações anteriores - relativas ao "problema da assimilação e da aculturação" - progressivamente anacrônicos.

Em resposta a essa nova realidade, podemos observar uma mudança de direção nos seus escritos a partir da década de 1960, representada pelo interesse em explicar o processo integrativo dos japoneses na estrutura socioeconômica brasileira, de forma que Saito possivelmente buscava responder a movimentos representativos para o desenvolvimento das ciências sociais no Brasil: uma série de críticas dirigidas aos estudos de comunidades; e a crescente presença de outras vertentes de estudos sociológicos ligadas à atuação de Florestan Fernandes em periódicos acadêmicos da área, utilizando-as como "caixa de ressonância" para legitimar seu projeto acadêmico sobre a formação da sociedade classes no Brasil moderno (JACKSON, 2004, p.267).

A obra de Hiroshi Saito sobre o cooperativismo agrícola japonês e, mais especificamente sobre a CAC, contribui ainda hoje para a compreensão da trajetória dessa organização. Contudo, a análise empírica empreendida pelo autor baseia-se em dados obtidos entre os anos de 1954 e 1962. Como foi anteriormente exposto, é a partir da década de 1960 que ela se torna Cooperativa Central e passa a atuar em todo o país, alterando significativamente a direção de seus empreendimentos e de sua capitalização.

Outra possível limitação da obra de Saito diz respeito às implicações contidas nos conceitos de "assimilação" e de "aculturação", difundidas nos meios acadêmicos e 
tributários de autores da Escola de Chicago e de seus mestres Emílio Willems e Donald Pierson. Basicamente, essas teorias continham

a suposição de que as diferenças culturais e sociais das populações imigradas são superáveis, permitindo a incorporação gradual à nova sociedade a partir da segunda geração. A autoconsciência nacional dos imigrantes, embora mantida pela primeira geração, limitando a assimilação, seria gradualmente perdida nas gerações subsequentes. (SEYFERTH, 2004, p.124)

Tais conceitos, concebidos no contexto norte-americano do início do século XX, serviram a propósitos diversos.

Se Saito utilizou tais conceitos enquanto ferramentas de análise sociológica para provar a assimilabilidade dos japoneses, o autor deixou de questionar a sua apropriação pelos formuladores de projetos nacionalistas, ou a ideia de "assimilação como questão nacional" que, segundo Seyferth, tinha como premissa a substituição dos símbolos "étnicos" por outros representativos da nação brasileira. Disso decorreu a imposição de práticas cívicas e o desmonte da estrutura comunitária "étnica" representada pelas escolas, associações e pelo uso das línguas maternas, por meio de práticas autoritárias e repressivas durante o governo de Getulio Vargas. Saito também não fornece maiores evidências sobre a possível influência do contexto político e do papel do Estado sobre a organização cooperativa japonesa. Sobretudo, o autor excluiu de sua análise o âmbito empresarial que, posteriormente, se relevou um espaço central para compreender a trajetória ascendente de um grupo de imigrantes.

Desde Saito, a CAC não foi mais estudada no âmbito sociológico, mas sim na geografia na década de 1970, e na economia agrária na década de 1990. Poucas foram, portanto, as continuidades de um projeto sociológico inicial que procurou intepretar a trajetória dessa cooperativa enquanto parte da história da imigração japonesa no Brasil. E, mais ainda, é praticamente inexistente um estudo dedicado à sua investigação que considere os acontecimentos políticos e econômicos da sociedade brasileira a partir da década de 1960. 
Em “As cooperativas mistas do estado de São Paulo”, publicado em 1977 como produto da tese do geógrafo Manoel Gonçalves Seabra, é possível encontrar dados que demonstram o progressivo crescimento das atividades da Cooperativa no mercado, bem como a expansão de sua área de abrangência. $\mathrm{O}$ autor confere atenção especial à $\mathrm{CAC}$ e à Cooperativa Central Agrícola Sul-Brasil, ambas associações mais representativas do setor e que foram criadas por imigrantes japoneses. Seabra expõe dados detalhados sobre a criação da CAC, a sua estrutura de funcionamento, as suas operações e atuação no mercado agrícola. Trata-se, possivelmente, do estudo mais minucioso já realizado especificamente sobre essa cooperativa.

Atenção especial é dada às cooperativas da coletividade japonesa porque, segundo o autor, o crescimento dos centros urbanos estimulou o aparecimento de atividades agrícolas voltadas à produção de gêneros alimentícios hortifrutigranjeiros, e a presença de imigrantes, especialmente os japoneses, foi marcante nesse tipo de atividade. Sobre essa questão, Seabra assim escreve na introdução de seu livro:

$\mathrm{Na}$ implantação destas atividades produtivas, os agricultores vinculados a uma destas coletividades de origem estrangeira tiveram um papel fundamental. Trata-se dos japoneses e seus descendentes que, proporcionalmente a outros imigrantes, entraram em pequena quantidade em São Paulo. [...]

Para a coordenação de sua atividade econômica, foram criadas, sob a orientação e incentivo do governo japonês, cooperativas agrícolas mistas, instaladas praticamente em quase todos os principais centros de concentração de agricultores japoneses no Estado de São Paulo e do Paraná.

As principais destas sociedades cooperativas na atualidade são justamente aquelas que surgiram nos arredores da capital paulista, e logo nela se sediaram, para coordenar as atividades horti-fruti-granjeiras dos imigrantes japoneses desta área. [...]

As peculiaridades que envolveram a presença da coletividade de origem japonesa no Brasil e em particular nos estado de São Paulo e Paraná, mas principalmente a rápida ascensão econômica e, ainda, a estreita vinculação com determinadas atividades de natureza agrícola que caracteriza a maioria de seus membros, tem despertado o interesse de estudiosos dos mais diferentes campos. (SEABRA, 1977, p.6-7)

O primeiro capítulo do livro é dedicado à análise evolutiva do quadro de associados dessas duas principais cooperativas agrícolas e também de outras 
cooperativas de menor porte. Tem destaque aqui o aumento do número de associados da Cooperativa, inclusive em outros estados do país, o que indicaria a expansão de sua área de atuação. Segundo o autor, isso teria ocorrido de forma mais acentuada entre 1957 e 1967, quando o número de associados mais do que dobrou.

No segundo capítulo Seabra descreve de forma breve a trajetória de imigrantes japoneses e, de forma mais detida, a criação das cooperativas agrícolas entre as décadas de 1920 e 1960 . O que se observa aqui é que desde os primeiros anos da sua fundação a CAC foi a maior cooperativa em número de associados. Tem destaque também a variação do número de cooperativas existentes de acordo com o contexto regulatório.

No terceiro capítulo o autor analisa as mudanças significativas pelas quais essa cooperativa passou a partir da década de 1960 como resultado de transformações na realidade econômica do país e da legislação cooperativista. Inicialmente o autor descreve a estrutura de organização e administração interna da CAC, tendo destaque a divisão territorial da sua área de abrangência em "bairros" e "distritos". A essas duas divisões caberiam toda a atividade de transporte, armazenagem e distribuição de produtos até os postos de vendas. Em relação às mudanças observadas a partir da década de 1960, possuem destaque a tentativa cada vez maior de industrialização de produtos agrícolas e a descentralização de atividades ligadas à produção e distribuição:

Eram, de certo modo, medidas como que a preparar o caminho para reforma mais profunda e mais ampla da organização, reforma esta que se vinha fazendo premente, fruto dos problemas gerados pelo seu próprio gigantismo em geral. Mas, reforma que se fazia premente também em razão da pressão exercida sobre ela pela legislação cooperativista e, portanto, pelo Governo. (SEABRA, 1977, p.94).

As "reformas" em questão retratavam adequações feitas ao contexto mais amplo de intervenções na economia colocadas em prática pelo novo governo militar e, em grande medida, à nova legislação cooperativista que entrou em vigor a partir de 1967. Basicamente, a CAC, agora Cooperativa Central, reformou a constituição e a representação em suas assembleias e a constituição de sua diretoria. Segundo o autor, 
não apenas essa cooperativa específica, mas também as outras cooperativas agrícolas do setor mudaram seus estatutos visando novas formas de obtenção de recursos, como cobranças compulsórias dos cooperados e capital de terceiros, especialmente de bancos públicos:

Finalmente, a outra importante fonte de recursos financeiros das cooperativas, principalmente nos últimos 15 anos vem sendo aqueles conseguidos junto a terceiros. Entre eles encontram-se os financiamentos e empréstimos bancários, sobretudo do Banco Nacional de Crédito Cooperativo, do Banco do Brasil e do Banco do Estado de São Paulo, portanto, bancos oficiais. (SEABRA, 1977, p.107).

A sua análise sobre a questão da capitalização dessa cooperativa apresenta as origens e aplicações dos seus recursos. Basicamente, no período analisado pelo autor observa-se que as aplicações passaram cada vez mais a ser utilizadas com cooperados e terceiros, e as imobilizações reduziram consideravelmente até o ano de 1970. Considerando o volume crescente de recursos obtidos pela CAC, esses dados demonstram que a sua capitalização no período foi direcionada para as operações com terceiros e cooperados, entre as quais se destaca o setor de crédito. Essa questão será exposta em maiores detalhes a partir da análise do estudo realizado por Vegro (1992).

No quarto capítulo Seabra apresenta dados sobre o crescimento dos setores de atividade da Cooperativa, tendo destaque a ampliação de sua rede de comercialização, o crescimento da exportação e a tendência crescente de beneficiamento e industrialização de produtos agrícolas, ou seja, em linhas gerais, a sua incursão no setor agroindustrial. Isso implicou o desenvolvimento de setores específicos para aperfeiçoar os processos de comercialização e industrialização. Considerando a suspensão dos benefícios fiscais anteriores a 1967, a readequação do setor de vendas da Cooperativa teve como reflexo, segundo o autor: "a intensificação de operações com terceiros, decorrente da insuficiência da produção entregue pelos associados em relação à infraestrutura de beneficiamento, industrialização e comercialização, objetivando manter a rentabilidade destes investimentos" (SEABRA, 1977, p.129). 
O seu setor de crédito também revelaria de forma bastante significativa o contexto mais amplo de mudanças no setor cooperativista conduzido pelo Banco Central do Brasil nos primeiros anos do governo militar e pela conjuntura inflacionária daqueles anos. Basicamente, esse órgão proibiu a conservação de depósitos de terceiros nas cooperativas, reduziu a taxa de juros nas mesmas taxas dos demais bancos e impôs limitações à retenção de recursos dos cooperados. Considerando os altos índices de inflação da metade da década de 1960, a atividade de poupança do agricultor via setores de crédito nas cooperativas deixou de ser uma forma de investimento mais rentável para os produtores. Dessa forma, os saldos dos depósitos na CAC foram atingidos e a orientação do crédito agora se voltava a buscar financiamentos para o produtor de forma a evitar redução na produção:

Com a fase mais crítica iniciada a partir do exercício de 1967, a necessidade de recorrer-se a recursos externos cresceu. No ano de 1967, na CAC, 43\% do montante dos financiamentos para custeio concedidos, foram obtidos externamente. No ano seguinte, dos 66 milhões de cruzeiros novos aplicados em financiamentos de custeio, 40,6 milhões foram obtidos externamente. Mas também para os adiantamentos cada vez mais recorreu-se a fontes externas. No exercício de 1969, do total de recursos externos recebidos a CAC empregou 22\% para custeio de atividades e $58 \%$ para adiantamentos mediante a entrega da produção, sendo quase a totalidade do restante usado para a empresa para a importação e exportação. (SEABRA, 1977, p.152)

Seabra ressalta que o comportamento do setor de crédito das cooperativas agrícolas foi diverso e, sobretudo a CAC seria a organização que mais contou com facilidades para captação de recursos. Entretanto, o autor não fornece maiores informações sobre a posição privilegiada dessa cooperativa diante das demais em sua relação com os órgãos públicos do setor agrícola.

O quinto capítulo de sua tese é bastante descritivo e procura analisar alterações na produção e no mercado em que a CAC e a Cooperativa Agrícola Sul-Brasil atuavam. São apresentados dados detalhados sobre as atividades dos cooperados, o que inclui tamanho das propriedades, usos da terra, maquinários, evolução da produção em zonas, usos da cooperativa pelos associados e principais produtos agrícolas. Por fim, o autor 
apresenta algumas considerações finais, dentre as quais é possível destacar: a nova lei cooperativista de 1967 repercutiu profundamente nas formas de organização das cooperativas agrícolas, que se viram obrigadas a adotar diferentes estratégias para superar a conjuntura inflacionária e, no caso da CAC, ao mesmo tempo, coordenar a sua expansão no mercado nacional e internacional. O crescimento das atividades da CAC teria implicado uma contínua preocupação com a racionalização de seus setores e a necessidade de aumentar a participação de empresários de maior porte. Uma das preocupações do autor foi também levantar questões sobre o futuro dessa cooperativa:

O progresso econômico mais ou menos generalizado dos agricultores de origem japonesa; o deslocamento progressivo de seus descendentes em direção aos centros urbanos à procura de novas atividades; a paralisação ou insignificância da entrada de novos contingentes de imigrantes japoneses; as facilidades crescentes que muitos agricultores cooperados ou não tem de acesso aos mercados de vendas de sua produção, tudo isto dentro de uma conjuntura em que as cooperativas agrícolas não mais dispõem de vantagens de natureza tributária, coloca em questão as perspectivas de evolução a curto e médio prazo de suas atividades.

(SEABRA, 1977, p.263)

De forma geral, o estudo de Seabra foi o primeiro nas ciências humanas a realizar um levantamento minucioso das atividades da CAC e de outras cooperativas agrícolas de origem japonesa no estado de São Paulo. Nele o autor apresenta a sua estrutura interna de funcionamento e suas atividades no mercado, e de que forma o conjunto dessas atividades se transformou ao longo do tempo, especialmente a partir de 1967. As informações organizadas permitem apontar a existência de um marco regulatório que, em grande medida, condicionou as mudanças no setor cooperativista brasileiro da época. Esse estudo revela, portanto, a necessidade de compreensão da atividade econômica da organização cooperativa em sua relação aos acontecimentos mais amplos da sociedade brasileira. Contudo, o autor pouco ressalta a natureza política dessas transformações e o papel efetivo de agentes e do Estado na coordenação da economia durante o governo militar.

Um estudo mais detido sobre a trajetória empresarial dessa cooperativa foi realizado somente na década de 1990 sob a forma de dissertação de mestrado na área de economia agrária: "Uma abelha circunscrita: um estudo sobre o sucesso empresarial da 
Cooperativa Agrícola de Cotia - CAC”, do agrônomo Celso Luís Rodrigues Vegro, foi defendida no ano de 1992. O título, apesar de otimista, não encontrou correspondência nos acontecimentos futuros, pois dois anos mais tarde a CAC encerrou as suas atividades, situada numa crise de endividamento financeiro.

O estudo representa um estudo de trajetória econômica baseada na análise de dados dos balanços financeiros da empresa entre 1967 e 1989. O primeiro capítulo é dedicado à discussão teórica em que dois conceitos são centrais: "conglomeração produtiva" e "processo de diversificação". No capítulo seguinte o autor apresenta um histórico sobre a criação da CAC no contexto da imigração japonesa no Brasil. Em seguida, o terceiro capítulo é dedicado ao desempenho econômico da Cooperativa nas décadas de 1970 e 1980. Vegro apresenta a hipótese de que a trajetória dessa cooperativa pode ser explicada pela determinação dos momentos privilegiados (nos quais ocorre "reorientação" da trajetória de expansão da empresa). Não é por acaso que essas reorientações ocorrem, pelo contrário, elas surgem em resposa às necessidades da empresa em adaptar-se a alterações: a) na política agrícola; b) nas tendências do desenvolvimento agroindustrial e; c) no ambiente macroeconômico (VEGRO, 1992).

É possível perceber, portanto, que o autor desse estudo adota uma perspectiva de análise interna à organização, considerando fatores estritamente econômicos de desempenho, de forma que fatores externos à gestão empresarial possuiriam pouca influência na trajetória dessa cooperativa.

Para o desempenho da década de 1970, têm destaque o aumento das imobilizações a partir de 1972 e um salto expressivo no ano de 1974. Essa estratégia representa uma reorientação na trajetória da CAC e aponta para um endividamento a longo prazo, cujos recursos teriam sido obtidos principalmente pelo BNCC e pelo Banco do Brasil. Segundo o autor, isso pode ter relações diretas com o II Plano Nacional de Desenvolvimento (II PND), instituído em fins de 1974 durante o governo de Ernesto Geisel. A evolução do quociente de imobilizações sobre o patrimônio líquido da Cooperativa revelaria, segundo o autor, a proporção de recursos próprios que estava sendo imobilizada, ou que não estava em giro. Segundo o autor, "em um período plenamente operacional tal quociente não deve aproximar-se, muito menos ultrapassar a 
1" (VEGRO, 1992, p.70). O quociente expressaria, portanto, a solvência da empresa, ou a sua capacidade de cumprir os compromissos financeiros com os recursos que constituem seu patrimônio ou seu ativo.

O autor constata que o ano de 1974 demonstra o maior índice desde 1967 e nos anos de 1975 e 1976 o quociente supera 1. Isso poderia ser explicado, segundo o autor, pela necessidade de investimentos da empresa por causa do II PND e também do início das atividades do Programa de Assentamento Dirigido do Alto Paranaíba (PADAP) em que a Cooperativa teve participação ativa.

No que se refere à questão da rentabilidade, expressa pelo quociente do Resultado Operacional sobre o Patrimônio Líquido, o autor afirma que nos anos subsequentes ao início da execução do PADAP e a uma estratégia de elevada capitalização, a cooperativa obteve números positivos. Em 1976 o quociente esteve sempre acima de 10\%. No período entre 1967 e 1973 esse quociente quase não havia ultrapassado $8 \%$. Tratar-se-ia, portanto, de uma estratégia empresarial bem-sucedida.

Com relação ao quociente de Débito dos Cooperados sobre o Movimento de Distribuição, os dados de Vegro confirmam as afirmações anteriores de Seabra, demonstrando a prática adotada pela CAC de oferecer crédito aos seus cooperados visando superar as dificuldades operacionais decorrentes das mudanças na legislação de 1967. Apesar de o autor não destacar a seguinte afirmação, é possível observar que a evolução do quociente de imobilizações sobre o patrimônio líquido da Cooperativa na década de 1980 atingiu níveis bastante elevados a partir de 1985, ultrapassando 2 em 1988 e 1989.

Vegro também destaca que os anos de 1985 e 1986 foram os de maior crescimento dos exigíveis de curto prazo oriundos de empréstimos e, além disso, os exigíveis oriundos de empréstimos a longo prazo representaram 40,4\% do total obtido. É possível observar, portanto, que na metade da década de 1980 a cooperativa adquiriu empréstimos vultuosos, principalmente junto ao BNCC, que entre 1980 e 1982 subsidiou cerca de $41 \%$ dos empréstimos da CAC.

No que se refere à rentabilidade da Cooperativa na década de 1980, os resultados operacionais indicavam que, principalmente a partir de 1987 a organização estaria 
bastante próxima de uma crise financeira, pois o quociente Resultado Operacional sobre o Patrimônio Líquido, em 1988 era de 0,08 e em 1989 era 0,04. Em relação ao quociente de Débito dos Cooperados sobre o Movimento de Distribuição, os dados de Vegro demonstram que a partir de 1988 os débitos dos cooperados passavam a superar o movimento gerado, o que poderia indicar um sinal de endividamento no setor creditício da cooperativa.

O estudo sobre a trajetória econômica da Cooperativa empreendido por Vegro apresenta dados que, pelo contrário, estariam indicando condições cada vez mais críticas de solvência. Conforme já foi destacado, o estudo analisa somente dados relativos ao desempenho da empresa, considerando fatores estritamente econômicos na análise. Poucas considerações são feitas sobre o contexto político e econômico turbulento que caracterizou o fim do regime militar no Brasil. A atenção maior sobre esses fatores, especialmente a extinção das facilidades na obtenção de recursos governamentais, só seria considerada em seu texto posterior, escrito em 1994, no ano de liquidação dessa cooperativa.

$\mathrm{O}$ artigo "Crise econômica e cooperativismo agrícola: uma discussão sobre os condicionantes das dificuldades financeiras da Cooperativa Agrícola de Cotia (CAC)", de Celso Luis Rodrigues Vegro e José Sidnei Gonçalves foi escrito com o objetivo de explicar os motivos da crise financeira da Cooperativa e que a levou à liquidação. Inicialmente, os autores apresentam as diferenças existentes entre os tipos de organização empresarial na agricultura, ressaltando a especificidade do cooperativismo, ou sociedade por cotas.

Em seguida, os autores apresentam o argumento sobre as mudanças mais gerais sofridas pelo cooperativismo a partir da década de 1960 e a crescente tendência à entrada das cooperativas no setor agroindustrial. Essa incursão teria demandado profundas transformações internas na organização das cooperativas agrícolas, inclusive na CAC. Mas, principalmente, esse processo de adaptação da cooperativa à industrialização modificou as relações internas de decisão coletiva, prejudicando principalmente os cooperados: 
A adaptação da cooperativa da comercialização em comum para a industrialização conjunta traz não só a exigência de maiores compromissos do cooperado com a organização em termos de prazos e qualidade, como necessita de que o "cooperativo" cada vez mais prevaleça sobre o individual. A cooperativa parece cada vez mais "sufocar" o cooperado enquadrando-o em normas cada vez mais rígidas de comportamento. (GONÇALVES; VEGRO, 1994, p.64)

Dessa forma, um dos problemas enfrentados pela CAC teria origem na dificuldade de garantir uma estrutura organizacional coerente com os princípios cooperativistas que a fundaram e, ao mesmo tempo, expandir as suas atividades. Ao analisar os dados referentes ao movimento global e à evolução das exportações, os autores afirmam que a Cooperativa continuou numa trajetória crescente no mercado. Porém, o setor de crédito teria sido o empreendimento condutor da crise financeira da organização.

As considerações mais significativas desse texto em relação ao anterior é que agora os autores destacam o abandono das facilidades governamentais anteriormente oferecidas à CAC:

[...] exatamente por ter uma face corporatista associada à empresa, a CAC sofreria os impactos da incapacidade governamental em realizar políticas ativas que contrarrestassem o ciclo de desaceleração. Enquanto empresa a CAC mantinha seu desempenho, e ainda continuou a crescer entre os anos de 1984 e 1990, conhecendo um pequeno recuo no triênio 1990-92, em termos de movimento global. Contudo, o período de 1984-1992 é uma fase de aumento do endividamento dos cooperados junto à CAC. Isso porque os débitos dos cooperados não só subiram em termos reais como avançaram expressivamente em relação ao movimento global até suplantá-lo. Essa ocorrência viria progressivamente a comprometer as finanças da empresa, empurrando-a para o endividamento progressivo, não para o investimento mas com vistas a cobrir operações de custeio não saldadas.

As razões desse acontecimento estão vinculadas à face corporatista da atuação da CAC, e mesmo continuando orquestrando os interesses de seu corpo associativo, a cooperativa não encontrou respaldo nas políticas públicas. Trata-se de um rompimento da lógica corporatista do lado do Estado que reorienta sua posição nesse processo. Essa mudança decorre que, estando desprovido de instrumentos financeiros, o Governo deixou de realizar o papel que cumpria anteriormente de bancar os custos do subsídio, obrigando a CAC a resolver sozinha o problema de ajustar à nova realidade suas relações com os cooperados. Exatamente isso não foi realizado a contento, e a despeito da modernidade engendrada e do avanço da produção industrializada, a CAC viu-se impactada num ponto crucial: a relação 
cooperativa-cooperado.(GONÇALVES; VEGRO, 1994, p. 72-73, grifo dos autores)

Os argumentos dos autores residem, portanto, na ruptura de seu "papel corporatista" de orquestração de interesses associado à conjuntura desfavorável vivenciado pelas cooperativas nas décadas de 1980 e 1990, de forma que o poder político das representações em diversos níveis entrou em choque com a racionalidade da estrutura departamental da CAC. Do ponto de vista organizacional interno, a dimensão adquirida por ela em seus processos de adequação à regulação estatal e do mercado teria distanciado cada vez mais o processo decisório de suas bases cooperadas. Esse argumento também é reproduzido por Marcovitch em "O caso Cotia: ascensão, queda e esperança", texto de análise econômica resultante de um seminário realizado em 1996 e, possivelmente, um dos últimos estudos sobre o tema.

A revisão bibliográfica aqui apresentada teve como objetivo mais amplo oferecer ao leitor uma breve exposição dos estudos propriamente acadêmicos sobre a CAC em áreas variadas do conhecimento. A diversidade de interpretações existentes pode revelar as demarcações teóricas e metodológicas resultantes de estratégias de pesquisa e análise de dados. Para os objetivos deste texto, ela possibilitou apontar as contribuições e limitações desses estudos e, principalmente, outras dimensões da trajetória da CAC que até o presente momento não foram contempladas. 


\title{
Capítulo 1 - Gestão, agentes e relações: entre as oportunidades e os limites da incorporação
}

\begin{abstract}
Quando, neste vasto Brasil, ainda não existe uma cooperativa agrícola perfeitamente organizada, que possa servir de exemplo para nós, qual a diretriz que conduzirá as nossas atividades futuras? Em meio à expectativa não só de japoneses, mas de todos os brasileiros interessados na lavoura, o êxito ou fracasso da nossa cooperativa não deixará de ter profunda influência na sociedade. É mister, portanto, termos uma vontade inquebrantável frente a mil obstáculos e contribuir para a expansão gradativa do meio rural brasileiro. ${ }^{15}$ (Palavras do Presidente (1927-1942) e membro-fundador da Cooperativa Agrícola de Cotia, Kenkiti Simomoto, em: "Passado, presente e futuro da Cooperativa Agrícola de Cotia" - Revista Cotia, n. 1, set. 1928, p.9)
\end{abstract}

Não negamos o esforço dos poderes públicos na estabilização da economia nacional, e, por outro lado, reconhecemos as dificuldades que se deparam naturalmente a uma nação de grande vitalidade, mas ainda na 'fase de "Adolescência"' em que os planejamentos e as medidas adotadas nunca podem atender a todos os setores. Dessa imaturidade econômica e cultural advém a alta responsabilidade dos governantes. A complexidade dos problemas e a urgência da estruturação de medidas oportunas, somadas a crises de ordem política, inegavelmente têm perturbado o desenvolvimento equilibrado da economia. A experiência de outros países nos testemunha a absoluta importância de continuidade das diretrizes traçadas e a execução corajosa de medidas criteriosamente estudadas. (Palavras do Presidente (1957-1990) da Cooperativa Agrícola de Cotia, Gervásio Tadashi Inoue, em: Relatório dos Serviços Sociais do ano Social de 1962/63, apresentado à XXXV Assembleia Geral Ordinária da Cooperativa Agrícola de Cotia, julho de 1963, p.1)

Os excertos acima foram retirados de publicações cuja circulação era interna à CAC. Ambos reproduzem, em épocas distintas, palavras dirigidas pelos presidentes daquela organização aos associados e funcionários. Essas palavras expõem minimamente os pontos de vista dos gestores - ou seja, de grupos ou indivíduos que ocupavam cargos máximos de liderança na hierarquia organizacional da Cooperativa - a respeito da situação em que o empreendimento se encontrava em seus respectivos

\footnotetext{
${ }^{15}$ Texto original escrito em língua japonesa. Tradução de Hiroshi Saito (1953). Fonte: Acervo pessoal de Hiroshi Saito.
} 
contextos. Por convenção, a principal publicação da Cooperativa sempre conteve um preâmbulo assinado pelo seu prócere.

Uma breve leitura desses dois excertos, quando somada à minha intenção de compará-los, torna evidente certas diferenças em relação ao seu conteúdo: o primeiro deles, datado de 1928, foi publicado em língua japonesa por Kenkiti Simomoto, imigrante japonês, líder-fundador e diretor-presidente da Cooperativa entre 1927 e 1942. A incerteza, a instabilidade e a existência de limites para a ação permeiam a sua narrativa, direcionada para um público composto majoritariamente por lavradores japoneses cooperados. Diante daquela conjuntura permeada por obstáculos, Simomoto sugere a adoção de uma postura baseada na dedicação ao trabalho como um valor coletivo prioritário.

O excerto seguinte foi publicado em 1963 e assinado por Gervásio Tadashi Inoue, advogado filho de cooperados, formado pela Faculdade de Direito do Largo São Francisco, e presidente da Cooperativa entre 1957 e 1990. De forma distinta à narrativa de Simomoto, aqui o universo da política se revela central; há maior certeza quanto às demandas coletivas e aos rumos que o cooperativismo deveria seguir. Inoue sugere deter conhecimento sobre o contexto político e econômico nacional, bem como sobre as responsabilidades atribuídas aos governantes são latentes. Sobretudo, ele conduz uma narrativa orientada por uma expertise que valoriza o planejamento e o estudo criterioso de políticas para a organização do mercado.

A comparação entre os dois excertos permite introduzir ao leitor dois personagens que ocuparam o mais elevado dos cargos decisórios de um mesmo empreendimento em épocas distintas. Entre outras, a conclusão mais direta de uma breve leitura é a identificação de narrativas temporalmente situadas, e fundamentadas em diferentes modelos cognitivos de gestão empresarial. Neste capítulo procuro demonstrar como esses diferentes modelos expressam também determinados processos sociais que podem ser melhor compreendidos a partir do percurso de lideranças da população de origem japonesa que, de forma concomitante e em diferentes momentos, ocuparam cargos decisórios na CAC. 
Argumento que muitas ações que teriam sido adotadas supostamente como respostas a situações de mercado podem ser melhor examinadas se concebidas como resultados do universo de relações de onde elas provêm. Se identificarmos que, em dois pontos distintos no tempo, há diferenças entre discursos e narrativas de lideranças que ocuparam a mesma posição na hierarquia empresarial, considero ser imprescindível investigar como essas diferenças foram construídas, ou seja, trata-se da tarefa de identificar quais relações sociais específicas subjacentes às ações dessas lideranças adquirem qualidade explicativa.

Este capítulo examina de maneira mais ampla o núcleo de gestão da CAC composto por imigrantes japoneses. Amparado por evidências empíricas, procuro demonstrar que as ações dos gestores do empreendimento não foram concebidas apenas a partir da instrumentalização de recursos disponíveis visando a objetivos próprios aos interesses de mercado. Ao longo de sua experiência migratória, algumas de suas ações foram orientadas pelo objetivo mais geral de reivindicar melhores oportunidades e de formular estratégias de incorporação, fossem elas passíveis de realização no âmbito econômico, político, cultural (ou no intercâmbio deles).

Ao complexificarmos o pressuposto de que esse empreendimento cooperativo representaria um agente atuante no mercado competitivo dotado de objetivos estritamente racionais, considero que, ao menos quando uma diretoria de primeira geração foi predominante na condução de sua gestão, a Cooperativa atuou mais enfaticamente como um dispositivo organizado de auxílio à reprodução da vida desses imigrantes. Outros significados subjacentes a essas ações são aqui considerados, principalmente aqueles inseparáveis da experiência migratória do grupo. E, sobretudo, argumento que os indivíduos que ocupavam posições de liderança na CAC estiveram presentes e foram ativos participantes desse ativo núcleo de lideranças intelectuais e políticas da população de origem japonesa em São Paulo.

É dessa forma que o caso da Cooperativa oferece um caminho alternativo para a investigação de processos de construção, conflitos e negociação de identidades étnicoraciais, pois considero que as relações entre as atividades econômicas, a política e a cultura são locais interdependentes e privilegiados de manifestação da realidade social. 


\subsection{Estado, imigrantes e cooperativismo}

Muito embora a reconstituição detalhada de conjunturas políticas em que as atividades da CAC estiveram localizadas não represente o objetivo central deste estudo, acredito haver razões suficientemente convincentes para, neste tópico, situar brevemente a emergência do cooperativismo de imigrantes japoneses nos primeiros 15 anos de governo de Getulio Vargas (1930-1945), período em que foi atingido o auge da entrada desses imigrantes no país. Entre outras características, nesse período a repressão contra estrangeiros se intensificou, ao tempo em que a atividade cooperativista, sob intenções modernizantes, passou a ser regulada e estimulada pelo Estado.

Sumariamente, nos primeiros 25 anos da vinda dos imigrantes japoneses para o Brasil (1908-33), os formuladores, os interessados e aqueles que repudiavam o projeto migratório disputavam a legitimidade dos diagnósticos a respeito desse fluxo migratório. Não constitui exagero a utilização do termo "diagnóstico" nesse caso, pois grande parte das avaliações a respeito da entrada dos imigrantes japoneses no Brasil (ou da sua breve experiência como colonos em fazendas de café entre as décadas de 1910 e 1920), fossem elas favoráveis ou contrárias, era tributária - ou mesmo representava aplicações diretas - de noções fisiológicas e naturais às relações sociais, característica marcante do pensamento científico da época ${ }^{16}$.

\footnotetext{
${ }^{16}$ A respeito de cientistas, instituições e a questão racial no Brasil entre 1870 e 1930, Schwarcz (1993) demonstra que a recepção do paradigma darwinista no Brasil teve inúmeras variantes, abrangendo literatura, faculdades de medicina, de direito, institutos de criminologia, histórico e geográficos etc. Mais especificamente, a autora identifica que a Faculdade de Medicina do Rio de Janeiro e a Faculdade de Medicina da Bahia foram espaços em que se disputou a hegemonia da medicina (uma prática profissional em construção) no Brasil. Em comum a elas era a ideia de que era a partir da miscigenação que se previa doenças ou se entendia a criminalidade, ou seja, os males sociais estariam associados a "doenças" que necessitavam ser tratadas visando a "perfectibilidade": "para os médicos cariocas, o simples convívio das diferentes raças que imigraram para o país, com suas diferentes constituições físicas, seria o maior responsável pelas doenças, a causa de seu surgimento e o obstáculo à 'perfectibilidade biológica" (SCHWARCZ, 1993, p.250). Para os médicos baianos, segundo a autora, o cruzamento racial seria o principal fator explicativo. Em início da década de 1920, a eugenia passou a ganhar evidência no meio médico: sem abandonar o princípio de seleção natural e o conceito de raça biológica, a diferença que se apresentava como novidade era que a visão eugênica não diagnosticava, a princípio, a falência irrevogável
} 
Na primeira década do fluxo migratório em questão, foram registrados casos de abandono de fazendas pelos colonos, relatos de fuga, quebras de contrato, e mesmo projetos de lei contrários à imigração ${ }^{17}$. Isso por vezes resultou em desentendimentos entre a Secretaria da Agricultura paulista e os órgãos de imigração do Japão (SAITO, 1964), ou mesmo em recomendações de cautela pelos órgãos diplomáticos. Em geral, segundo Leão Neto, esses episódios não teriam afetado o fluxo migratório de forma significativa: "Em nenhum momento porém parece ter havido iniciativas, seja a nível político seja nos escalões técnicos, que intereferissem no curso normal da imigração japonesa até início dos anos trinta" (LEÃO NETO, 1990, p.40).

$\mathrm{Na}$ literatura especializada, há consenso de que foi nos anos do Governo Provisório de Getulio Vargas (1930-1934) que episódios mais turbulentos envolvendo a imigração japonesa tiveram início, principalmente com a elaboração das políticas migratórias restritivas que viriam a ser aplicadas com a promulgação da Constituinte de $1934^{18}$ :

Com a Constituinte, teorias raciais e eugenistas, que até então ocupavam principalmente publicações e debates médicos, conseguiram influenciar também as instâncias políticas e as publicações oficiais, contando ainda com ampla divulgação pela imprensa. A defesa de critérios raciais e médicos para a seleção de imigrantes (racial ou individual), pôde ser somada à idéia de que a imigração era também a maior causa do desemprego, de desordem social e de formação de minorias étnicas. (ENDRICA, 2009, p.206)

\footnotetext{
de uma nação doente em razão da miscigenação. $\mathrm{O}$ "ideal" eugênico previa a possibilidade de reverter o processo degenerativo da mestiçagem. Não por acaso, os principais opositores da entrada de japoneses no Brasil foram, entre outros, o sanitarista baiano Artur Neiva e o diretor da Faculdade Nacional de Medicina do Rio de Janeiro, Miguel Couto.

${ }^{17}$ Em 1923, o Deputado Federal Fidélis Reis apresentou à Câmara um projeto de lei visando o veto à entrada de colonos pretos e a limitação da entrada de amarelos (LEÃO NETO, 1990, p. 35).

${ }^{18}$ Basicamente, podemos mencionar os acirrados debates favoráveis e contrários à entrada de japoneses no Brasil na Assembleia Nacional Constituinte, instalada em finais de 1933. Eles envolveram justamente políticos nativistas contrários à imigração, como Arthur Neiva, Xavier de Oliveira e Miguel Couto, entre outros, ou mesmo os que se opuseram a emendas restritivas, como Morais de Andrade, Arruda Falcão, Fernando de Abreu e Adolfo Konder e, além desses personagens, o debate mobilizou a diplomacia japonesa e brasileira. Para mais detalhes, ver: GERALDO, E. A "lei de cotas" de 1934: controle de estrangeiros no Brasil. Cad. AEL, v.15, n.27, 2009, p. 175-207; e LEÃO NETO, V.C. A crise da imigração japonesa no Brasil (1930-1934): Contornos diplomáticos. Brasília: Fundação Alexandre de Gusmão, 1989.
} 
A partir de 1935, portanto, a entrada de imigrantes japoneses no Brasil foi reduzida consideravelmente ${ }^{19}$. Na realidade, desde então a entrada de estrangeiros de maneira geral passou a obedecer critérios retritivos rigorosos, ao menos até 1950. No caso dos japoneses, alguns dos critérios utilizados como argumentos contrários à sua entrada no país - principalmente para os formuladores da Constituinte - foram sustentadas por categoria biologizantes de raça, culminando na crença de sua inassimilabilidade e em dúvidas acerca de sua miscibilidade. Essa crença era vista, portanto, como algo prejudicial ao projeto de uma nação brasileira, cuja composição abrigaria raças diferentes, mas para a qual a mestiçagem seria prejudicial por estar associada à degeneração. A essa visão, expressa por certos grupos políticos tradicionais, somava-se posturas cautelosas em âmbito diplomático, a exemplo de relatórios de Jorge Latour, que versava sobre uma possível "infiltração" japonesa no Brasil com interesses militares $^{20}$, ou mesmo livros de circulação nacional, como o A Ofensiva Japonesa no Brasil: Aspecto Social, Econômico e Político da Colonização Nipônica (1937), do advogado Carlos de Souza Moraes ${ }^{21}$.

Outro aspecto das medidas restritivas relativas à entrada de estrangeiros a ser considerado, principalmente a partir de 1938, é que elas também estiveram relacionadas à maneira pela qual o projeto de soberania nacional do Estado Novo (1937-1945) foi conduzido no plano da diplomacia internacional. Exemplos disso foram as conflituosas negociações entre o Itamaraty e embaixadores alemães a fim de se solucionar as restrições à entrada de alemães no país, bem como a série de medidas restritivas aos imigrantes já residentes em solo nacional ${ }^{22}$. Em linhas gerais, o Estado autoritário varguista impôs limites muito bem definidos à entrada dos estrangeiros no país e à sua participação nas atividades políticas. A Constituição de 1937 que inagurou o Estado

\footnotetext{
${ }^{19}$ Em 1934 haviam entrado 21.930 japoneses no país. Em 1935 o número foi reduzido para 9.611. Entre 1935 e 1952, 24.640 (LEVY, 1974).

${ }^{20}$ Para mais informações, ver: LESSER, J. A negociação da identidade nacional: imigrantes, minorias $e$ a luta pela etnicidade no Brasil. São Paulo: Unesp, 2001.

${ }^{21}$ Para mais informações sobre o livro, ver: TAKEUCHI, M.Y. "A comunidade nipônica e a legitimação de estigmas: o japonês caricaturizado". Revista USP, São Paulo, n.79, set./nov. 2008, p. 173-182.

22 Para mais informações sobre o tema, ver: SEITENFUS, R. A entrada do Brasil na segunda guerra mundial. Porto Alegre: Edipucrs, 2000.
} 
Novo e vários Decretos-Lei expedidos ao longo do regime corroboram essa afirmação ${ }^{23}$. Contudo, é interessante observar que a imposição de fronteiras de natureza política a esses estrangeiros teve lugar pari passu com alternativas oferecidas pelo Estado no plano econômico. Uma dessas alternativas que interessa mais diretamente aos objetivos desta pesquisa é o estímulo estatal à diversificação agrícola por meio de organizações cooperativas.

$\mathrm{Na}$ literatura especializada sobre as origens do cooperativismo no Brasil, a possibilidade de associação de pequenos produtores é muitas vezes interpretada como um processo localizado em um contexto político mais amplo e sobredeterminado pelo projeto centralizador e nacionalizante do Estado brasileiro ${ }^{24}$. Sob essa abordagem, a regulação do cooperativismo representaria um instrumento de subordinação política de frações de classe ao Estado. Interpretações assim formuladas talvez respondam de forma suficiente a objetivos específicos em análises de processos políticos históricos. Contudo, afirmações generalizantes por natureza restringem a capacidade de considerar especificidades. Quando a regulamentação do cooperativismo brasileiro é avaliada em sua efetividade, ou seja, considerando-se os seus resultados concretos para determinados grupos, a subordinação política ao Estado pode também revelar oportunidades sociais anteriormente inexistentes.

No caso dos imigrantes japoneses, o cooperativismo representou uma das formas alternativas de coordenação das atividades econômicas em relação ao colonato. Considerando esse fato, as categorias analíticas "autonomia" e "subordinação" parecem

\footnotetext{
${ }^{23}$ Neles podemos encontrar conteúdos que dispõem sobre: a restrição à entrada de estrangeiros no país (Decreto-lei n. 406, de 04 de maio de 1938), a proibição da atividade política de estrangeiros no país (Decreto-lei n. 383, de 18 de abril de 1938), o fechamento de escolas estrangeiras (Decreto-lei n. 868, de 18 de novembro de 1938), o congelamento de bens de estrangeiros de origem alemã, italiana e japonesa (Decreto-lei n. 4.166, de 11 de março de 1942) e o confisco de bens desses estrangeiros (Decreto-lei n. 5.777, de 26 de agosto de 1943).

${ }^{24}$ Sobre esse assunto, ver: MENDONÇA, S.R. A política de cooperativização do Estado brasileiro (1910-1945). Niterói: EDUFF, 2002. Nesse estudo, a autora demonstra a atuação política de vários indivíduos e grupos na criação de discursos cooperativistas enquanto formas de atualizar a vocação agrária do país a partir da década de 1920. Mendonça também demonstra como a legislação cooperativista do período foi influenciada diretamente por indivíduos portadores de posições divergentes sobre a natureza da atividade cooperativa a ser seguida. $\mathrm{O}$ argumento da autora é que a relação entre Estado e cooperativas pode ser interpretada não apenas enquanto instrumento de subordinação da pequena produção aos ditames da acumulação capitalista, mas também enquanto estratégia alternativa para o controle social e político dos agentes sociais por parte do Estado.
} 
ser parcialmente suficientes para a compreensão da trajetória desses imigrantes, visto que, ao menos até 1945, eles estiveram à margem de uma possível participação no projeto nacional de "cidadania regulada" 25 promovido pelo Estado durante o primeiro governo de Vargas.

Para esse grupo, em particular, argumento que o projeto varguista de inclusão impactou de maneira distinta ou até mesmo divergente, se comparada ao restante da população: conforme já foi exposto no plano político de direitos individuais, a inclusão dos estrangeiros passou a ser cada vez mais limitada, até atingir uma efetiva perseguição durante a Segunda Guerra. Contudo, do ponto de vista da participação desses imigrantes em atividades econômicas, a criação de leis trabalhistas, o estímulo à diversificação da produção agrícola e a criação da legislação cooperativista representaram possibilidades de acesso a benefícios sancionados que o Estado passou a oferecer. Ao final da década de 1930 era possível contabilizar a existência de 23 cooperativas de imigrantes japoneses, compostas por cerca de 5 mil cooperados, dentre as quais a CAC era a maior em número de associados ${ }^{26}$ e em volume de produção e comercialização, possuindo uma sede no bairro de Pinheiros, em São Paulo, inaugurada em 1935 (CAC, 1988).

\footnotetext{
${ }^{25}$ Autores que se dedicaram a analisar os primeiros 15 anos do governo de Getulio Vargas (1930-1945) reconhecem que a instituição de novos instrumentos de regulação com amplitude nacional a partir da década de 1930 representou uma mudança nas formas de relação do Estado com a população, especialmente no que se refere à criação de legislações trabalhistas e de proteção social. Contudo, como destaca Cardoso (2010), a inclusão no universo dos direitos podia ser efêmera e porosa, universal em seu discurso, porém revelava um caminho repleto de obstáculos para uma parcela da população.

${ }^{26}$ Segundo o relatório da CAC de 1965, no ano de 1939 havia 1.506 cooperados, em sua maioria chefes de família, associados à Cooperativa. Segundo Seabra (1977), a segunda cooperativa de origem japonesa com mais associados era a Cooperativa Agrícola de Bastos, com cerca de 700 associados.
} 
Figura 1 - Sede da Cooperativa Agrícola de Cotia no bairro de Pinheiros, São Paulo, década de 1930.

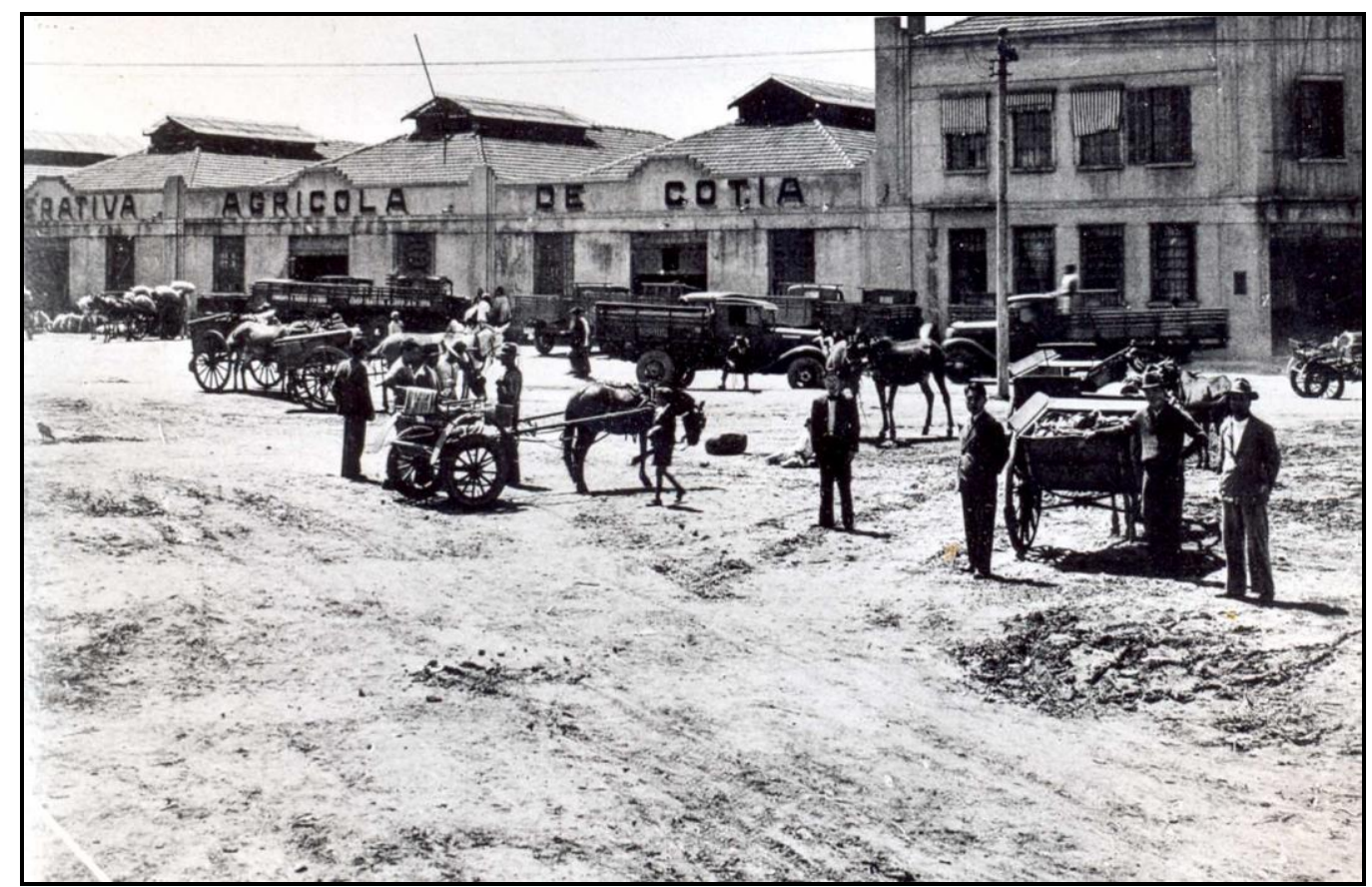

Fonte: Museu Histórico da Imigração Japonesa no Brasil.

A criação de uma legislação cooperativista em 1932 foi resultado de inúmeras disputas políticas, em curso ao menos desde a década de 1920. De acordo com Mendonça (2002), havia duas posições divergentes sobre os princípios que as cooperativas deveriam assumir no Brasil: uma propunha que as cooperativas fossem subordinadas a sindicatos e, a outra, que recusava tal subordinação. A legislação cooperativista de abrangência nacional resultou de disputas entre projetos políticos distintos, defendidos por agrônomos diplomados e de atuação profissional. Em linhas gerais, tais projetos cooperativistas emergiram sob influência de experiências internacionais, e buscavam responder às rápidas transformações urbano-industriais em curso ao promover, discursivamente, soluções modernizantes para a "vocação agrária" do país. Entre interlocutores políticos que eram favoráveis ao cooperativismosindicalismo, podemos citar: Custódio Alfredo de Sarandy Raposo e Juarez Távora. Entre os que discordavam desse projeto estavam: José Saturtino de Brito, Fábio Luz 
Filho e Luiz Amaral. Com exceção de Amaral, que foi diretor do Departamento de Assistência ao Cooperativismo do Estado de São Paulo (DAC), esses agrônomos ocuparam postos de destaque no Ministério da Agricultura, Indústria e Comércio.

Levando adiante as políticas de incentivo ao cooperativismo, tanto o governo federal quanto o governo estadual de São Paulo garantiam a sua ingerência no setor ao criar órgãos dedicados à fiscalização, controle e financiamento de cooperativas. Fazendo uso da proposta conceitual de Fligstein (1996), esse conjunto de regras que definem as relações de competição, cooperação, organização do mercado é definido aqui como estruturas de governança. Nos parágrafos a seguir são mencionadas algumas medidas que caracterizaram a centralidade do aparelho estatal na regulação da atividade cooperativista no Brasil durante os primeiros 15 anos do governo de Getulio Vargas.

A partir de 1933 foram realizadas reformulações administrativas no Ministério da Agricultura, resultando inclusive na reordenação dos grupos políticos ali alocados. Segundo Mendonça (2002), o novo ministro Juarez Távora se opunha a grupos políticos cafeeiros, estando mais inclinado à proposta governamental de diversificação da produção agrícola. Podemos citar como exemplos do estímulo à agricultura a transformação da Diretoria de Organização e Defesa da Produção (DODP) em Serviço de Economia Rural (SER) em 1937, a criação da Carteira de Crédito Agrícola e Industrial do Banco do Brasil (CREAI) em 1937, a criação da Caixa de Crédito Cooperativo (CCC) em 1943, o Patrimônio dos Consórcios Profissionais Cooperativos (PCPC) em 1943, a criação do Departamento de Assistência ao Cooperativismo pelo governo de São Paulo em 1933. Em linhas gerais, no segundo governo Vargas (19511954) a estratégia de intervenção do Estado no setor agropecuário foi intensificada (Beskow, 1999), foram criados outros órgãos como a Comissão Nacional de Política Agrária (CNPA) em 1951, e houve o aumento do crédito à produção e políticas de garantia de preços mínimos foram estabelecidos.

O Decreto n. 22.239 de 19 de dezembro de 1932 foi o primeiro dos nove decretos que regularam a atividade cooperativista durante o primeiro governo de Vargas. De autoria de Luz Filho e Brito, ele inaugura a participação efetiva do governo federal na regulação dessa atividade. A presença do tema do cooperativismo nas pautas 
do Ministério da Agricultura fez com que o Estado passasse a agir como mediador de conflitos entre pequenos produtores e frações dominantes de tradição oligárquica no setor agrário. O projeto que propunha o cooperativismo sem qualquer relação com sindicatos foi, ao final, o formato adotado pelo Estado. Contudo, como demonstra Mendonça (2002), os vários e sucessivos Decretos-lei sobre a atividade cooperativa expedidos até 1945 demonstram que houve uma intensa oscilação na legislação, traduzindo os conflitos internos e as aspirações das distintas frações do segmento agrário.

Ademais, as constantes mudanças na legislação cooperativista brasileira impunham obstáculos legais às próprias cooperativas, na medida em que, a cada novo decreto que entrava em vigor, havia uma crescente necessidade de adequar-se e ele. A burocratização da legislação caracterizou o período inicial de regulamentação do cooperativismo no Brasil, demandando a incorporação de setores técnicos profissionais especializados na gestão administrativa e legal dessas organizações, como contadores, administradores, agrônomos e advogados. O caso da CAC nos ajuda a compreender a afirmação anterior.

Documentos de fiscalização do Departamento de Assistência ao Cooperativismo de 4 de outubro de 1933 registraram várias irregularidades nos documentos exigidos à CAC, reportando a ausência de itens estatutários, registros junto a órgãos oficiais e prestação de informações para fins tributários. Episódio similar voltaria a acontecer em 22 de julho de 1937, pelos mesmos motivos. Em 1 de março de 1939 essa Cooperativa se encontrava em situação irregular junto à Secretaria da Agricultura. Na expectativa de contornar tal problema jurídico, a Cooperativa forneceu documentos que cumpririam as exigências do órgão fiscalizador, requisitando a sua regularização ${ }^{27}$. Em 16 de março um parecer negativo foi emitido pelo chefe da Seção de Registro e Fiscalização do DAC. Em 19 de junho de 1939, o Diretor-Presidente da CAC, Kameiti Yamashita,

\footnotetext{
${ }^{27}$ Segundo documento sob Registro n. 828, p. 30, de 01 de março de 1939, inventário Documentos da constituição: "A Cooperativa Agricola de Cotia, com sede nesta Capital á rua Cardeal Arcoverde $\mathrm{n}^{\circ}$ 2.539, a fim de regularizar a sua situação perante essa Repartição, toma a liberdade de passar às mãos de V. Excia. uma cópia dos seus documentos enviados para registro no Serviço de Economia Rural do Mlnistério da Agricultura e pede a V.Excia. que se digne determinar seu arquivamento, depois de devidamente aprovados". Fonte: Instituto de Cooperativismo e Associativismo, Núcleo de Documentação.
} 
recorreu a um advogado particular que, por meio de uma procuração, passou a cuidar do caso $^{28}$. Somente em 9 de setembro de 1939 a situação foi solucionada.

Episódios como esses foram recorrentes, não apenas nessa cooperativa, como em outras cooperativas agrícolas de origem japonesa, ao menos até o término do Estado Novo (1945), quando a legislação cooperativista obteve contornos mais bem definidos e órgãos setoriais e entidades de representação dos produtores foram criadas. Contudo, as fronteiras políticas ainda prevaleciam como rígidos obstáculos à população japonesa ao menos até que as relações diplomáticas com o Japão fossem retomadas por Vargas, em 1952.

Sumariamente, a emergência de cooperativas agrícolas de japoneses no Brasil está relacionada, em partes, aos resultados das políticas governamentais estaduais e federais de indução à formação de cooperativas, levadas a cabo entre 1910 e 1945, e ao comportamento dos imigrantes na estrutura ocupacional, à sua mobilidade inter-regional e à diversificação de sua produção agrícola.

O quadro a seguir apresenta as cooperativas criadas por imigrantes japoneses no final da década de 1930. Na grande maioria delas, os associados são japoneses ou descendentes. É possível observar que já naquele período esse tipo de organização passou a se difundir e a CAC era a maior delas, com 1.360 associados, cerca de duas vezes mais o número de associados da segunda maior cooperativa, a Cooperativa Agrícola de Bastos.

Por outro lado, conforme tenho argumentado, o projeto nacional varguista impactou de maneira distinta na população japonesa. Quando o degelo político teve lugar nos anos 1950, os japoneses e seus descendentes já haviam se distribuído de maneira significativa pelas oportunidades criadas no mercado de trabalho. Assim, no ano de 1958, se espalhavam por um número variado de ocupações: de um total de 150.271 japoneses ou descendentes, 84.408 ou cerca de $56 \%$ eram trabalhadores

\footnotetext{
${ }^{28}$ Segundo documento sob Registro n. 2.375, p.16, de 29 de junho de 1939, inventário Documentos da constituição, o advogado Abrahão Ribeiro assim finaliza a carta destinada ao DAC: "Em vista do exposto, espera a suplicante se digne v. Excia. de, dispensando-a de mais formalidades, atendê-la nos pedidos feitos até agora, quer quanto aos seus estatutos, quanto ao seu registro, aliás já feito no Rio de Janeiro, quer quanto a outros pontos, cuja falta de solução lhe vêm criando sérias dificuldades, morais e materiais". Fonte: Instituto de Cooperativismo e Associativismo, Núcleo de Documentação.
} 
agrícolas. Outros 65.863 , ou seja $44 \%$, já haviam se estabelecido no mercado de trabalho em ocupações não agrícolas (SUZUKI, 1964, p.241).

Quadro 1 - Cooperativas ligadas à coletividade de origem japonesa - associados segundo origem - final da década de 1930

\begin{tabular}{|c|c|c|c|c|}
\hline Cooperativas & Associados & Japoneses e descendentes (\%) & Brasileiros (\%) & Outros \\
\hline CAC & 1360 & 90,3 & 7,7 & 2 \\
\hline SCA de Bastos & 700 & 100 & - & - \\
\hline CA de Fda Tietê & 567 & 100 & - & - \\
\hline CAM de Mogi das Cruzes & 418 & 95,5 & 1,4 & 3,1 \\
\hline CP de Banana de Juquiá & 279 & 100 & - & - \\
\hline CAM de Cafelândia & 269 & 94,8 & 4,1 & 1,1 \\
\hline SC do 2 Núcleo colonial de Utsuka & 161 & 100 & - & - \\
\hline CA Garça-Vera Cruz & 157 & 100 & - & - \\
\hline CCA Sul-Brasil & 125 & 99,2 & 0,8 & - \\
\hline CAM de Pompéia & 117 & 100 & - & - \\
\hline SCA dos Agricultores de Registro & 85 & 100 & - & - \\
\hline CA de Getulina & 83 & 98,8 & 1,2 & - \\
\hline CA de Marília & 78 & 100 & - & - \\
\hline CA de Monte Alto & 71 & 100 & & \\
\hline CAM de Taquaritinga & 71 & 100 & - & - \\
\hline CA da Fazenda Aliança & 70 & 100 & - & - \\
\hline CA de Avaré & 69 & 100 & - & - \\
\hline CA de Paraguaçu & 63 & 100 & - & - \\
\hline CA de Araçatuba & 57 & 100 & - & - \\
\hline CA Bandeirante & 47 & 100 & - & - \\
\hline SCA Suburbana da Capital & 45 & 100 & - & - \\
\hline CA de Ourinhos & 36 & 100 & - & - \\
\hline CAM de Suzano & 10 & 100 & - & - \\
\hline
\end{tabular}

Fonte: SEABRA, 1977, p.33.

No que diz respeito à dinâmica da imigração japonesa no Brasil, vale ainda ressaltar que, na década de 1930, a entrada dos japoneses no estado ganhou uma intensidade maior se comparada às décadas anteriores: entre 1908 (quando tem início 
oficial a imigração japonesa) e 1934 (quando foram impostas restrições à entrada desse grupo), 164.387 japoneses desembaracaram em território nacional (LEVY, 1974). Já entre 1930 e 1939, 332.768 imigrantes de várias origens entraram no Brasil, sendo que desse total 99.222, ou 29,82\%, eram de nacionalidade japonesa. A respeito de sua concentração geográfica, o Censo de 1940 indica que cerca de 91,5\% dos japoneses residiam no estado de São Paulo (LEVY, 1974, p.80).

$\mathrm{Na}$ literatura especializada dedicada a explicar as causas do aumento da entrada de imigrantes japoneses no país é recorrente a afirmação de que foram fatores centrais a atuação das companhias de emigração e do governo japonês nos projetos migratórios, expressos pelo fato de que, a partir de 1926, as despesas de viagem para o Brasil passaram a ser subvencionadas integralmente pelo governo japonês. Acrescenta-se a isso o ritmo intenso de crescimento econômico, populacional e a exploração das áreas agrícolas da região Oeste do estado ${ }^{29}$. Para o ano de 1934, a Figura 2 a seguir ilustra a concentração da população de origem japonesa no estado de São Paulo.

${ }^{29}$ Para mais detalhes, ver: Saito (1961) e Nogueira (1973). 
Figura 2 - Concentração da população japonesa no estado de São Paulo, 1934

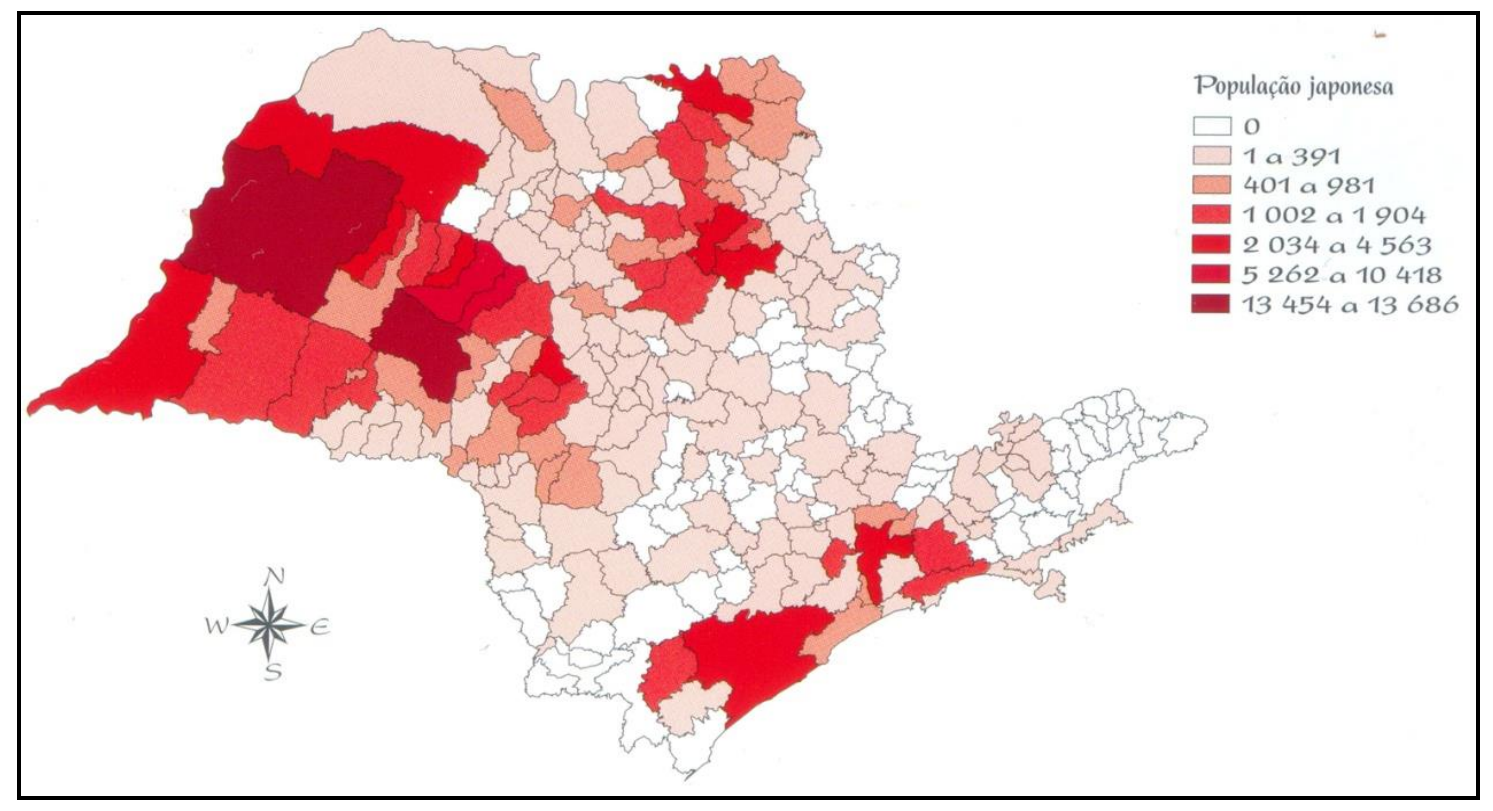

Fonte: Sakurai e Coelho, 2008.

Os dados indicam que, de um total de 131.709 japoneses ou descendentes residentes no estado, a parcela majoritária estava concentrada na região Oeste do estado, e uma fração minoritária entre 2.000 e 4.500 indivíduos já experimentava a vivência urbana na capital. Esses dados permitem referenciar minimamente a população japonesa em termos geográficos para uma data específica, representando uma espécie de "retrato" correspondente ao movimento mais amplo da trajetória desses imigrantes no estado. Mas, indo além de considerações estritamente dedicadas às características do movimento migratório, apresentamos outros aspectos relacionados à experiência das cooperativas agrícolas que interessam diretamente aos objetivos desta pesquisa, principalmente a posição de seus gestores na dinâmica interna de organização da população japonesa em São Paulo.

Em linhas gerais, neste tópico foi apresentado uma análise que situa o lugar do cooperativismo agrícola em relação a um contexto político específico. Por se tratar de 
um tipo de atividade que, no Brasil, historicamente dependeu da regulação estatal para ser desenvolvida, o cooperativismo esteve, de início, estritamente relacionado às políticas de modernização e diversificação agrícola dos primeiros 15 anos do governo de Getulio Vargas. Argumento que para o caso dos imigrantes japoneses a regulação estatal na atividade cooperativista se caracterizou por uma dualidade: ao passo que a repressão política contra grupos estrangeiros se intensificou, a atividade cooperativista, sob intenções modernizantes, passou a ser estimulada pelo Estado, oferecendo uma estrutura de suporte legal e creditício para os pequenos produtores agrícolas - inclusive os estrangeiros - dispostos a organizar sua produção naqueles moldes.

Mas, se a subordinação de pequenos proprietários ao Estado foi um requisito das políticas voltadas ao cooperativismo nas décadas de 1930 e 1940, esse tipo de controle não se traduziu, necessariamente, em formas limitadoras de cooptação das possibilidades inclusivas no mercado de trabalho. Premissas podem ser relativizadas ao investigarmos a trajetória de grupos sociais e de que forma, em cada caso, a presença do Estado condicionou a sua dinâmica de relações sociais. Essa ressalva contribui para ponderarmos leituras históricas que tendem a ressaltar apenas a posição política desvantajosa dos imigrantes na sociedade receptora: o caso do cooperativismo agrícola da população japonesa possui o potencial de demonstrar que perseguição política pode conviver com oportunidade econômica. E, para além de resultados observáveis em termos de mobilidade ocupacional, procuro demonstrar ao longo desta pesquisa que o mercado agrícola representou uma instância em que, principalmente em São Paulo, podemos observar a convergência entre o relativo êxito de empreendimentos fundados por japoneses - e projetos de incorporação social conduzidos por suas lideranças locais.

É válido ressaltar que a literatura especializada tem se revelado fundamental na tarefa de demonstrar que os imigrantes japoneses vivenciaram os acontecimentos políticos dos primeiros 15 anos do governo Vargas de forma bastante particular. Nesse sentido, estudiosos têm se dedicado a investigar os episódios de racismo entre 1920 e $1950^{30}$ e de perseguição política contra esse grupo entre 1937 e 1945, enfatizando a centralidade do contexto da Segunda Guerra Mundial. Pois, naquele confronto bélico, a

\footnotetext{
${ }^{30}$ Ver, por exemplo, TAKEUCHI, M.Y. O Perigo Amarelo em tempos de guerra. São Paulo: Imprensa Oficial do Estado, 2002.
} 
pátria de origem de muitos imigrantes que residiam no Brasil foi considerada um inimigo da nação brasileira. Contudo, devemos considerar que as reações dos imigrantes japoneses a esse contexto de progressiva repressão política foram diversas. Algumas delas se concretizaram na total recusa da participação na sociedade brasileira, a exemplo de assassinatos cometidos por japoneses contra seus compatriotas motivados pelo nacionalismo exacerbado. Outras buscaram reivindicar um espaço de reconhecimento social, a despeito de manifestações explícitas de resistência dos grupos já estabelecidos em aceitar as diferenças culturais de origem estrangeira.

É, portanto, em relação à conjuntura dos anos 1930 - em que no âmbito político inaugurava-se um controle amplo e sistemático do Estado sobre as condições de vida da população, e no plano cultural buscava-se a construção de valores e ideias definidores de uma "nação brasileira" - que podemos observar que o cooperativismo agrícola emergiu enquanto oportunidade institucionalizada. É a partir do relativo êxito de algumas cooperativas agrícolas que observamos as primeiras manifestações de um núcleo social de lideranças da coletividade japonesa da qual os principais gestores da CAC faziam parte. Esse núcleo foi capaz de produzir e disseminar ideias sobre a condição social de sua coletividade na sociedade local. Essas manifestações, em geral, operaram como respostas a adversidades como a recusa da aceitação de suas diferenças por certos grupos nativistas, as restrições à entrada de japoneses no país, bem como a repressão política contra estrangeiros intensificada em fins daquela década. 


\subsection{Modelos de gestão empresarial e clivagens geracionais}

As duas narrativas que inauguram o presente capítulo são registros que têm o potencial de expressar um conjunto de processos sociais considerados relevantes nesta pesquisa, por estarem diretamente relacionados às formas pelas quais uma fração da população japonesa residente em São Paulo vivenciou a experiência migratória. Tais processos adquiriram contornos bastante singulares por dependerem de significados e de interesses mediados por agentes situados em posições de liderança, a exemplo daqueles cujo espaço de atuação por excelência era o universo mercantil.

Em termos analíticos, considero que as ações de indivíduos em posições de liderança dependem de como esses agentes concebem o universo empresarial, de como contingências, situações de concorrência e estruturas de governança afetam decisões. A especificidade do grupo de lideranças da CAC é que o seu horizonte empresarial esteve, em maior ou menor grau, orientado por questões estreitamente relacionadas à trajetória da coletividade japonesa na sociedade paulista ao longo do século XX. Contudo, perspectivas sociológicas voltadas à análise de lideranças empresariais raramente consideram a origem e o percurso social como fatores explicativos relevantes.

Sumariamente, ao menos desde a década de 1950 o tema das lideranças empresariais tem despertado o interesse de sociólogos, especialmente na literatura norteamericana, em que estudos sobre organizações passaram a ser realizados de forma sistemática (SELZNICK, 1957). Nas décadas seguintes, esse tema passou a ser complementado por análises mais direcionadas ao ambiente institucional enquanto fonte de recursos estratégicos para a sobrevivência das organizações (MEYER; ROWAN, 1977; PFEFFER, 1981) e, posteriormente, o universo de lideranças despertou o interesse de estudiosos (FLIGSTEIN, 1987;POWELL; DIMAGGIO, 1991; PFEFFER, 1992; OCASIO, 1994; ZAJAC; WESTPHAL, 1996; THORNTON; OCASIO, 1999).

De forma sintética, é possível afirmar que abordagens institucionais sobre lideranças estão dedicadas a investigar como indivíduos em posições de comando nas firmas 
interpretam os ambientes internos e externos à organização para atuar política e estrategicamente. Essa atuação seria delimitada por aquilo que os indivíduos conhecem, pelas suas percepções sobre o ambiente, e pelo que seria reconhecido como comportamento organizacional adequado. Acredito que essas interpretações, contudo, satisfazem apenas parcialmente a uma análise criteriosa do universo de relações sociais em que os indivíduos estão imersos.

Ações de indivíduos em posições de liderança dependem também de arranjos situacionais envolvendo percursos coletivos, em que é possível identificar operações que extrapolam a condição de agentes concorrendo em um ambiente sob condições ideais de fluidez, transparência, cuja métrica de cálculo se apresenta de maneira plenamente instrumental. Acredito que, se bem situada em contextos dos regimes políticos a que esteve relacionada, acompanhar a formação de grupos sociais traz ganhos analíticos para a tentativa de apreender a atuação das lideranças de um empreendimento. A forma como essa fração dos japoneses experimentou a condição social de imigrantes na sociedade receptora revela que fatores de ordem política e cultural informaram, no plano geral, as possibilidades e os limites para a sua ação também no ambiente dos negócios. Por isso, nesta pesquisa, analiso a conformação e a dinâmica relacional de um grupo específico que, a partir da década de 1930, em São Paulo, atuou de forma decisiva na construção dos caminhos percorridos por essa Cooperativa.

Quando fora inicialmente composto por imigrantes japoneses, o núcleo gerencial da Cooperativa se afirmou como uma liderança local, restrita à coletividade, ou seja, possuidora de características eminentemente endógenas, pautadas por uma origem social compartilhada. Progressivamente, jovens estudantes brasileiros de origem japonesa, filhos desses imigrantes, passaram a reivindicar o reconhecimento de sua posição social, tanto por seus pares quanto pela sociedade paulista. Reivindicação essa que, em grande medida, esteve direcionada ao objetivo de enfrentar as barreiras políticas e culturais de aceitação social.

Desse grupo de jovens fizeram parte algumas das importantes lideranças locais, a exemplo dos primeiros políticos filhos de imigrantes japoneses (João Sussumu Hirata, 
Yukishigue Tamura, Yoshifumi Utiyama), e membros diretores da CAC, como Gervásio Tadashi Inoue e Fábio Ryodi Yassuda. Esse núcleo social vivenciou os episódios da Segunda Guerra Mundial de forma bastante particular, buscando alternativas de legitimação social em meio a nacionalismos conflitantes. Uma delas foi a busca por reconfigurar os parâmetros de diferenças étnico-raciais por meio da criação de narrativas próprias e da adoção de práticas que acenavam positivamente para a aceitação da origem japonesa no Brasil.

Fossem as gestões da CAC conduzidas por indivíduos de primeira ou de segunda geração de imigrantes, o fato é que a maneira pela qual os seus gestores vivenciaram certos eventos reverberou pelos seus repertórios de práticas empresariais: a origem japonesa desse grupo - com os vários processos visando a negociação e legitimação de tal origem - conduziu, dotando de sentido, muitas das ações de lideranças da CAC.

Ao longo deste capítulo apresento evidências empíricas que permitem esclarecer que fatores extraeconômicos podem direcionar ações de lideranças de um empreendimento. Dentre esses fatores sobressaem-se os diretamente relacionados à experiência migratória. No caso analisado, foi constatado que muitos dos significados sociais subjacentes às ações empresariais se basearam na busca por objetivos que extrapolavam a obtenção de melhores resultados financeiros. Formas de incorporação social e de reconfiguração dos componentes simbólicos de representação dos japoneses perante a sociedade paulista também foram propulsoras de objetivos para essas ações em períodos históricos específicos da sociedade brasileira.

Quando desarticulada da conformação de seus grupos de liderança, a análise de uma organização está sujeita a desconsiderar a forma dinâmica e processual que certos fatores sociais lhes conferem. E desse hiato resulta a dificuldade em compreender as razões pelas quais, entre outros eventos significativos, em 1969, durante o governo de Emílio Garrastazu Médici (1969-1974) - menos de 20 anos após o término do período de perseguição política à população de origem japonesa -, o então vice-presidente da CAC, Fábio Yassuda, viria a ser nomeado Ministro da Indústria e Comércio do Brasil, assumindo o cargo político mais elevado que um filho de japoneses havia alcançado em 
toda a América Latina até então. Esse evento será examinado em maiores detalhes no capítulo seguinte.

Neste tópico apresento dois diferentes modelos de gestão empresarial da Cooperativa, situando-os temporalmente em relação às suas características e diferenças mais manifestas. Em seguida, arguo que acompanhar o percurso de lideranças da CAC é profícuo para a discussão sobre incorporação de estrangeiros na sociedade paulista e, por esse motivo, tal movimento de análise é o eixo condutor desta pesquisa. A dinâmica de grupos de liderança implica, contudo, observar processualmente como certos padrões de comportamento são criados, reproduzidos e desestabilizados, considerando mecanismos que estruturam relações. Por esse motivo, ao final do tópico discorro sobre a ocorrência de transições geracionais no âmbito dessas lideranças, argumentando a favor de sua relevância analítica para o presente estudo.

A identificação de dois modelos cognitivos de gestão empresarial sugerida pela comparação entre os dois excertos no tópico anterior é adotada como um ponto de partida de análise, buscando sustentar a seguinte hipótese: os diferentes modelos de gestão indicam diferentes respostas dos gestores a conjunturas que ofertavam possibilidades historicamente situadas de atuação empresarial e de reconhecimento social. O percurso de grupos de liderança da população japonesa em São Paulo fortemente envolvidos com a gestão da CAC - é empiricamente relevante para a validação dessa hipótese: a sua investigação permite atestar a relevância de fatores de ordem política e cultural relativos à busca por formas de incorporação e reconhecimento social com base em diferenças.

O que deve ser sublinhado na afirmação anterior é que os dois modelos de gestão identificados somente adquirem sentido em relação à situação social e à atuação das lideranças de origem japonesa na sociedade paulista, em seus respectivos contextos de menor ou maior acesso a oportunidades para grupos estrangeiros. Na tentativa de estabelecer parâmetros gerais que permitam comparação e análise, ao longo deste capítulo recorro ao artifício de sintetizar eventos de forma a estabelecer dois períodos em que as fronteiras entre a população de origem japonesa e a sociedade receptora foram tensionadas por processos bilaterais de constante redefinição: um primeiro 
período entre as décadas de 1920 e 1940 (em que lideranças de primeira geração de imigrantes foram predominantes), e outro entre as décadas de 1950 e 1980 (em que lideranças de segunda geração de imigrantes foram predominantes).

No primeiro período considerado, as lideranças de origem japonesa de primeira geração foram formadas e progressivamente a partir da década de 1930 adquiriram legitimidade, estabelecendo um circuito social específico localizado na cidade de São Paulo. Essas lideranças buscaram formular estratégias particulares de incorporação, em grande medida sob os aspícios de órgãos diretamente ligados ao governo japonês. No segundo período, esse núcleo de lideranças sofreu transformações internas à medida em que uma segunda geração, nascida no Brasil, passou a reivindicar o reconhecimento de sua posição social. Estratégias distintas de incorporação foram então concebidas, principalmente no âmbito empresarial, político e intelectual. Nesses dois diferentes períodos é que os modelos de gestão empresarial da CAC emergiram como respostas situacionais, foram legitimados e reproduzidos sob a forma de convenções.

De forma sintética, as respostas desses gestores estiveram condicionadas por constrangimentos de ordem: i) legal, relativos aos parâmetros reguladores da atividade empresarial em âmbito institucional sob controle de instâncias governamentais públicas; ii) política, relativos aos direitos e limites de ação de estrangeiros em âmbito institucional sob controle de instâncias governamentais públicas; iii) simbólicoculturais, relativos a resistências de aceitação das diferenças que organizaram seletivamente o acesso a direitos e oportunidades; iv) intragrupo, relativos a processos que esmaeceram certas lógicas e convenções estabelecidas de organização grupal, originando novas formas de sociabilidade. Todos esses fatores, capazes de influenciar modelos cognitivos de gestão, não são mutuamente excludentes e em muitos casos encontraram caminhos convergentes.

Considerando a existência de dois modelos de gestão da CAC, podemos, então, caracterizá-los de forma aproximada, ou seja, no sentido weberiano de "tipos" que não necessariamente retratam fielmente a realidade, mas que podem, em maior ou menor grau, dela se aproximar. Replicando o modelo de tipos ideais de lógicas institucionais de Thornton e Ocasio (1999) para a indústria editorial de ensino superior estadunidense, e 
baseado em resultados de análise documental, as características gerais dos mandatos presidenciais dessa Cooperativa podem ser apresentadas segundo o Quadro 2.

O quadro indica que a gestão comandada por Kenkiti Simomoto (1927-1942) e a gestão comandada por Gervásio Inoue (1957-1990) são significativamente diferentes em ao menos dez características passíveis de classificação no ambiente institucional dessa Cooperativa. Essas diferenças foram concebidas processualmente, resultando em transformações na estrutura organizacional do empreendimento, hierarquia, objetivos, práticas, bem como nas formas de gestão e condução dos negócios.

O primeiro estatuto da Cooperativa reconhecido legalmente pelos órgãos reguladores da atividade agrícola em âmbito estadual e federal é datado de setembro de 1933, ainda que a fundação do empreendimento seja datada de 1927. Durante um intervalo de seis anos, a Cooperativa esteve registrada como Sociedade Anônima, visto que a legislação cooperativista entrou em vigor no Brasil em 1932. O primeiro estatuto fora apresentado em assembleia geral extraordinária e assinado pelos diretores Masuji Yano e Kenkiti Simomoto, quando a Cooperativa possuía cerca de 172 cooperados, todos eles imigrantes japoneses. No "Capítulo 1: Dos fins, denominação sede e duração" 31 são descritos os principais objetivos da associação:

Art.1 - A sociedade praticará as seguintes operações: a) compra em comum dos artigos de primeira necessidade; b) venda em comum dos produtos dos sócios; c) dar aos sócios, por empréstimos, dinheiro necessário para custeio de suas lavouras, recebendo em depósito a economia dos mesmos;

Art.4 - O raio de ação desta Sociedade fica limitado ao município de São Paulo e seus vizinhos, devendo os sócios ser agricultores independentes residentes dentro deste limite.

Art.5 - A duração da Sociedade é de 10 anos, a contar de 1 de janeiro de 1928, podendo esse prazo ser prorrogado por deliberação da assembleia geral.

31 "Cooperativa Agrícola de Cotia. Documentos de Constituição", 1937. Fonte: Instituto de Cooperativismo e Associativismo, Secretaria da Agricultura do Estado de São Paulo, Departamento de Assistência ao Cooperativismo. 


\section{Quadro 2 - Tipos ideais de dois períodos institucionais da Cooperativa Agrícola de Cotia}

\begin{tabular}{|c|c|c|}
\hline & $\begin{array}{l}\text { Gestão de Kenkiti SImomoto (1927- } \\
\text { 1942) }\end{array}$ & $\begin{array}{l}\text { Gestão de Gervásio Inoue } \\
(1957-1990)\end{array}$ \\
\hline Caracteristicas & $\begin{array}{l}\text { Orientada por benefícios coletivos, } \\
\text { predomínio do idioma japonês, } \\
\text { ausência de representação política, } \\
\text { predomínio da 1a geração em } \\
\text { posições de decisão }\end{array}$ & $\begin{array}{l}\text { Orientada por benefícios coletivos e } \\
\text { expansão das atividades, predomínio } \\
\text { do idioma português, presença de } \\
\text { representação política, predomínio da } \\
\text { 2a geração em posições de decisão }\end{array}$ \\
\hline Identidade organizacional & $\begin{array}{l}\text { Em prol da coletividade de } \\
\text { cooperados, origem japonesa }\end{array}$ & $\begin{array}{l}\text { Em prol da coletividade de cooperados } \\
\text { e da sociedade brasileira }\end{array}$ \\
\hline Estrutura organizacional & Cooperativa singular & $\begin{array}{l}\text { Cooperativa Central (controle de } 10 \\
\text { cooperativas associadas) }\end{array}$ \\
\hline Legitimidade & $\begin{array}{l}\text { Reputação intragrupo, expoente } \\
\text { comunitário }\end{array}$ & $\begin{array}{l}\text { Reputação intra e extragrupo, } \\
\text { expoente empresarial, reputação } \\
\text { profissional e expertise profissional }\end{array}$ \\
\hline Estruturas de autoridade & $\begin{array}{l}\text { Horizontal, liderança comunitária, } \\
\text { status baseado em reconhecimento } \\
\text { interno }\end{array}$ & $\begin{array}{l}\text { Vertical, liderança política e } \\
\text { intelectual, status baseado em } \\
\text { reconhecimento interno e externo ao } \\
\text { grupo }\end{array}$ \\
\hline Missão & $\begin{array}{l}\text { Melhorar as condições de produção e } \\
\text { de venda dos cooperados }\end{array}$ & $\begin{array}{l}\text { Melhorar as condições de produção e } \\
\text { de venda dos cooperados, contribuir } \\
\text { para a agricultura brasileira, alcançar } \\
\text { posição competitiva, incrementar os } \\
\text { lucros, modernização da agricultra }\end{array}$ \\
\hline Foco & Qualidade de vida dos cooperados & $\begin{array}{l}\text { Qualidade de vida dos cooperados, } \\
\text { expansão do mercado, diversificação e } \\
\text { qualidade na produção }\end{array}$ \\
\hline Estratégia & Crescimento a longo prazo & $\begin{array}{l}\text { Crescimento a curto e longo prazo, em } \\
\text { sintonia com as políticas econômicas }\end{array}$ \\
\hline Lógicas de investimento & $\begin{array}{l}\text { Aquisição de bens liquidáveis com } \\
\text { recursos majoritariamente próprios, } \\
\text { empréstimos de baixo valor, política } \\
\text { de baixo endividamento }\end{array}$ & $\begin{array}{l}\text { Aquisição de bens liquidáveis, plantas } \\
\text { industriais, tecnologia, recursos } \\
\text { majoritariamente adquiridos no } \\
\text { mercado ou por incentivos públicos, } \\
\text { empréstimos de alto valor, política de } \\
\text { alto endividamento }\end{array}$ \\
\hline Regras de sucessão & Legitimidade perante os cooperados & $\begin{array}{l}\text { Poder político, status, legitimidade } \\
\text { perante os cooperados e a sociedade } \\
\text { brasileira }\end{array}$ \\
\hline
\end{tabular}

Fonte: Elaborado pelo autor. 
O que se observa em seu primeiro estatuto é que a Cooperativa era voltada basicamente para o benefício mútuo dos cooperados, em sua maioria lavradores japoneses dedicados à pequena produção agrícola. O empreendimento almejava oferecer caminhos menos custosos para financiar ${ }^{32}$ a produção e para a venda de produtos $^{33}$, restringia-se ao município de São Paulo, e possuía um prazo estabelecido de funcionamento. A fundação do empreendimento resultou da presença de japoneses no município de Cotia, próximo à capital, conhecido à época com Moinho Velho. O estatuto em questão indica, entre outros, os principais objetivos da associação, sua identidade organizacional, estratégias de investimento.

Em termos gerais, é possível afirmar que a gestão comandada por Kenkiti Simomoto entre os anos de 1927 e 1942 assumiu características endógenas, ou seja, que suas ações estiveram direcionadas em grande parte à coletividade japonesa. Várias são as evidências que possibilitam sustentar essa afirmação: durante esse período, as assembleias eram realizadas em língua japonesa; a Cooperativa se mostrava bastante dependente dos órgãos reguladores, especialmente do Departamento de Assistência ao

\footnotetext{
32 Em relação ao crédito provido aos cooperados, vale ressaltar que valendo-se da legislação cooperativista em vigor a partir de 1932, a Cooperativa adotou um sistema de concessão de empréstimos via mecanismos de crédito rural oferecidos pelos governos federal e estadual: "[...] o Sistema de Poupança do Agricultor Diligente, constituído na Assembleia Geral de 1934, o qual, reforçado pela expressão Agricultor Feliz com a Poupança da Cooperativa, se constituiu, durante muitos anos, numa valiosa fonte de recursos para o desenolvimento das atividades da Cooperativa, sendo aproveitado, no Departamento de Crédito, como fundo para empréstimos a cooperados produtores" (CAC, 1988, p.213). Além dessa modalidade de crédito, havia o sistema pooling, em que "as despesas diretas ficaram por conta do produto vendido, e as despesas de administração da Cooperativa para serem cobertas mediante rateio entre os associados na proporção do crédito respectivo" (CAC, 1988, p.61).

${ }^{33}$ Empecilhos para a produção e venda de produtos eram as principais reclamações dos produtores locais, a exemplo da dificuldade de transporte, fraudes e trapaças cometidas por intermediários no Mercado de Pinheiros. Segundo um lavrador: "Penso que o cooperativismo vingou na região de Moinho Velho porque todos os lavradores japoneses sentiram a necessidade de organizar-se, tendo em vista as experiências infelizes que tiveram no mercado de Pinheiros. Os compradores do mercado eram quase que ladrões. Abusavam da nossa fraqueza: conhecimento insuficiente da língua portuguesa. Os negociantes falavam tão depressa que não entendíamos nada, e sem que nós déssemos sinal de consentimento, eles já iam mandando carregar os sacos de batatinha para seus carros. Não adiantava protestar ou denunciar aos fiscais pois eles eram muito mais hábeis que nós para oferecer explicações e justificar-se ante os fiscais". (Depoimento do Sr. Haruo Kasahara, 31 de agosto de 1953. Tradução de Hiroshi Saito). Fonte: Arquivo Hiroshi Saito.
} 
Cooperativismo (DAC) da Secretaria da Agricultura do Estado de São Paulo ${ }^{34}$; a sua estrutura organizacional possuía um baixo nível de hierarquização; a Cooperativa possuía pouca ou nenhuma representação política, e os assuntos legais envolvendo seus interesses eram representados por profissionais prestadores de serviço, especialmente advogados; a sua lógica de investimento era pensada a longo prazo $^{35}$; a legitimidade dos líderes da Cooperativa dependia de sua reputação entre a coletividade japonesa.

As características da Cooperativa anteriormente descritas sofreram transformações ao longo do tempo, e o contexto da Segunda Guerra parece ter sido um período definitivo para a ocorrência de mudanças significativas em seu núcleo gestionário. Os resultados dessas transformações se expressaram com maior vigor durante a gestão comandada por Gervásio Inoue, entre 1957 e 1990. Situada em uma conjuntura política e social mais favorável à população de origem japonesa, se comparada àquela vivenciada pelos imigrantes de primeira geração, a gestão sob o seu comando colocou em práticas várias mudanças na forma organizacional da Cooperativa, que podem ser exemplificadas a partir dos relatos da Assembleia Geral Extraordinária de 5 de maio de 1966 e do Relatório dos Serviços Sociais do ano 1966.

Na ocasião dessa Assembleia, foi aprovado um novo estatuto para reger as suas atividades, em grande medida em virtude da mudança substantiva na estrutura organizacional da Cooperativa (que já contava, a essa altura, com cerca de 14 mil

\footnotetext{
34 Durante o período, vários documentos reportam consultas da Cooperativa ao DAC, solicitando esclarecimentos a respeito da legislação, bem como concessões, autorizações para importação de produtos, dúvidas fiscais. Ademais, no Relatório dos Serviços Sociais de 1942, consta a seguinte afirmação, que revela uma dependência mais vigorosa das estruturas de governança: "No Brasil, cuja economia é baseada na produção agrícola, tudo devemos fazer em benefício das condições existenciais do lavrador. Eis a razão pela qual o nosso governo, através de uma legislação perfeita, assegurou proteção e estímulo às cooperativas. Nunca poderemos duvidar que a nossa sociedade conquistou a atual situação de prosperidade graças a essa assistência”. Fonte: Instituto de Cooperativismo e Associativismo, Secretaria da Agricultura do Estado de São Paulo, Departamento de Assistência ao Cooperativismo.

35 “A orientação da Cooperativa não visa uma expansão imediata e em curto prazo: visa, ao contrário, uma expansão lenta e firme para os próximos cinco ou dez anos, razão porque o primeiro cuidado após a criação consistiu em comprar uma área de 10 mil metros quadrados onde já se acha em andamento a construção do primeiro depósito, esperando-se também destinar próximos pagamento de quotas à construção de outro depósito e suas instalações". Kenkiti Simomoto, "Passado, presente e futuro da Cooperativa Agrícola de Cotia" - Revista Cotia, n. 1, setembro de 1928. Fonte: Arquivo Hiroshi Saito.
} 
cooperados, de vários estados do país), tornando-a Cooperativa Central ${ }^{36}$. A decisão teria se fundamentado em justificativas diretamente associadas ao mercado ou, mais especificamente, à performance do setor agrícola na economia nacional. Segundo a narrativa de Inoue:

No começo desta década, a inflação que começava a tomar um ritmo acelerado, provocando um processo de desgaste do meio rural, requereu modificações na estrutura econômica e financeira da Cooperativa [...] Assim, no ano de 1962, instituíram-se novos critérios de conjugação dos recursos dos associados e respectiva aplicação em investimentos, abrindo-se o caminho par a formação dos Grupos de Produção, preparando-se para um outra modificação na estrutura orgânica da Cooperativa. Isto porque a área de ação da Cooperativa não só se estendia aos estados vizinhos, como também o volume das atividades dificultava a administração [...] (Relatório dos Serviços Sociais do ano 1966, apresentado à I Assembleia Geral Ordinária da Cooperativa Agrícola de Cotia Cooperativa Central, dezembro de 1966, p.1)

A referida "modificação na estrutura orgânica" da Cooperativa inaugurou uma nova etapa em suas atividades no mercado, principalmente a partir dos benefícios governamentais de estímulo à agricultura entre as décadas de 1960 e 1970, eventos que serão analisados em outro capítulo desta tese. Retendo-nos a pontos específicos na tentativa de ilustrar uma comparação com a gestão anterior, no novo estatuto de $1966^{37}$ é possível inferir que o benefício mútuo dos cooperados permanece sendo um objetivo, mas agora bastante permeado pelos níveis organizacionais intermediários, por etapas do processo produtivo e por instâncias burocráticas de transmissão de crédito e financiamento. $\mathrm{O}$ escopo de atuação da organização passou a abranger os territórios dos estados de São Paulo, Guanabara, Rio de Janeiro, Minas Gerais, Paraná, Santa Catarina, Rio Grande do Sul, Mato Grosso, Goiás, Espírito Santo, Bahia e Distrito Federal; e o prazo de duração da sociedade passou a ser indeterminado. No Capítulo II do estatuto de

\footnotetext{
36 A constituição de cooperativas centrais passou a ser permitida pelo Decreto n. 22.239, de 19 de dezembro de 1932.

37 "Ata de Assembleia Geral Extraordinária da Cooperativa Agrícola de Cotia, realizada em 5 de maio de 1.966". Fonte: Instituto de Cooperativismo e Associativismo, Secretaria da Agricultura do Estado de São Paulo, Departamento de Assistência ao Cooperativismo.
} 
1966, "Da denominação, sede e foro da Sociedade", "Seção I. Do objetivo da sociedade", fora estabelecido que:

\begin{abstract}
Art. $2^{\circ}$ - A sociedade tem por objetivo praticar as seguintes operações: a) vender em comum produtos colhidos ou elaborados, entregues por suas associadas, podendo classificá-los, padronizá-los, depositá-los, armazená-los, beneficiá-los e industrializá-los; b) distribuir às associadas os bens de produção e utilidades necessárias a suas atividades; c) abastecer as seções de consumo das associadas, de gêneros alimentícios, artigos de vestuário e outros de uso e consumo pessoal, da família ou do lar; d) proporcionar financiamentos e adiantamentos típicos de crédito rural poder ter sob sua guarda economias diversas, cujos serviços regerse-ão por regulamento aprovado pelo órgão estatal competente; e) proporcionar a utilização de serviços comum, para incremento e defesa da produção e para assistência administrativa, técnica e social das cooperativas filiadas e respectivos associados, propugnando também pela educação cooperativista
\end{abstract}

Em termos gerais, é possível afirmar que a gestão comandada por Gervásio Inoue entre os anos de 1957 e 1990 foi menos motivada pela necessidade de suprir as necessidades básicas para a produção dos lavradores japoneses, e mais direcionada para um desempenho satisfatório no mercado. É razoável supor que na medida em que estruturas básicas de apoio à produção dos cooperados haviam sido estabelecidas pelas gestão anterior, práticas voltadas a atender esse tipo de demanda se tornaram progressivamente menos prevalecentes. Contudo, outras características dessa gestão nos informam que a composição endógena dos núcleos decisórios sofreu modificações irreversíveis, e passou-se a adotar métodos racionais de gestão voltados a melhorar a performance administrativa e dos lucros ${ }^{38}$.

Entre outras características, as assembleias passaram a ser realizadas em língua portuguesa; a sua estrutura organizacional se modificou em resposta a um conjunto de novas leis cooperativistas, a exemplo do seu escopo de atuação, ou mesmo do seu

\footnotetext{
38 "O processo de racionalização e melhoramento dos setores orgânicos da C.A.C. não só iniciou a modificação da nossa estrutura administrativa, com também das instalações que diretamente influem na vida econômica do associado" (Relatório da Diretoria - ano social 1965/1966, apresentado à Assembleia Geral Extraordinária realizada em 29 de julho de 1966). Fonte: Instituto de Cooperativismo e Associativismo, Secretaria da Agricultura do Estado de São Paulo, Departamento de Assistência ao Cooperativismo.
} 
sistema de crédito $^{39}$; a Cooperativa gozava de uma reputação bastante positiva diante dos órgãos reguladores e autoridades governamentais; o seu núcleo de diretores passou a possuir, desde a década de 1940, representação em órgãos classistas do setor agrícola, como a Sociedade Nacional de Agricultura $^{40}$, a Sociedade Rural Brasileira ${ }^{41}$ e a Federação das Associações Rurais do Estado de São Paulo (FARESP).

Tais mudanças, em comparação ao período de gestão anterior, foram expressas nas próprias palavras de Inoue:

Os associados fundadores se recordarão com saudade as lutas contra a incompreensão e contra aqueles que pretendiam enriquecer-se à custa da exploração desalmada dos desamparados lavradores; e os velhos funcionários relembrarão dos trabalhos diuturnos e árduos de longos anos, mas todos sentirão que viveram uma organização que cresceu como realização palpitante do cooperativismo, um verdadeiro milagre da solidariedade humana e do lema "união faz a força". (Relatório dos Serviços Sociais do ano 1966, apresentado à I Assembleia Geral Ordinária da Cooperativa Agrícola de Cotia - Cooperativa Central, dezembro de 1966, p.VIII)

Embora um estudo sobre a CAC deva considerar a processual transformação de sua lógica institucional, tenho argumentado que acompanhar o percurso dos gestores da CAC pode trazer ganhos analíticos para a tarefa de demonstrar que fatores extraeconômicos, entre eles os diretamente relacionados às estratégias de incorporação

\footnotetext{
${ }^{39}$ A legislação cooperativista de novembro de 1966 passou a limitar as atividades de crédito a instituições financeiras ou a cooperativas exclusivas para crédito. Diante dessas exigências, em abril de 1968 a CAC fundou a sua cooperativa de crédito, denominada Cooperativa Regional de Crédito Rural Ltda: "Entrando em atividade seis meses depois de criada [...], mediante consentimento do Banco Central, pôde, nesse período, ir absorvendo gradativamente os serviços da ex-Secretaria de Crédito [...] seu quadro associativo foi aumentando rapidamente, composto, na verdade, pelos próprios associados de Cotia. Ficava, assim, extinta a Poupança do Agricultor Diligente, que era formada pela retenção de $2 \%$ do valor da venda da produção, na Cotia, uma pessoa jurídica distinta da pessoa pesoa jurídica da CRCR" (CAC, 1988, p.214).

${ }^{40}$ A presença dos gestores da Cooperativa na Sociedade Nacional de Agricultura pode ser constatada na reportagem: "Uma escola para todos os que se interessam pelo cooperativismo. Visita a Cooperativa Agrícola de Cotia o sr. Artur Torres Filho, presidente da Sociedade Nacional de Agricultura”. Jornal de Notícias, 29 de junho de 1946.

41 A presença dos gestores da Cooperativa na Sociedade Rural Brasileira pode ser constatada na reportagem: "Poderosa organização destinada a controlar toda a pecuária em São Paulo e nos Estados vizinhos. As bases da nova entidade serão lançadas nesta capital na próxima semana - Fala à nossa reportagem". Jornal de Notícias, 08 de julho de 1947.
} 
durante a experiência migratória, podem direcionar ações de lideranças de uma organização. E, mais ainda, que transições geracionais são processos relevantes para compreender a dinâmica interna das lideranças da Cooperativa.

O que deve ser sublinhado aqui é que processos de transição geracional produziram desdobramentos nos mecanismos de legitimidade e poder internos ao grupo, bem como resultaram de situações de conflito entre gerações sucessivas. Portanto, a clivagem geracional representou uma importante forma de estruturação das relações intragrupo.

Quando se observa a sucessão geracional de dirigentes na trajetória da CAC, iniciada na década de 1940, certas características do grupo - principalmente a estrutura familiar, o idioma, a endogamia e os sistemas simbólicos que regiam e perpetuavam formas legítimas de conduta - passaram a conviver com assimetrias que esmaeceram certas instâncias anteriormente autênticas de sociabilidade intragrupo, como Saito (1964) já constatara. Mas, ao contrário desse autor, nesta pesquisa a cultura e a economia não são concebidas em esferas separadas de realização, e as características “étnicas" não são vistas de forma imutável e essencializadas. A abordagem aqui desenvolvida assume que os fenômenos de natureza social representam parte constituinte da vida econômica. Isso é especialmente importante de se ter em conta em empreendimentos cooperativos, como Cotia, que se constituíam em núcleos centrais de sociabilidade de indivíduos recentemente chegados a outra sociedade, profundamente diversa da sua própria, em termos culturais.

Enquanto conceito sociológico e da forma aqui empregada, "geração" pretende traduzir conceitos nativos de uma estrutura de organização de relações em que diferenciações internas passaram a ser produzidas. A nacionalidade certamente adquiriu importância simbólica decisiva em muitos momentos de conflito interno e externo ao grupo, porque constituía uma categoria de representação que informava limites e possibilidades de aceitação em conjunturas politicamente conturbadas, como o período da Segunda Guerra Mundial. Ademais, a clivagem geracional dificilmente corresponde à realidade se a imaginarmos como um movimento estático e contínuo, há porosidades, dissonâncias e conflitos que configuram as relações sociais. No limite, gerações 
sucessivas de um mesmo grupo imigrante dificilmente se reproduzem sob as mesmas formas, como observou Grün (1998) ao estudar o caso dos armênios em São Paulo.

As duas gerações de gestores da Cooperativa, apesar de compartilharem uma mesma origem social e, ainda que fossem os polos ligados pela transmissão de valores, costumes e normas, possuíam uma morfologia bastante complexa, ou seja, diferenças internas se manifestavam em uma ampla gama de variações. Entre os indivíduos nascidos no Japão, há evidências de que distinções se estabeleciam conforme a província de origem ${ }^{42}$, as variações idiomáticas, os costumes regionais, a condição financeira, as aspirações e as orientações políticas. Entre os indivíduos de segunda geração nascidos no Brasil, a condição financeira, a nacionalidade brasileira, o domínio da língua portuguesa e, principalmente, a escolaridade eram signos que indicavam posições sociais. Mas talvez a melhor expressão foi um restrito círculo de jovens estudantes.

Gervásio Inoue foi o sucessor de Kenkiti Simomoto na presidência do empreendimento, exceto pelo período em que a diplomacia brasileira rompeu relações com a japonesa no contexto da Segunda Guerra Mundial. Nesse período em que o âmbito da política mostrava-se bastante hostil à população japonesa, a Cooperativa foi presidida por indivíduos nascidos no Brasil e sem qualquer origem nipônica (19421957). Esse assunto será tratado em maiores detalhes no tópico 1.5. De maneira breve, nesse intervalo o ambiente político de cerceamento convenceu a diretoria de que a

\footnotetext{
${ }^{42}$ Depoimentos do Sr. Hauro Kasahara e do Sr. Kenkiti Simomoto revelam uma contradição a respeito desse assunto: "Pelo fato de a minha origem não ser da província de Kochi, sofri um bocado durante 25 anos da vida como cooperado. Algumas resoluções tomadas nas reuniões formais eram desrespeitadas ou não cumpridas por determinações posteriores nas reuniões íntima entre os cooperados originários da mesma província de Kochi. Não posso afirmá-lo expressamente, mas houve casos que me pareceram assim, pelo menos". Já Kenkiti Simomoto afirmava não haver conflitos pelo local de origem no Japão, ainda que admitisse a existência de diferenças: "Não me lembro de casos de antagonismo, motivados manifestadamente pela diferença da origem no Japão. Se houve pequenos desentendimentos entre os de Kochi-ken e de outros ken, foram devidos mais à diferença de linguagem (dialeto) e não por animosidade decorrente de preconceito ou de outros motivos" (Depoimento do Sr. Haruo Kasahara, 31 de agosto de 1953 e Depoimento de Kenkiti Simomoto, setembro de 1953. Tradução de Hiroshi Saito). Fonte: Arquivo Hiroshi Saito.
} 
melhor decisão a ser tomada era substituir os seus cargos máximos de comando, na expectativa de antecipar uma possível intervenção policial ${ }^{43}$.

Salvo esses 15 anos de excepcionalidade, a Cooperativa se caracterizou por manter um núcleo gerencial composto por japoneses natos ou filhos de japoneses, fato esse que assinala a favor da composição endógena nas suas altas hierarquias. De uma forma geral, ao contrário da geração anterior de diretores da CAC, os seus sucessores promoveram um tipo diferente de gestão, amplamente fundamentada em princípios racionais, habilidades técnicas e políticas. Novos padrões de condução dos negócios surgiram à medida em que essa cooperativa passou a atuar competitivamente no mercado e a criar mecanismos que pudessem influenciá-lo.

Em meio a esse processo, as linhas divisórias que separavam os grupos geracionais e de interesse se tornavam mais rígidas e, por vezes, conflituosas. Núcleos restritos de poder se formaram dentro do empreendimento cooperativo, e a possibilidade de interferência nas decisões empresariais se tornou ao menos seletiva, pois demandava dos agentes uma capacidade constante de mobilizar os repertórios legítimos para tal tarefa. Dentre estes, destaco os recursos diretamente relacionados ao conhecimento profissional da ciência econômica e à construção de relações com agentes externos, mobilizados principalmente por gestores de segunda geração. Se as credenciais profissional-administrativas suscitavam disputas e conflitos internos ao grupo, a sua eficácia dificilmente era questionada: a CAC foi capaz de produzir uma ordem simbólica mercantil (LEBARON, 2012), que informava sobre os procedimentos mais adequados para a produção e a comercialização agrícola (uma referência mental), cuja eficácia foi validada pela prática social (um espaço de ação para os agentes sociais). E, acompanhando o crescente movimento de expansão da atuação da Cooperativa no

\footnotetext{
${ }^{43}$ Nas palavras do então presidente da Cooperativa entre 1942 e 1957, Manoel Carlos Ferraz de Almeida: "Quando, em princípios do ano passado, o Brasil assumiu a atitude que lhe cumpria, em face da conflagração mundial, sob a alegação de que a maioria dos seus associados eram japoneses, esta cooperativa foi, por vezes, considerada um agrupamento nocivo à nação e, nestas condições, achou-se em face da maior crise que poderia alcançá-la, criando sérios obstáculos à consecução dos seus objetivos. A clarividência e a compreensão das nossas dignas autoridades, entretanto, levaram-nos à convocação da Assembleia Geral Extraordinária de 20 de abril de 1942, na qual foram eleitos, excluivamente, cidadãos brasileiros para a diretoria da sociedade" (Relatório da Diretoria da CAC, 1943, p.I). Fonte: Instituto de Cooperativismo e Associativismo, Secretaria da Agricultura do Estado de São Paulo, Departamento de Assistência ao Cooperativismo.
} 
mercado, cada vez mais os seus dirigentes passaram a ser reconhecidos como portadores de uma expertise em assuntos relacionados à agricultura no país.

O ambiente de gestão da Cooperativa indica, assim, a predominância de diferentes modelos de gestão em períodos distintos, constituindo formas organizacionais que procuravam oferecer respostas situacionais a diferentes conjunturas. Essas respostas foram influenciadas por fatores de dimensões amplas, a exemplo das estruturas de governança, políticas econômicas voltadas à agricultura, bem como a dinâmica da própria imigração japonesa na primeira metade do século XX. Mas elas também dependeram de maneiras pelas quais grupos e indivíduos se relacionaram com a sociedade local, produzindo diferentes respostas às estruturas de oportunidades.

Assim, de forma sintética, acredito que a geração constitui, no caso analisado, uma das categoriais centrais que nos permite reconstituir o processo de mudança de um modelo de gestão para outro no ambiente de direção da CAC. Isso é sustentado por evidências empíricas que serão apresentadas ao longo desta tese.

Em linhas gerais, podemos apresentá-las da seguinte forma: i) ao ser mediada pela nacionalidade (brasileira ou japonesa) de seus gestores, a clivagem geracional ocorrida no empreedimento não representou apenas uma sucessão temporal dos personagens que estiveram à frente da gestão da Cooperativa, ela também esteve relacionada à dinâmica da imigração japonesa no Brasil em seus aspectos mais amplos, incluindo períodos de maior ou menor acesso a oportunidades sociais oferecidas pelo Estado. A implicação disso é que em determinadas conjunturas políticas havia limites bem definidos para a ação de gestores de nacionalidade estrangeira; i) a geração nos indica como lideranças da coletividade japonesa em São Paulo - nascidas no Japão ou no Brasil - formularam diferentes respostas às barreiras de aceitação e de incorporação em sua capacidade de produzir narrativas e assumir posições políticas a partir da realidade do seu grupo social; ii) geração indica, no caso da Cooperativa analisada, a ocorrência de um progressivo abandono das características endógenas na gestão do empreendimento. Pois, progressivamente, gestores filhos de japoneses foram capazes de articular relações estratégicas para a coordenação do mercado, bem como produziram discursos gerenciais que exaltavam uma lógica racional de condução dos negócios. 
Assim, novas convenções e regras passaram a prevalecer no ambiente organizacional; iii) diferente do que previam os autores intérpretes do assimilacionismo, as paulatinas transformações geracionais desse grupo não significaram necessariamente 0 desaparecimento progressivo de manifestações "étnicas", como um resultado inevitável do encontro entre grupos portadores de características distintas (SEYFERTH, 1994). As representações acerca dos japoneses foram constantemente negociadas, reinventadas e ressignificadas em novos contextos.

De maneira a organizar o presente estudo, optei por dispor o seu conteúdo a partir do que foi identificado como dois modelos cognitivos de gestão empresarial. Dessa forma, os tópicos que compõem este capítulo estão centrados no período em que prevaleceram imigrantes japoneses de primeira geração na gestão da Cooperativa. No capítulo seguinte é abordada a atuação de gestores de segunda geração, filhos de imigrantes. 


\subsection{Lógicas de diferenciação interna e formação de lideranças}

Situar a posição social dos personagens responsáveis pela condução do empreendimento cooperativo constitui a etapa inicial desta pesquisa na tarefa de demonstrar que i) fatores extraeconômicos como aqueles diretamente relacionados à experiência migratória podem direcionar ações de lideranças de um empreendimento; ii) a CAC constituiu um espaço relevante para a direção da ação de indivíduos e grupos de origem japonesa que buscavam paulatinamente construir as suas estratégias de incorporação.

Em linhas gerais, busco acompanhar processos que tornaram esses gestores lideranças políticas e autoridades publicamente reconhecidas. Inicialmente, é importante esclarecer uma relação que considero significativa entre o núcleo de pequenos agricultores situados no município de Cotia e as lógicas de diferenciação social internas à população japonesa residente na cidade de São Paulo entre as décadas de 1910 e 1930. Demonstro que um órgão especifico - o Consulado Geral do Japão - influenciou fortemente as formas de organização social dos imigrantes japoneses na capital em razão da sua participação em processos de diferenciação, uma condição para a existência de grupos de liderança. Ao fazer parte desse circuito social e obter sucesso no empreendimento, a CAC encontrou caminhos para o reconhecimento, ainda que limitado à população de origem japonesa. $\mathrm{O}$ reconhecimento circunscrito significa que barreiras para a incorporação desses imigrantes na sociedade paulista eram sustentadas por fatores que se transformavam em ativos de diferenciação que as lideranças de primeira geração dificilmente dispunham: elas estiveram construídas sob categorias de diferenciação cultural, em que a nacionalidade, o idioma, os costumes e as credenciais compunham valiosos recursos. Nesse sentido, coube aos gestores da Cooperativa de segunda geração, em sua maioria nascidos no Brasil, a tarefa de criar estratégias que pudessem reinventar os significados das diferenças culturais. Esse último assunto será tratado no Capítulo 2. 
Neste tópico examino o processo de diferenciação social entre os imigrantes japoneses na cidade de São Paulo impulsionado pela presença de estratos vinculados ao Consulado Geral do Japão e órgãos encarregados de administrar a vinda de imigrantes para o país. Adiante, veremos como a criação da Cooperativa dependeu do suporte oferecido pelo órgão consular e, posteriormente, obteve reconhecimento e legitimidade que lhe consagrou como um expoente dos negócios.

Em 1914 o escritório do Consulado Geral do Japão foi transferido do Rio de Janeiro para a capital paulista, em grande medida motivado pelo crescente número de imigrantes japoneses que tinham como destino o estado de São Paulo ${ }^{44}$. O distrito da Sé, localizado na região central da cidade, foi escolhido como o local de seu estabelecimento e, ao menos até a década de 1940, a sua presença e atuação repercutiram tanto sobre a ocupação da cidade pelos japoneses, como sobre a estrutura de organização social do grupo que habitava a capital paulista.

Nos parágrafos a seguir reconstituo, parcialmente, certas características do processo de ocupação urbana dos japoneses em São Paulo entre as décadas de 1910 e 1930, ocorrido especificamente no bairro da Liberdade, na região central da cidade. A escolha por investigar esse espaço não foi aleatória, pois grande parte da literatura especializada é unânime em afirmar que a partir da década de 1910, nos arredores da Rua Conde de Sarzedas, teve início uma concentração japonesa no local.

$\mathrm{Na}$ literatura talvez haja pouco consenso quanto aos primeiros registros de imigrantes que habitaram a cidade de São Paulo: há relatos que remontam até mesmo ao período anterior ao início oficial da imigração ${ }^{45}$. Possivelmente esses casos tenham sido iniciativas de caráter mais individual, ou seja, que não se desdobraram continuamente em movimentos de ocupação. Para o pintor e memorialista Tomoo Handa, há menções que indicam a existência de dez imigrantes que, após desembarcarem do primeiro navio

\footnotetext{
44 Entre 1908 e 1914, 16.404 japoneses entraram no Brasil, e cerca de 98,5\% deles tiveram como destino o estado de São Paulo (LEVY, 1974).

45 Segundo Handa, os primeiros residentes japoneses em São Paulo teriam sido Takeo Goto, da Comercial Fujisaki e seus funcionários; os mascates e o supervisor de uma fábrica de brinquedos e, ainda, outros que prestavam serviços subalternos em hotéis (HANDA, 1987, p.153). Outros nomes podem ser incluídos nessa lista, como Rioichi Yassuda, Umekichi Akeho, Saburo Kumabe, Umekichi Akeho, Teijiro Suzuki (COMISSÃO, 1992, p.61).
} 
que deu início oficial à imigração japonesa no Brasil - o Kasato Maru -, saíram da Hospedaria de Imigrantes e se instalaram diretamente na cidade de São Paulo (HANDA, 1987, p.151).

A despeito das origens dessa ocupação, muitos autores que se dedicaram a analisar o tema afirmam que a presença mais efetiva de japoneses em São Paulo teria ocorrido principalmente pela instalação de estabelecimentos comerciais, pensões, escritórios e entidades associativas (COMISSÃO, 1992). Além da Rua Conde de Sarzedas, por volta de 1913 algumas famílias habitavam outras localidades próximas, ainda que, nesse caso, se tratasse de uma ocupação majoritariamente para fins domiciliares. É o caso da rua da Mooca. Segundo o antropólogo Takashi Maeyama:

\begin{abstract}
Pouco antes da chegada da terceira leva de imigrantes, os japoneses em São Paulo pontilhavam principalmente nos arredores das fábricas. No final da rua da Mooca, perto da fábrica de biscoitos Duchen e de fábricas de sapatos, moravam Matsunaga, Seihachi Kimura, [Takeo] Goto, a viúva Fujimoto, a dona Ko, que havia se separado, além de um grupo de três ou quatro jovens da Província de Saga, cada qual dedicando-se à vida laboriosa. O velho Norimatsu com a jovem mulher e a criança de peito, a família Junzo Nanba e outras duas famílias também moravam na vizinhança, enquanto parte central da rua Taquari, um pouco mais além, moravam Kenichi Ozawa e outras 17 ou 18 famílias das Províncias de Okayama e Ehime. Numa travessa da rua da Mooca se aglomeravam Kimura e mais quatro ou cinco famílias de imigrantes de Kumamoto. Salvo engano, nessa rua teve início o futuro Diário Nippak. As cercanias da rua São Paulo e a ladeira da Conde de Sarzedas tinham adquirido já nessa época traços de uma área de concentração de japoneses. (KOUYAMA apud MAEYAMA, 2004, p.89)
\end{abstract}

O relato acima nos fornece pistas indicativas da centralidade que a região da Rua Conde de Sarzedas passava a adquirir para os imigrantes que buscavam se estabelecer na grande cidade. Trata-se de um ponto de partida que contribui para a tarefa de compreender esse processo de ocupação japonesa entre as décadas de 1910 e 1930.

Neste trabalho, tento apresentar um modelo de interpretação com a intenção de analisar certas estruturas sociais de organização interna da população japonesa que habitava a região central da cidade. Argumento que essas estruturas formavam um 
universo de possibilidades em que as ações dos indivíduos podiam se realizar de maneira dinâmica e relacional. A capacidade de agência dos indivíduos não é, portanto, negligenciada e nem mesmo sobredeterminada: ao contrário, ela possui centralidade e é potencialmente transformadora, pois informa intenções que nos ajudam a desvendar as complexas formas de lidar com os impasses, as expectativas e as ambições vividas por essa população de imigrantes em uma metrópole em franca expansão. Essa estrutura de organização possuía centralidade pois congregava as principais representações oficiais dos japoneses no Brasil. E, dessa forma, compunha um circuito de sociabilidade e visibilidade. Não por acaso, as principais lideranças da CAC nele ingressaram, fossem elas Kenkiti Simomoto ou a segunda geração, como Gervásio Inoue e Fábio Yassuda.

Fazendo uso desse modelo, analiso como fatores eminentemente sociais - a exemplo de normas, status e valores - manifestavam-se em um ambiente de negociação de posições sociais, bem como estavam suscetíveis a processos de mudança e ressignificação. Essa análise possui uma dupla vantagem: permite atentar para a dinâmica de construção dos fenômenos analisados, e não apenas os seus resultados; e considera certos fenômenos, a exemplo das oportunidades de inserção social, como processos socialmente constituídos e presentes no imaginário coletivo (especialmente no caso da segunda geração, a ser tratado no Capítulo 2).

As interpretações do pintor e memorialista Tomoo Handa e do antropólogo Takashi Maeyama sobre o tema são referências importantes na literatura especializada, pois representam valiosos relatos de autores que vivenciaram esse contexto. Possivelmente, a reconstituição aqui apresentada pode estar limitada pela escassez ou mesmo confiabilidade dos dados, uma vez que nesta pesquisa não tive acesso a algumas fontes estatísticas primárias para a realização de checagem. Ainda assim, valho-me inicialmente de seus escritos como subsídios para a nossa argumentação. Apresento aqui, de forma sucinta, as considerações de cada autor sobre o surgimento dos estabelecimentos comerciais e de serviços de propriedade de japoneses, e de que forma eles transformaram a vida cotidiana dessa população que passava a habitar a região central da cidade. Em seguida, argumento a favor da relevância que certas instituições tiveram para os imigrantes, tendo contribuído para conformar um ambiente social singular na cidade de São Paulo da década de 1930. Aqui, possui destaque a presença 
efetiva de órgãos ligados ao governo japonês, especialmente o Consulado Geral do Japão. Este último particularizou as formas de organização do grupo ao estabelecer um processo de diferenciação social interno à população de imigrantes japoneses, como busco argumentar adiante.

Segundo a interpretação de Maeyama (2004) no capítulo "Os imigrantes japoneses na cidade de São Paulo”, os estabelecimentos da região da Rua Conde de Sarzedas possuíam uma característica singular no imaginário dos imigrantes, sendo capazes de atrair o público conterrâneo para a localidade, na medida em que convergiam trajetórias análogas marcadas por expectativas e necessidades compartilhadas:

Essa área era considerada pelos japoneses como sua terra natal em São Paulo. Eles começaram a se acomodar nos seus arredores por volta de $1910 \mathrm{e}$ a partir de 1913, aproximadamente, a área começou a adquirir aspectos de bairro japonês, em função do acelerado processo de urbanização dos imigrantes. Associações de moços, associações japonesas, escolas de japonês, pensões, times de beisebol, tudo teve início nessa área [...]

Rua Conde designava também toda a redondeza além da ladeira, incluindo outras ruas: Conselheiro Furtado, Irmã Simpliciana, Conde do Pinhal, Estudante, São Paulo, e Tomás de Lima. Considerando que mais de 95\% dos imigrantes japoneses moravam em zonas rurais e levavam um vida amarga, enfrentando duras condições de trabalho nas fazendas de café, mudar para a cidade de São Paulo significava uma grande meta, um sonho a concretizar, e a rua Conde foi convertida em símbolo de solidariedade e coexistência da colônia nikkei no Brasil. (MAEYAMA, 2004, p.155)

Nesse ponto, a interpretação de Handa é bastante similar. Para o autor, principalmente na Rua Conde de Sarzedas teriam surgido as primeiras pensões e mercearias com essas características. Localizadas em uma região central e acessível, esses estabelecimentos também serviam como pontos de referência aos japoneses recém-chegados à capital: "as hospedarias eram de grande utilidade às pessoas que vinham do interior, bem como serviam de ponto de apoio para quem procurava emprego em São Paulo" (HANDA, 1987, p.171).

Não por acaso, o autor, que viveu parte de sua vida naquela rua, referia-se a ela como um "oásis dos irmãos conterrâneos que viviam no Brasil". A metáfora do "oásis" ganha um sentido bastante elucidativo na medida em que Handa, ao discorrer sobre 
episódios cotidianos, relata as suas impressões acerca das novas possibilidades que o desenvolvimento do comércio e dos serviços trazia para a vida dos imigrantes que por ali transitavam. Entre outros eventos, as primeiras iniciativas de oferta de produtos e gêneros alimentícios tipicamente japoneses na cidade foram por ele flagradas:

Para os visitantes das mercearias japonesas, era uma alegria encontrar shôyu à venda. Por causa da existência do shôyu é que apareceram casas de tôfu e de udon e tornaram-se viáveis as pensões que ofereciam refeições japonesas $[\ldots]$

Sem dúvida, foi um grande acontecimento o surgimento do shôyu na vida alimentar dos japoneses no Brasil. (HANDA, 1987, p.171)

Como bem assinalou Maeyama, outras ruas adjacentes também passaram a fazer parte desse modesto circuito comercial e de serviços, ou seja, abrigavam estabelecimentos de propriedade de japoneses voltados principalmente ao público conterrâneo, como as ruas Conselheiro Furtado, Pirapitingui, Tomás de Lima, Conde do Pinhal, São Joaquim, Liberdade, Riachuelo. Dentre os estabelecimentos mais conhecidos à época, é possível mencionar, entre outros: a Pensão Ueji; o Hotel Tokiwa; a Mercearia Seki; a Casa Japão; a Casa Mikado; a Casa Tokyo; a Casa Hachiya; a Casa Nakaya; a Casa Kunii; a Casa Ohara; a Casa Kumaki Nakao; a Escola Primária Taisho; a Sociedade Japonesa de Beneficência no Brasil (Dojinkai); o escritório da Kaigai Kabushiki Kaisha (Companhia Ultramarina de Desenvolvimento S.A.); a Clínica Dentária Murakami; a Livraria Endo; a empresa jornalística Brasil Jihô.

Avançando nessa discussão, Maeyama apresentou informações sobre as categorias profissionais dos imigrantes japoneses para o ano de 1916. De forma similar, Handa retratou o surgimento $\mathrm{e}$ as atividades de alguns desses primeiros estabelecimentos em maiores detalhes no capítulo intitulado "Os imigrantes japoneses na cidade de São Paulo em 1933" (HANDA, 1987, p.575). Ali, o autor especificou algumas das principais categorias ocupacionais dos imigrantes japoneses que habitavam a cidade na década de 1930. Esse interesse específico, presente nas obras de ambos os autores, parece ser plenamente justificável: saber quais tipos de atividade profissional os japoneses exerciam pode informar muito a respeito das formas de inserção urbana e da organização social do grupo naquele contexto. 
Fazendo uso de um levantamento realizado pelo Consulado do Japão em São Paulo, Maeyama afirmou que em 1916 havia 1.333 japoneses residindo na capital paulista. De uma lista de 13 categorias ocupacionais, as mais recorrentes seriam: criados $(32,6 \%)$, carpinteiros $(21,7 \%)$, agricultores $(18 \%)$ e operários $(16,5 \%)$ (MAEYAMA, 2004, p.92).

Baseado em duas publicações que realizaram levantamentos de propriedades e de estabelecimentos de japoneses na década de $1930^{46}$, Handa localizou 61 categorias profissionais exercidas por imigrantes que residiam exclusivamente na cidade, desconsiderando apenas as atividades diplomáticas. Esses dados fundamentaram o argumento de que, no período considerado, uma parcela - ainda que reduzida - dos imigrantes passou a exercer atividades profissionais liberais:

Uma outra novidade, em comparação com os primeiros tempos, era o surgimento dos assalariados "colarinhos-brancos", embora em número ainda reduzido. Em decorrência do aumento do número de imigrantes, o Consulado-Geral do Japão havia ampliado o seu quadro de funcionários; a Companhia de Emigração, que passou a ter um volume maior de procedimentos administrativos, também resolvera contratar alguns imigrantes que considerasse mais capacitados e competentes; havia, ainda, os que trabalhavam como jornalistas, ou então, como funcionários administrativos na Associação dos Pais em Prol da Educação, nas associações japonesas, nas associações médicas - como a Dôjinkai - e em outras instituições. Estes "colarinhos-brancos" somavam um contingente de cerca de 70 pessoas e, juntamente com educadores, missionários, advogados e médicos - num total geral de umas 100 pessoas - formavam a chamada intelectualidade da colônia japonesa de então. (HANDA, 1987, p. 578).

Principalmente a interpretação acima de Handa permite-nos reconstituir minimamente determinados núcleos de interação social da década de 1930 que contribuíram para a conformação de um ambiente que, posteriormente, favoreceu a criação de cooperativas agrícolas, bem como a atividade estudantil de jovens filhos de japoneses. Dentre eles, o autor destaca que os órgãos diretamente ligados ao governo japonês e às companhias de emigração tiveram uma participação fundamental no

\footnotetext{
46 Trata-se das publicações Brasil Nenkan, da empresa jornalística Brasil Jihô e Zaihaku Nihon Ishokumin Nijyûgonen Kinenkan, da empresa jornalística Seishû Shinpo.
} 
processo de ocupação dos arredores da Rua Conde de Sarzedas. Essa afirmação é corroborada pelo livro da Comissão dos 80 anos da imigração japonesa no Brasil:

Outras causas, além das já referidas, contribuíram para incrementar o número de moradores nipônicos na cidade de São Paulo: a instalação, em 1916, do Consulado Geral do Japão, do escritório da Cooperativa de Emigração (em 1917 reorganizada como Kaigai Kogyo Kabushiki Kaisha). Um pouco mais tarde, em 1929, abrem-se os escritórios da Casa Tozan e da Bratac. Em 1933 instalam-se a Casa Bancária Tozan e outras empresas. (COMISSÃO, 1992, p.227)

Sobretudo, Handa nos fornece pistas para compreender que essa ocupação urbana não pode ser dissociada de processos de diferenciação social. Nas palavras do autor:

A distinção entre classes sociais na comunidade japonesa da cidade de São Paulo surgiu após a instalação do Consulado Geral e do escritório da Imin Kumiai (União das Companhias de Emigração para o Brasil). O Consulado instalou-se em setembro de 1914 e a União das Companhias de Emigrações para o Brasil, em 1916, com sede em São Paulo. (COMISSÃO, 1992, p.165)

Ou seja, embora fosse um universo bastante particular, restrito ao grupo imigrante, o ambiente denominado "intelectual" que ali se formou na década de 1930 expressava uma nova forma distinta e eminentemente urbana de diferenciação social, conduzida por uma fração desses imigrantes. Ainda que fosse possível distinguir processos de intenções subjetivas, o fato é que esse pequeno grupo composto pelos funcionários do Consulado Geral do Japão e a União das Companhias de Emigrações se singularizou em razão de suas credenciais profissionais e de seus hábitos.

Se desejarmos ir além das considerações de Handa, devemos considerar que a estrutura de organização social do grupo imigrante deve ser entendida em relação às propriedades que definem as diferentes posições dos indivíduos. O próprio termo "colarinhos-brancos" empregado pelo autor indica a existência de um segmento 
profissional alheio ao trabalho manual, principal atividade realizada por japoneses à época. Não obstante, certos códigos e valores que regem a prática social passaram a definir mais claramente os universos de pertencimento e de reconhecimento dos diferentes estratos, o que nos permite revelar a posição dos indivíduos nessa estrutura.

No tópico seguinte veremos quais foram os desdobramentos desse processo de diferenciação para os jovens estudantes filhos de japoneses. Por ora, se considerarmos procedente a afirmação de Handa a respeito da instalação do Consulado em São Paulo e a sua contribuição para uma nova configuração para as relações intragrupo, é importante nos determos nesse assunto, pois foi o Consulado quem procurou estimular a criação de cooperativas agrícolas entre os imigrantes.

O relato de Tomoo Handa a respeito da instalação das dependências do Consulado na cidade de São Paulo em setembro de 1914 exemplifica algumas formas de distinção que claramente demarcavam a distância social existente entre estratos superiores e o restante dos imigrantes japoneses:

Antes de se transferir para a cidade de São Paulo, o Consulado Geral do Japão funcionava nas dependências da delegação japonesa no Rio de Janeiro. No início o ministro acumulava o cargo de cônsul geral, mas a partir de 1913 o $1^{\circ}$ secretário foi quem passou a acumular essa função. Por essa época, Takeo Goto e elementos ligados à Companhia de Emigração se reuniram e deliberaram que "como o Estado de São Paulo já conta com mais de 10.000 habitantes compatriotas, é de absoluta necessidade que aqui seja instalado o consulado". Este pedido, encaminhado ao Ministério das Relações Exteriores do Japão, foi aceito, e, no ano seguinte, em $1^{\circ}$ de setembro de 1914 , foi enviado Sadao Matsumura, que acumulava os cargos de secretário e de cônsul geral. E assim, o cônsul geral Matsumura veio tomar posse no cargo de chefe do Escritório Consular em São Paulo.

Ao tempo desse escritório, o consulado geral ficava na Rua Augusta $n^{\circ}$ 279 (hoje pensando, era um ponto mais ou menos equidistante da cidade e da avenida Paulista). Um sobrado cuja parte inferior era usada para escritório e a superior para residência. Os móveis tinham sido adquiridos por Takeo Goto em leilão. Logo mais, foi oficialmente transferido para São Paulo, tornando-se o consulado geral do Império, com jurisdição sobre todo o território brasileiro. Depois o consulado geral foi transferido para o largo da Sé (hoje o local ficaria bem em frente à Catedral da Sé). Talvez por ser o único prédio novo, ficava um pouco recuado em relação aos demais. Na sua fachada, que dava para o largo, passou-se a hastear a bandeira japonesa e a exibir o brasão imperial de crisântemo. A residência oficial também foi transferida da rua Augusta para a avenida Paulista, ao lado do Hospital Santa Catarina. Também os móveis foram substituídos por novos, encomendados 
ao Liceu de Artes e Ofícios (a mais antiga escola profissionalizante de São Paulo). (HANDA, 1987, p.166-167)

Dessa longa citação, é possível afirmar, em primeiro lugar, que a transferência das dependências do Consulado do Rio de Janeiro para a cidade de São Paulo ocorreu de forma concomitante à ocupação da região central da cidade pelos imigrantes japoneses. Segundo, a posição dos indivíduos citados e os seus hábitos nos permitem observar que Handa está se referindo, de fato, a japoneses que aqui cumpriam compromissos profissionais diplomáticos ou mesmo se dedicavam às atividades empresariais. O fato de Takeo Goto ter encomendado móveis ao Liceu de Artes e Ofícios para decorar o escritório consular revela que suas credenciais não eram as mesmas da grande maioria dos japoneses, uma vez que o Liceu era uma das mais tradicionais e prestigiadas oficinas profissionais da cidade.

Takeo Goto foi um dos primeiros representantes comerciais de empresas japonesas no Brasil. Havia chegado em solo nacional em 1906, antes mesmo do início oficial da imigração japonesa, com a função de gerir uma das filiais das casas comerciais Fujisaki, pertencentes ao empresário Sakurosuke Fujisaki. Posteriormente passou a dirigir a matriz comercial, no Rio de Janeiro, posto que assumiu até 1926. Após o fechamento das lojas Fujisaki, Goto se tornou subgerente da Fazenda Tozan (COMISSÃO, 1992, p.346) e, a partir de 1935, passou a produzir saquê no município de Campinas. Tratava-se, portanto, de um homem de negócios.

Ademais, podemos observar na citação anterior que Goto possuía estreitas relações com a diplomacia japonesa, a ponto de influir em certas decisões minimamente estratégicas. De fato, é curioso observar que antes da instalação do escritório do Consulado em São Paulo, as Casas Fujisaki também atendiam certas demandas alheias à atividade propriamente comercial: "Nos primeiros anos da imigração japonesa no Brasil, as atividades das Casas Fujisaki não se restringiam ao âmbito comercial, mas apliavam-se para atender, nos mais variados aspectos, aos primeiros imigrantes. Assim, passou a atuar como "consulado informal do Japão" no Brasil”47.

\footnotetext{
${ }^{47}$ Informações presentes na publicação "Museu Histórico da Imigração Japonesa no Brasil", 2008, p.57.
} 
Sobretudo, o aspecto do relato de Handa que considero central é a afirmação de que a presença crescente dos "colarinhos-brancos" naquele espaço de sociabilidade japonesa dos arredores da Rua Conde de Sarzedas está atrelada a um "processo de diferenciação social". Um exemplo concreto disso é a fundação do Nippon Club, que congregava a "intelectualidade" japonesa da época, mas que, segundo o autor, excluiu os imigrantes que habitavam a parte baixa da cidade.

Relata a História dos 40 anos: "Nesta época foi organizado o Nippon Club (Clube Japonês) pelos chamados intelectuais da parte alta de São Paulo (região alta da Conde de Sarzedas), os quais convidaram a elite intelectual do interior a ingressar na associação". Mas, conforme relato de Takeo Goto, foi graças à iniciativa do cônsul geral Matsumura que na noite de Natal de 1914 teve lugar a cerimônia de fundação do Nippon Club na residência dos Goto, na rua Frei Caneca. Conforme a mesma História dos 40 anos, foram excluídos do evento os imigrantes da parte baixa da cidade. Entretanto, o clube só começa a consolidar-se como local de reuniões sociais depois do surgimento da União das Companhias de Emigração para o Brasil. (HANDA, p.165-166)

É possível observar nessa citação que a iniciativa da criação do Nippon Club veio diretamente do primeiro Cônsul Geral do Japão em São Paulo, Sadao Matsumura, sendo que a oficialização de sua fundação ocorreu na casa da família Goto, na noite de natal de 1914. É curioso observar a característica excludente de sua fundação, uma vez que foi organizado pela "intelectualidade" dos japoneses em São Paulo, tendo a "elite intelectual" do interior sido convidada a participar do clube. Possivelmente, essa característica foi se transformando ao longo do tempo, de forma que o clube se tornou mais receptivo ao público em geral. 
Figura 3 - Takeo Goto, diretor da matriz das Casas Fujisaki no Rio de Janeiro e sua esposa (à direita) e Seishiro Kumasaka, diretor da filial em São Paulo e sua esposa (centro).

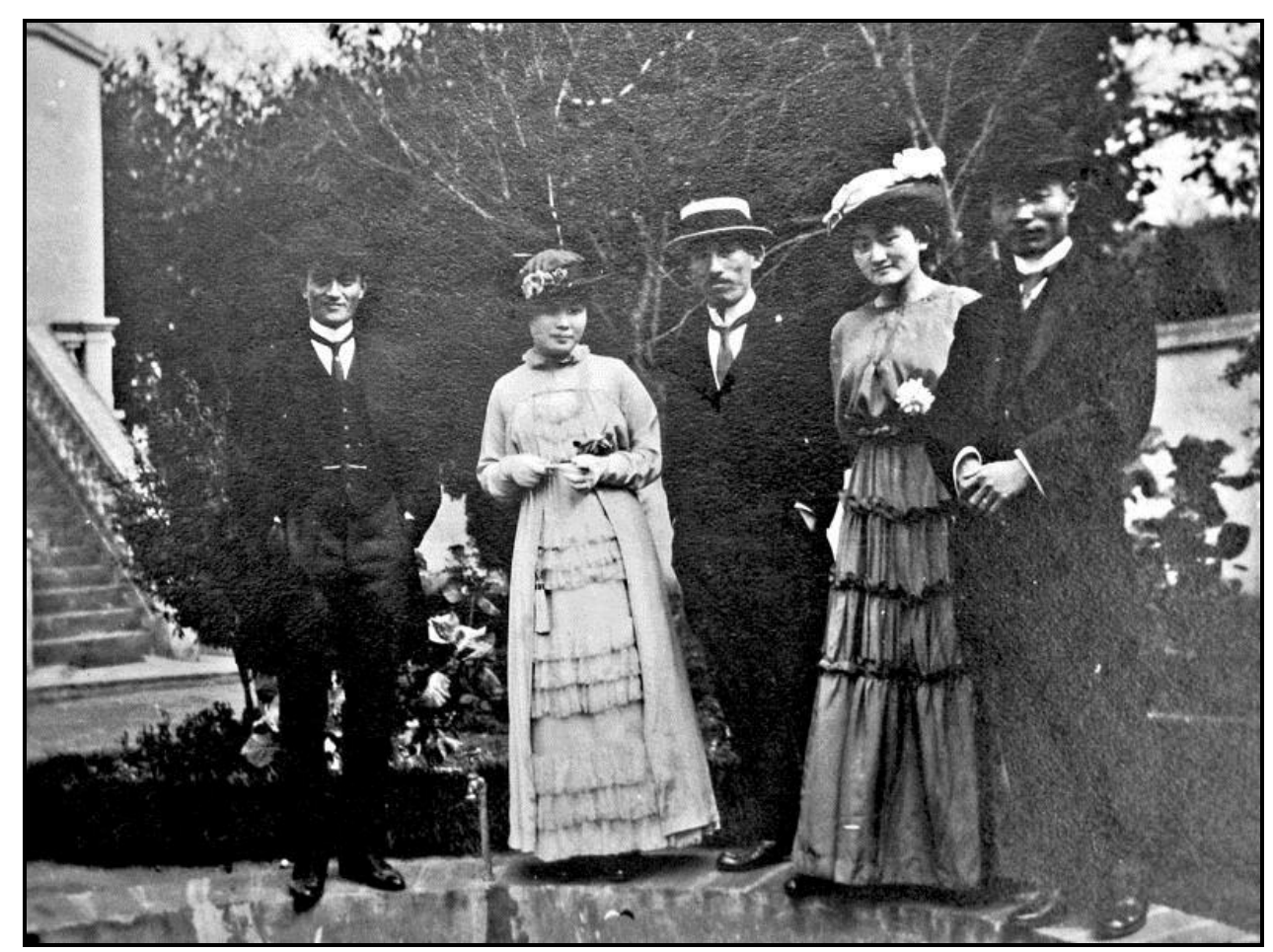

Fonte: Museu Histórico da Imigração Japonesa no Brasil.

Ademais, o relato desse acontecimento é um primeiro indício de que a atuação do Consulado ultrapassava as funções propriamente diplomáticas, estendendo-se ao universo de reprodução da vida dos imigrantes da época, especialmente aqueles que residiam na capital. Ainda assim, até os dias atuais praticamente inexistem pesquisas dedicadas a investigar a participação do Consulado do Japão em São Paulo nesse contexto urbano da experiência migratória.

No decorrer desta pesquisa, pudemos identificar a participação efetiva do Consulado em ao menos seis diferentes tipos de atividades diretamente voltadas à população de origem japonesa em São Paulo entre 1914 e 1938. São elas: as atividades culturais e esportivas realizadas no Nippon Club; a publicação do jornal Brasil Jihô; as atividades assistenciais e médicas promovidas pela Dojinkai (Sociedade Japonesa de 
Beneficência no Brasil); as atividades de educação e ensino, promovidas pela Escola Primária Taisho; a criação do órgão administrativo Cooperativa Central Agrícola NipoBrasileira e os subsídios oferecidos à criação de cooperativas agrícolas.

Vejamos a seguir uma breve descrição das instituições que, ao menos até a década de 1930, em maior ou menor grau, estiveram sob influência do Consulado Geral do Japão em São Paulo, ainda que outras instituições criadas e geridas por imigrantes japoneses possam ter existido durante o mesmo período ${ }^{48}$. Comecemos pela última delas, a que mais diretamente interessa a esta pesquisa, a Cooperativa Central Agrícola Nipo-Brasileira. Tratou-se de um órgão fundado em 1934 e que centralizava as atividades das primeiras cooperativas agrícolas de japoneses, entre elas a $\mathrm{CAC}^{49}$. As suas atividades tinham caráter administrativo, funcionando no escritório do Consulado Geral do Japão em São Paulo. Basicamente, essa cooperativa procurava representar as cooperativas agrícolas de origem japonesa, especialmente no que diz respeito a assuntos jurídicos, tributários e legais ${ }^{50}$. Por meio desse órgão centralizador é que foi organizada a Sanseiren Undo, uma organização que propunha estimular a participação de jovens no cooperativismo. Entre os principais entusiastas desse movimento estiveram Kenkiti Simomoto (TOYAMA, 2009).

O Nippon Club, já mencionado anteriormente, pode ser caracterizado como um espaço de convivência social e cultural, sob influência direta do Consulado e das

\footnotetext{
${ }^{48}$ Podemos citar, por exemplo, a Kyuyo Kyokai, a Associação Okinawa associação foi fundada em 22 de agosto de 1926, em São Paulo, com a denominação de Zen-Haku Kyuyo Kyokai, presidida por Sukenari Onaga. A associação também estimulava os filhos de imigrantes a estudar, oferecendo-lhes financiamento.

49 "Em 1934, quando o surto de cooperativismo começa a impressionar observadores, o cônsul-geral Iwataro Uchiyama promoveu uma reunião de "Executivos das Cooperativas Agrícolas Japonesas do Brasil". Dessa reunião originou-se a organização da Cooperativa Central Agrícola Nipo-Brasileira! Essa entidade prestou relevantes serviços como órgão de orientação e ligação das numerosas cooperativas rurais de nipônicos então formadas em muitas regiões do país. No momento da criação da Cooperativa Central, dela participaram 16 cooperativas. Esse número aumentou para 20 em 1939. Então havia em média 356 cooperados por cooperativa filiada. A CAC já contava 1.620 associados, desenvolvendo-se como uma organização econômica atuante não só numa localidade, mas abrangendo muitas, em diversas regiões. Durante a guerra (março de 1942), a Cooperativa Central Agrícola Nipo-Brasileira mudou o seu nome para Cooperativa Agrícola Central de São Paulo". (COMISSÃO, 1992, p.222)

50 Podemos mencionar documentos que atestam a sua atuação em nome da CAC, a exemplo do Certificado n. 6, de 30 de agosto de 1939, Carta de Registro n. 69-1/9/39, relativo à aquisição e à finalidade de terrenos para produção agrícola. Fonte: Centro de Documentação do Instituto de Cooperativismo e Associativismo, Secretaria da Agricultura do Estado de São Paulo.
} 
orientações governamentais japonesas. Ele foi criado em 1914 e há registros de que o clube organizava eventos esportivos, como campeonatos de beisebol (TOYAMA, 2009, p.179), possuía biblioteca e patrocinava exposições artísticas (HANDA, 1987, p.46). O Nippon Club operava, portanto, como uma instituição disseminadora da cultura japonesa, voltando-se em grande parte para o público imigrante da capital e também do interior. Foi nas dependências desse clube que em 1938, na Rua Riachuelo, onde ocorreu a primeira exposição do grupo Seibi, criado três anos antes. Trata-se do primeiro grupo de pintores vanguardistas de origem japonesa criado no Brasil ${ }^{51}$.

Ainda segundo Handa, o Nippon Club só teria se consolidado como um espaço de reuniões sociais após a instalação do escritório da União das Companhias de Emigração para o Brasil ${ }^{52}$, em 1917:

\begin{abstract}
Entretanto, o clube só começa a consolidar-se como local de reuniões sociais depois do surgimento da União das Companhias de Emigração para o Brasil e, ainda, depois que o primeiro navio de imigrantes fretado por ela chegou no porto de Santos, em junho de 1917, trazendo 1.300 emigrantes, ocasião em que também passou a circular o jornal Brasil Jiho (Notícias do Brasil), como veículo de educação da União das Companhias de Emigração para o Brasil. (HANDA, 1987, p. 166)
\end{abstract}

Novamente, as considerações do autor nos ajudam a interpretar os acontecimentos explorando a dimensão mais cotidiana do universo de sociabilidade dos japoneses na capital. Elas nos fornecem subsídios para confirmar que a instalação da Companhia de Fomento Industrial no Ultramar na cidade de São Paulo trouxe novas características para a organização social dos imigrantes na capital. Entre outros aspectos, observa-se, na citação, que o Nippon Club passou a se configurar como um ambiente de reuniões sociais da coletividade japonesa local e, possivelmente, os “colarinhos-brancos" encabeçavam o público que o frequentava e ali participava de

\footnotetext{
${ }^{51}$ Para mais informações, ver : MENEZES, P. Grupo Seibi - O Nascimento da Pintura Nipo Brasileira. Revista USP, São Paulo, v. 27, p. 102-115, 1995.

${ }^{52}$ Sobre o assunto ver NOGUEIRA, A.R. Companhias interessadas na introdução de asiáticos em São Paulo nos primeiros anos da República. São Paulo: Centro de Estudos Nipo-Brasileiros, 1979.
} 
forma ativa. Nesse sentido, há registros de que o próprio Consulado utilizava as dependências do clube para confraternizações ${ }^{53}$.

Mais adiante em seu texto, Handa informa que a instalação da Cooperativa de Emigração também veio acompanhada de um novo veículo de comunicação, o Burajiru Jihô (Notícias do Brasil), que passou a ser publicado em agosto de 1917, um ano após a criação do primeiro periódico japonês no Brasil, o semanário Nanbei.

Os jornais certamente merecem uma atenção especial na tentativa de compreender o contexto da década de 1930 da região da Rua Conde de Sarzedas e, de forma mais ampla, o circuito de atividades dos japoneses que residiam na cidade de São Paulo. Praticamente todos eles eram publicados em japonês, característica que progressivamente passou a entrar em conflito com as medidas cada vez mais restritivas do governo varguista. Contudo, até o final dos anos de 1930 eles representavam as principais fontes impressas de informação dos imigrantes, fato que pode ser reforçado pela seguinte afirmação: "Já em 1933, o Nippak e o Jihô, os dois rivais e maiores jornais, contavam cada um com mais de 60 funcionários distribuídos pela redação, fotogravura, impressão, administração, expedição, etc. Em 1940 cada empresa havia se expandido até 300 empregados" (COMISSÃO, 1992, p.235). Estima-se que para aquele ano de 1933 o Nippak Shinbun possuía uma tiragem de 19.500 exemplares, e o Burajiru Jiho, de 17 mil (COMISSÃO, 1992, p. 232). No caso do Brasil Jihô, a influência dos órgãos governamentais japoneses era percebida claramente pelo público leitor, a ponto de ser considerado um veículo de comunicação "do governo" japonês na cidade de São Paulo:

Era um semanário que saía às sextas-feiras e que passou a fazer concorrência ao jornal Nippak Shimbun, já existente há algum tempo. E, assim, passou-se a ter, de um lado, um veículo representativo do "governo" e, de outro, um representativo do "povo". (HANDA, 1987, p.167)

\footnotetext{
${ }^{53}$ Uma evidência disso pode ser obtida no prontuário DOPS/33.869, que passou a intervir na entidade, registrando as suas atividades. Em fevereiro de 1940 o Cônsul Geral do Japão em São Paulo Yodogawa solicitou ao delegado do DOPS autorização para comemorar o $25^{\circ}$ centenário da fundação do Império do Japão. Vale ressaltar que, sob intervenção policial, em abril de 1940 foi realizada uma reunião extraordinária presidida por Senichi Hachiya e Massao Kinoshita para mudar o nome do clube, nacionalizar a entidade e nomear diretores brasileiros. Dessa forma, o clube passou a ser presidido por José Amaral Vieira. Fonte: Arquivo Público do Estado de São Paulo.
} 
A análise da imprensa imigrante japonesa no Brasil talvez necessite de um estudo inteiramente dedicado a esse assunto, uma vez que a sua história mostra-se extremamente rica e complexa, e no espaço desta pesquisa, dificilmente poderíamos nos debruçar sobre ela de forma adequada. Atemo-nos a alguns aspectos que nos parecem centrais: o fato de que a imprensa imigrante japonesa colaborou para a disseminação de informações na coletividade, permitiu a multiplicação dos trabalhadores ocupados em profissões liberais (a chamada "intelectualidade da colônia"), e possibilitou também a existência de um debate público que expunha os diversos grupos portadores de pontos de vista variados - quando não conflitantes - sobre as questões candentes aos imigrantes japoneses.

Em relação às atividades assistenciais e médicas que foram criadas com o apoio consular, deve-se considerar que, principalmente no interior do estado de São Paulo, muitos imigrantes eram carentes de assistência médico-hospitalar e doenças como a malária, tracoma, leishmaniose e ancilostomíase eram bastante comuns entre os japoneses. Na busca por melhorar essas condições, em outubro de 1926, foi criada a Zai Burajiru Nihonjin Dojinkai (Sociedade Japonesa de Beneficência no Brasil), ou simplesmente Dojinkai, por iniciativa de médicos japoneses, contando com o apoio do Cônsul Geral do Japão ${ }^{54}$. Conta, ainda, que o então embaixador do Japão no Brasil, Akira Arioshi, também logo se tornou sócio da entidade ${ }^{55}$. Em 1931, a sede da Dojinkai se mudou para a Rua Galvão Bueno, ano em que o Cônsul Geral Iwataro Uchiyama tomou a iniciativa de organizar uma comissão com o objetivo de construir um hospital japonês em São Paulo. No dia 18 de junho de 1933, data em que se celebrava os 25 anos da imigração nipônica no Brasil, foi lançada a pedra fundamental do hospital, que a

54 Sumariamente, as atividades da Dojinkai eram definidas da seguinte forma: divulgação de noções higiênicas; trabalhos relativos a cobras venenosas; campanha profilática contra a febre tifóide; vacina contra a varíola; combate ao tracoma; assistência médica e conferências populares sobre higiene rural; estudo sabre a profilaxia prática contra a malária; consultório por correspondência sobre higiene; consultório médico gratuito; Instruções higiênicas aos imigrantes recém-chegados; publicações diversas sobre a profilaxia prática, curativos e tratamento; construção de hospitais. Ver Brasil e Japão - Duas civilizações que se completam, 1934, p.83.

55 Informações disponíveis em: <http://www.asiacomentada.com.br/2010/06/imigracao-japonesa-nobrasil-e-medicina-preventiva/>. Acesso em: ago. 2013. 
partir de 1939 passou a se chamar Sociedade de Beneficência Santa Cruz (HANDA, 1987, p.216).

Entre os órgãos de ensino existentes na região central da cidade durante a década de 1930, a Escola Primária Taisho possui destaque. Ela foi criada ainda na década de 1910 e estivera localizada na Rua Conde de Sarzedas. A escola era dirigida pelo professor Shinzo Miyazaki, falecido em 1924, e também morador da Rua Conde de Sarzedas. De acordo com informações do livro da Comissão dos 80 anos da imigração japonesa no Brasil, a escola teria sido o primeiro estabelecimento de ensino criado e gerido por imigrantes japoneses:

Está geralmente aceito entre os japoneses que foi a Escola Taisho, instalada em julho de 1915, na rua Conde de Sarzedas, 38, São Paulo, o primeiro estabelecimento de ensino criado e mantido por imigrantes nipônicos no Brasil. Existe, é verdade, a versão de que um jovem chamado Jinshiro Tagashira ensinara a língua japonesa de grau elementar por volta de 1914-15, na mesma rua Conde de Sarzedas. Consta mesmo que a Escola Taisho teria continuado o trabalho do jovem professor. O responsável pela Escola Taisho foi Shinzo Miyazaki, havendo mais alguns nomes entre os organizadores. (COMISSÃO, 1992, p.123)

Em linhas gerais, as entidades mencionadas refletem um processo de institucionalização da tutela governamental à população japonesa da cidade pelas mãos do Consulado Geral do Japão em São Paulo. Em partes, essa postura ativa pode ser compreendida em relação à crescente entrada de imigrantes japoneses no país, o que possivelmente demandou uma ampliação do seu escopo de atuação: entre 1921 e 1940 o governo japonês se tornou responsável por financiar a vinda desses imigrantes por meio do Kaigai Kogyo, órgão executivo de emigração criado em $1917^{56}$. Nesse período, esse órgão encaminhou cerca de 164.000 japoneses ao Brasil, configurando o auge da entrada de japoneses no país, em sua maioria em direção ao estado de São Paulo.

\footnotetext{
${ }^{56}$ Para mais informações, ver NOGUEIRA, A.R. A imigração japonesa para a lavoura cafeeira paulista (1908-1922). São Paulo: IEB, 1973.
} 
Os motivos que levaram à criação de cada uma dessas entidades não serão explorados em detalhes, havendo poucas dúvidas de que essa nova forma de atuação consular trouxe certos benefícios à população japonesa e causou impacto direto em seu cotidiano. A assistência médico-hospitalar era uma necessidade básica dos imigrantes e muitas epidemias se alastravam principalmente pelas áreas rurais do interior do estado, bem como a adaptação ao ambiente cultural distinto era facilitado pela instalação de escolas e veículos de comunicação em língua do país de origem. Mas, talvez de forma menos usual, procuro compreender essas novas iniciativas de atuação consular relacionando-as ao processo mais amplo de diferenciação social anteriormente anunciado.

Essa contextualização caracteriza, dentro de alguns limites, a conformação social da população japonesa na cidade de São Paulo, considerando a presença efetiva de órgãos ligados ao governo japonês, especialmente do Consulado Geral do Japão. Foi argumentado que este último particularizou as formas de organização do grupo ao fortalecer um processo de diferenciação social interno à população de imigrantes japoneses. Acrescenta-se a isso o fato de que o Consulado procurou incentivar a criação de cooperativas agrícolas, bem como ofereceu suporte ao seu auxílio administrativo. $\mathrm{O}$ tópico seguinte é dedicado a demonstrar de que formas a CAC esteve relacionada a esse circuito social, tendo posteriormente assegurado uma posição de reconhecimento restrito à população japonesa, ainda sem contar, contudo, com representações e laços no âmbito político nacional que pudessem influenciar de maneira significativa a sua atuação no mercado.

\subsection{A fundação da CAC e seu respaldo institucional}

As primeiras famílias de imigrantes japoneses chegaram ao município de Cotia em 1914, por sugestão de Teijiro Suzuki, um dos primeiros desbravadores daquelas 
terras $^{57}$. A principal atividade pretendida pelas cerca de 30 famílias que ali habitavam em $1915^{58}$ era o cultivo de batatas, visando à sua venda no mercado de Pinheiros, pois eram famílias que já haviam saído da condição de colonos em plantações de café e buscaram explorar pequenas lavouras arrendadas ao redor da capital paulista. Em sua maioria, os imigrantes que ali se estabeleceram haviam deixado o sistema de colonato, especificamente da Fazenda Guatapará ${ }^{59}$, bem como eram originários da mesma localidade no Japão, a província de Kochi, fato esse que facilitava a organização coletiva sob vários aspectos ${ }^{60}$.

O reconhecimento da origem comum teria facilitado, por exemplo, a criação da Associação da Comunidade Japonesa de Cotia em 1916 ${ }^{61}$. Tratava-se de uma entidade associativa que visava promover o desenvolvimento de técnicas agrícolas e prover educação aos filhos dos lavradores. Como desdobramento da associação, foi criada uma

57 "Os primeiros japoneses que entraram na região de Cotia foram um grupo de solteiros chefiados pelo T.Suzuki. Foram: Kayano, Koobara, Itami, Takakuwa (...) Isso em 1914. Esse grupo tinha entrado, primeiramente, na zona de Araçariguama, tendo se dedicado à cultura de milho feijão etc. Fracassados, retornaram em S.Paulo. Achando-se desempregados, conheceram fortuitamente o vigário da paróquia de Cotia, o que convidou-os para trabalharem na sua propriedade. Prometeu também que os financiaria. Aceitaram a oferta incontinenti, e foram se estabelecer num local distante algumas centenas de metros da atual Escola de Cotia. Levantaram uma choupana e plantaram batata e a cebola, segundo a informação do sr. Kayano" (Depoimento de Kenkiti Simomoto, sem data). Tradução de Hiroshi Saito. Fonte: Arquivo Hiroshi Saito.

58 "Assim, dos fins de 1915 até princípios de 1916, cerca de trinta famílias se estabeleceram na região de Cotia, todas na propriedade do vigário. Eram três "turmas": de Guatapará com 16 ou 17 famílias; de Pirajú com 5 famílias; da cidade com cerca de dez famílias" (Depoimento de Kenkiti Simomoto, sem data). Tradução de Hiroshi Saito. Fonte: Arquivo Hiroshi Saito.

${ }^{59}$ Segundo o pintor e memorialista Tomoo Handa: "Fazenda Guatapará, na Estação Guatapará da linha Paulista: Esta estação localizava-se na linha Paulista que ligava Ribeirão Preto a Araraquara, tendo o mesmo nome da fazenda. Esta, por sua vez, era uma empresa coletiva formada por sete sócios, dentre os quais um exercia a presidência. Dentro da fazenda corria uma linha de estrada de ferro destinada ao transporte de café. Era uma grande fazenda, com área de 9.000 alqueires, e tendo 1.800 .000 pés de café plantados. Nela adentrou Umpei Hirano, "dotado de extraordinário poder de liderança", conduzindo os 88 componentes das 23 famílias das províncias de Kagoshima, Kochi e Niigata". (HANDA, 1987, p.20-21).

${ }^{60}$ Segundo Kumaki Nakao, lavrador de Cotia e comerciante "Entre 1923 e 1925, o segundo grupo da "turma Guatapará" mudou-se a Cotia. Todos eram de Kochi, tendo como chefe o sr. Hirota. Com esse grupo, as famílias japonesas que se mudaram da Fazenda Guatapará a Cotia somam-se mais de trinta famílias, na sua maioria de Kochi". (Depoimento de Kumaki Nakao, 9 de maio de 1954). Fonte: Arquivo Hiroshi Saito.

${ }^{61} \mathrm{O}$ relato de Kenkiti Simomoto a respeito da criação da Associação Japonesa, revela o primeiro registro do contato com as autoridades consulares: "Meses mais tarde (da inauguração da sede), os japoneses receberam, orgulhosos, a visita oficial do então cônsul-geral sr. Matsumura e do cônsul Tarama, que se mostraram muito impressionados com o aspecto do casebre e, no entanto, não deixaram de proferir algumas palavras de estímulo aos japoneses". (Depoimento de Kenkiti Simomoto, 03 de setembro de 1953). Tradução de Hiroshi Saito. Fonte: Arquivo Hiroshi Saito. 
escola primária no mesmo ano, o que representou a configuração de um espaço local de convívio. Entre os membros da associação estavam Masuji Yano e Kenkiti Simomoto, os primeiros diretores da CAC (CAC, 1988). Essas foram as primeiras iniciativas coletivas de organização, que precederam a criação da Cooperativa.

A sua fundação havia sido antecedida por outras duas tentativas fracassadas de organização associativa visando à comercialização de batatas: a primeira em 1918, sob comando de Masuji Yano, e outra em 1924, sob iniciativa de Shigeru Takebe, ambos lavradores e lideranças locais. A primeira iniciativa foi motivada pelo consenso de que a aquisição de um depósito próprio dos japoneses de Cotia no mercado de Pinheiros era uma necessidade. Contudo, apesar de ter sido formalizada, essa iniciativa não chegou a se concretizar em virtude das intempéries climáticas que atingiram as lavouras de batata em $1918^{62}$. Centremos nossa atenção na segunda iniciativa que, apesar de também não ter alcançado sucesso, foi a primeira que contou com o suporte financeiro do Consulado Geral do Japão e obteve repercussão em jornais que circulavam entre a população japonesa, na capital e no interior do estado de São Paulo, como o Nippak Shimbun e Brasil Jihô (Notícias do Brasil), já mencionados neste tópico.

Como a produção de batatas em Cotia já havia alcançado um volume representativo, o então presidente da Associação da Comunidade Japonesa, Shigeru Takebe, propôs a criação de uma cooperativa agrícola. O jornal Brasil Jihô (Notícias do Brasil) em 20 de junho de 1924 assim noticiou o acontecimento:

Na Colônia de Cotia, muito conhecida pela sua produção de batata, residem atualmente umas cem famílias de japoneses. No passado houve algumas vozes isoladas preconizando a organização de uma cooperativa; no entanto, não chegou a organizar-se devido à imaturidade do assunto. Com a eleição da nova diretoria da Associação de Japoneses, realizada no mês passado, graças a intensos

\footnotetext{
${ }^{62}$ Segundo Kenkiti Simomoto: "Há cerca de dez anos foi ouvida a primeira voz para organizar uma cooperativa em Cotia. Os principais motivos da campanha eram: a necessidade de uma "Limpeza" de negociantes sem escrúpulos do mercado de Pinheiros, então único escoadouro par os bataticultores de Cotia, e a construção de um depósito pela cooperativa para regularizar o transporte precário [...] Lamentável é que, numa ocasião tão importante, sobreveio a grande geada de 1918 e ante a previsão de graves prejuízos de lavoura, os esforços daqueles esclarecidos redundaram em vão". "Passado, presente e futuro da Cooperativa Agrícola de Cotia" - Revista Cotia, n. 1, setembro de 1928, p.9. Fonte: Arquivo Hiroshi Saito.
} 
esforços desenvolvidos nesse sentido pelos presidente e vice-presidente, viu a concretizar essa ideia feliz. (Tradução de Hiroshi Saito. Fonte: Arquivo Hiroshi Saito)

A iniciativa de Takebe demandou uma intensa campanha para o convencimento das mais de 100 famílias locais, além de reuniões com o Cônsul Geral do Japão em São Paulo, de forma a solicitar financiamento para a aquisição do ambicionado depósito no mercado de Pinheiros. Em seu diário, Takebe expôs as suas expectativas, frustrações e inseguranças a respeito da empreitada, bem como detalha reuniões no Consulado e os empréstimos a ele concedidos ${ }^{63}$. A primeira reunião da "Cooperativa de Produção de Cotia, de responsabilidade limitada", sob inciativa de Takebe, ocorreu em 20 de junho de 1924, ocasião em que fora apresentado o seu estatuto ${ }^{64}$.

Os documentos analisados referentes às iniciativas de criação de cooperativas agrícolas em Cotia indicam a existência de ao menos dois fatos importantes para esta pesquisa: a legitimidade de lideranças japonesas em Cotia era um bem disputado pois, personificar uma liderança na coletividade local era um símbolo de status que indicava posições sociais; a presença ativa do Consulado Geral do Japão se fazia valer, principalmente pelas possibilidades de financiamento às iniciativas cooperativistas. É a partir da abrangência da atuação do Consulado, agora incluindo as cooperativas, que lavradores japoneses passaram a se relacionar mais diretamente com esse órgão.

A cooperativa de Takebe não obteve o sucesso esperado, e muitas são as narrativas que oferecem explicações ao acontecimento. Algumas versam a respeito da falta de prestígio do seu entusiasta ${ }^{65}$, outras afirmam a respeito da falta de adesão da

\footnotetext{
63 "Certificado de dívida. Importância: 5 contos de réis em moeda brasileira. Firmamos o presente em sinal de nosso agradecimento pelo empréstimo concedido por parte de V.Excia, na importância acima referida, para fazermos face a difculdades na aquisição de mantimentos para sustento de lavradores japoneses desta localidade, dificuldade essas decorrentes do estado de revolução em que se encontra o país. Até o fim do mês de Novembro faremos a cabal restitução da importância ora financiada. Com agradecimento de todos os japoneses residentes, dia 25 de julho de 1924. Em nome da colônia de Cotia, Sr. Takebe, presidente, G.Kusaka, vice-presidente. Ao Excelentíssimo senhor Cônsul-Geral Kazu Saito". (Diário de Shigeru Takebe, 9 de julho de 1924. Tradução de Hiroshi Saito. Fonte: Arquivo Hiroshi Saito)

${ }^{64}$ Brasil Jihô (Notícias do Brasil), 20 de junho de 1924. Fonte: Arquivo Hiroshi Saito.

${ }^{65}$ Segundo Kumaki Nakao: "O fracasso da cooperativa de Takebe deve-se, talvez, à pouca confiança que seu mentor desfrutava no seio de japoneses. A eleição do sr. Takebe na presidência da Associação Japonesa não foi por confiança ou influência pessoal; era uma espécie de penalidade aplicada. Ele era um elemento que às vezes provocava distúrbios no seio da associação por seus atos egoístas, como aconteceu
} 
maioria dos cooperados. O relato do Sr. Kumaki Nakao, agricultor e comerciante em Cotia, nos traz indícios de que a dinâmica de legitimidade de lideranças naquele universo particular dependia, em grande medida, da reputação dos candidatos a líderes. A confiança depositada pelos pares em suas ações era um recurso central para o processo de legitimidade social local, e a sua ausência podia resultar em punições e ostracismo.

Centremos nossa atenção na versão de Kenkiti Simomoto acerca do episódio. À época, Simomoto era uma liderança da juventude local e, em $1927^{66}$, conduziu junto a outros companheiros uma nova campanha para fundar uma cooperativa, também sob os auspícios do Consulado ${ }^{67}$ :

\begin{abstract}
A primeira tentativa para organização da cooperativa partiu do sr. Takebe. Como presidente da Associação de Japoneses, ele esteve em constante contato com o Cônsul Geral K. Saito e soube por intermédio deste que o governo japonesa estava disposto a conceder auxílios financeiros para as colônias japonesas no Brasil. A organização de uma cooperativa era um pretexto para conseguir o auxílio. O sr. Takebe elaborou estatutos, escolheu os membros que iriam compor a diretoria e iniciou a campanha para subscrição de quotas. Não conseguiu a repercussão que esperava por vários motivos: ele era um dos maiores plantadores de batata mas não era visto pelos membros da comunidade como um homem capaz de dirigir a organização da cooperativa, nem honestidade e reputação para representar a coletividade. (Depoimento de Kenkiti Simomoto, 4 de setembro de 1953. Fonte: Arquivo Hiroshi Saito)
\end{abstract}

naquele caso de restrição das épocas de plantio". (Depoimento de Kumaki Nakao, fevereiro de 1954. Tradução de Hiroshi Saito). Fonte: Arquivo Hiroshi Saito.

${ }^{66}$ Alguns depoimentos revelam a posição de destaque que Kenkiti Simomoto ocupava entre as famílias japonesa da região de Cotia em fins da década de 1920, sendo um dos responsáveis pela organização das atividades da associação local: "Quando eu estava desanimado com a morte da filha, visitou-me o sr. Shimomoto, que era então encarregado de educação na associação de japoneses. Convidou-me para lecionar na escola mantida pela associação; aceitei o convite porque a minha família estava na iminência da fome. Comecei a lecionar a partir do mês de abril de 1927. Tinha 36 alunos, os quais falavam o dialeto de Kochi" (Depoimento de Tunemi, outubro de 1953. Fonte: Arquivo Hiroshi Saito).

67 "Convinha aproveitar a oportunidade oferecida pelo Consulado para realização das ideias que eu concebera no Japão. Consultei meus companheiros Nakao e Murakami, estavam de acordo com as minhas ideias. Logo iniciamos a elaboração de um plano para organizar a cooperativa, cujo primeiro passo consistia em apresentar o orçamento para a construção do depósito em moldes mais compreensíveis e realizáveis". (Depoimento de Kenkiti Simomoto, 4 de setembro de 1953. Tradução de Hiroshi Saito. Fonte: Arquivo Hiroshi Saito) 
Talvez seja irrelevante averiguar se o insucesso da iniciativa de Takebe se deveu ou não à sua capacidade de liderança. $\mathrm{O}$ que os dados nos informam é que a liderança local em Cotia era um bem disputado, e Kenkiti Simomoto havia participado dessa disputa a ponto de narrar sua versão sobre os acontecimentos que culminaram na criação de uma cooperativa que obteve sucesso.

Em 1925, um ano após o fracasso da iniciativa de Takebe, o Consulado Geral do Japão em São Paulo manifestava mais explicitamente o seu interesse em subsidiar iniciativas de cooperativas agrícolas, e Simomoto, que havia viajado ao Japão, tomou conhecimento dessas informações após retornar ao Brasil ${ }^{68}$. A capacidade de ingerência do Consulado no incentivo às associações agrícolas dos imigrantes japoneses no Brasil foi estimulada pelo governo japonês, que lhe repassava verbas voltadas a essa finalidade. Entre 1927 e 1931, o governo japonês por meio do Consulado Geral estimulou o cooperativismo, fornecendo financiamentos para esse tipo de atividade. Rinzo Aoki, engenheiro que ocupou o cargo de Cônsul Geral em 1930, foi um dos grandes entusiastas do cooperativismo e criador da Cooperativa Central Agrícola NipoBrasileira, mencionada anteriormente. Sob essa configuração, não é incorreto dizer que os princípios cooperativistas propostos pelos imigrantes foram, em grande parte, trazidos do Japão. Nas palavras de Kenkiti Simomoto:

Nessa época, o Ministério de Relações Exteriores do Japão estava decidido a
conceder o famoso "empréstimo de 85 " (o empréstimo de 850 mil yens a juros
baixos) ao sr. Uetsuka para salvar uma colônia por este iniciada na zona Noroeste.
A dificuldade residia em que não existia qualquer órgão responsável que servisse
de intermediário entre o vendedor e o credor O Governo Japonês incumbiu o
Banco Espécie Yokohama (The Specie Bank of Yokohama) para atuar como
credor. O Governador lembrou-se então de promover a organização de
cooperativas de crédito nas colônias japonesas no Brasil como órgãos
responsáveis pelo cumprimento das cláusulas dos contratos de empréstimos. É
que no Japão se fazia intensa campanha em prol das cooperativas de crédito por

68 "Durante a minha ausência de Cotia, pela viagem ao Japão, o Sr. Sack Miura, do Nippak Shimbun, visitou os japoneses da região para sondar as opiniões de principais membros da comunidade quanto à possibilidade da organização de uma cooperativa. É que o cônsul [Sukeyuki] Akamatsu incumbiu-o de realizar investigações para escolher uma colônia japonesa em que possa ser organizada a cooperativa mediante a concessão de subsídios por parte do consulado. De volta à Cotia, eu soube desses fatos e achei que a oportunidade era única". (Depoimento de Kenikiti Simomoto, fevereiro de 1954. Tradução de Hiroshi Saito. Fonte: Arquivo Hiroshi Saito) 
iniciativa do Ministério da Agricultura. (Depoimento de Kenkiti Simomoto, 4 de setembro de 1953. Fonte: Arquivo Hiroshi Saito)

E, dando prosseguimento à iniciativa de criar uma nova cooperativa em Cotia, agora contando possivelmente com um maior amparo financeiro do Consulado, a primeira Assembleia da iniciativa capitaneada por Simomoto foi realizada em 11 de outubro de 1927, tendo como programa a aprovação de estatutos e eleição da diretoria. A primeira diretoria foi assim constituída: Kenkiti Simomomo, Diretor-Presidente; Kumaki Nakao, Diretor-Gerente; Turuki Mori, Diretor-Tesoureiro; Masuji Yano, Hatuji Kiyazaki e Kameiti Yamashita, membros do Conselho Fiscal; Masaji Matuoka e Masayori Tikami, suplentes do mesmo Conselho. A proposta foi levada adiante pelos lavradores e, em 30 de janeiro de 1928, a diretoria da CAC registrou o recebimento do empréstimo oferecido pelo Consulado ${ }^{69}$, bem como assinaram o contrato para aquisição de um terreno no bairro de Pinheiros ${ }^{70}$, onde foi construído o primeiro depósito voltado ao abastecimento do mercado local. Os estatutos da Cooperativa foram registrados conforme a Lei de 10 de janeiro de 1928 na Junta Comercial da Capital, entrando em vigor por publicação no Diário Oficial.

Os documentos analisados indicam, portanto, que a fundação da CAC foi possível, em seu aspecto financeiro, mediante o apoio do governo japonês e do Consulado Geral do Japão. E, mais ainda, o estabelecimento dessa relação institucional não se limitou ao referido financiamento: entre a década de 1930 até o ano de 1942, quando foram rompidas as relações diplomáticas entre o governo brasileiro e o japonês no contexto da Segunda Guerra Mundial, a CAC estabeleceu forte relação com a Cooperativa Central Agrícola Nipo-Brasileira, pois esta última era um órgão

\footnotetext{
${ }^{69}$ Conforme relatado na Revista Cotia, n. 1, de setembro de 1928: "No mesmo dia, (30/01/1928) a diretoria recebeu do Consulado a quantia de 100:548\$000 como subvenção do governo japonês. Para garantir as cláusulas constantes dos Art. 3 e 9 da respectiva Ordem os diretores assinaram uma letra de câmbio de igual importância no ato do recebimento do dinheiro. Essa subvenção oficial deverá ser devolvida ao Governo se, dentro de 10 anos, a cooperativa fora dissolvida; após dez anos a importância será definitivamente incorporada ao patrimônio da cooperativa" (Tradução de Hiroshi Saito. Fonte: Acervo Hiroshi Saito).

70 "A 30 de janeiro de 1928, os diretores assinaram no contrato de compra e venda do terreno destinado ao depósito". (Revista Cotia, n.1, de setembro de 1928. Tradução de Hiroshi Saito. Fonte: Acervo Hiroshi Saito)
} 
administrativo com sede no Consulado, e que centralizava as atividades de maior parte das cooperativas agrícolas da população japonesa no estado de São Paulo ${ }^{71}$.

\section{Figura 4 - Kenkiti Simomoto (em primeiro plano, à esquerda), seu irmão Ryotaro e sua esposa (à direita e ao centro) em Moinho Velho (atual município de Cotia), década de 1920.}

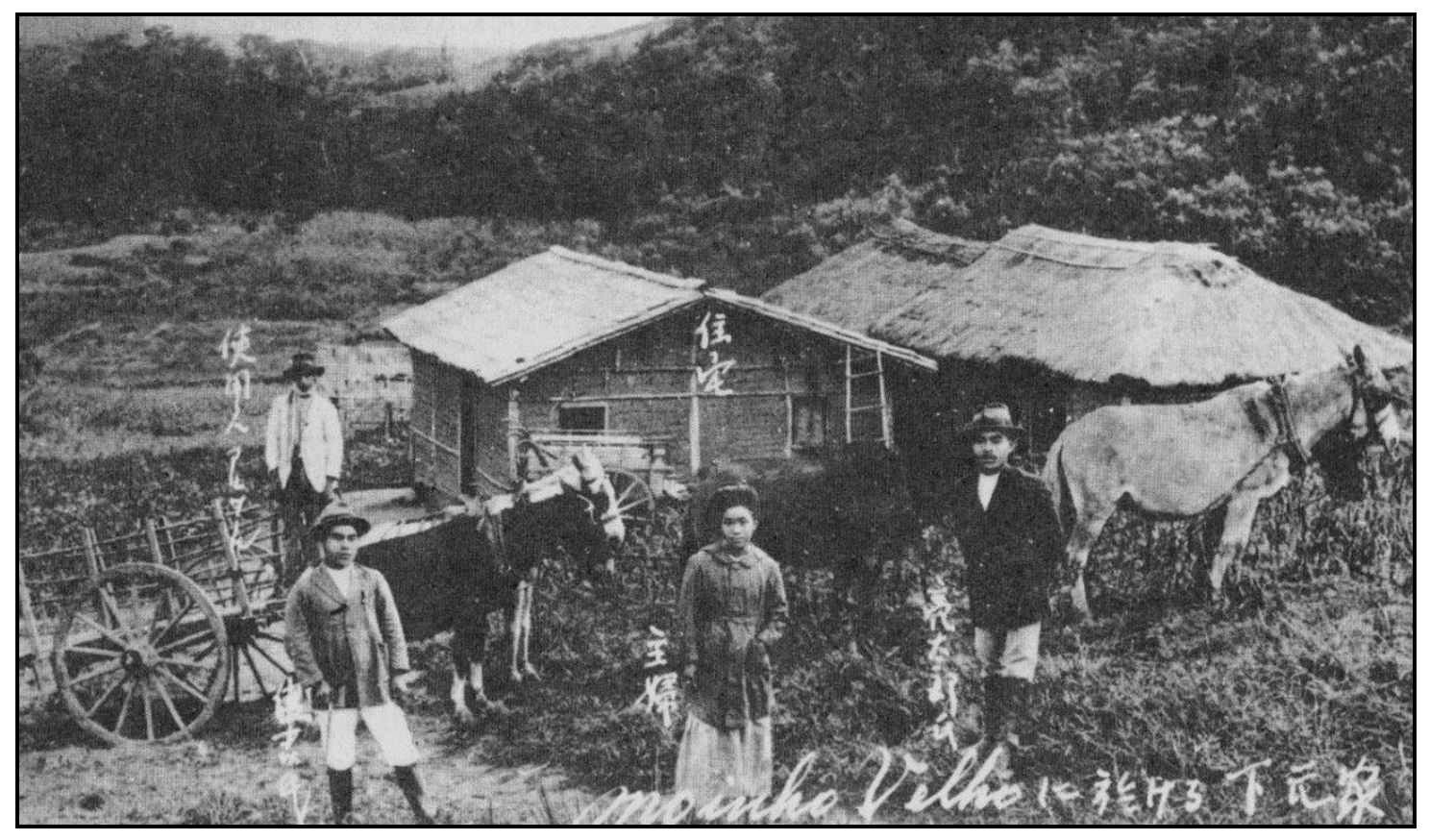

Fonte: CAC, 1988.

A despeito de períodos de maior adversidade, de forma geral entre a sua fundação em 1927 e o ano de 1942, a Cooperativa passou a assumir uma posição de

\footnotetext{
71 "Em 1934, quando o surto de cooperativismo começa a impressionar observadores, o cônsul-geral Iwataro Uchiyama promoveu uma reunião de 'Executivos das Cooperativas Agrícolas Japonesas do Brasil'. Dessa reunião originou-se a organização da Cooperativa Central Agrícola Nipo-Brasileira! Essa entidade prestou relevantes serviços como órgão de orientação e ligação das numerosas cooperativas rurais de nipônicos então formadas em muitas regiões do país. No momento da criação da Cooperativa Central, dela participaram 16 cooperativas. Esse número aumentou para $20 \mathrm{em} \mathrm{1939.} \mathrm{Então} \mathrm{havia} \mathrm{em}$ média 356 cooperados por cooperativa filiada. A CAC já contava 1.620 associados, desenvolvendo-se como uma organização econômica atuante não só numa localidade, mas abrangendo muitas, em diversas regiões. Durante a guerra (março de 1942), a Cooperativa Central Agrícola Nipo- Brasileira mudou o seu nome para Cooperativa Agrícola Central de São Paulo". (COMISSÃO, 1992, p.222)
} 
destaque entre as demais empresas do setor, diversificando a sua produção ao comercializar outros produtos como frutas, ovos, grãos, aves, hortaliças, chá, algodão, legumes. Com relação à abrangência de atuação, a partir do final da década de 1930, ela passou a operar em todo o estado de São Paulo, no município do Rio de Janeiro, nos estados do Paraná e Minas Gerais, criou e ampliou os depósitos regionais de distribuição, criou o setor de crédito para cooperados, órgãos de assistência aos cooperados (clube esportivo, assistência médica e social) e desenvolveu tecnologias para melhorias na produção. Progressivamente, ao longo dos anos de sua atividade a CAC passava a apresentar resultados financeiros positivos, contribuindo para o aumento da reputação do empreendimento entre a coletividade japonesa e da figura de seu principal líder, Kenkiti Simomoto ${ }^{72}$. Contudo, o relativo êxito econômico alcançado ocorria dentro dos limites de sua relativa dependência de órgãos oficiais brasileiros e japoneses. Para os gestores da Cooperativa, a política permanecia um espaço social majoritariamente alheio às atividades econômicas, ao menos até os acontecimentos da Segunda Guerra Mundial.

O que deve ser ressaltado neste tópico é que os dados coletados permitem caracterizar a Cooperativa enquanto um empreendimento criado de forma tutelada (mediante o apoio financeiro do Consulado Geral do Japão), fato que lhe permitiu integrar um circuito social em que se fazia sentir a presença de órgãos ligados ao governo japonês; e que do ponto de vista institucional o alcance da sua gestão possuía limites bem definidos pela nacionalidade e pela ausência de representantes de seus interesses em instâncias que pudessem influenciar seu desempenho no mercado. Pois seus gestores eram imigrantes estrangeiros com pouco ou nenhum domínio tanto da língua portuguesa quanto das estruturas de governança do setor agrícola, e suas representações e laços no âmbito político nacional eram distantes.

Em síntese, a presença da Cooperativa no mercado parecia se fazer mais pelo controle da produção de determinados produtos ou de certas inovações técnicas no plantio do que por sua capacidade de influenciar o planejamento e a estruturação do

\footnotetext{
72 Como relatou um entrevistado, Kenkiti Simomoto era um dos principais líderes da "colônia japonesa" em São Paulo e portador de grande carisma entre seus compatriotas, cooperados e personalidades diplomáticas japonesas locais (Entrevista realizada em 15 de março de 2013).
} 
setor agrícola, mediante representantes de seus interesses. E, dessa forma, a gestão da Cooperativa, sob comando de imigrantes japoneses, ocorria sob possibilidades circunscritas de atuação no mercado. A seguir, procuro sustentar essa afirmação demonstrando a relativa dependência da Cooperativa dos órgãos oficiais japoneses (principalmente do Consulado) e dos órgãos estaduais e federais (voltadas à supervisão das atividades cooperativistas).

A despeito do crescimento de sua atuação no mercado, do período de sua criação até 1942 as decisões da Cooperativa dependiam fortemente de orientações jurídicas e burocráticas dos órgãos reguladores da atividade agrícola. Isso se deve ao fato de que durante a década de 1930 a legislação cooperativista foi criada e constantemente modificada, exigindo um conhecimento técnico especializado que adequasse as suas atividades às disposições legais. Em grande medida, conforme já foi mencionado, as constantes mudanças na legislação cooperativista brasileira impunham obstáculos legais às próprias cooperativas, na medida em que, a cada novo decreto que entrava em vigor, havia uma crescente necessidade de adequar-se a ele.

Dessa forma, em várias ocasiões seus gestores encontravam-se em uma situação visivelmente limitada, pois o relativo êxito comercial da Cooperativa conviviva com a crescente demanda do conhecimento de dispositivos legais oficiais. A solução para esse impasse foi, em partes, resolvida com o recrutamento de profissionais especializados, mas, conforme procuro demonstrar ao final deste capítulo, também esteve sujeita aos acontecimentos da Segunda Guerra Mundial, e envolveu processos de transição geracional em que uma juventude estudantil adquiriu proeminência nos circuitos locais de liderança e visibilidade social dos imigrantes japoneses. 
Figura 5 - Ata da Assembleia de Constituição da Cooperativa de Responsabilidade Limitada dos Produtores de Batata de Cotia S.A. (1927) e registro na Junta Comercial do Estado de São Paulo (1933).

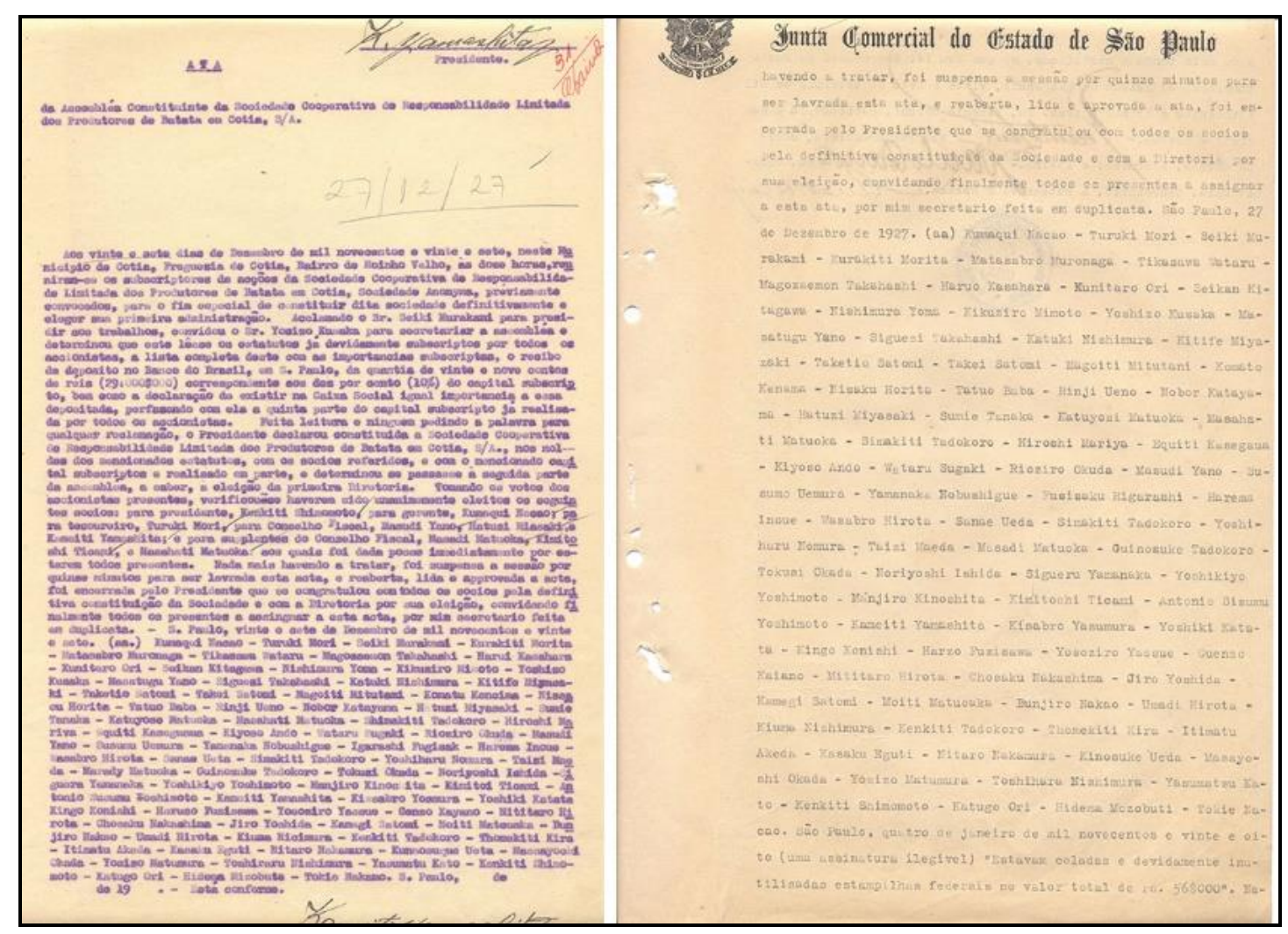

Fonte: Instituto de Cooperativismo e Associativismo, Secretaria da Agricultura do Estado de São Paulo, Departamento de Assistência ao Cooperativismo.

A burocratização da legislação caracterizou o período inicial de regulamentação do cooperativismo no Brasil, demandando a incorporação de setores técnicos profissionais especializados na gestão administrativa e legal dessas organizações, como contadores, administradores, agrônomos e advogados. A esse novo quadro institucional - em que o conhecimento técnico e da língua passava a ser cada vez mais decisivo -, somava-se outro aspecto oriundo da experiência migratória: no caso da CAC, entre os imigrantes lavradores havia o sentimento geral de que o conhecimento promovido pela 
educação superior dos seus filhos - principalmente o da legislação brasileira - seria um trunfo que possivelmente impediria a reincidência de epísódios negativos por eles vivenciados. E, dessa forma, o ingresso dos seus filhos em cursos superiores de Direito era algo valorizado, como é possível constatar no depoimento a seguir:

O processo sobre a fazenda, da qual fomos expulsos à força, teve desfecho favorável a nós, depois de 5 ou 6 anos de litígio. Fomos avisados do resultado, mas ninguém teve vontade de voltar a Santa Bárbara do Rio Pardo, cenário de tantas amarguras para nós. De uma coisa estávamos certos: aquele infortúnio decorreu da falta de conhecimentos da nossa parte; principalmente a falta de conhecimento da língua. Em vista dessa experiência amarga, tratamos de instruir os nossos filhos mandando-os às escolas superiores. Nós, que viemos como imigrantes, não poderíamos ter conhecimentos da língua tanto quanto brasileiros, mas os nossos filhos aqui nascidos e criados devem ter uma educação nunca inferior aos brasileiros - era meu pensamento. Só assim que os nossos filhos teriam as oportunidades de sucesso na sua vida. Por isso, o filho do sr. Inoue (Dr. Gervásio Inoue, atual diretor da C.A.C.) foi um dos primeiros filhos de japoneses a cursar a faculdade de direito. (Depoimento de Chosaku Nakashima, 27 de agosto de 1953, tradução de Hiroshi Saito. Fonte: Arquivo Hiroshi Saito)

É interessante notar que o entrevistado elege como exemplo de sucesso de uma trajetória educacional vislumbrada o caso de Gervásio Inoue, filho de Harema Inoue, um dos cooperados-fundadores da CAC. Como já foi mencionado, Gervásio foi DiretorPresidente da Cooperativa entre 1957 e 1990, tendo obtido o título de bacharel em Direito pela Faculdade de Direito do Largo de São Francisco em 1945. Logo após concluir o curso superior trabalhou no departamento jurídico da Cooperativa, sendo incorporado aos núcleos de direção do empreendimento três anos mais tarde, juntamente com Fábio Ryodi Yassuda. A ressalva a ser feita em relação ao depoimento é que o primeiro estudante de origem japonesa a se formar na Faculdade de Direito do Largo de São Francisco em 1936 foi Cássio Kenro Simomoto, sobrinho do líder-fundador da CAC, Kenkiti Simomoto ${ }^{73}$.

\footnotetext{
73 “Cassio Kenro Shimomoto (Província de Kochi, Japão, 1912 - São Paulo,1968). Veio para o Brasil ainda bebê. Primeiro nisei formado pela Faculdade de Direito do Largo São Francisco (1936). Ainda estudante, participou como voluntário da Revolução Constitucionalista de 1932”. (COMISSÃO, 1992, p.171)
} 
Ao final deste capítulo analiso a formação de um pequeno grupo de filhos de imigrantes japoneses, altamente escolarizado, surgido em meados da década de 1930 no bairro da Liberdade em São Paulo. Esse grupo esteve à frente da Liga Estudantina NipoBrasileira (1934-41), órgão patrocinado principalmente pelo Consulado, e por meio do qual uma privilegiada fração estudantil de filhos de japoneses formulou as primeiras manifestações públicas que buscavam combinar a herança japonesa e a brasileira, processo mais geral de reconhecimento público de sua posição social que autores como Lesser (2001) têm denominado "negociação" da identidade nacional. Desse grupo participaram, entre outros, Gervásio Inoue e Yukishigue Tamura, João Sussumu Hirata e Ioshifumi Utiyama, alguns dos primeiros políticos de origem japonesa no Brasil. Também demonstro adiante que o processo de formação desse grupo estudantil pode ser melhor compreendido se considerarmos uma lógica específica de sociabilidade da coletividade japonesa residente na região central da cidade, os interesses ali envolvidos, bem como se situarmos o papel das lideranças locais na conformação das relações sociais.

Por ora, ressalto que episódios decorrentes da burocratização da legislação brasileira no período inicial de regulamentação do cooperativismo foram recorrentes, não apenas no caso da CAC, como em outras cooperativas agrícolas de origem japonesa, ao menos até o término do Estado Novo (1945), quando a legislação cooperativista obteve contornos mais bem definidos e órgãos setoriais e entidades de representação dos produtores foram criadas.

Nesse referido período, conforme venho enfatizando, as lideranças da Cooperativa possuíam pouca ou nenhuma representação no âmbito da política, bem como seus gestores detinham pouco domínio sobre as disposições legais que regiam as estruturas de governança do setor agrícola. Esse é um dado relevante para os objetivos desta pesquisa, pois pressupõe-se que agentes em posições de comando nas firmas interpretam seus ambientes internos e externos para atuar politicamente com base em sua interpretação desses ambientes. Essa política é delimitada por aquilo que os agentes conhecem, as suas percepções sobre o ambiente, e por o que é definido como comportamento organizacional adequado (FLIGSTEIN, 1987). 
Em decorrência do limitado escopo de ação dos gestores da Cooperativa nessa estrutura de governança, a sua capacidade de influenciar as formas de coordenação da atividade econômica eram remotas, e as suas ações visando contornar conflitos locais dependiam da intervenção direta dos órgãos oficiais (japonês e brasileiro) e de assessores, profissionais liberais com domínio do idioma português. Posteriormente, a partir da década de 1950, veremos que por meio da atuação de seus gestores (principalmente os de segunda geração) essas ações passaram a se resolver em outros âmbitos que não dependiam tão fortemente desses órgãos oficiais, pois a Cooperativa já contava com representação em órgãos classistas e era capaz de influenciar decisões no âmbito econômico.

Dois casos exemplificam a referida limitação dos gestores da Cooperativa na década de 1930, quando era dirigida por indivíduos de origem japonesa. Trata-se do conflito travado com o Sindicato dos Proprietarios de Lavoura, Legumes e seus Similares de S.Paulo, em 1934, e o conflito com comerciantes que intermediavam a venda de batatas, ocorrido em fins daquele mesmo ano. O principal espaço de tais conflitos era o mercado municipal da Rua General Carneiro, na região central da cidade de São Paulo ${ }^{74}$. Em virtude da impossibilidade de lidar com esses conflitos pela ausência de um quadro profissional nativo (ou seja, de japoneses cooperados) que detivesse conhecimento dos meios legais para a sua resolução, a Cooperativa se reportou aos dois órgãos que lhe poderiam oferecer suporte: o Departamento de Assistência ao Cooperativismo (DAC) e o Consulado Geral do Japão. A resolução desses conflitos dependeu, em grande medida, da mediação do primeiro deles.

Uma pesquisa em documentos endereçados ao DAC revela dois pedidos de resolução de conflitos ${ }^{75}$ entre representantes da CAC e o referido sindicato; e um pedido

\footnotetext{
${ }^{74} \mathrm{O}$ mercado era situado na rua 25 de Março, no cruzamento com a rua General Carneiro. Foi inaugurado em 1867, também conhecido como "Mercado dos Caipiras" ou "Mercado Velho", e comercializava produtos agrícolas de pequenos produtores dos arredores da cidade. Para mais informações, ver: MARTINS, J.S. Subúrbio, Vida cotidiana e história no subúrbio da Cidade de São Paulo: São Caetano, do fim do Império ao fim da República Velha. São Paulo: Hucitec, 1992.

${ }^{75}$ Os documentos datam de 31 de julho e 14 de setembro de 1934. Fonte: Instituto de Cooperativismo e Associativismo, Núcleo de Documentação.
} 
de resolução de conflito com comerciantes intermediários ${ }^{76}$. Sumariamente, no primeiro caso, o sindicato procurou impedir a instalação dos estandes de verduras da Cooperativa, tendo os seus diretores até mesmo promovido uma campanha contrária publicada em jornais da época ${ }^{77}$, e a acionar autoridades governamentais. Os gestores Kenkiti Simomoto e Kameiti Yamashita recorreram ao diretor do DAC, Luis Amaral, solicitando medidas de solução, bem como foi requerido o contato com autoridades governamentais, incluindo o prefeito da cidade - sendo prontamente atendidos ${ }^{78}$. Por fim, mediante intervenção do DAC, foi garantida à Cooperativa o direito de instalar seus pontos de venda no Mercado.

O conflito seguinte ocorreu em novembro daquele ano de 1934: o boicote à produção de batatas dos lavradores japoneses de Cotia:

\footnotetext{
${ }^{76}$ Documento de 3 de dezembro de 1934. Fonte: Instituto de Cooperativismo e Associativismo, Núcleo de Documentação.

77 "A campanha contra nós movida, e que acima nos referimos, tem sido feita até pela imprensa, em termos injuriosos e caluniosos, chegando aquele Sindicato a alegar a não existencia de uma Cooperativa, e tão somente 'meia duzia de indivíduos gananciosos' que procuram prejudicar o negócio dos associados do mesmo Sindicato (palavras textuais), e ainda, com o fim de servir aos seus intuitos, chegaram aqueles senhores a telegrafar ao Ministro do Trabalho, e intervir junto ao Sr.Interventor Federal e Prefeito Municipal". (Carta da Cooperativa Agrícola de Cotia ao Departamento de Assistência ao Cooperativismo, 31 de julho de 1934. Fonte: Instituto de Cooperativismo e Associativismo, Núcleo de Documentação)
}

"Interessado na questão, e nos emprestando o seu apoio e valiosa influência, o Sr. Intendente Geral dos Mercados, Dr. Proença de Gouvêa, cujo alto espírito de justiça queremos agora revelar e deixar bem patente, nos solicitou a documentação que se fazia precisa, tal como estatutos e outros que provassem a existência da Cooperativa, e de posse desta documentação, fez com que a mesma junta ao processo que então se iniciava. Depois de informado pelos funcionários da Prefeitura, o processo que nos referimos teve do Sr. Prefeito Municipal o despacho final, nos concedendo o espaço de que tivéssemos necessidade, concedendo ao mesmo tempo isenção dos impostos de Indústria e Profissão. Parecia que finalmente havia a questão sido resolvida por uma vez, entretanto, assim não aconteceu, pois com a mudança do Prefeito, e, após a posse do Dr. Fábio da Silva Prado naquele cargo, iniciou o Sindicato uma nova campanha, ainda com as mesmas intenções. Nestas condições, quereríamos merecer de V.S. o grande obséquio de interferir ao Sr.Prefeito, a fim de que nos fosse concedido o que vimos pleiteando, e o que julgamos de inteira justiça, e dentro de todas as leis e dispositivos legais". (Carta da Cooperativa Agrícola de Cotia enviada ao Departamento de Assistência ao Cooperativismo, 14 de setembro de 1934. Fonte: Instituto de Cooperativismo e Associativismo, Núcleo de Documentação)

78 "Refiro-me a vosso ofício de 31 de julho. Hoje mesmo oficiei ao Sr. Prefeito da capital, conforme solicitais, esclarecendo devidamente o assunto e estou certo de que nenhum incômodo sofrereis, porquanto este Departamento não deixaria de ser ouvido, se porventura o caso, que expondes, tomasse vulto - o que não creio". (Comunicado de Luis Amaral à Cooperativa Agrícola de Cotia, 1 de agosto de 1934. Fonte: Instituto de Cooperativismo e Associativismo, Núcleo de Documentação)

"Refiro-me a vosso ofício de hoje. Hoje mesmo encaminhei ao Sr. Prefeito Municipal o assunto de que ele trata. Sirvo-me da oportunidade para informar-vos que, em ofício número 629 de 28 de agosto, o sr. Prefeito havia comunicado a este Departamento as providências tomadas no caso". (Comunicado de Lius Amaral à Cooperativa Agrícola de Cotia, 14 de setembro de 1934. Fonte: Instituto de Cooperativismo e Associativismo, Núcleo de Documentação) 
Em novembro desse ano, no auge da safra de batata, grandes comerciantes, (Loureiro, Guerreiro, Dab-Ada) se juntaram num movimento hostil, contra a aquisição de batata da Cooperativa, influenciando até os carrinheiros, vendedores ambulantes, que a deixaram de comprar. (CAC, 1988, p.53)

Segundo depoimentos dos gestores da Cooperativa e de publicações comemorativas internas, o conflito teria surgido como uma resposta dos comerciantes intermediários à expansão da venda direta de batatas para o estado do Rio de Janeiro: "O grande impacto para estes, e que lhes chamou a atenção, foi a decisão da Cooperativa de expandir suas vendas no Rio de Janeiro" (CAC, 1988, p.53).

Nas palavras dos então principais diretores do empreendimento, Kenkiti Simomoto e Kameiti Yamashita, a respeito do ocorrido em ocasião de uma mesaredonda em 1952:

Simomoto: - Começou no dia 28, segunda-feira. Naquela manhã, abrimos o depósito, mas ninguém apareceu para comprar batata. Por isso fomos todos ao Mercado ver o que acontecia. Lá estavam reunidos os comerciantes intermediários, mas ninguém queria comprar batata da C.A.C.. Diziam que comprariam batatas de produtores que tivessem levado seus produtos ao mercado, na qualidade de produtor individual. Ficamos espantados. Tivemos então que tomar contra-medidas e para isso convocamos uma reunião de dirigentes [...]

Yamashita: - Compareceram todos, desde representantes até chefes de distrito. E decidimos suspender as entregas [...]

Simomoto: - Durante uma semana não saiu uma batata para o mercado. O depósito da Cooperativa ficou de porta cerrada para o Mercado. (ANDO, 1961, p.65)

O trecho reproduzido indica que a resolução dos lavradores japoneses ao boicote sofrido se concretizaram em algumas contra-medidas: a suspensão do fornecimento do produto para o Mercado, o que se somou à venda direta aos varejistas. Em resposta, as reações dos comerciantes à interrupção do fornecimento do produto teria alcançado até 
mesmo os jornais $^{79}$, e a Cooperativa por sua vez distribuía panfletos com suas declarações a respeito do conflito ${ }^{80}$. O caso foi então levado ao Consulado Geral do Japão por iniciativa dos comerciantes. Em reunião, o Cônsul-Geral Kozo Itige - que no ano seguinte viria a dar suporte às primeiras iniciativas de manifestação pública dos filhos de japoneses em relação à questão identitária, estampadas no jornal Gakusei teria inicialmente sugerido a Kenkiti Simomoto a realização de um acordo, temendo que o caso se tornasse uma questão diplomática em uma conjuntura política já tensionada pela promulgação da constituinte ${ }^{81}$. De fato, na versão de Kenkiti Simomoto o caso já havia chegado a um ponto que passava a alimentar um certo sentimento coletivo contrário aos japoneses:

Planejaram com isso lançar o ódio sobre a Cooperativa e até provocar um movimento antijaponês, a fim de subjugar a C.A.C.. E na realidade, cidadãos de São Paulo, que desconheciam a verdade, ficaram revoltados ao ler a notícia publicada nos jornais. Chegou a brotar até um sentimento anti-Cotia no seio da opinião pública. (ANDO,1961, p.64)

O acordo sugerido pelo Cônsul não foi acatado por Kenkiti Simomoto. Por fim, o conflito culminou em um desfecho favorável para a Cooperativa, segundo indicam os relatos dos seus gestores e uma correspondência dirigida ao diretor do DAC, Luis $\mathrm{Amaral}^{82}$. Os comerciantes então retornaram às transações com os produtores japoneses.

\footnotetext{
79 "E recorreram a um golpe baixo, mandando escrever nos jornais que a 'Cooperativa Agrícola de Cotia, a fim de elevar o preço da batata, suspendera as entregas e recusava-se a vender aos comerciantes, motivando a falta de batata na praça de São Paulo"'. (ANDO, 1961, p.64)

80 "Então a Cooperativa publicou a seguinte declaração, a fim de esclarecer a sua posição. 'Comerciantes que ficam entre os produtores e os consumidores auferem lucros excessivos com produtos resultantes do suor dos lavradores. Os intermediários não só oprimem os lavradores como exploram os consumidores. Nós não queremos entregar nossos produtos a esses comericantes intermediários e sim, de acordo com o ideal cooperativista, fazer a venda direta ao consumidor, a preços baixos'. Milhares de cópias desse manifesto, mimeografado, foram distribuídas no Mercado Central, aos varejistas e ao povo em geral, a fim de expor a situação e definir a atitude da Cooperativa". (ANDO, 1961, p.65)

81 "Simomoto: - Disse me o Sr. Ichige: 'Parece que vocês criaram um caso bastante sério. Se ele se agravar se transformará em questão internacional, em caso diplomático. Por que não entrem em acordo?'. Percebi que os comerciantes haviam dado ao caso um sentido de disputa entre japoneses e a população de Sâo Paulo. Respondi então ao Cônsul Ichige que não se tratava de caso diplomático nem internacional. Era somente uma pendência entre produtores de batata e comerciantes. Se o consulado se intrometesse no caso, então sim a questão assumiria caráter internacional". (ANDO, 1961, p.65)

82 "Com a presente vimos cientificá-lo a de que os Snrs. Comerciantes de batatas que se achavam em guerra contra esta Sociedade, tendo até feito publlcações pela imprensa contra nós modificaram sua
} 
$\mathrm{Na}$ literatura especializada, podemos encontrar várias menções ao evento do boicote à Cooperativa ocorrido naquele ano de 1934. O caso por vezes foi interpretado como uma prova de superação das adversidades, especialmente nas publicações comemorativas (CAC, 1957; ANDO, 1961; CAC, 1988); teria um "efeito consolidador", resultando no "fortalecimento da consciência"83 dos membros da Cooperativa (SAITO, 1964); seria uma expressão da identidade nacional (LESSER, 2001) visto que a criação de um sistema permanente de distribuição de produtos agrícolas no contexto de nacionalismos conflitantes teria reforçado "ideias acerca do poderio japonês" 84 ; ou mesmo demonstraria o "poder dos atacadistas" japoneses no abastecimento da cidade e a "reação de especuladores na forma de discurso racista" (CYTRYNOWICZ, 2000, p.158).

De fato, em 1934 os produtores japoneses de Cotia eram vistos como um caso de sucesso no mercado agrícola em expansão da capital, o que por vezes poderia estimular conflitos com grupos produtores de outras nacionalidades ${ }^{85}$. Além disso, naquele

atitude, tendo nos procurado no sábado a tarde (dia 1) para um entendimento. Esta Cooperativa não fez acordo algum com os mesmos. Cientificou-os de que continuaria vendendo como e onde quisesse os seus produtos, de maneira tal que podemos considerar uma rendição incondicional. Felicitamos o Departamento na pessoa do seu Diretor pela grande vitória de nossos princípios e agradecemos maneira solícita com que V.S. se prontificou a nos defender em colaboração com o Chefe da $2^{\circ}$ seção". (Comunicado da Cooperativa Agrícola de Cotia enviado a Luis Amaral, 3 de dezembro de 1934. Fonte: Instituto de Cooperativismo e Associativismo, Núcleo de Documentação)

${ }^{83} \mathrm{Na}$ interpretação de Saito, pressupõe-se que por meio das cooperativas agrícolas é que os pequenos produtores japoneses poderiam enfrentar a competição de outras empresas no mercado. Dito isso, o caso do boicote de 1934 representaria a transição de uma "fase de competição" para uma "fase de conflito", indicando o que o autor denominou como "consolidação" e expansão das atividades da Cooperativa. Como resultado, o conflito teria "fortalecido a consciência" dos membros da direção, que adotaram medidas como a progressiva incorporação de cooperados nascidos no Brasil: "De fato, alguns entrevistados nossos, os quais estavam na direção da cooperativa por ocasião do boicote, informaram-nos que o maior receio que tiveram do caso era de que o conflito assumisse ou a ele fosse atribuído um caráter de conflito étnico entre os lavradores japoneses e comerciantes brasileiros, como pretendiam alguns jornais. Por isso, depois dessa experiência do boicote, os dirigentes da cooperativa encorajaram, conscientemente, a admissão de cooperados brasileiros" (SAITO, 1964, p.129, grifos do autor).

${ }^{84} \mathrm{Na}$ palavras de Lesser: "Quando a cooperativa começou a expandir suas atividades, entrando no ramo da distribuição, os intermediários brasileiros de descendência espanhola e italiana organizaram um boicote que veio a fracassar quando a CAC parou de vender para os não-cooperados. Embora seu diretor afirmasse que 'não se tratava de um caso diplomático nem internacional. Era somente uma pendência entre produtores de batata e comerciantes', a criação de um sistema permanente de distribuição reforçou as ideias acerca do poderio japonês. Esses incidentes representam diferentes expressões da identidade nacional" (LESSER, 2001, p.191-192).

${ }^{85}$ Ver o estudo "A immigração japoneza", de Eddy F. de Cryssiúma, publicado na íntegra pelo jornal $O$ Estado de S.Paulo (edições de 4 e 14 de dezembro de 1934). No estudo há um tópico analisando o caso de Cotia, denominado "O Japonez em Cotia", em que o autor considera os agricultores da localidade como 
mesmo ano a continuidade da imigração japonesa havia sido colocada em questão no debate público por certos grupos nativistas, e a nova Constituição parecia anunciar uma série de restrições que, nos anos seguintes, impôs limites muito bem definidos à entrada desses imigrantes no país e à sua participação nas atividades políticas. Alguns DecretosLei já mencionados, expedidos ao longo do período do Estado Novo (1937-1945), corroboram essa afirmação. Nessa conjuntura, categoriais raciais que fundamentavam os argumentos de repulsa aos japoneses facilmente compunham discursos sobre a sua não aceitação social no imaginário coletivo, criando assim um ambiente muitas vezes hostil a esses imigrantes.

Contudo, o que observamos nas interpretações desses diversos autores sobre o caso do boicote de 1934 são dois vieses: no caso do sociólogo Hiroshi Saito e do antropólogo Zenpati Ando (ambos japoneses) e das publicações comemorativas, os fatos são expostos de maneira seletiva, enfatizando-se aqueles que permitiriam explicar o relativo êxito comercial da Cooperativa enquanto um empreendimento de organização associativa do pequeno produtor imigrante. Por fim, tratar-se-ia de um caso que atestaria o alto grau de integração social dos japoneses na sociedade local. No caso dos historiadores Jeffrey Lesser e Roney Cytrynowicz, o caso em questão é analisado a partir de seus resultados, e não em sua dinâmica, servindo como mais um exemplo que atestaria o conflito étnico-racial de dimensões amplas envolvendo os imigrantes japoneses e outros grupos.

Em todas essas interpretações, observa-se que fatores de âmbitos organizacional e político não são considerados para a análise de atividades que se expressam no universo mercantil. Acrescenta-se a isso o fato de que o espaço social dos gestores da CAC não é definido, e a capacidade de agência dos indivíduos é sobreposta por determinantes de ordem cultural, o que por vezes resulta em conclusões generalizantes.

De forma complementar, acredito que a compreensão desses episódios envolvendo a Cooperativa possui ganhos analíticos se situarmos a posição e a participação desses gestores em um espaço social específico - o núcleo de lideranças da

um dos mais prósperos núcleos de concentração japonesa do estado de São Paulo. Trata-se de um trabalho feito por Eddy de Crissiuma, sob orientação do geógrafo Pierre Deffontaines, para o recém-inaugurado curso de Geografia da Universidade de São Paulo. 
coletividade japonesa na cidade de São Paulo na região central da cidade, conforme já foi exposto no tópico anterior. E, considerando-se os efeitos de determinantes políticos para a população japonesa naquela conjuntura e a dinâmica organizacional do empreendimento, podemos constatar que seu escopo de atuação possuía limites bem definidos por critérios de nacionalidade e pelo repertório restrito de recursos a serem mobilizados para um desempenho no mercado. É por essa razão que no período em que a direção do empreendimento era composta por japoneses natos, e quando as estruturas de governança lhes representava uma instância pouco acessível, a sua capacidade de influência na coordenação do mercado dependia de ações - ou ao menos era mediada em certo grau elevado - de órgãos diplomáticos japoneses e de órgãos setoriais brasileiros.

O que deve ser sublinhado aqui é que o evento do boicote à produção da Cooperativa no ano de 1934 é um caso que nos fornece subsídios para averiguar empiricamente, durante a vigência de um modelo de gestão de Kenkiti Simomoto (1927-1942), as respostas dos gestores da CAC a situações que ofertavam possibilidades historicamente situadas de atuação empresarial e de reconhecimento social. Essas possibilidades, como tenho argumentado, estiveram circunscritas pela nacionalidade e pelo repertório restrito de recursos a serem mobilizados para um desempenho no mercado. A diferença da abordagem realizada nesta pesquisa em relação a outras que analisaram o mesmo evento é que aqui o foco reside em expor a maneira pela qual os seus gestores vivenciaram certos acontecimentos, examinando de que formas isso reverberou pelos seus repertórios de práticas empresariais. Ao observarmos detidamente as ações desses gestores, verificamos que tais ações, que supostamente teriam sido adotadas como respostas a situações de mercado, resultaram em grande medida do universo de relações que as constituiu. É dessa forma que, entre outras, a origem japonesa se revelou central pois condicionou, dotando de sentido, as ações dos gestores da Cooperativa no caso analisado.

No tópico a seguir veremos que o respaldo institucional do Consulado e de órgãos setoriais brasileiros perdurou até o ano de 1942, quando a direção da Cooperativa sofreu transformações substantivas, principalmente em razão dos acontecimentos da Segunda Guerra. Ainda que reconstituir sistematicamente o contexto da guerra não 
represente um objetivo desta pesquisa, é válido mencionar que os japoneses vivenciaram os acontecimentos políticos dos primeiros 15 anos do governo de Getulio Vargas de forma bastante particular, segundo os estudiosos que se dedicaram a investigá-los ${ }^{86}$. Para a maior parte desses autores, há unanimidade na interpretação de que o rompimento das relações diplomáticas do Governo Brasileiro com os países do Eixo em 28 de janeiro de 1942 possui centralidade para a investigação de grupos imigrantes. Pois a partir desse evento, o ápice da intolerância política contra os estrangeiros pareceu ter sido alcançado, principalmente para os cidadãos de países inimigos de guerra do Brasil: aqueles de origem alemã, japonesa e italiana.

As reações dos imigrantes japoneses a esse contexto repressivo foram diversas. Algumas delas se concretizaram na total recusa de sua participação na sociedade brasileira (mesmo que aqui residissem), a exemplo de assassinatos cometidos por japoneses contra seus compatriotas, motivados pelo patriotismo radicalizado. Outras encontraram no universo mercantil o local para a sua realização, adequando a então questionada origem japonesa ao nacionalismo brasileiro da época. É este último caso que interessa diretamente a esta pesquisa. E, mais especificamente, foram analisadas as respostas dos gestores da CAC em relação a constrições decorrentes do conflito bélico, e que foram impostas ao empreendimento pelo Estado.

Mas, se durante a gestão de Kenkiti Simomoto os gestores da Cooperativa não dispunham de mecanismos de representação política e de recursos que pudessem influenciar as estruturas de coordenação do mercado, essa situação se alterou consideravelmente na gestão de Gervásio Inoue. Por isso mesmo convém abrir aqui um espaço para dedicar especial atenção a descrever um episódio da sucessão presidencial da Cooperativa, no contexto do rompimento das relações diplomáticas entre os governos brasileiro e japonês.

Esse episódio ilustra as estratégias adotadas pela gestão do empreendimento sob o comando de Kenkiti Simomoto em resposta a uma conjuntura delicada envolvendo nacionalismos conflitantes. Por causa do cerceamento do governo brasileiro às empresas de origem estrangeira que operavam no Brasil, naquele ano de 1942 Kenkiti Simomoto

\footnotetext{
${ }^{86}$ Ver, por exemplo, TAKEUCHI, M.Y. O Perigo Amarelo em tempos de guerra. São Paulo: Imprensa Oficial do Estado, 2002. 200p.
} 
avalizou a transferência dos principais cargos de decisão para gestores nascidos no país, sem qualquer descendência japonesa. Para o cargo de presidente foi escolhido Manoel Carlos Ferraz de Almeida, um advogado que desde 1938 prestava serviços de consultoria jurídica à Cooperativa, atuando nos setores de tributação de produtos agrícolas.

Talvez ao contrário do que esperavam as autoridades governamentais, a retenção momentânea do comando da Cooperativa pelos imigrantes japoneses resultou na formação de elos e de representação no âmbito da política. Posteriormente, a partir da década de 1950, os resultados dessas transformações no seio gestionário do empreendimento foram expressivas, pois a Cooperativa se tornou um dos maiores expoentes de produção e abastecimento no setor agrícola e passou a ser reconhecida como uma autoridade cultural entre a coletividade japonesa, capaz de produzir narrativas que atestassem a incorporação do grupo social na sociedade local. 
Figura 6 - Kenkiti Simomoto, Diretor-Presidente da CAC entre 1927 e 1942.

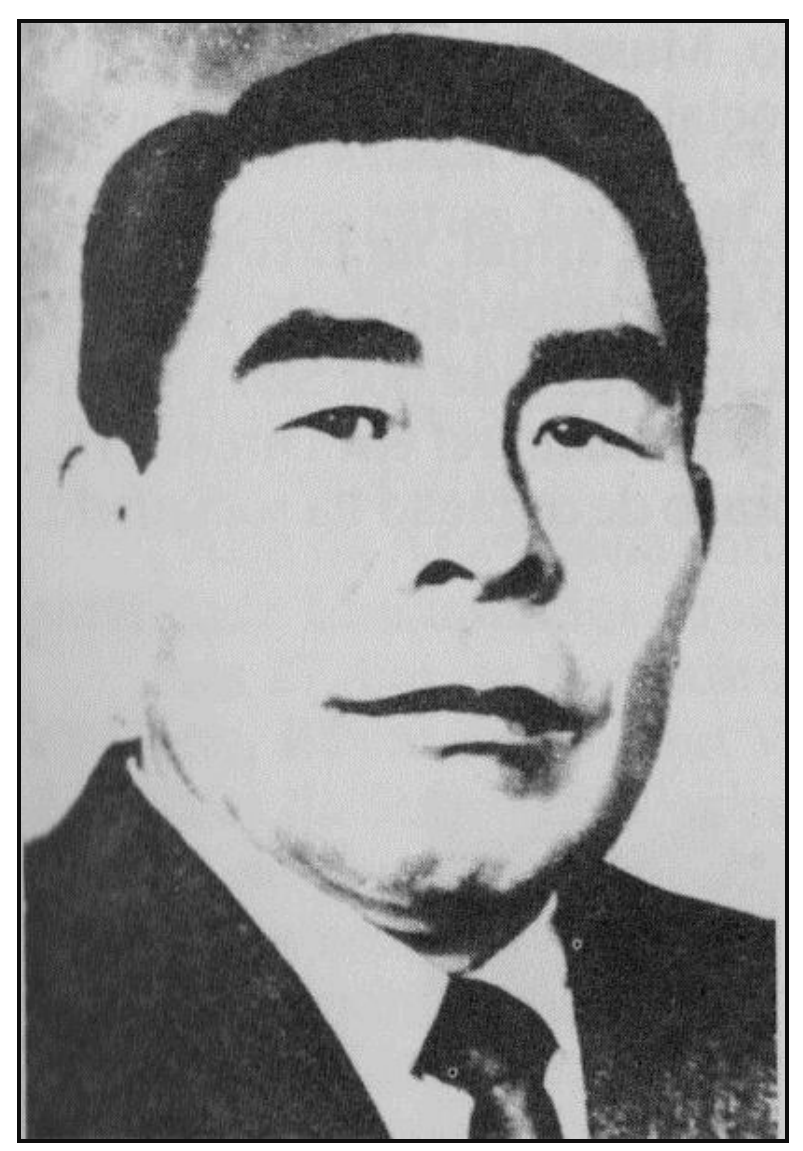

Fonte: CAC, 1988. 


\subsection{Gestores de primeira geração em meio a conflitos}

No final da tarde do dia 28 de janeiro, no Consulado-geral do Japão, todos abandonaram o local com o brado de banzai. O consulado enviou em nome do embaixador, às lojas comerciais japonesas e às principais famílias da cidade, um comunicado do fato e uma mensagem que dizia para não perderem suas forças, mantendo a receptividade e a amplitude de alma para perdoar e compreender. Em outras palavras, para não perderem a atitude digna de um grande povo.

Desaparecia do Brasil o representante do Império do Japão. Muitos ficaram chocados, mas já era proibido que nos bares e outros lugares públicos se conversasse em japonês. Nas redondezas da rua Conde de Sarzedas, que era onde os imigrantes residiam principalmente, eles iam e voltavam pelas ruas, em silêncio. Logo veio uma ordem de evacuação, para que os moradores dos arredores das ruas Conde de Sarzedas e dos Estudantes deixassem o local dentro de dez dias. A ordem foi repetida em setembro. A famosa rua Conde, onde apenas os nisseis podiam permanecer, ficava temporariamente estagnada. No entanto, a ordem de evacuação não foi tão rigorosa como aconteceu com o pessoal de Santos.

As notícias sobre a situação do interior chegavam à cidade de São Paulo pouco a pouco, através dos viajantes. Relatava-se que as cooperativas agrícolas passaram a ficar sob a fiscalização do governo, paralisavam-se as atividades e nas lojas comerciais havia a intervenção governamental, que atrapalhava o andamento de seus negócios. (HANDA, 1987, p.633)

O trecho acima reproduzido compõe parte dos relatos do pintor e memorialista Tomoo Handa sobre os episódios da guerra para o ano de 1942, quando as relações bilaterais entre os governo brasileiro e japonês foram oficialmente rompidas ${ }^{87}$. Dele extraímos algumas informações que se mostram relevantes: i) o autor revela a centralidade e a visibilidade que o Consulado Geral do Japão possuía entre os imigrantes japoneses, o "representante do Império do Japão" na cidade de São Paulo; ii) o comunicado que informava o fechamento do Consulado ${ }^{88}$, enviado pelo Cônsul Hara

\footnotetext{
${ }^{87}$ Entre 15 e 28 de janeiro de 1942 foi realizada a III Reunião de Consulta dos Ministros das Relações Exteriores das Repúblicas Americanas, no Rio de Janeiro, ocasião em que foram suspensas as relações comerciais entre o Brasil e o Japão. No dia 28 de janeiro as relações diplomáticas forma oficialmente rompidas. Para mais informações, ver Handa (1987) e Takeuchi (2008).

${ }^{88} \mathrm{O}$ Embaixador do Japão no Brasil à época, Ishii Itaro, e todo o corpo diplomático japonês deixaram o Rio de Janeiro em 4 de julho de 1942, sendo repatriados a bordo do navio MS Gripsholm (o primeiro navio de repatriação oficialmente negociado entre os Estados Unidos e o Japão). Seguiram para Nova Iorque, e de lá para Moçambique. Para mais informações, ver: SHINTANI A.H. World War II as Seen In
} 
Kaoru às "principais famílias" e estabelecimentos comerciais da cidade mantidos por japoneses, revela a existência de um círculo restrito de sociabilidade que congregava autoridades e expoentes do mundo dos negócios; iii) em razão de medidas nacionais de segurança, somente os nisseis (ou os filhos de imigrantes japoneses nascidos no Brasil) é que circulavam na região da Rua Conde de Sarzedas, principal local de concentração dessa população na cidade; iv) as cooperativas agrícolas de japoneses passavam a sofrer resultados diretos de medidas de restrição impostas às empresas de origem estrangeira adotadas pelo governo brasileiro.

A última informação extraída do trecho citado, relativa às cooperativas agrícolas, é de interesse central deste tópico e é examinada em maiores detalhes nos parágrafos a seguir. A fim de analisar como as medidas do Estado brasileiro contra empresas de origem estrangeira afetaram as cooperativas agrícolas fundadas e geridas por imigrantes japoneses, convém apresentar de forma breve a posição política internacional do governo Vargas no contexto da Segunda Guerra.

A política externa varguista, que entre 1934-1937 indicava uma maior aproximação de regimes totalitários europeus em detrimento de um pan-americanismo de influência norte-americana ${ }^{89}$ apresentou uma reviravolta durante o Estado Novo, segundo Seitenfus (2000). O Japão, que buscava a constituição da Grande Ásia, havia se alinhado à Alemanha desde a assinatura do Pacto Anti-Komintern, em janeiro de 1936. A Itália, sob a ditadura do fascismo de Mussolini, apoiava o governo de Hitler com base no Pacto Ítalo-Germânico de março de 1936. Progressivamente, os Estados Unidos buscaram assumir uma posição cada vez mais central nas direções da política externa e da economia brasileira, apesar de a postura por vezes simpática a estados totalitários (especialmente Itália e Alemanha) adotada por Vargas levantar suspeitas de Washington a respeito do caráter fascista do Estado Novo. Segundo o último autor, o fracasso do golpe integralista em maio de 1938 teria sepultado tal sentimento, contribuindo para

Life Records Of Japanese In Brazil: A Study Of Diaries, Newspapers And Radio Broadcasting. Master's Thesis. Kyoto University, 2013.

${ }^{89}$ Um exemplo dessa influência foi a criação, em agosto de 1940, de uma superagência de coordenação dos negócios interamericanos, sob a chefia de Nelson Rockefeller, chamada Office of the Coordinator of Inter-American Affairs (OCIAA). Para mais detalhes, ver: MOURA, G. Tio Sam chega ao Brasil - a penetração cultural norte-americana. São Paulo: Brasiliense, 1984. 
uma aproximação política e comercial mais efetiva com os Estados Unidos ${ }^{90}$, sem ainda romper relações definitivamente com os países totalitários.

Figura 7 - Nota Geral escrita pelo Cônsul-Geral Hara Kaoru e enviado às principais famílias e estabelecimentos comerciais mantidos por japoneses na cidade de São Paulo, em 28 de janeiro de 1942.

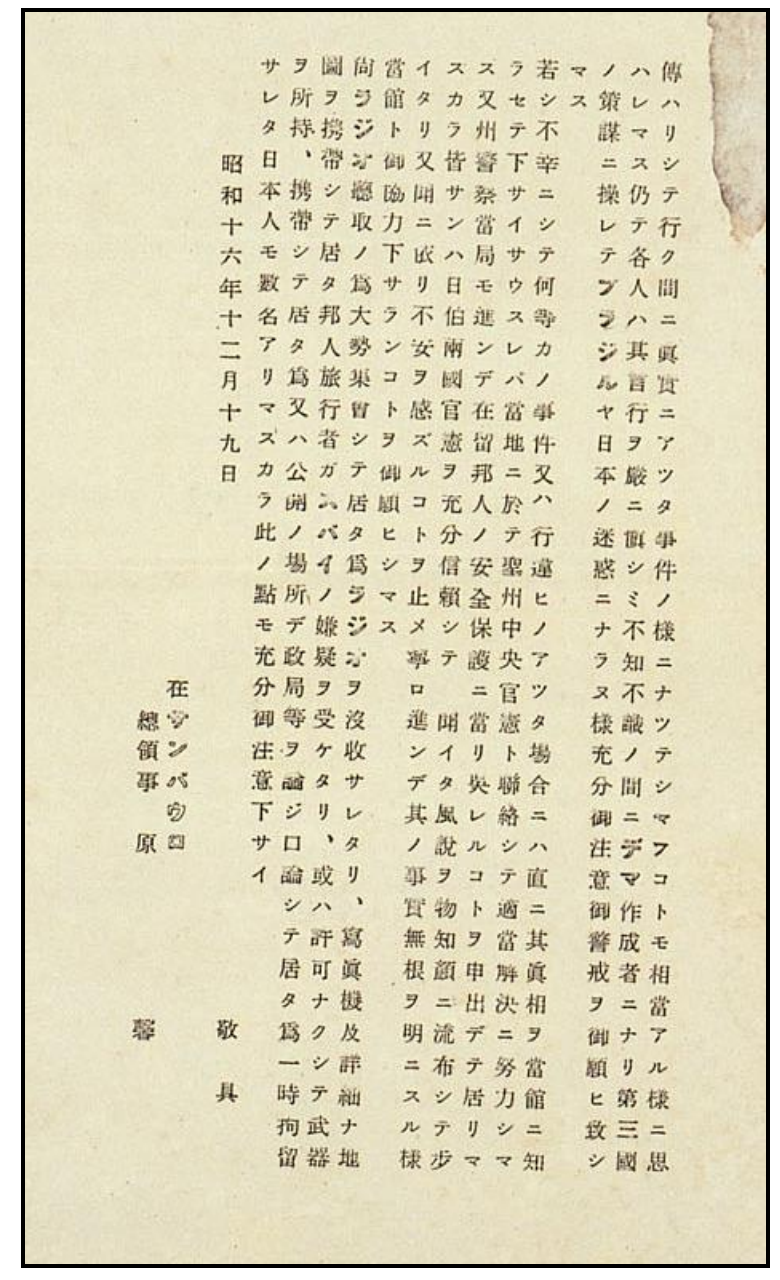

Fonte: National Diet Library, Japan.

\footnotetext{
${ }^{90}$ Segundo o autor: "O fracasso do golpe integralista suspende a última hipoteca que ainda pesava, aos olhos de Washington, sobre o governo Vargas. O Departamento de Estado saúda o desaparecimento dos camisas verdes. O substituto de Aranha em Washington, Mário Pimentel Brandão, declara ao The Washington Post que as suspeitas dos Estados Unidos sobre o caráter fascista do governo Vargas eram infundadas, como comprova o ataque ao Palácio Guanabara. A organização corporativista e a inspiração fascista do regime de Vargas não parecem mais inquietar os Estados Unidos" (SEITENFUS, 2000, p.139).
} 
O ataque japonês a Pearl Harbor em dezembro de 1941 resultou na imediata oficialização da entrada dos Estados Unidos na guerra e na sua união militar às forças aliadas. O governo estadunidense e o governo alemão passaram então a requerer um posicionamento do governo brasileiro no conflito, que por vezes expunha uma ambiguidade existente em seu núcleo: o ministro das Relações Exteriores, Oswaldo Aranha, possuía tendências democratas e apoiava os Estados Unidos, enquanto o Chefe do Estado-Maior do exército, Góes Monteiro, e o ministro da Guerra, Eurico Gaspar Dutra, teriam declarado possuir admirações pelo modelo autárquico e militarista dos estados totalitários (BONET, 2010). Contudo, por meio do Decreto-lei n. 3.911, de 12 de dezembro de 1941, uma primeira restrição foi imposta às empresas dirigidas por japoneses, alemães e italianos: que todas as transações comerciais e financeiras fossem reportadas previamente a fiscais do Banco do Brasil (HATANAKA, 2002).

Em 15 de janeiro de 1942, por convocação de Washington, ocorreu a III Reunião de Consulta dos Ministros das Relações Exteriores das Repúblicas Americanas, realizada no palácio Tiradentes, no Rio de Janeiro, de 15 a 28 de janeiro de 1942. O principal objetivo da reunião era a aprovação de uma resolução de rompimento imediato de relações diplomáticas e comerciais dos países do continente amerciano com o Eixo ${ }^{91}$. Somente no dia de encerramento da Conferência é que Vargas anunciou oficialmente a decisão de romper relações diplomáticas com a Alemanha, a Itália e o Japão. No continente, apenas Argentina e Chile não aderiram ao acordo. Segundo Bonet, Getúlio Vargas relatou em seu diário a forte pressão estadunidense para a tomada de sua decisão: "A maioria dos países americanos que adotaram essas soluções de declarar guerra ou romper relações não o fez espontaneamente. Foram coagidos pela pressão americana" (BONET, 2008, p.4). Naquele mesmo dia 28 de janeiro, o Consulado Geral do Japão em São Paulo fechava as suas portas, como escreveu Tomoo Handa no trecho

\footnotetext{
${ }^{91}$ Fonte: CPDOC/FGV. Informações disponíveis em: < http://cpdoc.fgv.br/producao/dossies/AEraVargas1/anos37-45/AGuerraNoBrasil/ReuniaoChanceleres $>$. Acesso em: dez. 2014.
} 
citado, e a CAC não podia mais contar com um dos seus principais esteios políticos e jurídicos.

A partir de 7 de janeiro de 1942, o governo estadunidense passou a incluir a CAC na Proclaimed List of Certain Blocked Nationals, uma lista assinada pelo presidente Franklin Delano Roosevelt em julho de 1941, e cujo objetivo, segundo Quintaneiro, eram restrições comerciais e financeiras a empresas dirigidas por indivíduos de nacionalidade japonesa, alemã e italiana, consideradas potencialmente perigosas:

O objetivo da PL era o bloqueio comercial e financeiro de empresas ou pessoas consideradas indesejadas, impedindo que, em âmbito hemisférico, fossem realizados quaisquer tipos de transações com elas. Para reforçar essas disposições, aqueles que insistissem em manter negócios com os interesses bloqueados podiam sofrer as mesmas conseqüências: congelamento de contas bancárias, interdição de importar ou representar produtos norte-americanos e, no limite, intervenção e liquidação dos estabelecimentos. (QUINTANEIRO, 2006, p.156)

Segundo a última autora, há indícios que ao menos desde fins da década de 1930 o governo estadunidense monitorava o comércio de matéria-prima brasileira para outras nações, especialmente as que compunham o Eixo. Em São Paulo, grande parte da produção agrícola dos imigrantes japoneses desde a primeira metade da década de 1930 era dedicada à cultura do algodão ${ }^{92}$, inclusive para exportação às empresas japonesas ${ }^{93}$, tendo o Consulado Geral do Japão até mesmo elaborado programas de estímulo do crédito à sua produção ${ }^{94}$. No contexto da guerra, contudo, a atividade passou a ser

\footnotetext{
92 "A proibição da plantação de novos cafezais no Estado de São Paulo resultou num vertiginoso crescimento da produção de algodão por parte de lavradores japoneses. Em 1933 ela alcançou $10 \%$ da produção total do Estado de São Paulo e em 1935, 50\%”. (COMISSÃO, 1992, p.122)

93 "grandes grupos econômicos japoneses como a Brascot, Mitsui Bussan, Nanbei Menka, Bratac Shoji, Kanematsu Gosho, C. Itoh, etc. lançaram-se à compra e exportação do algodão brasileiro". (COMISS ÃO, 1992, p.198)

94 "A organização de cooperativas por lavradores arrendatários se devia ao algodão. Embora a produção de algodão se expandisse muito, o sistema de financiamento rural era muito precário. O Consulado Geral do Japão em São Paulo reuniu então representantes de produtores de algodão de várias regiões junto com representantes da indústria têxtil japonesa para uma "Conferência de Algodão", com o fito de estudar um meio de financiar os cotonicultores. Isto resultou na formação dos "Grupos de Cinco" cotonicultores.
} 
considerada como potencialmente ameaçadora às nações aliadas, sob o argumento de contribuir para o fornecimento de matéria-prima para fins militares de Tokyo.

\section{Figura 8 - CAC na seção brasileira da lista de embargo comercial do governo estadunidense a empresas cuja origem estava ligada a países do Eixo.}

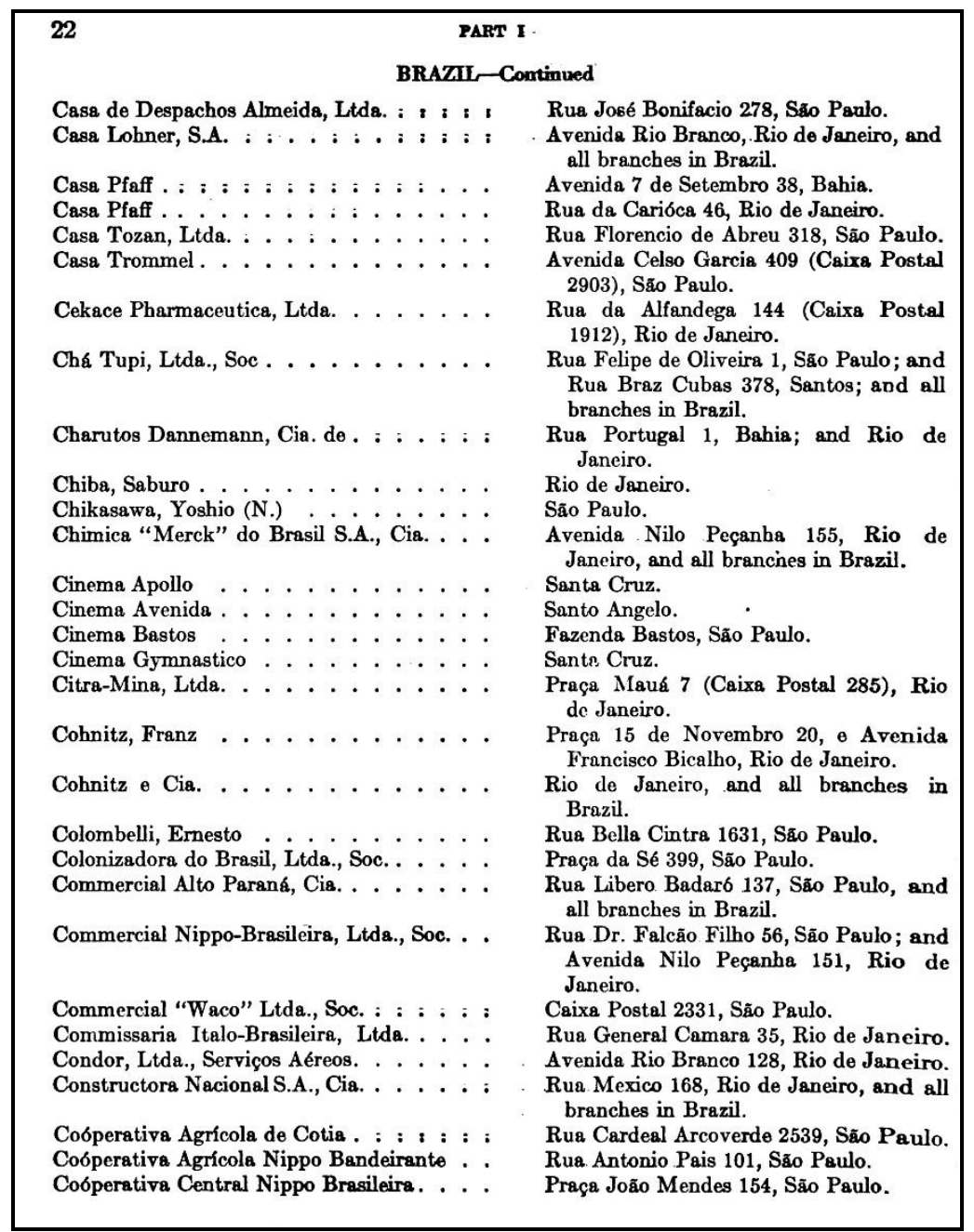

Fonte: UNITED STATES, 1942, p.22.

Consistia no seguinte: as empresas têxteis japonesas forneciam financiamento adiantado a esses Grupos de Cinco. Era o financiamento do plantio". (COMISSÃO, 1992, p.223). 
O governo brasileiro, frente aos acordos da III Reunião e das indicações contidas na Proclaimed List of Certain Blocked Nationals, não tardou a adotar medidas que atendessem às exigências de Washington ainda entre os meses de janeiro e março de 1942. O cerceamento do governo brasileiro às empresas cujos proprietários e dirigentes eram de origem japonesa, italiana ou alemã se mostrou visível por meio de medidas legais, dentre as quais destacamos três que atingiram diretamente as cooperativas agrícolas: i) a exigência de comprovação legal de registro junto ao Ministério da Justiça e Negócios Interiores às sociedades civis fundadas e mantidas por estrangeiros, essas que deviam também aguardar resultados de consultas do Departamento de Ordem Política e Social (DOPS) e da Delegacia de Estrangeiros ${ }^{95}$; ii) permissão apenas aos brasileiros natos e naturalizados o direito de exercer a função de classificador de produtos agrícolas e pecuários e das matérias-primas, seus subprodutos e resíduos de valor econômico ${ }^{96}$; iii) os bens e direitos dos súditos alemães, japoneses e italianos, pessoas físicas ou jurídicas, respondem pelo prejuízo causado ao Estado Brasileiro. Estes passam a indenizar à União uma parte de todos os depósitos bancários, ou obrigações de natureza patrimonial superiores a dois contos de réis, sejam titulares súditos alemães, japoneses e italianos, pessoas físicas ou jurídicas ${ }^{97}$.

$\mathrm{O}$ art. 12 do Decreto-lei n. 4.166 - relativo à indenização compulsória ao Estado brasileiro por súditos do Eixo - deixava claro que se tratava de um decreto ainda pouco elaborado em suas disposições legais, pois atribuía aos Ministérios da Justiça e Negócios Interiores e da Fazenda a função de expedir, no futuro, as instruções que se tornassem necessárias para a execução da lei ${ }^{98}$. Segundo Endrica (2007), o governo demorou 46 dias para baixar uma portaria ${ }^{99}$ que criava uma comissão responsável por examinar casos concretos relacionados ao Decreto. O que o autor observou foi uma distância entre os termos e a aplicação específica desses decretos e resoluções oficiais sobre os originários das nações do Eixo. Entre outros, em sua pesquisa foram analisados

\footnotetext{
${ }^{95}$ Portaria n. 7.572, de 28 de janeiro de 1942.

${ }^{96}$ Decreto-lei n. 4.118, de 20 de Fevereiro de 1942.

${ }^{97}$ Decreto-lei n. 4.166, de 11 de Março de 1942.

98 “Art. 12. Os Ministérios da Justiça e Negócios Interiores e da Fazenda expedirão as instruções que se tornarem necessárias para a execução desta lei”.

${ }^{99}$ Portaria n. 5.408, de 28 de abril de 1942.
} 
relatos de Elmano Cruz, um juiz do Distrito Federal autor de um livro sobre os "Direitos e Deveres dos Súditos do Eixo". O Juiz concluía que a eficácia de tais medidas pareciam residir mais em seu caráter preventivo do que em sua prática efetiva, a ser analisada caso a caso ${ }^{100}$.

Entretanto, o clima de repressão e controle das atividades dos imigrantes japoneses residentes em São Paulo, seus bens e negócios, gerava no mínimo incertezas a respeito do futuro de praticamente todos os empreendimentos até pouco tempo atuantes no mercado, principalmente os de maior capital envolvido, como bancos ${ }^{101} \mathrm{e}$ cooperativas agrícolas. Mesmo que o art. 6 da Portaria n. 5.408 reduzisse as restrições do Decreto-lei n. 4.166 para os produtores agrícolas ${ }^{102}$, os gestores da CAC anteciparam-se à portaria e convocaram uma reunião extraordinária para o dia 20 de abril de 1942. Obedecendo ao demarcador de fronteiras políticas nacionais definido pelo Estado, foi votada a substituição da diretoria de japoneses natos por brasileiros, sem descendência japonesa. Manoel Carlos Ferraz de Almeida foi, então, nomeado presidente da Cooperativa, e outros membros sem descendência japonesa ocuparam os cargos de mais alta decisão.

O quadro a seguir mostra a mudança no quadro diretivo e consultivo da empresa entre os anos de 1941 a 1945:

\footnotetext{
100 “a intenção da autoridade foi a de facultar às empresas o afastamento de empregados que pudessem ser perniciosos à segurança nacional, à produção ou à disciplina; o próprio Sr. Presidente da República, em discurso à Nação, acentuou que nada deveriam temer aqueles que aqui vivem honestamente, obedientes às leis nacionais [...] A demissão de todos os que nasceram em países com os quais o Brasil tenha rompido suas relações ou se encontre em guerra, se independesse de outras condições que a simples nacionalidade do empregado, não teria ficado condicionado ao exame de cada caso e à autorização prévia do Ministério do Trabalho, Indústria e Comércio". (ELMANO apud ENDRICA, 2007, p.150)

${ }^{101} \mathrm{Um}$ relato a respeito do período de restrições às empresas japonesas no Brasil sob o ponto de vista dos gestores do Banco América do Sul, empreendimento de destaque fundado por imigrantes japoneses, pode ser encontrado em: BANCO AMÉRICA DO SUL S.A. Breve história do Banco América do Sul S.A. Tóquio: Gráfica Hossokawa, 1960.

102 Art. 6: "Não se compreendem no decreto-lei n. 4.166 os atos usualmente praticados por agricultores, industriais ou comerciantes no interòssc da manutenção e prosperidade do seu comercio ou produção".
} 


\section{Quadro 3 - Relação da Diretoria da CAC - 1941 a 1945}

\begin{tabular}{|l|l|l|l|}
\hline \multicolumn{2}{|c|}{ 01/04/1941 a 20/04/1942 } & \multicolumn{2}{c|}{ 20/04/1942 a 31/05/1945 } \\
\hline Diretor-Presidente & Kenkiti Simomoto & Diretor-Presidente & $\begin{array}{l}\text { Manoel Carlos Ferraz de } \\
\text { Almeida }\end{array}$ \\
\hline Diretor-Gerente & Katuki Nishimura & Diretor-Gerente & Quintilano Moreira Cesar \\
\hline Diretor & Seiki Murakami & Diretor & Jose Silvestre da Rocha \\
\hline Diretor & Chosaku Nakashima & Conselheiro Fiscal* & Edmundo Schuetz \\
\hline Diretor & Kiyomi Ohira & Conselheiro Fiscal* & $\begin{array}{l}\text { Levem Vampre } \\
\text { (substituído pelo Sr. Sadaki } \\
\text { Serikawa) }\end{array}$ \\
\hline Diretor & Takahashi Kawakami & Conselheiro Fiscal* & Susumu Uemura \\
\hline Diretor & Saburo Toyota & Conselheiro Fiscal** & Gervásio Tadashi Inoue \\
\hline Diretor & Tomoyasu Yamamoto & Conselheiro Fiscal** & Ageo Ferreira de Camargo \\
\hline Conselheiro Fiscal & Marcelo Piza & Conselheiro Fiscal** & Kunitaro Ori \\
\hline Conselheiro Fiscal & Gervásio Tadashi Inoue & & \\
\hline Conselheiro Fiscal & Isamu Furuno & & \\
\hline
\end{tabular}

Fonte: CAC, 1988.

\section{* Cargo assumido em 1943}

** Cargo assumido em 1944

A abdicação formal do cargo de comando máximo pareceu não abalar o prestígio e a liderança de Kenkiti Simomoto entre os cooperados japoneses. Atas de assembleia da Cooperativa do ano de $1944^{103}$ mostram que boa parte das resoluções das reuniões de assembleia era por ele conduzida, bem como era referido como "Sr. Presidente". Convém notar no quadro acima que, pela primeira vez, o então recém-formado advogado Gervásio Inoue passou a compor o quadro diretivo do empreendimento, na função de conselheiro fiscal.

\footnotetext{
103 Ata da Assembleia Geral Extraordinária, realizada em 25 de setembro de 1944. Fonte: Instituto de Cooperativismo e Associativismo, Núcleo de Documentação.
} 
Em obras comemorativas sobre a história da Cooperativa existem informações de que, em 1942 e 1943, Manoel Carlos Ferraz de Almeida teria se empenhado em negociar soluções com Fernando Costa, político influente que havia sido Ministro da Agricultura (1938-1941) e ocupava o cargo de Interventor do Estado de São Paulo (1941-1945). O episódio é assim relatado pela Cooperativa em livro comemorativo que narra a sua história:

Em 1943, com a ajuda de Ferraz, que era muito bem relacionado com as autoridades, e como realmente a Cooperativa obedecia religiosamente às leis do país, e era grande produtora de alimentos, foi retirada da lista (em que aliás permaneceu não mais que uma semana), embora sob algumas condições: tinha que ficar sob intervenção do Ministério da Agricultura e que compor sua Diretoria exclusivamente por brasileiros. (CAC, 1988, p.79)

Ainda segundo as informações da própria Cooperativa, no final da negociação Ferraz de Almeida teria conseguido descongelar parcialmente os bens da Cooperativa. Contudo, há poucas evidências que possam indicar a atuação de algum personagem específico para o caso da CAC, bem como atualmente não dispomos de dados para afirmar se a decisão por substituir a sua direção foi uma condição imposta pelo governo brasileiro, ou se partiu de uma iniciativa dos gestores do empreendimento ${ }^{104}$. O fato é que a permanência da CAC na Proclaimed List of Certain Internationals durou, de fato, alguns poucos dias. No Suplemento 1, de 28 de fevereiro de 1942, a Cooperativa não esteve mais nas listas de Washington, estas que foram divulgadas até 1947.

Contudo, a própria existência oficial da Cooperativa pareceu ser um tanto incerta, pois o governo brasileiro, apesar de ter rompido relações diplomáticas com os países do Eixo ainda não havia entrado oficialmente na guerra, o que veio a acontecer somente em agosto. A respeito da participação brasileira na guerra, o relato de Tomoo

\footnotetext{
104 Há autores como Quintaneiro (2006), que afirmam que a substituição da diretoria da CAC por brasileiros natos foi imposta pelo governo brasileiro: "Em 1942, o governo brasileiro comprometeu-se a eliminar, da administração da Cooperativa de Cotia, os elementos nipônicos" (QUNTANEIRO, 2006, p.167). Contudo, as fontes de dados que a autora utiliza são obscuras, e não há menção a qualquer documento oficial que ateste tais afirmações.
} 
Handa de 18 de agosto de 1942 elucida o ambiente de tensão vivenciado pelos japoneses na capital paulista, e mensagens de Vargas anunciando a relocação da população do Eixo:

Cinco navios brasileiros são afundados em alto-mar perto de Natal em dois ou três dias sucessivos, e em sinal de protesto foi planejada, em São Paulo, uma manifestação pública contra os países do Eixo a ser realizada na praça da Sé, à noite. Apesar de os participantes serem em sua maioria estudantes de Direito, os jornais noticiaram que provavelmente haveria discursos sobre a necessidade de participação do Brasil na guerra [...]

No dia seguinte, a imprensa noticiava a manifestação que tivera lugar na praça da Sé. Dizia-se que o público atingira duzentas mil pessoas. Na Gazeta, a primeira e a última páginas estavam cobertas de fotografias do evento.

O presidente da República enviou uma mensagem aos manifestantes, mas não se pronunciou a respeito da participação do país na guerra. Somente dizia que a quinta-coluna seria enviada ao interior para trabalhar na construção e reforma de estradas, que os danos sofridos pelo país seriam resgatados pelos bens dos súditos do Eixo e que seus navios atracados nos portos brasileiros seriam arrestados. A posição do governo parecia ser a de não exaltar os sentimentos do povo. Na noite anterior, os mais exaltados apedrejaram algumas casas de japoneses. (HANDA, 1987, p.637-638)

As realocações anunciadas por Vargas naquela noite de agosto de fato viriam a ocorrer. Em 1942 e 1943 a realocação de japoneses foi realizada pelas forças de segurança pública. Na região Norte, foram enviados para vilarejos em Tome-Açu (PA), e outros casos de realocação forçada ocorreram no litoral do estado do Paraná, a Campo Grande, no estado de Mato Grosso, na cidade e na região litorânea de São Paulo, cujo caso mais famoso foi a realocação de cerca de 1.500 japoneses num curto prazo de 24 horas (COMISSÃO, 1992).

Oficializada a participação do Estado brasileiro no conflito no mês de agosto de 1942, as cooperativas viram suas operações bastante limitadas, mesmo que existisse certa cautela com empresas ligadas ao setor agrícola estratégico, como consta na já mencionada Portaria n. 5.408, que indicava ressalvas à aplicação do Decreto-lei n. 4.166. Soma-se a isso a distância entre os termos e a aplicação dos decretos, o que 
parecia garantir a análise judicial de casos de segurança nacional que viessem a ser considerados graves.

Por outro lado, em fins do ano de 1942, outros dois Decretos-lei foram expedidos visando fortalecer ainda mais o controle das empresas de origem japonesa, italiana e alemã instaladas no país. O Decreto-lei n. 4.717, de 21 de setembro de 1942, dispôs sobre as firmas individuais e as sociedades comerciais, inclusive as sociedades por ações, criadas ou administradas por indivíduos dessas nacionalidades. Elas deveriam fornecer informações mais precisas ao Departamento Nacional da Indústria e Comércio ou às Juntas Comerciais, sobre o tipo de atividade exercido, o montante de capital e suas partes, lista de nomes de sócios e acionistas, entre outros. Já o Decreto-lei n. 5.154, de 31 de dezembro de 1942, dispôs sobre a intervenção direta nas sociedades cooperativas. Ela concedeu permissão ao Ministério da Agricultura, por meio do Serviço de Economia Rural, para intervir nas sociedades cooperativas sob sua fiscalização por exigência da segurança pública.

A despeito desse cenário hostil às atividades de empresas criadas por imigrantes japoneses, os gestores da Cooperativa pareciam ter encontrado uma estratégia relativamente bem-sucedida visando garantir a sua sobrevivência no mercado. A substituição da sua diretoria logo repercutiu entre as demais cooperativas agrícolas japonesas, que passaram a reproduzir essa conduta. Nas palavras de Toyama: "O precedente estabelecido pela CAC foi útil para as demais cooperativas, salvando muitas delas do congelamento. Isso fez grande diferença - todas elas escaparam do empobrecimento. Os cooperados pelo menos encontraram um reduto" (TOYAMA, 2009, p.258). Mesmo diante das adversidades político-legais, em 1942 e 1943 a Cooperativa havia conseguido instalar outros nove depósitos regionais ${ }^{105}$ e passava a estender a produção de seus cooperados para outros tipos de cultura, como amendoim e hortelã. Ao final de 1943, Manoel Carlos Ferras de Almeida resumiu o período de sua gestão até então:

\footnotetext{
105 Localizados nos municípios de Álvares Machado, Itapetininga, Martinópolis, Piedade, Presidente Bernardes, Presidente Prudente, Registro, Tapiraí e santo Anastácio (CAC, 1988).
} 
A situação excepcional, criada pela nova guerra, originou um explicável estado de nervosismo, que muito dificultou a compreensão da realidade da nossa cooperativa e as suas verdadeiras finalidades. Chegamos até a sofrer acusações pessoais [...] E, afinal, nossos esforços desfizeram as interpretações errôneas. Especialmente, devido à justa compreensão das autoridades governamentais, vencemos a grande crise $[\ldots]$

Ao assumirmos a direção da Cooperativa, em face dos acontecimentos ligados à nova conflagração mundial, tínhamos a esperança de chegarmos a esta assembleia com a situação social quando muito equilibrada, sem lucros e sem "déficits". Por muitos dias, tememos ver o nosso esforço neutralizado, diante de possíveis prejuízos impostos à sociedade pelas contingências do momento. Entretanto, aqui estamos, nesta reunião, satisfeitos pelo que obtivemos com o nosso trabalho. (Relatório de Serviços Sociais da CAC, 1943, p.1-9).

As medidas adotadas pelo governo brasileiro no contexto da guerra buscaram, de forma explícita, reter momentaneamente o controle do empreendimento cooperativo das mãos do seu grupo de origem. Creio ser útil explorar o caráter político dessa medida enquanto uma estratégia adotada pela Cooperativa para a sua sobrevivência no mercado. Pois a mudança de sua direção teve, inclusive, implicações bastante favoráveis à Cooperativa, especialmente no que se refere à criação de relações no universo da política, que por vezes resultavam em efeitos diretos em sua atuação no mercado.

A necessidade de adequação às exigências dos órgãos reguladores do setor agrícola, bem como o enclaustro imposto às empresas japonesas no contexto da Segunda Guerra repercutiu na $\mathrm{CAC}$ como uma espécie de desafio de adequação à estrutura política da sociedade de destino. Pelas brechas dessa estrutura, a sua direção recorreu a brasileiros natos em um período de nacionalismos conflitantes, algo inédito para um empreendimento marcadamente caracterizado por sua característica endógena. E, para além do ineditismo, o relativo sucesso da iniciativa de conceder a sua direção a indivíduos brasileiros descortinou uma dimensão da prática empresarial cotidiana ainda inexplorada pela Cooperativa, a saber, a política. Na visão do próprio empreendimento:

A Guerra trouxe para a Cooperativa uma grande transformação. Até a eclosão das hostilidades, ela era uma sociedade composta por $99 \%$ de associados japoneses (isseis), como uma Diretoria também inteiramente constituída por japoneses. Era, no entanto, uma entidade bem vista pelas autoridades [...] 
Essas características refletiam, por outro lado, uma profunda mudança nas atitudes dos próprios associados, minimizando o complexo antibrasileiro tão enraizado dentro da colônia japonesa. [...]

Era um novo perfil, numa miscigenação de culturas e de valores. Enquanto muitas cooperativas criadas por japoneses, diante das pressões e da intervenção governamental, se mantinham em silêncio e discretas, a Cotia tomou posições corajosas e ousadas, expandindo suas atividades e integrando-se na sociedade brasileira. (CAC, 1988, p.83)

O fato a ser destacado com base nesse evento é que os dados parecem indicar a prevalência de certos fatores extramercantis na definição dos rumos dessa Cooperativa, bem como de outros empreendimentos controlados por estrangeiros de nacionalidade japonesa, italiana e alemã no Brasil. A ingerência estatal nas atividades dessas empresas, bem como as respostas dos agentes da CAC a constrições de natureza política foram decisivas para a sua sobrevivência no mercado.

Se até o advento da Segunda Guerra a Cooperativa era uma organização que não possuía relações políticas firmadas com agentes e partidos políticos, Ministério da Agricultura, secretarias, órgãos federais, isso mudou consideravelmente a partir da presidência de Ferraz de Almeida. Este criou condições para a sua participação em estruturas de governança e politizou a questão cooperativista de forma antes nunca experimentada pelos gestores anteriores. Entre 1945 e 1954 podemos enumerar alguns exemplos da atuação de Ferraz de Almeida.

Durante a sua presidência (1942-1957), Ferraz de Almeida estabeleceu um contato intenso com os meios de comunicação, especialmente com o periódico Jornal de Notícias, de forma que ao longo do tempo se tornou uma referência para assuntos relacionados à agricultura. Inicialmente, em 1945, os jornais passaram a noticiar as suas opiniões acerca das políticas de crédito agrícola do governo federal ${ }^{106}$. Nos dois anos seguintes, Ferraz de Almeida estabeleceu contatos com partidos políticos, deputados ${ }^{107}$,

\footnotetext{
106 "Financiamento para a pequena lavoura". O Estado de S. Paulo, 25 de abril de 1945.

107 "Deputados federais em S. Paulo. Visita à Cooperativa Agrícola de Cotia - Almoço nos Campos Elíseos”. O Estado de S. Paulo, 01 de junho de 1947.
} 
congressistas $^{108}$, bem como se aproximou de entidades rurais classistas, como a Sociedade Nacional de Agricultura ${ }^{109}$, a Sociedade Rural Brasileira ${ }^{110}$ e a Federação das Associações Rurais do Estado de São Paulo (FARESP), tendo sido diretor desta última em $1937^{111}$. Visitas de políticos e órgãos internacionais ${ }^{112}$ se tornaram comuns, bem como os seus eventos festivos contavam com a presença de governadores, secretários de abastecimento e representantes da presidência da república.

Em 1947, senadores visitaram a sede da CAC, que se preparava para as comemorações do vigésimo aniversário de sua fundação, comemorado em dezembro daquele ano ${ }^{113}$. No dia das festividades, o representante do ministro da agricultura, Lafayette Rezende, chegava ao aeroporto e partia em direção à sede da Cooperativa, trazendo em primeira mão a notícia da concessão de vinte milhões de cruzeiros pela Caixa de Crédito Cooperativo destinado aos agricultores do estado de São Paulo ${ }^{114}$. Em 1952, no aniversário de 25 anos do empreendimento, os festejos assumiam uma configuração similar, mas contando também com a presença do Governador do estado de São Paulo, Lucas Nogueira Garcez, do Secretário da Agricultura do estado de São Paulo, João Pacheco e Chaves, entre outras autoridades públicas.

\footnotetext{
108 "Visita de senadores à Cooperativa Agrícola de Cotia”. Jornal de Notícias, 10 de outubro de 1947.

109 "Uma escola para todos os que se interessam pelo cooperativismo. Visita a Cooperativa Agrícola de Cotia o sr. Artur Torres Filho, presidente da Sociedade Nacional de Agricultura". Jornal de Notícias, 29 de junho de 1946.

110 "Poderosa organização destinada a controlar toda a pecuária em São Paulo e nos Estados vizinhos. As bases da nova entidade serão lançadas nesta capital na próxima semana - Fala à nossa reportagem o sr. Manuel Carlos Ferraz de Almeida, diretor da Cooperativa Agrícola de Cotia". Jornal de Notícias, 08 de julho de 1947.
}

111 "Urge organizar um planejamento economico para a salvação dos pequenos lavradores. Recebido ontem pelo governador do Estado, os representantes de 39 cooperativas agrícolas do interior mostram a verdadeira situação de penuria da lavoura paulista - Solicitados pelo sr. Adhemar de Barros os processos referentes à criação da Carteira de Crédito Cooperativista". Jornal de Notícias, 01 de outubro de 1947.

${ }^{112}$ A internacionalização da CAC também passou a ocorrer, sendo possível mencionar visitas do diretor da Federação das Cooperativas Suecas em 23 de junho de 1950, a visita de representantes da Consultant Food and Agriculture Organization da ONU em 4 de junho de 1952.

113 "Comemora a Cooperativa Agrícola de Cotia o seu $20^{\circ}$ aniversário. Por se tratar de um incentivo ao cooperativismo, deram seu apoio às comemorações o presidente da República e o govêrno do Estado - $\mathrm{O}$ general Dutra, presidente de Honra da Comissão de Festejos”. Jornal de Notícias, 24 de dezembro de 1947.

114 “Amparo do governo federal às cooperativas paulistas”. Jornal de Notícias, 27 de dezembro de 1947. 
Figura 9 - Festejos comemorativos do 250 aniversário da CAC, 1952. Ao centro, cortando a fita, João Pacheco e Chaves, Secretário da Agricultura do Estado de São Paulo. Ao seu lado direito, o trio de gestores Kenkiti Simomoto, Manoel Carlos Ferraz de Almeida e Gervásio Inoue.

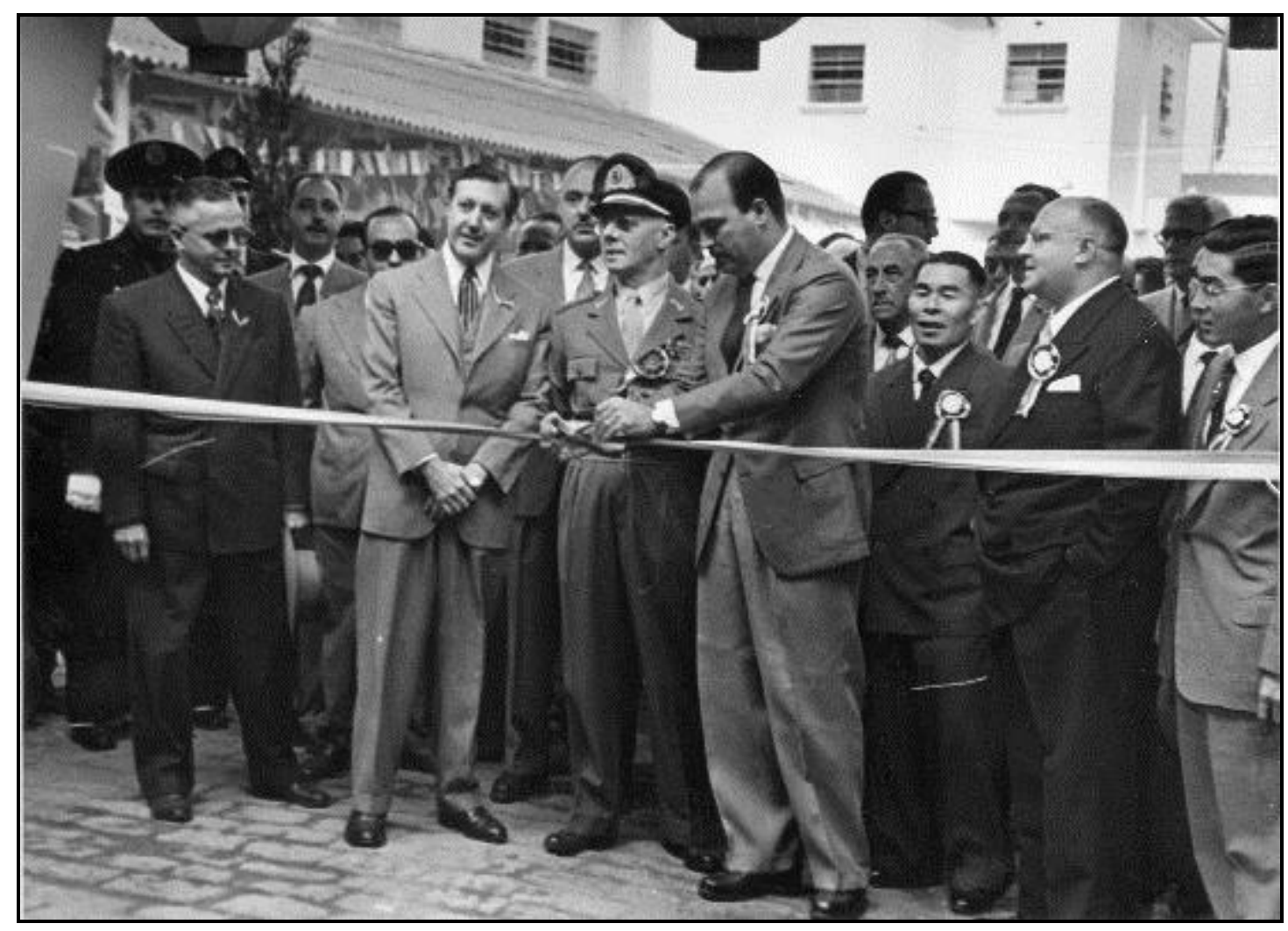

Fonte: "Festejos Comemorativos - Cooperativa Agrícola de Cotia". Coleção particular.

Ao final da década de 1940, a presença do presidente Ferraz de Almeida em negociações de crédito bancário do governo para o setor agrícola, especialmente para os pequenos produtores, tornou-se algo recorrente, o que revela ao menos dois aspectos importantes para este estudo: em primeiro lugar, a Cooperativa passou a possuir poder de negociação em políticas econômicas e monetárias federais. Em matéria de 6 de março de 1949 do Jornal de Notícias ${ }^{115}$, Ferraz de Almeida relata a sua reunião com o diretor da Carteira de Crédito do Banco do Brasil, Marino Machado, que resultou em um aumento considerável no volume de crédito concedido ao setor agrícola. Em

\footnotetext{
115 “O Banco do Brasil aumentou consideravelmente o financiamento à indústria e à agricultura". Jornal de Notícias, 6 de março de 1949.
} 
segundo lugar, a capacidade dos seus gestores de intervir nas estruturas de governança deve ser compreendida em sua relação com a sua atuação no mercado.

Esses dois aspectos mencionados reforçam o argumento da construção do mercado pela Cooperativa, evidenciando que o mercado não é uma entidade espontaneamente autorregulada; ao contrário, os que dele participam procuram, permanentemente, reduzir ao mínimo possível os riscos que correm pelo fato de estarem expostos ao sistema de preços (ABRAMOVAY, 2006). Os resultados empresariais desse processo de politização do mercado são assim relatados:

No final de 1952, a Cooperativa contava já com 34 Depósitos Regionais. Sua estrutura operacional incluía, além deles, com a sede (em Pinheiros), os armazéns do Depósito Urbano (nas ruas Anhangabaú, Mercúrio e Avenida do Estado), o Serviço de Compras em Comum, os Serviços de Utilização Mútua (farmácia, carpintaria, oficina mecânica, distribuição de peças e combustíveis, coleta da produção, mistura de rações para aves, classificação de ovos e distribuiç̧̃̃es diretas ao público), fabricação de adubos (no Jaguaré), Serviço de Incubação, Estação Experimental (Moinho Velho), Granja de Seleção de Galos e Reprodutoras (Moinho Velho), Granja de Linhagem (Caxingui), ambulatório e serviço médico, transporte marítimo e fluvial (embarcações Coopercotia I, II e III, que ligavam os portos fluviais de Juquiá, Registro e Iguape, e na orla marítima, os portos de Iguape, Santos, Caraguatatuba, S. Sebastião, Ubatuba e outros), transporte rodoviário (com os Grupos de Transporte Coletivo principalmente), assistência técnica agrícola, moto-mecanização, e outros mais. (CAC, 1988, p.113).

Nos anos de 1956 e 1957, os últimos da presidência de Ferraz de Almeida, o número de cooperados havia crescido cerca de 228\% em relação ao biênio 1941-1942, contabilizando 5.165 cooperados e cerca de 2.000 funcionários, conforme é possível visualizar no gráfico a seguir: 
Gráfico 1 - Evolução do número de cooperados da CAC, 1942-1957

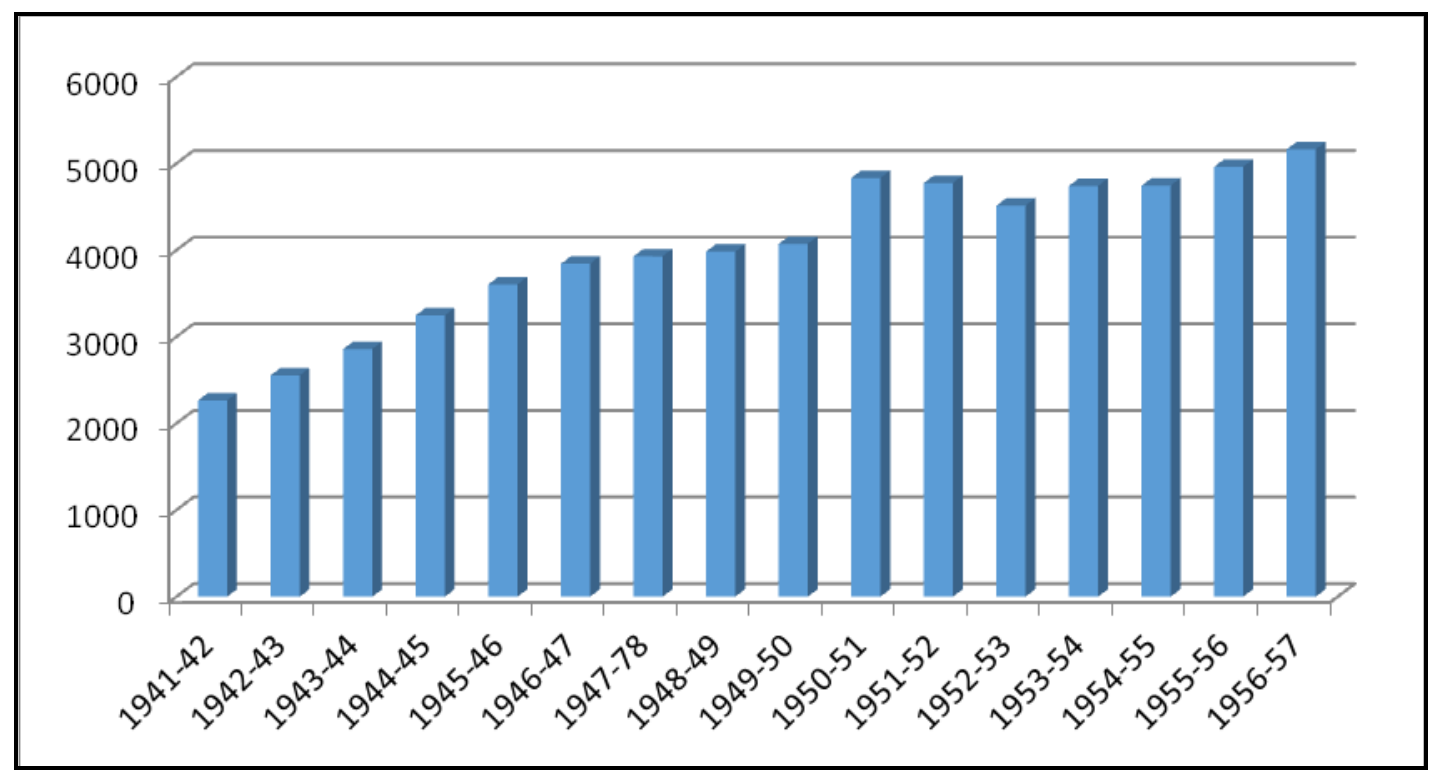

Fonte: Elaboração a partir do Suplemento Estatístico, Ano social 1965-1966, CAC.

O aumento do número de cooperados ocorreu também, em certa medida, por causa de projetos de imigração japonesa desenvolvidos pela própria Cooperativa. No ano de 1951, o então presidente Getulio Vargas acenou positivamente para a retomada da imigração japonesa no Brasil, mesmo que as relações diplomáticas entre os dois países ainda não tivessem sido restabelecidas. O Instituto Nacional de Imigração (INIC) foi então encarregado de elaborar projetos para encaminhar imigrantes japoneses a áreas agrícolas. Contudo, a Cooperativa parecia não estar de acordo com os projetos elaborados por esse órgão que, por muitas vezes, até expressou a possibilidade de abandonar essa iniciativa. Agora munida de uma capacidade de negociação política maior junto aos órgãos públicos, ela criou um projeto próprio de imigração em 1952 , articulando a Kaikyoren (Nihon Kaigai Kyokai Rengokai) ${ }^{116}$, o Ministério da Agricultura e o Ministério das Relações Exteriores do Japão.

116 Órgão criado em 1954 ligado ao Ministério das Relações Exteriores do Japão (TOYAMA, 2009, p.395). 
O projeto de imigração foi denominado Cotia Seinen (Os jovens de Cotia), visto que os imigrantes eram todos jovens e solteiros. Esse perfil era bastante distinto dos imigrantes que haviam chegado nos anos anteriores. Em sua maioria, os imigrantes japoneses chegavam ao Brasil em famílias já compostas. Essa característica diferenciada dos imigrantes do projeto Cotia Seinen resulta em grande parte da preocupação, anunciada por Kenkiti Simomoto, no sentido de garantir a mão de obra dedicada à produção, mantendo o perfil de cooperado de origem japonesa e almejando, assim, reproduzir os princípios cooperativistas que originaram o empreendimento de Cotia.

Após a retomada das relações diplomáticas com o Japão, a condução desse projeto pôde avançar. Do ponto de vista de suas implicações para os imigrantes japoneses que viviam no Brasil, o Tratado de Paz entre os dois países formalizou o encerramento das fronteiras políticas impostas pelo Estado e, dessa forma, criou-se um ambiente favorável para a retomada da imigração japonesa. Mas, o fim da Segunda Guerra não havia assegurado o término de prisões arbitrárias, conflitos internos e de violência física e simbólica, principalmente pelo clima de instabilidade existente entre os próprios imigrantes japoneses e seus descendentes.

Dois exemplos ilustrativos de episódio envolvendo as lideranças de primeira geração são a presença do nome de Kenkiti Simomoto na lista de alvos de assassinato por japoneses nacionalistas em 1946 e o inquérito visando a expulsão de Kenkiti Simomoto e de seus companheiros do território nacional em 1952.

Os dois episódios permitem apresentar, a partir da experiência do principal líder da CAC, os limites da incorporação de indivíduos japoneses na sociedade paulista. Mesmo que Kenkiti Simomoto gozasse de uma posição privilegiada e fosse reconhecido por seus pares como uma liderança do grupo, isso não lhe garantiu uma posição social confortável, em que pudesse equacionar a sua nacionalidade japonesa e o reconhecimento da sociedade receptora.

Conforme foi apresentado, as políticas de repressão política conduzidas pelo Estado Novo impactaram de forma bastante particular a população japonesa em São Paulo. O recrudescimento da tensão na relação entre os imigrantes e o Estado brasileiro durante a guerra, manifesto nas prisões arbitrárias, na proibição de falar a língua 
japonesa em lugares públicos, no confisco de rádios e empastelamento dos jornais escritos em japonês, no fechamento de suas escolas autônomas e na vigilância e controle difundiu entre os núcleos coloniais japoneses um clima de insegurança e isolamento, reforçado pela diferença linguística e cultural. Em reação a essa conjuntura ocorreu a formação de várias associações secretas entre os imigrantes, a mais famosa das quais se nomeava Shindô Renmei (Liga do caminho dos súditos ou dos que seguem as diretrizes imperiais), fundada no dia 15 de agosto de $1945^{117}$.

Por compor o grupos de lideranças intelectual e empresarial japonesa de São Paulo $^{118}$, Kenkiti Simomoto experimentou os acontecimentos da Segunda Guerra de forma particular. Basicamente, por ser reconhecido como uma das principais personalidades japonesas em São Paulo, a sua posição diante dos acontecimentos da guerra tinha repercussão entre a coletividade imigrante daquela origem. Ademais, as lideranças da coletividade japonesa em São Paulo haviam adotado explícitamente uma posição política por vezes impactante aos seus conterrâneos. Eles assumiam a derrota do exército japonês na guerra. A despeito das motivações ideológicas envolvidas em seu posicionamento, deve-se ressaltar que, diferente da maioria dos imigrantes japoneses residentes no Brasil, os membros desse grupo de lideranças possuíam um contato direto com a diplomacia, condição que lhes provia informações oficiais sobre o conflito bélico.

À época da rendição japonesa na segunda guerra, em setembro de 1945, essas lideranças foram responsáveis pela reprodução do Edito Imperial ${ }^{119}$ que declarava a

\footnotetext{
117 Ainda que a sua existência seja um fato, há atualmente um debate sobre o alcance de suas ações. Contudo, estudos afirmam que o principal objetivo dessa organização era a manutenção dos costumes e valores japoneses no Brasil. Para tal, a Associação pregava a fidelidade total ao Imperador do Japão, restauração das escolas japonesas, trabalhar pela construção de uma Grande Ásia Oriental sob a direção do Japão e repressão aos chamados "derrotistas", imigrantes japoneses que propalavam publicamente a notícia de que seu país natal havia perdido a guerra mundial.

118 A partir de 1946, Kenkiti Simomoto e seu círculo de amizades próximas reuniam-se semanalmente em sua residência ou na residência de outras lideranças, como Senichi Hachiya, presidente da Câmara de Comércio Brasil-Japão. Junto de colegas como o então estudante de sociologia Hiroshi Saito, o pintor Tomoo Handa, o antropólogo Takashi Maeyama, a linguista Geni Wakisaka, o filósofo Katsunori Wakisaka, o sociólogo Zempati Ando, entre outros, Kenkiti Simomoto integrava o Doyokai (Grupo do Sábado), grupo que congregava a intelectualidade de origem japonesa com o fito de discutir a situação dos japoneses e seus descendentes na sociedade brasileira (Entrevista com Katsunori Wakisaka, realizada em 05 de abril de 2012).

119 “A distribuição do Edito Imperial foi decidida numa reunião da Comissão de Estudos de Medidas para enfrentar a Conjuntura, realizada na sede da Cooperativa Agrícola de Cotia, e da qual participaram 300 pessoas interessadas, vindas do interior. Foi decidido então que os signatários da mensagem, já citados, e
} 
derrota do Império Japonês, que chegou ao Brasil no dia seguinte, pela Seção Brasileira da Cruz Vermelha Internacional, com sede no Rio de Janeiro. Após uma reunião urgente na sede da CAC da qual participaram cerca de 300 pessoas, ela fora assinada e distribuída em São Paulo por algumas das principais lideranças à época: Jinsaku Wakiyama, Shigetsuna Furuya, Kunito Miyasaka, Senichi Hachiya, Kiyoshi Yamamoto, Chibata Miyakoshi e Kameiti Yamashita. Na reunião também ficou estabelecido que haveria iniciativas de promover um movimento organizado dedicado a esclarecer a derrota japonesa na guerra e, por isso, tal movimento ficou conhecido como "esclarecido".

Esse posicionamento, evidentemente, não agradava os ultranacionalistas japoneses que rejeitavam tanto a notícia da derrota, quanto a postura das lideranças. Bastante conhecidos na literatura especializada (COMISSÃO, 1992; DEZEM, 2000; TAKEUCHI, 2009), os casos de assassinato de autoridades e as listas de alvos a serem assassinados fizeram parte da realidade de Kenkiti Simomoto e de seus colegas que compunham o restrito circuito de lideranças locais. O quadro a seguir informa os nomes presentes em listas de assassinatos da Shindo-Renmei, baseado nas informações fornecidas pela Comissão (1992). Em destaque estão membros da CAC.

outros fariam pessoalmente a explicação sobre o término da guerra e, ao mesmo tempo, aproveitariam a oportunidade para promover um organizado movimento esclarecedor sobre a derrota nipônica". (COMISSÃO, 1992, p.285) 


\section{Quadro 4 - Lista de lideranças a serem assassinadas pela Shindo-Renmei}

\begin{tabular}{|c|c|c|}
\hline & Nome & Cargo \\
\hline \multirow[t]{8}{*}{ Lista 1} & Suetaka Hayao & Encarregado de interesses japoneses da Legação da Suécia. \\
\hline & Chibata Miyakoshi & Diretor da filial brasileira da Companhia de Fomento Industrial do Além-Mar S.A \\
\hline & Shigetsuna Furuya & Antigo ministro japonês na Argentina \\
\hline & Kiyoshi Yamamoto & Gerente-Geral da Fazenda Tozan \\
\hline & Kenkiti Simomoto & Diretor-Gerente da CAC \\
\hline & Jinsaku Wakiyama & $\begin{array}{l}\text { Ex-Coronel reformado do Exército Japonês e ex-presidente da Cooperativa } \\
\text { Central Agrícola Nipo-Brasileira }\end{array}$ \\
\hline & Senichi Hachiya & Presidente da Câmara de Comércio Brasil-Japão \\
\hline & Kunito Miyasaka & $\begin{array}{l}\text { Diretor da Sociedade Colonizadora do Brasil [Bratac] e um dos fundadores do } \\
\text { Banco América do Sul }\end{array}$ \\
\hline \multirow[t]{14}{*}{ Lista 2} & Chuzaburo Nomura & $\begin{array}{l}\text { Jornalista e diretor do jornal Nippak Shimbun, ex-secretário-geral da Sociedade } \\
\text { de Difusão do Ensino dos Japoneses do Brasil }\end{array}$ \\
\hline & Takeo Kawai & Chefe da Seção de Engenharia da CAC \\
\hline & Eiji Kikuchi & Chefe da Seção de Kendô da Federação Brasileira de Judô e Kendô \\
\hline & Seigui Fujihara & Diretor da Federação de Atletismo da Colônia \\
\hline & Kiyotaka Emi & Ex-chefe da Seção de Economia do Nippak Shinbun \\
\hline & Kameiti Yamashita & Diretor do Departamento de Orientação da CAC \\
\hline & Takeshi Hasegawa & Chefe de Assuntos Internos da Companhia de Fomento Industrial do Além-Mar \\
\hline & Yasushi Sakamoto & Chefe da Seção de Imigração da Companhia de Fomento Industrial do Além-Mar \\
\hline & Masao Kinoshita & Advogado \\
\hline & Takeo Goto & Subgerente da Fazenda Tozan \\
\hline & Fumio Ishikawa & Chefe da Seção de Orientação da Cooperativa Central Agrícola Nipo-Brasileira \\
\hline & $\begin{array}{l}\text { Paulo Yoshikazu } \\
\text { Morita }\end{array}$ & Setor de Interesses Japoneses do Consulado da Suécia \\
\hline & Akira Otani & Ex-funcionário do Banco Espécie de Yokohama \\
\hline & Kanji Shirato & Membro da Embaixada Japonesa \\
\hline
\end{tabular}

Fonte: Elaborado pelo autor a partir de Comissão (1992). 
Vejamos alguns casos de assassinatos dos nomes dessa lista. Segundo os planos de Tatsuo Watanabe, membro da Shindo-Renmei, o assassinato de Kenkiti Simomoto estava planejado para ocorrer em fevereiro de $1946^{120}$. Contudo, Watanabe não teria localizado a residência de Simomoto e passou a procurar por Shigetsuna Furuya. No dia 1 de abril de 1946, no bairro do Jabaquara, em São Paulo, o jornalista e diretor do jornal Nippak Shimbun, Chuzaburo Nomura, foi assassinado por admitir a derrota na Guerra $^{121}$. Nomura, que havia sido detido pelo DEOPS em 1944 - e somente fora liberto em março de 1945, aparentemente sem justificativas ${ }^{122}$ - era próximo das lideranças da Cooperativa, especialmente de Gervásio Inoue, uma das pessoas que fez o reconhecimento da vítima no Instituto Médico Legal. Naquele mesmo dia, Shigetsuna Furuya sofreu um atentado, levando vários tiros, mas conseguiu sobreviver (HATANAKA, 2002). No dia 2 de junho, também em São Paulo, Jinsaku Wakiyama foi assassinado.

Dando prosseguimento à iniciativa de promover um movimento organizado dedicado a esclarecer a derrota japonesa na guerra, em meados de 1946 Kenkiti Simomoto passou a se empenhar no movimento dos "esclarecidos", também conhecido em termos nativos como Ninshikiha ou Makegumi. Utilizando mimeógrafos, cerca de dez boletins passaram a ser publicados naquele ano de 1946, dentre os quais possuímos registro de alguns: o Semanário [Shūhō] (publicado pela CAC entre maio e dezembro), o Informação [Jōhō] (publicado por Chibata Miyakoshi entre abril e setembro, totalizando 16 edições), o Shûsen-go no Okinawa Jijo (Situação de Okinawa no PósGuerra, publicado entre junho de 1946 e junho de 1948) (COMISSÃO, 1992).

\footnotetext{
${ }^{120}$ Segundo o seu depoimento nos autos do DEOPS fls. 1.783,1.345: “A ordem de Tsuji mandava matar primeiro Kenkiti Simomoto, diretor-gerente da Cooperativa Agrícola de Cotia, um dos mais ativos e influentes líderes dos esclarecidos; em segundo lugar vinha Chibata Miyakoshi, ex-diplomata japonês, e em terceiro o antigo ministro plenipotenciário do Japão em Buenos Aires, Shigetsuna Furuya" (COMISSÃO, 1992, p.344).

${ }^{121}$ Para mais informações, ver: MITA, C. Bastos: uma comunidade étnica japonesa no Brasil. São Paulo, Humanitas,/FFLCH/USP, 1999, e OKUBARO, J.J. O súdito: banzai, Massateru! São Paulo, Editora Terceiro Nome, 2006.

122 Prontuário DEOPS n. 47.444.
} 
brasileiras. Por outro lado, as suas atitudes constituíam, para japoneses ultranacionalistas, motivos para o seu assassinato. Ao final, Simomoto sobreviveu ao período de terror instaurado pelos ultranacionalistas, os quais, em sua maioria, foram investigados e presos pela polícia brasileira. Ainda assim, Simomoto enfrentaria outros empecilhos diretamente ligados à sua nacionalidade: em 1952, foi instaurado um inquérito visando à sua expulsão e de outros colegas, participantes do já mencionado grupo Doyokai.

O inquérito foi instaurado em 1 de dezembro de $1952^{123}$. Entre os indiciados estavam Hiroshi Saito, Kiyoshi Yamamoto, Takeo Kawai, Ryujo Ueki, Teiiti Suzuki, Tomoo Handa, Yoshiomi Kimura, Zempati Ando, Hideichi Massuda. Basicamente, as justificativas para a sua expulsão residiam no conteúdo de um artigo publicado no Japão na revista Chuo-Koron em junho de 1951, a respeito da imigração japonesa na Amazônia. Os termos foram considerado ofensivos à nação brasileira, na tradução feita pelo Departamento de Investigações do DEOPS. Por fim, Francisco Negrão de Lima, Ministro da Justiça e Negócios Interiores decidiu, em 30 de julho de 1953, pelo arquivamento do processo.

Os acontecimentos aqui examinados contribuem empiricamente para a tarefa de demonstrar a estreita inter-relação entre política e cultura nas atividades econômicas. A decisão da gestão de Kenkiti Simomoto em abdicar de seu cargo de presidente da Cooperativa, em 1942, dando lugar a dirigentes brasileiros deve ser compreendida também em sua relação com os acontecimentos vivenciados pelo grupo de que esse personagem fez parte. Em períodos de nacionalismos conflitantes, a sobrevivência da organização parecia depender menos das estruturas de concorrência no mercado e mais de fatores políticos. Em 1946, Kenkiti Simomoto integrou o movimento de lideranças engajados em informar aos seus conterrâneos a derrota japonesa na guerra, tornando a sede da CAC um local de reuniões em que também era publicado um informativo, onde expunha suas ideias.

${ }^{123}$ Prontuário DEOPS n. 55.796. 
Figura 11 - Festejos comemorativos do 25o aniversário da Cooperativa Agrícola de Cotia, 1952. Falando ao microfone à frente da bandeira brasileira, Manoel Carlos Ferraz de Almeida. Sentado, Kenkiti Simomoto.

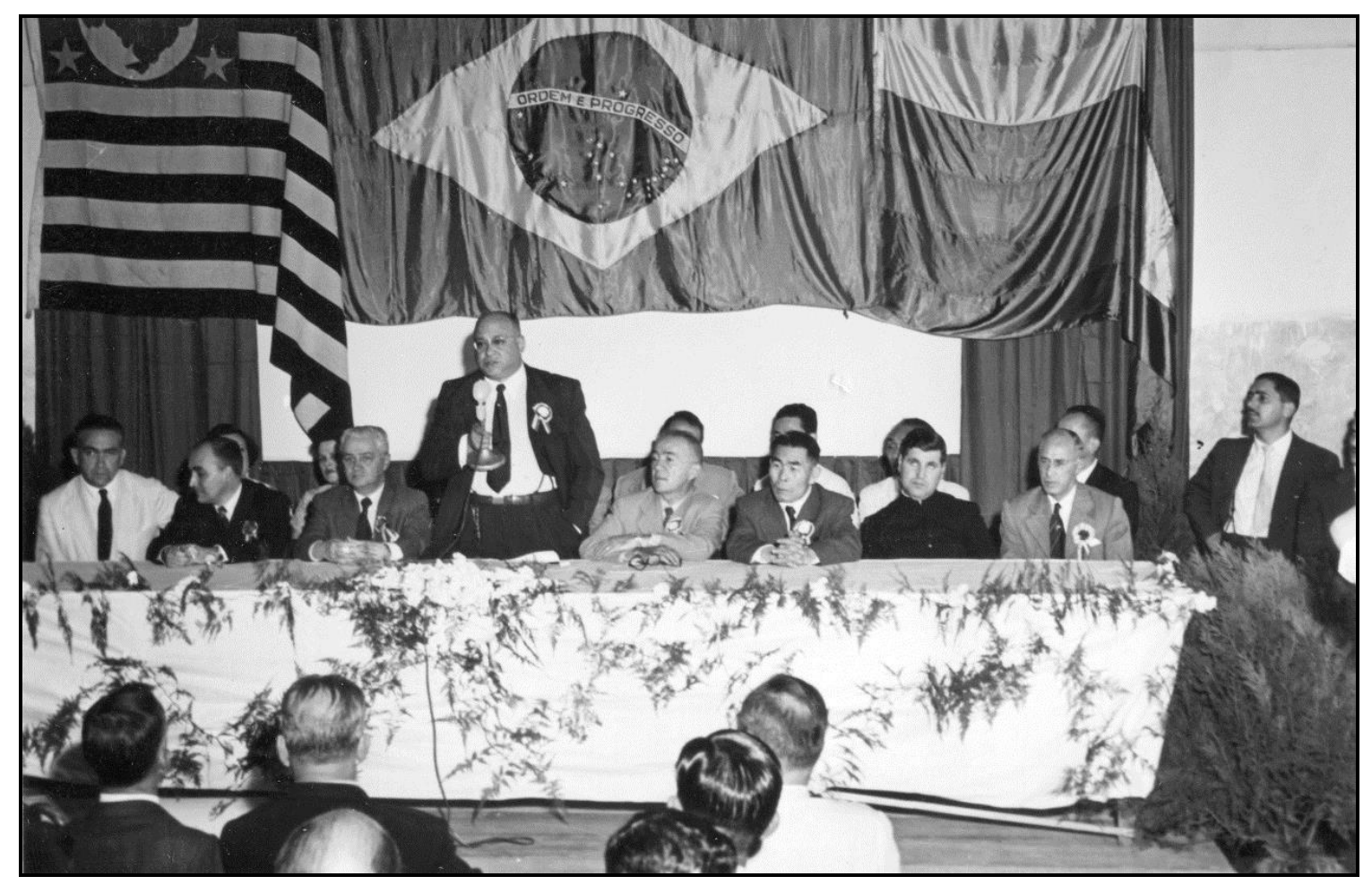

Fonte: “Festejos Comemorativos - Cooperativa Agrícola de Cotia". Coleção particular.

Ademais, a respeito do inquérito de expulsão de Kenkiti Simomoto do território nacional, é essencial considerar que, como vimos, desde 1951, a Cooperativa esteve envolvida com os projetos de retomada da imigração japonesa para o Brasil, por meio do projeto Cotia Seinen. Os imigrantes que chegaram ao país pelo projeto foram direcionados a assentamentos criados pela própria Cooperativa. Tendo em vista a retomada da imigração japonesa por iniciativa do empreendimento, os grupos de liderança intelectual de origem japonesa em São Paulo, próximos a Simomoto, produziram a sua própria avaliação a respeito da vinda de imigrantes para a Amazônia, o que, contudo, foi interpretado de maneira controversa pelas autoridades policiais. 
$\mathrm{E}$, dessa forma, argumento que as ações de gestores da CAC não se traduziram unicamente pela instrumentalização de recursos disponíveis visando a objetivos próprios aos interesses de mercado. Práticas que se expressam no mercado não deixam de ter implicações e de serem informadas por componentes extraeconômicos, diretamente relacionados a percursos de lideranças na experiência migratória dos japoneses no Brasil. As formas pelas quais os gestores da Cooperativa de primeira geração vivenciaram os episódios da Guerra foram qualitativamente distintas em comparação aos de segunda geração; bem assim, as respostas oferecidas por ambas expressam certas nuances que as diferenciam.

\section{Figura 12 - Manoel Carlos Ferraz de Almeida, Diretor-Presidente da Cooperativa Agrícola de Cotia (1942-1957).}

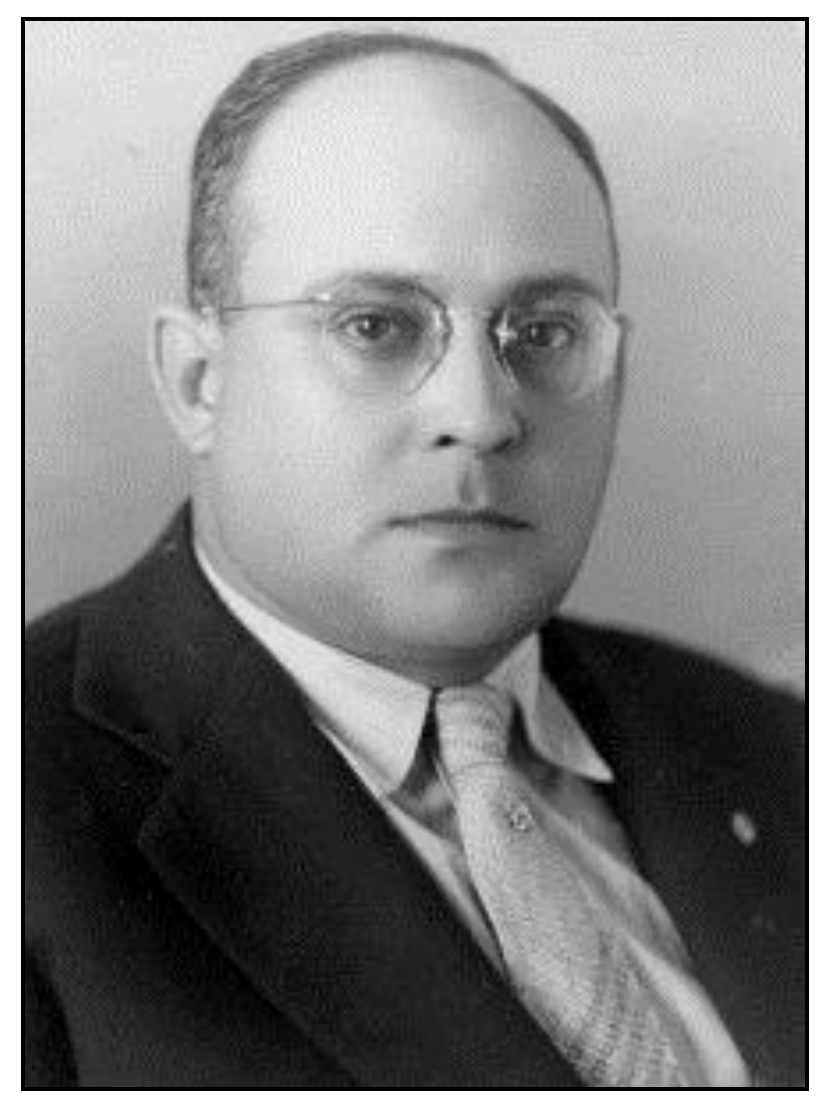

Fonte: "Festejos Comemorativos - Cooperativa Agrícola de Cotia". Coleção particular. 


\subsection{Uma segunda geração em busca de reconhecimento}

Este tópico examina a formação de um grupo de lideranças da população japonesa em São Paulo que passou a ganhar notoriedade na década de 1930 por meio da criação de uma liga estudantil. Dele fizeram parte os três primeiros políticos de origem japonesa no Brasil, bem como gestores da CAC, a exemplo de Gervásio Inoue e Fábio Yassuda. Ademais, durante a década de 1940, a CAC era um dos financiadores das publicações dessa liga estudantil, estampando anúncios nas primeiras páginas que eram dedicadas aos patrocinadores. Para bem entender-se porque a clivagem geracional das lideranças da CAC se manifestou em processos de transformações no âmbito da gestão do empreendimento, é fundamental acompanhar a formação das lideranças de segunda geração de imigrantes. Esse grupo formulou respostas distintas daquelas da primeira geração na tentativa de confrontar o desafio das diferenças étnico-raciais por narrativas próprias, as quais sustentaram a adoção de práticas que acenavam positivamente para aceitação da origem japonesa no Brasil. Ademais, a maneira pela qual os gestores de segunda geração da Cooperativa vivenciaram certos eventos teve igualmente impactos sobre as formas de gestão por eles adotadas.

Se a gestão de Gervásio Inoue foi caracterizada pelo abandono da endogenia prevalecente no núcleo de gestores, isso demandou a construção de uma imagem institucional da Cooperativa que a identificasse como brasileira, mas de origem japonesa. E, se essa gestão passou a ter maior representação política, coube a esses gestores construir e sustentar certos elos estratégicos a ponto de a Cooperativa ter acesso e poder de barganha em importantes núcleos de decisões econômicas governamentais.

No tópico 1.3 apresentei em linhas gerais a configuração das estruturas sociais de organização interna da população japonesa em São Paulo, tornadas factíveis entre as décadas de 1910 e 1940. Tais estruturas, sob forte influência do Consulado Geral do Japão, conformavam um universo de possibilidades em que as ações dos indivíduos podiam se realizar. Fatores eminentemente relacionais configuravam ambientes de negociação de posições sociais, bem como estavam suscetíveis a processos de mudança e ressignificação. Voltemos, então, àquele universo bastante particular para a população japonesa em São Paulo: 
Em sua última edição de 14 do findante, "ULTIMA HORA", o vespertino que apareceu há pouco nesta Capital, traz um artigo de título: "Bairro Japonês império do sol nascente, sem cerejeiras e sem kimonos e arco-íris". É dele que extraímos o que abaixo transcrevemos:

Ontem a reportagem de ULTIMA HORA esteve no Bairro Japonês. Viu garotinhos de olhos de amêndoa falando bem o português. Interrogamos um:

- Você é japonês ou brasileiro?

- Ué! Claro que sou brasileiro! Nasci aqui... Meu pai, sim, que é japonês.

Nem o mais leve sotaque estrangeiro. Tinha até gíria no meio...

O Bairro Japonês é uma das coisas mais pitorescas de São Paulo. Mesmo sem cerejeiras floridas, sem japonesinhas virando sombrinhas em cima dos ombros, sem pessoas de kimonos arco-íris, esse bairro é o Japão em miniatura. (Gakusei, n. 22, ano 3, maio 1938)

O trecho acima, publicado no jornal Gakusei, é um relato jornalístico que retrata o "descobrimento" do bairro da Liberdade pela imprensa local paulistana em fins da década de 1930. A curiosidade causada pela presença de garotos de aparência asiática com um bom domínio do idioma português levou os repórteres do jornal Última Hora a entrevistar um deles. A confirmação de que se tratava de garotos brasileiros, filhos de japoneses, reforçou a impressão exótica dos repórteres a respeito do "bairro japonês". Nas entrelinhas do texto, é possível nos deter a ao menos duas informações importantes: primeiro, o reconhecimento público de que havia um bairro considerado como uma referência para a população de origem japonesa em São Paulo à época: o "Japão em miniatura", de acordo com a reportagem; segundo, os garotos, filhos de imigrantes, reconheciam-se como brasileiros e possuíam total domínio da língua portuguesa.

O bairro da Liberdade - mais especificamente, os arredores da rua Conde de Sarzedas - é possivelmente um dos locais mais privilegiados para se compreender as experiências de imigrantes japoneses na cidade de São Paulo no período anterior à Segunda Guerra Mundial. Foi lá que surgiram a Liga Estudantina Nipo-Brasileira, em 1934, e o jornal Gakusei, que passou a ser publicado no ano subsequente.

A Liga Estudantina Nipo-Brasileira (LENB) foi fundada dia 21 de outubro de 1934 na cidade de São Paulo. A instituição foi organizada com apoio do Consulado 
Geral do Japão, de associações japonesas e de casas comerciais dirigidas por imigrantes japoneses no bairro da Liberdade. A LENB promovia sessões oratórias nas quais jovens jun-niseis $^{124}$ e dainiseis $^{125}$ podiam exercitar seus conhecimentos na língua portuguesa e expor suas ideias acerca da situação política, social e econômica da "colônia" japonesa. Para além dos encontros com finalidade esportivas, recreativas, a organização foi responsável pela produção de dois jornais e uma revista que circulavam principalmente no meio estudantil dos filhos de imigrantes japoneses que residiam na cidade de São Paulo: 1) a revista Gakuyu (em língua japonesa); 2) o jornal Gakusei (1935-38); 3) a revista Transição (1939-41).

Um perfil dos sócios da LENB foi apresentado por José Yamashiro - também membro da Liga - da seguinte forma:

Quanto à origem dos associados, podiam se identificar alguns segmentos socioculturais bem distintos, como por exemplo:

1) jovens nascidos no Japão que haviam feito estudos primários e secundários na terra natal;

2) filhos de famílias residentes em São Paulo, na maioria pertencentes à classe média (funcionários do consulado do Japão, de empresas nipônicas, como a Kaikô, a Bratac e outras, profissionais liberais, etc);

3) filhos de imigrantes residentes no interior, quase sempre lavradores, que, depois de terminado o primário, vinham estudar nos ginásios, escolas normais e outros estabelecimentos de ensino.

Muitos estudantes dos segmentos 1 e 3 moravam em casa de família, pensões ou pensionatos para estudantes, os chamados Kishukusha, quase sempre dirigidos por um educador ou uma pessoa de confiança dos pais dos jovens, considerada moralmente competente para dar-lhes orientação adequada, numa cidade como São Paulo. Os imigrantes lavradores em sua grande maioria, preocupavam-se muito com os perigos e tentações a que se exporiam seus filhos na grande metrópole.

No começo da Liga, eram poucos os estudantes dos últimos anos de curso ginasial ou cursando cursos superiores, ao passo que entre os issei ou jun-nisei havia alguns com curso secundário ou normal completos ou não, feitos no Japão. Por isso, inicialmente, a liderança da Liga coube em grande parte aos jun-nisei, embora o primeiro presidente,

124 “Ao pé da letra, "quase nisei". Aquele que veio jovem do Japão e completou sua formação no Brasil”. (COMISSÃO, 1992, p.175)

125 "Do japonês ni, segunda, e sei, geração. Filho de pais japoneses nascido no Brasil. Na colônia japonesa do Brasil usou-se dainisei até a década de 40, exatamente com o mesmo significado". (COMISSÃO, 1992, p.100) 
Cassio Kenro Shimomoto, fosse mais brasileiro do que jun-nisei, pois chegou aqui ainda bebê. (COMISSÃO,1992, p.174-75)

O quadro geral traçado acima situa os membros da LENB entre os raríssimos imigrantes japoneses e filhos de imigrantes nascidos no Brasil que lentamente galgavam o topo do sistema educacional paulista nos anos de 1930, moradores da cidade São Paulo, oriundos de famílias de classe média que atuavam no meio empresarial e em profissões liberais, ou mesmo casos de filhos de lavradores do interior que eram enviados à capital para estudar. Considerando a sua característica bastante exclusiva, retomo neste tópico a interpretação sobre diferenciação social interna à "colônia" japonesa para compreender o universo ideológico particular daqueles estudantes que começavam a galgar o ensino superior.

Em outubro de 1935 a LENB lançava o seu primeiro jornal escrito inteiramente em português: o Gakusei, publicado entre outubro de 1935 e setembro de 1938. O título que significa "O Estudante" revela que o órgão se pretendia o porta-voz da pequena camada de imigrantes jun-nisei e dainisei que no início dos anos de 1930 lentamente começava a ingressar nas prestigiadas instituições de ensino superior sediadas na capital paulista, em especial, na Faculdade de Direito do Largo São Francisco e na Faculdade de Medicina. A publicação se tornou um dos fatos culturais que marcaram o debate sobre os significados da imigração japonesa no Brasil na medida em que o Gakusei, tal como é predominante interpretado, seja pelos chamados "intelectuais da colônia japonesa" bem como teses acadêmicas, como um dos primeiros registros autônomos da mentalidade dos imigrantes japoneses de segunda geração e seus impasses na negociação da identidade nacional brasileira.

Essa perspectiva é empiricamente ressaltada com base no chamado "Caso Crisântemo". Trata-se de uma polêmica causada pela publicação do artigo "A Nossa Mentalidade" no primeiro número do Gakusei. O texto assinado por Cassio Kenro Simomoto - o primeiro bacharelando de Direito de origem japonesa, sobrinho do presidente da CAC, Kenkiti Simomoto, e então presidente da Liga Estudantina NipoBrasileira -, foi considerado como uma agressão ao Imperador do Japão, à pátria japonesa, e aos próprios isseis residentes no país assim que foi publicada a sua tradução 
para o japonês no quarto número da revista Gakuyu em 1936. O hiato entre a publicação original e o surgimento do escândalo indica que o japonês era o principal instrumento de comunicação e debate público entre a população de origem japonesa.

É também no primeiro número do jornal Gakusei, publicado em outubro de 1935, que podemos flagrar a influência do Consulado na iniciativa de criação da Liga Estudantina Nipo-Brasileira, ocorrida em outubro do ano anterior. Na primeira página da edição que inaugura o jornal, há um espaço para o artigo "Considerações", escrito pelo então Cônsul Geral do Japão em São Paulo, Kozo Itige. A presença de um artigo escrito pelo Cônsul não foi algo protocolar, nem mesmo se tratou de uma simples chancela formal, pois no texto é revelado que a Liga Estudantina Nipo-Brasileira teria sido fundada sob a tutela da Zai São Paulo Nihonjin Gakkô Fukeikai (Associação de Pais de Alunos de Escolas Japonesas de São Paulo) ou, nas palavras do Cônsul, a "Liga dos Amigos dos Estudantes de S.Paulo" ${ }^{126}$ :

A "Liga Estudantina Nipônica", fundada nesta capital em 21 de outubro de 1934, sob os auspícios da Liga dos Amigos dos Estudantes de S.Paulo e constituída por compatrícios e filhos de compatrícios e meus, congrega, em seu seio, a quase totalidade dessa mocidade que, nas Faculdades, nos Ginásios, nas Escolas de Comércio, Normais, Profissionais, Institutos, Associações e Liceus, buscam a aprendizagem das ciências, das letras e das artes". (Gakusei, 1935, n.1, p.1)

126 A entidade era conhecida como "Associação de Pais da Escola dos Japoneses Residentes em São Paulo", "Liga dos Amigos das Escolas Japonesas em São Paulo" ou ainda "Liga dos Amigos dos Estudantes de São Paulo" ou, simplesmente, Fukeikai. 
Figura 13 - A primeira edição do jornal Gakusei, de outubro de 1935.

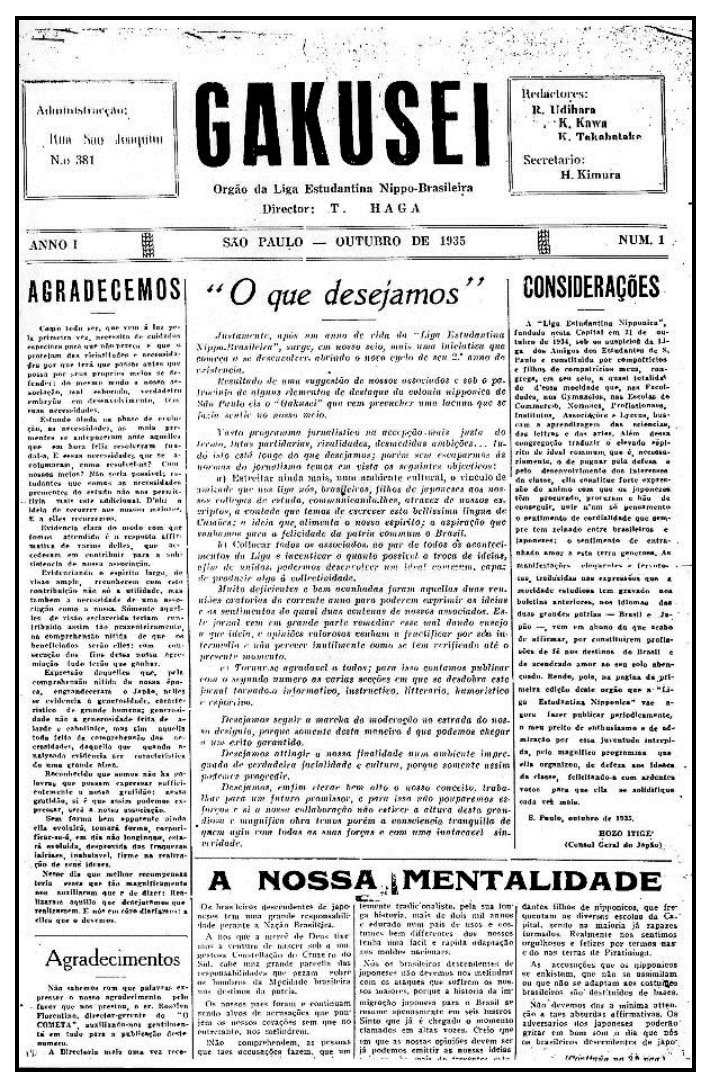

Fonte: Centro de Estudos Nipo-Brasileiros.

Entre os registros sobre a existência dessa entidade de onde teria surgido a Liga Estudantina Nipo-Brasileira, a publicação dos 80 anos da imigração japonesa no Brasil nos fornece informações valiosas. Ali consta que em 1927 teria sido fundada a Zaihaku Nihonjin Kyoiku-kai (Associação Educacional dos Japoneses do Brasil), por iniciativa do então Cônsul Geral do Japão em São Paulo, Sukeyuki Akamatsu ${ }^{127}$. O seu principal objetivo seria a difusão do ensino da língua japonesa entre os filhos dos imigrantes. Em

\footnotetext{
${ }^{127}$ Segundo edição de 15 de março de 1927 do jornal Burajiru Jihô (Notícias do Brasil), a nova entidade instalou filiais em São Paulo, Santos, Ribeirão Preto, Promissão, Presidente Prudente, Registro, Catanduva, Penápolis, Araçatuba e Ourinhos. Seus objetivos eram: atividade de ligação entre as escolas; unificação da orientação educacional de filhos de japoneses; melhoria da qualidade e do tratamento do professor; realização de seminários e conferências sobre a educação; aperfeiçoamento de livros didáticos (COMISSÃO, 1992, p.100).
} 
razão dos objetivos voltados à promoção da educação, a entidade contava com apoio direto do governo japonês. Dois anos mais tarde, em 1929, agora por intermédio do Cônsul Geral Nakashima, a entidade ganhou novo formato, sendo então nomeada Zai São Paulo Nihonjin Gakko Fukeikai (Associação de Pais de Alunos de Escolas Japonesas de São Paulo). Ainda segundo informações da publicação:

Em 1935 contava 36 filiais regionais. Todas as escolas primárias mantidas por japoneses participavam da nova entidade. Em março de 1936 ela reformou seus estatutos e mudou o nome para Burajiru Nihonjin Kyoiku Fukyu-kai (Associação de Difusão do Ensino de Japoneses do Brasil. (COMISSÃO, 1992, p.213)

Portanto, a criação da Liga Estudantina Nipo-Brasileira em 21 de outubro de 1934 decorreu de iniciativas anteriores voltadas à promoção da educação em língua japonesa, que contaram com a iniciativa e o suporte direto do Consulado. Mais ainda, da citação anterior, podemos destacar que o Cônsul Kozo Itige revela que os estudantes que compunham a LENB pertenciam a um círculo próximo de amizades, pois eram “compatrícios e filhos de compatrícios" seus.

Como foi dito anteriormente neste tópico, nos primeiros anos de seu funcionamento, a LENB era composta por um público bastante restrito, em sua maioria jun-niseis, sendo poucos os filhos de imigrantes que habitavam a capital com a finalidade de realizar os estudos. Isso não significa, contudo, que se tratava de um público homogêneo. Como já foi mencionado, havia basicamente três perfis mais gerais de estudantes que a compunham. A partir da lista de membros publicada na revista Gakuyи em agosto de 1936 pude identificar alunos filhos de japoneses oriundos de ao menos dezesseis instituições de ensino diferentes, entre eles escolas ginasiais, escolas normais, liceus, escolas de negócios e faculdades.

Após essa breve descrição, buscamos localizar a Liga Estudantina NipoBrasileira e o jornal Gakusei no escopo desse universo institucional, ressaltando os significados que a educação - e as oportunidades por ela mediadas - passaram a adquirir no imaginário coletivo. 
Essas afirmações não pressupõem, contudo, que tal influência ocorreu de forma estática e simétrica. Certamente, a sua efetividade repercutiu no cotidiano dos jovens estudantes filhos de japoneses sob diversas maneiras, e dependia de como esse grupo ou indivíduos a compreendiam. Consideramos também que essa influência se modificou ao longo do tempo, e certos acontecimentos históricos tiveram importância central nessa mudança, como as restrições impostas aos estrangeiros pelas mãos do Estado brasileiro, o rompimento das relações diplomáticas com o Japão na década de 1940 e a progressiva autonomia dos jovens estudantes dainisei. Ainda assim, para o ano de 1934, o universo de atividades da população japonesa era fortemente mediada pelo Consulado.

A criação do jornal Gakusei possui uma complexidade maior do que uma simples resposta imediata aos acontecimentos políticos, especialmente à Constituição de 1934 como afirma Lesser (2001), ainda que esse acontecimento possa ter motivado muitas das posições políticas dos autores que escreviam naquele jornal. Entretanto, sob essa perspectiva, pouco se explora a dinâmica interna de organização social do grupo. De maneira a complementar tal abordagem, acredito ser imprescindível articular a diferenciação social, a educação e os significados atribuídos pelos agentes. 
Figura 14 - Reunião de membros da Liga Estudantina Nipo-Brasileira, agosto de 1936.

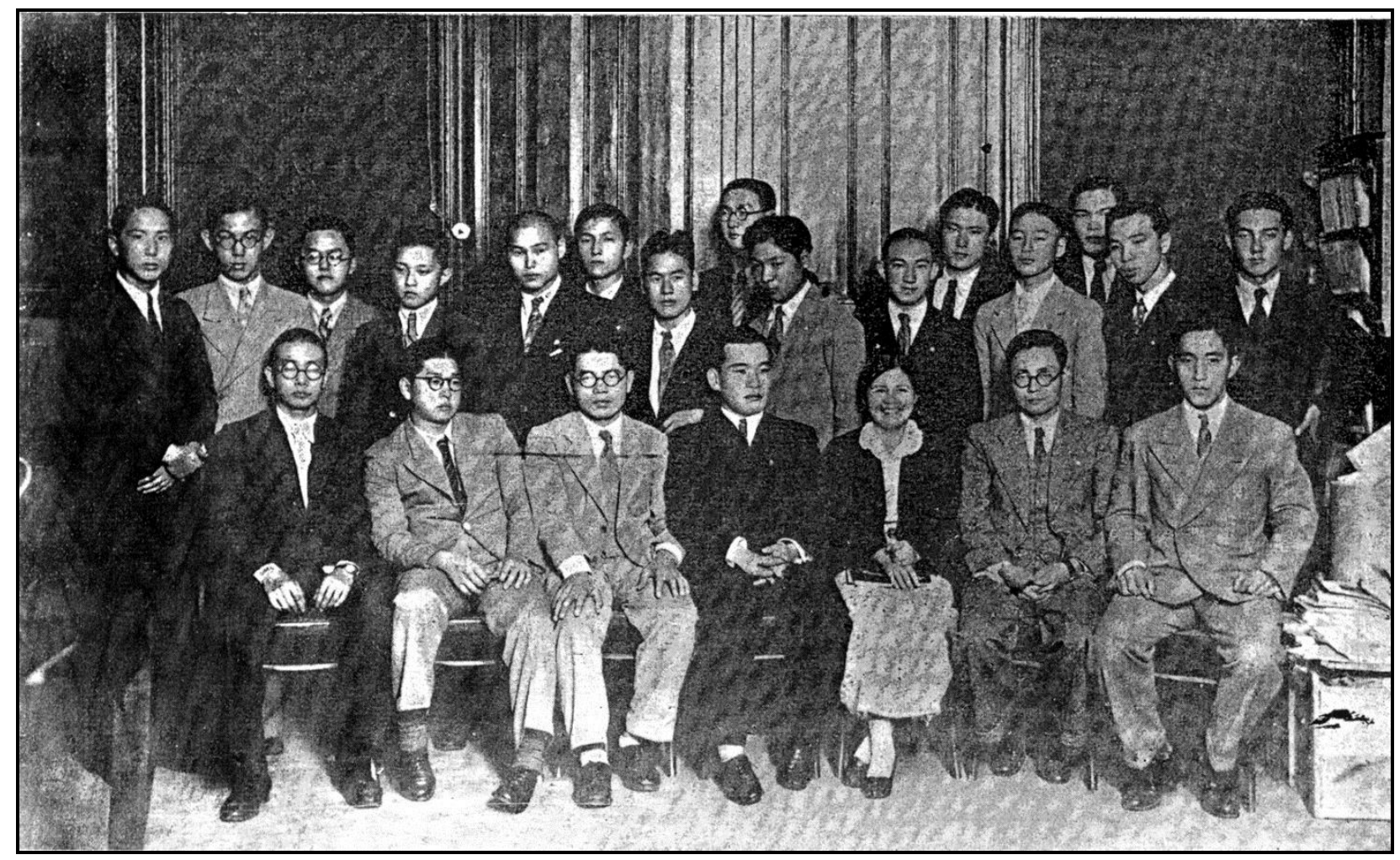

Fonte: Museu Histórico da Imigração Japonesa no Brasil.

Da esquerda para a Direita, em pé: Yassuni Tanigaki, loshifumi Utiyama, Teiichi Haga, João Sussumu Hirata, Motoaki Higuchi, Antonio Shimomoto, Jorge Ishimaru, Riutaro Kiyohara, Hideo Matsumoto, Yasuo Ogawa, Anze Sunao, Tsuneo Nishioka, Iwata Jozo, Yukishigue Tamura. Sentados: Kyoshi Takabatake, Massaki Udihara, Ayami Tsukamoto, Cassio Kenro Shimomoto, Yoneko Nishie, Kiyoshi Kawahara, Hiroshi Kimura.

No contexto do bairro da Liberdade na primeira metade da década de 1930, a existência de uma diferenciação social pressupunha linhas divisórias entre estratos do grupo social de imigrantes japoneses que habitavam a cidade de São Paulo, estando baseadas em códigos e valores publicamente reconhecidos como legítimos por seus membros. Sob esse ponto de vista, considero que certas práticas demarcavam claramente os estratos, pois os seus sentidos permitiam que, no âmbito cognitivo, se estabelecesse uma associação do indivíduo ao grupo a que ele pertencia. É somente assim que o termo "colarinhos-brancos" adquiria sentido. 
Mas, entre outras práticas existentes, também havia aquelas que por excelência cabiam aos jovens realizar, e elas estavam diretamente relacionadas ao universo da educação. Não por acaso, o Consulado estimulava a educação dos filhos de imigrantes: na posição de um órgão representativo do governo imperial japonês em São Paulo, é possível constatar que o Consulado adotava um discurso em que a educação assumia um papel central na busca pela progressiva melhoria das condições de vida dos imigrados e na formação de laços entre o país de origem e o de destino ${ }^{128}$, bem como atuava de forma a estimular atividades estudantis por meio da criação de entidades, conforme já demonstramos anteriormente.

Havendo, portanto, uma prática socialmente reconhecida e valorizada de forma unânime pelos vários estratos do grupo e, principalmente, pelo órgão consular, cabe analisar qual seria a dinâmica de seu funcionamento e os significados do protagonismo dos jovens filhos de japoneses. Considero que no intermédio dos polos que diferenciavam internamente o grupo, havia vetores de aproximação e distanciamento que, a depender do seu alcance, tornavam certos indivíduos aptos a transitar facilmente entre as distintas posições, diminuindo as diferenças entre elas.

No caso dos filhos de imigrantes japoneses, a educação, ou o sucesso na conclusão do ciclo escolar - e preferencialmente o ingresso nas instituições de ensino universitário mais prestigiadas à época - eram laureadas pelo reconhecimento dos estratos superiores. Era uma espécie de estímulo que alimentava expectativas em relação a oportunidades, como as de ultrapassar as barreiras de aceitação na sociedade e de mobilidade social. Somente após alcançarem o sucesso dessa empreitada e obterem o almejado reconhecimento é que os jovens estudantes poderiam definir a sua posição na estrutura social do grupo e, dessa forma, estariam aptos a construir discursos que os situassem como exemplos de sucesso da trajetória daquela população de imigrantes.

\footnotetext{
128 Em 1933, em virtude da comemoração do vigésimo quinto aniversário da imigração japonesa no Brasil, assim afirmou o Cônsul Geral do Japão em São Paulo, lwataro Uchiyama: "O governo Imperial tem apenas o desejo de que os japoneses domiciliados no Brasil sejam individualmente felizes, consigam aqui melhores condições de vida e desenvolvimento, melhores possibilidades para a educação de seus filhos brasileiros; se tornem, em uma palavra, dignos e úteis cidadãos da nação amiga" (UCHIYAMA, 1934, p.39).
} 
Considerando tais significados, portanto, entendo que, para os jovens estudantes filhos de imigrantes japoneses que habitavam a cidade de São Paulo no início da década de 1930, um dos marcadores centrais de diferenciação social no universo grupal estava ligado à educação. Em termos numéricos, devemos lembrar que estamos nos referindo a um universo bastante limitado de indivíduos, pois estima-se que do contingente que variava entre 2.500 a 4.500 japoneses que habitavam a cidade em 1934, cerca de 300 deles eram jovens estudantes ${ }^{129}$. É nesse contexto que, no ano de 1933, Cassio Kenro Simomoto afirmou publicamente e pela primeira vez as suas posições abertamente direcionadas aos filhos de japoneses, argumentando a favor de uma identificação com a sociedade brasileira e ressaltando a importância da educação para esse público ${ }^{130}$.

Algumas leituras afirmam que o caráter antinipônico das leis de imigração sancionadas pela constituição de 1934 tenha sido particularmente chocante para muitos filhos de japoneses que supunham estar nas classes médias e alta, e as reações mais sofisticadas a elas não poderiam ter saído senão das salas da Faculdade de Direito do Largo São Francisco, com sua tradição progressista e antigetulista. Contudo, afirmo que o percurso desses jovens estudantes organizados na LENB deve ser compreendido em relação às lógicas de organização grupal a que eles pertenciam. Em linhas gerais, os membros da LENB colocaram em negociação a questão de sua identidade ao se perceberem como filhos de japoneses em contextos em que a necessidade de adesão a valores locais era crucial. Não por acaso boa parte do conteúdo do jornal Gakusei é dedicado a debates sobre quais seriam as melhores estratégias de se combinar a herança japonesa e a brasileira.

Apesar dessa leitura mais evidente que ressalta o início de um processo de negociação identitária, acredito que a compreensão desse grupo demanda considerar que esses jovens, em grande medida, se dedicaram a cumprir um modelo de ascensão social

\footnotetext{
${ }^{129}$ Ver o artigo de Cassio Kenro Shimomoto “A nossa mentalidade”. Gakusei, n. 1, 1935, p.1.

${ }^{130}$ Por ocasião da comemoração do $25^{\circ}$ aniversário da imigração japonesa, ocorrido em 1933 , o jornal Diário de São Paulo, dos Diários Associados (de propriedade de Assis Chateaubriand), teve a iniciativa de publicar, em edição especial, um conjunto de artigos assinados por diversas autoridades e personalidades da época. Com o apoio do consulado geral do Japão em São Paulo, no ano seguinte essa edição foi organizada em formato de livro, intitulado "Brasil e Japão - duas civilizações que se completam" (1934). O texto "Uma exortação aos brasileiros descendentes de japoneses", que reproduz uma entrevista com Cassio Kenro Simomoto, compõe essa coletânea.
} 
afinado com o republicanismo paulista, em que as credenciais educacionais representariam o principal recurso a ser mobilizado para alcançar uma posição legítima de reconhecimento social.

Esse "projeto de ascensão" juvenil também é perceptível na segunda publicação da LENB, a revista Transição, publicada entre junho de 1939 e setembro de 1941. Nela, as próprias representações acerca do dainisei passaram a ganhar outros componentes importantes, revelando o caráter dinâmico do meio social que o produziu. Além disso, observa-se a presença mais recorrente de autores sem descendência japonesa, principalmente estudantes ligados ao Centro Acadêmico XI de Agosto, da Faculdade de Direito. A tendência em possuir cada vez mais autores sem descendência japonesa, no entendimento dos membros da LENB, representava a prova empírica de que o projeto de incorporação e ascensão social dos jovens estudantes era então algo factível. E isso já havia sido anunciado no Gakusei: de forma emblemática, a última página do último número do jornal (setembro de 1938) foi composta apenas de textos escritos por não descendentes, entre eles, Ulysses Guimarães. Os editores assim afirmaram: "O nosso coração exulta de alegria. É um dos grandes momentos na história do Gakusei. Com ela terá o nosso órgão cumprido uma de suas mais altas finalidades: o intercâmbio cultural e espiritual entre os brasileiros e os brasileiros filhos de japoneses".

O jornal Gakusei e a revista Transição são fontes documentais valiosas para melhor compreendermos a trajetória de uma fração da população japonesa que construiu de forma bastante singular as suas estratégias de incorporação na sociedade brasileira na década de 1930. É na revista Transição que o apoio incondicional da CAC se mostrava mais evidente, patrocinando praticamente todas as suas edições. Não por acaso, Gervásio Inoue, que à época era membro da LENB e um dos redatores da revista, fora recrutado por Kenkiti Simomoto em 1940 para prestar serviços de consultoria jurídica à Cooperativa. Entre outros personagens que tiveram as suas vidas fortemente relacionadas à LENB estiveram os primeiros políticos brasileiros de origem japonesa, como os ex-deputados Yukishigue Tamura, João Sussumu Hirata e Ioshifumi Utiyama; além de conhecidos jornalistas como José Yamashiro, Hideo Onaga, Chuzaburo Nomura; os primeiros médicos brasileiros de origem japonesa, como Massaki Udihara, Shizuo Hozoe (contribuinte da LENB), Antonio Simomoto, entre outros. 
A LENB esteve ativa a partir de 1934, e em 1941 foi extinta pois passou a sofrer forte intervenção policial. Para que seja possível oferecer uma compreensão sobre a trajetória dessa organização estudantil é necessário, portanto, considerá-la enquanto uma resposta formulada por imigrantes de segunda geração a questões relacionadas à incorporação e à nacionalidade. Esses personagens, posteriormente, constituíram o grupo de lideranças da coletividade de origem japonesa em São Paulo.

Ao final do ano de 1942, poucos meses após a entrada das Forças Expedicionárias Brasileiras na guerra, medidas de segurança adotadas pelo governo brasileiro buscavam evitar que japoneses, italianos e alemães residissem próximos ao litoral brasileiro. Além disso, o trânsito era controlado mediante exigências de porte de documentos, bem como reuniões deveriam ser previamente comunicadas à Delegacia de Ordem Política e Social (DEOPS). José Yamashiro assim relatou o ambiente de repressão por ele vivenciado:

Durante a guerra era proibido falar japonês. Então houve casos de niseis que não sabiam japonês serem detidos por policiais "porque estavam conversando em japonês".

Em tempo de guerra, acontecem os casos mais absurdos. Havia os maus policiais, que, aproveitando o estado psicológico dos súditos do Eixo (japoneses, alemães e italianos), procuravam arrancar dinheiro sob os mais ridículos e estapafúrdios pretextos. (COMISSÃO, 1992, p.186)

O ambiente de intolerância e prisões arbitrárias levou o grupo de jovens da LENB a formular um manifesto de "brasilidade", redigido em 28 de setembro de 1942 e dirigido ao presidente da república Getulio Vargas ${ }^{131}$. Assinaram o manifesto 39 filhos de japoneses, em sua maioria estudantes de nível superior e ginasial ${ }^{132}$. Entre eles, José

\footnotetext{
131 Fonte: Prontuário DEOPS n. 24.234.

132 Assinaram o manifesto: José Yamashiro, tradutor público; Yukishigue Tamura, advogado; Hideo Onaga, estudante de Direito; Kentaro Takaoka, estudante de Medicina; Keize Harada, estudante de Medicina; Gervásio Inoue, estudante de Direito; Kenji Nomiyama, estudante de Medicina; Nobor Yamashita, ginasiano; Ruy Onaga, estudante de Comércio; Miyahara Shiney, estudante de Comércio; Mário Nakaoski, estudante; Carlos Toyoda, estudante; Tohoma Iosio, estudante; Tooru Yafuso; Hirosi Nagano; Job S. Nogami; Ticara Kume; Nitsuo Shibuya; Camilo Yonanine; Catuo Watanabe, estudante de Medicina; Luiz Tanigaki, estudante de Medicina; Koei Yamaki, médico; Hirondo Kobayashi; Yoshiharu; Eduardo Hanada, estudante; Konei Yamaki, estudante de Medicina; Hiroci Toqueci, médico; Mario Kinjô, estudante; Tomio Kitice; Jorge Watanabe; Kira Yssao, estudante; Hiroki Aoki; Fudjio Aoki;
} 
Yamashiro, Yukishigue Tamura, Hideo Onaga, Gervásio Inoue, Massaki Udihara (que serviu o exército brasileiro na Segunda Guerra), Teiichi Haga, entre outros. Reproduzo o manifesto na íntegra:

Nós, brasileiros, filhos de japoneses, diante da agressão de que foi vítima o Brasil em sua soberania e em sua honra, e ante a briosa atitude do Governo, revidando o ataque, com a declaração do estado de beligerância contra os países agressores e, mais recentemente, com o decreto de mobilização das forças nacionais, vimos hipotecar a nossa irrestrita e integral solidariedade a esse ato do Governo e a todos os que dele decorreram no sentido de prevenir e reprimir a ação dos elementos que, dentro do território brasileiro, exercem atividades contrárias aos interesses da Nação. Esta nossa atitude seria perfeitamente dispensável por ato que emana da própria constituição. Vemo-nos, porém, na obrigação de dar expressão ao que sentimos, e todo brasileiro que se orgulha de sê-lo, deve sentir o amor à Pátria, à terra em que nascemos. Isso se nos afigura, a nós, brasileiros, descendentes de japoneses, uma obrigação, porque não podemos permitir que paire a menor sombra de dúvida, quanto ao nosso sentimento de brasilidade. Amamos a nossa pátria e é essa a razão porque não podemos admitir dúvidas em relação ao nosso modo de pensar. Essas dúvidas são absolutamente injustificáveis, porquanto o fato de descendermos de estrangeiros, não impede, como realmente não impediu, de recebermos de nossos pais uma educação orientada num só patriotismo pela terra em que nascemos e que tão hospitaleiramente os recebeu há cerca de três décadas. Somos todos brasileiros, capazes - legal, física e espiritualmente $-\mathrm{s}$ de servir à Pátria.

Como as mães brasileiras, como os nossos pais, como os nossos professores, como todo o Brasil enfim, não desejávamos a guerra: todavia, ela foi brutalmente imposta a cada um dos brasileiros.

Concretizada esta situação, é com alegria que, nós, brasileiros, de ascendência japonesa, vemos chegado o momento de provarmos ao Brasil, que acima de tudo estremecemos, os nossos sentimentos de amor e de brasilidade.

São Paulo, 28 de setembro de 1942.

Yamamura; Kahoru Haga; Massaki Udihara, médico; Newton S. Miyashiro; Teiichi Haga, advogado; Américo Sugai; 
Figura 15 - Manifesto de brasilidade assinado por filhos de imigrantes japoneses, endereçada ao presidente da república Getulio Vargas, 28 de setembro de 1942.

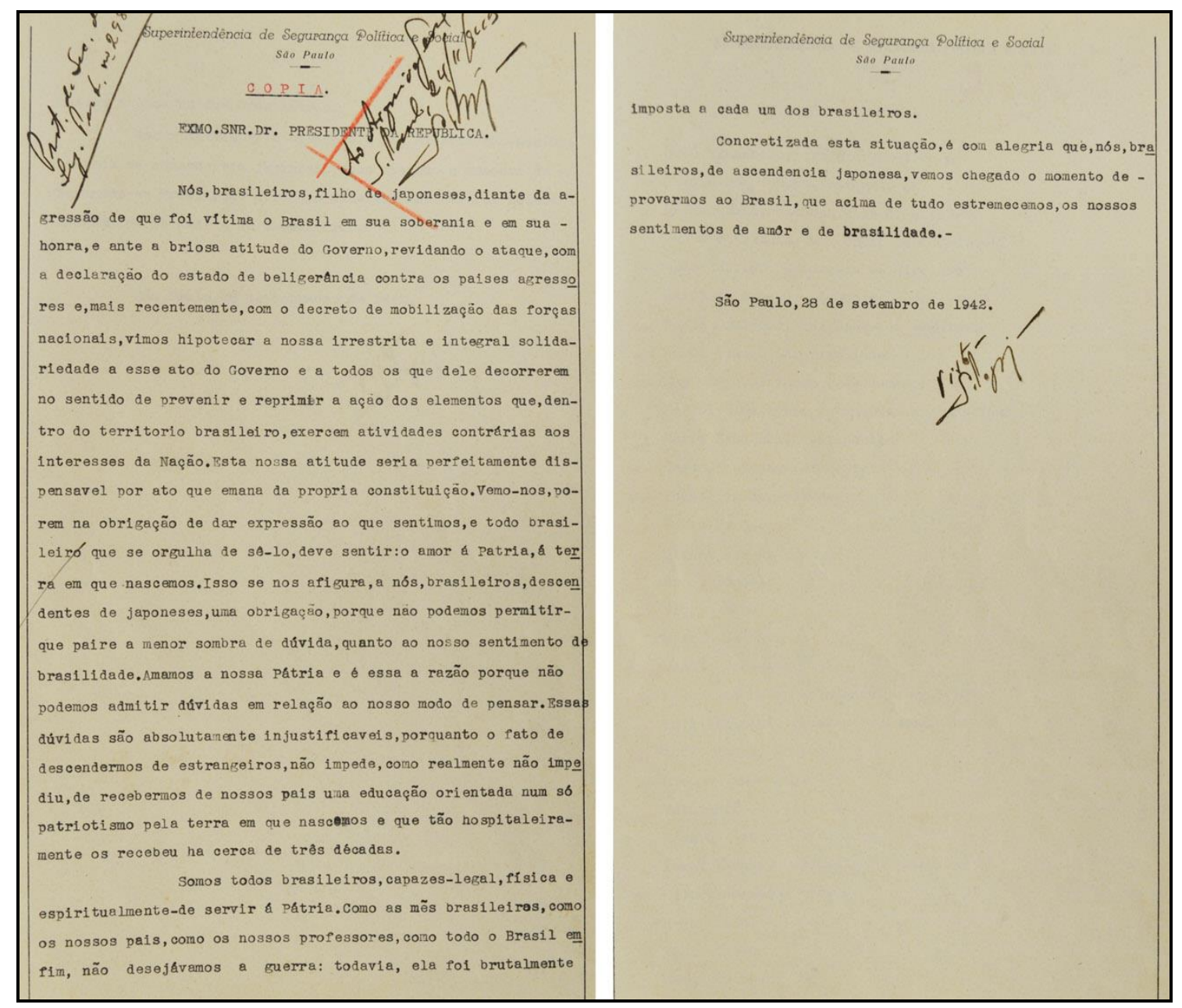

Fonte: Arquivo Público do Estado de São Paulo.

O manifesto em questão, se interpretado em relação ao meio social em que foi produzido, contribui para a afirmação de que as lideranças de segunda geração da coletividade japonesa residente em São Paulo formulou respostas singulares às barreiras de incorporação na sociedade local. Mas mesmo que esses jovens estudantes filhos de japoneses manifestassem publicamente a sua completa devoção à nação brasileira por 
meio do manifesto e de suas extintas publicações, como o Gakusei e o Transição, isso pareceu não ter lhes assegurado insuspeição pelas autoridades policiais. Uma pesquisa dos prontuários do DOPS referentes a membros da LENB confirma o episódio já relatado por José Yamashiro. O autor menciona o "evento de Eldorado", ocorrido em 9 de dezembro de 1942, quando dois membros da LENB, Hideyuki Oda e Isaura Murai, comemoravam o seu matrimônio no município de Eldorado, localizado no Vale do Ribeira, próximo ao litoral Sul paulista (COMISSÃO,1992, p.185). Na ocasião, vários membros da LENB foram presos, entre eles Massami Hirota ${ }^{133}$, Eduardo Riomey Yassuda $^{134}$, Francisco Xavier Motoaki Higuchi ${ }^{135}$, Yukishigue Tamura ${ }^{136}$, Gervásio Tadashi Inoue ${ }^{137}$, José Yamashiro ${ }^{138}$, Sojiro Kawanami ${ }^{139}$, Kazuo Murai ${ }^{140}$. Segundo relato de José Yamashiro, as prisões ocorreram em virtude de boatos de um complô orquestrado por japoneses em que se estaria construindo um submarino naquela região.

Essas prisões indicam que a repressão política e a violência - física e simbólica do Estado brasileiro colocaram obstáculos à existência da LENB em um período de nacionalismos conflitantes, mesmo que seus membros tivessem nascido no Brasil. O seu último presidente, Hideo Onaga, se viu obrigado a abandonar o posto e extinguir a entidade pela forte perseguição sofrida no ano de 1941. Desses eventos podemos corroborar interpretações já existentes, que sugerem que esse pequeno círculo de jovens estudantes deu início às primeiras manifestações públicas de identificação com a nação brasileira, resguardando a origem japonesa.

Entretanto, mais do que simplesmente encerrar uma iniciativa de jovens estudantes filhos de japoneses, ressaltamos os possíveis significados que a repressão ilustrado pelo evento de Eldorado - trouxe àquele grupo. Pois, os seus projetos de incorporação e ascensão social, fortemente arraigados em um discurso pautado pela formação educacional encontraram um limite, talvez inesperado. Em outras palavras, a

\footnotetext{
133 Prontuário DEOPS n. 24.230.

134 Prontuário DEOPS n. 24.231.

135 Prontuário DEOPS n. 24.232.

136 Prontuário DEOPS n. 23.143.

137 Prontuário DEOPS n. 24.233.

138 Prontuário DEOPS n. 24.234.

139 Prontuário DEOPS n. 24.235.

140 Prontuário DEOPS n. 24.236.
} 
extinção da LENB e os casos de prisão de seus membros, intensificados a partir de 1941, pareciam anunciar que havia outros componentes em jogo, e que vislumbrar uma formação educacional era apenas o início de um longo processo de negociação. Aqui, certamente a questão identitária foi um processo relevante para compreender os impasses que afligiam a população de origem japonesa no Brasil, conquanto uma análise mais detida em grupos possui o potencial de relativizar certos consensos: a dimensão política parecia se revelar central.

A escolaridade da segunda geração e, mais especificamente, as credenciais profissionais, configuraram processualmente recursos que atestavam a legitimidade em ambientes de gestão. No ambiente da Cooperativa, possuir um diploma de uma das faculdades mais prestigiadas do Brasil era um bem ao alcance de poucos indivíduos. Nesse sentido, talvez o projeto de ascensão daqueles jovens da LENB tenha se realizado. Contudo, os usos desses recursos ganhariam expressão mais evidente fora do ambiente institucional quando relacionados à atividade no âmbito da política. No capítulo seguinte demonstro que entre a décadas de 1940 e 1970 os primeiros políticos de origem japonesa se dedicaram a questões relacionadas à agricultura (DIAS, FRANCISCO e CAVALLI JÚNIOR, 2008), quando não a questões pontualmente interessantes à CAC. A partir do caso de Fábio Yassuda, vice-diretor da Cooperativa que foi nomeado ministro da Indústria e Comércio em 1969, examino a participação dos filhos de japoneses no sistema político brasileiro em um período conhecido como “intervalo democrático", iniciado em 1945 e interrompido em 1963. Em seguida, analiso o caso da Cooperativa no período do regime militar.

\section{Capítulo 2 - Pela consagração de uma jornada ascendente}

Rituais de consagração geralmente ocorrem envoltos por uma forte simbologia cuja capacidade de organizar bens imateriais e dispô-los em uma ordem reconhecida e compartilhada de organização social os difere de acontecimentos ordinários. A sua 
dinâmica temporal obedece a um interesse categórico que almeja uma dupla direção nos caminhos da memória coletiva: perpetuar o presente na história e também legitimá-lo perante os eventos que ainda estão por vir. E é em relação com o passado que essa dinâmica adquire o seu sentido mais pleno. Inicio este capítulo abordando de forma mais detida um evento específico - a posse de Ministro da Indústria e Comércio pelo diretor-gerente da Cooperativa durante o regime militar (1964-1985) - na tentativa de qualificá-lo como um ponto de partida para a análise de fenômenos sociais mais abrangentes, situando a participação efetiva de personagens centrais da CAC.

Em 24 de outubro de 1969 o Brasil era dirigido por uma Junta Governativa Provisória pela impossibilidade do Marechal Artur da Costa e Silva terminar o seu mandato. A Junta havia impedido a posse do vice-presidente da república por meio de uma emenda constitucional e tornou legítima a sucessão do General Emílio Garrastazu Médici. Naquela data os jornais noticiavam a nomeação dos ministros escolhidos por Médici para o mandato presidencial seguinte (1969-1974) ${ }^{141}$. Em 28 de outubro de 1969 o Diretor-Gerente da CAC e Secretário de Abastecimento do município de São Paulo, Fábio Ryodi Yassuda, renunciou a esses dois principais cargos que até então ocupava e aceitou o convite - feito pessoalmente pelo General Emílio Garrastazu Médici ${ }^{142}$ - para assumir o Ministério da Indústria e Comércio.

A cerimônia de posse de Médici ocorreu em 30 de outubro, e uma parte de sua equipe de ministros, incluindo Yassuda, foi empossada dois dias depois ${ }^{143}$. A centralidade política e econômica do ministério que Fábio Yassuda assumira induziu um

\footnotetext{
141 "Garrastazu já com seu ministério escolhido“. Correio da Manhã, 24 de outubro de 1969, p.1.

${ }^{142}$ Sobre o convite, Fábio Yassuda relatou em entrevista: "Eu estava num hotel do Rio, quando um coronel do Exército veio me buscar dizendo que o assunto era sigiloso mas que iria me levar ao Galeão. Naquela fase da ditadura, o aeroporto do Galeão simbolizava o local de prisão dos ativistas de esquerda. $\mathrm{O}$ coronel me tranqüilizou lembrando que no Galeão também aconteciam decisões políticas nacionais. De fato, apesar de Brasília existir há uma década, muitos ministérios e órgãos do governo federal continuavam no Rio, e no Galeão ficava a residência oficial do ministro da aeronáutica, que é onde os presidentes se hospedavam quando estavam no Rio. Felizmente, fui levado para essa residência. $\mathrm{O}$ presidente Emílio Garrastazu Médici, eleito pelo Congresso Nacional na véspera, veio me receber e depois apresentou me a dez coronéis presentes. Entretanto, a conversa foi reservada, só eu e o presidente". Entrevista com Fábio Yassuda. Disponível em: <http://www.culturajaponesa.com.br/htm/entrevista.html>. Acesso em: março de 2013.

${ }^{143}$ Assumiram posse no dia 31 de outubro: Mário Gibson Barbosa (Exterior), Júlio Barata (Trabalho), Higino Corsetti (Comunicações), João leitão de Abreu (Casa Civil) e Fábio Yassuda (Indústria e Comércio). Fonte: Jornal do Brasil, 1 de novembro de 1969, p.1.
} 
tom especial à solenidade que marcou o seu discurso de posse. Sob a ótica de Fábio, o país estaria diante de um cenário metafórico de "guerra", e aqui destaco alguns trechos de seu discurso, em que a nação, o desenvolvimento, a gestão racional e as empresas formavam os "aparatos bélicos" a serem utilizados no "campo de batalha":

"Penso que o Brasil se encontra hoje diante de uma guerra, e para esta tem de mobilizar-se integralmente. Guerra do seu desenvolvimento, do seu engrandecimento, de sua afirmação histórica"

Afirmou o novo titular da Indústria e Comércio que o nosso desenvolvimento depende do emprego mais racional e eficiente dos nossos meios de ação, para tornar os meios adequados aos fins. Neste momento não há outra solução para o país senão a da eficiência integral e a da completa mobilização [...]

"Quem cria a riqueza nacional?" perguntou o ministro depois de declarar que o rumo evidente do País é o desenvolvimento, com o máximo aumento do produto nacional.

"São todos quantos trabalham - nas atividades primárias, na agricultura e nas indústriais extrativas; os que transformam a matéria-primea em bens mais valiosos; o comércio e as atividades intermediárias; os técnicos, os empresários, os administradores, os servidores públicos, e todos os que produzem bens imateriais, como professores, cientistas, artistas, os construtores da cultura que nos identificam como povo e como Nação" [...]

E aos empresários, que papel cabe? O da vanguarda. A indústria e o comércio têm a responsabilidade de se atirar para a frente, crescer, inverstir agressivamente, "com dureza de ação e sobriedade de comportamento". ("Yassuda recomenda a mobilização geral". O Estado de S.Paulo, 01 de novembro de 1969)

Fábio Yassuda e seus cinco irmãos nasceram na cidade de Pindamonhangaba, no estado de São Paulo, filhos de Ryoity e Shiduca, ambos imigrantes japoneses. Seu pai Ryoity, contudo, não chegou ao Brasil seguindo o fluxo migratório iniciado oficialmente em 1908: havia desembarcado em Santos dois anos antes, em 1906, como enviado especial do Ministério da Agricultura do Japão e da Câmara Mundial de Kagoshima, sua terra natal. Ao lado de Saburo Kumabe e Ryo Mizuno, considerados os pioneiros da imigração japonesa no Brasil, esteve incumbido da tarefa de relatar para as autoridades governamentais as possibilidades de o Brasil receber imigrantes japoneses 
por vias institucionais ${ }^{144}$. E foram justamente as referências biográficas da família Yassuda que encerraram o seu discurso de posse ministerial, de maneira ao menos significativa. A condição de filho de japoneses assumia novos significados no imaginário coletivo, pois operava simbolicamente e era aceita como qualidade impulsionadora de um perfil desejável, e não como impedimento.

Desejo registrar que não andei muito para aqui chegar, pois venho de perto. Venho do Vale do Paraíba, que tanto contribuiu no Império e que tanto hoje volta a contribuir para o País. Venho de Pindamonhangaba, de quase trezentos anos, onde se sente ainda a presença de seus velhos e respeitados vultos históricos. Venho de uma casa rural, onde, guiado pelas mãos honradas e capazes de meu saudoso pai vanguardeiro de sua corrente imigratória - e pelas mãos carinhosas de minha mãe, hoje aqui presente para minha alegria, aprendi, juntamente com meus irmãos (como aprenderam os filhos de imigrantes que contribuíram para formar o povo brasileiro) a amar o Brasil, a cultuar envaidecido os nossos maiores e os nossos episódios históricos, sem perder o respeito às tradições da terra de meus ancestrais. ("Yassuda assume o MIC e convoca o País para 'a guerra do desenvolvimento e da afirmação'". Folha de S. Paulo, 01 de novembro de 1969, p.5)

Os anseios de uma aflita segunda geração por sua aceitação pública, como aquela autora do manifesto de "brasilidade" em 1942 (mencionado no capítulo anterior), enfim pareciam encontrar correspondência pelas vias da consagração. Aos olhos da população de origem japonesa - principalmente da segunda geração - a imagem de Yassuda como partícipe do núcleo central de poder político governamental parecia ser mais um exemplo consumado da trajetória vislumbrada por aqueles jovens no universo de oportunidades econômicas e sociais do Brasil no período pós-guerra. Pois, principalmente na capital paulista e com regularidade cada vez constante, os filhos de japoneses passavam a ingressar com representatividade no sistema educacional e, em geral, realizavam a transição para ocupações mais bem remuneradas no mercado de trabalho.

Ainda que haja escassez de dados para o aprofundamento dos determinantes de mobilidade entre origem social e destino desse grupo, havia uma crença generalizada

144 "Pai de Yassuda iniciou a imigração de japoneses". Jornal do Brasil, 3 de novembro de 1969, p.5. 
entre as famílias japonesas, de que a escolaridade seria uma variável central para o sucesso da transição do sistema de ensino para o mercado de trabalho. Na prática, era possível que tal crença fosse correspondida, afinal, eram os casos de sucesso que alimentavam expectativas das famílias que investiam na escolarização dos seus filhos.

Mesmo que os indivíduos de origem japonesa, vindos de famílias majoritariamente rurais, fossem considerados uma população não branca, a variável raça/cor parecia ter menos efeitos negativos nas chances relativas desse grupo realizar transições (escolares e para o mercado de trabalho), o que parece sugerir uma aproximação - bastante profícua em termos analíticos - desse grupo com a população branca, ao menos no que se refere à estrutura de estratificação social. Pois, se mesmo em dias atuais no Brasil a variável cor/raça possui efeitos negativos sobre as chances de os não brancos realizarem mobilidade ascendente ${ }^{145}$ - especialmente nos estratos de renda mais altos -, parece-me interessante problematizar como a população japonesa parece ter distanciado cada vez mais de uma condição em que essa variável determinou a sua trajetória. Compreendê-la sugere que devemos recorrer a formas não convencionais de observação da realidade, ou seja, não apenas na estrutura de estratificação e por meio de dados quantitativos mas, principalmente, em outras dimensões da experiência social.

Por ora, centremos nossa atenção em dados do survey The japanese Immigrant in Brazil (1969) de forma a pontar regularidades que sugerem um padrão de mobilidade social ascendente da população japonesa, fenômeno que ganhou proporções mais consideráveis a partir da década de 1930. A exposição dos dados permitirá ilustrar as razões pelas quais a mobilidade operou como subsídio para narrativas que diagnosticavam o "êxito" desse grupo migratório.

Entre 1908 e 1958 uma parcela significativa dos imigrantes japoneses no Brasil experimentou processos de mobilidade de status ocupacional, mesmo se restrita às

\footnotetext{
${ }^{145}$ Nas ciências sociais, o movimento de transição de indivíduos em idade adulta para o mercado de trabalho representa um importante fenômeno de compreensão da dinãmica societal de forma mais ampla, e a sua análise permite destacar outras variáveis que determinam os resultados das transições, a exemplo da raça/cor. No Brasil, ao menos desde o final da década de 1970 estudiosos da área da estratificação (HASENBALG, 1979) têm demonstrado a existência de desigualdades de oportunidades educacionais marcadas pela estratificação racial.
} 
ocupações de atividade econômica agrícola. Essa mobilidade de status foi acompanhada de intensos deslocamentos geográficos, inicialmente em direção à Região Oeste do estado e, posteriormente, em direção à cidade de São Paulo (SAITO, 1961). Nos arredores da capital é que muitas das cooperativas agrícolas foram fundadas. É possível afirmar que foram especificamente três características próprias a essa população que possibilitaram o progressivo desenvolvimento da pequena produção agrícola e da subsquente forma associativa de produção: mudança da situação ocupacional, mudança do tipo de produção e o deslocamento inter-regional dessa população.

Entre 1943 e 1958 a concentração de japoneses nas principais zonas agrícolas do estado de São Paulo (a Noroeste, a Alta Paulista, a Sorocabana e a Zona Velha do Café) passou a diminuir, sendo ao mesmo tempo visível o crescimento da concentração no município de São Paulo e nos seus arredores. Segundo dados do survey, a zona que sofreu maior desconcentração em relação ao total entre 1943 e 1947 foi a Noroeste $(23,6 \%)$, e o local que mais recebeu imigrantes foi o município de São Paulo. Esta tendência se mantém constante para o período entre 1948 e 1952, sendo que 24,9\% deixaram a zona Noroeste e 26,5\% se direcionaram à capital. Entre 1953 e 1958 os números foram $21,5 \%$ e $38,6 \%$, respectivamente.

No ano de 1958 os japoneses e descendentes já se distribuíam em um número variado de ocupações (SCHPUN, 2008), sendo que dos 150.271 entrevistados pelo survey, 84.408 ou cerca de $56 \%$ eram trabalhadores agrícolas e 65.863 ou $44 \%$ estavam distribuídos em ocupações não agrícolas (ver Tabela 1). As mulheres tiveram participação considerável nas ocupações relacionadas a serviços $(34,4 \%)$ e ocupações profissionais e técnicas $(34,3 \%)$. 
Tabela 1 - Pessoas empregadas com 10 anos de idade ou mais por grupo ocupacional e porcentagem de mulheres, 1958.

\begin{tabular}{lccc}
\hline & $\mathbf{N}$ & Empregados & \% de mulheres \\
\hline Total & 150.271 & 100 & \\
Agricultores & 84.408 & 56,2 & 22,1 \\
Profissionais e & & & \\
técnicos & 5.328 & 3,5 & 34,3 \\
Administradores & 1.262 & 0,8 & 1,2 \\
Auxiliares de & & & \\
escritório & 5.088 & 3,4 & 28,8 \\
Comércio & 23.881 & 15,9 & 15,9 \\
Pescadores & 129 & 0,1 & 2,3 \\
Mineiros & 4 & 0 & 0 \\
Transportadores & 3.272 & 2,2 & 0,2 \\
Artesãos & 18.451 & 12,3 & 22 \\
Manuais sem qualificação & 464 & 0,3 & 12,7 \\
Serviços & 7.984 & 5,3 & 34,4 \\
& & & \\
\hline
\end{tabular}

Fonte: The Japanese Immigrant in Brazil, 1964, v.2, p.55, tabela 25.

Estimulados pelo evento da posse de Fábio Yassuda, as matérias jornalísticas da época são fontes documentais que parecem traduzir uma conjuntura social mais favorável à população de origem japonesa em comparação ao período que se estendeu até o fim do Estado Novo (1937-1945). Ou seja, que a partir do final da década de 1940 no Brasil parecia haver um movimento de gradativa mudança nas formas de organização das diferenças sociais e das oportunidades, tendo como resultado um inédito ambiente de maior aceitação desse grupo pela sociedade local e sua incorporação em instâncias variadas da vida social, cujos resultados se faziam valer no sistema educacional, no mercado de trabalho, nas formas de organização coletiva e nos núcleos de poder.

No tópico a seguir procuro problematizar a conjuntura de conformação desse cenário, demonstrando que um exame sociológico detido dos gestores da CAC pode 
contribuir para a produção de conhecimento científico das áreas disciplinares localizadas na interface entre imigração e atividades econômicas.

A partir da análise dos dados empíricos, singularidades emergiram enquanto desafios interpretativos mediante a constatação de que em São Paulo tais processos dependeram fortemente da atuação de lideranças intelectuais, políticas e empresariais da coletividade japonesa local: um círculo de indivíduos que em maior ou menor grau esteve ligado aos gestores da CAC. É desafiador, por um lado, porque demanda acompanhar uma dinâmica processual que opera em âmbitos mais amplos - na transição de regimes políticos, de desenvolvimento econômico e transformações sociais -, bem como sucessões geracionais de imigrantes na composição dessas lideranças e dos núcleos de gestão empresarial. Por outro lado, a natureza do objeto estudado requer um relativismo das explicações estritamente culturais para assumir que as atividades econômicas podem traduzir um conjunto de repertórios advindos de relações extramercantis.

Explicações globais talvez possam oferecer argumentos iniciais para a compreensão do caso dos imigrantes japoneses no Brasil, situando-os em processos mais amplos de oportunidades, progressiva tolerância e aceitação de grupos estrangeiros a partir do período pós-guerra. Contudo, quando se estabelece uma relação causal entre condicionantes estruturais e resultados de processos, os estudos sobre o tema geralmente negligenciam a capacidade de agência de indivíduos, os seus interesses e a importância de suas relações sociais na conformação desses resultados. Na tentativa de complementar os caminhos interpretativos já existentes, o presente estudo move-se por um terreno ainda inatingido pelos estudiosos: a formação e o intercâmbio entre expoentes empresarial e intelectual de origem japonesa em São Paulo, dispostos a formular e conduzir projetos de incorporação. Se fatos que atestassem a incorporação do grupo social na sociedade local foram vislumbrados por essas lideranças, neste capítulo veremos que alguns deles foram justamente consumados no âmbito da Cooperativa.

Ao analisar fenômenos que possuíram lugar no mercado, proponho um caminho investigativo não convencional na literatura brasileira dedicada a grupos migratórios. Considerar que os empreendimentos agrícolas de produção associativa criados por 
imigrantes japoneses - como é o caso da CAC - resguardaram um espaço de atuação relevante para a direção da ação de indivíduos e grupos de origem japonesa que buscavam paulatinamente construir as suas estratégias de incorporação à sociedade paulista, demanda reconhecer que processos sociais envolvendo grupos possuem um eixo dinâmico cuja pluralidade de determinações permite constantes reavaliações.

Insisto, portanto, em um exame das dimensões interdependentes em que a experiência social se manifesta: as atividades econômicas, a política e a cultura. Em posse de dados empíricos que permitem validar os argumentos aqui defendidos, demonstro a conformação dessas dimensões no mercado, como o caso específico dos gestores desse empreendimento parece bem exemplificar.

Figura 16 - Emílio Garrastazu Médici e seus Ministros durante cerimônia de posse presidencial. Em destaque, o Ministro da Indústria e Comércio Fábio Ryodi Yassuda.

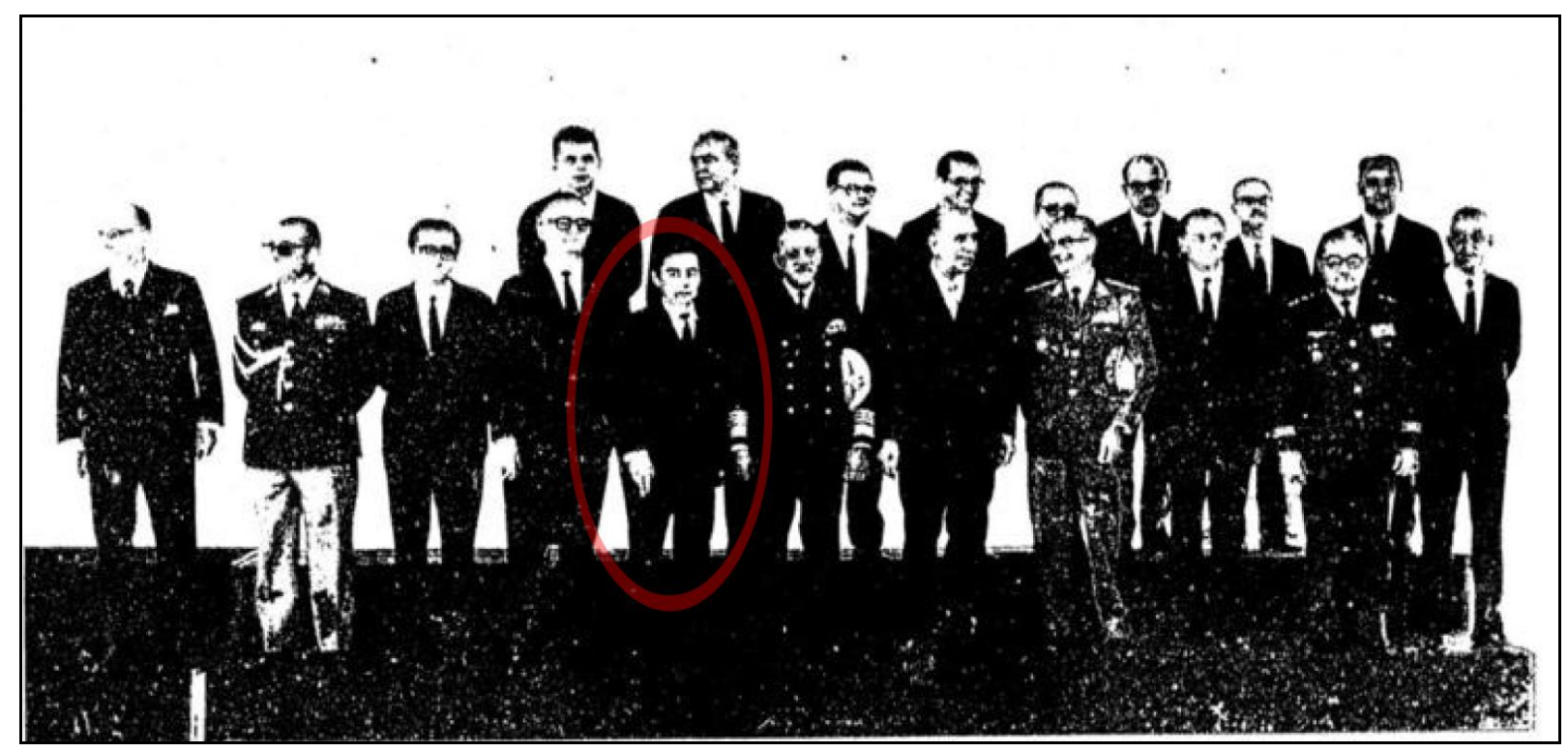

Fonte: Folha de S.Paulo, 31 de outubro de 1969, p.6. 
Figura 17 - General Macedo de Soares (à direita) transfere o cargo de ministro da Indústria e Comércio para Fábio Ryodi Yassuda.

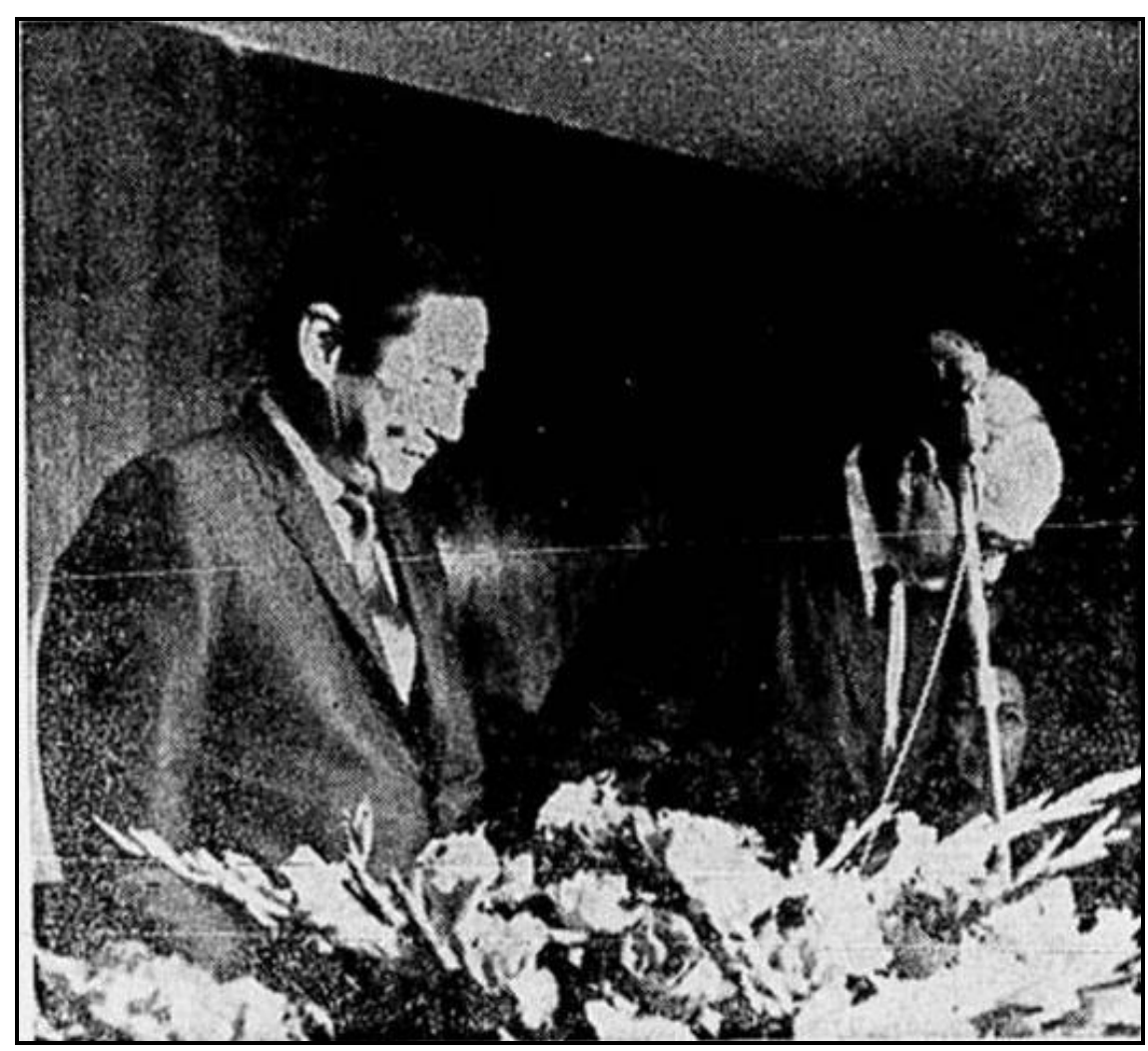

Fonte: Jornal do Brasil, 1 de novembro de 1969, p.1. 


\subsection{Os imigrantes japoneses e a democracia racial}

Sobretudo, no meio nativo, a simbologia que envolve o evento de posse de Yassuda frequentemente assume uma forma narrativa marcada pela positividade: $o$ retrato de uma trajetória ascendente de um indivíduo pertencente a uma família rural, estrangeira, em uma sociedade de destino economicamente dinâmica, que principalmente a partir do final do século XIX acolheu populações de origens diversas. De fato, Yassuda foi o primeiro filho de imigrantes japoneses a assumir um ministério em toda a América Latina, e esse fato era possivelmente motivo de orgulho para aqueles que o viam como um semelhante. Tal sentimento parecia então anunciar a superação dos traumas de um passado recente, em que a violência - física e simbólica - contra a população de origem japonesa fora promovida publicamente pelo próprio Estado brasileiro em um contexto de nacionalismos conflitantes das décadas de 1930 e 1940.

Mas a positividade em questão não esteve contida apenas do ponto de vista exclusivo dos que possuíam a origem japonesa, seja de forma direta, por aqueles que eram imigrantes, seja por seus descendentes que consideravam o Japão uma referência virtual de ancestralidade. Essa positividade parecia traduzir o senso comum, então aceitável na sociedade brasileira, de que a origem japonesa estaria associada a valores e características até mesmo desejáveis. Na São Paulo da década de 1960 promanavam manifestações culturais que, em seu conjunto, produziam um ambiente de maior aceitação desse grupo pela sociedade local - uma espécie de credencial para a sua incorporação em instâncias variadas da vida social. Isso se tornava perceptível, por exemplo, na instrumentalização positiva da figura do indivíduo de origem japonesa ou mesmo do Japão em escolas e universidades, em propagandas de jornal, televisão, e seriados (LESSER, 2008), estratégia essa que parecia produzir um certo fascínio no público consumidor. A produção cinematográfica da época também não deixou de representar, sob formas peculiares, a ideia de que a origem japonesa estava ligada a 
valores positivos, ao trabalho e à produtividade. Neste caso, o filme "Meu Japão brasileiro" (1964), de Amácio Mazzaropi, é possivelmente o exemplo mais evidente ${ }^{146}$.

Conquanto fosse um sentimento majoritário, a associação da população japonesa a valores positivos no Brasil não era sinônimo, contudo, de homogeneidade. Havia ainda aqueles descendentes que por vezes recusaram as valorações a eles atribuídos, como demonstra o estudo de Lesser (2008). Não obstante, a tônica de alguns dos principais meios de comunicação impressos da época era justamente a que associava a ascensão de Fábio Yassuda a uma narrativa de êxito da imigração japonesa no Brasil. No caderno de política da edição de 3 de novembro de 1969 do Jornal do Brasil, uma página inteira apresentava um breve histórico da imigração, tratando de assuntos como a agricultura, as cooperativas agrícolas dos japoneses e as colônias instaladas no estado do Pará. Outro tópico enfatizava a origem de Fábio Yassuda e de sua família. Em destaque, sob o título de "O Nissei", o jornal estampava uma foto de Yassuda, com a seguinte legenda: "Fábio Yassuda comprova a ascensão política da comunidade japonesa no Brasil".

Entre outos exemplos, o que será aqui analisado de forma mais detida é a reportagem especial de nove páginas publicada pela revista Veja em 19 de novembro de 1969. A sua escolha como fonte documental obedece a alguns critérios: tratava-se de um periódico de circulação nacional e, dentre outras publicações, foi aquela em que pudemos constatar uma ênfase maior em associar o evento de posse de Fábio Yassuda e o constructo de que a origem japonesa estaria associada a valores positivos e desejáveis.

A reportagem é composta por duas partes: a primeira, intitulada "A ascensão de Yassuda", relata a carreira e os planos do novo ministro para a sua pasta; a segunda, "Dos frutos da terra à política", é dedicada a considerações sobre a trajetória dos imigrantes japoneses no Brasil, em que foram sublinhadas a relevância da CAC, a presença crescente de filhos de japoneses junto a outros grupos estrangeiros no mercado

\footnotetext{
$146 \mathrm{Na}$ trama, um agricultor, interpretado por Mazzaropi, encontra-se indignado com a presença de atravessadores que o exploram na tarefa de transportar a sua produção. Mazzaropi então junta-se a imigrantes japoneses e decidem fundar uma cooperativa agrícola. Para mais informações sobre a produção cinematográfica e o tema de identidade nipo-brasileira, ver: LESSER, J. Uma diáspora descontente. Os nipo-brasileiros e os significados da militância étnica. São Paulo: Paz e Terra, 2008.
} 
de trabalho e nas universidades e, por fim, a miscigenação. Centremos nossa atenção em alguns trechos da reportagem:

\begin{abstract}
dos seiscentos e poucos mil habitantes de origem japonesa, apenas 170.000 não nasceram no Brasil - prosseguiram a sua revolução na agricultura brasileira. Essa revolução é importante: embora não cheguem a $1 \%$ da população do campo, os japoneses e nisses produzem - ou dirigem a produção de - $6 \%$ do café, $11 \%$ do algodão, $40 \%$ do amendoim, $12 \%$ dos ovos, quase $100 \%$ do chá e da pimenta-doreino, mas de $60 \%$ dos tomates e perto de $30 \%$ das batatas, além de quase $60 \%$ do rami. Isso em nível nacional. em São Paulo, o cinturão verde, que também abastece o Rio, é um cinturão japonês: $90 \%$ dos pepinos, $80 \%$ das abobrinhas, vagens e ervilhas, $70 \%$ dos repolhos e dos carás, das alfaces e das cenouras são "nisseis" [...] O sociólogo Hiroshi Saito (issei, nascido no Japão) explica em seu livro "O Japonês no Brasil" algumas das causas dos alto rendimento da agricultura "japonesa" em comparação com a agricultura "cabocla". Diz Saito que os japoneses vieram para o Brasil, no início, não para ficar, mas com o sonho de todo emigrante: enriquecer e voltar à terra natal. Os caboclos trabalhavam no campo como sempre tinham trabalhado: apenas o suficiente para sobreviver. Os japoneses, além de plantar e colher para comer, procuravam plantar e colher mais, para vender [...]

Tudo isso tornou os japoneses muito mais capazes do que os caboclos - e mesmo mais do que os imigrantes europeus - para a lavoura comercial que começava a surgir junto ao nascente mercado consumidor das cidades. (Veja, 19 de novembro de 1969, p.34-36)
\end{abstract}

Apropriando-se do repertório argumentativo do sociólogo Hiroshi Saito, a reportagem buscava enfatizar a forte presença dos japoneses na agricultura brasileira e, especialmente, no mercado de produtos hortifrutigranjeiros. É interessante observar dois aspectos do trecho acima reproduzido: a legitimidade conferida à narrativa de Hiroshi Saito sobre a imigração japonesa no Brasil, em que a produtividade dos japoneses é comparada e considerada superior à dos "caboclos" e de outros grupos de imigrantes; e o lugar das cooperativas agrícolas no processo de formação de um mercado agrícola de gêneros alimentícios nas grandes cidades. Em seguida, a reportagem conferiu atenção especial à CAC, empresa em que Fábio Yassuda havia ocupado cargos de direção por mais de 20 anos.

Em linhas gerais, os trechos da reportagem em destaque são exemplos oportunos para se constatar que na publicação impressa, de circulação nacional, o cooperativismo agrícola dos imigrantes japoneses ocupava lugar de destaque em uma narrativa de êxito 
da imigração desse grupo no Brasil. E, ao ser considerada o maior empreendimento do setor à época, a CAC era apresentada ao público como o grande expoente de sucesso da coletividade japonesa:

Foi a primeira cooperativa agrícola da América Latina. As cooperativas, as técnicas agrícolas tornaram ainda mais independentes os prquenos lavradores japoneses [...] São mais de 35.000 famílias, 25 nacionalidades - na maior parte, japoneses e descendentes - nas cooperativas fundadas por japoneses: Cotia, Sul-Brasil, Bandeirante, Central Mogi das Cruzes, as maiores do país. Só a Cotia tem 3.500 funcionários e em 1968 exportou, para dezessete países, 8 milhões de dólares. Dela comprarm os alimentos cotidianos e 1 e meio milhão de paulistanos e 1.300 .000 cariocas. Também Brasília, Curitiba, Belo Horizonte dependem, pelo menos para verduras e legumes, dos japoneses e seus descendentes. (Veja, 19 de novembro de 1969, p.36)

Ao apresentar de maneira breve esses dados, reitero a problematização que orienta a análise contida neste capítulo: interpretar processos que possibilitaram uma maior aceitação da população japonesa em São Paulo situando agentes que, em maior ou menor grau, tornaram a CAC um espaço relevante para a construção de relações de poder e de estratégias de incorporação. Essa problematização relaciona mercado e cultura sob o entendimento de que processos que culminaram em um ambiente de maior aceitação social dos japoneses se desenvolveram em confluência com o sucesso econômico de seus maiores empreendimentos agrícolas. 
Figura 18 - Rede de comercialização da produção da CAC, 1970

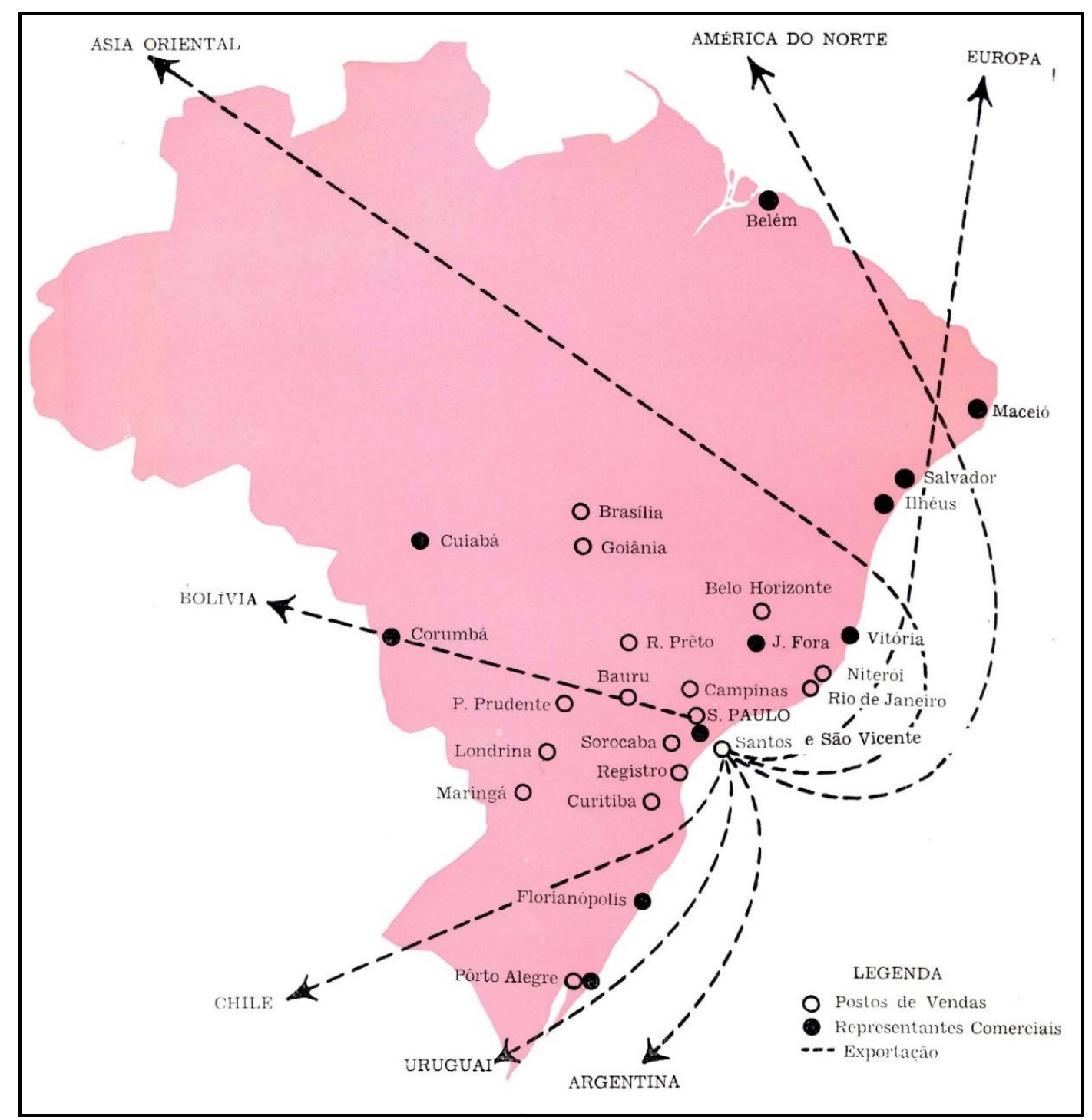

Fonte: Relatório de Serviços Sociais da CAC, 1970.

Neste capítulo procuro demonstrar que esses processos dependeram da forma como, no período pós-guerra e dependendo das condições oferecidas pelo Estado, a sociedade local e os grupos estrangeiros mobilizaram categorias centrais para a conformação de um novo contexto de oportunidades e diversidade social, como 
"nação", democracia", "desenvolvimento" e "raça". Em âmbito relacional, estratos privilegiados da coletividade japonesa se valeram de recursos ao seu alcance para experimentar a sua inserção no meio profissional, intelectual e em núcleos de poder em âmbito político e econômico. Individualmente, certos personagens - especialmente os de segunda geração - foram proeminentes na tarefa de disseminar e validar uma narrativa de sucesso da trajetória migratória, ou mesmo publicizar uma imagem positiva de si próprios enquanto retrato do sucesso por muitos vislumbrado.

A minha opção por abordar, inicialmente, a conformação desse ambiente mais favorável à população de origem japonesa pode ser entendida em seu aspecto propositivo. Ela é engajada em estimular a reavaliação de um constructo: o senso comum, presente no cotidiano da cidade de São Paulo à época da posse de Fábio Yassuda, de que a origem japonesa estaria associada a valores positivos e desejáveis. Essa tarefa não constitui necessariamente uma novidade, pois já há alguns anos o tema vem sendo considerado no campo de estudos dedicado ao tema das identidades étnicas no Brasil, como podemos constatar a partir do trabalho de Lesser (2008). Há um ponto central de discussão que, contudo, permite complementar a interpretação conduzida por esse último autor, produzindo caminhos alternativos de investigação que considerem a importância das atividades econômicas em trajetórias de grupos estrangeiros no Brasil.

Por estar interessado na dinâmica de produção de identidades (nacional e diaspórica), Lesser desconsidera que tal dinâmica é balizada pela estrutura de relações raciais que historicamente caracterizou a sociedade brasileira. Enquanto desdobramento disso, ficam ocultos o papel do Estado em processos de reconfiguração dessa estrutura durante o período do intervalo democrático e a sua continuação durante o regime militar, bem como a formação e a atuação de grupos formados por intelectuais e empresários da coletividade japonesa de São Paulo diante desse cenário. Esse diagnóstico parece ser compreensível na medida em que o interesse do autor incide sobre biografias "descontentes" com as representações que a elas eram atribuídas, fossem elas identidades diaspóricas, nacionais, ou a interrelação destas. O autor aborda, portanto, casos que a partir da década de 1960 ofereceram respostas diversas e 
alternativas às ideias presentes no senso comum a respeito da população japonesa, o que colocou à prova a flexibilidade da produção dessas identidades ${ }^{147}$.

A qualidade investigativa desse útimo autor trouxe inegáveis contribuições para o debate acadêmico dedicado às migrações e ao estudo da construção de identidades por grupos estrangeiros no Brasil. Entretanto, ao olharmos para o extremo oposto das experiências identitárias analisadas pelo autor, deparamo-nos com o fato de que justamente os indivíduos e grupos de origem japonesa em São Paulo que mais estiveram engajados na produção dessas representações positivas sobre a imigração no imaginário coletivo no período pós-guerra têm sido, ainda, pouco estudados. É atribuindo-lhes capacidade de agência em processos transformadores - e considerando-os objeto de estudo - que esta pesquisa procura se situar no debate especializado.

Outra problematização conduzida por este estudo a ser ressaltada decorre da escolha por circunscrever o espaço desses agentes: a tarefa de demonstrar que as atividades econômicas, além de serem ordenadas por uma métrica racional visando a resultados, traduzem a trajetória de um grupo de origem estrangeira, bem como por ela é constituída. Isso porque muitos desses principais personagens engajados em associar a imigração japonesa à positividade foram, ao mesmo tempo, lideranças intelectuais, políticas e empresariais da coletividade japonesa em São Paulo e pertencentes ao círculo de indivíduos ligados à gestão da CAC.

Essa fração de indivíduos pode, à primeira vista, parecer marginal para exigir uma análise sociológica detida. Procuro, no entanto, seguir em direção oposta a essa suposição, e estimulado pelas considerações de Williams (2011) sobre o estudos de grupos, atento para o que eles realizaram e no que seus modos de realização podem nos contar sobre as sociedades mais amplas com as quais eles mantiveram relações. Assim

\footnotetext{
${ }^{147}$ Em seu estudo, o autor analisa, entre outros, casos como o do militante da Vanguarda Popular Revolucionária (VPR), Shizuo Osawa, conhecido como "Mário Japa". Preso em 1970 e vítima de torturas por policiais, Osawa esteve no epicentro do episódio de sequestro do Cônsul-Geral do Japão em São Paulo, Nobuo Okuchi. Seus companheiros realizaram o sequestro com o objetivo principal de libertá-lo da prisão mediante a troca de reféns, o que se concretizou em março daquele ano e contou com grande cobertura da imprensa. Um fato a ser ressaltado é que, se em 1969, com a ascensão de Yassuda, foi possível observar nos meios de comunicação a emergência de uma narrativa que exaltava o êxito da imigração japonesa, o episódio do sequestro do Cônsul novamente tensionou a vigência dessa narrativa: havia filhos de imigrantes japoneses na militância revolucionária capazes de realizar "atos terroristas", segundo a avaliação da época.
} 
como ocorreu como outras coletividades de origem estrageira residentes na cidade de São Paulo na segunda metade do século XX (a exemplo dos sírios e dos libaneses), indivíduos de origem japonesa que transitavam em meio a restritos grupos - geralmente impusionados pelo sucesso profissional, artístico-intelectual ou nos negócios assumiram posições de liderança e visibilidade na "colônia" (ou seja, entre aqueles para quem a ancestralidade adquiria um sentido de pertencimento), bem como inauguraram experiências de incorporação em circuitos restritos de sociabilidade da sociedade local.

Esse tipo seletivo de inserção de grupos e indivíduos parece indicar a reprodução de uma característica própria à sociedade paulista republicana: uma ordem social hierarquizada em que a posse de determinados bens materiais ou simbólicos (ou mesmo a conjunção deles) geralmente representava uma condição de legitimidade necessária para a distinção, capitalizada por lideranças políticas e porta-vozes de coletividades. Mutatis mutandis, frações de indivíduos de origem japonesa residentes em São Paulo buscaram se projetar diante da sua coletividade e perante a sociedade local sob essa lógica de visibilidade social, formulando estratégias diversas que visavam a maior aceitação e garantia de oportunidades para o grupo de pertencimento em períodos de regimes políticos bastante particulares, que intercalaram ditadura e democracia.

Conforme foi demonstrado no capítulo anterior, ao menos desde a década de 1930 o universo social das lideranças de origem japonesa em São Paulo - àquela época centralizada pelos órgãos diplomáticos - passou a incluir, entre outros expoentes do universo empresarial, os gestores da CAC. Principalmente nos anos subsquentes ao término da Segunda Guerra, o empreendimento agrícola esteve no epicentro de um processo simbólico de legitimação que lhe chancelou o título de um dos "três baluartes" da "colônia" japonesa ${ }^{148}$. Assim, no imaginário popular dos japoneses que viviam no

\footnotetext{
${ }^{148}$ A CAC, a Cooperativa Agrícola Sul-Brasil e o Banco América do Sul são considerados os três grandes empreendimentos de imigrantes japoneses no Brasil, segundo a Sociedade Brasileira de Cultura Japonesa e de Assistência Social (Bunkyo), principal órgão nipo-brasileiro, localizado no bairro da Liberdade. No texto "Imagens e Breve Cronologia da Imigração Japonesa no Brasil", podemos encontrar a seguinte menção: "As cooperativas agrícolas de Cotia e Sul-Brasil, juntamente com o Banco América do Sul criado como uma facilidade de crédito para os imigrantes japoneses -, foram acompanhando o ritmo acelerado de crescimento do pós-guerra e se tornaram os principais empreendimentos nipo-brasileiros". Disponível em: $<$ http://www.bunkyo.bunkyonet.org.br/index.php?option=com content \&view=article\&id=64:imagens-ebreve-cronologia-da-imigracao-japonesa-no-brasil\&Itemid=1\&lang=br>. Acesso em: abr. 2013.
} 
Brasil e no imaginário em relação a eles, a Cooperativa passou a representar uma referência constante em múltiplas dimensões, mas principalmente no que diz respeito aos aspectos positivos do trabalho e da agricultura na experiência migratória desse grupo $^{149}$. À frente dessa imagem, estiveram os seus gestores.

Para uma pesquisa interessada na organização de grupos sociais e, principalmente, se desejarmos situar bem o ambiente de maior aceitação da população de origem japonesa a partir do pós-guerra, o período de intervalo democrático (19451964) possui centralidade. Podemos questionar como os grupos passaram a ser paulatinamente reconhecidos e incorporados nos planos político, econômico e cultural, em uma equação capaz de balancear um regime de caráter elitista porém inclusivo em certos aspectos, e ao mesmo tempo em que categorias centrais para a construção de direitos e oportunidades como "nação", "democracia" e "inclusão" foram mobilizados por grupos organizados e pelo Estado, adquirindo novos significados.

De maneira geral, nesse referido período de intervalo democrático, principalmente as cidades de São Paulo e do Rio de Janeiro experimentavam uma efervescência econômica e industrial estimulada por ideias de desenvolvimento que buscavam situá-las nos caminhos da modernização. Os seus efeitos locais tiveram inegáveis desdobramentos para os temas que interessam diretamente ao estudo de grupos estrangeiros, a exemplo de grandes mudanças na composição populacional, a migração rural-urbana, a mobilidade social, a estratificação e a estruturação do mercado de trabalho. Tratou-se de uma modalidade de desenvolvimento econômico transformador, inseparável de processos de industrialização e diversificação estrutural das bases produtivas do país e, também, por estabelecer mecanismos de controle dos interesses organizados das massas pelo Estado, algo que teve início ainda na década de 1930 com Getulio Vargas.

No âmbito do planejamento econômico, tanto a natureza do regime democrático quanto as instituições e atores políticos pareciam moldar a formação e os resultados das

Ademais, "três baluartes" da "colônia japonesa" é uma expressão usada pelo jornalista Osamu Toyama para se referir a esses empreendimentos. Ver: TOYAMA (2009).

149 A exemplo disso, podemos mencionar o caderno especial dos 80 anos da imigração japonesa do jornal O Estado de S. Paulo de 18/06/1988, em que a agricultura e o trabalho cooperativo têm como referência a CAC. 
estratégias de desenvolvimento, ao apresentar continuidades e também rupturas com o regime político anterior. Vertentes econômicas propositivas divergentes encontraram-se em uma arena política e em um quadro institucional diferentes daquele inaugurado por Vargas:

Para além dos valores - e das estratégias econômicas - por meio dos quais uma longa linhagem de economistas democráticos buscara legitimar critérios substantivos de democracia - abria-se espaço para integrar, também, demandas de cepa liberal. A democracia representativa e o ethos da responsabilidade, tal como as demandas por transparência nas decisões políticas e eficiência na gestão dos recursos públicos, emergiram como novos (velhos) valores convertidos em restrições inarredáveis para as novas elites governamentais, por meio da luta política e através de um novo ordenamento legal. (SOLA, 1998, p.21)

Em relação a direitos políticos e ao exercício dos direitos civis, a elaboração da Constituição de 1946 trouxe consigo novidades. Sob forte influência de um léxico trabalhista, partidos políticos nacionais com programas ideológicos definidos e identificados com o eleitorado puderam se (re)organizar, o que também possibilitava, ao menos em tese, a progressiva participação política de grupos que até então haviam contado com pouca representatividade. Contudo, mesmo que o sistema político vigorasse em sua legitimidade por uma lógica competitiva e de qualidade inclusiva, para autores como Sola (1998) e Soares (1973), as arenas decisórias centrais - especialmente a econômica - gozaram de um alto grau de proteção por setores restritos das elites governamentais diante dos interesses de grupos organizados majoritários: "Tratava-se de uma característica distintiva que se apresentava como um paradoxo: o caráter profundamente elitista do populismo à brasileira" (SOLA, 1998, p.21).

A organização de grupos sociais durante o período em questão ocorreu em meio à formulação de um projeto nacionalista, tanto em termos econômicos quanto culturais (GUIMARÃES, 2002, p.86), em que a noção de democracia racial vigorou como um pacto social, um compromisso racial e de classes sob bases material e simbólica, conduzido pelas mãos do Estado: 
em meados dos anos 1950, ao lado de conceitos como "povo" e "nacionalidade", a noção de "democracia" é central no léxico político brasileiro. Ela tem um poder semântico do qual nenhum grupo político pode prescindir, pois marca o afastamento seja da ditadura varguista, seja do fascismo e do nazismo derrotados na II Guerra. À medida porém que os anos avançam, e recrudescem a Guerra Fria e o anticomunismo, acirra-se também a crítica da esquerda à democracia representativa e cresce em seu seio a ideia de democracia como mistificação formal e ideológica. Mas nos anos 1950 ainda prevalece o consenso democrático, embora a democracia já comece a ser adjetivada, o que culmina nos anos 1960: democracia política, econômica, social, cooperativista, socialista, positiva, étnica e (por que não?) racial. São os agrupamentos políticos unidos na luta antifascista que procuram agora se diferenciar e traçar, por meio dos adjetivos, a sua trajetória particular.

A mobilidade da população japonesa e a construção de suas diferenças na sociedade local ocorreram em meio ao funcionamento desse pacto, em um regime democrático em que os conceitos de "cultura" e "classe social" adquiriram maior proeminência diante do conceito de "raça". Conforme apresento mais adiante, o término da Segunda Guerra havia criado um ambiente propício para a reformulação das bases de conflito de tensões de cunho étnico-racial na sociedade brasileira, seja por vias governamentais ou na produção acadêmica. E isso incluía situar o contingente de imigrantes na constituição de um "povo brasileiro". O caso dos imigrantes japoneses parecia ser atraente para colocar à prova uma ideia de sociedade livre de preconceitos, justamente por serem considerados uma população não branca e possuírem traços culturais e costumes bastante distintos dos imigrantes europeus. A categoria biologizante de "raça" amarela, em voga no vocabulário de políticos, médicos e intelectuais das décadas de 1920 e 1930 no Brasil caiu progressivamente em desuso para se referir aos japoneses, enquanto categorias culturais passaram a prevalecer enquanto signos de alusão ao grupo.

Esse sutil, porém poderoso processo de modificação de categorias culturais, foi, ao mesmo tempo, parte de um movimento de escala internacional no pós-guerra - em que o racismo biologizante passou a ser rejeitado enquanto conhecimento de bases científicas pelos Estados nacionais e por órgãos internacionais como a Organização das Nações Unidas para a Educação, a Ciência e a Cultura (UNESCO) -, bem como foi 
suplantado no pensamento social da época pelo repertório argumentativo e conceitual de cientistas sociais dedicados ao estudo de imigrantes no Brasil na década de 1940, como o antropólogo Emílio Willems e, posteriormente, o sociólogo Hiroshi Saito. Cerca de 20 anos separavam o pessimismo do poeta modernista Manuel Bandeira em relação ao conflito étnico-racial na sociedade brasileira, ou o "salão de sangues misturados" - o baile de carnaval em que a figura da "fração incipiente amarela", representada pelo "japonês", podia encontrar apenas momentaneamente a liberdade de dançar maxixe ${ }^{150}$ de um contexto social efetivamente mais favorável em termos de oportunidades e aceitação da população japonesa.

É nesse contexto mencionado que o ambiente de maior aceitação da população de origem japonesa teve início e passou a ganhar contornos mais específicos com a atuação de certos agentes centrais, a exemplo de lideranças do grupo, cujas atividades estiveram concentradas em São Paulo. De forma alternativa à perspectiva de Lesser (2001), para quem "o mundo étnico brasileiro", de imigrantes não brancos e não pretos teria corrido paralelamente à sociedade tradicional preta/branca ${ }^{151}$, acredito que a compreensão da estrutura de relações raciais no período do intervalor democrático é algo imprescindível e preliminar à investigação de grupos estrangeiros em São Paulo. Pois, a construção de uma imagem positiva sobre a população japonesa, residente principalmente em São Paulo, ocorreu enquanto parte de um processo de maior amplitude e sob as bases de uma estrutura de relações raciais, em um contexto de regime político específico na história brasileira.

A perspectiva aqui adotada se baseia no argumento de Fernandes, contido no texto "Imigração e relações raciais" (1965), para quem: “A imigração não contribuiu para alterar, nem de modo imediato, nem a longo prazo, a estrutura do sistema preexistente de relações raciais" (FERNANDES, 2007, p.145). Mais ainda, para o autor, se em alguns aspectos a imigração teria tido pouca ou nenhuma capacidade de alteração dessa estrutura, em outros aspectos ela teria até mesmo a agravado:

\footnotetext{
${ }^{150}$ Ver o poema "Não sei dançar" (1925), de Manuel Bandeira, em: BANDEIRA, M. Libertinagem; Estrela da manhã : edição crítica. Paris:, Edições UNESCO, 1998.

${ }^{151}$ Para este autor, "É explorando o que acontecia fora do continuum preto/branco que poderemos analisar melhor de que forma os encontros culturais geraram as novas etnicidades hifenizadas, que tinham em comum, todas elas, sua brasilidade" (LESSER, 2001, p.31).
} 
Ao que parece, a imigração tornou-se um fator neutro em face da democratização das relações raciais porque o que se poderia chamar de "problema" negro" não chegou a afetar o desenvolvimento da ordem social competitiva. Deixando de ser mão de obra privilegiada e, por qualquer razão, fator ou impedimento de crescimento econômico, o "negro" perdeu importância histórica para o branco. Nada poderia envolver os imigrantes, portanto, nas malhas dos interesses ou dos valores sociais que se vinculariam com a implantação da democracia racial. A imigração também teria sido neutra com as circunstâncias históricas que a convertiam, espontânea e inevitavelmente, num fator de concentração racial de renda, do prestígio social e do poder. Foi graças a essa razão, aliás, que ela contribuiu para agravar, de maneira evidente, as aparências e a realidade da desigualdade racial [...]

Se a imigração repercutiu dramaticamente nas manifestações da desigualdade racial, isso se deu porque ela era um dos fatores da aceleração do crescimento econômico e do desenvolvimento social da comunidade. Os grupos que contavam com posições mais ou menos vatanjosas na estrutura de poder e de competição, também contavam, naturalmente, com as oportunidades mais vantajosas de participação nesses dois processos. Na verdade, como a estrutura do sistema de relações raciais excluía o "negro" de tais oportunidades, os brancos praticamente monopolizaram as vantagens dela decorrentes. Tudo isto que dizer que a imigração apenas agravou, como e enquanto fator histórico, as diferentes expressões assumidas pela desigualdade racial na vida social do negro e do mulato. (Fernandes, 2007, p.150-51)

Em sua análise, Florestan Fernandes pretendeu avaliar o impacto causado pela imigração, enquanto fator estrutural e dinâmico, nas relações raciais em São Paulo, ao sugerir que a "A imigração se adaptou às inconsistências do sistema brasileiro de relações racias" (Fernandes, 2007, p.132). Dando continuidade à afirmação desse autor, acredito que é considerando o continuum preto/branco - e a estrutura de relações raciais que lhe sustenta - que a conformação de processos de mobilidade e de aceitação cultural da população japonesa pode ser analisada nesta pesquisa. Isso porque se os processos envolvendo esse grupo ocorreram dentro de uma estrutura de relações raciais que privilegia indivíduos brancos, a população japonesa em São Paulo teve que reivindicar um lugar à imagem da realidade de uma sociedade competitiva, economicamente dinâmica e marcada por desigualdades raciais em âmbito estrutural.

Amparados pela breve exposição do contexto em que a anteriormente citada reportagem foi publicada, podemos então intepretá-la, buscando compreender os significados pelos quais a sua segunda seção teve início com o subtítulo: "Levou quase 
300 anos para os 'portugueses do Brasil' se considerarem brasileiros. Para os japoneses do Brasil, demorou muito menos ${ }^{152 "}$. O destaque conferido a essa afirmação sugere que os editores da reportagem se sentiam bastante à vontade para tecer algumas conclusões a respeito de questões sobre nacionalidade e incorporação dos japoneses, destacando a sua rápida identificação com o que se considerava enquanto "nação brasileira".

A miscigenação também foi uma questão abordada, uma vez que a reportagem acreditava até então ter oferecido ao leitor os argumentos suficientes para a sua explicação - e isso incluía recorrer a argumentos científicos providos por uma interpretação bastante arbitrária da obra de Hiroshi Saito. Em uma espécie de releitura de ideias miscigenacionistas defendidas durante a década de 1930 por autores como Bruno Lobo, a reportagem não deixava de sugerir que a aceitação das diferenças da população de origem japonesa deveria ceder suas aspirações a um ideal de brancura para adquirir legitimidade:

E um fenômeno estranho, para o qual não existem palavras em japonês [...] começou a acontecer no Brasil: a miscigenação crescente [...]

Numa palestra para um auditório só de japoneses, o sociólogo Hiroshi Saito pediu para levantar a mão quem tivesse um filho, sobrinho ou primo casado com pessoa "brasileira". Surpresa para Saito: quase todos levantaram a mão ${ }^{153}$.

A legenda de uma foto de página inteira então publicizava o saldo positivo de uma miscigenação desejável e o devir por ela exemplificado: "O japonês lourinho: é Moacyr Júnior, de dois anos, filho de Moacyr Gomes, gerente de banco em Tomé-Açu, Pará, e de Graziela Taeko Gomes"154.

\footnotetext{
${ }^{152}$ Veja, 19 de novembro de 1969, p.34.

${ }^{153}$ Veja, 19 de novembro de 1969, p.37.

${ }^{154}$ Veja, 19 de novembro de 1969, p.35.
} 
Figura 19 - Moacyr Júnior, o “japonês lourinho”.

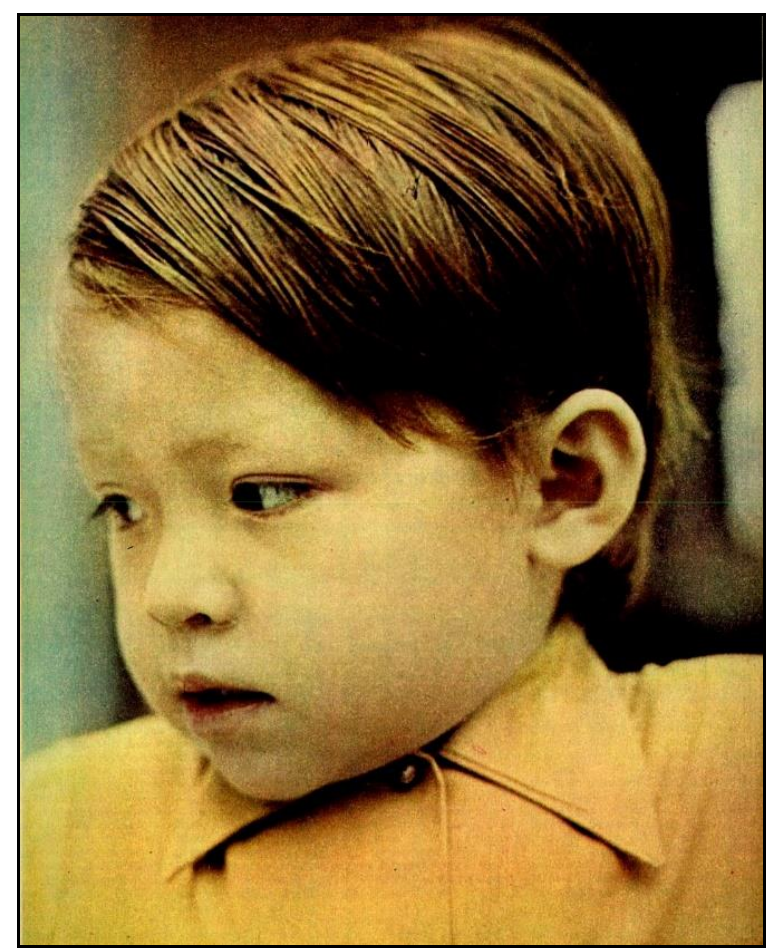

Fonte: Veja, 19 de novembro de 1969, p.35.

Em um contexto específico de produção acadêmica no Brasil - justamente no período entre as décadas de 1940-1960 - o casamento interétnico era apresentado, no plano cultural, como um importante indício positivo de avaliação da adaptação de imigrantes no Brasil. A diferença dessa perspectiva em relação às miscigenacionistas era, possivelmente, a proeminência dos fundamentos culturais de explicação em detrimento dos biológicos. Para Maio, o Brasil do pós-guerra era visto por organismos internacionais (como a UNESCO) "como o 'laboratório sócioantropológico' privilegiado para desqualificar a importância conferida aos constructos raciais em nome da promissora experiência de miscigenação e assimilação" (MAIO, 1999, p.19). Essa é uma avaliação importante que permite situar a produção pioneira sobre os japoneses no Brasil pelas ciências sociais brasileira, inaugurada no início da década de 1940 com os 
trabalhos do antropólogo Emílio Willems e do etnólogo Herbert Baldus. O primeiro havia nascido na Alemanha ${ }^{155}$, e o segundo era filho de imigrantes alemães.

No âmbito do interesse da UNESCO em realizar pesquisas centradas em temas como tensões, conflitos étnicos e relações raciais em vários países do mundo pósguerra $^{156}$, Willems foi autor de um relatório sobre o caso dos imigrantes no Brasil publicado em 1955, como parte de uma publicação intitulada "The Positive Contribution by Immigrants" ${ }^{157}$. Em síntese, em seu relatório Willems argumentou que o estudo da contribuição dos imigrantes no Brasil ocorreria majoritariamente pelo caminho do desenvolvimento econômico e da vida cultural do que da estrutura política. No tópico "Assimilação e casamento interétnico como meio de eliminação de tensões", o autor reconhece, no Brasil, a existência do casamento interétnico como um "postulado" e um instrumento ideológico de lealdade política. Do ponto de vista da sociedade majoritária, o objetivo final da homogeneidade de grupos culturalmente heterogêneos seria a produção da "raça brasileira":

The ruling Luso-Brazilian majority was unwilling to conceive of a national society other than in terms of a culturally homogeneous structure striving toward a 'Brazilian race' to be achieved by intensive intermarriage. Whatever the wishful image of a 'Brazilian race' is, it certainly centres round the idea that the darker strains will eventually be absorbed by the lighter ones. (WILLEMS, 1955, p.143)

\footnotetext{
155 Para mais informações, ver EUFRASIO, M. Apresentação da Tradução. Mudança cultural entre imigrantes japoneses no Brasil, no Vale do Ribeira de São Paulo". PLURAL, Revista do Programa de Pós-Graduação em Sociologia da USP, São Paulo, v.19.1, p.135-138, 2012. Ver também, no mesmo número da revista, o artigo "Mudança cultural entre imigrantes japoneses no Brasil, no Vale do Ribeira de São Paulo" (1942), de Emilio Willems e Herbert Baldus, traduzido por Gustavo T. Taniguti.

156 Para mais informações sobre o projeto UNESCO sobre relações raciais, ver: PEREIRA; C.; SANSONE, L. (Org.). Projeto Unesco no Brasil. 1.ed. Salvador: EDUFBA, 2008; e MAIO, M.C. O projeto UNESCO: Ciências Sociais e 'credo racial brasileiro'. S.Paulo, Revista da USP, n. 46, p. 115-128, 2000.

157 A publicação The Positive Contribution by Immigrants (1955), foi organizada pelo sociólogo Oscar Handiin (Harvard) e pelo economista Brinley Thomas (University College, Cardiff) parte da série Population and Culture, publicada pela UNESCO. A publicação continha relatórios sobre os seguintes países: Argentina, Austrália, Brasil, Reino Unido e Estados Unidos. Foi uma publicação que surgiu como desdobramento da Conferência Geral da UNESCO de 1952. A execução das pesquisas foi realizada com apoio da International Sociological Association e à International Economic Association, posterior a um simpósio sobre as "Contribuições Positivas dos Imigrantes".
} 
Vale informar que Willems, também um imigrante ${ }^{158}$, estava bastante engajado no debate público sobre o tema da assimilação de grupos estrangeiros no Brasil, seja pelos grandes jornais como O Estado de S.Paulo ou periódicos especializados como a Revista Imigração e Colonização (NUCCI, 2010). Em 1945, o autor afirmara na Revista de Estudos Pedagógicos que: "palavras como "quisto", “enquistamento", "afinidade étnica", "inassimilabilidade", "miscibilidade", e outras exercem na boca de sociólogos bisonhos o efeito de embasbacar o público" (WILLEMS, 1945, p.173). Para bom entendedor, isso representava um ataque frontal à presença ideológica do eugenismo no debate sobre imigração. Ainda que o autor possuísse ressalvas ao ideal de "raça brasileira" então vigente, o seu arcabouço argumentativo residia em aspectos do contato cultural entre grupos. E, dessa forma, as suas posições acerca do preconceito e o racismo contra os japoneses encontravam nos processos de aculturação - especialmente no casamento interétnico - uma evidência empírica capaz de produzir contraargumentos substantivos.

Sobretudo, Willems enfatizava a necessidade de se considerar um relativismo em situações de casamento interétnico, ou seja, que o matrimônio com um japonês dependia não somente do estrangeiro, mas também do brasileiro:

Não há necessidade de apontar as diferenças culturais em geral entre japoneses e brasileiros, nem tão pouco o grau de integração relativamente alto das instituições trazidas pelos imigrantes nipônicos [...]

O nosso estudo restringe-se á miscigenação e esta é condicionada sobretudo pela organização da família.

Em outras palavras: um aumento da miscibilidade dos japoneses depende, em primeiro lugar, da desintegração da família nipônica no meio brasileiro.

O problema da miscibilidade do japoneses (e de outros grupos étnicos) apresenta ainda um outro aspecto que é geralmente esquecido quando se afirma que "japonês não se casa com brasileiro". Evidentemente, o casamento é um ato bilateral e sua realização não depende apenas da vontade de um dos contraentes. Importa saber, não somente se o japonês aceita o brasileiro, mas também se o brasileiro aceita $o$ japonês como cônjuge. As experiências que resultam do contato com imigrantes japoneses, na população de São Paulo, levaram, presumivelmente, à formação de atitudes mais ou menos definidas com relação a esse grupo racial. A afirmação gratuita de que "no Brasil não existe preconceito racial" não nos pode

\footnotetext{
158 De acordo com Villas Bôas, a experiência de imigrante constituiu uma das fontes subjetivas da originalidade e fecundidade intelectual de Emilio Willems. Para mais detalhes, ver VILLAS-BÔAS, G. De Berlim a Brusque, de São Paulo a Nashville - a sociologia de Emílio Willems entre fronteiras. Tempo Social, v. 12, n. 2, p. 172-73, 2000.
} 
demover do intuito de examinar e reexaminar esse problema toda vez que nos parecer conveniente ou necessário. (Willems, 1948, p.108-109, grifos meus)

O fato é que a eliminação de tensões étnico-raciais representava, no âmbito da produção de conhecimento, uma solução para conflitos entre grupos no contexto brasileiro pós-guerra, uma perspectiva influenciada por autores estrangeiros e formulada nas duas principais e então promissoras instituições acadêmicas de ciências sociais recém-criadas em São Paulo: a Escola Livre de Sociologia e Política (ELSP) e a Faculdade de Filosofia, Ciências e Letras (FFCL), esta última em que Willems viria ocupar a primeira cadeira de professor de antropologia em 1949.

O pacto político e de classes que sustentou as bases do mito da democracia racial e a aceitação das diferenças da população japonesa no intervalo democrático foram, portanto, fenômenos que tiveram relações mais profundas do que costumamos observar na literatura sobre estudos migratórios, possuindo também desdobramentos e continuidades no regime político seguinte em que Fábio Yassuda foi consagrado. Essa aceitação pode ser entendida como um processo singular, ocorrido na sociedade brasileira, cuja compreensão demanda considerar, ao menos do ponto de vista mais amplo, a estrutura de relações raciais historicamente vigente no país e o papel do Estado na conformação de maior ou menor oportunidades e direitos. A isso se somam aspectos da organização social do grupo analisado, especialmente a mobilidade dos japoneses, o seu tipo de inserção na sociedade local e o advento da guerra, situação esta que foi central para a redefinição das identidades reclamadas por grupos estrangeiros no Brasil ao longo do século XX.

Sob essas condições é que estratos privilegiados da coletividade japonesa se valeram de recursos ao seu alcance para experimentar a sua inserção no meio profissional, intelectual e em núcleos de poder em âmbito político e econômico da sociedade paulista. Um olhar detido em certas biografias, por sua vez, permite-nos demonstrar como esses personagens se empenharam em disseminar e validar uma narrativa de sucesso da trajetória migratória, muitos deles que em maior ou menor grau estiveram ligados à CAC. Examino a seguir dois casos que nos fornecem dados capazes 
de sustentar essas afirmações. São eles o Jornal Paulista e o ingresso do filho de japoneses Yukishigue Tamura na vida política.

\subsection{O Jornal Paulista e os primeiros políticos de origem japonesa}

Talvez um exemplo analiticamente profícuo da relação entre o pacto político e de classes que sustentou as bases do mito da democracia racial e a aceitação das diferenças da população japonesa no intervalo democrático a que me refiro seja o artigo intitulado "Democracia racial", publicado no segundo número do Jornal Paulista, de 4 de janeiro de 1947. Ele deixa explícito a crença dos editores do jornal na inexistência do racismo no Brasil e as suas consequências para os imigrantes japoneses. Impresso em São Paulo, o Jornal Paulista teve o seu primeiro número lançado em 1 de janeiro de 1947 e, quanto à tipografia, caracterizava-se por ter a primeira página publicada em língua portuguesa e as restantes em língua japonesa. O seu conteúdo era diversificado, abrangendo temas sobre política, economia, esportes, bem como era recorrente trazer aos seus leitores notícias do Japão.

A nova constituição brasileira, promulgada no ano anterior, permitia a publicação de periódicos em língua estrangeira, impulsionando a reorganização da imprensa japonesa, silenciada durante quase uma década. Desse modo, em $1^{\mathrm{o}}$ de dezembro de 1946 eram editados o São Paulo Shimbun, o Nanbeijiji e o Brasil Jihô e, no ano seguinte, era publicado o Jornal Paulista (HANDA, 1987, p.666). Tratava-se de uma publicação que reunía a intelectualidade de origem japonesa, alguns deles oriundos da extinta Liga Estudantina Nipo-Brasileira, bem como possuía suporte financeiro e também ideológico de Kenkiti Simomoto, líder-fundador da CAC. Vejamos trechos do artigo em questão:

Os "Diários Associados" anunciaram recentemente a sua intenção de favorecer a integração de alienígenas ao meio social brasileiro, tomando a iniciativa de educar 
às suas expensas alguns filhos de japoneses. O exemplo é edificante e fala mais a favor da tese que sustentamos sempre: a ausência do preconceito racial e a boa vontade para com os estrangeiros, que caracterizam o Brasil. [...]

A tendência geral do Brasil é receber de braços abertos todos os estrangeiros e viver em harmonia com eles e seus descendentes, sem perguntar da sua ascendência. Nesse ponto ele poderá se orgulhar de ser um dos povos mais democráticos, senão o mais democrático do mundo. Tal índole do povo brasileiro não deve ser nunca esquecida pelos japoneses e seus descendentes, muitos dos quais, mal orientados ainda pelas doutrinas antiquadas e racistas, parecem perdidos em ideias e pensamentos inadequados, quando não prejudiciais ao Brasil. ("Democracia racial". Jornal Paulista, 4 de janeiro de 1947, p.1, grifos meus)

O Jornal Paulista foi criado em substituição aos já mencionados boletins informativos produzidos em 1946 pelo grupo "esclarecido" ou "derrotista" dentro da coletividade japonesa de São Paulo (isto é, aqueles que admitiam a derrota do Japão na Segunda Guerra Mundial). Não por acaso a sua criação teve o apoio direto de Kenkiti Simomoto, conforme demonstrarei adiante a partir de relatos. O jornal se propunha a representar uma reação crítica à expansão do ultranacionalismo japonês, ao defender abertamente a integração à sociedade e cultura brasileira como forma de ascensão social dos japoneses e seus descendentes no país ${ }^{159}$. Recusar o ultranacionalismo japonês e admitir a crença na inexistência de preconceito racial no Brasil parecia ser a forma encontrada para a construção de um novo ambiente de maior tolerância em uma nação democrática.

A equipe que fundou o periódico era composta pelo tradutor José Yamashiro (colunista), Hideo Onaga (redator-chefe), Massaki Udihara (colunista), Shuichi Takeuchi (diretor), Yoshiomi Kimura (redator-chefe da parte japonesa), Tokuya Hiruta (gerente), e Hiroshi Saito, que naquele mesmo ano se matriculou como estudante de graduação em Ciências Sociais na Escola Livre de Sociologia e Política de São Paulo ambiente intelectual que lhe permitiu o contato com renomados cientistas sociais da

\footnotetext{
${ }^{159}$ Exemplos da posição dos editores pode ser conferida em artigos como: "Volta à ação os facínoras da 'Shindo-Renmei"" (7 de janeiro de 1947), "A fixação do imigrante japonês" (1 de fevereiro de 1947), "Anti-niponismo?", de Shomei Kobayashi (8 de fevereiro de 1947), "Da mentalidade japonesa", de José Yamashiro (8 de fevereiro de 1947), "Tabus destronados", de Hiroshi Saito (15 de fevereiro de 1947), "O japonês é excelente homem do campo" (22 de março de 1947), "A derrota é uma verdade absoluta" (8 de outubro de 1947).
} 
época, como Emilio Willems, Roger Bastide, Oracy Nogueira, Donald Pierson, Charles Wagley, entre outros. Foram essas relações que permitiram o contato de Hiroshi Saito com o antropólogo japonês Seiichi Izumi, para quem trabalhou coletando dados de campo sobre a população japonesa no Brasil nos anos de 1951 e 1952, no âmbito de uma pesquisa da UNESCO interessada em avaliar conflitos intergrupos no contexto pósguerra $^{160}$.

$\mathrm{Na}$ equipe do Jornal Paulista, os ex-membros da Liga Estudantina NipoBrasileira, ex-editores do jornal Gakusei, da revista Transição, e também signatários do "Manifesto de brasilidade" (1942) eram: José Yamashiro, Hideo Onaga e Massaki Udihara. A respeito de sua participação no Jornal Paulista, José Yamashiro e Hideo Onaga relataram em reunião realizada em 11 de agosto de 1989, denominada "A Liga revisitada meio século depois":

- José Yamashiro: "No pós-guerra, em meio à confusão criada pelo conflito entre 'esclarecidos' e 'vitoristas', participei da fundação do Jornal Paulista com o Hideo e outros companheiros do extinto Nippak Shinbun como Shuichi Takeuchi (diretor), Tokuya Hiruta (gerente do novo jornal) e Yoshiomi Kimura (redator-chefe da parte japonesa)."

- Hideo Onaga: "Fui convidado para ser o diretor legal do jornal. Fui falar com o sr. Kenkiti Simomoto - líder da Cooperativa Agrícola de Cotia e também um dos próceres do movimento esclarecedor (em relação ao fim da guerra). Ele era um grande esteio moral e financeiro do grupo fundador do jornal, destinado a informar a verdade sobre o fim da guerra com a derrota do Japão, pois a maioria dos japoneses do Brasil não acreditava no revés militar do seu país. A única condição que impus foi: não conheço o idioma japonês, então precisamos fazer uma página em português. Assim surgiu a página portuguesa do Jornal Paulista, cuja publicação começou a $1^{\circ}$ de janeiro de $1947^{\prime \prime}$.

"Não foi propriamente uma continuidade, mas as idéias defendidas na Transição foram defendidas no Jornal Paulista e fomos um pouco adiante e aí foi uma briga danada...” (COMISSÃO, 1992, p.187)

\footnotetext{
${ }^{160}$ A pesquisa da UNESCO era intitulada "The nature of conflict - studies on the sociological aspects of international relations", foi coordenada por Robert C. Angell, Raymond Aron, T. H. Pear, o Centre d'Etudes Sociologiques (Paris) e Tom Bottomore. A participação do Japão ocorreu por incentivo do Ministério da Educação e da Associação Japonesa de Ciências Culturais, sendo liderada por Tomoo Otaka (coordenador), Kunio Odaka e Seiichi Izumi. Ao total, cerca de 50 cientistas sociais japoneses estiveram envolvidos no estudo de nove grupos, entre os quais os japoneses do Brasil. O relatório principal da pesquisa foi publicado em 1957. Os relatórios produzidos por Izumi e Saito foram publicados somente no Japão. Em português, Izumi publicou o capítulo "A Estrutura da Psicológica da Colônia Japonesa" no livro Assimilação e integração dos Japoneses no Brasil (1973), organizado por Hiroshi Saito e pelo antropólogo Takashi Maeyama.
} 
O Jornal Paulista foi o veículo impresso de circulação periódica de um grupo restrito que, sob os auspícios do maior empreendimento da coletividade japonesa de São Paulo, a CAC, congregava intelectuais, estudantes, jornalistas, militantes, artistas, políticos e profissionais liberais que tiveram vínculos em maior ou menor grau com o empreendimento agrícola. Nesta pesquisa, a análise do jornal se limitou ao conteúdo de sua primeira página, em língua portuguesa, entre 1947 e 1948. É justamente nesse período que, acredito, o engajamento político de seus editores em questões relacionadas ao racismo, ao preconceito e à aceitação social dos japoneses se apresentou de maneira mais direta por meio de reportagens.

Isso não significa que outras publicações não tratassem de temas próximos, envolvendo nacionalidade, incorporação, traços culturais e imigração: a revista Jidai (Era) é outro exemplo de periódico que expunha pontos de vista de uma pequena fração de intelectuais de origem japonesa em São Paulo, o já mencionado grupo Doyokai (Grupo do Sábado), fundado em 1946. Foi na revista Jidai que Hiroshi Saito publicou um de seus primeiros artigos de caráter sociológico, justamente refletindo sobre a questão da assimilação de imigrantes japoneses no Brasil, cujo título em português seria, aproximadamente: “A questão da assimilação" (1946). A despeito da existência de outras fontes documentais que possam contribuir para a tarefa de reconstituir o universo intelectual dos japoneses em São Paulo, o Jornal Paulista adquire centralidade para esta pesquisa por ter sido fundado, segundo os seus membros, enquanto um veículo de comunicação declaradamente engajado, em consonância com as posições políticas de Kenkiti Simomoto e com o apoio financeiro da CAC. Vale ressaltar que, no universo da população japonesa residente no estado de São Paulo à época, a posição assumida pelo jornal era considerada minoritária e não consensual, o que revela o estado heterogêneo da produção de ideias por esses imigrantes.

Empiricamente, o Jornal Paulista é o periódico que permite identificar de forma mais direta, no período pós-guerra, a abrangência do empreendimento agrícola em instâncias da vida social que extrapolam o universo dos resultados econômicos. Em outras palavras, o jornal lidou publicamente com os temas considerados por seus 
editores como indispensáveis à construção de uma narrativa que fosse capaz de contestar os argumentos contrários à aceitação dos imigrantes japoneses no Brasil, inclusive do ponto de vista científico, tendo o caso da CAC como exemplo central.

Foi em 1954 que o primeiro estudo sociológico dedicado inteiramente à CAC teve início e foi publicado no meio acadêmico ${ }^{161}$. Trata-se da pesquisa de mestrado em sociologia de Hiroshi Saito, sob orientação do sociólogo norte-americano Donald Pierson, intitulada "O cooperativismo e a comunidade: caso da Cooperativa Agrícola de Cotia". O interesse do autor pela Cooperativa então ultrapassava o simples fato de que esse era um dos maiores e mais representativos empreendimentos cooperativistas à época no Brasil. O inegável sucesso econômico do empreendimento era um dado atrativo, pois poderia representar uma evidência da adaptação dos japoneses no Brasil, em perspectiva bastante próxima à de Emilio Willems. É válido ressaltar que tanto na pesquisa de mestrado de Saito quanto no restante de sua obra dedicada à imigração japonesa praticamente não há menções aos acontecimentos da Segunda Guerra. Constatação essa que evidencia a orientação mais geral conferida pelo autor aos seus escritos, centrada em atestar cientificamente a por vezes contestada capacidade de assimilação dos japoneses no Brasil em âmbito cultural.

No prefácio à sua pesquisa de mestrado, Donald Pierson reforçou os argumentos que sustentavam a hipótese da "transplantação" de um complexo cultural (o cooperativismo agrícola japonês) para outra localidade, e os elementos que permitiram ou facilitaram a "incorporação" do grupo social japonês na sociedade brasileira. Tal perspectiva privilegiava o contato entre grupos portadores de traços e costumes distintos. Por pressupor que desse contato decorreria um inerente processo de "aculturação", Hiroshi Saito entendia que as formas sociais internas de organização dos japoneses - e cuja característica associativa teria destaque - possuíam funções específicas, mas que progressivamente estariam desvanecendo. Em sua interpretação, as mudanças experimentadas pela Cooperativa seriam, portanto, indícios de que a população japonesa estaria se "integrando" à sociedade brasileira, ou seja, "deixando de

\footnotetext{
${ }^{161}$ Inicialmente em uma série de artigos na revista Sociologia e, posteriormente (1964), sob o formato de livro.
} 
ser imigrante" (SAITO, 1964, p.168). Assim, a Cooperativa passava a ser, a um só tempo, produtora e objeto de conhecimento.

Para Taniguti e Jesus (2012), o sociólogo japonês Hiroshi Saito teve importância central na institucionalização dos estudos sobre japoneses no Brasil. Trata-se de um imigrante que havia deixado as lavouras de algodão no interior paulista e, ao ingressar na atividade jornalística, engajou-se em questões diretamente relacionadas à vida dos imigrantes japoneses no Brasil. Posteriormente, no início da década de 1950, Saito construiu uma carreira no restrito meio acadêmico da época. A partir de seu contato como informante de campo de Emílio Willems na década de 1940, o jovem estudante japonês levou adiante o objetivo de construir uma narrativa sobre a imigração japonesa no campo das ciências sociais brasileira ${ }^{162}$, e o fez sob forte influência de autores norteamericanos ${ }^{163}$ que obteve contato na Escola Livre de Sociologia e Política. Ademais, a partir da década de 1950 a legitimidade do argumento científico de Hiroshi Saito a respeito da imigração japonesa no Brasil se disseminou e não deixou repercutir fora do âmbito acadêmico, a exemplo da interpretação de Fábio Yassuda sobre o papel do cooperativismo na agricultura nacional ${ }^{164}$.

\footnotetext{
${ }^{162}$ Em artigo publicado no Jornal Paulista em 1947, ano em que ingressou no curso de sociologia, Saito afirmou: "São raros os estudos de caráter científico sobre os imigrantes japoneses no Brasil e seus descendentes. Se, no campo da sociologia, há alguns estudos sobre a assimilação, ou melhor, a acultaração japonesa neste país, estudos esses realizados por cientistas brasileiros, como o eminente professor Emílio Willems, pode-se afirmar que não existe até agora, relativamente aos característicos somáticos dos imigrantes e sua modificação nos descendentes, nenhum estudo antropológico, em flagrante contraste com os Estados Unidos [...]

Pelo que posso aquilatar, não há nisseis que estejam presentemente decididos a contribuir para os estudos do processo aculturativo da imigração japonesa, estudos esses de vital importância para a solução dos problemas com que se defrontam issei e nissei. Não deixa de ser lamentável essa constatação" (SAITO, H. As modificações somáticas dos descendentes de japoneses. Jornal Paulista, 5 de março de 1947, p.1)

163 "Nesse campo, constitui obra de relevante interesse os célebres e já clássicos estudos de Franz Boas, falecido em 1942, sobre as modificações somáticas apresentadas pelos descendentes de imigrantes europeus nos Estados Unidos, seguindo-lhe outros autores não menos notáveis como Shapiro, Davenport, Herskovits e Goldstein, todos, direta ou indiretamente, influenciados pelo primeiro, chamado por essa razão o 'pai da antropologia americana'". (SAITO, H. As modificações somáticas dos descendentes de japoneses. Jornal Paulista, 5 de março de 1947, p.1).

${ }^{164}$ Ver: YASSUDA, F.R. O cooperativismo e a organização rural. In: O japonês em São Paulo e no Brasil. São Paulo: Centro de Estudos Nipo-Brasileiros, 1971, p.181-190.
} 
Figura 20 - Hiroshi Saito (em destaque) na sede do Jornal Paulista, no Bairro da Liberdade. São Paulo, maio de 1949.

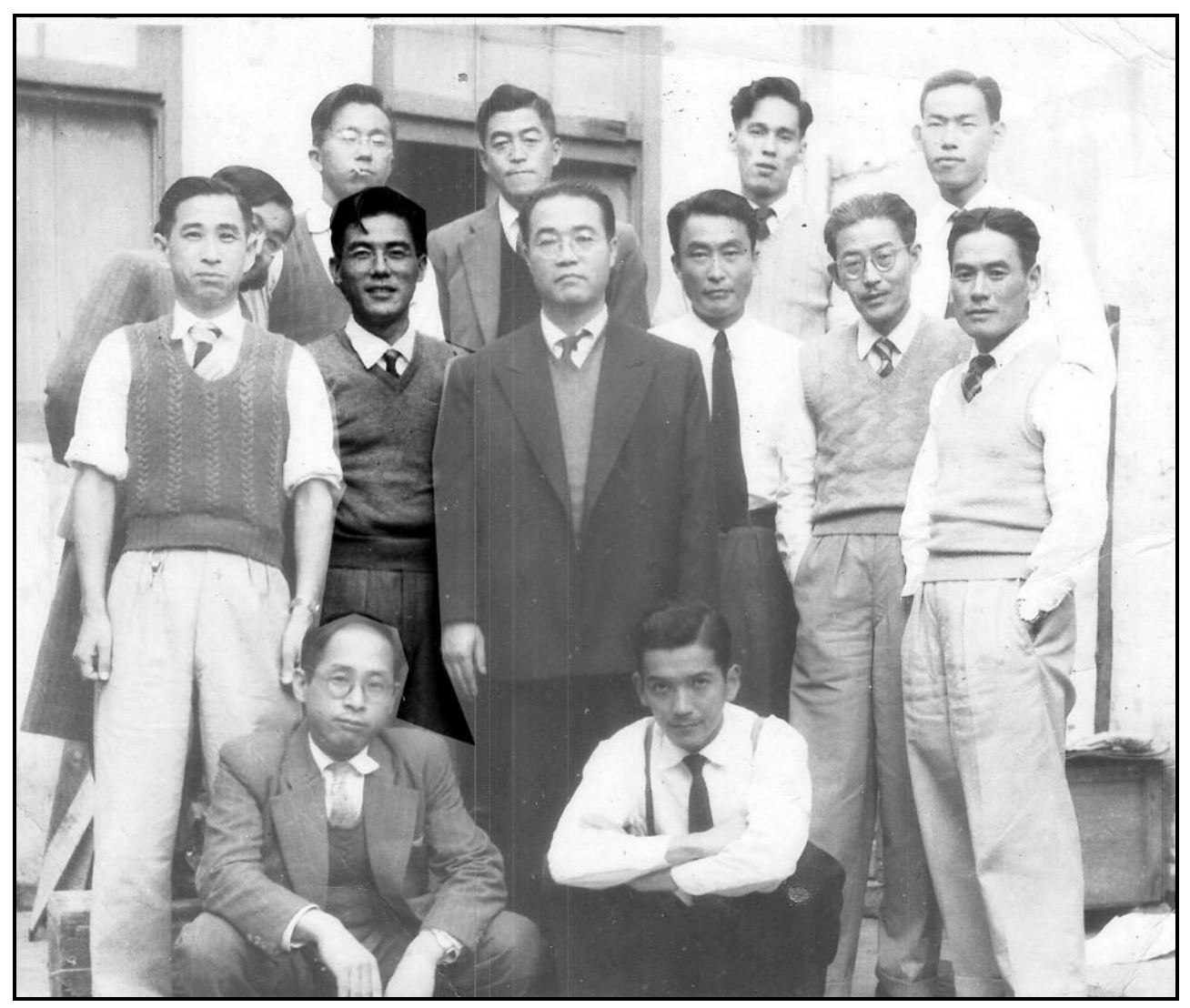

Fonte: acervo da família Saito.

O Jornal Paulista constitui, assim, uma fonte documental relevante que indica a forte relação da CAC com uma fração intelectualizada da coletividade japonesa em São Paulo. A sua criação na segunda metade da década de 1940 foi possível em um contexto político democrático, sendo válido ressaltar que o engajamento de grupos sociais organizados por meio de jornais não foi uma exclusividade dos imigrantes japoneses ${ }^{165}$. Contudo, o periódico apresenta características que não se resumem apenas às oportunidades abertas pelo novo regime político e, sim, devem ser compreendidas em

\footnotetext{
${ }^{165}$ Ver, por exemplo, o caso do jornal Quilombo, criado em 1948, cujo estudo pode ser encontrado em: GUIMARÃES, A.S. Quilombo: vida, problemas e aspirações do negro. São Paulo: Editora 34, 2003. Edição em fac-símile.
} 
relação à experiência migratória do grupo - principalmente às formas pelas quais os imigrantes japoneses vivenciaram o período de repressão política do Estado Novo - e à formação de um núcleo de intelectuais engajados. Pela sua orientação política "esclarecida", ao menos nos primeiros anos de sua publicação o períodico esteve dedicado a combater o preconceito racial e à busca pela afirmação social da população japonesa na sociedade local. A integração dos imigrantes era então apresentada como alternativa ao ultranacionalismo japonês e enquanto reação a crenças nativas sobre a sua inassimilabilidade. Além disso, o periódico reproduzia notícias diversas vindas do Japão, bem como estreitou contatos com intelectuais japoneses. Para os interesses desta pesquisa, sobretudo, o Jornal Paulista representou um importante instrumento para o processo de produção de um ambiente de maior aceitação da população japonesa no Brasil, algo constitutivo da trajetória da CAC, bem como da formação de grupos de liderança da coletividade japonesa residente em São Paulo.

Conforme foi exposto anteriormente, a elaboração da Constituição de 1946 possibilitou, do ponto de vista legal, a reorganização de grupos impedidos de atuar durante o Estado Novo, ou mesmo a inédita inserção de grupos antes marginalizados do universo da política. A despeito disso, o cenário político de democratização se mostrava nitidamente conturbado, seja do ponto de vista da transição para um novo regime político, quanto da organização partidária em um contexto de forte espírito anticomunista reinante naquele tempo ${ }^{166}$. Para os interesses desta pesquisa, o que se observou na capital paulista já em fins da década de 1940 foi o início da inserção de filhos de alguns grupos de imigrantes em cargos políticos - principalmente os de vereador e de deputado. Nas palavras de Truzzi, ao tratar do início da atividade em carreiras políticas por filhos de sírios e libaneses em São Paulo:

No Brasil, a conjuntura de redemocratização, aberta com o fim do Estado Novo, acenava com possibilidades nunca antes oferecidas às primeiras e segundas gerações de filhos de imigrantes. No caso de sírios e libaneses, a maior parte

\footnotetext{
${ }^{166}$ Para mais detalhes sobre o contexto político em questão, bem como sobre a elaboração da Constituição de 1946, ver: BAUAB, J. D. "A primeira eleição ao parlamento paulistano pós-ditadura Vargas e o drama dos vereadores comunistas". In: MANECHINI, L.C. (Org.) São Paulo na Tribuna : primeira legislatura (1948-1951)/Escola do Parlamento da Câmara Municipal de São Paulo. São Paulo: Imprensa Oficial do Estado de São Paulo, 2012.
} 
daqueles que nos anos subsquentes se lançariam em carreiras políticas procedia de famílias cujos pais haviam começado como mascates, apenas uma geração atrás. Seus filhos - muitos deles formados, como visto anteriormente, em escolas de prestígio -, ao postularem cargos políticos, de certa forma buscavam dar continuidade a trajetórias inseridas num processo vigoroso de ascensão social. (TRUZZI, 2009, p.181)

No pleito para a legislatura de 1947-1951 para eleição de senador, governador, deputados estadual e federal, ocorrido em 19 de janeiro de 1947, o primeiro filho de japoneses que viria a ingressar na política nacional lançou sua candidatura a deputado estadual pelo Partido Democrata Cristão (PDC): "Luiz" Yukishigue Tamura. A sua primeira candidatura não foi vitoriosa, fato que contudo não o impediu de concorrer aos pleitos municipais que elegeram prefeitos e vereadores - a primeira eleição para a Câmarara Municipal de São Paulo desde 1934 -, realizados em 9 de novembro daquele mesmo ano.

Seu nome brasileiro, "Luiz", fora concedido em cerimônia de batismo realizada na Igreja de São Gonçalo pelas mãos do padre Guido Del Toro, conforme relato contido em Maeyama (2004) ${ }^{167}$. Filho de comerciantes, Tamura viveu a sua infância e juventude no bairro da Liberdade, e a Igreja de São Gonçalo lhe proveu uma formação religiosa de orientação católica. Ao ingressar na Faculdade de Direito, Tamura participou da edição dos periódicos Gakusei e Transição, bem como do circuito estudantil de filhos de japoneses capitaneado pela Liga Estudantina Nipo-Brasileira em meados da década de 1930.

Em 1947, o ineditismo de sua candidatura causou de imediato um certo impacto no público em geral, pois as ideias e valores presentes no debate público e no senso comum a respeito do Japão e dos japoneses dificilmente escapavam dos acontecimentos da guerra, em que aquela nação foi declarada inimiga do Brasil. Além disso, naquele ano ainda eram reportadas ações de grupos ultranacionalistas japoneses no Brasil, fato

\footnotetext{
167 "Fui batizado em 15 de novembro de 1926, sendo Luís o meu nome de batismo. A primeira comunhão foi em 11 de dezembro. Foi um dia de batismo coletivo e nesse dia foram batizadas 45 crianças" (MAEYAMA, 2004, p.155). Para ver a lista completa das crianças batizadas na Igreja de São Gonçalo naquela data, ver a página 173 da mesma referência.
} 
esse que prolongava o clima de tensão envolvendo a maior parte da população dessa nacionalidade residente no país, e principalmente no estado de São Paulo.

A resistência de certos grupos tradicionais à entrada de descendentes de japoneses no universo da política também ocorreu enquanto um retrato daquela conjuntura: ao iníciar o seu mandato de vereador, em 1948, Yukishigue Tamura relatou ter ouvido frases como: "Japonês quer agora tomar conta do Brasil" (SAKURAI, 1993, p.10). A despeito de episódios de intolerância como o acima mencionado, o aspecto a ser destacado é que os pleitos de 1947 traziam uma mudança na composição dos ocupantes dos cargos políticos, incluindo agora filhos de imigrantes possuidores de uma trajetória ascendente, como bem aponta Truzzi (2009). Vejamos um exemplo semelhante, ilustrativo dessa tendência naquele contexto, para além do caso dos japoneses.

Entre os filhos de sírios e libaneses, o último autor citado contabilizou sete candidatos eleitos naqueles dois pleitos: Anis Aidar, Nicolau Tuma e Camilo Ashcar (para cargos de vereador); e Alfredo Farhat, Juvenal Sayon e Salomão Jorge (para cargos de deputado estadual). Em comum a esses candidatos - com exceção do último é o fato de que eles possuíam o título de bacharel em direito pela Faculdade de Direito do Largo São Francisco, o que ressalta a importância da instituição como credenciadora dos que aspiravam uma carreira política em São Paulo - característica já reconhecida ao menos desde a segunda metade do século XIX, como assinala Adorno (1988). Para os filhos de imigrantes japoneses, a relação entre as credenciais providas pela Faculdade de Direito e a vida política em São Paulo possuía validade tanto do ponto de vista de um grupo de origem estrangeira iniciante nesse tipo de carreira, quanto representava - como tenho enfatizado - uma importante forma de diferenciação interna ao grupo. Conforme já foi mencionado, a presença de japoneses e filhos de japoneses na Faculdade de Direito do Largo São Francisco foi inaugurada por Cássio Kenro Simomoto, que ingressou na instituição de ensino superior no ano de 1932 e obteve o título de bacharel quatro anos mais tarde. Ele era sobrinho do líder-fundador da CAC, Kenkiti Simomoto.

O núcleo social de conformação de uma segunda geração, filhos de japoneses, altamente escolarizada, esteve centralizado no bairro da Liberdade, sob forte incentivo 
de instituições diplomáticas e comerciais japonesas, dentre as quais o Consulado Geral do Japão possuiu destaque. No capítulo anterior foi demonstrado que os principais gestores da CAC passaram a integrar esse circuito de visibilidade social, bem como a própria CAC, na ocasião de sua fundação, foi subvencionada pelo Consulado e teve as suas funções administrativas centralizadas pelo órgão. Essa compreensão adquire maior vigor analítico ao situarmos a condição social do grupo em um regime político democrático, em que vigorou o que denominamos de pacto político e social da democracia racial. Tal crença possuiu vigência simbólica enquanto discurso no meio nativo das lideranças de origem japonesa que buscava a sua aceitação em um contexto pós-guerra, inclusive expressando interesses dos setores denominados "esclarecidos", ou que aceitavam a derrota japonesa. Entre os seus expoentes estavam as lideranças da CAC.

Sob essa leitura, alguns fatos que despontam como diferenciais dos filhos de japoneses que aspiravam a carreira política naquele pleito em comparação a outros grupos de imigrantes podem ser resumidos pela situação do Japão enquanto recente nação inimiga, pelo surgimento de movimentos ultranacionalistas organizados no Brasil, e pela utilização de categorias raciais na produção das diferenças da população japonesa. Essa especificidade significa que experimentar a vida política parecia possuir mais do que o simples retrato de uma trajetória ascendente de sucesso de famílias japonesas residentes na capital. O fim do Estado Novo trazia, de fato, aspirações de caráter democrático no sentido de conquistar um espaço de representação e de mudanças valorativas na utilização de categorias étnico-raciais, especialmente para aqueles que haviam vivenciado um período de intensa repressão policial como o próprio Yukishigue Tamura e Gervásio Inoue, detidos em 6 de dezembro de 1942, no já mencionado evento de Eldorado, ou mesmo o líder-fundador da CAC, Kenkiti Simomoto, que se viu forçado a abandonar o cargo máximo de liderança do empreendimento para dar lugar a brasileiros natos sem descendência japonesa.

Analisar os impasses que envolveram as candidaturas de Yukishigue Tamura a deputado estadual e vereador naquele ano se mostrou uma tarefa bastante profícua para esta pesquisa, pois o seu pioneirismo ocorreu em meio a intensos debates pelos grupos de intelectuais da coletividade japonesa, de primeira e de segunda geração. 
Basicamente, os posicionamentos das lideranças locais ocorriam segmentadas pelo crivo geracional e pela nacionalidade, defendendo crenças sobre quais seriam as melhores formas de o grupo alcançar a tão almejada incorporação à sociedade local no novo contexto democrático. No caso das candidaturas, discutia-se sobre o quão vantajoso seria eleger políticos filhos de japoneses segundo essa proposta coletiva de incorporação.

O debate da época ocorria por meio de reuniões que congregavam expoentes de grupos denominados “intelectuais", ou seja, representantes: da juventude estudantil (em sua maioria membros da extinta Liga Estudantina Nipo-Brasileira), da intelectualidade nascida no Japão (em sua maioria do grupo Doyokai), da CAC - esta última que promovia as reuniões em sua sede, no bairro de Pinheiros.

Ainda que o tema dos partidos políticos naquela conjuntura possua certa relevância, ele não será abordado em detalhes nesta pesquisa. Como tenho argumentado, em geral os setores majoritariamente urbanos da classe trabalhadora puderam se organizar em legendas. Limito-me à consideração de que a despeito da predominância dos partidos de maior expressão nacional (como a UDN e o PTB), o pleito de 1947 representou um espaço político mais diversificado, em que outras legendas de menor expressão também ingressaram na disputa eleitoral ${ }^{168}$, oferecendo a oportunidade de ingresso na política para frações escolarizadas de filhos de imigrantes residentes principalmente na capital. Segundo relatado em entrevista ${ }^{169}$, a já mencionada formação católica de Tamura teria contribuído, em partes, para o lançamento de sua candidatura pelo PDC, ao passo que o título de bacharel em Direito, obtido em 1939, fornecia as credenciais necessárias para o seu ingresso na carreira política.

Ainda que a denominada "intelectualidade" japonesa de Sâo Paulo fosse composta por um número bastante restrito de indivíduos, ela se caracterizou por

\footnotetext{
${ }^{168}$ Segundo Bauab, nos pleitos municipais ocorridos em novembro de 1947: "Onze partidos (PST, PSP, UDN, PSD, PTB, PDC, PR, PSB, PDT e a coligação PTN-PRD - "Frente Trabalhista Popular") passaram a lutar pela conquista da simpatia dos 523.932 eleitores inscritos nas seis Zonas Eleitorais então existentes na capital paulista" (BAUAB, 2012, p.33).

${ }^{169}$ Entrevista com Yukishigue Tamura. Disponível em:

<http://www.culturajaponesa.com.br/htm/yukishiguetamura.html〉. Acesso em: abr. 2014.
} 
produzir posições diversificadas a respeito de questões como nacionalidade, assimilação e preconceito. E, dessa forma, mesmo que muitos dos ingressantes na vida política e dos editores do Jornal Paulista circulassem nos mesmos espaços de sociabilidade, a questão da candidatura de Yukishigue Tamura gerou tensões e polarizações. Sumariamente, ao defender uma postura mais idealista de assimilação e ausência de preconceito racial no Brasil, em geral os editores do Jornal Paulista se opuseram à candidatura de filhos de japoneses na política, bem como produziram ataques diretos à candidatura de Yukishigue Tamura a deputado estadual. Seus argumentos se baseavam na necessidade de formação de uma base política mais fortalecida, e desejavam evitar o voto condicionado pela origem. Já os primeiros políticos filhos de japoneses acreditavam que, ao ingressar na política, estariam ocupando uma posição conciliatória necessária para o projeto de integração do grupo.

Três artigos do Jornal Paulista ilustram o posicionamento do periódico em relação à candidatura dos filhos de japoneses: o primeiro, intitulado "Inconvenientes da candidatura de nissei", foi escrito anteriormente ao pleito e assinado por Hideo Onaga, diretor do jornal. Já o segundo, intitulado "O importante é ganhar - ser deputado", não possui autoria e representa uma crítica direta a Tamura, sendo atribuído ao editorial. $\mathrm{O}$ terceiro, intitulado "O nissei político", foi escrito por Antônio Shimomoto, então estudante de Medicina e sobrinho do líder-fundador da CAC, Kenkiti Simomoto:

Há dois meses aproximadamente um grupo de filhos de japoneses, a maioria frequentando nossas escolas superiores, pediu minha opinião sobre o lançamento da candidatura de um nissei a deputado.

Uma pergunta que exigia séria meditação. À primeira vista, a ideia se afigurava muito boa. Pois não seria sinal de integração dos descendentes de japoneses na comunhão nacional? Uma sinal positivo, portanto?

Após alguma reflexão porém manifestei-me contrariamente [...]

A votação em massa de filhos de japoneses em candidatos filhos de japoneses tenderá fatalmente a produzir esse indesejável enquistamento. Quisto racial agravado por enquistamento político. Está claro que tais condições gerarão necessariamente deputados políticos diferenciados, com problemas específicos, problemas que justamente devemos a todo custo evitar, pois o desejo de todos os descendentes de estrangeiros deve ser a integração e não a diferenciação na comunidade brasileira. ("Inconvenientes da candidatura de nissei", Jornal Paulista, 7 de janeiro de 1947, p.1) 
A intromissão de influências nipônicas na política nacional representa: a solidificação do quisto que era se esboça [sic]: e ser considerado um candidato da colônia, em vez de apenas um candidato brasileiro: esses e outros fatores negativos no que concerne à assimilação dos filhos de japoneses, naturalmente não interessarão. O importante é ganhar. O importante é ser deputado. Não é verdade, dr. Yukishigue Tamura?. ("O importante é ganhar - ser deputado". Jornal Paulista, 14 de janeiro de 1947, p.1)

Desculpem-me a falta de modéstia, mas pelo cálculo das probabilidades, quero crer que sou um dos primeiros nissei nascidos nesta boa terra, e pelo menos na colônia japonesa de Cotia pretendo ser o primeiro filho de imigrante japonês. Este intreito, senhores leitores, não é para me dar maior autoridade no assunto que vou tratar, mas simplesmente para mostrar que não sou despido de credencial para emitir uma opinião a respeito da estreia do "nissei" na política brasileira, pretendendo eleger um ou dois deputados estaduais no pleito de 19 de janeiro passado. Não sei de que conchavos políticos surgiram tais candidaturas, mas podemos crer que eles se portaram como verdadeiros "neófitos" em matéria política [...]

Pela confusão reinante, até mesmo entre nissei, não é de pasmar que o apoio deles faltasse aos candidatos citados. Bastaria uma simples "trança Ungnas", entre alguns japoneses, e seus filhos eleitores não votariam em fulano ou sicrano. Para o eleitor nissei o seu ambiente eleitoral não está ainda formulado. Não está articulado e não sabe como se portar frente às urnas. ("O nissei político". Jornal Paulista, 8 de março de 1947, p.1)

Mesmo enfrentando oposições declaradas, Yukishigue Tamura enfim alcançou o cargo de vereador do município de São Paulo em fins de 1947, beneficiado pela cassação dos candidatos do Partido Social Trabalhista (PST). Sumariamente, diante da cassação do Partido Comunista Brasileiro (PCB) ocorrida em em 7 de maio de 1947 por decisão do colegiado do Tribunal Superior Eleitoral (TSE), e da negação do registro do Partido Popular Progressista (PPP), os comunistas se viram obrigados a encontrar abrigo no PST para concorrer às eleições municipais de novembro (BAUAB, 2012). Empecilhos à participação desse partido no pleito logo começaram a surgir antes mesmo do início da corrida eleitoral, como o não reconhecimento da existência legal dos diretórios estaduais e municipais do partido pelo Tribunal Regional Eleitoral Paulista. A despeito das incertezas em meio às eleições, o PST garantiu a sua participação no pleito mediante intervenção da Corte Regional, e os resultados foram a princípio bastante positivos para o partido: calculando-se o quociente eleitoral e partidário, o PST foi o partido mais votado, com 72.985 votos dos 345.971 votos válidos, e elegeu nove 
representantes na Câmara. Pela regra vigente, seis cadeiras não foram preenchidas e teriam de ser concedidas ao partido de maior votação. O PDC, de Yukishigue Tamura, foi o sexto partido mais votado (24.898 votos) e garantiu inicialmente três cadeiras: Miguel Franchini Neto (1.587 votos), Jânio da Silva quadros (1.707) e Valério Giuli (2.326).

Ainda segundo (BAUAB, 2012), a diplomação dos 45 vereadores eleitos ocorreu às 15 horas do dia 26 de novembro de 1947, no Salão do Tribunal do Júri do Palácio da Justiça, concomitante ao clima de tensão a respeito da situação política dos comunistas, que colhiam assinaturas a serem enviadas para o Congresso Nacional visando impedir processos de cassação de mandatos de senadores e deputados comunistas do PCB já eleitos no pleito de janeiro. Em 31 de dezembro de 1947, um dia antes da instalação das Câmaras Municipais, o TRE paulista comunicava a inexistência dos registros de todos os candidatos do PST no estado de São Paulo. Como resultado, os vereadores eleitos por esse partido não puderam tomar posse e as 15 cadeiras foram distribuídas entre as demais legendas. O PDC foi então beneficiado, e Yukishigue Tamura, suplente com 1.436 votos, tomou posse no dia seguinte.

Por meio de entrevistas com Yukishigue Tamura, Yoshifumi Utiyama, João Sussumu Hirata e Diogo Nomura - alguns dos primeiros políticos filhos de japoneses -, a pesquisadora Célia Sakurai identificou que suas narrativas a respeito do ingresso na vida política em fins da década de 1940 e início da década de 1950 remetiam à existência de um duplo desafio: conquistar a confiança dos membros da "colônia", bem como enfrentar as resistências das elites tradicionais já estabelecidas que os viam como representantes de uma minoria étnico-racial:

São pressões e resistências de ambos os lados enfrenteados pelos jovens postulantes a uma carreira até então restrita. Era necessário garimpar o terreno, abrir caminhos, apresentar novas propostas, quebrar tabus, enfrentar as resistências. É nesse momento que a ideia de "missão" vem à tona. "Disposição" (Nomura), "idealismo" (Utiyama), "dom de serviço (Tamura) são os termos utilizados para justificar a motivação que os lançou para a vida pública. (SAKURAI, 1993, p.10)

A missão de "elevar o nome da colônia", tantas vezes repetidas nas entrevistas, aponta para aquilo que se descreveu na parte II: era necessário consolidar a unidade interna da comunidade japonesa, e para isso, era necessário também abrir caminho 
na sociedade brasileira. Na trajetória política dos quatro deputados, há uma nítida tendência para esses dois lados da questão. A política foi o instrumento para um trabalho continuado. (SAKURAI, 1993, p.15).

No seio da intelectualidade japonesa da época havia, portanto, uma disputa de legitimidade sobre as formas mais adequadas de se alcançar uma incorporação desejável à sociedade brasileira. Tal disputa ocorria entre gerações diferentes de imigrantes, ou mesmo entre indivíduos de segunda geração, como os dados apresentados parecem indicar. Era o início de uma realização coletiva envolvendo lideranças locais, que nos dizeres nativos por vezes era definida como a "missão de elevar o nome da colônia", como escreve Sakurai.

Se as candidaturas de Yukishigue Tamura a deputado e a vereador nos pleitos de 1947 ocorreram, por um lado, em meio a um cenário político marcado por transformações e turbulências, por outro elas estimularam um debate público produzido por uma fração expoente das lideranças da coletividade japonesa residente em São Paulo. O seu espaço de realização foi a sede da CAC, o que indica o envolvimento dos gestores do empreendimento em questões e dilemas diretamente relacionados à experiência migratória dos japoneses em território nacional. É retendo os fundamentos sociais que permearam os caminhos percorridos por essa Cooperativa que podemos compreendê-la enquanto produto de relações sociais e de interesses diversos.

Ao complexificarmos o pressuposto de que esse empreendimento representaria um agente atuante no mercado competitivo dotado de objetivos estritamente racionais, devemos considerar então que, ao menos quando uma diretoria de primeira geração foi predominante na condução de sua gestão, a Cooperativa atuou mais enfaticamente como um dispositivo organizado de auxílio à reprodução da vida desses imigrantes. Essa característica adquiriu proporções mais irrestritas à medida que o empreendimento passou a se expandir - tanto em sua capacidade comercial quanto em número de cooperados e produção -, e seus gestores passaram a ser vistos enquanto lideranças, presentes em circuitos que monopolizavam os canais oficiais de transmissão de informações, de elaboração das políticas migratórias e de atuação da diplomacia 
japonesa. O seu envolvimento na tarefa de transmitir a derrota japonesa na guerra ou mesmo a elaboração de projetos migratórios (o projeto Cotia Seinen, criado em 1952) são alguns exemplos de tal característica.

O caso das candidaturas de Yukishigue Tamura é uma espécie de porta de entrada para compreendermos, no contexto pós-guerra, o alcance da área de influência da Cooperativa nos acontecimentos mais notáveis e prementes da coletividade japonesa da época: mais do que uma empresa cujo espaço de atuação se limitaria ao mercado, a Cooperativa se apresentava como uma organização coletiva de notável capacidade de controle e disseminação de ideias. O que se sobressai dessa característica é o seu comprometimento com um projeto coletivo de incorporação à sociedade brasileira formulado pela fração intelectual do grupo, em um contexto político de redemocratização.

\subsection{Incorporação em debate: gerações de lideranças se encontram}

Conforme foi mencionado anteriormente, as diversas formas de se conceber um projeto de incorporação naquele meio intelectual foi marcado por disputas internas: vertentes geracionais, apesar de estarem em conformidade na linha sucessiva, apresentavam conflitos valorativos e as diferenças culturais eram apontadas como fatores de divergência. Assim, a inserção dos filhos de japoneses na política abriu espaço para a renovação de um debate existente naqueles círculos intelectuais ao menos desde a metade da década de 1930 com a publicação dos periódicos Gakusei e Transição: os devires da segunda geração no processo de adaptação e fixação dos imigrantes no Brasil. O debate ganhava novos contornos no final da década de $1940 \mathrm{em}$ virtude da possibilidade de inserção dos descendentes nas carreiras políticas, fato que trazia consigo novas aspirações e conferia maior legitimidade aos filhos de japoneses nascidos no Brasil. Naquele contexto específico, a questão geracional foi a pauta central de importantes reuniões daquele pequeno grupo de intelectuais. 
Ao passo que desde 1942 - sob presidência de Manoel Carlos Ferraz de Almeida - a CAC vinha estabelecendo contatos mais frequentes com autoridades governamentais, o prestígio e a influência de seus gestores japoneses em meio aos imigrantes conferia a ela uma capacidade bastante singular de congregar os representantes da denominada "intelectualidade" do grupo. Ao final de 1947 e início de 1948 foram realizadas reuniões na sede da Cooperativa com a finalidade de reunir aqueles que eram considerados os expoentes de primeira (isseis) e segunda geração (nisseis) de japoneses, como relata matéria do Jornal Paulista de 20 de dezembro de 1947 intitulada: "O que desejam os nisseis dos issei?" - interessante reunião hoje na sede da C.A.C.- Participarão dos debates intelectuais japoneses e "nisseis". Entre os 58 participantes listados, estavam Yukishigue Tamura, o estudante de Direito e futuro presidente da CAC, Gervásio Inoue, o estudante de sociologia, Hiroshi Saito, o líderfundador da Cooperativa, Kenkiti Simomoto, entre outros ${ }^{170}$. Nas palavras do pintor e memorialista Tomoo Handa, que presenciou o evento:

Realmente, era uma ironia da história, mas a nova geração - surgida em meio a esses distúrbios sociais - se desenvolvia abandonando a velha geração.

Nessa época, houve um idealista que reuniu os nisseis para um bate-papo com a finalidade de transmitir o pensamento dos isseis para se fazerem compreender melhor, mas viu-se que mesmo essa pessoa - considerada esclarecida, admitindo, inclusive, que o Japão havia perdido a guerra - não tinha conseguido acompanhar os nisseis com relação às mudanças trazidas pelos novos tempos. Além disso, havia o fato de os nisseis se revoltarem contra a atitude autoritária dos isseis de sempre os considerarem o lado passivo do mecanismo da educação e formação, de modo que a reunião não trouxe nenhum resultado positivo.

\footnotetext{
170 A lista de convidados para a reunião de 20 de dezembro de 1947 relatada pelo Jornal Paulista contabilizou 58 participantes, entre eles os principais líderes da CAC, ex-membros da Liga Estudantina Nipo-Brasileira e intelectuais do grupo Doyokai: "Dos "nisseis": Srs. Gervásio Tadashi Inoue, Kenro Simomoto, Keize Harada, Teiichi Haga, Massahiro Yoshimoto, Motoaki Higuchi, Isao Kira, Tomio Kitice, Yukishigue Tamura, Massami Hirota, Americo Sugai, Luis Tanigaki, Yassuo Ogawa, Mario Uemura, Antonio Simomoto, Hideo Onaga, Massaki Udihara, José Yamashiro, Toshio Oda, Hiroshi Kimura, David Aoki, Akimi Tsukamoto, Ryutari Kiyohara, Issoo Sakate, Katsunori Wakisaka, Shigueru Mitsutani. Da revista "Jidai": Srs. Zempati Ando, Tomoo Handa, Zentoku Motoyama, Teiichi Suzuki, Kiyotaka Emi, Kikuo Furuno, Takeo Kawai, Hiroshi Saito, Kenziro Masuda e Yutaka Kubo. Dos "instrutores": Srs. Tatsuo Ishihara, Tadashi Enomoto, Wataru Nakashima, Kozo Ebina, Hiroshi Osaka, Motohisa Kikawa, Toshio Kasai, Masaichi Takaki, Takeo Takatsu, Yoshio Saito, Ktsuzo Magami, Gitaro Takenaka, Seizo Okabe, Tatsuo Higuchi, Shigueo Katsuura e Seichi Kikichi. Da Cooperativa: Srs. Kenkiti Simomoto, Kameichi Yamashita, Masaru Shimizu, Tomoyo Mabuchi, Nobukane Ishii e Sussumu Hirose". Fonte: Jornal Paulista, 20 de dezembro de 1947, p.1.
} 
Mas, muitos são partidários da opinião de que uma outra reunião chegou a marcar época, trazendo bons resultados: o encontro que reuniu, na noite de 20 de dezembro de 1947, na Cooperativa Agrícola de Cotia, um grande número de isseis e os nisseis mais ativos, num diálogo franco que resultou num firme compromisso de ambas as partes no sentido de se esforçarem em prol do esclarecimento e orientação dos integrantes da colônia japonesa.

De qualquer forma, a aproximação dos isseis aos nisseis eliminou as diferenças de status entre eles e deu condições para cada um tomar consciência de que deveria haver um diálogo em pé de igualdade, trazendo grandes perspectivas e esperanças em relação aos tempos futuros. (HANDA, 1987, p.661)

Hiroshi Saito, que à época ocupava a função de jornalista e redator do Jornal Paulista, se incumbiu de redigir um relato a respeito daquela reunião em artigo publicado em 1 de janeiro de 1948. Entre os participantes de segunda geração, outras duas lideranças também publicaram as suas impressões no periódico: Antônio Shimomoto $^{171}$ e Massaki Udihara ${ }^{172}$. Centremos nossas atenções no artigo de Saito. Apesar de apresentar um certo ceticismo em relação aos pontos de vista dos participantes da reunião, Saito procurou ressaltar que o seu saldo teria um aspecto positivo: a compreensão recíproca entre os indivíduos de primeira e segunda geração. Em seu ponto de vista, o conflito de gerações seria algo já existente e de natureza inevitável entre os imigrantes japoneses residentes no Brasil. Para o autor, o eixo fundamental desse conflito residiria no plano da cultura e, mais especificamente, nas tentativas de reprodução da estrutura familiar japonesa e nas resistências a ela:

A reunião de isseis e nisseis realizada sob o patrocínio da direção juvenil da C.A.C. atingiu plenamente seus objetivos, apesar de que a discussão dos problemas caísse em terreno estéril, como frequentemente acontece em reuniões dessa espécie. Deunos ela provas insofismáveis da possibilidade de mútua compreensão entre isseis e nisseis, o que é importantíssimo. Pelo que pude observar, a discussão girou em torno de dois pontos fundamentais: o conflito de gerações e a conveniência ou não de formar agremiações de nisseis [...]

Quais serão, então, os meios que nos conduziriam a uma solução geral? Posso resumir meu ponto de vista no que segue: primeiro, compreensão mútua das diferenças culturais que separam as duas gerações. Para tal, torna-se necessário o

\footnotetext{
${ }^{171}$ SIMOMOTO, A. "Na reunião do dia 20". Jornal Paulista, 13 de janeiro de 1948, p.1.

172 UDIHARA, M. "Alhos por bugalhos". Jornal Paulista, 17 de janeiro de 1948, p.1.
} 
conhecimento, até certo grau, das culturas a que pertencem (linguagem, costumes, tradições, etc.). Segundo, remoção dos rígidos conceitos morais decorrentes do sistema familiar nipônico, a fim de que se atenuem os choques entre pai e filho. Somente dessa forma tornar-se-ia realizável uma colaboração útil e amistosa, fundada na compreensão mútua dos dois mundos "morais" em que vivem os pais imigrantes e seus filhos aqui nascidos. ("Compreensão recíproca". Jornal Paulista, 1 de janeiro de 1948, p.1)

É interessante notar que a argumentação de Saito a respeito do conflito geracional, posto em debate pela intelectualidade japonesa da época, convergia com a perspectiva de Emílio Willems a respeito dos fatores que retardariam a assimilação do grupo. Para o úlitmo autor, o principal deles seria a organização da família japonesa:

A organização da família japonesa, como a de qualquer outra sociedade, tende a perpetuar a tradição cultural do país de origem. Quanto mais diferente essa tradição da nossa, tanto mais contribui a influência dos pais para retardar a assimilação dos filhos. Digo 'retardar' porque 'impedir' a assimilação é praticamente impossível".

("Condicionada a integração do nissei à sua participação na vida social brasileira Em interessante entrevista concedida ao Jornal Paulista o eminente sociólogo, professor Emílio Willems aborda problemas apresentados pelos filhos de japoneses em face à assimilação. (Jornal Paulista, 29 de abril de 1947, p.1)

E, dessa forma, sob nítida influência das considerações de Willems a respeito do processo de assimilação dos japoneses, Saito anunciava o declínio do sistema patriarcal japonês - processo em curso inclusive em sua terra natal -, fato esse que, além de facilitar o processo de assimilação, poderia abrir novas possibilidades de igualdade dos sexos:

no próprio Japão, o velho sistema patriarcal se encontra em franco desmoronamento após a guerra, com a introdução de ideias democráticas e reconhecimento da igualdade dos sexos, e esse fato não tardará em se refletir na coletividade japonesa aqui radicada. É pelo menos o que espero. (SAITO, 1948, p.1) 
Outra reunião com propósitos semelhantes ocorreu em 21 de fevereiro daquele ano de 1948, e o Jornal Paulista assim a divulgou: "'O que desejam os japoneses de seus filhos?' - Mais uma reunião promovida pela CAC. - Participarão dos debates figuras representativas da colônia nipônica" ${ }^{" 173}$. Por coincidência ou não em relação às considerações de Saito sobre a igualdade dos sexos, essa reunião contou com uma novidade: a presença de 15 mulheres entre os 96 participantes. Entre elas, a reconhecida assistente social Margarida Watanabe, cuja biografia foi estudada pelo antropólogo Takashi Maeyama (2004). A abertura da reunião ocorreu mediante as palavras de entusiasmo de Kenkiti Simomoto ${ }^{174}$ e, novamente, contou com a presença de lideranças de segunda geração, como Gervásio Inoue e Yukishigue Tamura, entre outros.

As discordâncias em torno das candidaturas a cargos políticos por indivíduos de segunda geração emergiram em meio a intensos debates promovidos pela intelectualidade japonesa da época, o que indica a existência de uma heterogeneidade de interesses e de pontos de vista a respeito de uma proposta coletiva de incorporação. Ademais, tenho demonstrado que gestores da CAC de primeira e de segunda geração vivenciaram o contexto de repressão política do Estado Novo de formas qualitativamente distintas e, por isso, suas respostas às constrições se expressaram de maneira diferenciada.

Em 1947, as discordâncias em debate pela intelectualidade japonesa refletiam também os diversos prognósticos existentes sobre a melhor forma de se alcançar uma incorporação econômica, social e, principalmente, sobre a tentativa de equacionar uma complexa ordem cultural de constituição de diferenças visando à aceitação social, objetivo demarcado pela nacionalidade e pela geração. Independente de quais prognósticos mais se aproximaram dos eventos que estariam por vir, o que podemos constatar em fins da década de 1940 é a conformação de um círculo social que congregava as lideranças intelectual, política e empresarial de origem japonesa em São Paulo.

\footnotetext{
173 Jornal Paulista, 24 de janeiro de 1948, p.1.

174 "Calorosos debates travados na sede da C.A.C.". Jornal Paulista, 26 de fevereiro de 1948, p.1.
} 
Esse universo específico de agentes, disposto a pensar a realidade dos imigrantes japoneses no Brasil, representou um espaço de produção de ideias e valores caracterizado por sua interdependência com os núcleos decisórios da CAC. Pois, ao menos entre as décadas de 1930 e 1980 foi decisiva a presença dos gestores do empreendimento na formação desses círculos, bem como as ideias e visões de mundo produzidas por aquele meio social por vezes se refletiram sobre a atuação da Cooperativa no mercado, a exemplo da ênfase conferida pelos primeiros políticos filhos de japoneses a um tema que diretamente interessava às cooperativas agrícolas: a agricultura.

Ao longo de suas carreiras como deputados estaduais, os primeiros políticos de origem japonesa na Assembleia Legislativa do Estado de São Paulo (ALESP) estiveram empenhados na criação de projetos e leis no âmbito da agricultura, como a isenção de tarifas e subsídios aos pequenos produtores rurais, além de empreendimentos em parceria com o capital estrangeiro japonês (DIAS, FRANCISCO e CAVALLI JÚNIOR, 2008). Novamente pioneiro, Yukishigue Tamura foi o primeiro filho de japoneses a ocupar o cargo na ALESP (1951-55), e ao seu mandato se seguiram outros, como os de João Sussumu Hirata (1955-59 e 1959-63), Shisuto José Muraiama (1955-59 e 195963), Ioshifumi Utiyama (1959-63 e 1963-67) e Diogo Nomura (1963-67). Outra característica em comum a esses mandatos - além da mencionada ênfase conferida à agricultura - foi o envolvimento desses políticos e de membros daquele círculo de intelectuais na busca por retraduzir as categorias de representação da população japonesa na sociedade local visando à construção uma imagem associada a valores positivos.

Esse assunto é analisado em maiores detalhes no tópico seguinte, em convergência com o início da presidência de Gervásio Inoue na CAC, em 1957, e com a criação de comissões para a organização do Cinquentenário da Imigração Japonesa, comemorado 17 de junho de 1958. A ocasião desse evento permite observar, por um lado, a interrelação das lideranças intelectual, política e empresarial de origem japonesa em São Paulo no processo de conformação de ideias e valores que amparassem um ambiente de maior aceitação da população de origem japonesa e, por outro, a estreita 
relação de processos dessa natureza com a atuação da CAC no mercado. É sob essa abordagem que, acredito, a afirmação a seguir adquire sentido mais pleno:

A colônia japonesa a partir da década de 1950 passa a ganhar uma visibilidade diferente daquela das décadas anteriores: não é mais o "perigo japonês" que está em questão, mas é o enaltecimento do trabalho, do esforço gera sucesso, que agora vem à tona. A imagem positiva que os brasileiros têm hoje em relação aos nikkeis é em parte, fruto de uma estratégia conjunta das lideranças da colônia, (onde se incluem os parlamentares), de "limpar" a sua imagem diante da sociedade mais ampla. (SAKURAI, 1993, p.17)

De maneira não convencional, ao examinarmos detidamente certos agentes e grupos em posição de liderança da coletividade japonesa, e considerando o contexto de certos acontecimentos de caráter mais amplo envolvendo relações raciais no Brasil, é que podemos identificar que a CAC resguardou um dos espaços centrais de atuação de lideranças. Esses agentes, por sua vez, contribuíram de maneiras variadas para formular estratégias e prognósticos voltados à incorporação dos japoneses em São Paulo. No contexto do intervalo democrático, em que a democracia racial passou a vigorar como pacto político e de classes, essa Cooperativa experimentou uma ampliação considerável em sua atuação no mercado, caminhando em direção a um empreendimento de relevância no setor agrícola, bem como passou a deter progressivamente a qualidade de uma autoridade cultural. Fato esse que apresenta uma riqueza analítica por meio da constatação geral, porém não óbvia, de que se trata de uma trajetória empresarial de relevância no setor agrícola brasileiro extremamente tributária de processos de construção, conflitos e negociação de identidades étnico-raciais na experiência migratória de um grupo.

O lugar de uma população não branca de origem asiática passava a ser redefinido no contexto de um novo regime político no Brasil. Aguardando, novamente, o reconhecimento do seu grupo de origem na sociedade local, agentes situados no plano intelectual, político e empresarial lideraram a criação dos repertórios simbólicos voltados à realização dessa empreitada. A tarefa de retraduzir as categorias de representação da população japonesa na sociedade local visando à construção de uma 
imagem associada a valores positivos amplamente reconhecidos pode ser entendida como o padrão mais geral de processos que se manifestaram sob várias formas, situações e locais na experiência migratória dos japoneses no Brasil. Nesta pesquisa circunscrevemos nossa atenção à participação das lideranças dessa coletividade em um processo iniciado logo após o término da Segunda Guerra Mundial, e que contou com um declarado incentivo da CAC.

Foi argumentado que o intervalo democrático inaugurado com o fim do Estado Novo ofereceu possibilidades inéditas à geração de filhos de imigrantes na cidade de São Paulo em fins da década de 1940, como ilustram os casos dos primeiros políticos de origem síria, libanesa e japonesa. A respeito desses últimos, pudemos constatar a proeminência da formação de um círculo de lideranças na cidade de São Paulo que, retendo os elementos de interesse desta pesquisa, foi capaz de produzir e disseminar valores e ideias a respeito da experiência migratória do grupo. Tal capacidade decorreu da posição de prestígio adquirida pelo grupo em meio à coletividade japonesa e perante a sociedade local - resultado de processos sociais ocorridos principalmente com o advento da guerra, em um contexto mais geral de redefinição de condicionantes de ordem cultural, como a nacionalidade, a geração, a reprodução da estrutura familiar, a raça, o idioma e os costumes.

A relação desse círculo de lideranças com empreendimentos fundados por japoneses no Brasil e cuja atuação no mercado era expressiva - como a CAC - em muitos casos não se constituiu mediante o encontro de trajetórias paralelas, limitadas pelos espaços sociais de atuação por excelência dos agentes. Ocorre que em muitas interpretações vigentes, a separação da experiência social mediante categorias - a política, a cultura, o mercado - por vezes ultrapassa o sentido estritamente analítico que lhes fora inicialmente atribuído pelos estudiosos, tipificando formas de ação excessivamente objetivadas, o que termina por conferir validade discursiva a eventos entendidos como estritamente políticos, culturais, ou econômicos. Ainda que nesta pesquisa essas categorias sejam mobilizadas para indicar a natureza de certas ações e fazer referência a certos eventos, a convergência entre os universos intelectual e da política com o mercantil é considerada em uma dinâmica interdependente de relações. 
Dessa formulação decorre o entendimento de que as ações de gestores da CAC não se traduziram unicamente pela instrumentalização de recursos disponíveis visando a objetivos próprios aos interesses de mercado, nem foram condicionadas por fatores estritamente culturais. Outros interesses subjacentes a essas ações por vezes podem ser apreendidos, favorecendo a compreensão de que certos fenômenos ganham validade explicativa por meio de fatores inseparáveis da experiência migratória dos japoneses no Brasil. É sob essa abordagem que retomo a análise do evento de posse ministerial de Fábio Yassuda em 1969 - um acontecimento bastante circunscrito se comparado a outros mais amplos em curso na sociedade brasileira da época e que, entretanto, representa uma espécie de eixo catalisador de processos centrais que interessam diretamente a esta pesquisa.

\subsection{A guerra como metáfora}

Assumo esta Pasta movido por profunda convivção interna. Em minha plena consciência, penso que o brasil se encontra hoje diante de uma guerra, e para esta tem de mobilizar-se integralmente. Guerra do seu desenvolvimento, do seu engrandecimento, da sua afirmação histórica.

Talvez pareça a expressão um pouco forçada, excesso de hipérbole para um ministro de Indústria e Comércio, e ainda mais para alguém cuja biografia faz supor que esteja habitualmente voltado para as coisas concretas e dados empíricos. $\mathrm{E}$, contudo, creio que a ideia - quando não a palavra - é perfeita e justa. Nosso desenvolvimento, nossa grandeza, dependem do emprego mais racional e eficiente dos nossos meios de ação para a realização dos grandes objetivos nacionais permanentes $[\ldots]$

Ao empresariado nacional, muito particularmente, por estar mais diretamente vinculado à área de ação do MIC, quero dizer que é nossa tarefa ajudá-lo a fortalecer-se.

$\mathrm{Na}$ verdade, o desenvolvimento real consiste no poder de decisão. Mas é importante que o empresariado nacional se engaje integralmente no seu papel de exercê-lo, porque não será com proteções passivas contra a técnica, a capacidade de organização, o domínio dos meios racionais e a eficiência gerencial dos estrangeiros, e sim com o enrijecimento dos nosso próprios músculos, que estaremos em condições de sobreviver e prosseguir. Por assim dizer, temos de nos tornar capazes de bater os nossos concorrentes no seu próprio jogo. ("Yassuda assume o MIC e convoca o País para 'a guerra do desenvolvimento e da afirmação'". Folha de S. Paulo, 01 de novembro de 1969, p.5) 
A metáfora da "guerra" produzida por Fábio Yassuda em seu discurso de posse ministerial no ano de 1969 - ocasião de apresentação pública dos núcleos de poder governamental - constitui, dentre outros passíveis de análise, um exemplo de ação intencional capaz de articular uma visão de mercado a aspectos biográficos diretamente relacionados à experiência dos imigrantes japoneses no Brasil. De maneira talvez sutil, ela sugere a ressignificação das noções de conflito social presentes no imaginário coletivo sobre a guerra, dispondo-os sob um novo encadeamento semântico que dissociava as conotações negativas do confronto de qualquer grupo social que compusesse a nação. Ao transpor o sentido de conflito do plano cultural para o econômico, a sua fala tencionava validar uma significativa virada cognitiva no esquema simbólico coletivo anteriormente existente. Em seu discurso, o "inimigo" da nação brasileira não eram grupos de determinadas nacionalidades, e sim os empecilhos ao desenvolvimento, e a "batalha" contra esse inimigo assumia lugar no mercado.

É válido ressaltar que a formulação aqui apresentada procura identificar apenas alguns aspectos de intencionalidade manifestas pelo agente histórico em questão, o que não pressupõe, contudo, exacerbações que tanto assumem uma total capacidade de controle dos agentes sobre os eventos quanto reduzem as ações intencionais em detrimento de motivações mais complexas que possivelmente influenciam decisões.

Sob análise está um constructo, um conjunto de ideias produzido em um evento localizado, de dimensão restrita, cuja compreensão - mediante a identificação de interesses específicos ali existentes -, é dependente do exame de processos que possibilitaram que grupos minoritários passassem a ser paulatinamente reconhecidos e incorporados nos planos político, econômico e cultural na sociedade brasileira. Pois, além de interesses estritamente econômicos que a figura de gestor da Cooperativa fizesse à primeira vista prevalecer, é compreensível que, para o primeiro ministro de origem japonesa a ser nomeado em toda a trajetória diaspórica - um filho de imigrantes que havia presenciado no seu seio familiar a repressão política contra seu grupo de origem (seu irmão Eduardo foi preso em 1942) - houvesse intenções subjetivas 
suficientemente válidas para subverter qualquer noção prejudicial e indesejável que o termo "guerra" pudesse expressar.

Metáforas, como argumenta Marshall Sahlins, nos permitem observar que a eficácia histórica emerge do seu valor cultural, ou significação: uma dinâmica cujos arranjos particulares dela resultante sedimentam novos valores. Em outras palavras, que a história é organizada por estruturas de significação. Interpretarei a metáfora em questão baseando-me no esquema sahlinsiano, cuja compreensão da história privilegia a relação entre estrutura e prática, sistema e ação. Para o autor, "o fato simbólico é um 'símbolo' fenomênico cujo 'tipo' é seu modo de existência na cultura-tal-comoconstituída" (SAHLINS, 2008, p.129). O signo, por sua vez, apenas significa, "em virtude de todas as relações possíveis com outros signos, de todas as suas possíveis ocorrências; é 'livre de estímulos'" (SAHLINS, 2008, p.129). Seria então a ação de sujeitos que atribuem valor (ou significação) a signos (interesses) em um sistema ordenado de símbolos:

Qualquer compreensão da história como significado precisa reconhecer o papel distintivo do signo na ação, em oposição à sua posição na estrutura. A ação, dizemos, é intencional: norteia-se pelos propósitos do sujeito agente, pelo viver social dele ou dela no mundo. Engajados assim em projetos de vida, os signos por meio dos quais as pessoas agem são levados a relações referenciais com os objetos das ações dessas pessoas, dotando assim os valores conceituais de significados contextuais particulares. De novo na ação, os signos estão sujeitos a arranjos e rearranjos contingenciais, relações instrumentais que também afetam potencialmente os seus valores semânticos. Todas essas inflexões de significado dependem do modo como o ator experiencia o signo enquanto interesse: o lugar do signo num esquema ordenado de meios e fins. ( SAHLINS, 2008, p.127)

Em síntese, para o autor, os signos, em ação e em meio à capacidade que possuem de serem interesses, podem adquirir novos valores conceituais, contanto que dispostos em novas relações com: 1) os objetos no interior do processo referencial; e 2) outros signos no interior do processo instrumental. E, uma vez que o mundo "objetivo" ao qual esses signos se aplicam possui as suas próprias características e dinâmica refratárias, os signos - e, por extensão, as pessoas que por meio deles vivem - podem ser categorialmente reavaliados. 
Se interpretarmos os significados contidos na metáfora produzida por Fábio Yassuda mediante os conceitos formulados pelo último autor, podemos identificar a congruência entre objetivos empresariais, diretrizes governamentais e referências diretas a uma história particular que remonta à trajetória de um grupo de imigrantes, reavaliada no plano simbólico sob influência de interesses específicos. Ademais, é válido mencionar um dado importante: que em 1969 Fábio Yassuda já havia participado dos núcleos de gestão da CAC por mais de duas décadas, pois, juntamente com Gervásio Inoue, os dois haviam sido os primeiros filhos de japoneses nascidos no Brasil a compor a diretoria do empreendimento, em 1948. Fábio Yassuda foi nomeado Diretor-Gerente da Cooperativa em 1960, e Gervásio, Diretor-Presidente em 1957. E, dessa forma, a carreira profissional de Yassuda havia sido construída, em grande parte, no universo empresarial.

$\mathrm{Na}$ literatura especializada, a ascensão de Yassuda ao cargo de ministro é comumente referida como um caso exemplar da inserção dos filhos de japoneses em núcleos governamentais de poder (LESSER, 2008). Ainda que essa avaliação possua alguma correspondência com acontecimentos mais gerais, da forma como o evento é apresentado ele não possui nenhuma validade explicativa. Na tentativa de torná-lo analiticamente relevante segundo os propósitos desta pesquisa, três observações podem ser feitas. Em primeiro lugar, ao assumir o evento de posse de Fábio Yassuda enquanto resultado de um processo linear de inserção de cunho econômico-cultural, pouca ou nenhuma atenção é conferida às características mais gerais dos regimes políticos em que essa inserção se processou, ou aos seus efeitos para os imigrantes e seus descendentes. Segundo, em decorrência do estabelecimento de uma relação causal (em que outros determinantes além de um movimento universal de inserção não são considerados), negligencia-se todo um conjunto de relações estabelecidas entre os universos mercantil e o da política. E terceiro, aspectos biográficos, a capacidade de agência do indivíduo e a posição social de agentes não são considerados. 
Dessa forma, quando estudiosos tendem a interpretar a ascensão de Fábio Yassuda enquanto um fenômeno circunscrito ao âmbito de carreiras políticas, fatores potenciais que o tornam um fenômeno social mais complexo se encontram limitados pelo viés que insiste apenas em observar um movimento de incorporação social aplicado a um tipo de atividade profissional, reduzindo-o a um caso cuja validade se resume à simples exemplificação.

No tópico anterior foi analisado o contexto social em que as carreiras políticas de filhos de japoneses tiveram início na cidade de São Paulo, contexto esse que trazia uma mudança na composição dos ocupantes dos cargos políticos, incluindo agora filhos de imigrantes, em geral beneficiados por uma trajetória familiar ascendente. Enquanto desdobramento desse movimento inicial, o que se observou entre as décadas de 1960 e 1980 foi uma gradativa presença de filhos de japoneses em cargos políticos municipais: nas eleições de 1976, por exemplo, Sussumu Miyao (1980) afirma que dos sete (1,3\%) dos 561 prefeitos eleitos no estado de São Paulo, 18 (3,3\%) dos 551 vice-prefeitos e 148 $(2,5 \%)$ dos 5.897 vereadores eram descendentes de japoneses.

Entretanto, mesmo que a ampliação do número de candidatos de origem japonesa tenha se processado ao longo de duas décadas desde o pleito de 1947, há de se observar que os cargos de maior centralidade nos núcleos de poder governamental dos anos de 1960 não eram ocupados por indivíduos que haviam investido em carreiras estritamente políticas. Principalmente a partir de 1964, eram recrutados para os cargos de poder decisório governamental aqueles indivíduos que, inseridos em determinadas instituições setoriais e possuindo boas relações com personagens centrais no governo, demonstravam deter certas credenciais, habilidades técnico-administrativas, ou eram expoentes do universo empresarial - este último que interessa mais diretamente aos objetivos desta pesquisa.

Fábio Yassuda parecia possuir algumas das características acima descritas, qualidades que à época de sua nomeação o tornavam um expoente do universo empresarial agrícola passível de compor os quadros governamentais - posição que possibilitava que suas declarações repercutissem e influenciassem, de maneira geral, o 
imaginário coletivo da população de origem japonesa. Mas a sua visibilidade enquanto figura pública havia sido construída com o respaldo da $\mathrm{CAC}^{175}$, e por esse motivo examino a seguir algumas de suas ações em posição de comando no empreendimento a partir da década de 1950, quando, ao lado de Gervásio Inoue, os dois personagens consolidaram sua gestão no núcleo decisório sendo representantes de uma segunda geração. Destarte, ao possuírem ao seu alcance recursos que a primeira geração não dispunha - como aqueles diretamente relacionados ao conhecimento profissional da ciência econômica e à construção de relações com agentes externos - a gestão empresarial da Cooperativa passou a adquirir novos contornos. Basicamente, a composição endógena dos núcleos decisórios sofreu modificações irreversíveis, passouse a adotar métodos racionais de gestão voltados a melhora da performance administrativa e dos lucros.

\subsection{Gestores de segunda geração e o seu protagonismo}

O biênio 1956-1957 foi marcado por acontecimentos de importância central no núcleo de direção da Cooperativa. No dia 2 abril de 1956 faleceu o Diretor-Presidente Manoel Carlos Ferraz de Almeida, encerrando um período de gestão iniciado ainda no contexto da Segunda Guerra Mundial. Dois dias depois, foi convocada uma reunião da diretoria da Cooperativa com o objetivo de nomear um substituto ao cargo. Conforme já era esperado, pelo seu prestígio diante dos cooperados e diretores, na reunião houve unanimidade no sentimento de que Kenkiti Simomoto é quem deveria retornar ao posto de Diretor-Presidente da Cooperativa. Contudo, este recusou a proposta e indicou seu

\footnotetext{
175 "Oriundo da Cooperativa de Cotia, resposável por pelo menos $60 \%$ do abastecimento de São Paulo e em cerca de $40 \%$ do Rio, o Sr. Fábio Yassuda é considerado pelos empresário cariocas como úm grande administrador' (...) Respeitado pelos empresários como 'um homem que sabe se assessorar e não terá dificuldade alguma em escolher a dedo os seus colaboradores', o Sr. Fábio Yassuda terá com certeza muita chance de conhecer de perto setores como o da siderurgia, indústria naval, indústria automobilística, indústria química e outros". ("Yassuda vê problemas no comércio". Jornal do Brasil, 31 de outubro de 1969, p.13)
} 
sucessor: Gervásio Inoue ${ }^{176}$. Ao lado de Fábio Yassuda, desde 1948 os dois eram os únicos diretores de segunda geração presentes no núcleo gestionário da Cooperativa. Em linhas gerais, foram justamente esses dois personagens que deram continuidade a uma forma de gestão inaugurada por Manoel Carlos Ferraz de Almeida, caracterizada pelo fortalecimento de relações estabelecidas no universo da política.

Conforme foi apresentado no capítulo anterior, durante a gestão de Manoel Carlos Ferraz de Almeida a CAC passou a estabelecer um contato mais próximo com autoridades governamentais e a garantir a presença de seus representantes em órgãos classistas do setor agrícola estadual e nacional. Entre as décadas de 1950 e 1960 Gervásio Inoue e Fábio Yassuda reproduziram essa conduta, segundo podemos constatar a partir de notícias da época coletadas principalmente no jornal $O$ Estado de S.Paulo. Nesse período, Fábio Yassuda ocupou os postos de representante das cooperativas e conselheiro na Comissão Federal de Abastecimento e Preços (COFAP), do Ministério do Trabalho, Indústria e Comércio, de presidente da Confederação Nacional da Agricultura ${ }^{177}$, além de cargos de direção na Federação da Associações

\footnotetext{
176 "Pedindo a palavra, o sr. Fábio Riodi Yassuda, ponderando vários fatores, sugere o nome do sr. Kenkiti Simomoto para dirigir os destinos da organização até o fim do presente mandato da diretoria, proposta essa imediatamente aceita por todos os presentes. Usando da palavra, o sr. Kenkiti Simomoto agradece a confiança nele depositada, mas faz sentir aos presentes que tal incumbência significaria um fardo por demais pesado, tendo em conta a sua idade um tanto avançada, agravada ainda pelo atual estado de saúde de sua pessoa. Os presentes reconhecem as justas alegações do sr. Diretor-Gerente, mas pedem para que ele que já tantos sacrifícios tem feito em prol da Cooperativa, faça mais este que é de grande precisão para o momento. O sr. Kenkiti Simomoto volta a falar, insistindo com os presentes para que não lhe façam tal pedido que é por demais pesado para ele. Após vários debates o sr. Kenkiti Simomoto propõe à casa que seja eleito para o cargo de Presidente o dr. Gervásio Tadashi Inoue, um dos diretores que vinha acompanhando mais intimamente, através de contatos cotidianos, as atividades e a orientação do Dr. Manoel Carlos Ferraz de Almeida. Disse ainda o sr. Kenkiti Simomoto que ao dr. Gervásio Tadashi Inoue daria todo o apoio, pedindo da mesma forma a colaboração de todos. Pedindo a palavra o dr. Gervásio Tadashi Inoue agradece a sua indicação, mas a exemplo dos demais é de opinião que o sr. Kenkiti Simomoto é quem deve aceitar tal encargo. O sr. Kenkiti Simomoto torna a falar demonstrando firme propósito de não aceitar o cargo pelas razões já expostas. Os presentes considerando as palavras do sr. Kenkiti Simomoto fazem um apelo ao Dr. Gervásio Tadashi Inoue para que este aceite a indicação de seu nome para Presidente da Cooperativa, tendo em vista as qualidades de que o mesmo é possuidor para dirigir com brilhantismo os destinos da nossa querida organização. $\mathrm{O}$ dr. Gervásio Tadashi Inoue faz uso da palavra para dizer que aceita a presidência". (Ata de Reunião de Diretores da Cooperativa Agrícola de Cotia, realizada em 4 de abril de 1956. Fonte: Instituto de Cooperativismo e Associativismo, Núcleo de Documentação)

177 Ver as reportagens: "A fixação de preços de frutas e de verduras pela Prefeitura". O Estado de S.Paulo, 14 de abril de 1956, p.9"; "Criação da SUNAB: opinam consumidores e técnicos do setor". O Estado de S.Paulo, 27 de setembro de 1962, p.17.
} 
Rurais do Estado de São Paulo (FARESP) ${ }^{178}$; Gervásio Inoue ocupou cargos de presidente e vice-presidente ${ }^{179}$ da União das Cooperativas do Estado de São Paulo $(\mathrm{UCESP})^{180}$, de presidente da Aliança Brasileira de Cooperativismo (ABCOOP) ${ }^{181}$, de membro da Comissão Administradora do Fundo de Fomento e Propaganda do Cooperativismo $^{182}$, bem como recepcionou entidades de outros países interessadas no desenvolvimento da agricultura, a exemplo dos Estados Unidos ${ }^{183}$ e do Japão ${ }^{184}$.

Empreendimentos de grande porte possuírem representantes em órgãos classistas do seu setor de atividade pode, à primeira vista, ser interpretado como uma prática recorrente no mercado nacional em expansão de fins da década de $1950^{185}$. Contudo,

\footnotetext{
178 "A FARESP encaminhou ontem representação ao secretário da Agricultura solicitando usa intervenção junto ao Governo Federal no sentido de ser impedida qualquer importação de pêssego industrializado ou semi-industrializado. A representação foi pessoalmente entregue por uma comissão integrada pelos sr. Fábio Yassuda, diretor do Departamento de Frutificultura da FARESP[...]". ("Contra a importação de pêssego". O Estado de S.Paulo, 14 de novembro de 1951, p.26)

${ }^{179}$ Ver as reportagens: "É necessário que o algodão reassuma a liderança perdida". O Estado de S.Paulo, 25 de fevereiro de 1958, p.20 e "União das Cooperativas do Estado de São Paulo". O Estado de S.Paulo, 12 de setembro de 1958, p.13.
}

180 A UCESP era um entidade classista estadual promovida pelo Departamento de Assistência ao Cooperativismo (DAC), da Secretaria da Agricultura do Estado de São Paulo, criada em 30 de junho de 1952.

181 "Em audência especial, o Presidente Costa e Silva recebeu na quinta-feira, no Palácio do Planalto, numerosa delegação da Aliança Brasileira de Cooperativas, integrada de dirigentes cooperativistas procedentes de todos os estados, tendo à frente o sr. Gervásio Inoue, presidente da ABCOOP". ("Delegação de ABCOOP recebida pelo presidente da república". Correio da Manhã, 28 de março de 1968, p.3)

182 O Fundo de Fomento e Propaganda do Cooperativismo também funcionava sob os auspícios do DAC, e foi criado pelo decreto 29.636 de 11 de setembro de 1957, do governo do estado de São Paulo. Uma de suas atividades principais era promover congressos com a temática do cooperativismo.

183 "Segue hoje, às 18:30 horas, pela Varig, com destino a Nova York, o sr. Gervásio Tadashi Inoue, presidente da Cooperativa Agrícola de Cotia, na condição de bolsista, a convite do Ponto IV, para dez semanas de estudos de crédito agrícola, da International Cooperation Administration, U.S. Department of Agriculture and Land-Crant Colleges Corporating. O viajante, um dos líderes da classe agrícola e do cooperativismo sul-americano, em razão da distinção que lhe foi conferida, foi alvo de homenagens em São Paulo, por parte de autoridades, classes agrícolas e cooperativistas, e aqui no Rio, ontem, lhe foi oferecido um almoço no Mesbla, com a participação de diretores e funcionário, por iniciativa de dirigentes de cooperativas do Distrito Federal". (Correio da Manhã, 7 de abril de 1959, p.15)

184 "Acha-se no Brasil um grupo de autoridades japonesas ligadas ao cooperativismo e sob a chefia do sr. Yasushi Hassumi, presidente da Cooperativa Nacional do Japão [...] O grupo foi recebido ontem em Brasília pelo ministro Renato Costa Lima, da agricultura, estando os visitantes acompanhados do sr. Gervásio Inoue, presidente da Cooperativa Agrícola de Cotia". ("Japão quer enviar ao Brasil agricultores". Correio da Manhã, 11 de agosto de 1962, p.2)

185 Para mais informações sobre os órgãos de representação classista do setor agrícola no período, como a FARESP e a SRB, ver: DRAIBE, S. Rumos e metamorfoses: um estudo sobre a constituição do Estado e as alternativas da industrialização no Brasil, 1930-1960. Rio de Janeiro: Paz e Terra, 1985; e 
tenho buscado demonstrar que no caso da CAC esse tipo de representação esteve condicionado pela dinâmica geracional que se processou tanto no âmbito de lideranças da coletividade japonesa quanto no núcleo de gestão da Cooperativa, quando filhos de japoneses nascidos no Brasil passaram a experimentar uma inédita inserção em profissões liberais, no mercado de trabalho, no meio empresarial e na política. Foi justamente no período em que a CAC era presidida por Manoel Carlos Ferraz de Almeida, e quando Yukishigue Tamura ocupava o cargo de deputado estadual pelo PDC (1951-1955), que podemos observar a emergência de um novo tipo de gestão, distinto daquele praticado por Kenkiti Simomoto.

Em 1951, uma das reivindicações dos produtores agrícolas por meio da FARESP era impedir a entrada de batatas vindas da Holanda no mercado nacional, principalmente em São Paulo - reivindicação essa que vinha sendo dirigida às autoridades governamentais ao menos desde $1948^{186}$. Segundo a Cooperativa, em 1950 o estado de São Paulo havia sofrido forte estiagem, o que havia comprometido a produção local de batatas (CAC, 1988). A importação do produto havia sido a solução encontrada para atender a demanda interna, o que passava a desestabilizar o seu preço no mercado, bem como trazia prejuízos aos produtores cooperados. Em 1951, além de presidir a Cooperativa, Manoel Carlos Ferraz de Almeida também ocupava o cargo de presidente da FARESP, e em 23 de julho o deputado estadual Yukishigue Tamura apresentava a reivindicação do gestor em sessão da Assembleia Legislativa:

A seguir tomo a liberdade de comunicar a V.Exa. e à Casa o teor de um telegrama que me foi encaminhado pelo Sr. Manoel Carlos Ferraz de Almeida, Diretor da FARESP e Presidente da Cooperativa Agrícola de Cotia: "Cumpro dever afirmar prezado amigo que seu pensamento

TOLENTINO, C.A.F. O farmer contra o jeca: o projeto de revisao agrária do governo Carvalho Pinto. Marília: Oficina Universitária, 2011.

186 Segundo a CAC: "A batata holandesa, causa dessa situação, atingira um total de um milhão de sacas no mercado, fazendo o preço situar-se no nível de 20 cruzeiros por saca, um décimo das cotações de 1948. Lideradas pela FARESP (Federação das Associações Rurais do Estado de São Paulo), a Cotia e as demais cooperativas agrícolas passaram à reação, a situação se tornara insustentável. Reuniram-se, em setembro, num $1^{\circ}$ Encontro dos Produtores de Batata, em Capão bonito, e após acalorados debates, resolveram dirigir-se ao Governo Federal para solicitar-lhe a proibição da importação de batata estrangeira". (CAC, 1988, p.126) 
externado nessa digna Assembleia Legislativa sobre a importação produtos agrícolas em prejuízo da lavoura nacional representa com absoluta exatidão o princícipio defendido pelos legítimos órgãos rurais FARESP, RURAL BRASILEIRA SOCIEDADE NACIONAL AGRICULTURA (sic). Precisamos trabalhar a favor de nossa população consumidora, todavia devemos atender interesses nossa terra objetivando produzir mais e melhor única saída para os que sinceramente desejam contribuir organização econômica (sic) nosso povo. Nossa Cooperativa é uma sociedade em nome coletivo impessoal que luta para defender pequeno agricultor (sic) propugnando para organização e racionalização da produção. Comunidade Rural Brasileira sem discrepância reiteradamente em todos os tempos sempre pensou como nobre deputado isenta (sic) livre influências quaisquer relação de interesse. Manoel Carlos Ferraz de Almeida, Presidente da Cooperativa Agrícola de Cotia". (CONSIDERAÇÕES SOBRE A COOPERATIVA AGRÍCOLA DE COTIA. Discurso de Yukishigue Tamura na Assembleia Legislativa de São Paulo, Caixa 19, Pasta 118, Leg. 2a, 82a Ord da $1^{a}$ Sessão, 23/07/1951.

Fonte: Acervo Histórico da Assembleia Legislativa de São Paulo)

Conforme foi mencionado no capítulo anterior, Yukishigue Tamura e os primeiros políticos de origem japonesa trataram com prioridade os temas relacionados à agricultura e aos pequenos produtores rurais na Assembleia Legistativa do Estado de São Paulo, tendo Tamura sido membro da Comissão da Agricultura entre 1951 e $1955^{187}$. As características acima expostas parecem contribuir para duas avaliações: que as propostas defendidas por Yukishigue Tamura em seu espaço de atividade política devem ser compreendidas a partir de sua trajetória social enquanto filho de imigrantes, estreitamente vinculada ao circuito de lideranças da coletividade japonesa de São Paulo da qual os gestores da CAC eram expoentes; e que a compreensão de que certas ações que supostamente teriam sido adotadas como respostas a situações de mercado em grande medida são produtos do universo de relações que as constitui.

Essas considerações também parecem ser válidas para outros discursos de Yukishigue Tamura na Assembleia, quando o deputado defendeu a isenção de impostos estaduais dos produtos comercializados pelas cooperativas agrícolas em $1953^{188}$, ou

\footnotetext{
187 "Como seria marcante na atuação dos primeiros parlamentares nikkeis, Tamura pode ser identificado com a corrente de pensamento que defendia a prioridade das ações do governo para a agricultura (...) Os plantadores de batata também enfrentavam dificuldades. Faltavam batatas-sementes, que na época eram importadas da Holanda. O maior problema residia no rígido controle que o governo federal exercia sobre as importações, desde 1947. Na época, Tamura apresentou proposição solicitando uma cota de dólares para a importação da semente de batata; argumentou que a importação estimularia a produção, contribuiria para baixar o custo de vida, além de diminuir a importação de batatas para o consumo, colaborando para reduzir as pressões sobre as divisas". (DIAS, FRANCISCO e CAVALLI JÚNIOR, 2008, p.31)

188 "No dia 4 do corrente outros ilustre líderes do cooperativismo solicitaram ao Sr. Governador do Estado a mesma medida nos termos do seguinte memorial, cujos termos passor a ler para conhecimento dos Sr.
} 
quando em 1954 a importação de batatas holandesas novamente era uma questão levantada pelas cooperativas ${ }^{189}$. Além de Yukishigue Tamura, podemos mencionar a defesa do projeto de criação do Centro Estadual de Abastecimentos S.A (CEASA) pelo deputado estadual João Sussumu Hirata ${ }^{190}$ em 1959. Tratava-se da criação de um grande complexo de distribuição e comercialização de produtos hortifrtuigranjeiros na cidade de São Paulo, localizado a poucos metros das instalações da Cooperativa, projeto que Fábio Yassuda havia acompanhado de perto, segundo relatos de publicação comemorativa do empreendimento (CAC, 1988).

O que podemos observar, portanto, é que a gestão de Gervásio Inoue teve início em um ambiente de atuação empresarial distinto para a CAC, especialmente se comparado ao período em que Kenkiti Simomoto esteve no comando da empresa. Basicamente, os gestores do empreendimento passaram a valorizar certas relações que pudessem influenciar o mercado por vias políticas, e muitas de suas demandas então não eram mais dirigidas unicamente ao Departamento de Assistência ao Cooperativismo

Presidente e dos meus nobres pares, principalmente do ilustre Presidente dessa Assembleia, a quem solicito urgência na discussão e votação do Projeto de Lei em trâmite nesta Casa, que cancela os impostos e multas fiscais exigidos das sociedades cooperativas". (Sobre executivos fiscais providos contra cooperativas. Discurso de Yukishigue Tamura na Assembleia Legistlativa de São Paulo, Caixa 5, Pasta

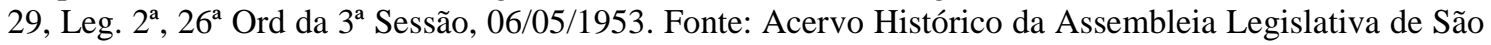
Paulo)

189 "Sr.Presidente e Srs. deputados, visando atender aos reclamos da lavoura e tendo a preocupação precípua de atender ao abastecimento de batata à população, encaminhamos, ontem, à Mesa da Assembleia, para que fosse remetida com urgência ao Executivo, uma indicação visando obter de S.Exa. o Sr. Governador do Estado a sua inteira solidariedade para com os produtores de batata e, em consequência, com os consumidores, indo S.Exa. entende-se com as autoridades federais, no sentido de obter, com certa facilidade, para os produtores, para entidades assistenciais da lavoura e para os comerciantes que negociam com esse tubérculo, o direito de obter dólares, as divisas necessárias para a importação, da Holanda, dessas 500 mil caixas, das quais fiz referências a V.Exa., Sr. Presidente, e aos meus ilustres pares. Isto para atender às necessidades da plantação de batatas em setembro e outubro deste ano. Pedi,ainda, nesta indicação, ao Sr. Governador que fizesse sentir ao Poder Público Federal a necessidade de eliminar a cobrança de $8 \%$ de imposto de importação que recai nas importações de sementes e que esta franquia, que este benefício fosse estendido, também, a todas as sementes destinadas à produção de gêneros alimentícios, para contribuir decisivamente no fomento à produção destes gêneros, abaixo custo de produção e visando um maior rendimento". (Abastecimento de batata à população paulista. Discurso de Yukishigue Tamura na Assembleia Legistlativa de São Paulo, Caixa 13, Pasta 89, Leg. 2a $74^{\mathrm{a}}$ Ord da $4^{\mathrm{a}}$ Sessão, 16/07/1954. Fonte: Acervo Histórico da Assembleia Legislativa de São Paulo)

${ }^{190}$ Instalação do centro de abastecimento da capital, em Jaguaré. (Discurso de Joao Sussumu Hirata na Assembleia Legistlativa de São Paulo, Caixa 15, Pasta 5, Leg. 4ª $3^{\mathrm{a}}$ Ord da $1^{\mathrm{a}}$ Sessão, 18/03/1959. Fonte: Acervo Histórico da Assembleia Legislativa de São Paulo) 
como ocorria anteriormente, e sim eram apresentadas como pautas de negociação por meio de órgãos classistas do setor agrícola.

Gervásio Inoue assumiu a presidência da Cooperativa cerca de um ano e meio antes da morte de seu principal líder, Kenkiti Simomoto, falecido em 25 de setembro de 1957. Mesmo que Simomoto não ocupasse mais o cargo máximo de direção na empresa, ele gozava de inegável prestígio entre os imigrantes japoneses e as autoridades nipônicas. $\mathrm{O}$ seu último projeto de grande envergadura esteve relacionado à retomada da imigração japonesa, possibilitado por vias legais somente após o reestabelecimento das relações diplomáticas entre o Brasil e o Japão, em 20 de abril de 1952. Kenkiti Simomoto esteve à frente de dois projetos de imigração, denominados Jovens Imigrantes da Cotia e Grupo de Jovens para o Desenvolvimento Industrial e, por esse motivo, estabelecia estreitas relações com o governo japonês.

O primeiro projeto esteve mais diretamente orientado para estabelecer um fluxo contínuo de imigrantes japoneses, que eram enviados a núcleos de colonização da Cooperativa, bem como a empresa se responsabilizava por boa parte das questões legais e burocráticas necessárias à vinda dos imigrantes ${ }^{191}$. É válido ressaltar que inicialmente o projeto encontrou resistências vindas de setores como a Sociedade Rural Brasileira, o que motivou Yukishigue Tamura a fazer um discurso na Assembleia Legislativa a favor do projeto migratório planejado pela Cooperativa ${ }^{192}$. O segundo projeto havia sido

\footnotetext{
191 Segundo informações contidas em Comissão (1992, p.387): "Sob a liderança do diretor-gerente Kenkiti Simomoto, a CAC prosseguiu com tenacidade nas negociações com o governo brasileiro no sentido de conseguir a introdução de jovens imigrantes pelo "método Nokyo". Esse método estabelecia o seguinte: os imigrantes seriam recebidos por lavradores cooperados da $\mathrm{CAC}$ e os serviços burocráticos necessários ficariam a cargo da CAC; a seleção dos emigrantes no Japão ficaria a cargo da Cooperativa Central das Cooperativas Agrícolas do Japão Nokyo, comissionada pela CAC, e o serviço de emigração, pela Federação das Associações Ultramarinas de Emigração. Uma divisão de trabalho combinada. As negociações entabuladas pela Cooperativa Agrícola de Cotia chegaram a um final feliz: em 4 de janeiro de 1955, o Instituto Nacional de Imigração e Colonização autorizou oficialmente a CAC a introduzir 500 jovens lavradores por ano durante três anos, no total de 1.500 ".
}

192 "O sr. Yukishigue Tamura, falando ontem na Assembleia Legislativa, sobre as notícias da próxima vinda de quarenta e cinco mil imigrantes japoneses para o Brasil, manifestou seu júbilo por esse fato (...) Comentando declaração de um diretor da Sociedade Rural Brasileira, que fez restrições à conveniência da vinda de japoneses para o Brasil, o orador lamentou que ainda surjam esporádicas manifestações nesse sentido, quando as mais altas autoridades da República, como o presidente Getúlio Vargas, já demonstraram seu apreço pela ajuda do imigrantes japoneses ao progresso do País. Disse o sr. Yukishigue Tamura que, orgulhando-se de sua nacionalidade brasileira, sente o dever cristão e cívico de batalhar pelo crescente intercâmbio entre o Brasil e a pátria de seus ascendentes". ("Considerações sobre a vinda de imigrantes japoneses para o Brasil". O Estado de S.Paulo, 6 de dezembro de 1952, p.8) 
criado por iniciativa do governo japonês, e planejava atuar no setor de beneficiamento de produtos agrícolas. Para recebê-los, Kenkiti Simomoto havia planejado criar um órgão específico, a Associação Central de Cooperativas Agrícolas de Colonização do Estado de São Paulo. Contudo, Simomoto faleceu antes da criação da entidade, que foi concretizada por Gervásio Inoue em 26 de outubro de 1957. Em linhas gerais, os projetos foram encerrados na década de 1960, tendo trazido cerca de 2.000 novos imigrantes japoneses para o Brasil (CAC, 1988). 
Figura 21 - Assembleia de fundação da Cooperativa Central Agrícola e de Colonização do Estado de São Paulo, presidida por Gervásio Inoue.

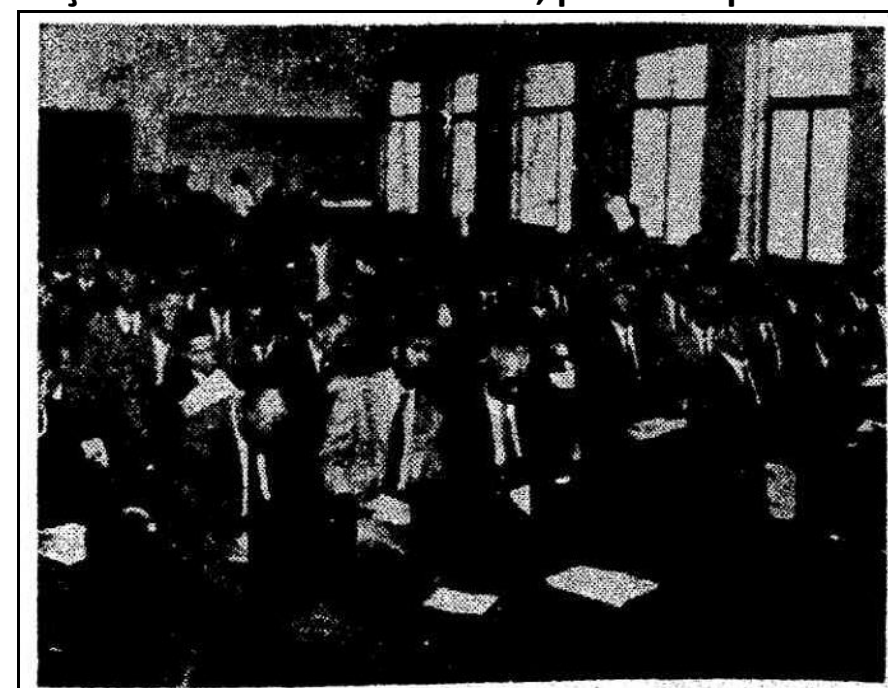

Nova Cooperativa Agricola - Realizou-se anteontem, no Galvăo Bulẩo do cine Niteroi, na rua Central Agricola e de Colonização do Estado de São Paulo, que terá como objetivo contribuir para o desenvolvimento da agricultura, organizada nas bases do cooperativismo, e possibilitar a fixação do ruricola, offerecendo-lhe assistencia e orientação necessarias para a consolidação de suas bases economicas.

Os trabalhos foram presididos pelo dr. Gervasio Tadashi Inoue, diretor-presidente da Coopentiva Agricola de Cotia, tendo comparecido 132 aderentes e mais 66 se fizeram representar por procuração.

Após serem discutidos e aprovados os estatutos sociais, procedeul-se á eleição do Conselho de Administraçăo e do Conselho Fiscal, que ficaram assim constituidos: Conselho de Administraçâo - Anze Molizi, Masao Aikawa, Kou Kuma, Shuichiro Wada, Klunoske Kanegae, Shigueru Ushikussa, Kumaki Nakao, Shizuo Hosoe e José Senoi; Conselho Fiscal - Gisuke Takenaka, Sasaichi Mazaki e Chinai Yoshiwara; suplentes, Shungoro Wako, Matajiro. Yamagushi e Soiti Taruma.

Terminada a eleição, o Conselho de Administração escolteu a Diretoria Executiva: diretor-presidente, Anze Molizi; diretor-gerente, Kou Kuma, e diretor-secretario, Masao Aikawa.

o sr. Kenkiti Simomoto, fundador da Cooperativa Agricola de Cotia e um dos ploneiros do cooperativismo no Brasil, foi um dos maiores batalhadores pela organização da entidade recém-fundada. Nia gravura, aspecto da assembléia de fundaçáo.

Fonte: O Estado de S.Paulo, 29 de outubro de 1957, p.15.

É também em fins da década de 1950 que podemos constatar o início da participação dos gestores de segunda geração de Gervásio Inoue e Fábio Yassuda em ações do restrito grupo de lideranças da coletividade japonesa no Brasil, como bem ilustram as ocasiões da organização e dos festejos comemorativos do cinquentenário da imigração japonesa. Sobre esse assunto, duas considerações merecem destaque: segundo 
registros nativos ${ }^{193}$, foi na década de 1950 que se observou um movimento - conduzido pelas lideranças do grupo - capaz que congregar a população de origem japonesa e reestabelecer um canal de contato desse grupo com as autoridades governamentais japonesas, o que teria contribuído para eliminar, em certo grau, as diferenças de posições políticas assumidas ainda no período da Segunda Guerra (COMISSÃO, 1992, p.397); esse movimento ocorreu, entre outros aspectos, mediante a produção e a disseminação de uma narrativa de êxito da experiência migratória dos japoneses no Brasil.

No início do ano de 1952 a comissão responsável pela comemoração dos 400 anos da cidade de São Paulo, a ser celebrada em 1954, passou a mobilizar associações de grupos entrangeiros e suas representações diplomáticas visando a sua participação. Em janeiro do ano seguinte, foi organizada uma comissão entre os japoneses residentes no Brasil, denominada Comissão Colaboradora da Colônia Japonesa Pró-IV Centenário da Cidade de São Paulo. Essa teria sido, segundo Comissão (1992, p.397), a "primeira entidade que engloba toda a colônia nikkei do Brasil, em toda a sua história, abrangendo o período anterior e posterior à guerra".

Em 1955, aproveitando-se da estrutura de organização da comissão do IV centenário da cidade de São Paulo, a celebração dos 50 anos da imigração japonesa no Brasil passou a ser organizada mediante a criação da Sociedade Paulista de Cultura Japonesa. O seu presidente era Kiyoshi Yamamoto (gerente-geral da Casa Tozan); vicepresidentes Kumaki Nakao (comerciante e ex-diretor da CAC) e Américo Sugai (advogado eleito vereador em 1963); e presidente do Conselho Deliberativo, Kunito Miyasaka (fundador do Banco América do Sul). Em 1968 o seu nome foi alterado para Sociedade Brasileira de Cultura Japonesa.

Essa Sociedade teve uma característica centralizadora de grande parte das atividades de membros da "colônia" de origem japonesa, pois grande parte dos

\footnotetext{
${ }^{193}$ A referência aqui utilizada é o livro Uma epopéia moderna - 80 anos da imigração japonesa no Brasil. São Paulo: Hucitec/Sociedade Brasileira de Cultura Japonesa, 1992, de autoria da Comissão de Elaboração da História dos 80 Anos da Imigração Japonesa no Brasil. Considero-a um registro nativo pelo fato do seu conteúdo ter sido produzido por personagens e instituições da coletividade japonesa no Brasil que, por vezes, tiveram participação nos festejos do cinquentenário da imigração japonesa. Somase a isso o fato de a obra em questão ter sido publicada com o objetivo de representar uma narrativa sistemática e objetiva da imigração japonesa.
} 
acontecimentos de grande repercussão envolvendo a imigração japonesa ocorreram sob os auspícios dessa entidade. Dessa forma, em novembro de 1956 formou-se a Comissão Preparatória do Cinquentenário da Imigração Japonesa, que contou com 422 comissões deliberativas em todo o país. Ainda segundo relatos contidos em Comissão (1992), a comemoração do cinqüentenário da imigração foi especialmente significativa para os imigrantes japoneses e seus descendentes residentes no Brasil, pelos seguintes motivos:

- representou o ponto final do período de intensos sofrimentos dos primeiros imigrantes e das fases imediatamente anterior e posterior da guerra, quando se verificou intensa campanha antijaponeses no Congresso Nacional e na imprensa brasileira; e o fim da triste época da divisão da comunidade em duas facções antagônicas;

- apontou uma nova direção para o futuro da colônia nikkei, mediante a criação de uma nova entidade integrada e representativa da comunidade nipônica do Brasil. (COMISSÃO, 1992, p.400)

Foi, portanto, naquele contexto de celebração do cinquentenário da imigração japonesa no Brasil que, entre outros, foram criadas associações e entidades consideradas promotoras da cultura japonesa no país. Podemos mencionar, por exemplo, a atual Sociedade Brasileira de Cultura Japonesa, a entidade de assistência médica Beneficência Nipo-Brasileira de São Paulo, além da realização do primeiro survey de abrangência nacional sobre a população japonesa, posteriormente publicado em dois volumes, sob o título The Japanese Immigrant in Brazil. A participação dos gestores da CAC naquele contexto ocorreu mais diretamente nas atividades de organização dos festejos comemorativos, bem como na comissão que deu origem à Aliança Cultural Brasil-Japão em 17 de novembro de 1956: "da qual faziam parte figuras de niseis influentes como João Sussumu Hirata, Gervário Inoue e Fábio Yassuda. O movimento contou com decidido apoio de líderes da colônia, como Kiyoshi Yamamoto, Kunito Miyasaka, Kenkiti Simomoto e outros" (COMISSÃO, 1992, p.404). Sumariamente, essa entidade teve como objetivo estreitar o intercâmbio cultural entre o Brasil e o Japão, ao promover pesquisas, conceder bolsas de estudos, instalação de bibliotecas, cursos, realização de conferências. 
Por fim, as festividades do cinquentenário da imigração japonesa tiveram início em 19 de junho de 1958 no Parque do Ibirapuera, e se prolongaram até dezembro do mesmo ano, tendo contado com amplo apoio dos governos japonês e brasileiro. Na ocasião, o governo japonês foi representado oficialmente pelos príncipes Takahito Mikasa e Yuriko Mikasa, recebidos pelo governo brasileiro com honras de hóspedes de Estado. A estadia no Brasil entre 17 e 22 de junho de 1958 era um dos destinos na agenda do casal, que incluía ainda o Peru e a Argentina. Os príncipes fizeram visitas pelo estado de São Paulo e Paraná, e entre os acontecimentos de destaque em São Paulo, é possível mencionar a sua visita ao Museu do Ipiranga, em que foram recebidos por ninguém menos que o etnólogo Herbert Baldus (um dos pioneiros dos estudos dos imigrantes japoneses no Brasil), e a sua visita às maiores cooperativas agrícolas fundadas por japoneses à época: a CAC, a Cooperativa Agrícola Bandeirante e a Cooperativa Agrícola Sul-Brasil ${ }^{194}$.

Vale ressaltar que se tratou da primeira visita oficial de membros da família imperial japonesa após o evento da Segunda Guerra, o que nos faz atentar para a relevância simbólica desse acontecimento. Nos jornais foram reportados os discursos de Takihito na sede da CAC e no museu do Ipiranga, e aqui reproduzimos alguns trechos em que a agricultura e o cooperativismo foram associados a uma narrativa de êxito da experiência da imigração japonesa no Brasil:

Soubemos, com satisfação, que essas cooperativas que acabo de visitar foram fundadas por imigrantes japoneses e que hoje se tornaram grandes e modelares, tendo em seu seio, como cooperados, agricultores de todas as nacionalidades.

Fomos informados, também, que graças a essas organizações agrícolas, os agricultores japoneses puderam colaborar no desenvolvimento da agricultura deste Estado e da Nação Brasileira.

Desejamos formular sinceros votos para que outras cooperativas como estas de desenvolvam, não só para o progresso e felicidade dos seus próprios cooperados como para que a colaboração dos imigrantes japoneses no setor da agricultura continue sempre e cada vez mais. ("Os príncipes Mikasa visitam as entidades e organizações da coletividade japonesa". O Estado de S.Paulo, 20 de junho de 1958, p.10)

\footnotetext{
${ }^{194}$ Ver: "Os Príncipes Mikasa visitam as entidades e organizações da coletividade japonesa". O Estado de S.Paulo, 20 de junho de 1958, p.10.
} 
Dentre aqueles que se encontravam, naquela manhã, na Catedral da Sé muitos haviam, por certo, que perderam seus entes queridos na árdua luta de colonização, sem atingirem a sua finalidade. E isto não em condições normais, mas na luta contra as intempéries e vicissitudes da própria natureza. Não foram pequenas, também, as dificuldades de aclimatação a um meio de condições tão diversas das do seu país de origem. E assim, desanimados e já sem espírito de luta, muitos se foram sem poderem ver este magnífico resultado de hoje.

Quando refletimos na realidade crua desses fatos, torna-se fácil reconhecer que atrás daquelas instalações modelares, como daqueles produtos agrícolas tão maravilhosos, que nem no Japão se vêem iguais, que vimos por ocasião das visitas às cooperativas Bandeirante, Sul-Brasil e Cotia, existem, como íamos dizendo, atrás de tudo isso, sacrifícios, muitas vezes inexprimíveis em palavras. E é justamente por isso que esse grande sucesso dos imigrantes japoneses nos comove sobremaneira. ("Programa de ontem dos príncipes Mikasa - Solenidades no Ibirapuera, cerimônia do chá e visita ao Museu do Ipiranga". O Estado de S.Paulo, 22 de junho de 1958, p.18)

\section{Figura 22 - O Príncipe Takahito Mikasa e sua esposa Yuriko Mikasa em discurso nas instalações da CAC no Bairro do Jaguaré, em São Paulo, por ocasião do cinquentenário da imigração japonesa no Brasil. 19 de junho de 1958.}

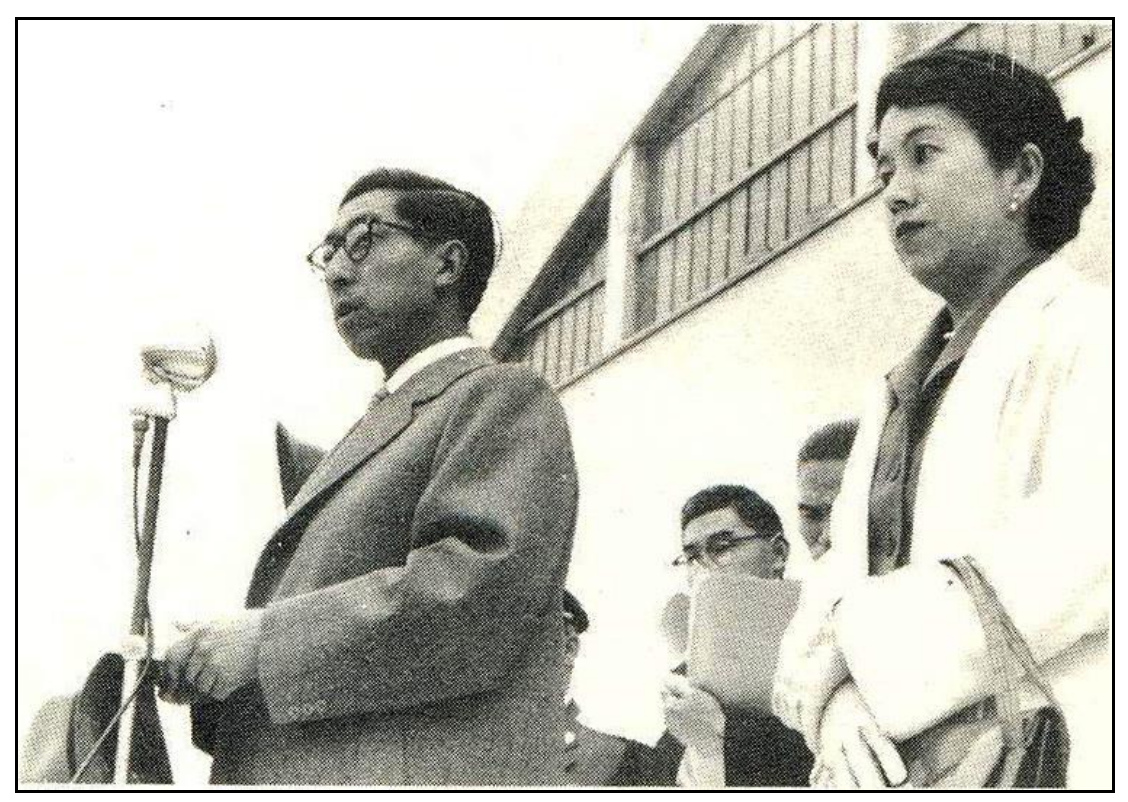

Fonte: CAC, 1988. 
A presença e o discurso da família imperial justamente na sede da Cooperativa parece, portanto, não ter ocorrido de maneira aleatória: o que se observa é que desde 1955, Kenkiti Simomoto, Gervásio Inoue e Fábio Yassuda tiveram participação efetiva nas iniciativas das lideranças da população japonesa em São Paulo que visavam celebrar a imigração japonesa no Brasil enquanto um caso exitoso de experiência migratória. Assim, a CAC passava a garantir um espaço de reconhecimento público, e os acontecimentos aqui apresentados parecem contribuir para a existência de um processo de construção simbólica do empreendimento enquanto uma fonte de autoridade cultural. Um exemplo que pode ilustrar esse protagonismo cultural pela Cooperativa é a realização da Exposição dos Sete, ocorrida em sua sede no ano de $1960^{195}$, ocasião em que aqueles que eram considerados os maiores artistas plásticos da coletividade japonesa expuseram suas obras. Entre eles, o pintor e memorialista Tomoo Handa ${ }^{196}$ e o pintor Manabu Mabe.

A década de 1960 pareceu reproduzir, com intensidade até mesmo maior, certas ações diretamente relacionadas às atividades da CAC em espaços que podemos identificar como extramercantis. Elas parecem contribuir para verificar formas pelas quais - quando a CAC foi comandada pela segunda geração - os universos da política e da cultura também constituíram espaços privilegiados de atuação dos gestores do empreendimento.

A questão do Imposto sobre Circulação de Mercadorias (ICM) parecia ter grande impacto para os lucros da produção agrícola em fins da década de 1960, tendo efeitos

195 Participaram da exposição Tikashi Fukushima (1920-2001), Manabu Mabe (1924-1997), Yoshiya Takaoka (1909-1978), Walter Shigueto Tanaka (1910-1970), Yuji Tamaki (1916-1979), Tomoo Handa (1906 - 1996). Outro(s) participante(s) não foram identificados.

196 Tomoo Handa (1906-1996) nasceu em Utsunomiya, Japão e chegou ao Brasil em 1917. Após trabalhar na lavoura de café no interior paulista, mudou-se para São Paulo em 1921, no Bairro da Liberdade, tendo estudado na Escola Profissional Masculina do Brás (1927 e 1929) e na Escola de Belas Artes de São Paulo (1932 a 1935). Tomoo Handa foi um dos fundadores do Grupo Seibi, o primeiro grupo de artistas japoneses no Brasil. Participou da $1^{a}$ Bienal Internacional de São Paulo, em 1951, do $1^{\circ}$ Salão de Arte Moderna de São Paulo e do $1^{\circ}$ Salão de Arte Moderna do Rio de Janeiro, ambos em 1952. Foi um dos realizadores do $1^{\circ}$ Salão de Arte da Colônia Japonesa em São Paulo, em 1952. Na década de 1930 teve contato com o modernista Mario de Andrade, segundo relatou em entrevista: "Eu morava na casa de uma aluna dele do Conservatório Musical. Na formatura do Conservatório, resolveram adotar música japonesa, mas comparativamente com a música do Ocidente. Eu então estudei a música japonesa e lhe fiz um relato verbal, comparando-as. A partir dessa experiência, toda semana eu ia encontrar-me com Mário de Andrade na rua Lopes Chaves, onde discutíamos sobre a Arte em geral [...] Nós falávamos sempre sobre o Grupo (Seibi) e a minha primeira mostra foi ele que conseguiu" (LOURENÇO, 1995, p.92). 
bastante negativos principalmente para os pequenos proprietários rurais. Ao menos desde 1964 a sua isenção já havia constituído uma demanda pelos grupos organizados, principalmente pelas cooperativas agrícolas do estado de São Paulo. Para a CAC, é possível afirmar que os principais obstáculos apontados pelos gestores naquele período eram a inflação e a carga tributária considerada excessiva (especialmente o ICM) sobre determinados produtos como a batata, o qual a Cooperativa era responsável por cerca de 47\% do abastecimento nos estados de São Paulo e Guanabara:

Com o excesso de produção no país,a elevação da alíquota do ICM e a retração do consumo, um preço médio obtido de NCr\$12,62 (NCr\$14,45 em 1967), por saca, muitas vezes inferior ao custo da produção, o ano foi de crise para o setor. A venda foi de 2.216.000 sacas contra 2.054.000 do ano anterior. Não obstante, nossa participação no abastecimento dos Estados de São Paulo e Guanabara atingiu a 47\% do total. Uma das medidas para contornar a crise do setor seria a isenção ou a redução do ICM. pois a carga tributária se revelou como o fator mais oneroso à economia do produto. (Relatório de Serviços Sociais da CAC, 1968, p.IV)

Em 1967 e 1968 podemos observar, novamente, a atuação do deputado federal Yukishigue Tamura (ARENA) com o objetivo de propor a isenção do imposto para as cooperativas no Congresso:

[...] as cooperativas de produção, que tinham o mesmo espírito ou mais perfeito ainda, de associar as forças individuais, pequenas, fracas, e organizá-las em grandes entidades, como o são hoje a Cooperativa Agrícola Sul-Brasil, a Cooperativa Agrícola de Cotia, a Central, a Cooperativa Suburbana, a Mauá, a Bandeirantes, a Mogi das Cruzes etc. São organizações esplêndidas, que constituem hoje um patrimônio nacional. No entanto, elas tendem a desaparecer. Por que? Por causa da instituição do Imposto de Circulação de Mercadorias. ("Cooperativismo e Isenção do Imposto de Circulação aos Horti-Granjeiros na Constituição Brasileira - Defesa no Congresso Nacional pelo Deputado Yukishigue Tamura". O Estado de S.Paulo, 18 de janeiro de 1967, p.13)

Ah, este ICM como está prejudicando a lavoura! Conheço bataticultores que venderam 100 sacas e, antes mesmo de receberem o produto delas, pagaram ao Governo 17 sacas. Sabemos que a produção de batata este ano foi prejudicial, porque não alcançou sequer, no mercado interno, o custo da produção.

Salve, Sr. Presidente da República, a lavoura nacional! ("Crise com os plantadores de batata". O Estado de S.Paulo, 9 de outubro de 1968) 
A representação de interesses da Cooperativa em órgãos classistas do setor agrícola - principalmente a FARESP, a UNASCO e a UCESP - parecia ter centralidade para as estratégias do núcleo gerencial, a ponto de Gervásio Inoue e Fábio Yassuda disputarem com veemência seus pontos de vista e os cargos de comando desses órgãos, o que por vezes resultou em cisões internas. Em julho de 1964 Gervásio Inoue e Fábio Yassuda viram ameaçadas as suas funções na UCESP, por divergirem de certas decisões da direção do órgão, principalmente da transferência de um congresso nacional de cooperativismo de São Paulo para Recife. O jornal Correio da Manhã noticiava o acontecimento com o título de reportagem "Declarada a cisão no cooperativismo"197. Segundo a declaração de Fábio Yassuda, o conflito teria ocorrido porque:

Instalados em alguns postos-chave da UCESP e da União Nacional da Associações Cooperativas (UNASCO), os srs. Francisco Antônio de Toledo Piza, Renato Correia da Rocha e outros elementos que, assessorados por conhecido comunista de São Paulo, integraram o dispositivo de agitação comuno-peleguista, hoje, não nos perdoam o fato de, quando a subversão estava em marcha, termos resistido à dubiedade de sua conduta e de seus desígnios. (...) Escolheram-nos, assim, para a punição exemplar porque denunciamos, em tempo oportuno, as tentativas de engajar o cooperativismo na máquina subversiva que funcionava sob o governo anterior - pelo menos no setor cooperativista - aí continuam, como a mesma técnica, a disseminar a discórdia e a desunião entre os que dão o melhor de seus esforços pelo maior bem-estar do nosso povo, dentro das instituições democráticas.

No dia seguinte à publicação dessa notícia, a direção da CAC estampou uma nota pública no jornal O Estado de S.Paulo ${ }^{198}$, explicando a posição contrária de seus gestores em relação à transferência do congresso para Recife, e informando que Gervásio Inoue seria expulso da UCESP, e Fábio Yassuda considerado persona non grata. Em 14 de julho, pressionados pela saída de várias outras cooperativas da UCESP em solidariedade à Cotia, os diretores do órgão então formalizaram um acordo,

\footnotetext{
${ }^{197}$ Correio da Manhã, 10 de julho de 1964, p.5.

198 "Seção livre - Aos cooperativistas, ao povo, às autoridades". O Estado de S.Paulo, 11 de julho de 1964, p.19.
} 
mantiveram a realização do congresso na cidade de Recife, porém desconsideraram qualquer possibilidade de desligamento dos gestores de Cotia ${ }^{199}$. E, principalmente, foi acordado que haveria uma reestruturação da direção do órgão, por solicitação de Gervásio Inoue e Fábio Yassuda ${ }^{200}$. Em 1966, Yassuda garantia o seu cargo de vicepresidente da UCESP ${ }^{201}$.

Em fins da década de 1960 dois acontecimentos tiveram destaque para a coletividade japonesa de São Paulo: a vinda dos príncipes-herdeiros Akihito e Michiko em 1967 (como parte de um roteiro que incluía ainda a Argentina e o Peru), e um simpósio realizado em 1968, que ocorreu como parte da comemoração dos 60 anos da imigração japonesa no Brasil. Novamente, podemos constatar a presença de Fábio Yassuda e Gervásio Inoue nesses eventos, o que será relatado brevemente a seguir.

A visita dos príncipes-herdeiros do Japão ocorreu entre 22 e 28 de maio de 1967, tendo o casal visitado os estados de Minas Gerais, São Paulo, Rio de Janeiro e Brasília. É válido ressaltar o aspecto da parceria comercial entre Brasil e Japão, que passava a se fortalecer cada vez mais. Ao menos desde o governo de Juscelino Kubitschek (19561961), empresas japonesas eram estimuladas a investir na indústria nacional de base, e acordos comerciais passaram a ser planejados, como havia declarado o príncipe Mikasa $^{202}$. A partir de 1967, durante o regime militar, o Japão se tornou um importante parceiro comercial do governo brasileiro, tendo aumentado consideravelmente o montante de investimentos no país na década de 1970 (LESSER, 2008).

\footnotetext{
199 "Falou o presidente da UCESP, sr. Francisco Antõnio de Toledo Piza, agradecendo as manifestações de solidariedade e a compreensão geral, afirmando que os companheiros da Cotia continuavam a merecer o mesmo respeito de sempre e que eram elementos de alta consideração e dinamismo dentro do movimento cooperativista; declarou que na crise, felizmente superada, se fosse obstáculo para a harmonização que se processava, não hesitaria em afastar-se para que o objetivo fosse conseguido". ("Superada a crise no movimento cooperativista de São Paulo". O Estado de S.Paulo, 14 de julho de 1964, p.11)

200 "a CAC dirigiu-se às diversas cooperativa que a apoiaram no episódio (algumas das quais se desligaram da UCESP em sinal de solidariedade à CAC) e às que não fazem parte da UCESP (cooperativas de cafeicultores, de plantadores de cana, de citricultores etc.), dando-lhes ciência do termos do protocolo referido e solicitando sua colaboração para a projetada reestruturação do órgão de cúpula do cooperativismo paulista, com vistas a tornar o mais amplo possível o caráter representativo desta entidade". ("Cooperativa de Cotia quer reestruturação da UCESP". Folha de S.Paulo, 19 de julho de 1964, p.3)

${ }^{201}$ Quer voltar à FAESP. O Estado de S.Paulo, 26 de agosto de 1966, p.16.

202 "Melhoria no comércio entre os dois países". O Estado de S.Paulo, 13 de junho de 1958, p.1.
} 
Figura 23 - Gervásio Tadashi Inoue, Diretor-Presidente da CAC (1957-1990).

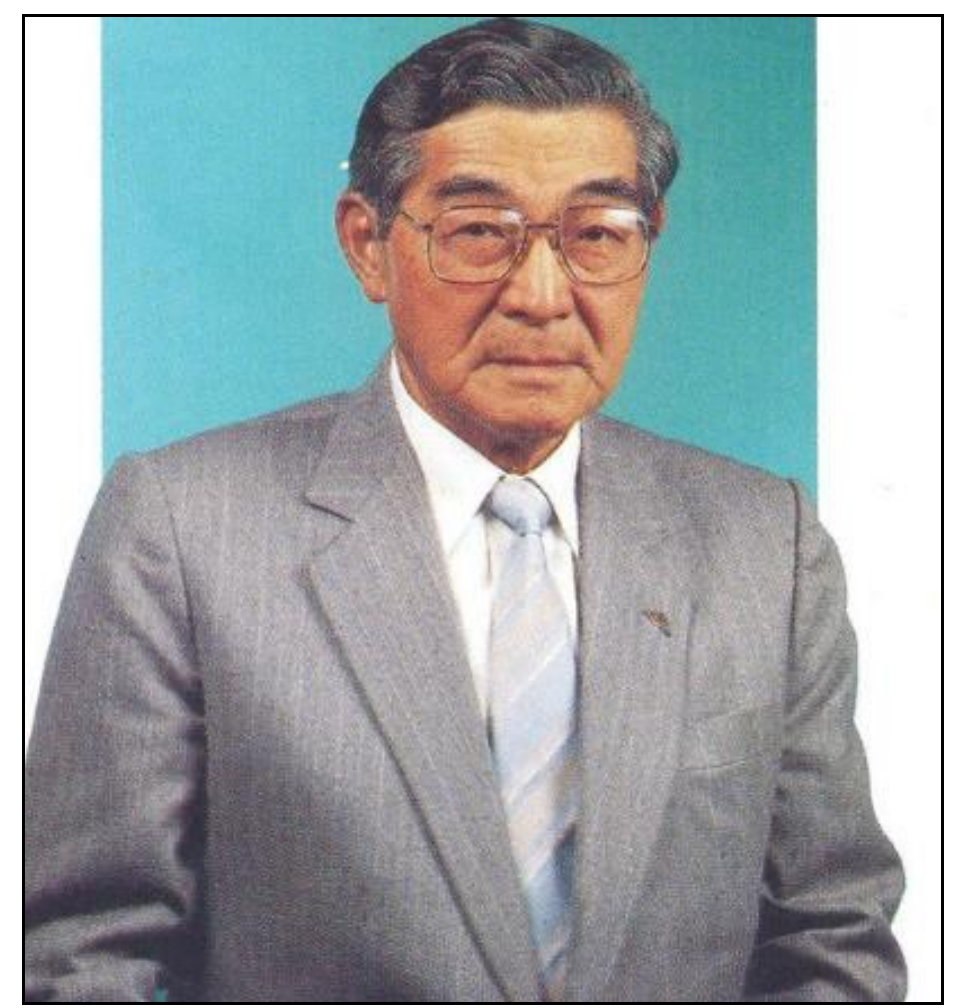

Fonte: Coopercotia 50 anos (CAC, 1992).

O casal imperial foi recebido pessoalmente pelo presidente Costa e Silva no Palácio da Alvorada, e a visita a São Paulo foi marcada por uma celebração ocorrida no estádio do Pacaembu, em que compareceram cerca de 70 mil pessoas ${ }^{203}$. Na ocasião, ao lado de autoridades governamentais e expoentes de lideranças das coletividade japonesa, Gervásio Inoue ocupava a função de mestre de cerimônias, segundo relatou Tomoo Handa:

Às $10 \mathrm{~h} 08 \mathrm{~m}$ os príncipes herdeiros tomaram lugar no palanque especial. A seu lado sentaram-se o governador e sra. Abreu Sodré, pouco atrás o prefeito de São Paulo e sra. Faria Lima, embaixador Keiichi Tatsuke, Kunito Miyasaka, presidente do

${ }^{203}$ Ver as reportagens: "Pacaembu vive seu dia de maior gala e 70 mil foram ver o príncipe". O Estado de S.Paulo, 26 de maio de 1967, p.1. 
Comitê de Recepção. Nos assentos próximos tomaram lugar pessoas, entre condecorados e anciãos.

Ao redor do local das cadeiras imperiais, uma área de quatro metros quadrados, foram colocados enfeites com flores. Às $10 \mathrm{~h} 10 \mathrm{~m}$, num silêncio absoluto, iniciou-se a cerimônia de recepção, com o discurso de Tadashi Inoue, mestre-de-cerimônias, seguido dos hinos nacionais dos dois países, cantados por um coral de 2.000 participantes. (HANDA, 1987, p.778)

Os jornais acompanharam a visita dos príncipes-herdeiros durante toda a sua estadia no Brasil, e a publicização de uma narrativa de êxito da imigração japonesa podia ser encontrada em títulos de reportagens como "O sonho vai da terra à faculdade"204, em que a ascensão dos imigrantes era enfatizada. A aceitação dos japoneses na sociedade local parecia não mais representar um ponto de interrogação para grande parte da opinião pública e, nesse caso, é válido destacar que tal aceitação esteve por vezes associada à ideia de que da inexistência de preconceito racial na sociedade brasileira. É dessa forma que o já mencionado pacto da democracia racial conduzido pelas mãos do Estado a partir da década de 1940 ganhava continuidade na década de 1960 enquanto discurso oficial, ao menos para a tarefa de explicar os motivos da aceitação da população de origem japonesa no Brasil, conforme a reportagem "Professor Negro fará a tradução"205 nos informa:

O prof. José Santana do Carmo, descendente da raça negra, é quem traduzirá para o príncipe Akihito, em japonês, o discurso de saudação que será proferido pelo deputado estadual Antonio Morimoto, amanhã, no Pacaembu, em nome do Poder Legislativo. O professor, que desde 1937 [sic] ministra aulas de japonês na Aliança Cultural Brasil-Japão, foi escolhido pelo parlamentar, seu ex-aluno, que pretende, com a iniciativa, demonstrar ao ilustre visitante a inexistência da discriminação racial no Brasil, o que possibilitou a integração da coletividade japonesa na grande família brasileira.

Entre os acontecimentos que fizeram parte dos festejos dos 60 anos da imigração japonesa no Brasil em 1968, merece destaque aqui o simpósio denominado O japonês

${ }^{204}$ O Estado de S.Paulo, 24 de maio de 1967, p. 12.
${ }^{205}$ O Estado de S.Paulo, 24 de maio de 1967, p.12. 
em São Paulo e no Brasil, formalizado pelo Secretário da Agricultura do Estado de São Paulo, Herbert Levy ${ }^{206}$. Conforme será tratado adiante, o empresário e político Herbert Levy havia sido presidente nacional da União Democrática Nacional, partido a que Fábio Yassuda e seu irmão Eduardo eram filiados.

O simpósio em questão foi, possivelmente, o principal evento de grande porte dedicado a discutir a imigração japonesa sob uma perspectiva assumidamente acadêmica em que podemos constatar a presença de grandes expoentes das ciências sociais brasileira da época. Outras iniciativas como o I Painel Nipo-Brasileiro (1956) sob coordenação de Hiroshi Saito e realizado na Escola de Sociologia e Política haviam ocorrido anteriormente, na década de 1950, também promovendo avaliações acadêmicas sobre o tema da imigração. Contudo, para os interesses desta pesquisa, o simpósio O japonês em São Paulo e no Brasil foi aquele em que pudemos constatar a presença efetiva dos dois gestores da CAC, bem como uma narrativa positiva a respeito da imigração japonesa no Brasil parecia adquirir maior vigor, a ponto de ser validada até mesmo por prestigiados intérpretes da sociedade brasileira no meio acadêmico profissional.

Os participantes do simpósio eram, em sua maioria, pesquisadores e professores universitários e membros de grupos da intelectualidade japonesa. O simpósio ocorreu em pareceria com a Universidade de São Paulo, e teve Gervásio Inoue como membro da comissão organizadora e Hiroshi Saito como secretário-geral. No evento foram realizadas conferências e apresentações de 24 trabalhos entre os dias 19 e 22 de junho de 1968, e os temas abordados foram inteiramente dedicados à imigração japonesa no Brasil.

Entre os participantes do simpósio, podemos destacar: a historiadora Arlinda Rocha Nogueira; o antropólogo Zempati Ando; o filósofo e linguista Katsunori Wakisaka; o advogado Teiiti Suzuki; o sociólogo Maurício Tragtenberg; o empresário e bibliófilo José Mindlin; o economista e ex-prefeito de São Paulo (1973 e 1975) Miguel Colasuonno; o presidente da Fundação Anchieta, Ruy Nogueira Martins; o Presidente

206 "O secretário Herbert Levy, da Agricultura, presidiu ontem o início dos trabalhos do simpósio 'O japonês em São Paulo e no Brasil'. O titular da Agricultura enalteceu a contribuição dos nipônicos para o desenvolvimento do País. O governador Abreu Sodré foi representado pelo Sr. Eduardo Yassuda, secretário de Obras". (O Estado de S.Paulo, 19 de junho de 1968, p.10) 
do Banco Central do Brasil (1967-1968) Rui Aguiar da Silva Leme; o sociólogo Vicent Unzer de Almeida; o deputado estadual Diogo Nomura; a socióloga Maria Isaura Pereira de Queiroz; o antropólogo Orlando Sampaio Silva; o diretor-gerente da CAC Fábio Riodi Yassuda; o sociólogo Oracy Nogueira; o sociólogo José Pastore; a antropóloga Francisca Isabel Schurig Vieira; o antropólogo João Baptista Borges Pereira; a cientista política Eunice Ribeiro Durham; o sociólogo Cândido Procópio Ferreira de Camargo; o sociólogo José Arthur Rios; o sociólogo Alfonso Trujillo Ferrari; o historiador Sérgio Buarque de Hollanda; a historiadora Emília Viotti da Costa; a economista Diva Benevides Pinho; o pintor e memorialista Tomoo Handa; o sociólogo Octávio Ianni; o sociólogo Florestan Fernandes.

Os eventos aqui analisados permitem exemplificar algumas das ações dos principais gestores de segunda geração da CAC em universos que extrapolam os espaços usualmente referidos como mercado entre fins da década de 1950 e 1960. Do ponto de vista argumentativo, o que deve ser ressaltado é que o entendimento das atividades de empresas pode ser proficuamente complementado ao considerarmos fatores além daqueles que representam a instrumentalização de recursos disponíveis visando unicamente ao alcance de interesses racionais, ou seja, ao considerarmos fatores inseparáveis da experiência de grupos em posições de comando.

No caso da Cooperativa, a clivagem geracional operou como um condicionante que, somado a fatores mais amplos, a exemplo da regulação estatal, da estrutura de direitos em regimes políticos, conformou conjunturas que ofertavam possibilidades historicamente situadas de atuação empresarial e de reconhecimento social. Busquei aqui analisar algumas das respostas dos gestores da Cooperativa a essas conjunturas com o intuito de demonstrar que a visibilidade dos gestores desse empreendimento em fins da década de 1960 possuía uma origem, e esteve relacionada a processos envolvendo a experiência migratória dos japoneses no Brasil, em que uma segunda geração de imigrantes passava a experimentar a sua inserção em dimensões importantes da vida social. Assim, acredito que a ascensão de Fábio Yassuda ao ministério da Indústria e Comércio em 1969 é um epísódio ilustrativo, e muitos dos significados ali existentes possibilitam uma compreensão sociológica de interesses que, à primeira vista, poderiam ser definidos como estritamente pertencentes a uma lógica utilitária. No tópico 
a seguir procuro apresentar a estrutura de decisão econômica governamental do regime político em que Fábio Yassuda foi nomeado ministro, ressaltando a posição estratégica que a CAC passou assumir nas relações entre Estado e empresas.

\subsection{Por dentro da estrutura de poder e decisão política}

Ainda que nesta pesquisa seja conferida especial atenção ao caso de Fábio Yassuda, é importante mencionar outros exemplos relevantes, pois eles fornecem dados que contribuem para a constatação de que houve um movimento de inserção de seletos filhos de imigrantes em núcleos centrais de poder ao final da década de 1960, durante o regime militar. Esse tipo de participação ocorreu em meio à conformação de um novo quadro de profissionais que caracterizou o regime autoritário brasileiro, ou a "tecnocracia", se assim pudermos qualificá-los segundo os conceitos formulados por Octávio Ianni (2009). Possuem destaque, entre outros, os casos de Shigeaki Ueki ${ }^{207}$, Paulo Yokota ${ }^{208}$, Akihiro Ikeda e Eduardo Yassuda, este último que era irmão de Fábio Yassuda. Entre expoentes de outros grupos de imigrantes, possui destaque Paulo Salim Maluf $^{209}$, filho de imigrantes libaneses que haviam alcançado sucesso nos mundo dos negócios em São Paulo ${ }^{210}$.

\footnotetext{
${ }^{207}$ Shigeaki Ueki foi assessor do Ministro da Indústria e Comércio Paulo Egydio Martins durante o governo de Castelo Branco (1964-67), presidente da Petrobras Distribuidora, ministro de Minas e Energia do Brasil no governo Ernesto Geisel (1974-79) e presidente da Petrobras (1979-84) no governo de João Figueiredo (1979-1985).

${ }^{208}$ Paulo Yokota foi assessor do Ministro da Fazenda Antonio Delfim Netto, Diretor do Banco Central do Brasil (1971), Presidente do Instituto Nacional de Colonização e Reforma Agrária (INCRA) (1979).

${ }^{209}$ Paulo Salim Maluf ocupou os cargos de Presidente da Caixa Econômica Federal (1967-1969), Prefeito de São Paulo (1969-1971 e 1993-1996), Secretário dos Transportes do governo do estado de São Paulo (1971-1975), Governador do estado de São Paulo (1979-1982) e Deputado federal (1983-1987).

${ }^{210}$ Segundo Truzzi, Paulo Maluf "Casou-se com uma das filhas de Fuad Luftalla, que tinha sido um dos grandes da colônia no setor têxtil, e por treze anos ocupou, ao lado de seu irmão primogênito e de sua mãe, do amplo leque de negócios controlados por sua família. Em 1964, assumiu a vice-presidência da Associação Comercial de São Paulo, na quela Eduardo Saigh, sogro de seu irmão, já havia sido presidente" (TRUZZI, 2009, p.216).
} 
Uma primeira observação a respeito desses mencionados personagens é a sua ascensão, a partir de 1967, em cargos decisórios reconhecidamente relevantes no universo da política. Demonstrarei a seguir que, preenchidas algumas condições que favorecessem o seu ingresso em carreiras políticas na época, como a formação universitária e a docência em instituições reconhecidas, esse movimento de ascensão dependeu da emergência de uma nova estrutura estatal de poder e de decisão política, bem como da posição dos agentes nessa estrutura. Outro fator que possivelmente favoreceu o seu ingresso e sua permanência nos quadros governamentais eram as relações com agentes detentores de poder na estrutura, dentre os quais tem destaque o economista Antonio Delfim Netto. Este último que, a partir de seu ingresso no Ministério da Fazenda do governo de Arthur da Costa e Silva (1967-1969), se tornou o principal condutor das políticas econômicas governamentais entre as décadas de $1960 \mathrm{e}$ 1970. Nas palavras de Elio Gaspari: “Catedrático de Economia Brasileira da Faculdade de Ciências Econômicas da Universidade de São Paulo aos trinta anos, ministro da Fazenda aos 38, aos 44 exercia no cargo um poder sem paralelo na história nacional. Nenhum ministro concentrou, como ele, poder e sucesso" (GASPARI, 2003, p.257).

A carreira política meteórica de Delfim Netto se construiu inicialmente na Faculdade de Economia e Administração (FEA) da Universidade de São Paulo, onde se formou no curso de economia e, em 1963, se tornou professor ${ }^{211}$. Foi como catedrático que estabeleceu contatos mais próximos com os até então hegemônicos economistas do Rio de Janeiro que viriam a assumir os cargos centrais de planejamento econômico após 1964, durante o governo de Castelo Branco (1964-67), como Mário Henrique Simonsen,

\footnotetext{
${ }^{211}$ Segundo o relato de Roberto Macedo: "Começou modestamente, com um boné, pois trabalhou como office-boy de uma empresa. Seu caminho educacional - do primário ao ensino médio - iniciou-se no Liceu Siqueira Campos, levando-o à Escola Técnica de Comércio Carlos de Carvalho, de onde saiu, em 1946, como Contador, título então sem nível superior. Para chegar a este, ingressou na Universidade de São Paulo em 1948, no curso de Economia da hoje Faculdade de Economia, Administração e Contabilidade, conhecida como FEA. Em 1952, logo depois de formado, tornou-se o segundo assistente da Cadeira de Estatística I. Chegou, por concurso, a professor catedrático em 1963, sendo de sua cadeira as disciplinas Análise Macroeconômica, Contabilidade Nacional, Teoria do Desenvolvimento Econômico, Economia Brasileira e Planejamento Governamental. Foi o primeiro aluno da FEA a tornar-se um de seus catedráticos. Paralelamente à carreira na USP, atuou como consultor, no setor privado e no setor público. Em 1966 tornou-se secretário da Fazenda do Estado e, no ano seguinte, ministro da Fazenda, cargo que deixou em 1974. Depois, foi embaixador na França, retornando à FEA, em 1978, como chefe do Departamento de Economia. Voltou ao governo em 1979 como ministro da Agricultura, daí passando ao Ministério do Planejamento, de onde saiu em 1985. Elegeu-se deputado federal em 1986, e está hoje no seu quarto mandato" (MACEDO, 2001, p.375).
} 
Roberto Campos (Ministro do Planejamento) e Octávio Gouvêa Bulhões (Ministro da Fazenda) ${ }^{212}$. Ademais, quando ainda lecionava na Universidade de São Paulo, Delfim Netto participou de projetos como a Comissão Interestadual da Bacia Paraná-Uruguai (CIBPU), em $1962^{213}$. Projeto este que estreitou o seu contato - e de seus alunos, como Paulo Yokota e Akihiro Ikeda - com autoridades governamentais: o Ministério do Planejamento, o Ministério da Fazenda, o Itamaraty, além da Associação Nacional de Pesquisas Econômicas e Sociais Aplicadas (ANPES) e a Associação Comercial de São Paulo, essas duas últimas entidades que eram mantidas por empresários. A respeito desse assunto, Paulo Yokota afirma que:

\begin{abstract}
Nos anos conturbados que antecederam 1964, enquanto trabalhava na CIBPU e na Faculdade de Economia da USP, o professor Antonio Delfim Netto já recebia alguns encargos federais, como a sua participação no Conselho Nacional de Economia. Antes disso, ele já tinha colaborado com alguns governos do Estado de São Paulo, como os de Carvalho Pinto e Adhemar de Barros, e também em entidades empresariais, como a Associação Comercial e a Bolsa de Mercadorias $[\ldots]$

Instalado o novo Governo Castello Branco, o professor Delfim Netto e alguns dos seus auxiliares passaram a colaborar de maneira intensa, principalmente com o Ministério do Planejamento, ocupado pelo ministro Roberto campos. Mas também tiveram ação com o Ministério da Fazenda, ocupado pelo ministro Octávio Gouveia de Bulhões. O professor Delfim Netto assessorou, entre outros projetos, o Planejamento Geral no Instituto de Pesquisas Econômicas Aplicadas (IPEA), que tinha como secretário executivo João Paulo dos Reis Velloso, depois ministro do Planejamento. (YOKOTA, 2008, p.106-108)
\end{abstract}

Reconhecida a sua competência nos meios acadêmico e de formulação de políticas públicas governamentais, especialmente no que diz respeito a temas como a

\footnotetext{
212 Para mais detalhes, ver a reportagem: “O chefe”. Piauí, n. 96, 2014, p.18-28.

${ }^{213}$ Na visão de Paulo Yokota: "O nome da CIBPU esteve ligado às Nações Unidas, pela colaboração em um planejamento energético da região Centro-Sul do Brasil, nessa época [...] Com o Itamaraty, à frente da Comissão de Faixa da Fronteira, ele colaborou cno desenvolvimento das cidades fronteiriças do Brasil. Com o Ministério do Planejamento, no Instituto de Pesquisas Econômicas Aplicadas, ele ajudou na implantação do setor de Planejamento Regional, depois de 1964” (YOKOTA, 2008, p.87).
} 
inflação, o crescimento e a produção agrícola ${ }^{214}$, em 1966 Delfim Netto já havia adquirido prestígio entre as autoridades oficiais, e em janeiro foi designado secretário da Fazenda do Governo do Estado de São Paulo durante a gestão de Laudo Natel (19661967), que substituiu Adhemar de Barros, cassado pelo regime. Segundo Delfim, a indicação de seu nome para a secretaria teria partido do próprio Laudo Natel, que conhecera na Associação Comercial de São Paulo ${ }^{215}$. Entidade esta que parece ter sido central para a relação do empresariado paulista com a projeção de carreiras políticas. Foi ali que Delfim conheceu Paulo Egydio Martins ${ }^{216}$, que viria a ser Ministro da Indústria e Comércio (1966-1967) e governador do estado (1975-1979).

Em 1963, Paulo Egydio de Martins era presidente da Alcoa e diretor da Associação Comercial de São Paulo, em cujo departamento econômico Delfim Netto prestava assessoria. Ao assumir o ministério da Indústria e Comércio do governo de Castelo Branco em 1966 (substituindo Daniel Faraco), Paulo Egydio relatou em entrevista ter convidado Delfim Netto para compor o quadro de seus assessores por se tratar de um especialista no tema do café ${ }^{217}$, bem como por indicação do presidente da Associação Comercial de São Paulo, Daniel Machado de Campos, convidou Shigeaki Ueki para ser seu assessor. À época, Shigeaki Ueki era funcionário da Cooperativa Agrícola Bandeirante e da Câmara de Comércio Brasil-Japão, e por isso tinha assento no

\footnotetext{
214 Para mais detalhes sobre os trabalhos de Delfim Netto durante a década de 1960, ver: MACEDO, R. Antonio Delfim Netto. Estud. av., v.15, n.43, p.375-388, 2001; SKIDMORE, T. Brasil: de Castelo a Tancredo. Rio de Janeiro: Ed. Paz e Terra, 1988; e GONÇALVES NETO, W. Estado e agricultura no Brasil: política agrícola e modernização econômica brasileira, 1960-1980. São Paulo: Editora Hucitec, 1997.

${ }^{215}$ Ver a já citada reportagem: “O chefe”. Piauí, n. 96, 2014, p.18-28.

${ }^{216}$ Segundo Paulo Egydio de Martins, a respeito da Associação Comercial de São Paulo: "Eu era o diretor primeiro-secretário, responsável pela administração da Associação e de seus departamentos. A Associação Comercial era na época a entidade empresarial mais representativa do Brasil. Nós cobríamos todo o estado de São Paulo. Éramos muito mais importantes que a Federação das Indústrias, que era muito menor do que nós. Para dar uma idéia, nós tínhamos um departamento jurídico composto de vários advogados, cujo chefe era Boaventura Farina. No nosso departamento econômico, o chefe era o economista José Luís Nogueira Porto, e o segundo era Antonio Delfim Netto, que já era professor titular de economia da USP” (MARTINS et. al. 2007, p.153).

217 "Para meu chefe de gabinete, trouxe Boaventura Farina, chefe do Jurídico da Associação Comercial de São Paulo, portanto, um homem que tinha experiência com legislação comercial e industrial. Para a parte de café, trouxe um economista da Associação Comercial, Antonio Delfim Netto, que tinha defendido uma tese sobre café no concurso para professor titular de economia da usp. Como era professor da usp, Delfim indicou para ficar permanentemente no ministério seu assistente, Carlos Alberto de Andrade Pinto, que também ficava no meu gabinete, em contato direto com o ibc”. (MARTINS et. al., 2007, p. 209).
} 
Conselho da Associação Comercial ${ }^{218}$. Posteriormente, impulsionado pelo seu reconhecimento interno na função de assessor, Ueki foi indicado para o cargo de ministro de Minas e Energia, que ocupou entre 1974-1979.

Terminados os dois anos de mandato de Laudo Natel no governo do estado de São Paulo, em fevereiro de 1967 Delfim Netto foi novamente nomeado Secretário da Fazenda para o governo paulista seguinte, do ex-udenista Roberto Costa de Abreu Sodré (1967-71). A equipe de novos secretários de Sodré também contava com o engenheiro e professor da Faculdade de Higiene e Saúde Pública, Eduardo Ryomei Yassuda, irmão de Fábio Yassuda, designado para a secretaria de Obras do estado, além do empresário Herbert Levy para a secretaria da Agricultura. Um mês depois de sua nomeação, Delfim Netto deixava o cargo de secretário para assumir o Ministério da Fazenda no governo de Costa e Silva (1967-1969), trazendo consigo, entre outros, seus assessores Paulo Yokota e Akihiro Ikeda, e deixando a vaga para o Secretário de Economia e Planejamento, Luis Arrobas Martins $^{219}$. Era o início de um período reconhecidamente distinto em termos de planejamento econômico, em que o Ministro da Fazenda também concentrava grande poder de influência política, para o qual o seu êxito como gestor contribuía cada vez mais.

\footnotetext{
${ }^{218}$ Sobre o episódio em que Shigeaki Ueki passou a ganhar notoriedade como assessor do Ministério da Indústria e Comércio, Paulo Egydio de Martins relata: "Eu era obrigado a comparecer às reuniões do "Sunabão", onde estavam presentes Bulhões, Campos, o superintendente da Sunab e Denio Nogueira, presidente do Banco Central. Um dia, numa dessas reuniões, a discussão girou em torno de um ponto qualquer do preço de um produto do Sul no Nordeste, e eu me lembrei de que, num dos seus relatórios, o Ueki abordava esse problema e propunha uma solução [...] Nesse momento, eu disse ao Bulhões que um dos meus assessores tinha abordado o problema num relatório, e eu gostaria que ele abrisse uma exceção e me permitisse trazê-lo para a reunião. Ele concordou. Dei ordem para no dia seguinte Ueki me acompanhar a uma reunião no Ministério da Fazenda [...] Quando Bulhões lhe deu a palavra, ele começou gaguejando, mas foi adquirindo confiança e expôs toda a sua idéia. Quando acabou de falar, Roberto Campos virou-se e disse: "Está aí a solução. É a única possível. Não temos mais nada a dizer". Ueki fez um sucesso enorme na reunião, e eu disse que ele podia me aguardar no carro. Roberto e Bulhões quiseram saber: "Onde é que você descobriu esse japonês? Foi uma solução genial, a que ele adotou!" Eu disse: "É, foi uma solução muito boa". Eu não estava achando genial nada, porque estava preocupado com outras coisas. Cheguei ao meu gabinete e recebi um telefonema do Geisel: "Paulo, quem é esse japonês gênio que você descobriu?" Já tinha corrido o boato. Já tinha chegado no Golbery, no Geisel e, provavelmente, no presidente. Eu disse: "O japonês é um nissei de Bastos, São Paulo, indicado por um tio meu, presidente da Associação Comercial. Está aqui sem muita função, e por isso dei a questão da Sunab para ele analisar". Esse episódio deu projeção ao Ueki no governo. Da noite para o dia ele se tornou um gênio. Para falar a verdade, após esse acontecimento, passei a aproveitá-lo mais, ele foi se envolvendo em outros assuntos do ministério e acabamos nos tornando amigos" (MARTINS et. al., 2007, p.263-64).

${ }^{219}$ A respeito do pedido de demissão de Delfim Netto da secretaria da Fazenda do Estado de São Paulo, ver a reportagem: "Sodré escreve a Delfim Netto". O Estado de S.Paulo, 7 de março de 1967, p.4.
} 
A exemplo de sua capacidade de influir em decisões como a escolha de nomes para cargos dentro do aparelho estatal, em 1967 havia incertezas sobre a nomeação do presidente da Caixa Econômica Federal e, Paulo Salim Maluf, com indicação de Delfim Netto, era um dos candidatos ${ }^{220}$. Os dois haviam se conhecido na Associação Comercial de São Paulo, onde em 1964 Paulo Salim Maluf havia ocupado o cargo de vicepresidente. Enfim, em 26 de abril de 1967, aos 35 anos, Maluf foi nomeado presidente da Caixa Econômica Federal. Dois anos depois, em um clima de disputa com outros quatro nomes ${ }^{221}$ - Luis Arrobas Martins (Secretário da Fazenda e preterido do Governador Abreu Sodré), Firmino da Rocha de Freitas (Secretário de Transportes), Onadyr Marcondes (Secretário de Planejamento), Eduardo Ryomei Yassuda (Secretário de Obras) -, porém contando novamente com o apoio de Delfim Netto, Paulo Maluf foi nomeado prefeito de São Paulo pelo governador em 8 de abril de 1969.

Dois dias depois de oficializada a nomeação de Paulo Maluf como prefeito da capital, a solenidade em virtude da posse de seus secretários foi então realizada, e contou com a presença do então Ministro da Fazenda Delfim Netto. O evento também trazia uma novidade: a nomeação de um expoente gestor do setor agrícola para a secretaria de Abastecimento. O empossado era Fábio Ryodi Yassuda, diretor-gerente da $\mathrm{CAC}^{222}$, presidente da Confederação Nacional da Agricultura, membro da Confederação de Comércio de São Paulo ${ }^{223}$ e chefe de comissões do Itamaraty ao Japão ${ }^{224}$. Era o início da curta, porém significativa carreira política de Fábio Yassuda, que ainda viria a ser nomeado ministro da Indústria e Comércio no mesmo ano. Para os interesses desta pesquisa, destaco uma questão central, a saber: um dos principais gestores da CAC enfim obtinha acesso às estruturas de poder governamental, o que lhe abria possibilidades de ser partícipe - ou mesmo influir - no planejamento econômico.

\footnotetext{
${ }^{220}$ Para mais detalhes da biografia de Paulo Maluf, ver: MALUF, P. S. ELE: Paulo Maluf, trajetória da audácia. São Paulo: Edioura, 2008. Em outro documento da Câmara Municipal, a indicação de Maluf por Delfim é também enfatizada. Fonte: Câmara Municipal de São Paulo. Projeto de Decreto Legislativo 020113/1996. Concede ao eng. ${ }^{\circ}$ Paulo Salim Maluf o título de "Prefeito Emérito da Cidade de São Paulo".

221 Ver a reportagem: "Chanceler e Sodré falam sobre política". O Estado de S.Paulo, 1 de março de 1969, p.4.

222 Ver a reportagem: "O secretariado foi empossado". O Estado de S.Paulo, 10 de abril de 1969, p.4.

223 Ver entrevista com Fábio Yassuda. Disponível em:

<http://www.culturajaponesa.com.br/htm/entrevista.html >. Acesso em: mar. 2013.

224 "Brasil vai à Expo-70". O Estado de S.Paulo, 16 de fevereiro de 1969, p.6.
} 
Mesmo que não tivesse se candidatado a nenhum cargo político, Fábio Yassuda era filiado à União Democrática Nacional ${ }^{225}$, pois seu pai Ryoiti havia contribuído para a fundação de um diretório local no município de Pindamonhangaba ${ }^{226}$. Seu irmão Eduardo, também udenista, se tornou mais próximo do influente empresário Herbert Levy, que no início da década de 1960 havia sido presidente nacional do partido. Conforme foi mencionado anteriormente, esses dois últimos haviam sido secretários (respectivamente Obras e Agricultura) durante o governo estadual de Roberto Costa de Abreu Sodré, um dos fundadores da UDN. Após a dissolução do partido em $1965^{227}$, tanto Eduardo Yassuda, Herbert Levy, Abreu Sodré, quanto outros políticos filhos de japoneses como Yukishigue Tamura e João Sussumu Hirata se filiaram a um novo partido, a Aliança Renovadora Nacional (ARENA).

Ainda que constitua um tema relevante, a dinâmica partidária não é tratada aqui em maiores detalhes. Na tarefa de examinar a ascensão política de filhos de imigrantes em meados da década de 1960, maior ênfase será dada à caracterização da estrutura estatal de poder e decisão política do novo regime - especialmente na sua dinâmica de planejamento econômico -, referida aqui como "tecnoestrutura". Essa caracterização, apoiada nas formulações conceituais de Octávio Ianni e Fernando Henrique Cadoso, possibilitará: elucidar a relação singular entre o capital privado e o Estado durante o regime militar; situar a posição dos gestores da Cooperativa e de Fábio Yassuda nos núcleos de poder governamental, bem como suas relações com agentes centrais; avaliar os desdobramentos do sistemático encadeamento das relações políticas e econômicas em âmbito decisório para os caminhos percorridos pela CAC a partir de então.

Inicialmente, centremos nossa atenção em um trecho de uma reportagem especial sobre o contexto de atuação de Delfim Netto no Ministério da Fazenda, em que

\footnotetext{
${ }^{225}$ Ver seu apoio à candidatura de Helio Motta à vice-prefeito de São Paulo em 1957, em que Fábio Yassuda e Eduardo Yassuda são apresentados como membros signatários do partido, em: "Ao povo da capital". O Estado de S.Paulo, 14 de março de 1957, p.2.

226 "Fábio Yassuda parece ter herdado suas evidentes habilidades políticas do pai Ryoiti, um dos fundadores da União Democrática Nacional e grande chefe político em sua cidade (Pindamonhangaba) e em quase todo o Vale do Paraíba (região entre São Paulo e Rio de Janeiro, ao longo do rio Paraíba)" (Veja, 19 de novembro de 1969, p.29).

${ }^{227}$ Em virtude da criação do Ato Institucional n. 2, em 27 de outubro de 1965 (que extinguiu o pluripartidarismo).
} 
são ressaltados o seu êxito como gestor e a dinâmica de formulação de políticas econômicas por ele controlada:

A consolidação do poder de Delfim, contudo, também dependeu de um critério objetivo: seu êxito como gestor econômico [...] Com estímulos de crédito e subsídios, a economia, que já se beneficiava das reformas anteriores feitas por Campos e Bulhões, passou a crescer às maiores taxas da sua história: entre 1968 e 1973, o menor incremento anual do PIB foi de 9,5\% em 1969. Um crescimento ainda mais impressionante porque vinha acompanhado, nos primeiros anos, de uma inflação declinante. Foram os resultados de Delfim sob Costa e Silva que garantiram sua permanência no Ministério da Fazenda no governo seguinte, do general Emílio Garrastazu Médici (1969-74).

$\mathrm{O}$ crescimento econômico era a melhor peça de propaganda do regime, e os generais garantiam liberdade de ação a seu gestor. O ex-ministro Maílson da Nóbrega, que começou a trabalhar no Banco do Brasil na década de 1960 e é uma das pessoas que mais conhecem a burocracia brasileira, argumenta que Delfim acumulou poderes que deveriam caber ao Legislativo, então manietado. $\mathrm{O}$ Ministério da Fazenda tinha controle quase total sobre o Orçamento e, portanto, sobre gastos que, num regime democrático, deveriam ser definidos pelo Congresso. A injeção de recursos na economia também era feita por meio dos bancos estatais, controlados por Delfim.

Para entender o poder do Delfim, além da sua capacidade de articulação, tem que ver que ele operava num contexto de absoluta facilidade. $\mathrm{O}$ ministro da Fazenda tinha poderes de autorizar qualquer despesa que lhe desse na telha. Não só os empresários, os políticos também batiam à porta da Fazenda. Havia crédito e subsídio de toda ordem (CARIELLO, 2014, p.24).

O trecho reproduzido pode ser entendido enquanto uma avaliação mais geral da dinâmica de poder e decisão política econômica do regime millitar a partir de 1967, e nos oferece pistas iniciais para um exame da estrutura do Estado brasileiro vigente à época. Nele são ressaltados, principalmente, o poder de decisão e influência do Ministro da Fazenda no planejamento econômico e a política de oferta de crédito. Ao caracterizar tal estrutura destaco, em primeiro lugar, a crescente importância da participação estatal nos rumos da economia, o que implicou a ampliação da esfera de planejamento econômico governamental. Apoiando-me na interpretação de Ianni (2009), pressupõe-se que, na sociedade brasileira da época, esse tipo de planejamento representou uma novidade se comparada aos regimes políticos anteriores, pois: i) compreendeu a estrutura política nas relações e nos processos políticos por meio dos quais ela se 
concretizou; ii) destinou-se, explicitamente, a transformar ou consolidar uma dada estrutura econômica e social; iii) em concomitância, e em consequência, ele implicou a transformação ou consolidação de uma estrutura de poder; iv) envolveu as relações entre o Poder Executivo e o Poder Legislativo no âmbito do Estado, por vezes resultando no crescimento, ou mesmo na hegemonia do Poder Executivo; v) compreendeu a criação de estruturas político-administrativas especiais.

Principalmente, o que Octávio Ianni destaca é um conjunto sistemático de características de poder do regime político, que determinava as operações de planejamento em ámbito estatal, um tipo de estrutura política denominada pelo autor como "tecnoestrutura estatal". Uma de suas características centrais seria o encadeamento recíproco das relações políticas e econômicas no âmbito das decisões: "a tecnoestrutura é a esfera do poder na qual se verifica o intercâmbio e a metamorfose do político em econômico e vice-versa" (IANNI, 2009, p.295). Outras características dessa estrutura foram definidas pelo autor:

a noção da tecnoestrutura estatal envolve os seguintes elementos e relações: a) o encadeamento entre a tecnocracia e os órgãos de planejamento; b) a utilização crescente de certas modalidades do pensamento técnico-científico; c) o fortalecimento do Poder Executivo, em detrimento do Poder Legislativo; e d) o sistemático encadeamento recíproco das relações de dominação (políticas) e apropriação (econômicas). (IANNI, 2009, p.295)

É dessa forma que, a fim de compreender a participação e a posição ocupada por Fábio Yassuda no governo Médici, argumento em favor da caracterização da estrutura estatal vigente naquele regime. Dois aspectos dessa estrutura merecem atenção: a relação entre o Estado e o capital privado e a emergência da "tecnocracia" e sua lógica de operação. A respeito do primeiro desses aspectos, Cardoso identificou, no governo Médici, a presença efetiva do capital privado na estrutura estatal, nela operando de forma singular: "a presença das forças econômicas privadas beneficiárias diretas do regime [...] fez-se sentir através de sua incorporação a mecanismos políticos ainda pouco estudados que tenho chamado de 'aneis burocráticos'." (CARDOSO, 1975, 
p.206). O conceito de "aneis burocráticos" formulado pelo autor procura captar a forma dinâmica em que determinadas forças econômicas passaram a prevalecer no âmbito estatal. Esse conceito, como veremos, estaria associado à emergência de um quadro técnico-administrativo, bem como deve ser entendido enquanto característica do regime autoritário.

Para esse último autor, principalmente o governo de Emílio Garrastazu Médici representaria, no caso brasileiro, o modelo de regime autoritário enquanto forma de dominação. Nele, teria se consolidado um "pacto de dominação" em uma ordem dual e contraditória: o regime utilizaria mecanismos de cooptação e de representação limitados. A aparente solução para essa contradição teria ocorrido pela criação de duas linhas decisórias, a político-administrativa-autoritária e a político-econômica. Tratar-seia de um regime peculiar, em que é possível identificar a relação das forças sociais que se "beneficiam" do regime com as forças políticas que o "articula", garantindo o funcionamento do aparelho de Estado restritivo, em que as pressões da sociedade civil, a organização partidária e as funções do Parlamento eram limitadas. No que se refere ao fortalecimento do poder Executivo enquanto núcleo de poder político, as perspectivas de Cardoso e Ianni são convergentes:

É óbvio que num regime que restringe as funções do Parlamento e dos partidos, o jogo político se concentra no executivo e faz-se por intermédio de seus funcionários. Subsiste a questão de determinar quem se beneficia com as políticas propostas e como se fazem sentir (e não necessariamente representar) os interesses concretos das classes dominantes. (CARDOSO,1975, p.205-6)

Nesse regime, as classes dominantes e as "facções dirigentes" seriam distintas no que se refere aos interesses que elas representam e às suas formas de articulação com o aparelho de Estado. Uma novidade seria a inclusão dos policy makers, novos personagens que, se ainda não estivessem incluídos no círculo restrito da fração dirigente do aparelho de Estado, "puderam ser partícipes das decisões do Estado através de mecanismos mais flexíveis de incorporação e cooptação política" (Cardoso, 1975, 
p.205). A emergência dos policy makers a que Cardoso se refere é aqui complementada pelo conceito de "tecnocracia" formulada por Ianni por dizerem respeito, em minha interpretação, a um fenômeno em comum. Nas palavras do autor:

Se a caracterização se fizer em termos mais empíricos quanto aos grupos sociais onde são recrutados os agentes das frações no poder, ver-se-á que as decisões são tomadas por intermédio de funcionários (civis e militares) e de pessoas que exercem cargos no Estado, recrutadas fundamentalmente entre quadros das empresas, privadas ou públicas, entre tecnocratas, planejadores, economistas, engenheiros, administradores de empresas etc. (Cardoso, 1975, p.205)

O que Cardoso destaca nessa passagem é a identificação de um núcleo de poder, cujos agentes que o compõem seriam recrutados em quadros como o empresarial justamente aquele a que Fábio Yassuda pertencia. Por sua vez, Ianni aborda os núcleos de poder enfatizando a questão do planejamento econômico, elaborado pelo conjunto de técnicos (em geral altamente qualificados e expoentes de um pensamento técnicocientífico). A singularidade da emergência desses novos personagens, para ambos os autores, é que se trataria de uma transformação no seio do aparelho burocrático estatal brasileiro. Segundo Ianni:

à medida que crescia a importância relativa e absoluta da participação do Estado na economia, havia uma contínua incorporação de conselheiros, assessores, técnicos, engenheiros, estatísticos, economistas nos órgãos de formulação, execução e controle da política econômica governamental. Pouco a pouco, formou-se uma dependência muito especial do Poder Executivo com os característicos de uma nova estrutura burocrática. $\mathrm{Ou}$ seja, progressivamente, os funcionários, conselheiros, assessores, engenheiros, estatísticos, técnicos, economistas foram constituindo uma categoria especial no âmbito do sistema político-administrativo. Devido ao estilo de pensamento peculiar desse grupo (um tipo de pensamento técnico-científico, em contraposição ao pensamento político que tendia a predominar em outras esferas do poder, as pessoas que compunham essa tecnoestrutura estatal passaram a representar uma dimensão nova e importante do Poder Executivo. Assim, a hipertrofia crescente do Executivo (em detrimento do Legislativo) caminha de par em par com a crescente importância do grupo que compõe essa nova estrutura burocrática.

Em outros termos, os novos auxiliares diretos do Executivo (economistas, engenheiros, geógrafos, agrônomos, arquitetos, urbanistas, educadores, estatísticos etc.) passam a compor os órgãos por meio dos quais se formula e põe em prática a política econômica governamental. Assim, o presidente da República e os ministros 
de Estado passam a compor o vértice de uma nova estrutura de poder: a tecnoestrutura estatal. Trata-se de uma estrutura de poder largamente apoiada em novas organizações burocráticas, dispondo dos recursos específicos de um certo tipo de pensamento técnico-científico, e com acesso muito mais amplo e sistemático do que qualquer outra esfera do governo, aos elementos indispensáveis à formulação de uma visão de conjunto, e detalhada, do sistema político-econômico do País. (IANNI, 2009, p.291-94)

Os interesses representados por esses novos personagens expressariam a presença crescente do próprio Estado enquanto organização (como burocracia) e enquanto empresa (portanto, como Estado capitalista produtivo) e a presença do grande capital, multinacional e local. A incorporação desse capital a um mecanismo político, os "aneis burocráticos", teria garantindo ao setor privado a possibilidade de se articular politicamente para influir nas decisões do Estado. Os "aneis burocráticos", contudo, não se resumiriam somente ao interesse econômico e, havendo um "círculo de interessados", a sua vigência estaria centralizada em torno de algum cargo no aparelho de Estado:

As qualidades para o pertencimento a um "anel", entretanto, não advêm da existência de solidariedades ou da possibilidade de busca de recursos políticos comuns entre camadas ou frações de classe mais amplas, mas da definição, nos quadros dados pelo regime, de um interesse específico que pode unir, um "círculo de interessados" na solução de um problema: uma política energética ou rodoviária, o encaminhamento de uma sucessão estadual, a defesa de uma política tarifária etc. O que os distingue de um lobby é que são mais abrangentes (ou seja, não se resumem ao interesse econômico) e mais heterogêneos em sua composição (incluem funcionários, empresários, militares etc.) e, especialmente, que para ter vigência no contexto político-institucional brasileiro, necessitam estar centralizados ao redor do detentor de algum cargo. Ou seja, repetindo, não se trata de um instrumento de pressão da sociedade sobre o Estado, mas da forma de articulação que sob a égide da "sociedade política", assegura ao mesmo tempo um mecanismo de cooptação para integrar nas cúpulas decisórias membros das classes acima referidas que se tornam participantes da arena política, mas a ela se integram qua personae e não como "representantes" de suas corporações de classe. (CARDOSO, 1975, p.207)

Essas são algumas das características do aparelho estatal durante o regime militar que acredito serem relevantes para a discussão pretendida por esta pesquisa. Em sua vigência, assegurou-se a cooptação (e não representação) limitada da sociedade civil e sua extrema debilidade como força política autônoma, bem como o pacto político que 
sustentou a "tecnoestrutura estatal" foi possível, em termos gerais, mediante a centralidade do Estado como agente repressivo, cooptativo e propulsor ativo das decisões político-econômicas a partir do funcionamento de um núcleo decisório restrito em que o Ministro da Fazenda concentrava grande poder. Sobretudo, mediante mecanismos específicos localizados no aparelho estatal, interesses relacionados ao capital privado passaram a prevalecer e agentes expoentes do mundo empresarial, administrativo, técnico, acadêmico etc. - mesmo que não encontrassem respaldo em uma carreira política em sua biografia -, passaram a ocupar posições nos núcleos decisórios do planejamento econômico.

Ao passo que em 1969 a Cooperativa já operava em todo o país - em razão da mudança em seu estatuto um ano antes - e possuía controle sobre grande parte do fornecimento e do preço de determinados produtos agrícolas nos principais entrepostos de alimentos de São Paulo, da região metropolitana e de outros estados, a pauta governamental da modernização da agricultura e do estímulo à ampliação da produção parecia ser cada vez mais priorizada. Por esse motivo, a principal frente de batalha do ministério assumido por Fábio Yassuda rumo ao desenvolvimento almejado pelos governantes parecia ser o setor agrícola e, especificamente, o sistema de abastecimento de gêneros alimentícios ${ }^{228}$.

E, dessa forma, a posse ministerial de Fábio Yassuda pareceu repercutir baseada em sua imagem de gestor especializado em questões agrícolas e no abastecimento de gêneros alimentícios. Nos meios internos de divulgação de informações do governo federal foram registradas algumas impressões, contidas nos Boletins Informativos do Serviço Nacional de Informações ${ }^{229}$, meio restrito de informações oficiais do governo:

\footnotetext{
228 A respeito da importância da CAC no setor de abastecimento de gêneros alimentícios, Delfim Netto revelou em entrevista: "Durante muitos anos nós tivemos um contato muito íntimo, não só com a Cooperativa de Cotia, mas com alguns elementos do setor agrícola, para você poder minimizar o efeito estacional produzido pelo tempo. Agora, por exemplo, vai ter um aumento dos preços de verduras. Isso tinha uma importância muito maior do que hoje, porque você tinha uma inflação muito mais ativa, tinha correção de preços bimestral. Uma vez elevado o preço, aquilo levava o resto tudo atrás. Não adiantava dizer que aquilo era um aumento estacional" (Entrevista realizada em 21 de janeiro de 2014).

${ }^{229}$ Boletins Informativos do Serviço Nacional de Informações, disponíveis em:

<http://www.arquivoestado.sp.gov.br/noticia_ver.php?id=483 >. Acesso em: nov. 2014.
} 
Poderá haver total reformulação no sistema de abastecimento de gêneros alimentícios em São Paulo, se o prefeito aprovar plano elaborado pelo ex-secretário do Abastecimento e atual Ministro da Industria e Comércio, Fábio Yassuda [...] ULTIMA HORA/S.PAULO: "Yassuda deixou um plano para mudar o abastecimento em SP". (Boletim Informativo n. 256, Serviço Nacional de Informaçôes, 03 de novembro de 1969, p.4)

As classes produtoras de São Paulo estão muito confiantes na atuação de Fábio Yassuda à frente do Ministério da Indústria e Comércio. De uma coisa estamos certos: as cooperativas receberão tratamento prioritario e muitos dispositivos legais contrários a elas serão revogados. (GZ MERCANTIL). (Boletim Informativo n²57, Serviço Nacional de Informaçôes, 04 de novembro de 1969, p.6)

As breves informações contidas nesses trechos indicam justamente interesses específicos de produtores agrícolas (o "círculo de interessados") na solução de um problema (dispositivos legais contrários) e centralizados ao redor do detentor de um cargo. Fábio Yassuda havia conquistado uma posição estratégica na estrutura estatal de poder. Entretanto, ele permaneceu no cargo de ministro por apenas alguns meses ${ }^{230}$, e as narrativas mais recorrentes apontam um conflito direto com Delfim Netto como a principal razão de sua saída do ministério ${ }^{231}$ :

A gestão econômica, formalmente distribuída por alguns ministérios, passou a se concentrar cada vez mais nas mãos do titular da Fazenda. Quem resistia a esse controle era forçado a sair. Eduardo de Carvalho, então seu principal assessor, lembra que o chefe era especialista em derrubar ministros. $O$ primeiro a ser

\footnotetext{
${ }^{230}$ Ver a reportagem "Yassuda sai na segunda". O Estado de S.Paulo, 21 de fevereiro de 1970, p.1.

${ }^{231}$ A respeito do episódio, é válido destacar trechos de reportagem especial publicada na revista Piauí, em que pessoas próximas a Delfim relatam suas versões sobre o fato: "Ernane Galvêas, à época presidente do Banco Central, lembra que Yassuda chegou ao Ministério recitando uma "catilinária". Acusava o Instituto Brasileiro do Café de fazer "operações especiais" que "não cheiravam bem". O órgão, cujo diretor de Comercialização era Carlos Alberto de Andrade Pinto, subordinava-se ao Ministério da Indústria e Comércio. No relato de Andrade Pinto, com o objetivo de derrubar Delfim, Fábio Yassuda "inventou que havia corrupção no IBC". O episódio deixou o ministro da Fazenda furioso. "O Yassuda havia sido colocado lá pelas mãos do Delfim", disse Ernane Galvêas. "O Delfim um dia se vira para mim e diz assim: 'Eu vou tirar esse indivíduo do Ministério com um peteleco'. Assim mesmo:'Eu vou tirar o Yassuda de lá porque ele é desleal, inconfiável'". Andrade pinto contou que Delfim, então, o convocou para ir à Brasília. "No avião, ele me disse: 'Você vai ser demitido porque o negócio do Yassuda foi longe demais. Fica quieto. Não tem importância nenhuma. Mas o Yassuda sai'”, (...) Delfim conseguiu derrubar Yassuda, concluiu Andrade Pinto, porque garantiu a Médici que não havia corrupção no IBC. "Milico tem disso, né? Se ele acredita em você, ele mata e morre. Tem que escolher um lado. Não sei se o Delfim colocou a opção 'Ou ele ou eu'. Mas saiu da sala e me disse: 'Liquidado. O Yassuda está fora, e você sai do IBC e vai comigo para o gabinete'. Teve essa troca. O peão da saída do Yassuda fui eu”. (CARIELLO, 2014, p.24-5).
} 
atropelado foi Fábio Yassuda, nomeado ministro da Indústria e Comércio em 1969.

(CARIELLO, 2014, p.24).

Para além das várias versões existentes sobre a saída de Fábio Yassuda do ministério da Indústria e Comércio, o que procuro destacar aqui é que o seu caso é ilustrativo da ascensão de filhos de imigrantes nos núcleos de poder estatal em um regime político dotado de características singulares no âmbito do planejamento econômico. De forma geral, os desdobramentos da mudança de regime político se apresentaram para as lideranças de origem japonesa em São Paulo como um novo desafio de adequação, tanto do ponto de vista da estrutura burocrática, quanto em relação às benesses que a incorporação em núcleos de poder e de representação de interesses pudessem oferecer. No imaginário coletivo, a repercussão da saída de Fábio Yassuda do núcleo central de poder do governo foi possivelmente menos impactante do que o momento de sua consagração, pois o que se apresentava com ineditismo em 1969 era a participação de um filho de japoneses na política governamental, talvez independente do sucesso que pudesse ser obtido nessa empreitada. Após sua saída do ministério em fevereiro de 1970, pudemos constatar a indicação de seu nome, entre outros, para o cargo de governador do estado de São Paulo por Abreu Sodré ${ }^{232}$. Mas Fábio Yassuda não retornou mais à direção da Cooperativa, sendo substituído por Américo Utumi e, posteriormente, por Yaçuo Ogawa. Entretanto, mesmo sem contar com um representante no ministério, veremos nos parágrafos a seguir que a CAC havia encontrado formas de se adequar a essa nova conjuntura de desenvolvimento econômico ao alcançar uma posição capaz de operar a articulação entre os interesses empresariais e os núcleos de poder decisório estatal.

\subsection{Agricultura em evidência e personificação exemplar}

${ }^{232}$ Ver: NERY, S. Folclore político: 1950 histórias. São Paulo: Geração Editorial, 2002. 
Foi argumentado que no novo regime político se desenvolveu uma estrutura estatal de poder amplamente apoiada em organizações burocráticas, dispondo dos recursos específicos de um certo tipo de pensamento técnico-científico personificado por agentes que, em muitos casos, gozavam de prestígio no meio acadêmico ou empresarial. Em linhas gerais, essas eram as características mais notáveis do governo Médici que interessam diretamente a esta pesquisa. Na tentativa de bem situar o lugar da agricultura nos planos econômicos desse governo - e como a CAC buscou se adaptar a esse novo ambiente -, é conveniente apresentar de maneira breve as políticas econômicas em curso em fins da década de 1960 e início da década de 1970.

Além da referida conformação de uma nova estrutura de poder governamental colocada em prática no governo Médici, um aspecto a ser ressaltado durante os primeiros anos do regime militar é a ocorrência de uma mudança nas orientações do discurso político-econômico, segundo sugerem alguns estudiosos (MACARINI, 2005). Nesse aspecto, o governo de Castello Branco (1964-1967) se caracterizou por promover o combate à inflação, o favorecimento de um ambiente de estabilidade e livre-iniciativa, a racionalidade gerencial e a internacionalização do comércio. Já no governo de Costa e Silva (1967-1969) uma mudança teria ocorrido, pois ganhou vigor a ideia de construção de um projeto nacional na tentativa de demonstrar a viabilidade do desenvolvimento brasileiro, como seria explicitado no Programa Estratégico de Desenvolvimento. Ainda segundo o último autor citado, no governo Médici - e sob influência direta do pensamento de Delfim Netto - a perspectiva de crescimento seria privilegiada, colocando em segundo plano as preocupações com a inflação. E, mais ainda, segundo o autor, Delfim Netto defendia a retórica de um modelo agrícola-exportador para o desenvolvimento, ou a ideia de que dos dois setores básicos (agricultura e exportações) surgiriam condições para uma rápida ampliação do mercado interno:

o governo Médici elegeu a agricultura sua prioridade. A retórica da política econômica identificará 1970 ao "ano da agricultura", tal o tratamento a ela dispensado. A retórica justifica-se, tendo em vista o conjunto de incentivos dados ao setor. Incentivos esses visando à ampliação da mecanização e do uso de insumos modernos, consolidando a sua transformação em agronegócio [...]

A isso tudo some-se a farta disponibilidade de crédito, a juros favorecidos. O volume de financiamento de tratores, em termos reais, realizado pelo Banco do 
Brasil a uma taxa de juros fixa em 15\% a. a., após sofrer uma retração em 1969, cresce $16,5 \%$ em 1970 e, em seguida, praticamente triplica até 1973 . O volume de crédito para fertilizantes, em termos reais, após sofrer retração em 1969, cresce acima de $150 \%$ em 1970 e acima de 200\% em 1971: em 1973, alcançando um valor 4,5 vezes maior que o de 1970 , já representava $14 \%$ do volume total do crédito rural (em 1969 apenas 3,6\%). Note-se que, pelo Fundag, a taxa de juros nessa modalidade permaneceu fixa em $7 \%$ a. a. E o crédito rural total, por sua vez, cresce $18,8 \%$, em termos reais, em 1970, e simplesmente dobra até 1973. A sua política econômica foi uma vez descrita por Delfim Netto como uma "política de libertação do empresário": ao libertá-lo, o governo tornava viável o desenvolvimento com base na agricultura e nas exportações. (MACARINI, 2005, p.73-4)

A respeito do estímulo à produção agrícola visando à ampliação do mercado interno, Delfim Netto nos relatou em entrevista ${ }^{233}$ :

O estímulo à agricultura era imenso por uma razão muito simples. O subsídio que você dá à agricultura retorna em aumento de produtividade, e retorna, na verdade, para o consumidor. Se você olhar o que aconteceu com os preços nesse período, os subsídios não eram incorporados pelo setor agrícola. Como ele é um setor muito competitivo, os ganhos de produtividade do setor eram transferidos para os preços. Ou seja, os estímulos que você dá à agricultura quando é competitiva, ela acaba se transferindo para os consumidores na forma de menores preços.

- Havia um interesse específico no setor de abastecimento agrícola?

Claro que sim. No fundo, a taxa de inflação depende muito da oferta agrícola, porque a demanda é muito inelástica. Se os preços agrícolas crescem dez por cento, a demanda física dos produtos agrícolas cai dois por cento. Ou seja, se você tem uma queda de safra de quatro por cento, você precisa de um aumento de preço de vinte por cento para equilibrar o processo. Ele tem uma ligação muito estreita, e tem uma consequência diferente, porque afeta a demanda dos outros setores. $\mathrm{O}$ consumo, a alimentação, é grosseiramente vinte cinco por cento do orçamento familiar. Se você aumenta, digamos, dez por cento dos preços agrícolas... como eles têm preferência, isso significa que você encurtou a demanda dos outros produtos. Quando sobe o preço dos produtos agrícolas, cai a demanda de geladeira, cai a demanda de automóvel, porque é o setor que você tem menos capacidade de acomodação.

Em 1970 surgiram sinais de que a política de crescimento econômico de 9\% pretendida por Delfim Netto seria possível, tendo o Produto Interno Bruto crescido 10,4\%, a agropecuária crescido 11,4\% em 1971 e a lavoura cerca de 14,8\%. O crescimento econômico, adjetivado na opinião pública como "milagroso", parecia

\footnotetext{
${ }^{233}$ Entrevista realizada em 21 de janeiro de 2014.
} 
ganhar concretude, e a sua rápida manifestação parecia impressionar mais ainda em termos de resultados. Segundo Macarini (2005, p.89), o ano de 1970 teria sido "o momento em que a política econômica concebida por Delfim Netto tornou-se hegemônica, aparecendo o 'modelo agrícola-exportador' como a quintessência do projeto Brasil Grande Potência”.

Conforme foi referido, a década de 1970 trazia mudanças efetivas à atuação das cooperativas agrícolas: o governo federal ofereceu grandes estímulos à agricultura, especialmente sob a forma de crédito, a legislação cooperativista sofreu alterações, e programas de parceria público-privada foram criadas, o que indica o papel ativo do Estado na coordenação da economia. Ao longo das transições políticas, especialmente para o regime militar, as estratégias de desenvolvimento estiveram no centro das decisões de políticas econômicas governamentais, mas de forma distinta, apresentando rupturas e continuidades com a gestão anterior. Isso porque o regime de 1964 no Brasil e as experiências de autoritarismo na América Latina desmistificaram os postulados que vinculavam, no plano teórico, a modernização econômica ao desenvolvimento político democrático. O processo de estabilização econômica passou a ser então realizado de forma autoritária pelos novos decisores, ao passo que foi possível observar a permanência e a centralidade do Estado como agente propulsor e coordenador do desenvolvimento ${ }^{234}$.

Nesse período da história brasileira, portanto, o Estado teve papel proeminente ao centralizar as decisões políticas voltadas para o desenvolvimento econômico e as instituições agrícolas inter e intrassetoriais, mas a sua capacidade de intervenção na economia sob os auspícios de um regime autoritário não adveio de um conjunto coerente de prescrições, ou seja, de uma estratégia ex-ante, ao menos até o início do regime militar. Tratou-se de processos de formação de política econômica, resultantes de uma sucessão de experimentos em diferentes conjunturas de incertezas. Foi no decurso desses processos, especialmente a partir de 1964, que os gestores da Cooperativa atuaram de forma decisiva, reorientando a sua trajetória de expansão de acordo com as direções da política, obtendo e canalizando recursos de naturezas diversas que pudessem contribuir para o seu desenvolvimento. Uma estrutura que

\footnotetext{
${ }^{234}$ Para mais detalhes ver Sola (1998).
} 
adequasse a Cooperativa aos planos econômicos, à modernização da agricultura e às mudanças na legislação cooperativista do novo regime foi criada sob o discurso de uma gestão racional.

Em um primeiro momento, na segunda metade da década de 1960, uma série de dificuldades operacionais ameaçava a $\mathrm{CAC}^{235}$, resultante em grande parte da necessidade de se adequar a um conjunto de substantivas mudanças legais, financeiras e creditícias colocadas em prática pelo novo regime político ${ }^{236}$.

A maior mudança verificada na CAC na década de 1960 foi a transformação de sua estrutura organizacional para Cooperativa Mista Central de Segundo Grau ${ }^{237}$, o que a tornou cooperativa central. Basicamente, a Cooperativa Agrícola de Cotia Cooperativa Central (CAC-CC) passou a centralizar a administração de outras oito cooperativa associadas (CAC - Norte de São Paulo, CAC - Norte do Paraná, CAC - Sul do Paraná, CAC - Oeste de São Paulo, CAC - Sudoeste de São Paulo, CRAC - Rio de

\footnotetext{
${ }^{235}$ Segundo a visão de seus gestores, contida no relatório da Cooperativa para o ano de 1964: "A lavoura enfrentou no último ano conjuntura das mais graves e dífíceis. A estiagem, que foi a maior verificada nos últimos 70 anos e que se prolongou por mais de seis meses nos maiores centros agrícolas do nosso Estado, causou sérios transtornos às atividades produtoras, chegando mesmo a provocar o alastramento de incêndios de proporções catastróficas. A posterior ocorrência de trombas d'água causou novas destruições nas lavouras e estradas nas regiões da Alta Paulista e Alta Sorocabana. Ao mesmo tempo, a inflação galopante, que fez aumentar os preços de adubos, inseticidas e máquinas agrícolas em mais de $100 \%$, motivando elevação vertiginosa do custo de produção, trouxe como resultado a evidente descapitalização do meio rural, desatualizando ainda mais as bases do crédito agrícola, não obstante os reajustes efetuados pelos bancos oficiais. A instabilidade social provocada pela orientação política, aumentando a insegurança aos produtores agrícolas pelas diretrizes impostas aos sindicatos rurais e à reforma agrária, inegavelmente foi outro fator de desestimulo à produção agrícola. As ameaças constantes de congelamento de preços e de intervenção estatal no campo da economia privada, fazendo pressentir o perigo da implantação de um novo regime, felizmente debelado em tempo, contribuíram também para criar um ambiente de desorganização econômica e financeira, de gravíssima repercussão na agricultura" (Relatório de Serviços Sociais da CAC, 1963-4, p.1).

236 O Decreto-lei n. 59, de 21 de novembro de 1966, modificou a legislação cooperativista e criou o Conselho Nacional do Cooperativismo. A CAC teve que se adequar à nova legislação, que entrou em vigor a partir do Decreto n. 60.597, de 19 de abril de 1967. Foram criados três níveis de atuação de cooperativas agrícolas conforme a área de abrangência, o que obrigou a CAC a se tornar Cooperativa Central e também restringiu as atividades de crédito a cooperados. Nesse mesmo ano de mudança da legislação, o Imposto sobre Circulação de Mercadorias (ICM) foi instituído pela Lei n. 5.172, de 25 de outubro de 1966. A alíquota do ICM era consideravelmente maior (15\%) em relação ao tributo que veio a substituir, o Imposto sobre Vendas e Consignações (IVC), cuja alíquota era de 6,6\% em 1965.

237 “Por determinação da Assembléia Geral Extraordinária, realizada em 5 de maio de 1966, que procedeu a reforma dos estatutos sociais, tendo entre outros, prorrogado o prazo de duração da Sociedade para tempo indeterminado, e transformado em Sociedade Cooperativa de Segundo Grau, modificando a sua denominação para Cooperativa Agrícola e Cotia - Cooperativa Central, o nosso exercício social passou a coincidir com o ano civil" (Relatório de Serviços Sociais da CAC, 1966).
} 
Janeiro, CAC - Regional Cinturão Verde de São Paulo, CAM - Sul Matogrossense), que possuíam autonomia do ponto de vista operacional ${ }^{238}$. Dessa forma, a Cooperativa passou a atuar no país todo, o que demandou o desenvolvimento de setores específicos como: assistência técnica, exportação, importação, tecnologia, crédito, financiamento, comercialização, armazenagem e transporte. O seu escopo de atuação agora alcançava âmbito nacional na produção e internacional na comercialização, e a sua estratégia de capitalização contava em grande parte com subsídios de órgãos públicos, principalmente federais.

Em 1971 a lei do cooperativismo novamente sofreu mudanças que objetivavam estimular as exportações e, principalmente, acompanhar a crescente demanda gerada pelas rendas reais urbanas e pelo crescimento da população ${ }^{239}$. Um aspecto importante contido nessa lei foi a admissão da existência de setores específicos de crédito dentro das cooperativas, sob regulação do Banco Central. Uma série de medidas visando colocar em prática o modelo agrícola-exportador desejado pelo ministro da Fazenda foram então realizadas, resultando em uma considerável melhora no desempenho comercial da Cooperativa, que à época já contabilizava cerca de 11 mil cooperados:

com os estímulos sempre crescentes que a agricultura vem recebendo a partir do primeiro Governo da Revolução de 1964, pôde ela chegar ao indicador de 11,4\% já mencionado. As inúmeras medidas governamentais adotadas revelaram-se não só propulsores desse crescimento, mas como estímulos para arrancada talvez maior.

Foi a reformulação da política agrária (Estatuto da Terra), que visou aproveitamento mais racional da terra e consequente aumento de produtividade; a

\footnotetext{
${ }^{238}$ Em linhas gerais, as responsabilidades da cooperativas associadas e a central definidas da seguinte forma: as associadas se responsabilizavam pela produção, enquanto a central se responsabilizava pela comercialização, fornecimento de insumos, financiamento, compras, custos operacionais (CAC, 1988).

239 "No setor do cooperativismo, tivemos em 16/12/1971 a Lei n5.764, que vem, em substituicão ao Decreto-Lei nº59, de 21/11/1966, trazer para ele importantes inovações, tais como as faculdades previstas em seus artigos 85 e 86, de operar excepcionalmente com terceiros, em casos limitados, cujos resultados são revertidos ao fundo educacional e social, e no art. 82, que permite a emissão de 'Conhecimentos de Depósitos' e de Warrants para os produtos de seus associados, de par com a manutenção, e ampliação, de inúmeras outras faculdades indispensáveis ao bom funcionamento do sistema cooperativista na área rural. A nova lei, sem dúvida, vem trazer maiores condições de desenvolvimento para o meio rural, quando criou melhores condições para a expansão do cooperativismo, sabidamente a melhor solução para a atividade agrícola, não só em nosso país, como em todo o mundo, como nos ensinam o exemplo dos países europeus e o da América do Norte, do Canadá e do Japão, cujas cooperativas são responsáveis pelo abastecimento de aproximadamente $30 \%$ dos produtos agro-pecuários dos respectivos mercados". (Relatório de Serviços Sociais da CAC, 1971, p.II)
} 
regulamentação da ocupação das terras ao longo da Transamazônica; a instituição de recursos mais volumosos para o crédito agrícola a custos mais baixos para o mutuário; foram os incentivos fiscais aos produtos agro-pecuários destinados à exportação e os destinados a insumos agrícolas. Foi o Proterra, que fixou recursos da ordem de quatro bilhões de cruzeiros, aplicáveis no período de 1972 a 1976, para financiamento à distribuição de terras a pequenos e médios agricultores e para estímulo à agro-indústria do Norte e do Nordeste, com vistas ao incremento da produção e da exportação. Foi o Convênio Ministério da Agricultura- Secretaria da Agricultura do Estado de São Paulo, que destinou quarenta milhões de cruzeiros a serem aplicados no período de 1972 a 1974, em trabalhos de pesquisas básicas, fundamentais para o desenvolvimento da agricultura paulista, e foram as medidas tomadas pela Secretaria da Agricultura de São Paulo pára recuperação da agricultura do Vale do Ribeira, no Sudoeste do Estado.

Tais, dentre outras, as iniciativas governamentais no setor agrícola, cujos efeitos foram e serão os mais benéficos às atividades rurais em todo o país. (Relatório de Serviços Sociais da CAC, 1971, p.II)

Os anos de 1972-1973 colhiam os frutos do rápido crescimento da economia brasileira, mas, segundo Macarini, a questão do combate à inflação passou a ser uma preocupação de Delfim Netto: “a política econômica declarava pretender uma redução significativa da inflação, num gradualismo rápido, e, ao mesmo tempo, perpetuar o crescimento acelerado - portanto, com a manutenção de uma política monetária passiva" (Macarini,2005, p.83). Contudo, na busca por manter um modelo de incentivo à agricultura, a oferta de crédito ao setor seria mantida: "estabilidade monetária sim, mas nada de arrocho fiscal, monetário ou creditício que fatalmente afetariam o ritmo de crescimento" (Macarini,2005, p.83).

Em 1974 o governo Médici chegava ao fim projetando a continuidade de um ciclo de crescimento, enquanto o seu sucessor Ernesto Geisel (1974-1979) e o ministro da Fazenda Mário Henrique Simonsen recebiam a tarefa de administrar uma economia com inflação em alta ${ }^{240}$ e endividamento externo, o que demandou ações de contenção na execução da política macroeconômica ${ }^{241}$. Ao mesmo tempo, o governo lançava em fins daquele ano o II Plano Nacional de Desenvolvimento (PND), documento que

\footnotetext{
${ }^{240}$ Em 1973 e 1974 verificou-se a duplicação da taxa de inflação, de 20 para 40\% (Fishlow, 1986).

241 "é um fato que a Fazenda esboçou uma ação contencionista na execução da política macroeconômica. O descontrole monetário observado em 1973, e que projetava sobre 1974 um rastro de novas pressões inflacionárias (o 'ecletismo' de Simonsen sabidamente incorporava a componente de 'ortodoxia monetária'), seria sucedido pelo anúncio (já em abril) de volta à disciplina, com a programação monetária estabelecendo a meta de crescimento dos meios de pagamento de 35\%" (MACARINI, 2008, p.9).
} 
norteou a política econômica durante a primeira metade do governo Geisel. Contudo, há autores que afirmam a existência de mudanças substantivas na orientação das políticas, mesmo que houvesse continuidades em relação ao governo anterior, a exemplo dos estímulos à agricultura ${ }^{242}$. Foi nesse contexto que a CAC adotou uma estratégia de investimentos centrada no endividamento a longo prazo para o autofinanciamento de suas imobilizações.

Mais ainda, o governo federal, em parceria com a Cooperativa e governos estaduais, implantou projetos de desenvolvimento agrícola em algumas regiões do país, principalmente em Minas Gerais, como o Programa de Desenvolvimento do Vale do Rio São Francisco (PROVALE) (iniciado no ano de 1972) e o Programa de Assentamento Dirigido do Alto Paranaíba (PADAP) (iniciado no ano de 1974). Cabe aqui apresentar algumas informações relevantes que contribuem para situar a posição dos gestores da Cooperativa - especialmente de Gervásio Inoue - nos núcleos de poder governamental à época da elaboração de projetos de assentamento dirigido da Cooperativa em consonância com as diretrizes de desenvolvimento agrícola do regime militar.

Em 1971, o agrônomo Alysson Paulinelli ocupava o cargo de Secretário da Agrícultura do governo de Minas Gerais, sob o comando de Rondon Pacheco. Com estímulo do governo federal, Paulinelli passou a elaborar um plano de desenvolvimento agrícola no estado, e a garantia de crédito havia sido assegurada pelo ex-assessor do ministro Delfim Netto, Paulo Yokota, que ocupava a direção do setor de crédito rural do Banco Central ${ }^{243}$. A partir disso, foi dado início a projetos como o PROVALE e o

\footnotetext{
${ }^{242}$ Essa abordagem pode ser encontrada em Macarini (2008, p.17), para quem: "Os traços de continuidade se manifestam, por exemplo, na ênfase dada à agricultura e às exportações (quintessência da retórica da política econômica do governo Médici), na política de endividamento externo, até mesmo nas políticas de mercado de capitais e de conglomeração financeira. Mas o foco do II PND naquelas prioridades de investimento, menos pela magnitude almejada (embora nisso também resida um elemento funcional) e mais pela mudança qualitativa projetada, constitui um diferencial substantivo".

${ }^{243}$ Segundo relatou Alysson Paulinelli: "O economista Paulo Yokota, Professor da USP, com lugar de destaque no time do Ministro Delfim Netto, assumiu o lugar de Fernando Reis no Banco Central. Rondon Pacheco era parceiro da ideia de que o nosso projeto somente teria alguma chance se as regras do crédito rural fossem alteradas. Trouxemos Paulo Yokota a Minas Gerais, em várias ocasiões. Porém, ele achava nossa ideia muito ambiciosa para ser iniciada em escala nacional. Até que ele próprio ofereceu a solução: - Por que vocês não usam o BDMG para isso? - E você coloca o dinheiro à disposição? - contrapôs Rondon. - Isto eu garanto... Pode deixar. Corria o ano de 1971... Nascia o Plano de Crédito Rural Integrado - o PCRI, que levaria Minas alem de plantar 350 mil hectares de reflorestamento e produzir
} 
PADAP. Inicialmente, segundo relatos de um entrevistado ${ }^{244}$, ex-diretor da Cooperativa, a participação da Cooperativa nos projetos em questão sofreu com empecilhos que criaram atrasos sucessivos e teria resultado em prejuízos financeiros:

em dado momento a Cotia ficou tão grande que ela quis fazer o papel do governo. Não teve competência para dizer não. O governo de Minas falou "A Cotia tem quer vir aqui fazer o desbravamento da região de Paracatu, que é um cerradão". Aí a Cotia ia lá e mexia durante três, quatro anos. Porque para tornar um cerrado produtivo, tem que ter matéria orgânica, tem que fazer estrada, tem que fazer escola para os assentados... Isso tudo a custo da Cotia. O governo do estado falava: "eu pago um dia, um dia..."

Os possíveis atrasos na execução dos projetos eram por vezes mencionados por Gervásio Inoue como um espécie de moeda de troca em negociações realizadas diretamente com o Ministério da Fazenda. Basicamente, como relatou o principal assessor de Delfim Netto em 1973, Eduardo de Carvalho, era comum o governo recorrer a Gervásio Inoue quando o fornecimento de determinados produtos agrícolas sofria queda, alterando o seu preço no mercado. Pela grande participação da CAC no setor de abastecimento, o assessor requisitava o envio de produtos a fim de estabilizar os preços, bem como mediava o contato com o secretário da agricultura de Minas Gerais, Alysson Paulinelli:

"Dava uma geada aqui em São Paulo. Aí, de vinte caminhões de tomate que entravam por dia no CEASA, caía para cinco. O preço do tomate disparava. Precisava por mais quinze caminhões por dia no CEASA. Como é que fazia?" A solução era ligar para o Gervásio. "Gervásio, era o cara que mandava na cooperativa de Cotia, a grande produtora agrícola da época. 'Gervásio, preciso que você me mande caminhão de tomate para o Rio'". O responsável pela cooperativa

$52 \%$ do café brasileiro e a viabilizar o sonho dos projetos integrados para o desenvolvimento dos seus Cerrados. Paulo Yokota cumpriu o prometido e disponibilizou dinheiro suficiente [...] No segundo ano, já tivemos problemas para responder ao tamanho da demanda: mais de mil produtores submeteram pleitos ao banco. E aí começamos a nos perguntar: por quê não fazemos projetos consorciados e integrados, com 50, ou mais, produtores? Assim nasceram os Projetos de Assentamento Dirigido, que começou com o extremamente bem sucedido PADAP, do Alto Paranaíba" (PAULINELLI, A. "As terras de fazer longe". Disponível em: 〈http://forumdofuturo.com.br/?p=56>. Acesso em: dez. 2014).

${ }^{244}$ Entrevista realizada em 19 de março de 2013. 
agrícola, então, fazia exigências, que Carvalho relembra: "Pô, Edu, até hoje não conseguimos fazer aqueles assentamentos em Minas, as coisas não estão andando', ele me dizia. Ligo pro Paulinelli, que era secretário da Agricultura em Minas, e digo pra ele: 'Paulinelli, preciso que você resolva aquele problema da cooperativa no Vale do São Francisco. Eu quero amanhã. Paulinelli, quem está sustentanto os seus agrônomos sou eu, sou eu que estou dando o dinheiro. Faz o seguinte: liga pro Gervásio e combina isso com ele". Em algum momento, feitas as gestões, os caminhões se materializavam no Rio, e a oferta abundante reduzia os preços. (CARIELLO, 2014, p.25).

No governo seguinte, de Ernesto Geisel, Alysson Paulinelli foi nomeado ministro da Agricultura, e outros projetos de assentamento dirigido foram criados em várias regiões do país contando com a participação da Cooperativa, dentre os quais podemos mencionar: o Programa de Desenvolvimento do Vale do rio São Francisco (PROVALE), em 1972; o Programa de Desenvolvimento dos Cerrados (POLOCENTRO), em 1975; o Programa de Assentamento Dirigido do Sul de Minas (PADSUL I) em 1975; o Programa de Cooperação Nipo-Brasileira para o Desenvolvimento dos Cerrados (PRODECER), em 1979; o PADSUL II, em 1982; o PROCEDER II, em 1982; o PADSUL III em 1985; (CAC,1988). Esses projetos não são examinados em maiores detalhes nesta pesquisa, que se limita a utilizá-los como exemplos ilustrativos para a tarefa de situar a posição dos gestores da Cooperativa no círculo restrito da fração dirigente do aparelho de Estado.

O que os dados parecem indicar é que, diferente de qualquer outro empreendimento cooperativo do setor agrícola, a CAC apresentava sinais evidentes de ter alcançado uma posição estratégica no mercado de abastecimento nacional, a ponto de ser partícipe dos planos de desenvolvimento agrícola do governo militar. Posição essa que se mostrava diferente daquela observada na década de 1950, pois as iniciativas de representação por meio de órgãos classistas pareciam então ter sido colocadas em segundo plano ${ }^{245}$, ainda que a Cooperativa ali garantisse a presença de alguns de seus diretores, como Américo Utumi ${ }^{246}$. O fato é que muitas de suas demandas possivelmente

\footnotetext{
245 "Cooperativas criticam a ingerência 'oficial". O Estado de S.Paulo, 28 de junho de 1981, p.53.

246 Américo Utumi, filho de japoneses e bacharel em Direito pela Faculdade de Direito do Largo São Francisco. Ocupou o cargo de vice-presidente da CAC em 1969, substituindo Fábio Yassuda quando este foi nomeado ministro. Posteriormente, entre 1972-1989, ocupou ali ininterruptamente cargos de direção,
} 
dispensavam longos processos de negociação mediante as entidades de representação classistas, como a Organização das cooperativas Brasileiras (OCB), ou mesmo órgãos estaduais, como o Departamento de Assistência ao Cooperativismo da Secretaria da Agricultura do Estado de São Paulo. O depoimento a seguir ${ }^{247}$ reforça o argumento da existência de um canal direto de contato com personagens em posições estratégicas no núcleo dirigente das políticas econômicas:

Eu via muito o Gervásio, gostava muito dele. Naquele tempo, havia uma teoria de que quem causava a inflação era a inelasticidade da oferta agrícola, o que era completamente falso. Mas era a teoria da CEPAL, que era uma forma estruturalista. "O país tem inflação porque o agricultor não responde aos estímulos de preço". Isso foi desmontado em um tese do Pastore. Mas era o contrário. A experiência mostrava que principalmente a cooperativa era um ente de razão e os preços relativos tinham importância.

A participação da Cooperativa em projetos governamentais por meio de parcerias público-privadas ao longo da década de 1970 e 1980 possivelmente tornava a pasta da agricultura um espaço de convergência de informações e interesses da empresa e do setor público. Acompanhando esse novo tipo de conduta, as ações dos gestores da Cooperativa nessa conjuntura usualmente se apoiavam em uma retórica singular, produzindo discursos em sintonia com um tipo de pensamento técnico-científico vigente. Conforme foi apresentado no capítulo anterior, a partir da década de 1960, durante a presidência de Gervásio Inoue, pudemos identificar transformações que se processaram na estrutura organizacional da Cooperativa, afetando a sua organização hierárquica, bem como as formas de gestão e de condução dos negócios passaram a ser apresentados em torno de uma narrativa que privilegiava métodos racionais e objetivos de decisão. Se Delfim Netto havia sido um dos maiores expoentes do pensamento

\footnotetext{
também ocupando os cargos em outros órgãos do ramo cooperativo, como presidente da Organização Cooperativas Estado de São Paulo (OCESP), assessor da Presidência no Serviço Nacional de Aprendizagem do Cooperativismo (Sescoop), membro do Conselho Estadual de Segurança Alimentar (CONSEA) do Governo do Estado de São Paulo e membro do Conselho Superior do Agronegócio da FIESP, secretário executivo do Comitê Agrícola da Aliança Cooperativa Internacional (ACI), superintendente e vice-presidente da OCB, membro do Conselho de Administração da Organização das Cooperativas da América (OCA) e secretário de Abastecimento do município de São Paulo.

${ }^{247}$ Entrevista com Delfim Netto, realizada em 21 de janeiro de 2014.
} 
técnico-científico na formulação das políticas econômicas, a Cooperativa por vezes se esforçava para demonstrar o estado de sintonia de seus gestores, estampando frases do economista em seu relatório de serviços sociais ${ }^{248}$.

\section{Figura 24 - Ocasião da comemoração do cinquentenário de fundação da CAC no Palácio de Convenções do Anhembi, São Paulo, 1977.}

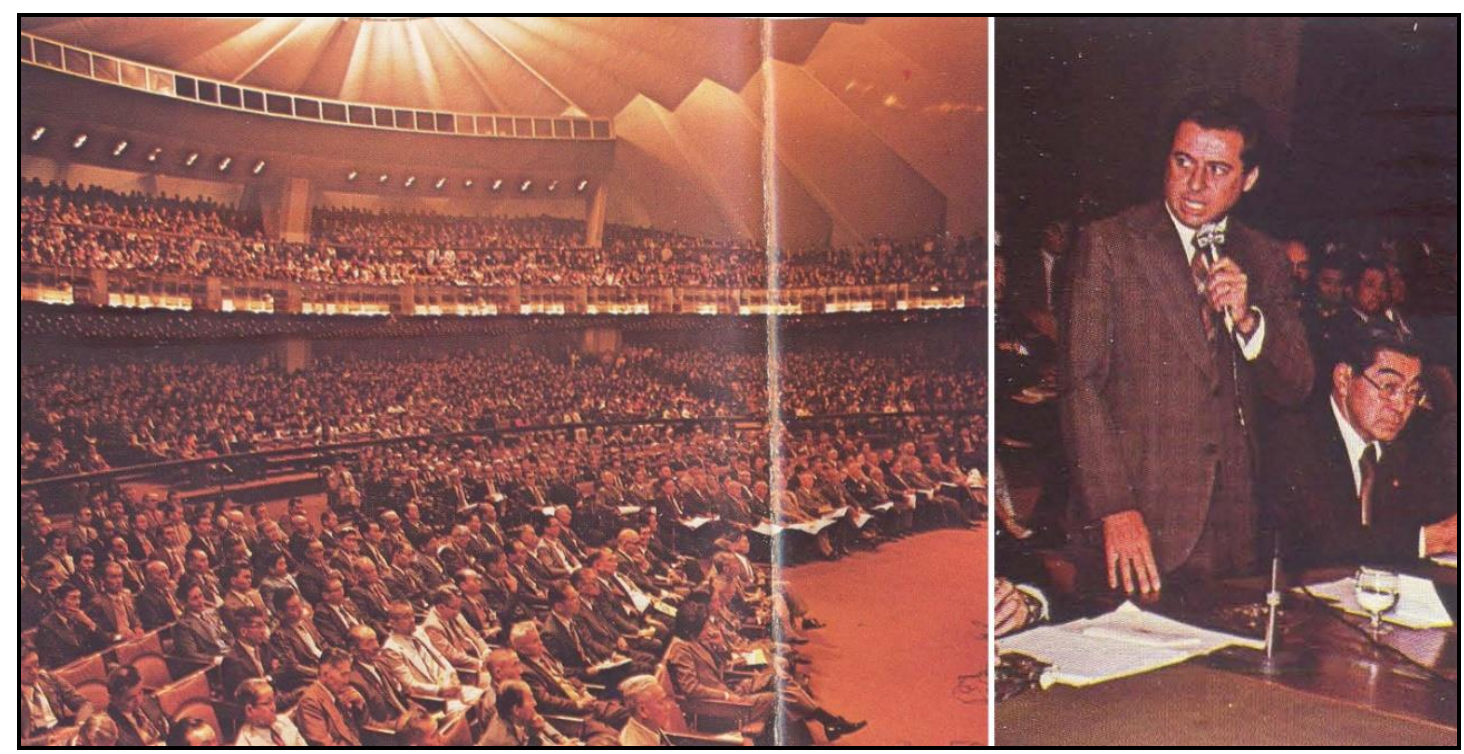

Fonte: Relatório de Serviços Sociais da CAC, 1977.

À direita, em pé, o ministro da Agricultura, Alysson Paulinelli. Sentado, o diretorpresidente da CAC, Gervásio Inoue.

À frente do empreendimento, Gervásio Inoue também gozava de prestígio em meio à opinião pública, a ponto de ser considerado um expoente das lideranças da coletividade de origem japonesa no Brasil e uma autoridade em temas relacionados à agricultura. Foi demonstrado que a sua participação na tarefa orquestrada de produzir narrativas que atestassem a incorporação do grupo social na sociedade local - enquanto processos de construção de identidades étnico-raciais na experiência migratória dos japoneses - teve início ainda na década de 1940, quando teve participação em iniciativas estudantis como a Liga Estudantina Nipo-Brasileira. Já nas décadas de 1950 e 1960, no

\footnotetext{
${ }^{248}$ Ver Relatório de Serviços Sociais da CAC, 1983.
} 
posto de presidente da Cooperativa, identificamos a sua participação ativa em projetos de intercâmbio cultural entre o Brasil e o Japão, bem como em eventos comemorativos da imigração japonesa. Segundo relata um entrevistado ${ }^{249}$, a figura de Gervásio Inoue no imaginário coletivo teria sido ainda mais beneficiada pela participação da Cooperativa nos referidos programas de assentamento dirigido criados em início da década de 1970:

O Gervásio, ele ficou assim famoso porque na gestão dele é que começaram esses grandes projetos de assentamento. Ele era entusiasta disso. Dourados, Paracatu, São Joaquim... E isso realmente teve uma repercussão nacional. Perante o governo federal a Cotia virou... teve um status. Quando tinha assentamento a Cotia tinha que estar presente. E Cotia falava, "vamos que vamos". Em dado momento a área começou a ser produtiva. Mas o custo do passivo ficou.

A compreensão aqui assumida, de que certas ações dos gestores da CAC podem ser examinadas em sua relação com fatores inseparáveis da experiência migratória dos japoneses no Brasil, também encontra correspondências na gestão de Gervásio Inoue entre as décadas de 1970 e 1980. Nesse período, a sua imagem enquanto um expoente do mundo dos negócios era frequentemente associada a uma narrativa exitosa da imigração em jornais e revistas de ampla circulação ${ }^{250}$ : uma espécie de personificação exemplar, cujo sucesso profissional e econômico oferecia indícios que pudessem atestar a "integração" dos japoneses na sociedade brasileira. Em reportagem especial de 1978 sobre os 70 anos da imigração japonesa no Brasil intitulada "Nossos olhos puxados", a revista Veja entrevistou Gervásio Inoue, e no tópico "Brasilidade" questionava se a ampla atuação da CAC no mercado seria uma prova de integração dos imigrantes japoneses no Brasil. A resposta de Gervásio Inoue foi indireta, ressaltando a composição heterogênea do quadro de associados da Cooperativa. Mais ainda, o gestor indicava o abandono do termo "colônia", rejeitando as conotações endógenas que o termo pudesse implicar:

\footnotetext{
${ }^{249}$ Entrevista com ex-diretor da CAC, realizada em 19 de março de 2013.

${ }^{250}$ Ver, por exemplo: "Os empresários" (suplemento especial dos 80 anos da imigração japonesa). $O$ Estado de S.Paulo, 18 de junho de 1988, p.16.
} 
No setor agrícola, cresceram as cooperativas agrícolas de produção - notadamente a pioneira de Cotia [...] Sua atuação, com nove cooperativas associadas, abrange setenta municípios em sete estados brasileiros, e dentre os projetos que desenvolve encontra-se a produção de café e trigo no cerrado de Minas e de diversas lavouras no vale do São Francisco. Seria essa uma prova de integração? "Temos associados de 37 nacionalidades aqui", responde o advogado Gervásio Tadashi Inoue, de 60 anos, há 22 anos na presidência da Cooperativa. "Não me arrisco nem em falar em colônia, pois posso até ser demitido". Shiniti Aitiba, ao lado de Inoue uma das personalidades de mais prestígio da colônia nipônica, como diretor e vicepresidente e um dos fundadores do Banco América do Sul, concorda integralmente com a necessidade de integração dos japoneses e seus descendentes na vida brasileira. (Veja, 21 de junho de 1978, p.56, grifos meus)

Na tentativa de interpretar o fenômeno da associação de um expoente do mundo dos negócios a uma narrativa exitosa da imigração japonesa - ilustrado pelo trecho citado -, duas observações merecem atenção: primeiro, o formato assumido pela noção de "integração" nessa conjuntura deve ser analisado enquanto um produto cultural historicamente situado de relações sociais, em que a mobilização de categorias classificatórias são constituintes de processos de construção de diferenças e reconhecimento. A questão que me parece profícua em termos analíticos é examinar os significados e interesses atribuídos pelos agentes nesses processos, o que relativiza a capacidade explicativa de condicionantes estruturais, ou mesmo de exageros conceituais. Segundo, essa noção de "integração" pressupõe uma clara divisão, que imputa aos grupos "minoritários" a condição de sujeição a grupos (ou à sociedade) “dominante”. Dessa composição desigual decorre uma característica que, acredito, particulariza as relações entre grupos na sociedade brasileira: a postulação a priori de fatores que atestem um relativo sucesso, ou ao menos desassociem dos grupos e indivíduos certas pré-noções que os diferenciam, em detrimento da noção de igualdade.

Considerar a capacidade de agência de indivíduos em processos de construção e negociação das diferenças sociais se apresenta, portanto, como uma alternativa aqui adotada. Ao examinar o núcleo de gestores de um empreendimento, identifiquei discursos nativos, características, interesses e motivações inseparáveis da experiência desses personagens enquanto imigrantes e descendentes de imigrantes. $\mathrm{O}$ conjunto desses fatores condicionou, em maior ou menor grau, as ações de gestores da CAC, e 
aqui procurei reconstituir algumas situações em que esses fatores se expressaram de forma mais evidente. Nos casos analisados, as ações dos gestores indicam não terem sido informadas unicamente pela instrumentalização de recursos disponíveis visando a objetivos próprios aos interesses de mercado, nem encontram em fatores unicamente estruturais a sua explicação. Uma análise de grupos em posições privilegiadas de liderança revela a relação de interdependência, por vezes negligenciada, entre as atividades econômicas, a política e a cultura no percurso de uma parcela de imigrantes japoneses no estado de São Paulo. Um espaço de manifestação dessa relação foi, entre outros, o núcleo de gestão da CAC.

Por fim, creio que é válido deixar explícito ao leitor que o foco conferido ao protagonismo dos gestores analisados em processos de construção de diferenças sociais não esgota o complexo universo de relações e de experiências ocorridas no ambiente gestionário da Cooperativa: ele é um dos vários aspectos ali existentes que busquei analisar de forma detida nesta pesquisa. No tópico seguinte procuro demonstrar que, além dos fatores já mencionados, nos últimos anos de atividade da Cooperativa as ações de seus principais gestores também foram condicionadas por fatores externos (como as políticas creditícias para o setor agrícola) e por fatores internos à organização (a exemplo de conflitos de interesse e disputas de poder).

De forma sintética, no tópico a seguir abordo os anos finais da trajetória empresarial da CAC, considerando: o comportamento da agricultura na economia brasileira e os efeitos de medidas governamentais voltadas ao financiamento do setor; as mudanças na estrutura organizacional da Cooperativa; a configuração de uma dinâmica no núcleo gestionário que adquiriu cada vez mais dimensões políticas, e em que a disputa por recursos e poder de decisão passou a ser constitutivo; a posição de agentes em disputas de poder e a ocorrência de conflitos de interesse.

\subsection{Mudança organizacional e declínio}

Entre as décadas de 1980 e a primeira metade da década de 1990, Gervásio Inoue vivenciou o declínio de seu prestígio, bem como progressivamente deixou de 
fazer parte do núcleo gestionário responsável pelas principais decisões empresariais da Cooperativa. Em grande medida, esse declínio acompanhou o processo de crise financeira do empreendimento, que culminou no encerramento das suas atividades em 1994. No início da década de 1990 era possível observar nos jornais que a narrativa de êxito da imigração japonesa associada à Cooperativa dava lugar ao acompanhamento da situação de crise enfrentada pela empresa ${ }^{251}$. Entre 1990 e 1994 a CAC teve os seus últimos três presidentes, que respectivamente foram: Kazuo Katayama, Irineu Yuji Koyama e Keyro Simomoto, filho de Kenkiti Simomoto. A Gervásio Inoue foi concedido o cargo simbólico de Presidente Honorário do Conselho Consultivo. O desfecho falimentar deu início a um processo judicial de liquidação dos bens da Cooperativa $^{252}$.

Neste tópico busco demonstrar quais possíveis fatores podem estar relacionados à conformação desse cenário e de que formas eles influenciaram o repertório de motivações dos gestores da Cooperativa.

No capítulo denominado "Uma avaliação dos estudos sobre a CAC", afirmo que Seabra (1977) identificou, de forma pioneira, um conjunto de tendências significativas que podiam explicar o comportamento da Cooperativa no mercado a partir da década de 1970, como: as mudanças na sua estrutura operacional sob efeito de políticas econômicas e das novas leis cooperativistas (de 1967 e 1971); a sua capitalização, direcionada para as operações com terceiros e cooperados, dentre as quais se destaca o setor de crédito; a posição privilegiada da CAC na captação de recursos governamentais.

Conforme já foi mencionado neste capítulo, durante o governo militar a modernização da agricultura foi estimulada pela criação de órgãos setoriais e pela facilidade na obtenção de subsídios, principalmente o crédito rural. Essas políticas também buscavam surtir efeitos para os pequenos e médios produtores, ampliando, assim, a base social das políticas governamentais. Mas a modernização da agricultura

\footnotetext{
${ }^{251}$ Ver, por exemplo: "CAC enfrenta maior crise de sua história". O Estado de S.Paulo, 22 de maio de 1993, p. 63 e "Fleury busca saída para crise da CAC". O Estado de S.Paulo, 25 de maio de 1993, p.38.

252 Processo n. 361.01.1999.012014 - Número 1680/99 - 4ª Vara Cível da Comarca de Mogi das Cruzes.
} 
demandou das grandes cooperativas agrícolas sobretudo um ajustamento dos princípios básicos de sua estrutura interna, uma espécie de transformação organizacional ${ }^{253}$.

Entre outros objetivos, a modernização da agricultura buscava estimular a expansão da agroindústria de processamento e a transição de uma estrutura voltada majoritariamente ao comércio e à distribuição para uma outra, fortemente mecanizada e industrial. Os reflexos dessas políticas puderam ser observadas na cadeia de produção das cooperativas agrícolas que se dispuseram a acompanhá-las. Isso porque, no formato concebido anteriormente às reformas legais, as cooperativas agrícolas se distinguiam das empresas não cooperativas: elas não exerciam atividades endogenamente à produção porque não possuíam compromisso com o produtor, e sim na comercialização dos produtos, ou seja, estariam situadas no elo final da cadeia. No caso das empresas não cooperativas (sociedade por ações), elas podiam atuar na comercialização e na produção, associando-se ao processamento e ao beneficiamento de matérias-primas e estabelecendo relações contratuais diretas com agricultores.

No período anterior à mudança de sua estrutura organizacional no ano de 1966, a CAC atuava geralmente na produção, incorporando pequenos e médios agricultores e aumentando a sua participação no valor adicionado. Era uma organização que possibilitava a compra e venda em comum para a distribuição conjunta de produtos. Do ponto de vista das relações contratuais, diferente das outras associações, cada cooperado possuía poder de voto nas decisões.

Contudo, a mudança organizacional em questão teve impactos no processo de produção e na organização interna da CAC, pois principalmente a partir da década de 1970 ela também passou a adicionar valor agregado à mercadoria nas operações de transformação. O diagnóstico do então Diretor-Presidente em 1993, Kazuo Katayama,

\footnotetext{
253 “As mudanças não se restringiram ao tamanho das cooperativas, ampliando o número de cooperados numa quantidade menor de entidades. Houve uma metamorfose na concepção da atuação das cooperativas agropecuárias, uma vez que das chamadas organizações atuando na comercialização, como associações de compra e venda em comum, adotaram-se estratégias de integração para frente e para trás, entrando na produção industrial. Dessa maneira, as cooperativas agropecuárias deixaram de ser uma simples resposta à intermediação do capital comercial para assumirem a posição de concorrentes do grande capital produtivo. Desse modo, auferem parcela maior do valor adicionado e, com isso, da renda, gerado em toda cadeia produção/consumo. Essa integração tem reflexos tanto nas estratégias adotadas como na relação da cooperativa com seu cooperado”. (GONÇALVES; VEGRO, 1994, p.63)
} 
sobre a crise financeira enfrentada pelo empreendimento ${ }^{254}$, revela a existência de um grande investimento em operações no setor agroindustrial que, contudo, teria acarretado severos prejuízos:

resolvemos entrar no segmento da agroindústria, através do qual buscou-se aumentar o ganho para os nossos cooperados.

Primeiro foi a fiação. O projeto foi aprovado após rigoroso estudos técnicos do montante previsto, contando também com diversos incentivos por parte dos governo estadual e municipal [...] o restante dos recursos, para não paralisar as obras, foram captados no mercado a custos que mais tarde comprometeriam a viabilidade do projeto.

Assim como a fiação, entramos no projeto de supergelados, importante é verdade, mas infelizmente foi uma atividade que não chegou a dar o retorno esperado e seu resultado, durante muito tempo, foi negativo.

Continuamos investindo em novos silos, em câmaras frigoríficas, em um novo centro padronizador de hortifrutigranjeiros no Rio de Janeiro, todos igualmente importantes para a cooperativa e para os cooperados, mas de retorno duvidoso, já que os custos financeiros cresciam desmedidamente, comprometendo e asfixiando a situação financeira da cooperativa.

Indo além das considerações de Kazuo Katayama, o depoimento de um entrevistado que ocupou cargo de direção no Banco Central durante a década de 1970 revela que a incursão da Cooperativa no setor agroindustrial obteve suporte de agentes facilitadores, como o ex-ministro do Planejamento (1964-1967) Roberto Campos ${ }^{255}$ :

A Cotia se meteu em outras coisas, tipo agroindústria porque o Roberto Campos ajudou muito nisso. O Roberto Campos achava também que dava para usar a Cotia para fazer outras coisas relacionadas à agroindústria.

Além das progressivas exigências de um quadro técnico e administrativo especializado, ao estabelecer um novo tipo de organização empresarial, o cooperado passou a ocupar uma posição diferente na cadeia produtiva. Ele cumpria um papel intermediário na produção dos bens finais ao apenas fornecer a matéria-prima necessária. Estabeleceu-se, dessa forma, uma verticalização das relações contratuais

\footnotetext{
${ }^{254}$ Informativo Cotia, ano XI, n. 128, agosto de 1993, p.2.

${ }^{255}$ Entrevista realizada em 17/04/2012.
} 
anteriormente inexistente ou mais branda, o que resultou em um distanciamento cada vez maior entre a base cooperada e os núcleos de decisão empresarial. Em um empreendimento com as dimensões da CAC, dado a sua complexidade e diversidade de produtos, a necessidade de adequação a essas mudanças era maior, e a incapacidade de lidar com elas, mais problemática.

Uma das transformações organizacionais ocorridas na Cooperativa que busco enfatizar foi relatada por um entrevistado que ocupou cargos na Secretaria da Agricultura da Prefeitura de São Paulo, na Assessoria do Ministério da Fazenda e bancos, além de prestar assessoria à Cooperativa ${ }^{256}$. Em suas considerações, o entrevistado discorre sobre a emergência de uma dimensão política na gestão do empreendimento, caracterizada por disputas internas por poder e recursos:

Quando ela começa a diversificar, e a Cooperativa Mista passa a ter vários produtos, passa a ter um problema político sério. Porque sendo uma sociedade não de capital, mas de indivíduos, onde o voto é individual, por pessoa, e não por quantidade de recursos que ele pôs na empresa, o elemento político passa a ser predominante para saber como aquilo vai ser dirigido. Para aonde você vai distribuir os benefícios, onde você vai investir? Eu vou investir na infra-estrutura de batatas ou na de hortaliças? Ou na infraestrutura de frutas, ou de ovos? Bom, mas aí depende dos votos que tenho de cada um desses setores. Porque quando você pensa em agricultura numa coisa só, não é. São milhares de atividades diferentes, concorrentes entre si por recursos, por capital, por gente especializada, por infraestrutura de comercialização e etc. E aí a gestão disso passa a ser uma gestão de natureza política, cada vez se afastando mais de uma gestão de natureza econômica, o que leva a uma baita distorção. Quando você começa a perder os seus constituintes... por que eu faço essa fábrica de batatas? Porque essa fábrica de batatas vai atender os interesses dos bataticultores e, portanto, eu tenho o apoio político nas eleições dos dirigentes do pessoal de batatas porque eu fiz esse benefício para eles [...] E eu não estou aqui para acusar, eu estou refletindo sobre o que eu aprendi. Eu tinha passado vinte e cinco anos trabalhando com a Cotia e nunca tinha visto isso.

Segundo outros dois entrevistados, um ex-membro e de um ex-funcionário da Cooperativa $^{257}$, podemos constatar a existência de uma narrativa centrada no caráter

\footnotetext{
${ }^{256}$ Entrevista realizada em 02/10/2012.

${ }^{257}$ Entrevistas realizadas em 19/05/2013.
} 
ambíguo que o empreendimento teria progressivamente adquirido ao conduzir uma política administrativa que não estaria voltada, em primeiro plano, às reivindicações dos seus cooperados, postura que era considerada um de seus princípios fundantes:

O cooperado, na verdade era o dono. Os funcionários são empregados dos cooperados, mas inverteu o papel. Os funcionários tinham que trabalhar para os cooperados, assim era a primeira geração, por isso que a Cotia cresceu. Aí foi passando, passando. Foi crescendo achando que faz o que querem. Tanto é que, no final, o cooperado ficou relegado a último plano.

Essa mudança eu acho que é significativa. É. Quando começou a entrar uma geração seguinte de representantes começou a ter problemas. Problemas no seguinte sentido, o cara estava olhando para o seu interesse, para o seu umbigo. Antes, não. Tudo estava mudando, na verdade.

É possível identificar, portanto, um primeiro aspecto que caracterizou os últimos anos da gestão de Gervásio Inoue: as mudanças na estrutura organizacional da Cooperativa que impactaram na dinâmica de funcionamento do ambiente gestionário. Além dos já referidos efeitos sobre a organização da cadeia produtiva, destaco que essas mudanças contribuíram para configurar um ambiente marcado por disputas por cargos decisórios e por recursos e investimentos. Os personagens dessas disputam eram, principalmente, membros da diretoria e representantes das cooperativas regionais filiadas à Central.

Em seu aspecto formal, a partir de 1977 a organização do núcleo central de direção da Cooperativa passou a ser composta por um Conselho de Administração, uma Diretoria-Executiva e um Conselho Fiscal (ver o organograma a seguir). Basicamente, os membros do Conselho Administrativo eram eleitos em assembleias-gerais (das quais participavam cooperados e delegados das cooperativas regionais), e os membros da diretoria eram nomeados a partir dessa eleição. Assim, os conselheiros atuavam também como diretores. 
Figura 25 - Organograma da Cooperativa Agrícola de Cotia, 1988.

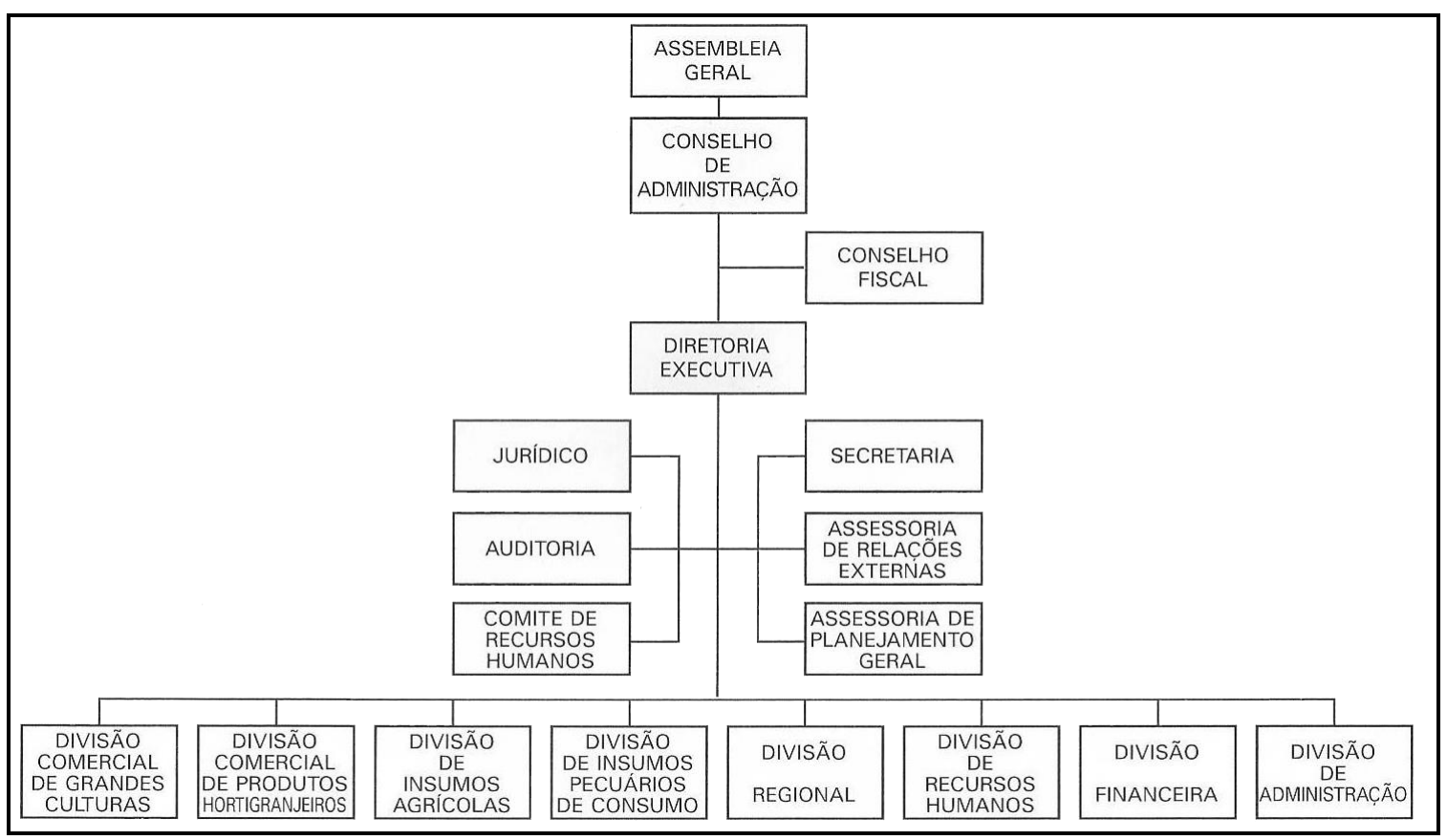

Fonte: CAC, 1988.

Um exemplo do funcionamento da disputa por cargos de direção é relatado pelo jornalista Osamu Toyama, ao avaliar eventos que culminaram na renúncia de Gervásio Inoue da presidência e de Yaçuo Ogawa do cargo de Diretor-Superintendente, ocorrida em março de 1990. Segundo o autor, já em fins da década de 1980 esses dois gestores sofriam forte oposição de uma das maiores cooperativas regionais filiadas, a do Norte do Paraná:

Os cooperados regionais, via de regra, desconheciam o que se passava na administração central. Isso os deixava confusos todas as vezes que participavam como representantes nas assembleias de suas regionais. Assim, quando eles chegavam à sede, diretores e funcionários graduados responsáveis por suas regiões os abordavam ao lado da mesa para orientá-los acerca dos assuntos da pauta. Naturalmente, nascia aí a oportunidade de manipulá-los, como fizeram para convencer o presidente e o diretor-superintendente a renunciar a seus cargos e aceitar um lugar no conselho consultivo. (TOYAMA, 2009, p.482) 
Figura 26 - Reunião do Conselho Administrativo da Cooperativa Agrícola de Cotia, 1977.

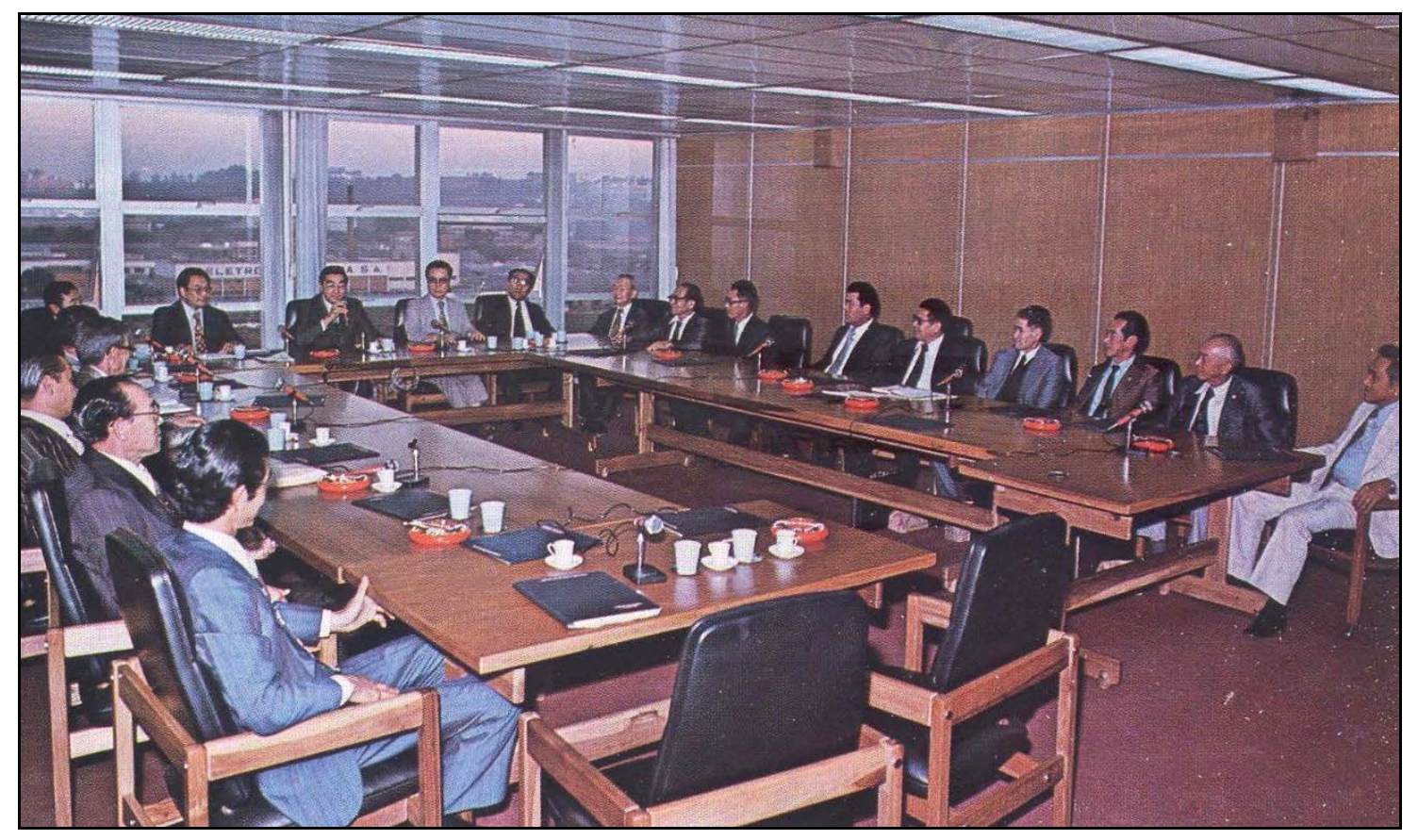

Fonte: Relatório de Serviços Sociais da CAC, 1977.

Outro aspecto que julgo importante para a compreensão do ambiente gestionário sob análise é o processo de endividamento da Cooperativa, intensificado a partir de meados da década de 1970. Ele teria motivado, entre outros, a referida oposição a Gervásio Inoue e Yaçuo Ogawa, evidenciando também as disputas internas por poder e por posições nos cargos de comando.

Antes de apresentá-lo, ressalto que a forma como esse fenômeno é aqui abordado não se resume ao objetivo descrevê-lo e identificar seus possíveis determinantes causais de natureza estritamente econômica. Tampouco tenciono apresentá-lo como uma versão irrefutável dos acontecimentos que resultaram no encerramento das atividades da Cooperativa. Procuro interpretá-lo enquanto resultado de decisões tomadas em um horizonte de possibilidades, informadas por um complexo conjunto de variáveis. Dito de outra forma, procuro situar esse processo de endividamento em um contexto histórico 
específico, em que a presença estatal na condução das políticas econômicas possuía grandes impactos no desempenho das empresas do setor agrícola (principalmente por meio da oferta de crédito). E, do ponto de vista interno à empresa, esse processo de endividamento ocorreu sob vigência de um modelo de gestão empresarial singular, que por vezes buscou acompanhar a direção das políticas econômicas e, por outras, entrou em descompasso com elas.

Sobretudo, os dados colhidos por meio de entrevistas parecem indicar a existência de uma considerável margem para decisões tomadas em âmbito individual naquele ambiente gestionário. Acredito que a tarefa de analisá-las possui ganhos ao complexificarmos o pressuposto de que se tratam de operações estritamente mercantis, expressas sob uma métrica de cálculo visando unicamente a melhores resultados. Principalmente em altos cargos de comando, certas decisões foram possivelmente tomadas enquanto produto de relações de poder e de interesses diversos. Em alguns casos, é possível que interesses ali existentes estivessem centrados na manutenção ou em mudanças nos cargos de comando. E, assim, o exame das relações sociais que organizavam as práticas no ambiente gestionário devem ser consideradas.

Ao verificarmos dados do desempenho financeiro da Cooperativa na década de 1970, podemos destacar o aumento de suas imobilizações a partir de 1972 e o seu salto expressivo no ano de 1974. Esse movimento representou uma reorientação na trajetória da empresa por meio de um endividamento conduzido a longo prazo, cujos recursos teriam sido obtidos principalmente pelo Banco Nacional de Crédito Cooperativo (BNCC) e do Banco do Brasil. A evolução do quociente de imobilizações sobre o patrimônio líquido (I/PL) da Cooperativa reproduzido na tabela a seguir retrata a proporção de recursos próprios que estava sendo imobilizada, ou que não estava em giro. Segundo Vegro: “em um período plenamente operacional tal quociente não deve aproximar-se, muito menos ultrapassar a 1" (VEGRO, 1992, p.70). O quociente expressaria, portanto, a solvência da empresa, ou a sua capacidade de cumprir os compromissos financeiros com os recursos que constituem seu patrimônio ou seu ativo. 
Tabela 2 - Evolução do quociente Imobilizações/Patrimônio Líquido da CAC (19671989)

\begin{tabular}{cc|cc}
\hline Anos & I/PL & Anos & I/PL \\
\hline & & & \\
1967 & $-0,72$ & 1979 & 0,68 \\
1968 & 0,66 & 1980 & 0,61 \\
1969 & 0,75 & 1981 & 0,51 \\
1970 & 0,59 & 1982 & 0,74 \\
1971 & 0,6 & 1983 & 0,49 \\
1972 & 0,65 & 1984 & 0,62 \\
1973 & 0,65 & 1985 & 0,96 \\
1974 & 0,93 & 1986 & 0,86 \\
1975 & 1,03 & 1987 & 1,44 \\
1976 & 1,05 & 1988 & 2,23 \\
1977 & 0,81 & 1989 & 2,36 \\
1978 & 0,9 & & \\
& & & \\
\hline
\end{tabular}

Fonte: Reprodução a partir de Vegro, 1992.

A tabela indica que o quociente atingiu níveis bastante elevados a partir de 1985, ultrapassando 2 em 1988 e 1989. O autor citado também destaca que os anos entre 1985 e 1986 foram os de maior crescimento dos exigíveis de curto prazo oriundos de empréstimos e, além disso, os exigíveis oriundos de empréstimos a longo prazo representaram 40,4\% do total obtido. É possível observar, portanto, que na metade da década de 1980 a cooperativa adquiriu empréstimos vultuosos, principalmente junto ao BNCC, que entre 1980 e 1982 subsidiou cerca de $41 \%$ dos empréstimos da Cooperativa.

De forma geral, a agricultura brasileira na década de 1980 teve taxas de crescimento positivas e mais elevadas do que os demais setores da economia. A sua base técnico-produtiva estava modernizada a ponto de concorrer no mercado externo mas, evidentemente, por se tratar de uma estrutura produtiva heterogênea, as condições e o desempenho das empresas não seguiram um padrão único e o estímulo cada vez maior à industrialização da agricultura foi priorizado, de forma que o cooperativismo se adequasse a essa nova situação. Isso, como vimos, teve implicações se considerarmos as 
conformações básicas das empresas agrícolas e a sua atuação na cadeia produtiva. Na primeira metade dessa década o financiamento externo se tornou escasso e as taxas de juros se elevaram, criando dificuldades para a balança de pagamentos. O principal sintoma desse período foi a inflação, que em 1985 chegava a 250\% e em aceleração, e uma das posições de política econômica do governo Figueiredo foi um ajustamento recessivo baseado na redução do investimento público, na desvalorização cambial e taxas de juros mais elevadas.

No caso da CAC, os altos índices de inflação criavam problemas para os custos da produção, especialmente para os cooperados e, além disso, as facilidades governamentais agora eram muito mais restritas ou mesmo deixaram de existir. Por mais que os dados referentes ao movimento global da Cooperativa entre 1980 e 1993 não transparecessem uma situação de crise financeira, o débito de seus cooperados - ou seja, os compromissos financeiros oriundos de obtenção de crédito pelos quais a organização respondia - aumentaram continuamente até a situação final de endividamento. Em 1984, a relação débito/movimento total do ano era de $15 \%$ e, em 1992, essa relação chegou a 125,88\%, segundo Vegro (1992).

Esse processo de endividamento, agravado pelo setor de crédito, foi também acompanhado do declínio dos incentivos públicos para o desenvolvimento da agricultura $^{258}$ e das mudanças nas políticas governamentais para o crédito rural. A partir de 1981, sob dificuldades de obtenção de crédito no exterior e recessão, a política agrícola se voltou para a reorientação das despesas, e o crédito rural foi reduzido drasticamente $^{259}$. A política mais marcante de compensação dessa redução de crédito foi a Política de Garantia de Preços Mínimos (PGPM). Entretanto, esse tipo de intervenção demandava grandes volumes de recursos que não puderam ser mantidos a partir das

\footnotetext{
${ }^{258}$ Marcovitch, ao analisar o caso da Cooperativa argumenta que: "Os grandes programas de governo, seus grandes investimentos e todo o sistema de desenvolvimento nacional entraram em colapso. Sucederam-se os planos econômicos que foram impotentes para conter as taxas de inflação crescente e castigaram duramente a atividade empresarial. Essa situação representou para a Cotia o fim de sua participação em projetos do governo dedicados à expansão da fronteira agrícola. Perdeu benefícios propiciados por incentivos e o acesso a capitais vultuosos decorrentes de sua presença em regiões nas quais sua ação, de fornecimento de insumos e de comercialização da produção, era essencial para os agricultores" (MARCOVITCH, 1996, p.21).

${ }^{259}$ Resolução n. 698, de 17 de junho de 1981, do Banco Central do Brasil.
} 
crises da dívida interna e externa pelas quais passou a economia brasileira na década de 1980. E os sucessivos planos de estabilização (Planos Cruzado, Bresser e Verão) exigiam o ajuste fiscal, o que foi fatal para esse tipo de política diante da necessidade de cortes de despesas (GASQUES et al., 2004).

A respeito da conjuntura econômica brasileira da década de 1980, da redução da oferta de crédito à Cooperativa e das dívidas dos cooperados, retomo novamente a avaliação de Kazuo Katayama. É importante ressaltar que, sob a intenção de explicar os motivos da crise financeira da Cooperativa, o Diretor-Presidente destaca que mesmo em períodos de instabilidade monetária, os gestores do empreendimento optaram pela obtenção de crédito no mercado privado a juros altos - decisão que, segundo Katayama, representou uma espécie de medida de compensativa visando à manutenção do financiamento para a produção dos cooperados:

\begin{abstract}
Outros fatores conjunturais ajudaram a aumentar a crise dos cooperados e da cooperativa. Os choques econômicos, por exemplo, que foram cinco no total [...]

Tivemos também uma brutal redução dos recursos do crédito rural. Para se ter uma ideia da magnitude do seu efeito, no período de 1980 o crédito rural representava em torno de 50 por cento do PIB-Agrícola, um montante absoluto próximo a 22 bilhôes de doláres e em 1991 esse mesmo crédito se reduziu para um nível próximo de 15 por cento do PIB-Agrícola, algo em torno de 5 bilhões de dólares.

Com essa falta crônica de recursos do crédito rural, o setor teve que se sujeitar a recursos de mercado com seus custos financeiros incompatíveis com a renda gerada pela produção agrícola, na maioria dos casos. Além disso, quando os cooperados não conseguiam recursos na rede bancária, a cooperativa tinha que bancar as suas necessidades para manter a produção e a cobertura desses empréstimos na falta do crédito rural era feita com recursos do mercado a custos proibitivos. Todos sabem, por outro lado, que a cooperativa teve que suportar a inadimplência de muitos cooperados que receberam nosso financiamento. Se calculados a base do custo de mercado, as dívidas dos cooperados, que hoje precisam ser contabilizadas a crédito em liquidação ou prejuízo, montam a aproximadamente 350 milhões de dólares. Isso pode ser considerado com um outro fator de violenta pressão sobre a administração financeira da cooperativa.
\end{abstract}

A despeito de oferecer informações centrais para se avaliar a crise financeira experimentada pela Cooperativa, o diagnóstico do Diretor-Presidente não nos permite identificar quais interesses estiveram subjacentes às decisões que, segundo a sua 
avaliação, culminaram em um quadro financeiro problemático. Ou seja, há poucas evidências que descrevam o protagonismo de agentes decisórios nesse processo.

$\mathrm{Na}$ visão de um entrevistado ${ }^{260}$ - que, ao ocupar o cargo de direção no Banco Central, mantinha contato regularmente com os diretores da Cooperativa - a respeito do processo de endividamento em questão, os gestores da Cooperativa, especialmente Gervásio Inoue, teriam optado por escolhas que não necessariamente eram consideradas as mais adequadas em termos de resultados. Ao contrário, segundo o entrevistado, os riscos e os custos das operações financeiras visando a obtenção de crédito não teriam sido um fator de constrição para a tomada de decisões:

Dois erros. Primeiro, a Cooperativa achava que era grande o suficiente, e o governo de algum jeito ia ajudá-lo. Eu saí do Banco Central em 1974. Já estava começando a reduzir (o crédito). Eu dava muito crédito porque eu estava dentro de um movimento chamado Revolução Verde e melhorando semente, fertilizante, mesmo sem ensinar o agricultor a fazer curvas de nível, técnicas modernas de agricultura. Se a semente tinha uma produtividade do dobro - essa que é a chamada Revolução Verde - aumenta a produção por ele usar a semente. Então eu dava crédito muito barato para comprar sementes e fertilizantes selecionados. O pessoal se acostumou com esses incentivos e achava que a agricultura seria sempre beneficiada, ajudada pelo governo. Quando eu saí do governo, eles acabaram com isso e passaram a cobrar taxa de mercado. E a Cotia já tinha dívidas. Eu falava para eles: "Vocês têm que se preparar porque o custo do financiamento vai subir". Eles sempre achavam que dava para conseguir. E então o que aconteceu? Eles conseguiam uma parte pelo crédito rural, que tinha taxas privilegiadas, e o resto contraía no mercado, dos bancos. A dívida estava crescendo. Eu falava - e eu já estava fora desse negócio: "Gervásio, isso vai quebrar". Mas ele achava que em algum momento o governo viria em socorro dele porque a Cotia era muito grande e importante no mercado.

Nas entrelinhas do seu depoimento, o que o entrevistado parece sugerir é que na década de 1980 houve uma mudança na postura governamental em relação à oferta de crédito rural no país, movimento que não impediu que a Cooperativa buscasse outras fontes de financiamento, mesmo que fosssem a juros mais elevados. Conforme já foi exposto no tópico anterior, durante a década de 1970 a Cooperativa participou intensamente de projetos de assentamento dirigido em várias regiões do país sob forte estímulo governamental, principalmente por meio de créditos subsidiados. O desejo de

\footnotetext{
${ }^{260}$ Entrevista realizada em 17/04/2012.
} 
dar continuidade a esses projetos possivelmente se sobrepunha aos riscos de prejuízos no mercado, amparado por uma confiança desproporcionada nas entidades financeiras governamentais. Embora o endividamento da Cooperativa tivesse início em meados da década de 1970, Toyama (2009) afirma que somente em 1989 a grave situação financeira foi exposta pela primeira vez, ainda no restrito ambiente da direção.

Em decorrência da inesperada revelação, o prestígio de Gervásio Inoue e do Diretor-Superintendente Yaçuo Ogawa encontrou o seu esgotamento em meio à diretoria: por decisão realizada em Assembleia Geral, ocorrida em março de 1990, os dois principais gestores da Cooperativa foram deslocados de suas atividades da Diretoria Executiva e passaram a integrar cargos simbólicos honorários no Conselho Consultivo $^{261}$. O agrônomo Kazuo Katayama substituiu Gervásio Inoue na presidência, permanecendo no cargo até 1993. A sua gestão se caracterizou por tentativas de contornar a crise financeira, principalmente pela negociação das dívidas junto a bancos (Banespa, Banco do Brasil, BNDES, BCN, Banco Nacional, Bamerindus, Banco Holandês) e por tentativas (frustradas) de pedidos de empréstimos junto ao Banco do Brasil $^{262}$ e ao governo japonês ${ }^{263}$. O total dessas dívidas, segundo o próprio Katayama, aproximava-se do montante de 800 milhões de dólares.

Findadas as tentativas de obtenção de empréstimos visando ao pagamento de suas dívidas, porém sem nenhum sucesso, em 20 de agosto de 1993 ocorreu uma Assembleia Geral em que Gervásio Inoue e Yaçuo Ogawa foram oficialmente desligados da Cooperativa. Uma nova diretoria foi eleita, e o cargo de presidente foi ocupado por Irineu Koyama, que o exerceu por cerca de um ano. O último presidente da Cooperativa assumiu o cargo em julho de 1994, em meio a uma conjuntura econômica

\footnotetext{
261 Ao público em geral, a Cooperativa divulgou a mudança de sua direção de maneira discreta: "Recompondo a estrutura de seu Conselho de Administração, que se reduziu para 12 membros com funções corporativas e não executivas; instituiu, também, um Conselho Consultivo, para o qual foram conduzidos o dr. Gervásio Inoue e o sr. Yaçuo Ogawa, que continuam, assim, emprestando toda sua capacidade gerencial e sua experiência à nova direção da Cooperativa" (Relatório de Serviços Sociais da CAC, 1990, p.1).

${ }^{262}$ Pedido feito em 1991, por meio do programa Empréstimo do Governo Federal (EGF) que, contudo, foi recusado.

${ }^{263}$ Pedido feito ao Ministério das Relações Exteriores do Japão em 1992, por meio do programa Overseas Economic and Finance Corporation (OECF), vinculado a empréstimos do Fundo Nakasone à normalização dos pagamentos da dívida externa do Brasil.
} 
possivelmente mais promissora, em que uma nova moeda havia sido criada e buscava-se alternativas ao turbulento cenário do início daquela década. Ainda assim, naquele ano a segunda maior cooperativa agrícola fundada por imigrantes japoneses declarava o encerramento de suas atividades: a Cooperativa Agrícola Sul-Brasil.

O presidente eleito era Keyro Simomoto, filho de Kenkiti Simomoto, que havia ocupado o cargo de Diretor-Superintendente entre 1975 e 1981. Keyro, contudo, havia sido demitido de seu cargo naquele ano de 1981, e uma das principais versões sobre o fato pode ser encontrada em Toyama (2009). Segundo esse autor, Keyro foi demitido em virtude de manobras contábeis por ele realizadas e que haviam sido repudiadas por outros diretores, principalmente por Gervásio Inoue. Essa narrativa não deixa de aventar a possibilidade de uma disputa interna de poder como motivador da demissão do filho de um dos mais respeitados líderes do empreendimento, e que passava a ganhar espaço de influência no núcleo de direção.

No período de três meses em que Keyro foi presidente (de julho a setembro de 1994) parecia não restar muitas possibilidades de ação adiante da gigantesca dívida existente, da inadimplência na devolução de seus empréstimos e da paralisação parcial de suas atividades de distribuição e comercialização. Seus funcionários já não recebiam mais salários, passaram a ser demitidos e boa parte dos diretores havia abandonado o seu otimismo. Após outras tentativas frustradas de voltar à diretoria, Keyro Simomoto havia, enfim, chegado à presidência. Uma Assembleia Geral foi então marcada para o dia 30 de setembro de 1994, em que participaram cerca de 150 pessoas, entre elas, Gervásio Inoue.

Um entrevistado que esteve presente na assembleia relata que não havia um consenso em relação ao futuro da empresa ${ }^{264}$. Alguns julgavam que a melhor resolução a ser tomada naquela assembleia seria a sua liquidação em razão do valor atingido pelas dívidas. Outros preferiam insistir em alternativas para contornar a situação, principalmente com apoio governamental. Keyro Simomoto se mostrou a favor da liquidação e, segundo o entrevistado, a sua fala esteve empenhada em convencer os cooperados presentes de que essa seria a melhor escolha a ser feita. Treze anos após o

\footnotetext{
${ }^{264}$ Entrevista realizada em 15/03/2013.
} 
seu turbulento afastamento da diretoria, Keyro voltava ao cargo máximo de decisão, agora sem precisar enfrentar possíveis oposições de outros influentes gestores. A forma pela qual o núcleo gestionário da Cooperativa se configurou ao longo de quase três décadas pareceu se distanciar da vontade do líder Kenkiti Simomoto, cujas últimas palavras, inscritas no busto que lhe homenageia ${ }^{265}$, foram: "Protejam a Cotia de mãos dadas, sem desavenças". Sob a presidência de seu filho Keyro, naquela assembleia de 1994 foi votado o encerramento das atividades da Cooperativa, após sessenta e sete anos de existência.

${ }^{265} \mathrm{O}$ busto de Kenkiti Simomoto, anteriormente localizado na entrada principal da sede da CAC, está localizado atualmente no Museu Histórico da Imigração Japonesa, no bairro da Liberdade, em São Paulo. 


\section{Considerações finais}

Oscilando entre períodos de profusão e escassez de pesquisas acadêmicas ${ }^{266}$, processos de incorporação de imigrantes na sociedade paulista ao longo do século XX têm atraído a atenção de pesquisadores das ciências humanas, seja no Brasil ou mesmo em âmbito internacional. Entre os diversos grupos emigrados, o dos japoneses foi um daqueles que experimentaram, seja por intermédio de propagandas oficiais ou utilizando contatos interpessoais, as então propaladas promessas de oportunidades extraordinárias em terras além-mar. Se, inicialmente, a realidade muitas vezes se contrapôs às expectativas, e a sociedade que outrora se apresentava diplomaticamente amistosa aos estrangeiros mostrou-se conduzida por elites políticas republicanas profundamente comprometidas em adotar os costumes de origem europeia e pela preferência por imigrantes brancos, a década posterior ao início da Segunda Guerra Mundial trazia indícios de que certos impedimentos institucionais e simbólicos para a incorporação desse grupo em grande medida haviam sido desabilitados.

Considerado nesta pesquisa enquanto produto de relações sociais de natureza e de dimensões diversas, o relativo sucesso da população japonesa em alcançar melhores posições na estrutura social se converteu da condição de aspiração a um fenômeno passível de generalização, ou seja, resultou em um fato observável para uma parcela considerável desse grupo residente no estado de São Paulo. E isso é especialmente válido para aqueles indivíduos que realizaram transições do sistema de colonato (e,

\footnotetext{
${ }^{266}$ Para uma revisão mais ampla dos estudos sobre imigração nas ciências humanas, ver: SEYFERTH, G. Os estudos sobre imigração no Brasil: notas sobre uma produção multidisciplinar. In: NÚCLEO INTERDISCIPLINAR DE ESTUDOS MIGRATÓRIOS; SEYFERTH, G. Mundos em movimento: ensaios sobre migrações. Santa Maria: Editora UFSM, 2007; e TRUZZI, O. Assimilação ressignificada: novas interpretações de um velho conceito. Dados, Rio de Janeiro, v.55, n.2, 2012.
} 
portanto, da condição de trabalhadores rurais contratados) para a pequena produção agrícola, ou mesmo para ocupações não manuais ${ }^{267}$.

Entre os cientistas sociais que se dedicaram ao estudo da imigração japonesa no Brasil, o movimento ascensional dessa população representou um ponto de partida de análise, nutrindo o interesse investigativo desses pesquisadores em explicá-lo. A revisão da literatura existente nos permite observar que os fatores culturais adquiriram proeminência nos argumentos de alguns principais estudiosos, como Saito $(1961,1964)$, Cardoso (1972) e Nogueira (1973). Nesta tese considerou-se, por certo, o movimento ascensional dos imigrantes japoneses como um importante ponto de inflexão; entretanto, este ponto foi aqui tomado de forma distinta, de modo a enriquecer o seu entendimento e melhor dimensionar a influência de múltiplos fatores explicativos. Para tal, tomou-se para exame um objeto empírico específico: a CAC.

Refiro-me aqui à forma como desenvolvi uma interpretação que posiciona esta tese em relação ao campo de estudos, bem como oferece caminhos alternativos de investigação. Por um lado, dialogando com o campo da sociologia histórica das migrações, assumi que a CAC é reveladora de processos dinâmicos de relações que colocaram à prova a capacidade de transformação das estruturas de oportunidade que historicamente no Brasil moldaram as bases das relações entre a sociedade nativa e os grupos estrangeiros. Ao longo de diferentes regimes políticos, e considerando o peso dos condicionantes de natureza política e organizacional, desloquei a análise dessas questões para o universo dos agentes e grupos responsáveis pelas principais decisões empresariais da Cooperativa. As percepções que os seus gestores possuíram sobre acontecimentos e momentos históricos específicos, bem como as respostas por eles formuladas ao sistema de alocação de direitos e oportunidades oferecidos aos estrangeiros na sociedade brasileira ao longo do século XX, indicam um protagonismo

\footnotetext{
${ }^{267}$ Segundo dados do IBGE (2008), em 1920 cerca de 50\% da população de origem japonesa exercia atividade remunerada em ocupações agrícolas. Ao longo das décadas esse percentual foi progressivamente diminuindo, e em 1960 o percentual era de cerca de 23\%. Em 1958, dados do survey The Japanese Immigrante in Brazil indicam que $81,1 \%$ dos imigrantes haviam sofrido mobilidade ascendente de status ocupacional, $16 \%$ encontravam-se na mesma situação e somente $2,9 \%$ haviam sofrido mobilidade descendente (SUZUKI, 1969).
} 
fortemente comprometido em garantir a aceitação pública de suas diferenças. E, apresentando evidências empíricas, argumentei que processos sociais inseparáveis da experiência migratória dos japoneses no Brasil reverberaram, em muitos casos, no repertório de motivações desses gestores, cujas ações, à primeira vista, responderiam a objetivos estritamente mercantis.

Por outro lado, valendo-me do debate contemporâneo do campo da sociologia econômica, relacionei as trajetórias de grupos e o universo das atividades econômicas. Enfatizei que, no caso analisado, o mercado possui valor heurístico se concebido analiticamente enquanto um espaço em que fenômenos relevantes para grupos sociais se conformaram, como é o caso de processos de incorporação experimentados pela população de origem japonesa. O mercado é, portanto, concebido nesta tese enquanto resultado de produtos históricos, de formas de interação correspondentes a certas relações de forças entre grupos. Embora interpretações eminentemente culturais oferecidas pela literatura certamente possuam um considerável valor explicativo, o caso da CAC demanda dos pesquisadores a ampliação do seu arcabouço argumentativo. A forma que optei por atendê-la se fez pelo exame dos fatores políticos e culturais que informaram o ambiente de funcionamento do universo empresarial. Por esse motivo, identifiquei inicialmente dois modelos de gestão do empreendimento, capazes de sintetizar as formas organizacionais das práticas de seus gestores. Esses modelos foram predominantes em épocas distintas e representaram respostas a diferentes conjunturas que ofertavam possibilidades historicamente situadas de atuação empresarial e de incorporação.

A análise do ambiente gestionário da CAC permitiu sobretudo revelar a conformação de um grupo de lideranças da coletividade japonesa em São Paulo por meio da imbricação de expoentes do universo empresarial, intelectual e político. Caracterizei esse grupo a partir da participação dos gestores da Cooperativa, qualificando-os como um núcleo de sociabilidade cujos membros foram capazes de produzir e disseminar ideias sobre a condição social do grupo na sociedade local, e para quem interessava conceber projetos que pudessem resultar de maneira geral em benesses coletivas pelas vias da incorporação social. 
Por se tratar de um espaço relacional e dinâmico, esse núcleo de sociabilidade esteve permeado por vetores de influência diversos, associados a várias biografias; assim, esteve sujeito a transformações e foi moldado por interesses e relações de poder em âmbito interno e externo. A geração de seus membros foi um dos principais eixos para análise. Esse foi um fator condutor de mudanças internas ao sintetizar, em termos nativos, as dissonâncias entre a primeira e a segunda gerações de imigrantes no que se refere à estrutura familiar, ao idioma, à endogamia e aos sistemas simbólicos que regiam e perpetuavam suas formas de conduta. Ademais, em conjunturas políticas adversas aos estrangeiros, como nos anos do Estado Novo, a depender de como esses indivíduos equacionavam a sua nacionalidade com valores, categorias raciais e culturais, os limites para o seu reconhecimento social, seus direitos e oportunidades se impunham de maneira bem definida. Embora o grupo de lideranças da coletividade japonesa de São Paulo fosse numericamente uma fração restrita, pude constatar ali uma heterogeneidade de visões acerca dos projetos de incorporação vislumbrados, bem como a geração se mostrou um marcador central nas formas de condução dos negócios. Pois a primeira e a segunda gerações de gestores da CAC vivenciaram os contextos de relação entre a sociedade local e os estrangeiros de formas qualitativamente distintas, o que contribuiu para que suas respostas às constrições se expressassem de maneira diferenciada.

Por mais que a primeira geração de lideranças almejasse conduzir processos bilaterais de redefinição dos parâmetros reguladores - políticos e simbólicos - que distanciavam a população japonesa de sua aceitação, coube à segunda geração protagonizá-la de forma mais plena. Algumas situações, envolvendo os gestores da Cooperativa, foram trazidas à luz, e são aqui retomadas, por bem ilustrá-lo. Assim, por exemplo, mesmo que tivesse abdicado formalmente do cargo máximo de comando do empreendimento e se apresentasse publicamente como um dos líderes do movimento “esclarecedor" sobre a derrota japonesa na Segunda Guerra, isso não garantiu a Kenkiti Simomoto a salvaguarda de suspeições. Ao final de sua vida, ele se deparou com um inquérito instaurado por autoridades policiais, e que visava a sua expulsão e de seus colegas japoneses (como o sociólogo Hiroshi Saito, o pintor e memorialista Tomoo Handa e o sociólogo Zenpati Ando) do território nacional. Seu sucessor Gervásio Inoue, embora houvesse vivido a repressão política por meio de sua detenção em 1942, teve 
proeminência na tarefa de disseminar e validar uma narrativa de sucesso da trajetória migratória, ou mesmo publicizar uma imagem positiva de si próprio enquanto retrato do sucesso empresarial. O segundo personagem na hierarquia de comando da Cooperativa, Fábio Yassuda, consagrou a ascensão política da segunda geração, enquanto filho de imigrantes japoneses, expoente do universo empresarial, ao assumir o cargo de ministro da Indústria e Comércio no governo de Emílio Garrastazu Médici.

Ao evidenciar o intercâmbio entre as atividades econômicas, a política e a cultura, esta tese oferece subsídios para esclarecer certas dinâmicas de relações próprias a grupos dirigentes na sociedade brasileira, e demonstra que a origem social dos agentes que a compõem são fatores determinantes para a compreensão de fenômenos mercantis. Os resultados desta pesquisa indicam que, além de uma trajetória empresarial, a CAC resguardou um espaço de atuação relevante para a ação de indivíduos e grupos de origem japonesa que buscavam paulatinamente construir as suas estratégias de incorporação à sociedade paulista. 


\section{Referências Bibliográficas}

ABRAMOVAY, R. Para una teoría de los estudios territoriales. In: MANZANAL, M.; Guillermo NEIMAN, M.L. (Org.). Desarrollo rural - Organizaciones, instituciones y territorios. Buenos Aires: Ciccus, 2006, p. 51-70.

ADORNO, S. Os aprendizes do poder. Rio de Janeiro: Paz e terra, 1988.

ALBA, R.D.; NEE, V. Remaking the American mainstream assimilation and contemporary immigration. Cambridge, Mass: Harvard University Press, 2003.

ANDO, Z. Pioneirismo e cooperativismo: história da cooperativa agrícola de Cotia. São Paulo: Editora Sociologia e Política/Fundação Escola de Sociologia e Política de São Paulo, 1961.

BALDUS, H.; WILLEMS, E. Casas e túmulos japoneses no vale do Ribeira de Iguape. Revista do Arquivo Municipal, São Paulo, v. LXXVII, p. 121-135, 1941.

BANCO AMÉRICA DO SUL S.A. Breve história do Banco América do Sul S.A. Tóquio: Gráfica Hossokawa, 1960.

BANDEIRA, M. Libertinagem; Estrela da manha: edição crítica. Paris: Edições UNESCO, 1998.

BAUAB, J.D. A primeira eleição ao parlamento paulistano pós-ditadura Vargas e o drama dos vereadores comunistas. In: MANECHINI, L.C. (Org.). São Paulo na Tribuna: primeira legislatura (1948-1951)/Escola do Parlamento da Câmara Municipal de São Paulo. São Paulo: Imprensa Oficial do Estado de São Paulo, 2012.

Beckert, J. What is Sociological about Economic Sociology? Uncertainty and the Embeddedness of Economic Action. Theory and Society, v. 25, p.803-840, 1996.

The social order of markets. Discussion Paper 07/15. Koln: Max-PlanckInstitut fur Gesellschaftsforschung, 2007.

BONET, F. Autoritarismo e nacionalismo: o discurso oficial sobre o envolvimento do Brasil na Segunda Guerra Mundial, através das páginas da revista "Cultura Política". Dissertação (Mestrado) - Porto Alegre, UFRGS, 2001.

O discurso oficial brasileiro durante a II Guerra Mundial: O Brasil se une para a Guerra. IX Encontro Estadual de história. ANPUH, 2008.

BOSCHI, R.R. Elites industriais e democracia. Rio de Janeiro: Graal, 1979.

BOSCHI, R.R.; DINIZ, E.; SANTOS, F.G.M. Elites políticas e econômicas no Brasil contemporâneo: a desconstrução da ordem corporativa e o papel do Legislativo no cenário pós-reformas (n. 18). Rio de Janeiro: Fundação Konrad Adenauer, 2000. 
BRESSER-PEREIRA, L.C. Empresários e administradores no Brasil. São Paulo: Editora Brasiliense, 1974.

[CAC] COOPERATIVA AGRÍCOLA DE COTIA. História da Cooperativa Agrícola de Cotia. São Paulo: CAC, 1957.

CANDIDO, A. A Sociologia no Brasil. Tempo Social, São Paulo, v. 18, n. 1, p. 271-30, 2006[1959]..

CARDOSO, F.H. Desenvolvimento econômico e empresário industrial. São Paulo: Difel, 1964. Autoritarismo e democratização. Rio de Janeiro: Paz e Terra, 1975.

CARDOSO, A. Uma utopia brasileira: Vargas e a construção do estado de bem-estar numa sociedade estruturalmente desigual. Dados, Rio de Janeiro, v. 53, p. 775-819, 2010.

CARDOSO, R.C.L. Estrutura familiar e mobilidade social:estudo dos japoneses no estado de São Paulo. São Paulo: Primus, 1995 [1972].

CARIELLO, R. O chefe. PIAUÍ, n. 96, ano 8, p. 18-28, 2014.

CARVALHO, J.M. A construção da ordem: a elite política imperial. Teatro de sombras: a política imperial. 2.ed. Rio de Janeiro: Relume-Dumará, 1996.

CENTRO DE ESTUDOS NIPO-BRASILEIROS O Japonês em Sâo Paulo e no Brasil. São Paulo: Centro de Estudos Nipo-Brasileiros, 1971.

COMISSÃO de Elaboração da História dos 80 Anos da Imigração Japonesa no Brasil. Uma Epopéia Moderna: 80 Anos Da Imigração Japonesa no Brasil. São Paulo: Hucitec/Sociedade Brasileira de Cultura Japonesa, 1992.

COOPERATIVA AGRÍCOLA DE COTIA. CAC - Cooperativismo que deu certo, 1988.

CORRÊA, M. (Org.). História da antropologia no Brasil (1930-1960). Testemunhos: Emílio Willems e Donald Pierson. Campinas: Editora da Unicamp/Vértice, 1987.

COSTA, E.V. Cotia e Itapecerica da Serra, subúrbios agrícolas. In: AZEVEDO, A. (Coord.) A cidade de São Paulo: estudos de geografia urbana. Volume IV: Os subúrbios paulistanos. São Paulo: Cia. Editora Nacional, 1958, p.109-152.

CYTRYNOWICZ, R. Guerra sem guerra: a mobilização e o cotidiano em São Paulo durante a Segunda Guerra Mundial. São Paulo: Geração Editorial, 2000.

DEZEM, R. Shindô Renmei: terrorismo e repressão. São Paulo: Arquivo do Estado/Imprensa Oficial, 2000.

DIAS, C.A.U.; FRANCISCO, H.S.; CAVALLI JÚNIOR, J. Os nikkeis na Assembleia de São Paulo. São Paulo: Assembleia Legislativa do Estado de São Paulo, 2008 
DINIZ, E. Empresário, Estado, e capitalismo no Brasil, 1930-1945 (vol. 27). Rio de Janeiro: Paz e Terra, 1978.

DOBBIN, F. Forging Industrial Policy: The United States, Britain, and France in the Railway Age. Cambridge: Cambridge University Press, 1994.

A Market is a Market is a Market?: Institutional Conditions for the Construction of Market Mechanisms. BISS Public, Berlin, v. 27, p. 53-72, 1999.

DRAIBE, S. Rumos e metamorfoses: um estudo sobre a constituição do Estado e as alternativas da industrialização no Brasil, 1930-1960. Rio de Janeiro: Paz e Terra, 1985.

ENDRICA, G. $O$ "perigo alienígena": política imigratória e pensamento racial no governo Vargas (1930-1945). Tese (Doutorado) - Campinas, UNICAMP, 2007.

A "lei de cotas" de 1934: controle de estrangeiros no Brasil. Cad. AEL, v.15, n.27, p.176-206, 2009.

EUFRASIO, M. Apresentação da Tradução. Mudança cultural entre imigrantes japoneses no Brasil, no Vale do Ribeira de São Paulo. PLURAL, Revista do Programa de Pós-Graduação em Sociologia da USP, São Paulo, v.19, n.1, p.135-138, 2012.

FAORO, R. Os donos do poder: formação do patronato político brasileiro. 3.ed. São Paulo: Globo, 2007 [1958].

FERNANDES, F. O negro no mundo dos brancos. 2.ed. São Paulo: Global Editora, 2007.

FISHLOW, A. A economia política do ajustamento brasileiro aos choques do petróleo: uma nota sobre o período 1974/84. Pesquisa e Planejamento Econômico, v. 16, n. 3, p507-550, dez. 1986.

FLIGSTEIN N. The Intraorganizational Power Struggle: Rise of Finance Personnel to Top Leadership in Large Corporations, 1919-1987. American Sociological Review, v.52, p.44-58, 1987. Press, 1990.

The transformation of corporate control. Cambridge, Mass: Harvard University

. Markets as politics: A political-cultural approach to market institutions. American sociological review, v. 61, n. 4, p. 656-673, 1996.

Organizations:Theoretical Debates and the Scope of Organizational Theory. University of California, Berkeley. 2001. Disponível em: <http://sociology.berkeley.edu/sites/default/files/faculty/fligstein/inter.handbook.paper.p df>. Acesso em: 13 maio 2015.

Fields, Power, and Social Skill: A Critical Analysis of the New Institutionalisms. International Public Management Review, v.9, p.227-52, 2008.

GASPARI, E. A ditadura derrotada. São Paulo: Companhia das Letras, 2003. 
GASQUES, J.G. et al. Desempenho e crescimento do agronegócio no Brasil. Brasília: IPEA, 2004 (Texto para discussão, 1009).

GONÇALVES, J.S.; VEGRO, C.L. Crise econômica e cooperativismo agrícola: uma discussão sobre os condicionantes das dificuldades financeiras da Cooperativa Agrícola de Cotia (CAC). Agricultura em São Paulo, v. 41, n. 2, p. 57-87, 1994.

GONÇALVES NETO, W. Estado e agricultura no Brasil: política agrícola $e$ modernização econômica brasileira, 1960-1980. São Paulo: Editora Hucitec, 1997.

GRANOVETTER, M. Economic action and social structure: the problem of embeddedness". American journal of sociology, v. 91, n. 3, p. 481-510, 1995.

GRÜN, R. Economia étnica, teoria econômica e a "escola da vida". Pro-Posições, Campinas, v. 9, n. 1, p. 92-112, 1998.

GRYNSZPAN, M. Ciência política e trajetórias sociais: uma sociologia histórica da teoria das elites. Rio de Janeiro: Ed. Fundação Getulio Vargas, 1999. 35-84, 1996.

A Teoria das Elites e sua genealogia consagrada. BIB, Rio de Janeiro, n. 41, p.

GRYNSZPAN, M., GRILL, I.G. Elites: recursos e legitimação. R. Pós Ci. Soc. v.8, n.15, jan./jun. 2011, p.9-14.

GUIMARÃES, N.A. Caminhos cruzados: estratégias de empresas e trajetória de trabalhadores. São Paulo: Editora 34, 2004.

GUIMARÃES, A.S.A. Classes, raças e democracia. São Paulo: FUSP/Editora 34, 2002.

Quilombo: vida, problemas e aspirações do negro. São Paulo: Editora 34, 2003. Edição em fac-símile.

HANDA, T. O Imigrante japonês: História de sua vida no Brasil. São Paulo: Centro de Estudos Brasileiros, 1987.

HASENBALG, C.A. Discriminação e desigualdades raciais no Brasil. Rio de Janeiro: Graal, 1979.

HATANAKA, M.L.E. O processo judicial da Shindo-Remmei: um fragmento da história dos imigrantes japoneses no Brasil. São Paulo: Annabume, 2002.

HEINZ, F.M. (Org.) Por outra história das elites. Rio de Janeiro: FGV Editora, 2006.

(Org.) História social de elites. São Leopoldo: Oikos, 2011.

HIRATA, N. Inovações tecnológicas baseadas no conhecimento tácito: o caso da comunidade japonesa na construção da Cooperativa Agrícola de Cotia. Dissertação (Mestrado), FFLCH/USP, 2001.

IANNI, O. Estado e planejamento econômico no Brasil. Rio de Janeiro: Ed.UFRJ, 2009 [1971]. 
JACKSON, L.C. A sociologia paulista nas revistas especializadas (1940-1965). Tempo Social, São Paulo, v.16, n.1, p. 263-283, 2004.

LEÃO NETO, V.C. A Crise da imigração japonesa no Brasil (1930-1934): contornos diplomáticos. Fundação Alexandre Gusmão/IPRI, 1990.

LEBARON, F. A formação dos economistas e a ordem simbólica mercantil. Revista Espaço de Diálogo e Desconexão, Araraquara, v. 4, n. 2, jan/jul. 2012.

LESSER, J. A negociação da identidade nacional: imigrantes, minorias e a luta pela etnicidade no Brasil. São Paulo: Unesp, 2001.

. Uma diáspora descontente. Os nipo-brasileiros e os significados da militância étnica. São Paulo: Paz e Terra, 2008.

LEVY, M.S. O papel da migração internacional na evolução da população brasileira (1872-1972). Revista de Saúde Pública, v. 8, p. 49-90, 1974.

Contemplating Delivery: Futures Trading and the Problem of Commodity Exchange in the United States, 1875-1905. American Historical Review, v.111, n.3, p. 307-335, abr. 2006.

LIMA, M.R.S.; CHEIBUB, Z. Instituições e valores : as dimensões da democracia na visão da elite brasileira. Revista Brasileira de Ciências sociais, São Paulo, n. 31, p. 83110, 1996.

LOURENÇO, M.C.F.Tomoo Handa - Eu sigo meu caminho, seguindo meus olhos e meus sentimentos. Rev.Inst.Est.Bras. São Paulo, n.39, p.91-97, 1995.

MACEDO, R. Antonio Delfim Netto. Estud. Av., v.15, n.43, p. 375-388, 2001.

MACARINI, J.P. A política econômica do governo Médici: 1970-1973. Nova Economia, Belo Horizonte, v.15, n.3, p.53-92, 2005.

Governo Geisel: transição político-econômica? Um ensaio de revisão. Texto para Discussão. IE/UNICAMP, Campinas, n. 142, 2008.

MAEYAMA, T. Margarida Vatanabe: 53 anos de assistência a imigrantes e idosos. São Paulo: Zipango, 2004.

MAIO, M.C. O Projeto Unesco e a agenda das ciências sociais no Brasil dos anos 40 e 50". Revista Brasileira de Ciências Sociais, v.14, n.41, p.141-158, 1999.

. O projeto UNESCO: Ciências Sociais e "credo racial brasileiro". Revista da USP, n. 46, p. 115-128, 2000.

MALUF, P.S. ELE: Paulo Maluf, trajetória da audácia. São Paulo: Edioura, 2008.

MARCOVITCH, J. O caso Cotia: ascensão, queda e esperança”. IV Seminário Internacional Gerenciamento de Conflitos nos Sistemas Agroindustriais, PENSA/FIA USP, 1996. 
MARTINS, J. de S. Subúrbio, Vida cotidiana e história no subúrbio da Cidade de São Paulo: São Caetano, do fim do Império ao fim da República Velha. São Paulo: Hucitec, 1992.

MARTINS, P.E.; ALBERTI, V.; FARIAS, I.C.D.; ROCHA, D. Paulo Egydio conta: depoimento ao CPDOC - FGV. São Paulo: Imprensa Oficial, 2007.

MENDONÇA, S.R. de. A política de cooperativização do Estado brasileiro (19101945). Niterói: EDUFF, 2002.

MENEZES, P. Grupo Seibi - O Nascimento da Pintura Nipo Brasileira. Revista USP, São Paulo, v. 27, p. 102-115, 1995.

MEYER, J.W.; ROWAN, B. Institutionalized Organizations: Formal Structure as Myth and Ceremony. American Journal of Sociology, v.83, n.2, p.55-77, jul. 1977.

MICELI, S. Intelectuais e classe dirigente no Brasil (1920-1945). São Paulo: DIFEL, 1979.

Nacional estrangeiro: história social e cultural do modernismo artístico em São Paulo. São Paulo: Companhia das Letras, 2003.

MITA, C. Bastos: uma comunidade étnica japonesa no Brasil. São Paulo: Humanitas,/FFLCH/USP, 1999.

MIYAO, S. Posicionamento social da população de origem japonesa. In: SAITO, H. (Org.) A Presença japonesa no Brasil. São Paulo:Assembleia Legislativa do Estado de São Paulo, 1980, p.91-100.

MOURA, G. Tio Sam chega ao Brasil - a penetração cultural norte-americana. São Paulo: Brasiliense, 1984.

NERY, S. Folclore político: 1950 histórias. São Paulo: Geração Editorial, 2002.

NOGUEIRA, A.R. A imigração japonesa para a lavoura cafeeira paulista (1908-1922). São Paulo: IEB, 1973.

- Companhias interessadas na introdução de asiáticos em São Paulo nos primeiros anos da República. São Paulo: Centro de Estudos Nipo-Brasileiros, 1979.

NOGUEIRA, E. da C.; NUNES, F.M. Propriedades de japoneses na região de Cotia. Geografia Agrária, n.9, p.38-59, out. 1951.

NUCCI, P. Os intelectuais diante do racismo antinipônico no Brasil: textos e silêncios. São Paulo: Annablume, 2010.

OCASIO, W. Political Dynamics and the Circulation of Power: CEO Succession in U.S. Industrial Corporations, 1960-1990. Administrative Science Quarterly, v.39, n.2, p.285312, jun. 1994.

OKUBARO, J.J. O súdito: banzai, Massateru! São Paulo: Editora Terceiro Nome, 2006.

OLIVEIRA, R.C.D. O trabalho do antropólogo. 6.ed. São Paulo: Editora Unesp, 2006. 
ORLÉAN, A. Analyse économique des conventions. Paris: Presses Universitaires de France, coll. "Quadrige", 2ème édition revue et corrigée, 2004[1994].

PAULINELLI, A. As terras de fazer longe. Disponível em: <http://forumdofuturo.com.br/?p=56>. Acesso em: dez. 2014.

PENTEADO, A.R. Os subúrbios de São Paulo e suas funções. In: AZEVEDO, A. de (Coord.) A cidade de São Paulo: estudos de geografia urbana. Volume IV: Os subúrbios paulistanos. São Paulo: Cia. Editora Nacional, 1058, p.5-60.

PEREIRA; C.; SANSONE, L. (Org.). Projeto Unesco no Brasil. 1.ed. Salvador: EDUFBA, 2008.

PERISSINOTTO, R.M.; CODATO, A. Apresentação: por um retorno à Sociologia das Elites. Rev. Sociol. Polit., Curitiba, v. 16, n. 30, jun. 2008.

PFEFFER, J. Power in Organizations. Marshfield, MA: Pitman, 1981. Managing with Power. Boston: Harvard Business School Press, 1992.

PIERSON, D. Introdução. In: SAITO, H. O cooperativismo na região de Cotia: estudo de transplantação cultural (I). Sociologia: revista dedicada à teoria e pesquisa nas Ciências Sociais. Escola de Sociologia e Política de São Paulo, v. 16, n. 3, p. 248-283, 1954.

PIERSON, D. Introdução. In: SAITO, H. O cooperativismo e a comunidade. Caso da Cooperativa Agrícola de Cotia. São Paulo: Ed. Sociologia e Política/Fundação Escola de Sociologia e Política de São Paulo, 1964, p.11-14.

POWELL, P.J.; DIMAGGIO (Eds.). The new institutionalism in organizational analysis. Chicago: University of Chicago Press, 1991.

QUINTANEIRO, T. Plantando nos campos do inimigo: japoneses no Brasil na segunda guerra mundial. Estudos Ibero-americanos, PUCRS, v. XXXII, n. 02, p. 155-169, dez. 2006.

REIS, E. Elites agrárias, state-building e autoritarismo. Dados, v.25, n.3, p. 275-96, 1982.

REVISTA TOMO. Dossiê: Sociologia do poder $e$ das elites. São Cristovão-SE, NPPCS/UFS, v.10, n.13, 2008.

REVISTA DE SOCIOLOGIA E POLÍTICA. Dossiê: Elites e instituições políticas. Departamento de Ciências Sociais/Universidade Federal do Paraná. Curitiba-PR, v.16, n.30, 2008.

REVISTA DE SOCIOLOGIA E POLÍTICA. Dossiê: Elites em diferentes escalas: teoria e metodologia no estudo dos grupos dirigentes. v. 22, n. 52, 2014.

SAHLINS, M. Metáforas históricas e realidades míticas estrutura nos primórdios da história do reino das ilhas Sandwich. Rio de Janeiro: Zahar, 2008.

SAITO, H. Compreensão recíproca. Jornal Paulista, 1 de janeiro de 1948, p.1. 
O cooperativismo na região de Cotia: estudo de transplantação cultural (I). Sociologia: revista dedicada à teoria e pesquisa nas Ciências Sociais. Escola de Sociologia e Política de São Paulo, v. 16, n. 3, p. 248 - 283, ago. 1954.

O cooperativismo na região de Cotia: estudo de transplantação cultural (II). Sociologia: revista dedicada à teoria e pesquisa nas Ciências Sociais. Escola de Sociologia e Política de São Paulo, v. 17, n. 1, p. 56 - 71, mar. 1995a.

- O cooperativismo na região de Cotia: estudo de transplantação cultural (III). Sociologia: revista dedicada à teoria e pesquisa nas Ciências Sociais. Escola de Sociologia e Política de São Paulo, v. 17, n. 2, p. 163 - 195, maio. 1955b.

O cooperativismo na região de Cotia: estudo de transplantação cultural (IV). Sociologia: revista dedicada à teoria e pesquisa nas Ciências Sociais. Escola de Sociologia e Política de São Paulo, v. 17, n. 3, p. 254 - 268, ago. 1955c.

- O cooperativismo na região de Cotia: estudo de transplantação cultural (V). Sociologia: revista dedicada à teoria e pesquisa nas Ciências Sociais. Escola de Sociologia e Política de São Paulo, v. 17, n. 4, p. 355 - 370, out. 1955d.

- Mobilidade de ocupação e de status de um grupo de imigrantes". Sociologia: revista dedicada à teoria e pesquisa nas Ciências Sociais. Escola de Sociologia e Política de São Paulo, v. 22, n. 3, p. 241 - 253, set. 1960.

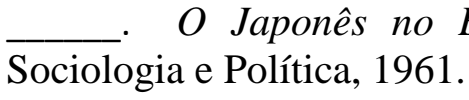

- O cooperativismo e a comunidade. Caso da Cooperativa Agrícola de Cotia. São Paulo: Ed. Sociologia e Política, Fundação Escola de Sociologia e Política de São Paulo, 1964.

SAITO, H.; MAEYAMA, T. Assimilação e integração dos Japoneses no Brasil. Petrópolis: Editora Vozes, 1973.

SAKURAI, C. Descendentes de japoneses e participação política - perfil de quatro políticos. XVII Encontro Anual da ANPOCS, Caxambu, 1993.

SAKURAI, C.; COELHO, M.P. Resistência \& integração: 100 anos de imigração japonesa no Brasil. Rio de Janeiro: IBGE, 2008.

SALGADO, G.M. Discussões legislativas do Código Civil de 1916: Uma revisão historiográfica. Âmbito Jurídico, Rio Grande, XV, n. 96, jan. 2012.

SCHPUN, M.R. Imigração japonesa no Brasil: riquezas de uma presença secular. In SAKURAI, C. (Org.). Resistência \& integração: 100 anos de imigração japonesa no Brasil. Rio de Janeiro: IBGE, 2008, p. 136-149.

SCHWARCZ, L.M. O espetáculo das raças: cientistas, instituições e questão racial no Brasil, 1870-1930. São Paulo: Companhia das Letras, 1993.

SCHWARTZMAN, S. São Paulo e o Estado nacional. São Paulo: Difel, 1975. 
SEABRA, M. Vargem Grande; organização e transformações de um setor do cinturãoverde paulistano. São Paulo, Universidade de São Paulo, Instituto de Geografia, 1971.

As cooperativas mistas do Estado de São Paulo. São Paulo, IGEOG, Série teses e monografias, n.30, 1977.

SEITENFUS, R. A entrada do Brasil na segunda guerra mundial. Porto Alegre: Edipucrs, 2000.

SELZNICK, P. Leadership in administration: A sociological interpretation. Berkeley: University of California Press, 1957.

SEYFERTH, G. Identidade étnica, assimilação e cidadania: a imigração alemã eo Estado brasileiro. Rev. bras. Ci. Soc., São Paulo, v.9, n.26, p.103-122, 1994.

A idéia de cultura teuto-brasileira: literatura, identidade e os significados da etnicidade. Horizontes antropológicos, v.10, n.22, p.149-197, 2004.

Os estudos sobre imigração no Brasil: notas sobre uma produção multidisciplinar". In: SEYFERTH et al. Mundos em movimento: ensaios sobre migrações. Santa Maria: Editora UFSM, 2007, p.15-44.

SHINTANI, A.H. World War II as Seen In Life Records Of Japanese In Brazil: A Study Of Diaries, Newspapers And Radio Broadcasting. Dissertação (Metrado). Kyoto University, 2013.

SIMOMOTO, A. Na reunião do dia 20. Jornal Paulista, 13 de janeiro de 1948, p.1.

Calorosos debates travados na sede da C.A.C. Jornal Paulista, 26 de fevereiro de 1948, p.1.

SKIDMORE, T. Brasil: de Castelo a Tancredo. Rio de Janeiro: Ed. Paz e Terra, 1988.

SOARES, G.A.D. Sociedade e politica no Brasil (Desenvolvimento, classe e política durante a Segunda República). São Paulo: Difusão Européia do Livro, 1973.

SOLA, L. Idéias econômicas, decisões políticas. São Paulo: Edusp, 1998.

SPITZER, L. Vidas de entremeio: assimilação e marginalização na Austria, no Brasil e na Africa Ocidental, 1780-1945. Rio de Janeiro: EdUERJ, 2001.

STEINER, P. A sociologia econômica. São Paulo: Atlas, 2006.

SUZUKI, T. (Ed). The Japanese Immigrant in Brazil. Statistical tables. Tokyo: University of Tokyo Press, 1964. Press, 1969.

The Japanese Immigrant in Brazil. Narrative part. Tokyo: University of Tokyo

SWEDBERG, R. Markets in society. In: SMELSER, N. J.; SWEDBERG, R. (Ed.). The handbook of economic sociology. Princeton, N.J.: Princeton University Press, 2005, p.233-253. 
TAKEUCHI, M.Y. O Perigo Amarelo em tempos de guerra. São Paulo: Imprensa Oficial do Estado, 2002. 200p.

. A comunidade nipônica e a legitimação de estigmas: o japonês caricaturizado. REVISTA USP, São Paulo, n.79, p. 173-182, set./nov. 2008.

Entre gueixas e samurais: a imigração japonesa nas revistas ilustradas (18971945). Tese (Doutorado). São Paulo, FFLCH/USP, 2002.

TANIGUTI, G.T.; JESUS, M.G. Sociologie de l`immigrant: Hiroshi Saito et l'institutionalisation des études sur les Japonais du Brésil (1940-1960). Brésil(s), v. 2 , p.201-224, 2012.

THORNTON, P.H.; OCASIO, W. Institutional Logics and the Historical Contingency of Power in Organizations: Executive Succession in the Higher Education Publishing Industry, 1958-1990. American Journal of Sociology, v. 105, p.801-843, 2012.

TOLENTINO, C.A.F. O farmer contra o jeca: o projeto de revisao agrária do governo Carvalho Pinto. Marília: Oficina Universitária, 2011.

TOYAMA, O. Cem anos de águas corridas. São Paulo: AGWM, 2009.

TRUZZI, O.; KERBAUY, M.T.M.; BARBOSA, A. de S. Mudança de fronteiras étnicas e participação política de descendentes de imigrantes em São Paulo. Rev. bras. Ci. Soc., São Paulo, v. 27, n. 80, out. 2012.

TRUZZI, O. Patrícios: sírios e libaneses em São Paulo. 2.ed. São Paulo: Editora UNESP, 2009.

. Assimilação ressignificada: novas interpretações de um velho conceito. Dados, Rio de Janeiro, v.55, n.2, 2012.

UCHIYAMA, I. Um quarto de século de colaboração japonesa no progresso do Brasil. In: Brasil e Japão: duas civilizações que se completam. São Paulo: Empreza Gráphica da "Revista dos Tribunaes", 1934.

UDIHARA, M. Alhos por bugalhos. Jornal Paulista, 17 de janeiro de 1948, p.1.

UNITED STATES. Dept. of State. The proclaimed list of certain blocked nationals-Supplement 1-4: Feb. 28-May 1, 1942. Washington: U. S. Govt. print. off., 1942, p.22.

VEGRO, C.L. Uma abelha circunscrita: um estudo sobre o sucesso empresarial da Cooperativa Agrícola de Cotia - CAC. Dissertação (Mestrado) - Rio de Janeiro, UFRRJ, 1992.

VILLAS-BÔAS, G. De Berlim a Brusque, de São Paulo a Nashville - a sociologia de Emílio Willems entre fronteiras". Tempo Social, v. 12, n. 2, p. 171-188, p. 172-73, 2000 .

YASSUDA, F.R. O cooperativismo e a organização rural. In: O japonês em São Paulo e no Brasil. São Paulo: Centro de Estudos Nipo-Brasileiros, 1971, p.181-190.

YOKOTA, P. O olhar dos nisseis paulistanos. São Paulo: Editora JBC, 2008. 
WILLEMS, E. Assimilação e Educação. Revista Brasileira de Estudos Pedagógicos. v. IV, n. II, p. 173-181, 1945.

Aspectos da aculturação dos japoneses no estado de São Paulo. FFCL-USP/ Boletim LXXXII - Antropologia n. 3, São Paulo, 1948.

Brazil. In: INTERNATIONAL SOCIOLOGICAL ASSOCIATION. The positive contribution by immigrants. Paris: Unesco, 1955.

WILLIAMS, R. Cultura e Materialismo. São Paulo: UNESP, 2011.

ZAJAC, E.J.; WESTPHAL, J.D. Director Reputation, CEO-Board Power, and the Dynamics of Board Interlocks. Administrative Science Quarterly, v. 41, p. 507-529, 1996.

ZELIZER, V.A.R. Economic lives: how culture shapes the economy. Princeton, N.J.: Princeton University Press, 2010. 


\section{Fontes consultadas}

Arquivo Público do Estado de São Paulo

Núcleo de Documentação do Instituto de Cooperativismo e Associativismo, Secretaria da Agricultura do Estado de São Paulo, Departamento de Assistência ao Cooperativismo Centro de Estudos Nipo-Brasileiro

Museu Histórico da Imigração Japonesa no Brasil

Acervo pessoal de Hiroshi Saito

\section{Periódicos}

Correio da Manhã

Folha de S.Paulo

Jornal de Notícias

Jornal do Brasil

Jornal Paulista

O Estado de S.Paulo

Veja

Gakusei

Gakuyu

Transição

Informativo Cotia

\section{Legislação}

Decreto n. 22.239 de 19 de dezembro de 1932

Decreto n. 5.966, de 30 de junho de 1933

Decreto-lei n. 406, de 04 de Maio de 1938

Decreto-lei n. 383, de 18 de Abril de 1938

Decreto-lei n. 868, de 18 de Novembro de 1938

Decreto-lei 3.911 de 12 de dezembro de 1941 
Decreto-lei n. 4.118, de 20 de Fevereiro de 1942

Decreto-lei n. 4.166, de 11 de Março de 1942

Portaria n. 5.408, de 28 de abril de 1942

Decreto-lei n. 4.717, de 21 de Setembro de 1942

Decreto-lei n. 5.154, de 31 de Dezembro de 1942

Decreto-lei n. 5.777, de 26 de Agosto de 1943

Decreto n. 29.636 de 11 de setembro de 1957

Decreto-lei n. 59, de 21 de Novembro de 1966

Decreto n. 60.597, de 19 de Abril de 1967

Resolução n. 698, de 17 de junho de 1981 do Banco Central do Brasil.

Projeto de Decreto Legislativo 02-0113/1996

\section{Sítios da internet}

$<$ http://www.bunkyo.bunkyonet.org.br/index.php?option=com_content\&view=article\&i $\mathrm{d}=64$ :imagens-e-breve-cronologia-da-imigracao-japonesa-nobrasil\&Itemid=1\&lang=br $>$. Acesso em junho de 2013.

<http://www.asiacomentada.com.br/2010/06/imigracao-japonesa-no-brasil-e-medicinapreventiva/>. Acesso em agosto de 2013

<http://www.culturajaponesa.com.br/htm/entrevista.html>. Acesso em março de 2013.

$<$ http://www.bunkyo.bunkyonet.org.br/index.php?option=com_content\&view=article\&i $\mathrm{d}=64$ :imagens-e-breve-cronologia-da-imigracao-japonesa-no-

brasil\&Itemid=1\&lang=br $>$. Acesso em abril de 2013.

<http://www.culturajaponesa.com.br/htm/yukishiguetamura.html >. Acesso em abril de 2014.

<http://www.arquivoestado.sp.gov.br/noticia_ver.php?id=483>. Acesso em novembro de 2014.

<http://forumdofuturo.com.br/?p=56>. Acesso em dezembro de 2014.

\section{Outros materiais}

Relatório de serviços sociais da CAC 
Festejos Comemorativos - Cooperativa Agrícola de Cotia Boletins Informativos do Serviço Nacional de Informações 


\section{Anexos}

Relação cronológica dos componentes da diretoria, conselho de administração conselho fiscal da cooperativa agrícola de cotia, 1928-1992

\section{$1928(01 / 01 / 1928$ a 31/03/1929)}

Diretor Presidente

Diretor Gerente

Diretor Tesoureiro

Conselheiro Fiscal

Conselheiro Fiscal

Conselheiro Fiscal
Kenkiti Simomoto *

Kumaki Nakao

Tsuruki Mori

Masuji yano

Hatsuji Miyazaki

Kameiti Yamashita

\section{9 (01/04/1929 a 31/03/1930)}

Diretor Presidente

Diretor Gerente

Diretor Tesoureiro

Conselheiro Fiscal

Conselheiro Fiscal

Conselheiro Fiscal

$1930(01 / 04 / 1930$ a 31/03/1931)

Diretor Presidente

Diretor Gerente

Diretor Tesoureiro

Conselheiro Fiscal

Conselheiro Fiscal

Conselheiro Fiscal
Kenkiti Simomoto *

Kumaki Nakao

Yoshikiyo Yoshimoto

*(Afasta-se do cargo em 16/06/1929 por motivos particulares, sendo substituído pelo Sr. Seiki Murakami

Masaji Mtasuoka

Masuji Yano

Kameiti Yamashita
Masuji yano

Susumu Yoshimoto

Yoshikiyo Yoshimoto

Hatsuji Miyazaki

Kameiti Yamashita

Masaji Matsuoka 
1931 (01/04/1931 a 31/03/1932)

$\begin{array}{ll}\begin{array}{l}\text { Diretor Presidente } \\ \text { Diretor Gerente } \\ \text { Diretor Tesoureiro }\end{array} & \begin{array}{l}\text { Masuji yano } \\ \text { Kenkiti Simomoto } \\ \text { Hatsuji Miyazaki }\end{array} \\ \begin{array}{l}\text { Conselheiro Fiscal } \\ \text { Conselheiro Fiscal }\end{array} & \begin{array}{l}\text { Kameiti Yamashita } \\ \text { Shigeji Takahashi }\end{array} \\ \text { Conselheiro Fiscal } & \text { Susumu Yoshimoto }\end{array}$

$1932(01 / 04 / 1932$ a 31/03/1933)

Diretor Presidente

Masuji yano

Diretor Gerente

Kenkiti Simomoto

Diretor Tesoureiro

Hatsuji Miyazaki

Conselheiro Fiscal

Kameiti Yamashita

Conselheiro Fiscal

Shigeji Takahashi

Conselheiro Fiscal

Toyokichi Nakao (substituído pelo sr. Magozaemon)

1933 (01/04/1933 a 05/09/1933)*

Diretor Presidente

Masuji yano

Diretor Gerente

Kenkiti Simomoto

Diretor Tesoureiro

Miyoji Torihara

Conselheiro Fiscal

Takaji Okamura

Conselheiro Fiscal

Seiro Kubo

Conselheiro Fiscal

Tamotsu Hidaka

* Para adaptar o estatuto à nova Lei cooperativista, convoca-se uma Assembléia Geral

Extraordinária que, por falta de quórum, é realizada numa segunda convocação, no dia 20 de agosto de 1933. O novo estatuto aumenta o número de diretores para 9 e o resultado da eleição

fica como segue:

\section{3 ( 06/09/1933 a 31/03/1934)}

Diretor Presidente

Diretor Gerente

Diretor

Diretor

Diretor

Diretor

Diretor

Diretor

Diretor

Conselheiro Fiscal
Masuji yano

Kenkiti Simomoto

Miyoji Torihara

Kameiti Yamashita

Tomoyasu Yamamoto

Yasumatsu Kato

Kimitoshi Tikami

Katsue Miyata

Magozaemon Takahashi

Shigeji Takahashi 
$\begin{array}{ll}\text { Conselheiro Fiscal } & \text { Keitaro Moriya } \\ \text { Conselheiro Fiscal } & \text { Magoichi Mitsutani }\end{array}$

1934 (01/04/1934 a 31/03/1935)

Diretor Presidente

Masuji yano

Diretor Gerente

Kenkiti Simomoto

Diretor

Miyoji Torihara

Diretor

Kameiti Yamashita

Diretor

Kimitoshi Tikami

Diretor

Katsue Miyata

Diretor

Magozaemon Takahashi

Diretor

Katuki Nishimura

Diretor

Yasumatsu Kato *

*Empreendeu viagem ao Japão e é substituído pelo sr. Kameiti

Yamashita

Conselheiro Fiscal

Seiki Murakami

Conselheiro Fiscal

Kunitaro Ori

Conselheiro Fiscal

Kyoichi Kurokawa (substituído pelo Sr. Masahachi Mtasuoka)

\section{5/36/37 (01/04/1935 a 31/03/1938)}

Diretor Presidente

Diretor Gerente

Diretor

Diretor

Diretor

Diretor

Diretor

Diretor

Diretor

Diretor

Diretor

Diretor

1936

Conselheiro Fiscal

Conselheiro Fiscal

Conselheiro Fiscal

1937

Conselheiro Fiscal

Conselheiro Fiscal

Conselheiro Fiscal
Kameiti Yamashita

Kinkiti Simomoto

Miyoji Torihara

Katuki Nishimura

Seiki Murakami

Kunitaro Ori

Susumu Uemura

Magozaemon Takahashi

Masahashi Matsuoka

Keitaro Moriya

Katsue Miyata

Chosaku Nakashima

Masuji Yano

Seiro kubo

Takaji Okamura

Keitaro Moriya

Chosaku Nakashima

Yoshiharu Nomura 
1938/39/40 (01/04/1938 a 31/30/1941)

$\begin{array}{ll}\text { Diretor Presidente } & \text { Kameiti Yamashita } \\ \text { Diretor Gerente } & \text { Kinkiti Simomoto } \\ \text { Diretor } & \text { Katuki Nishimura } \\ \text { Diretor } & \text { Chosaku Nakashima } \\ \text { Diretor } & \text { Seiki Murakami } \\ \text { Diretor } & \text { Masuji Yano } \\ \text { Diretor } & \text { Shuzou Kayano } \\ \text { Diretor } & \text { Sajima Ishiwa } \\ \text { Diretor } & \text { Rinzo Ishikawa }\end{array}$

1938

Conselheiro Fiscal

Seiro Kubo (substituído pelo Sr. Takaji Okamura em novembro de Conselheiro Fiscal 1938)

Magozaemon Takahashi

Conselheiro Fiscal

Kunitaro Ori

1939

Conselheiro Fiscal

Kiyomi Ohira

Conselheiro Fiscal

Kikujiro Mimoto

Conselheiro Fiscal

Tsukuru Myojin

\section{0}

Conselheiro Fiscal

Taichiro Hashizume

Conselheiro Fiscal

Susumu Uemura

Conselheiro Fiscal

Tsukuru Mori

1941 (até 20 de abril)

Conselheiro Fiscal

Kikujiro Mimoto

Conselheiro Fiscal

Tsukuru Myojin

Conselheiro Fiscal

Tadashige Morioka

1941/42 (01/04/1941 a 20/04/1942) *

Diretor Presidente

Kinkiti Simomoto

Diretor Gerente

Katuki Nishimura (licenciado)

Diretor

Seiki Murakami

Diretor

Chosaku Nakashima

Diretor

Kiyomi Ohira

Diretor

Takahashi Kawakami

Diretor

Saburo Toyota

Diretor

Tomoyasu Yamamoto

* No dia 4 de fevereiro de 1942 os membros japoneses da Diretoria renunciam em virtude do 
rompimento das relações diplomáticas entre o Brasil e o Japão, por causa da II Guerra Mundial. Convoca-se a Assembléia Exstraordinária em 12 de fevereiro de 1942 para resolver este problemas, mas esta só é realizada em 20 de abril, quando se elege nova Diretoria, com alguns japoneses no cargo de diretor-assistente

1941 (de 20 de abril)

Conselheiro Fiscal

Marcelo Piza

Conselheiro Fiscal

Gervásio Tadashi Inoue

Conselheiro Fiscal

Isamu Furuno

1942/43/44 (20/04/1942 a 31/05/1945)

Diretor Presidente

Manoel Carlos Ferraz de Almeida

Diretor Gerente

Quintilano Moreira Cesar

Diretor

Jose Silvestre da Rocha

1943

Conselheiro Fiscal

Edmundo Schuetz

Conselheiro Fiscal

Levem Vampre (substituído pelo Sr. Sadaki Serikawa)

Conselheiro Fiscal

Susumu Uemura

1944

Conselheiro Fiscal

Gervásio Tadashi Inoue

Conselheiro Fiscal

Ageo Ferreira de Camargo

Conselheiro Fiscal

Kunitaro Ori

\section{5/46/47 (01/04/0945 a 31/03/1948)}

Diretor Presidente

Diretor Gerente

Diretor

Diretor

Diretor

Diretor

Diretor

Diretor

Diretor

\section{5}

Conselheiro Fiscal

Conselheiro Fiscal

Conselheiro Fiscal

1946

Conselheiro Fiscal
Manoel Carlos Ferraz de Almeida

José Silvestre da Rocha

Kenkiti Simomoto

Quintilano Moreira Cesar

Luiz Yoshimichi Nagai

Gervásio Tadashi Inoue

Hajime Matsuoka

Ernesto benedito de Camargo

Edmund Schuetz (renunciou)

Takahashi Kawakami

Cassio da Rocha Pimentel

Flavio Resende de Carvalho (Substituído ple Sr. Sabro Abbe)

Leonardo S. Rodrigues 
Conselheiro Fiscal

Conselheiro Fiscal

\section{7}

Conselheiro Fiscal

Conselheiro Fiscal

Conselheiro Fiscal
Tsukuru Myojin

Yoshimatsu Maeda

Mario de Almeida Oliveira

Takashi Kawakami

Zenjiro Yamaguchi

1948/49/50 (01/04/1948 a 31/03/1951)

Diretor Presidente

Diretor Gerente

Diretor

Diretor

Diretor

Diretor

Diretor

Diretor

Diretor

\section{8}

Conselheiro Fiscal

Conselheiro Fiscal

Conselheiro Fiscal

\section{9}

Conselheiro Fiscal

Conselheiro Fiscal

Conselheiro Fiscal

\section{0}

Conselheiro Fiscal

Conselheiro Fiscal

Conselheiro Fiscal
Manoel Carlos Ferraz de Almeida

Kenkiti Simomoto

Gervásio Tadashi Inoue

Quintilano Moreira Cesar

José Silvestre da Rocha

NobuoYamashita

Fabio Ryodi Yassuda

Minou Ihara

Kiyomi Ohira

Jose Benedito Xavier de Lima

Kunitaro Ori

Kazushi Nishioka

Seiti Kikuchi

Kakushige Taue

Ernesto Benedito de Camargo

José Benedito Xavier de Lima

Fumio Koike

Yanao Ninomiya

\section{1/52/53 (01/04/1951 a 31/03/1954)}

Diretor Presidente

Diretor Gerente

Diretor

Diretor

Diretor

Diretor

Diretor

Diretor
Manoel Carlos Ferraz de Almeida

Kenkiti Simomoto

Gervásio Tadashi Inoue

Katuki Nishimura

Quintilano Moreira Cesar

Fabio Ryodi Yassuda

Kameiti Yamashita

Kiyomi Ohira 
Diretor

\section{1}

Conselheiro Fiscal

Conselheiro Fiscal

Conselheiro Fiscal

1952

Conselheiro Fiscal

Conselheiro Fiscal

Conselheiro Fiscal

1953

Conselheiro Fiscal

Conselheiro Fiscal

Conselheiro Fiscal
Chosaku Nakashima

\author{
Yoshimaru Maeda \\ Masao Aikawa \\ Jarbas do Amaral Carvalho
}

\section{4/55/56 (01/04/1954 a 31/03/1957)}

Diretor Presidente

Diretor Gerente

Diretor

Diretor

Diretor

Diretor

Diretor

Diretor

Diretor
Manoel Carlos Ferraz de Almeida *

Kenkiti Simomoto

Gervásio Tadashi Inoue

Katuki Nishimura

Kiyomi Ohira

Fabio Ryodi Yassuda

Kameiti Yamashita

Quintiliano Moreira Cesar

Massao Aikawa

* o Sr. Manoel Carlos Ferraz de Almeida falece no dia 02 de abril de 1956. Dois dias depois, o Dr. Gervásio Tadashi Inoue assume a presidência.

\section{4}

Conselheiro Fiscal Conselheiro Fiscal Conselheiro Fiscal

1955

Conselheiro Fiscal Conselheiro Fiscal Conselheiro Fiscal

\section{6}

Conselheiro Fiscal
José Silvestre da Rocha

Yoshimaru Maeda

Tsuneo

Toshimaru Kacuta

Masato Yamada

Jarbas do Amaral Carvalho

Tadashi Takakusa 


$\begin{array}{ll}\text { Conselheiro Fiscal } & \text { Tsuneo Mukai } \\ \text { Conselheiro Fiscal } & \text { Kensabro Shimomoto }\end{array}$

\section{7/1958/1959 (01/04/1957 a 31/03/1960)}

Diretor Presidente

Diretor Gerente

Diretor

Diretor

Diretor

Diretor

Diretor

Diretor

Diretor
Gervásio Tadashi Inoue

Kenkiti Simomoto*

Fabio Ryodi Yassuda

Quintiliano Moreira Cesar

Kiyomi Ohira

Katuki Nishimura

Masao Aikawa

Tadashi Takakusa

Kensabro Shimomoto

* O sr. Kenkiti Simomoto falece no dia 25 de semtembro de 1957, sendo substituído pelo Sr.

Kiyomi Ohira. E para preencher a vaga deixada na Diretoria, é eleito pela Assembléia Ordinária o Sr. Jarbas do Amaral Carvalho

\section{7}

Conselheiro Fiscal

Masaki Kurokawa

Conselheiro Fiscal

Jarbas do Amaral Carvalho

Conselheiro Fiscal

Yoshio kakuda

\section{8}

Conselheiro Fiscal

Conselheiro Fiscal

Chitose Miyaji

Conselheiro Fiscal

Tocio Kira

Seiro Tamura

\section{9}

Conselheiro Fiscal

Taichiro Hashizume

Conselheiro Fiscal

Sunao Ito

Conselheiro Fiscal

Ayahiko Miyamoto

\section{0/1961/1962 (01/04/1960 a 31/03/1963)}

Diretor Presidente

Diretor Gerente

Diretor

Diretor

Diretor

Diretor

Diretor

Diretor

Diretor
Gervásio Tadashi Inoue

Fabio Ryodi Yassuda

Tadashi Takakusa

Katuki Nishimura

Kiyomi Ohira

Jarbas do Amaral Carvalho

Quintiliano Moreira Cesar

Masao Aikawa

Kensabro Shimomoto 
1960

Conselheiro Fiscal

Conselheiro Fiscal

Conselheiro Fiscal

1961

Conselheiro Fiscal

Conselheiro Fiscal

Conselheiro Fiscal

1962

Conselheiro Fiscal

Conselheiro Fiscal

Conselheiro Fiscal
Ryuji Ueki

Yoshikazu Watanabe

Mitsuo Ogai

Masaki Kurokawa

Tsuneo Mukai

Tosaku Kida

Chitose Miyaji

Yoshimatsu Maeda

Tadao kimura

1963/1964/1965 (01/04/1963 a 31/03/1966)

Diretor Presidente

Gervásio Tadashi Inoue

Diretor Gerente

Fabio Ryodi Yassuda

Diretor

Katuki Nishimura

Diretor

Jarbas do Amaral Carvalho*

Diretor

Kensabro Shimomoto

Diretor

Diretor

Hifumi Ogasawara

Diretor

Masao Aikawa

Diretor

Masaki Kurokawa

* O sr. Jarbas do Amaral Carvalho falece em 20 de abril de 1966, vítima de um acidente automobilístico

1963

Conselheiro Fiscal

Tsuneo Mukai

Conselheiro Fiscal

Ktasuo Yamamoto

Conselheiro Fiscal

Tantsu Okubo

\section{4}

Conselheiro Fiscal

Conselheiro Fiscal

Tsutomu Kawakami

Conselheiro Fiscal

Jun Hirakui

Kingo Kogishi

\section{5}

Conselheiro Fiscal

Masao Tokumoto

Conselheiro Fiscal

Masatoshi Ono

Conselheiro Fiscal

Seiro tamura 


\section{6/1967/1968 (29/07/1966 a 31/12/1968)}

Em 05 de maio de 1966 realiza-se uma Assembléia Extraordinária, a fim de discutir-se a transformação da Sociedade para cooperativa segundo grau, ou seja, Cooperativa Central, e consequentemente reforma estatutária. A Administração é composta, elegendo-se seus membros.

Diretor Presidente

Diretor Gerente

Diretor

Diretor

Membro
Gervásio Tadashi Inoue

Fabio Ryodi Yassuda

Masao Aikawa

Kensabro Shimomoto

Masaki Kurokawa (p)

Toshimaru Kacuta (p)

Masatoshi Ono (p)

Hifumi Ogasawara (p) (Katsuo Yamamoto)

Tadashi Takakusa (p) (Hideki Yamaguchi)

Tsunezo Ozaki ( $p)$

Yutaro Kawamoto (p)

Heitor Carvalho Gomes (p) +

Tsuneo Mukai

Tantsu Okubo

Mitsuo Ogai

Haruji Maruki

Chitose Myiaji

Eiichi Tashiro

Masao Igarashi

Yoshimatsu Maeda

Linneu Carlos de Souza Dias

Cyro Imoto

Shigeo Hirama

João Nelson Sommier Molina

Tosaku Kida *

Kaneyoshi Kamogari *

(p) significa Presidente Singular associada, e por isso membro-nato do Conselho.

(* p) a constituição da associada Cinturão Verde de São Paulo atrasa-se.

(+) a filiada, Cooperativa Taquaritinga, desliga-se da Central

* Os srs. Okamoro e Kamogari foram eleitos na Assembléia

Ordinária de 1968, para preencher as vagas aumentadas pela reforma do estatuto.

* Os srs. Yamamoto e Yamaguchi substituíram os titulares do Conselho, pois o primeiro tinha relação parentesca com o sr. Hirama e o segundo igualmente com o sr. Kurokawa. 
1966

Conselheiro Fiscal

Conselheiro Fiscal

Conselheiro Fiscal

1967

Conselheiro Fiscal

Conselheiro Fiscal

Conselheiro Fiscal

1968

Conselheiro Fiscal

Conselheiro Fiscal

Conselheiro Fiscal

1969/1970/1971

Diretor Presidente

Diretor Gerente

Diretor

Diretor

Diretor

Diretor

Diretor

Membro
Sunao Ito

Tatsuo Yamamoto

Ichiji Jinzenji

Tsutomu Hirata
Tsuguio Kobayashi
Mitsuo Ideriha

Chota Tsuno

Tsutomu Kawakami

Guensiki Mizoguti

Gervásio Tadashi Inoue

Fabio Ryodi Yassuda *1

Terumi Takinagi

Yaçuo Ogawa

Masao Aikawa

Tantsu Okubo

Tsuneo Mukai *2

Masaki Kurokawa (p) (Koichi Watanabe) *3

Toshimaru Kacuta $(p) * 5$

Masatoshi Ono (p)

Hifumi Ogasawara (p)

Tadashi takakusa $(p)$

Kenkiti Nakagawa $(p) * 4$

Moriyoshi Fukuda (p)

Rikio Sudo $(p)$

*1 O sr. Fábio Yassuda é nomeado Secretário Municipal de Abastecimento em abril de 1969 sendo substituído pelo Sr. Ogawa.

* 2 O Sr. Mukai demitiu-se em outubro de 1969. No ano seguinte, por ocasião da Assembléia Geral Ordinária a vaga é preenchida pelo Sr. José Gonzaga Trigo Muniz.

* 30 sr. Kurokawa é substituído por ter relação parentesca com o sr. Tadashi Takakusa

*4 O sr. Nakagawa licencia-se por motivo de saúde, sendo substituído pelo sr. Kazuo Ohira.

*5 Em 1970 o sr. Kacuta, também por motivo de saúde, é substituído pelo sr. Yoshitaro

Muramatsu

* O sr. Fábio Yassuda é designado para o cargo de Ministro da Indústria e Comércio, demitindo-se definitivamente do cargo na Sociedade, cuja vaga é preenchida pelo Sr. Américo Utumi, em março de 1971. 
1969

Conselheiro Fiscal

Conselheiro Fiscal

Conselheiro Fiscal

1970

Conselheiro Fiscal

Conselheiro Fiscal

Conselheiro Fiscal

1971

Conselheiro Fiscal

Conselheiro Fiscal

Conselheiro Fiscal

1972/1973/1974

Presidente

Vice-presidente

Superintendente

Diretor

Diretor

Diretor

Diretor

Membro
Yoshimatsu Maeda

Chitose Miyaji

Ichiji Jinzenji

Toshio Ueda

Tsuguio Kobayashi

Yoshimatsu Maeda

Nobuki Kawakami

Tsutomu hirata

Kanji Aoki

Gervásio Tadashi Inoue

Yaçuo Ogawa

Terumi Tanigaki *1

Américo Utumi

Nobuki Kawakami

José Gonzaga trigo Muniz

Guensiki Mizoguchi

Koichi Watanabe $(p)$

Yoshijiro Muramatsu (p)

Minoru Tabata (p)

Moriyoshi Fukuda (p)

Hifumi Ogasawara $(p) * 2$

Shinzo Ishii ( $p$ )

Susumu Sudo (p)

*1 Em 1973 há reforma do estatuto, que cria o sistema de 3 superintendentes, na ocasião ocupados pelos srs. Ogawa, Ogasawara e Kawakami, e o sr. tanigaki assume a Vice-presidência. Foram adicionados também mais 6 componentes à Diretoria: srs. Cyro Imoto, Shimhatiro Hashizume, Mtasuo Yokota, Kazuo Ohira, Keyro Simomoto e Takafumi Fukushima *2 Em outubro de 1974 o sr. Ogasawara demite-se por motivo de saúde.

1972

Conselheiro Fiscal

Conselheiro Fiscal

Conselheiro Fiscal

1973

Conselheiro Fiscal
Masami Fukuzawa

Cyro Imoto

Shigeru Nishikawa

Masami Fukuzawa 
Conselheiro Fiscal

Conselheiro Fiscal

\section{4}

Conselheiro Fiscal

Conselheiro Fiscal

Conselheiro Fiscal

$1975 / 1976 / 1977$

Presidente

Vice-presidente

Superintendente

Diretor

Diretor

Diretor

Diretor

Diretor

Diretor

Diretor

Diretor

Membro
Kichishiro Endo

Shigeru Yamamoto

Tokuro Nakashima

Toyoaki Tamura

Haku Hara

Gervásio Tadashi Inoue

Yaçuo Ogawa

Keyro Simomoto

Américo Utumi

José Gonzaga Trigo Muniz

Matsuo Yokota

Masaki Kurokawa

Guensiki Mizoguti *

Kazuo Katayama

Shihatiro Hashizume

Yasuo Sugawara

Haruji Maruki

Tadashige Ishimoto $(p)$

Eiji Miyanaga * $(p)$

Ushitaro Abe ( $p)$

Takafumi Fukushima (p)

Tokuro Nakashima (p)

Shinzo Ishii (p)

Sussumu Sudo $(p)$

Tomijiro Hiroi ( $p$ )

* O sr. José Gonzaga Trigo Muniz falece em novembro de 1975

* Sr. Mizoguti renuncia ao cargo em 1975 e a vaga é preenchida pelo Dr. Tsuguio Kobayashi, eleito na Assembléia Geral Ordinária do ano seguinte.

* Sr. Miyanaga é substituído pelo sr. Izuyoshi Jinzenji em 14 de fevereiro de 1978.

\section{5}

Conselheiro Fiscal

Conselheiro Fiscal

Conselheiro Fiscal

1976

Conselheiro Fiscal

Conselheiro Fiscal

Conselheiro Fiscal
Haru Hara

Saburo Yamanaka

Kaneo Monma

Kaneo Monma

Kaichi Fukagawa

Katsuo Yamamoto 
1977

Conselheiro Fiscal

Conselheiro Fiscal

Conselheiro Fiscal

1978/1979/1980

Presidente

Vice-presidente

Superintendente

Diretor

Diretor

Diretor

Diretor

Diretor

Diretor

Membro
Kaichi Fukagawa
Kiloya Sato
Hidetaro Tamoto

Gervásio Tadashi Inoue

Yaçuo Ogawa

Keiro Simomoto

Américo Utumi

Kazuo Katayama

Masaki Kurokawa

Shimhatiro Hashizume

Matsuo Yokota

Yasuo Sugawara

Takafumi Fukushima

Keniti Aramaki

Tsuguio Kobayashi

Shiro Takakusa

Ktasuo Yamamoto

Ushitaro Abe

* A partir desse triênio é abolido o regime de membro-nato

\section{8}

Conselheiro Fiscal

Conselheiro Fiscal

Conselheiro Fiscal

\section{9}

Conselheiro Fiscal

Conselheiro Fiscal

Conselheiro Fiscal

\section{0}

Conselheiro Fiscal

Conselheiro Fiscal

Conselheiro Fiscal

$1981 / 1982 / 1983$

Presidente

Vice-presidente

Superintendente
Haku Hara

Mitsuo Jisaka

Tohoru Nishi

Tohoru Nishi

Akira Kawakami

Hikoya sato

Hikoya sato

Tadao Ota

Hideo Kawamata

Gervásio Tadashi Inoue *1

Yaçuo Ogawa *3

Keiro Simomoto $* 2$ 


$\begin{array}{ll}\text { Diretor } & \text { Américo Utumi } \\ \text { Diretor } & \text { Kazuo Katayama *4 } \\ \text { Diretor } & \text { Takafumi Fukushima } \\ \text { Diretor } & \text { Yoshio Kawakami } \\ \text { Diretor } & \text { Shimhatiro Hashizume } \\ \text { Diretor } & \text { Keniti Aramaki } \\ \text { Diretor } & \text { Yasuo Sugawara } \\ \text { Membro } & \text { Shiro Takakusa } \\ & \text { Paulo Takeshi Shimada } \\ & \text { Takeshi Hizuka } \\ & \text { Mitsuo Jisaka } \\ & \text { Koichi Watanabe }\end{array}$

*1 O Estatuto é reformado em 11 de novembro de 1982, criando-se 3 diferentes cargos: Diretor Presidente, Diretor Vice-presidente, e Diretor Superintendente, abolindo-se os anteriores.

*2 O Sr. Simomoto renuncia ao cargo em 21 de dezembro de 1981

*3 Assume o cargo de Diretor Superintendente, substituindo o sr. Simomoto

*4 Fica com o cargo de Diretor Vice-presidente

*5 Na Assembléia Geral Ordinária de março de 1983 há eleição para preenchimento de vagas criadas pela reforma estatutária e nela se elegem os srs. Takeshi Nishiyama, Shoichi Kobayachi e Yukihiko Ikeda

\section{1}

Conselheiro Fiscal

Haruji Maruki

Conselheiro Fiscal

Ichiki Watanabe

Conselheiro Fiscal

Yukihiro Ikeda

\section{2}

Conselheiro Fiscal

Conselheiro Fiscal

Conselheiro Fiscal

\section{3}

Conselheiro Fiscal

Conselheiro Fiscal

Conselheiro Fiscal

\section{4/1985/1986}

Diretor Presidente

Diretor Vice-Presidente

Diretor Superintendente

Diretor

Diretor

Diretor
Haruji Maruki

Kozo Kawakami

Munetaka Matsubara

Munetaka Matsubara

Kozo Kawakami

Tadao Ota

Gervásio Tadashi Inoue

Kazuo Katayama

Yaçuo Ogawa

Américo Utumi

Yasuo Sugawara

Shimhatiro Hashizume 


$\begin{array}{ll}\text { Diretor } & \text { Takafumi Fukushima } \\ \text { Diretor } & \text { Keniti Aramaki } \\ \text { Diretor } & \text { Munetaka Matsubara } \\ \text { Membro } & \text { Shiro Takakusa } \\ & \text { Paulo Takeshi Shimada } \\ & \text { Koichi Watanabe } \\ & \text { Maruo Kawakami } \\ & \text { Mario Massaharu Ogasawara } \\ & \text { Massanori Nagao * } \\ & \text { Osamu Iwaki } \\ & \text { Yukio Sasaki }\end{array}$

* O sr. Nagao falece em 02 de agosto de 1986

\section{4}

Conselheiro Fiscal

Toshiyuki Maezono

Conselheiro Fiscal

Hideo Kawamata

Conselheiro Fiscal

Haruji Maruki

\section{5}

Conselheiro Fiscal

Wataru Takahashi

Conselheiro Fiscal

Sasaki Hiroshi

Conselheiro Fiscal

Kozo Kawakami

\section{6}

Conselheiro Fiscal

Sasaki Hiroshi

Conselheiro Fiscal

Tadashi Kamitori

Conselheiro Fiscal

Yukihiko Ikeda

\section{7/1988/1989}

Diretor Presidente

Gervásio Tadashi Inoue

Diretor Vice-Presidente

Kazuo Katayama

Diretor Superintendente

Yaçuo Ogawa

Diretor

Américo Utumi

Diretor

Shimhatiro Hashizume

Diretor

Takafumi Fukushima

Diretor

Yasuo Sugawara

Diretor

Minoru Takano

Diretor

Sasaki Hiroshi

Diretor

Maruo Kawakami

Diretor

Diretor

Toshiyuki Maezono

Yukihiro Ikeda

Membro

Shiro Takakusa

Paulo Takeshi Shimada 
Mitsuo Jisaka

Kozo Kawakami

Akira Tamura

\section{7}

Conselheiro Fiscal

Mario Massaharu Ogasawara

Conselheiro Fiscal

Tadashi Kamitori

Conselheiro Fiscal

Akio Mori

\section{8}

Conselheiro Fiscal

Mario Massaharu Ogasawara

Conselheiro Fiscal

Shuzo Yoshiizumi

Conselheiro Fiscal

Haruji Maruki

\section{9}

Conselheiro Fiscal

Shuzo Yoshiizumi

Conselheiro Fiscal

Adolfo Hideo Hayashida

Conselheiro Fiscal

Joaquim Itiro Nakamura

\section{0}

Diretor Presidente
Diretor Vice-Presidente
Diretor-Superintendente
Diretor
Diretor
Diretor
Diretor
Diretor
Diretor
Diretor
Membros

Kazuo Katayama

Américo Utumi

Minoru Takano

Akira Akamatsu

Katsunori Koga

Minoru Osada

Motoharu Sonomura

Sigueaki Ogassavara

Vergílio Chokiti Yao

Waldyr Vicente de Souza

Adolfo Hideo Hayashida

Américo Utumi

Horácio Takeu Muraoka

Katsuhiko Kodama

Keniti Aramaki

Mikio Jinzenji

Minoru Takano

Shimhatiro Hashizume

Shiro Takakusa

Shuzo Yoshiizumi

Toshiyuki Maezono

Conselho Consultivo 
Presidente-Honorário

Superintendente-Honorário

Conselheiro Fiscal

Conselheiro Fiscal

Conselheiro Fiscal

Conselheiro Fiscal

Conselheiro Fiscal

Conselheiro Fiscal

\section{1}

Diretor Presidente

Diretor Vice-Presidente

Diretor-Superintendente

Diretor

Diretor

Diretor

Diretor

Diretor

Diretor

Diretor

Membros
Gervásio Tadashi Inoue

Yaçuo Ogawa

\author{
Mário Massaharu Ogasawara \\ Mitsuo Jisaka \\ Joaquim Itiro Nakamura \\ Manabu lida \\ Akio Mori \\ Kouya Yamaguchi
}

Kazuo Katayama

Américo Utumi

Minoru Takano

Akira Akamatsu

Katsunori Koga

Minoru Osada

Motoharu Sonomura

Sigueaki Ogassavara

Vergílio Chokiti Yao

Waldyr Vicente de Souza

Adolfo Hideo Hayashida

Américo Utumi

Horácio Takeu Muraoka

Katsuhiko Kodama

Keniti Aramaki

Mikio Jinzenji

Minoru Takano

Shimhatiro Hashizume

Shiro Takakusa

Shuzo Yoshiizumi

Toshiyuki Maezono

Gervásio Tadashi Inoue

Presidente-Honorário

Superintendente-Honorário

Conselheiro Fiscal

Conselheiro Fiscal

Conselheiro Fiscal

Conselheiro Fiscal

Yaçuo Ogawa

Paulo Kunishiro Yoshida

Mitsuo Jisaka

Kimihiro Kagawa

Asawo Nishida

Osvaldo Fumiaki Nagano 
Conselheiro Fiscal

\section{2}

Diretor Presidente

Diretor Vice-Presidente

Diretor

Diretor

Diretor

Diretor

Diretor

Diretor

Diretor

Membros
Diretor-Superintendente

\section{Minoru Tabata}

Kazuo Katayama

Américo Utumi

Minoru Takano

Akira Akamatsu

Katsunori Koga

Minoru Osada

Motoharu Sonomura

Sigueaki Ogassavara

Vergílio Chokiti Yao

Waldyr Vicente de Souza

Adolfo Hideo Hayashida

Américo Utumi

Horácio Takeu Muraoka

Katsuhiko Kodama

Keniti Aramaki

Mikio Jinzenji

Minoru Takano

Shimhatiro Hashizume

Shiro Takakusa

Shuzo Yoshiizumi

Toshiyuki Maezono

Gervásio Tadashi Inoue

Conselho Consultivo

Superintendente-Honorário

Yaçuo Ogawa

Conselheiro Fiscal

Conselheiro Fiscal

Paulo Kunishiro Yoshida

Joaquim Itiro Nakamura

Takashi Nishioka

Yukihiko Ikeda

Manabu lida

Akira Kawakami 